Universidade de São Paulo

Faculdade de Filosofia, Letras e Ciências Humanas

Departamento de Sociologia

Programa de Pós-graduação em Sociologia

\title{
Casas burguesas e arquitetos modernos: condições sociais de produção da arquitetura paulista
}

\section{Camila Gui Rosatti}

Tese apresentada ao Programa de Pósgraduação em Sociologia da Faculdade de Filosofia, Letras e Ciências Humanas da Universidade de São Paulo, para obtenção do título de Doutor em Sociologia.

Orientador:

Prof. Dr. Sergio Miceli Pessôa de Barros 
Autorizo a reprodução e divulgação total ou parcial deste trabalho, por qualquer meio convencional ou eletrônico, para fins de estudo e pesquisa, desde que citada a fonte.

\section{Catalogação na Publicação \\ Serviço de Biblioteca e Documentação \\ Faculdade de Filosofia, Letras e Ciências Humanas da \\ Universidade de São Paulo}

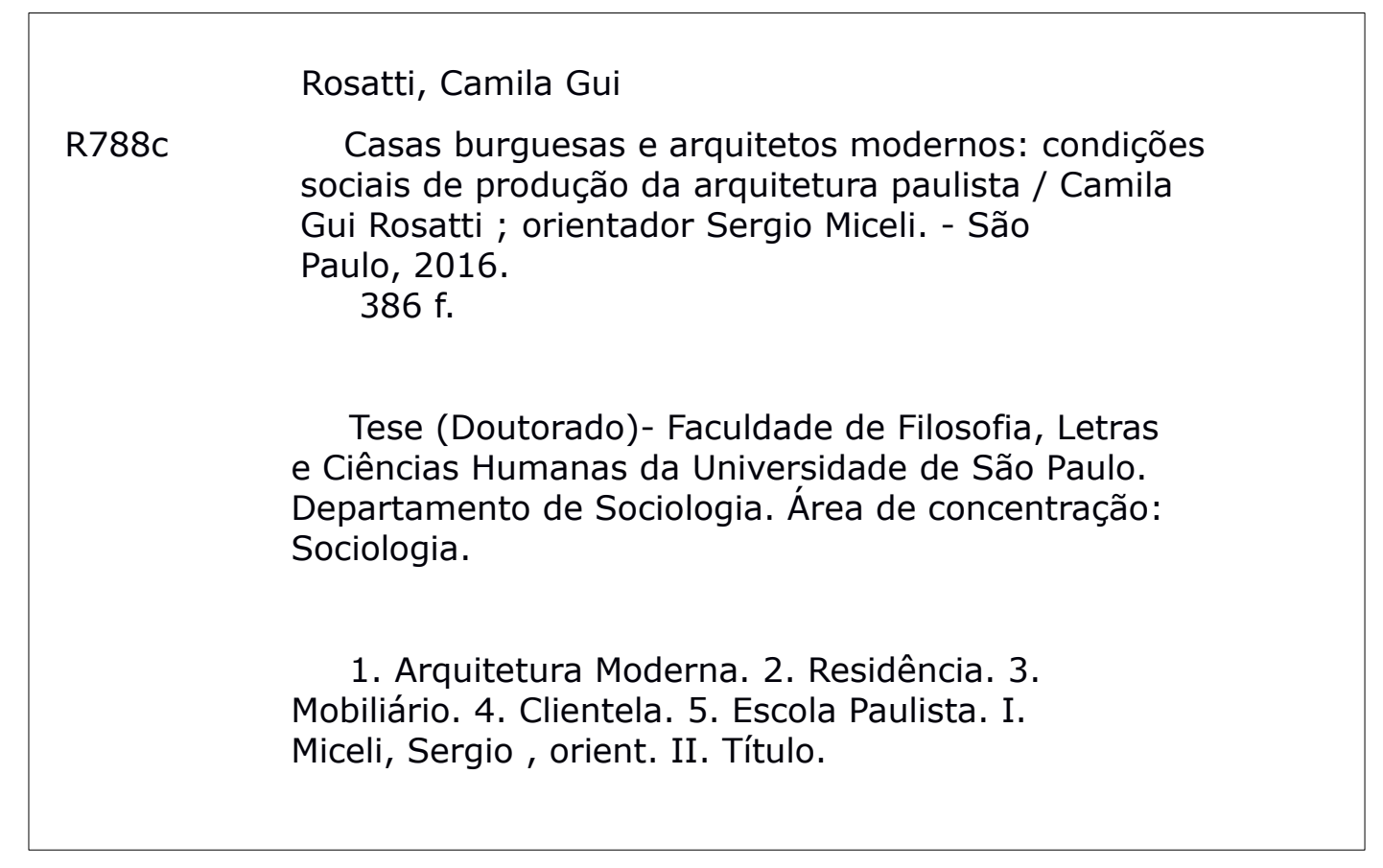


Nome: ROSATTI, Camila Gui

Título: Casas burguesas e arquitetos modernos: condições sociais de produção da arquitetura paulista.

Tese apresentada ao Programa de Pós-graduação em Sociologia da Faculdade de Filosofia, Letras e Ciências Humanas da Universidade de São Paulo, para obtenção do título de Doutor em Sociologia.

\section{Aprovada em:}

\section{Banca Examinadora:}

Prof. Dr. Instituição:

Julgamento: Assinatura:

Prof. Dr. Instituição:

Julgamento: Assinatura:

Prof. Dr. Instituição:

Julgamento: Assinatura:

Prof. Dr. Instituição:

Julgamento: Assinatura:

Prof. Dr. Instituição:

Julgamento: Assinatura: 


\section{AGRADECIMENTOS}

A feitura desta tese, entre 2012 e 2016, contou com suporte institucional, financeiro, intelectual, técnico, afetivo e toda sorte de estímulo e vibração. Ao longo do percurso, devo meu reconhecimento e gratidão às imprescindíveis redes de apoio e manifestações de entusiasmo.

É um privilégio ter Sergio Miceli como orientador. Leitor atento, comentador acurado e rigoroso, grande incentivador da pesquisa. Muito obrigada pelo encorajamento constante e por nos oferecer uma sociologia tão inspiradora.

Agradeço ao professor Afrânio Garcia, que me recebeu por um ano na École des Hautes Études en Sciences Sociales, quando realizei meu estágio de pesquisa. Com generosidade, debateu minhas ideias e ofereceu um olhar aguçado sobre a sociologia da arquitetura.

Sou grata às agências nacional e estadual de fomento à pesquisa, que possibilitaram a plena dedicação aos estudos. Ao CNPq, Conselho Nacional de Desenvolvimento Científico e Tecnológico, que disponibilizou apoio financeiro nos primeiros oito meses da pesquisa. À Fapesp, Fundação de Amparo à Pesquisa do Estado de São Paulo, pela concessão da bolsa de doutorado no país e no estágio de pesquisa no exterior, assim como pelos recursos disponibilizados para a participação em diversos eventos científicos.

Nas oportunidades de apresentação da pesquisa, em colóquio, congresso e sala de aula, vários docentes debateram versões em andamento do trabalho. Muito obrigada pelos apontamentos, críticas e incentivos: Ângela Alonso, Ricardo Benzaquem, Marcelo Mari, Roberto Grün, Fernando Pinheiro, Marcelo Ridenti, José Carlos Durand, Adrian Gorelik, Heloísa Pontes, Heitor Frúgoli, Gustavo Sorá e Maria Arminda do Nascimento Arruda.

Dmitri Cerbonccini e Carolina Pulici tiveram a gentileza de examinar meus rascunhos, em 2011, antes mesmo de eu redigir o projeto de pesquisa. Agradeço pelas primeiras contribuições e pelas várias oportunidades em que acompanharam os avanços da investigação.

Aos professores que participaram da banca de qualificação, Luiz Carlos Jackson e Silvana Rubino, agradeço o interesse com que leram o material e as indicações de novos caminhos.

Às professoras Paula Marcelino e Sylvia Garcia, que me receberam como monitora nos estágios do Programa de Aperfeiçoamento do Ensino (PAE). Exemplos de dedicação à docência, com elas pude experimentar o empenho e o compromisso do professor e do sociólogo em sala de aula.

Aos funcionários do Programa de Pós-graduação, por intermédio da figura de Gustavo Mascarenhas, agradeço todo o zelo e a paciência com o corpo discente. 
Aos funcionários da FAU-USP, deixo meu agradecimento pessoal à bibliotecária Rejane Alves e à responsável pelo Cesad, Eunice Barbosa.

Aos funcionários do Instituto Lina Bo e P. M. Bardi, principalmente a Vivian Lazzareschi, que me franqueou o acesso ao material do acervo e respondeu inúmeras de minhas questões.

Aos informantes e entrevistados desta pesquisa, que me ofereceram seus relatos e partilharam a memória de suas famílias.

Aos amigos José Muniz Jr. e Elisa Klüger, companheiros de toda a jornada do doutorado, frequentamos congressos, grupos de estudos;

compartilhamos nossos textos, algumas inseguranças e muitas risadas. A convivência generosa e o apoio constante tornaram esta pesquisa menos solitária e mais solidária. Estendo os agradecimentos a outros interlocutores, os participantes do nosso grupo de estudo, o "Corte e Cultura", Lorena Avellar, Maria Carolina Oliveira, Bruno Zorek, Guilherme Arduíni, João Ivo Guimarães e Lidiane Rodrigues, colegas sempre dispostos a decifrar as relações entre arte, sociedade, intelectuais e poder.

Aos amigos da Plural, nas figuras de Mariana Toledo e Lucas Oliveira, pela oportunidade em colaborar na organização da revista do nosso Programa de Sociologia, um espaço de diálogo e produção científica que minha experiência na universidade.

A Larissa Alves de Lira, pela antiga amizade parisiense, e Marcela Purini, pela nova amizade parisiense: as duas trouxeram companheirismo e vivacidade à nossa estadia em terra estrangeira.

Ruy Fausto, pela camaradagem das conversas e passeios aqui e acolá. Topou visitar comigo as casas de Le Corbusier em Paris, enquanto narrava as aventuras de sua família, também encomendantes de casas modernas.

Bruno Carvalho acompanhou de perto o andamento de meus estudos. Agradeço a presença preciosa.

Michel Chauí e Fernanda Senda, amigos da Faculdade de Arquitetura e Urbanismo e, desde então, de toda a vida, sempre presentes em afeto. Mesmo que o dia a dia dificulte nossos encontros, a afeição sempre permanece.

Maria do Carmo Alves e Lúcia Helena Alves, amigas dedicadas e incentivadoras.

A Vincent Jacques, por toda a leveza e a intensidade, impulso determinante para a conclusão da tese.

À minha família: meu pai, Antonio, minha mãe, Neide, e minha irmã, Carolina. Minha gratidão a tudo que é impossível de nomear, mas que será sempre reconhecido. 


\section{RESUMO}

ROSATTI, Camila Gui. Casas burguesas e Arquitetos Modernos: condições sociais de produção da arquitetura paulista. 2016. 386f. Tese (Doutorado em Sociologia). Faculdade de Filosofia, Letras e Ciências Humanas, Universidade de São Paulo, São Paulo, 2016.

A proposta da tese é investigar um grupo geracional de arquitetos ligados à Faculdade de Arquitetura e Urbanismo da Universidade de São Paulo. O grupo, que formou uma linhagem com trunfos e oportunidades para controlar sua reprodução institucional, foi classificado por seus propagadores como "Escola Paulista" ou "Escola Brutalista", designação que dá ênfase a um programa estético reconhecido pela geometria concisa e pela austeridade da matéria-prima. A radicalidade formal e o compromisso social constituíram o mito de origem dessa linguagem, elementos ressaltados no processo de canonização dos arquitetos, celebrados em instâncias nacionais e internacionais. A análise privilegiou as trajetórias de Lina Bo Bardi, Vilanova Artigas e Paulo Mendes da Rocha, com a intenção de identificar os fatores que contribuíram para a viabilidade dessas carreiras. Buscou-se, sobretudo, situar as condições sociais dessa produção na trama de relações entre arquitetos, clientes, divulgadores e instituições. Enfatizase que, dependentes do mecenato privado, eles projetaram e mobiliaram residências de uma parte da burguesia ilustrada paulistana, grupos com disposições materiais e culturais para arcar com os arrojos formais do grupo. Essas frações emergentes acompanharam os novos andamentos da cultura e exprimiram seus gostos artísticos e posicionamentos políticos também nas formas de morar.

Palavras-chave: arquitetura moderna; São Paulo; residência; mobiliário; encomenda; clientela; Lina Bo Bardi; Vilanova Artigas; Paulo Mendes da Rocha. 


\section{ABSTRACT}

ROSATTI, Camila Gui. Bourgeois Houses and Modern Architectes: social production of São Paulo's architecture. 2016. 386f. Tese (Doutorado em Sociologia). Faculdade de Filosofia, Letras e Ciências Humanas, Universidade de São Paulo, São Paulo, 2016.

This thesis analyzes a generational group of architects connected to the Faculdade de Arquitetura e Urbanismo da Universidade de São Paulo (Architecture and Urbanism College of the University of São Paulo). The group, which established a powerful lineage and had unique opportunities to control their institutional breeding, was classified by its disseminators as "Paulista School" or "Brutalist School". The designation emphasizes an aesthetic program recognized by its concise geometry and rugged materials. Formal radicality and social commitment composed the myth of origin of their collective project and language concerning it. Those elements were highlighted in the canonization of the architects of this group, who were celebrated nationally and internationally. The dissertation focuses on the trajectories of Lina Bo Bardi, Vilanova Artigas, and Paulo Mendes da Rocha. The research aims to identify the factors that contributed to the achievement of their careers. Specifically, it aims to understand the social conditions of this production in the web of relations between architects, clients, publishers and institutions. The dissertation demonstrates that these architects (dependent on private patronage) designed and furbished residences belonging to a part of the illustrated bourgeoisie in the city of São Paulo, a social group with sufficient capital and culture to bear the expenses of design boldness. These emerging fractions followed new cultural movements of the time and expressed their taste and political position through their lifestyles, of which architecture and design were an essential part.

Keywords: modern architecture; São Paulo; residence; furniture; orders; clientele; Lina Bo Bardi; Vilanova Artigas; Paulo Mendes da Rocha. 
$\begin{array}{lr}\text { INTRODUÇÃO } & 10\end{array}$

$\begin{array}{ll}\text { Apresentação } & 10\end{array}$

Um movimento chamado "Escola Paulista"? 15

A casa moderna como um exercício desprestigiado da profissão $\quad 21$

Habitat e habitus: alguns apontamentos $\quad 31$

$\begin{array}{ll}\text { Materiais e Métodos } & 38\end{array}$

\section{CAPÍTULO 01}

Moderno sob encomenda:

produtores e clientes do mobiliário nos anos 1950.

Novos produtores em cena

Promessas de democratização e marcadores de distinção

Expectativas em curso

Arquitetos, firmas e clientes: produção e consumo do mobiliário moderno

Lina Bo Bardi e o Studio Palma

Jacob Ruchti e a Branco \& Preto

Zanine Caldas e a Móveis Artísticos Z

Formação do gosto moderno e detração do gosto hegemônico

Gostos e estilos de vida sob medida

\section{CAPÍTULO 02}

Prática profissional e engajamento: projeto modernizador de Vilanova Artigas

Anos de formação: arquitetura versus engenharia

Construtora Marone e Artigas (1937-1944)

Causas operárias: os advogados Rio Branco Paranhos, Rivadávia e Rubens

Artigas em escritório próprio

A fundação da FAU-USP

Edifício Louveira para os irmãos Alfredo, Esther e Lia Mesquita

Alice Brill e Juljan Czapski

Deocélia Vianna e Oduvaldo Vianna 


\section{CAPÍTULO 03}

Depuração estética e sublimação do social:

Paulo Mendes da Rocha e sua clientela

Engenhosidade familiar

A formação no Mackenzie e as possibilidades de renovação estética

Requisitos de ingresso na profissão

Encomenda pública e privada, arquitetura erudita e de mercado

Concreto bruto para o gosto refinado

Uma casa bandeirista para cliente "quatrocentona"

Casa, fazenda e apartamento

\section{CAPÍTULO 04}

A consagração de uma estética:

o Pritzker de Paulo Mendes da Rocha

Apogeu de uma trajetória, triunfo de uma Escola

Instituição de uma raridade no campo da arquitetura

Sociologia de uma premiação: quais critérios, quem premia, quem é premiado

\section{APÊNDICES}
A: Roteiro do Questionário
B: Encomendantes de Vilanova Artigas e Paulo Mendes da Rocha
C: Encomendantes de Lina Bo Bardi 


\section{INTRODUÇÃO}

\section{Apresentação}

Os cruzamentos entre sociologia e arquitetura se apresentam como um domínio raramente estudado nas pesquisas no Brasil ${ }^{1}$. A sociologia da cultura e das artes pouco se deteve às especificidades da produção arquitetônica, assim como os intérpretes da disciplina se aproximaram brevemente das matrizes sociológicas para investigar esse objeto ${ }^{2}$. Esta pesquisa de doutorado procura constituir um ponto de vista a partir do qual se possa investigar a arquitetura moderna brasileira, assumindo como estudo a arquitetura e o design produzidos por um grupo geracional ligado à Faculdade de Arquitetura e Urbanismo da Universidade de São Paulo, arquitetos que estabeleceram vínculos com a instituição na condição de aluno ou de docente. Motivados por uma grade de valores de racionalidade e modernização, esses agentes assumiram, desde os anos 1950, a função de portadores de um discurso da renovação estética. Com certa fluidez, passaram a ser identificados pela historiografia da arquitetura como "Escola Paulista" ou "Escola Brutalista", designação coletiva que procurou captá-los em termos de um programa estilístico reconhecível pelo uso do concreto aparente, dos grandes vãos, do bloco único marcado pela geometria concisa e pela austeridade do material em estado bruto. A radicalidade formal e 0 compromisso social constituíram o mito de origem dessa linguagem,

1 Mesmo na França, o domínio da arquitetura tem recebido, como afirma o sociólogo francês Bruno Péquignot, pouca atenção dos praticantes da disciplina cf. PÉQUIGNOT, Bruno. "A sociologia das artes e da cultura na França. Gênese, desenvolvimentos e atualidade de uma área de pesquisa. In: QUEMIN, Alain e VILLAS-BOAS, Glaucia (dir). Arte e Vida Social. Marseille, OpenEdition Press, 2016.

2 Um dos primeiros trabalhos foi a pesquisa de mestrado de José Carlos Durand, interpelando a arquitetura por meio da sociologia da profissão, e de doutorado, sobre a formação do campo artístico e arquitetônico brasileiro. Neste, o autor se vale do arcabouço teórico da sociologia de Pierre Bourdieu para constituir análise de um amplo período de emergência e consolidação das instituições artísticas no Brasil. DURAND, Jose' Carlos. A profissão de arquiteto: estudo sociológico. Rio de Janeiro: CREA, 1972. DURAND, José Carlos. Arte, privilégio e distinção. Artes Plásticas, Arquitetura e Classe Dirigente no Brasil, 1855/1985. São Paulo: Perspectiva/EDUSP, 1989. DURAND, José Carlos; "Négociation politique et rénovation de l'architecture". In: Actes de la recherche em sciences sociales. Vol.88, juin. pp.61-77, 1991. 
elementos replicados no processo de canonização dos arquitetos, que passaram a ser celebrados em instâncias nacionais e internacionais.

Entre as diversas modalidades possíveis de carreira, a história do campo privilegiou distingui-los pelo estatuto de arquiteto-autor. Esse modelo vocacional com função sagrada se pauta pela ideia de originalidade, princípio segundo o qual se reconhece a invenção de um estilo próprio, uma marca distintiva. Nessa definição de atuação profissional, a ideia de criação se opõe à execução. O arquiteto produz uma raridade, um objeto que é reconhecido pela sua singularidade. Foram alçados a essa posição de destaque Vilanova Artigas (1915-1985) e Paulo Mendes da Rocha (1928), o primeiro na condição de mestre, e o segundo, de discípulo dileto. A arquiteta Lina Bo Bardi (1914-1992), mulher, estrangeira e formada na Itália, também foi incluída no panteão em uma etapa posterior de reconhecimento internacional, o que anuncia os regimes de visibilidade em que foram inseridos. Desenhando móveis e edifícios, eles conseguiram se consagrar como árbitros do gosto legítimo, entraram para a história canônica da arquitetura brasileira e seus projetos foram dotados da marca de autoria. A se considerar o prestígio que alcançaram, é possível dizer que esses produtores se valeram de posições sociais estratégicas e se mostraram mais aptos, em seus contextos específicos, a vencer a concorrência estabelecida com os pares.

Procurou-se situar as condições sociais de produção dessa renovação simbólica no arranjo de forças entre arquitetos, clientes e divulgadores. Tal trama analítica, que articula produtores, consumidores e instâncias de consagração, estrutura a tese e orienta o fio narrativo dos capítulos. Eles foram organizados de modo a recompor os dados biográficos dos arquitetos, as posições ocupadas e os investimentos profissionais feitos em nome da atualização das diretrizes estéticas. Inseridos no sistema de ensino e na dinâmica de organização do ofício em São Paulo, as propriedades sociais e as relações objetivas com as instituições e clientes foram colocadas em evidência, pois é esse contexto de formação educacional e exercício profissional que amarrou a ação dos agentes.

Ainda que a maioria dos projetos dos arquitetos modernos tivesse se 
voltado para o atendimento de encomendas de casas individuais ${ }^{3}$, os estudos sobre arquitetura moderna brasileira privilegiaram as encomendas exercidas pelo mecenato estatal e silenciaram em relação aos padrões de consumo e formação do gosto da arquitetura erudita na esfera privada. Com o propósito de preencher essa lacuna, o recorte desta pesquisa incide sobre uma modalidade específica de mecenato arquitetônico: a encomenda de residências unifamiliares e as práticas de consumo em matéria de decoração. Por se tratar de produtos confeccionados sob demanda, ou seja, personalizados às necessidades da clientela, a análise da condição da encomenda pretendeu lançar luz sobre o recrutamento social desses consumidores diferenciados em busca de produtos distintivos. Sob perspectiva da constituição das preferências estéticas, a pesquisa buscou compreender a propagação dos modos de morar modernos.

No capítulo I, as trajetórias e as práticas de Lina Bo Bardi, Jacob Ruchti (1917-1974) e Zanine Caldas (1919-2001) foram investigadas tendo em vista a formação da área do design, linguagem especializada que floresceu nos anos 1950. Nas firmas que conduziram, cada um desses designers deu respostas diferentes a disseminação do produto, soluções que podem ser atribuídas a condicionantes sociais específicos e possibilidades materiais de produção, com consequências para seleção do público consumidor. Momento decisivo do processo de metropolização da capital paulistana, do rearranjo das instituições políticas, sociais e culturais e do acolhimento de novas expressões estéticas, o design é um dessas áreas que surge investidas de intenções progressistas. Linhas concisas e inovadoras, leves e depuradas podem ser situadas como respostas estéticas ao ímpeto de modernização do período. O desafio era de suprimir os ornamentos e

3 Em amplo levantamento dos exemplares da arquitetura moderna paulista, Ruth Verde Zein nos mostra que de um universo de quase 600 exemplares, 214 são casas, defendendo assim que as residências unifamiliares configuram as realizações mais importantes dessa tendência arquitetônica. ZEIN, Ruth Verde. A Arquitetura da Escola Paulista Brutalista: 1953-1973. Tese de Doutorado, Porto Alegre, UFRGS, 2005. p.222. 
industrializar a produção, aposta estética e social que visaria a democratização do acesso a esses bens. Tendo em vista a relação entre produção e consumo, focalizou-se a encomenda de móveis e os projetos de ambientação dos espaços privados de moradia, buscando cotejar o papel dos produtores e especificidade das experiências. Com o objetivo de trazer em questão a atuação dos arquitetos na formação do gosto moderno, procurou-se mostrar o engajamento desses profissionais no jogo de lutas simbólicas. Lina Bo Bardi pleiteou o lugar de autoridade estética, venerando ou detratando práticas de consumo, ou seja, atuando como perito na definição do gosto moderno como universalmente válido e legítimo.

No capítulo II, o percurso de Vilanova Artigas é analisado tendo em vista a organização da profissão, o engajamento político e da institucionalização do ensino de arquitetura. Galgando posições institucionais fundamentais, a trajetória do arquiteto foi pontuada por diversos marcadores desse processo de construção institucional, acadêmica e profissional do campo arquitetônico em São Paulo - investimentos que contribuíram para que fosse alçado a lugar de destaque na renovação da arquitetura produzida na cidade. Imbuído de um projeto para a nação, o arquiteto conferiu um caráter missionário à profissão, com defesa da função social do arquiteto. Nessa aposta de ação profissional, sustentou que a contribuição da categoria para o desenvolvimento do país viria com a industrialização da produção. Formas modernas, racionalização dos componentes, nova organização do trabalho e institucionalização do ensino: tais transformações teriam que ser acompanhadas de outra faceta dessa modernização, a formação de um mecenato politicamente empenhado e esteticamente exigente, disposto a patrocinar uma arquitetura arrojada. Ainda que o horizonte de atuação fosse a produção de habitação popular via aparato estatal, foi a emergência de um público esclarecido e engajado que permitiu que as propostas de Artigas encontrassem eco em uma clientela disposta a validar o gosto pelas formas puras.

No capítulo III, a análise procura articular as dimensões individuais e institucionais para situar a trajetória de Paulo Mendes da Rocha. A socialização familiar, escolar e profissional foi reconstituída a fim de se 
compreender as disposições individuais que contribuíram para que se alcançasse ao lugar de principal de herdeiro da corrente paulista. Filho e neto de engenheiros, a relação que estabeleceu com a técnica serviu de justificativa para aliar o rigor construtivo à uma experiência criativa. Foi, no entanto, no âmbito institucional que a experiência geracional mostrou-se decisiva para afiançar a entrada na carreira. O convite de Vilanova Artigas para atuar como assistente de ensino the garantiu definitivamente a inserção na linhagem dos arquitetos paulistas. Mendes da Rocha lapidou a matéria bruta que tomou como herança, depurou as formas e arrefeceu o discurso de missão política da arquitetura. Realizou uma arquitetura austera e sofisticada destinada predominantemente a frações sociais com trânsito nos meios artísticos, clientes que puderam expressar suas inclinações estéticas por meio da moradia. A investigação da trajetória e da clientela do arquiteto, bem como o processo de acúmulo de reconhecimento, permitem explicitar as linhas de força dominantes na consagração da "Escola Paulista", quando ela dispensa de reclamar um projeto de nação.

O capítulo IV trata do percurso de consagração do arquiteto Paulo Mendes da Rocha, cujo ponto culminante foi a conquista, em 2006, do prêmio Pritzker. Principal honraria mundial do campo da arquitetura, a premiação expressa o capital simbólico acumulado pelo agente ao longo de sua trajetória e coloca em evidência as disputas em torno da afirmação de uma doutrina estética e ética. Por meio de uma sociologia do prêmio, procurou-se entender a lógica de produção de reputações considerando as relações entre os agentes - premiadores e premiados. Tanto na dinâmica mais ampla de afirmação do estatuto artístico da profissão, quanto nas disputas locais pela autoridade do arquiteto, o ritual em torno da honraria vocalizou os valores do campo da arquitetura. Ao eleger a "Escola Paulista" como uma tradição exitosa, a distinção magnetiza toda a linhagem de arquitetos (pertencentes e postulantes), assim como os consumidores dessa estética. Pensado como um epílogo da construção da hegemonia do grupo, o desfecho explicita a fixação de uma linha interpretativa vitoriosa que tem realçado a missão moral e a função social da arquitetura paulista. 


\section{Um movimento chamado "Escola Paulista"?}

Sem absorver as definições dos grupos e ratificar a validade dos termos, cabe sinalizar, logo de início, que as categorizações de tendências, linhagens e movimentos podem ser pensadas, sociologicamente, em seus usos, valorações, seleções e disputas entre os diversos agentes que compõem o campo da arquitetura. Como modo de se referir a uma tendência arquitetônica regional, há divergências entre produtores e historiadores, o que gera embates acerca de questões classificatórias. Há aqueles que nem mesmo reconhecem a existência de especificidades da produção de uma escola regional paulista, por considerá-la, no conjunto, manifestação de uma única "arquitetura brasileira", portanto, produto da constituição da identidade nacional moderna. No entanto, é preciso esclarecer que as tentativas de fixar a coesão do grupo de arquitetos paulistas, em valores e condutas artísticas, se fez, em grande medida, em contraponto a assim nomeada "Escola Carioca".

As designações "Escola Paulista" e "Escola Carioca" foram mobilizadas por produtores e intérpretes a partir de um esquema de oposições centrado na distinção de formas estéticas e valores éticos. A comparação do repertório formal e ideológico se constituiu referenciada na linhagem moderna dos arquitetos radicados no Rio de Janeiro, cujo grande destaque foi Oscar Niemeyer (1907-2012). De modo esquemático, de um lado, estariam os cariocas, com suas linhas curvas que revelariam a sinuosidade do ritmo brasileiro, tomado como expressão de um formalismo, e de outro, os paulistas, que com seus volumes rígidos representariam a racionalidade da técnica e do cálculo, visto como postura de engajamento (BRUAND, 1999; SEGAWA, 2002; BASTOS e ZEIN, 2010).

Se é possível intitulá-los sob o signo de pertencimento a um movimento, deve-se considerar, para além das representações colocadas em disputa, as modalidades de financiamento que os arquitetos lograram mobilizar. A inserção no aparelho de estado teve consequências no exercício da profissão e no programa arquitetônico realizado. O recrutamento dos arquitetos cariocas pela classe dirigente foi a condição decisiva que definiu a 
supremacia dessa linhagem ${ }^{4}$. Apoiados pelos líderes modernistas instalados na repartição pública federal, o efetivo suporte do Estado garantiu legitimidade para a imposição de um movimento de renovação estética. A produção arquitetônica da "Escola Carioca" conquistou o apoio de figuras centrais das elites políticas e culturais desde os anos 1930, no período varguista, o que garantiu o fortalecimento e a fixação do programa estético, permitindo a irradiação para outras cidades, como Belo Horizonte, e de modo definitivo, na construção da capital federal. A força do grupo amparou-se na vinda de uma estrela mundial, o arquiteto francês Le Corbusier, convidado a colaborar nos primeiros projetos liderados por Lúcio Costa (1902-1998). O patrocínio estatal e a articulação dos mentores modernistas funcionaram como marcador decisivo na sustentação da linguagem arquitetônica, o que contribuiu para fixar em diversos edifícios públicos e na forma urbana a imagem apoteótica de certa "arquitetura moderna brasileira". Com Brasília, a plasticidade das curvas e o traço límpido de Niemeyer transformaram-se em emblema oficial do Brasil moderno. Cumpre apontar que, nos meados dos anos 1950, Vilanova Artigas articulou equipe de uspianos para concorrer no concurso de Brasília, competição que deu vitória às diretrizes urbanísticas de Lúcio Costa.

Enquanto o acesso privilegiado às elites burocráticas permitiu ao grupo carioca a atuação próxima ao poder, os paulistas ficaram constrangidos, sobretudo, às encomendas de famílias endinheiradas e cultivadas. Em São Paulo, a negociação na esfera política foi pouco exitosa, o que os deixou dependentes do mecenato privado. Os arquitetos foram acionados nas relações sociais com uma burguesia ilustrada, grupos sociais que prosperaram com as reconfigurações sociais dos meados do século XX. Esses novos agentes que concentravam capitais econômicos e culturais direcionaram seus investimentos para a construção de seus espaços de moradia.

Ainda que o nascimento do termo "Escola Paulista" seja incerto, é possível sintetizar um percurso da origem de sua reivindicação. A busca

4 A respeito do papel do mecenato estatal na promoção da arquitetura da "Escola Carioca", cf: DURAND, José Carlos. "Négociation politique et rénovation de l'architecture". In: Actes de la recherche em sciences sociales. Vol.88, juin. pp.61-77, 1991. 
pelo pioneirismo dos paulistas veio com o ímpeto bairrista de creditar a Gregori Warchavchik (1896-1972) o início da arquitetura moderna no Brasil, no final dos anos 1920, momento de afirmação do legado da Semana de Arte Moderna 5 . Como se verá, Mário de Andrade (1893-1945), no início dos anos 1940, instigou o cotejo entre as duas supostas vertentes, valorizando a presença de Vilanova Artigas, posição que foi retomada pelo crítico de arte e agente interno ao grupo de arquitetos, Flávio Motta (1923) e, em seguida, consolidada pelo historiador francês Yves Bruand (1926-2011). Ainda que seja um caminho sem ligações imediatas, imbuídos pela mesma atmosfera de valorização do métier, esses mentores se mostraram identificados com os arquitetos paulistas e encarregaram-se de infundir um ponto de vista produzido no interior do grupo.

Responsável por formular nos anos 1960 um manual que cumpriu papel definitivo de nomeação das duas tendências, Bruand vocalizou uma linha dominante que adquiriu força na historiografia. Ao falar das "aspirações espirituais e plásticas" e do "amor pelos materiais sem revestimento" de Vilanova Artigas, as sentenciações do historiador deram entonação aos conflitos. Segundo sua visão: "não é exagero falar de uma Escola Paulista de ambições vigorosas, decidida a suplantar, no futuro, sua rival carioca no panorama brasileiro" (BRUAND, 1999, p.305, grifos meus). De modo mais amplo, os princípios propalados pelos arquitetos paulistas foram incorporados em boa parte das leituras dos historiadores e intérpretes, mesmo as mais recentes. Formados na mesma instituição, a maioria dos trabalhos contribuiu para reproduzir a grade de valores progressistas e o papel político dos arquitetos. As querelas bairristas entre paulistas e cariocas ou as disputas em torno dos precursores em São Paulo esconderam a adesão primeira à agenda doutrinária do grupo. Constituiu-se uma aura de vanguardismo e engajamento que os protegeu das críticas.

Quando se tratou de construir as definições e defender as supostas singularidades da arquitetura paulista, diversos atributos procuraram ser nomeados e infundidos pelos intérpretes. (Quem são os arquitetos que

5 Cf. LIRA, José Tavares Correira de. Warchavchik: fraturas da vanguarda. São Paulo: Cosac Naify, 2011. 
fazem parte? Quando e quem iniciou o movimento? Quais são os elementos estéticos predominantes? Quem são os precursores, mestres, discípulos e epígonos? Qual a obra inaugural e quais são os edifícios modelares? Qual abrangência territorial e temporal da tendência? Quais são as influências da arquitetura internacional? $\mathrm{O}$ que define esteticamente a linguagem desse grupo? Qual o compromisso político de tal aposta estética?). Esses pontos, cujas formulações demandam por designações de origem, precursores, pertencentes, impostores, formas e valores, assinalam os principais critérios de análise erigidos pelos historiadores. As balizas classificatórias estiveram orientadas para definir a importância de uma obra, o grupo de pertencimento, as relações de empréstimos formais entre os arquitetos e as influências estéticas, ênfase analítica que recai sobre questões estilísticas em detrimento da experiência social que fundamentou essas práticas.

Se entre os historiadores há embates para construir consenso, as recusas e as disputas pelo poder de classificação se expressam também nas falas dos arquitetos, que deixam resvalar o interesse na construção do protagonismo ou debochar da classificação. Para além do conteúdo específico das querelas, o depoimento dos arquitetos serve como testemunhos que deixam entrever o funcionamento da produção dos bens simbólicos, no qual se pode reconhecer a força dos agentes mediadores na estabilização dos sentidos. As declarações ganham inteligibilidade quando se tem em vista o processo coletivo em torno do qual se constroem valores, filiações e periodizações, dinâmica na qual os arquitetos estão enredados e que orienta o móvel na imposição de uma narrativa hegemônica.

A posição emblemática de quem afirma que "de toda minha geração, eu era o único que não tinha nada que ver com essa corrente" é de Fábio Penteado (1926-2011). Formado no Mackenzie no começo dos anos 1950, o arquiteto assumiu ao longo de sua trajetória a função de jornalista de arquitetura na imprensa especializada e também trabalhou em parceria com Artigas e Mendes da Rocha, no final dos anos 1960 e início dos anos 1970. Em uma posição de distanciamento do grupo, deixou explícita sua crítica à vulgarização do estilo ao reportar o conteúdo estético rústico dessa arquitetura à falta de técnica e à precariedade do método construtivo: 
"O que aconteceu em São Paulo foi uma obsessão pelo concreto aparente e como não tinha tecnologia disponível, chamava brutalismo, de tão mal feito: usar tábua de madeira, mão de obra não qualificada é uma coisa mal feita. Ficou na moda, o que não fosse de concreto aparente não era bom. E aqui [em São Paulo] tem um pequeno museu de horrores, melancólico" ${ }^{6}$

Carlos Lemos (1925), historiador, docente da FAU-USP e arquiteto que chefiou o escritório de Oscar Niemeyer em São Paulo nos anos 1960, também procurou demarcar uma posição de afastamento a uma imposição estilística absoluta. O arquiteto se recusou a produzir casas seguindo o programa moderno restrito. Aqueles que, em nome da primazia dos ideais estéticos, seguiram irrefletidamente essas orientações, foram acusados de serem servis ao gosto da clientela modernosa. Na sua visão, negligenciaram as funções básicas da habitação. Justificando os projetos residenciais que realizou, que se valeram do repertório estético tradicional, realçou a importância do conforto ambiental como guia para a prática da arquitetura:

"Já os remediados, em suas encomendas arquitetônicas, muitas vezes em tentativas de ascensão social, privilegiam a intenção plástica própria da arquitetura dos abonados, contando com a conivência de projetistas complacentes, que acabam perpetrando projetos modernosos, mas inadequados à sua vida cotidiana. O que almejam mesmo é a exterioridade, a aparência, o partido 'moderno. Resultam em casas quentes no verão, geladíssimas no inverno, devassadas e sem nenhuma proteção acústica e, também faltas de ventilação natural que a simples física aplicada pode proporcionar. Esse desconforto é que procurei evitar a todo custo, apelando à experiência acumulada nos antigos. Não sou um retrógrado nem saudosista, satisfaço a programas modernos numa continuidade espacial própria dos dias de hoje" ${ }^{\prime \prime}$.

6 Depoimento do arquiteto a Gabriel Rodrigues da Cunha. CUNHA, Gabriel Rodrigues. Uma análise da produção de Vilanova Artigas entre 1967 a 1976. Dissertação (mestrado). Escola de Engenharia de São Carlos da Universidade de São Paulo, 2009. p.200.

7 LEMOS, Carlos Alberto Cerqueira. Viagem pela carne. São Paulo: Editora da Universidade de São Paulo, 2005. p.150. 
Paulo Mendes da Rocha, um dos reconhecidos expoentes do grupo paulista, quando questionado sobre a existência de uma "Escola", em um primeiro momento desconsidera a possibilidade de unidade para, em seguida, nublar a ideia de que se tratava de um movimento geograficamente localizado, restrito a um conjunto de colegas da FAU-USP. No entanto, a classificação que utilizava é marcadamente em termos formais, pautada pelo empréstimo e circulação de soluções estéticas e estruturais. Ao tentar avaliar a existência de coesão do grupo em São Paulo, credita a origem à influência da linguagem estética dos arquitetos cariocas, via Afonso Reidy (1909-1964), que fez uso do concreto aparente na Escola Brasil-Paraguai, de 1952, edifício construído em Assunção. Assumindo a condição de herético, o arquiteto demove a baliza fixada pelos historiadores, também interessados em mostrar o elo formal entre cariocas e paulistas, mas que até então, como obra inaugural dessa arquitetura, tinham apontado o Museu de Arte Moderna do Rio de Janeiro (MAM-RJ), de 1953, localizado no Aterro do Flamengo, no Rio de Janeiro, por seus pórticos estruturais e uso do cimento em estado bruto:

"Eu nunca fui um estudioso disso. Vi surgir a expressão e a nomeação de uma 'Escola Paulista' nas críticas, nos comentários feitos, digamos, fora do meu raciocínio. Pelo seguinte: eu sei o que se diz e não reconheço muito por que é assim [...] Não vejo bem a ideia de uma 'Escola Paulista', mas compreendo os críticos que querem resumir e enquadrar. Acho que o Afonso Eduardo Reidy teve bastante influência na nossa obra, até no Artigas, com a escola do convênio Brasil-Paraguai, os pórticos e tudo mais. Posso chamar isso de uma 'Escola Paulista'. Acho que os irmãos Roberto [Marcelo e Milton] pertencem a essa escola, até certo ponto... Não sei quem é da 'Escola Paulista' lá pelas tantas. O que eu sei, e que gostaria muito de ver dito por outras pessoas, é que o ginásio que fiz para o Clube Atlético Paulistano em 1957 foi absolutamente revolucionário na cabeça de muitos arquitetos, e inclusive na cabeça do próprio Artigas" ${ }^{\prime \prime}$.

As declarações são expressivas dos debates travados em torno das 
conceituações, das lideranças e da demarcação dos estilos. Ora rejeitando a classificação, ora alargando ou embaçando os referenciais de origem, os arquitetos foram chamados a se posicionarem em relação à constituição de uma tradição. Paulo Mendes da Rocha, o principal herdeiro, contesta os enquadramentos operados, embora reconheça a importância da função desempenhada pelos intérpretes. No entanto, não escapa de querer ser lembrado pelo pioneirismo de seu projeto para o Clube Paulistano, obra de estreia na carreira do arquiteto, com a qual ganhou o concurso logo após formado, aos 29 anos de idade, e que foi instituída como anúncio da consolidação de uma nova geração da arquitetura brasileira.

\section{A casa moderna como um exercício desprestigiado da profissão}

Desde o final dos anos 1920, o foco disseminador da agenda internacional para a arquitetura moderna esteve nos congressos internacionais, o que permitiu a difusão de palavras de ordem em torno de uma pauta coesa ao métier. Essas reuniões internacionais, que arregimentaram arquitetos de diferentes países, defenderam a ruptura estética com o passado e inculcaram a questão social nos horizontes de atuação profissional ${ }^{9}$. Do ponto de vista programático, a fundação dos Congressos Internacionais de Arquitetura Moderna (Ciam), em 1928, contribuiu para a organização da profissão, orientando ideias e condutas para a resolução, sobretudo, dos problemas de habitação popular, tema que seria convertido em tomada de posição estética e política.

Os Ciams constituíram um esforço coletivo de proposição de práticas racionalizadoras e engajadas com o objetivo de se distinguirem das diretrizes que dominavam o campo da arquitetura na época. A máxima "a forma segue a função", que se tornou redução eloquente do programa da

9 Champy Florent, "L'engagement des professionnels comme conséquence de tensions consubstantielles à leur pratique: l'architecture moderne entre les deux guerres." , Sociétés contemporaines $1 / 2009\left(n^{\circ} 73\right)$, p. 97-119 
arquitetura funcionalista, é emblemática da relação de concorrência dos arquitetos modernos contra os ecléticos, cuja orientação estética esteve fundada na arquitetura beaux-arts. A coesão em torno da missão do arquiteto e da racionalidade construtiva se apresentaria como um instrumento para subversão da ordem simbólica.

Analisando os discursos e as condutas dos arquitetos nesses espaços de afirmação profissional, o sociólogo Florent Champy apontou que a necessidade de adotar uma postura política apresentou-se como uma estratégia para resolução de tensões inerentes à prática do ofício de arquiteto. $\mathrm{O}$ apelo ao compromisso social converteu-se em agenda coletiva destinada a superar o modelo anterior, monopolizado pelas escolas do início do século $\mathrm{XX}$, que legou uma atuação vista como elitista e atada aos esquemas neoclássicos. No embate entre as concepções do papel do arquiteto, os novos profissionais defenderam uma pauta contra os modelos tradicionais, historicamente ligados ao poder e às elites. Para desbancar os concorrentes, os arquitetos modernos se lançaram como agentes interessados na edificação de um novo modelo de sociedade e não apenas direcionados a responder a uma encomenda específica, pontual e personalizada. Na disputa com os estabelecidos, os recém-chegados visavam transpor a concorrência intraprofissional e pleitear os benefícios do patrocínio estatal.

Mobilizados por uma agenda social, os arquitetos modernos trouxeram questões de salubridade das habitações, insolação e ventilação, com vistas a cumprir requisitos higienistas e implementar o programa do urbanismo racional. É nessa chave que o antropólogo Lauro Cavalcanti, em Moderno e Brasileiro, analisa a produção habitacional direcionada à população de baixa renda. Para o autor, desde os anos 1930 os profissionais brasileiros propagandearam um sentido ético e estético à arquitetura moderna buscando incorporar a moradia popular no rol das atividades centrais do ofício, programa que se punha a combater o viés predominantemente artístico das Belas Artes e o acento tecnológico dos engenheiros. Segundo a análise de Cavalcanti:

"No Brasil dos anos 1930, o estabelecimento de um discurso propondo 
soluções para a morada dos mais pobres constituiu a última base do tripé - junto com a construção de prédios monumentais e a instalação de uma política de preservação da memória nacional - que possibilitou aos modernos o domínio do campo arquitetônico, derrotando os acadêmicos e os neocoloniais"10.

Para os arquitetos que pretendiam cavar uma posição de vanguarda, a defesa da utilidade social da profissão passaria pela sustentação da habitação popular como fundamento ideológico, uma garantia, portanto, do compromisso do ofício ao um movimento mais amplo de transformação da sociedade. No entanto, se no âmbito internacional o programa da arquitetura moderna nasceu por meio da necessidade de conciliar soluções de saúde pública e produção em massa para resolver o problema de moradia da população de baixa renda, no Brasil, a representação monumental de um país moderno foi a tônica. Sustentada pelas classes dirigentes, arquitetura moderna foi elevada à condição de símbolo nacional, em ações orquestradas pelos agentes do poder público, que se valeram dessa linguagem para construir a imagem de um país atado ao progresso.

Com vistas a materializar em formas arquitetônicas o desejo de uma nova sociedade, os repertórios da linguagem moderna foram manejados pela ação de diversos agentes - representantes políticos, frações dirigentes, intelectuais instalados nos aparatos burocráticos e arquitetos, em um concerto de interesses que uniram mecenas e criadores. Os grandes projetos de linguagem marcadamente moderna patrocinados pelo aparato estatal - entre eles, o Ministério da Educação e Saúde Pública, no Rio de Janeiro em 1936; o Conjunto da Pampulha, no início dos anos 1940 em Belo Horizonte; o Conjunto do Ibirapuera, de 1954, em São Paulo; e a construção de uma capital, Brasília, no final dos anos 1950 - contribuíram para fixar a aura de grandiosidade e imponência da nossa arquitetura. As negociações institucionais e políticas asseguraram a produção dos grandes

10 CAVALCANTI, Lauro. Moderno e Brasileiro. A história de uma nova linguagem (1930-1960). Rio de Janeiro, Jorge Zahar Ed. 2006. p. 123. Cf. principalmente os capítulos que tratam da construção dos primeiros conjuntos habitacionais, no Rio de Janeiro dos anos 1930, programa arquitetônico que celebra o discurso de "casas para o povo". 
ícones modernos. Foi esse patronato que esteve na base da relação entre a arquitetura e a representação de um país que se queria avançado ${ }^{11}$.

Malgrado as grandes obras modernas, no Brasil, o desafio de produção de habitações em larga escala não encontrou o mesmo incentivo governamental. Nos anos 1950, em que pese a grande penetração da arquitetura moderna incentivada pelo poder público, os paulistas não conseguiram instituir de modo abrangente seus serviços ao mecenato estatal e ficaram constrangidos à realização do programa residencial a uma clientela particular. Ao analisar o programa da entidade representativa da classe, o IAB, José Carlos Durand nota "a omissão (ou falta de ênfase) no problema da habitação popular", indicando que "as teses que marcaram a postura de uma arquitetura de esquerda estão diluídas numa visão que privilegia a 'despoluição' visual do ambiente urbano" (DURAND, 1972, p. 88).

Mal-estar entre os arquitetos paulistas, a dificuldade de serem aliciados pelo poder público é observada por Richard Morse, quando escreveu a biografia dos 400 anos da cidade de São Paulo. O historiador apontou o dilema dos arquitetos de São Paulo que, em relação a outros profissionais, se vangloriavam de possuir formação humanística, porém, frustravam-se por responder às demandas individuais, vistas como menos importantes do que as intervenções na escala da metrópole:

"Algumas residências são talvez mais notáveis que os edifícios públicos [...] Os arquitetos, entretanto, cônscios da potencialidade da cidade para a beleza e o serviço funcional, sentem-se profundamente frustrados por se confinarem a construções individuais, muitas das quais residências particulares que simplesmente aumentam o conforto que os ricos já desfrutam, ou então aranha-céus que intensificam o congestionamento urbano. Não é de se admirar que muitos arquitetos dessem as boas-

11 Diversas pesquisas mostraram que o incentivo e a promoção governamental estiveram diretamente associados à consagração da arquitetura moderna brasileira nos projetos entre os anos 1930 a 1960, produções arquitetônicas que ganharam grande visibilidade e circulação internacional. Além dos trabalhos de Durand, cf. CAVALCANTI, Lauro (org). Modernistas na repartição. Rio de Janeiro, UFRJ/Paço Imperial, 1993 e Moderno e brasileiro: a história de uma linguagem na arquitetura (1930-1960). Rio de Janeiro: Jorge Zahar Ed., 2006. Em São Paulo, a construção do Parque Ibirapuera para a comemoração dos 400 anos da cidade, cf. ARRUDA, Maria Arminda do Nascimento. São Paulo no meio do século XX, Bauru, SP: EDUSC, 2001. 
vindas a uma disposição político-econômica pela qual sua visão mais completa da vida humana substituísse a do engenheiro, para servir, não ao indivíduo isolado, superprivilegiado, mas à comunidade, às múltiplas comunidades da metrópole urbana."12

Comparadas aos projetos demandados pelo Estado - os edifícios públicos de função político-administrativa, os projetos urbanos e os conjuntos habitacionais, programas que concentraram o título das "boas causas" da arquitetura moderna - , as residências particulares eram vistas como projetos desprestigiados, serviço submetido às conveniências dos clientes endinheirados. Considerando o diferencial com que os arquitetos pretendiam se impor na concorrência com outras profissões, as casas feitas sob encomenda explicitariam o afastamento à propalada utopia moderna de mudança social. Na visão dos arquitetos de esquerda, ela se distancia do conjunto habitacional e do projeto urbano, intervenções de dimensão coletiva que representariam o engajamento da profissão às necessidades das camadas desprivilegiadas e à transformação das cidades.

Se a implementação da missão civilizadora dos arquitetos paulistas havia encontrado resistências do poder público, com a ditadura militar, a pauta modernizadora estaria constrangida à cooptação ao novo regime. Momento mais amplo de crise política e institucional do país, o afastamento dos arquitetos de esquerda da FAU-USP trouxe desdobramentos e impasses à prática profissional e à consolidação de uma tradição dentro da universidade. Contraditoriamente, foi com apoio dos militares que Vilanova Artigas, Paulo Mendes da Rocha, Fábio Penteado e equipe de colaboradores conseguiram dar vazão a um projeto de habitação popular. Encomendado pela Caixa Estadual de Casas para o Povo (CECAP) em 1967, o projeto previa a construção de cerca de 10 mil unidades habitacionais para trabalhadores sindicalizados ${ }^{13}$. As cidades escolhidas para a construção dos conjuntos tinham perfil operário: Cubatão, Americana, Mogi-Guaçu, Jundiaí,

12 MORSE, Richard M. De comunidade à metrópole. Biografia de São Paulo. Comissão do IV Centenário da Cidade de São Paulo. 1954. p.304

13 BUZZAR, Miguel Antonio. João Batista Vilanova Artigas: elementos para a compreensão de um caminho da arquitetura brasileira, 1938-1967. São Paulo: Unesp:Senac São Paulo, 2014. 
Marília e Jaú. A aposta desenvolvimentista dos arquitetos era que, com o mecenato estatal, conseguiriam implementar um programa habitacional que atingisse as massas. O desenho arquitetônico com vistas à transformação social seria o instrumento de intervenção dos arquitetos. Orientados pelos ideais de progresso, previam que seria necessário incorporar o processo industrial à produção de moradias. Nos anos 1960, a questão da industrialização se fixou como um paradigma para o ofício: permeava o vocabulário dos profissionais e era encampada como requisito para o desenvolvimento nacional ${ }^{14}$.

No entanto, quanto ao programa do CECAP, ao longo dos anos 1970, apenas um terço do projeto foi implementado, frustrando as expectativas de que o desenho de arquitetura pudesse atender a população de baixa renda e produzir uma ampla transformação social. O modelo visionário colocava os arquitetos como orquestradores de mudanças sociais, com a pretensão de ditar os modos de morar em todos os setores da vida, do "garfo à cidade", ou seja, prescrevendo o desenho arquitetônico, a técnica construtiva, o modelo urbano e as necessidades sociais da população. Como chegaria a afirmar Fábio Penteado, um dos integrantes da equipe, a proposta era fantasiosa ${ }^{15}$. Ainda que defendessem que a solução da habitação popular passaria pela produção pré-fabricada, racionalizada e em larga escala, os

14 Cabe nuançar que o tema da industrialização, do desenvolvimento e do projeto brasileiro também norteava o debate entre sociólogos paulistas e cariocas. A urgência de implementar o processo, bem como os obstáculos ao desenvolvimento das forças produtivas dominaram a pauta da intelligentsia brasileira nos anos 1950 e 1960. A "fe' no desenvolvimento" e a "superação do atraso" orientaram o ideal de intervenção social dos sociólogos e suas pesquisas, tanto no ISEB, no Rio de Janeiro, quanto no CESIT, centro vinculado à Universidade de São Paulo. Cf. ARRUDA, Maria Arminda do Nascimento. "A sociologia no Brasil: Florestan Fernandes e a "escola paulista". In. MICELI, Sergio (org.) História das ciências sociais no Brasil, v.02, São Paulo: Sumaré, 1995. KEINERT, Fábio Cardoso. Cientistas sociais entre a ciência e política (Brasil, 1968-1985). Tese (Doutorado em Sociologia). Faculdade de Filosofia, Letras e Ciências Humanas, Universidade de São Paulo, São Paulo, 2011. ROMÃO, Wagner de Melo. Sociologia e política nos anos 1960: a experiência do Cesit. São Paulo: Associação Editorial Humanitas, 2006.

15 De acordo com o arquiteto Fábio Penteado, que trabalhou junto com Artigas no projeto do CECAP, a atuação dos arquitetos era utópica e irreal. "Fazendo uma crítica, a proposta foi fantasiosa, como se fosse possível fazer uma cidade com tudo dela autônomo, escolas autônomas, hospitais autônomos, tudo. Era uma visão fantasiosa, no meu modo de ver, influenciada por fantasias. Como a proposta de Niemeyer na Argélia, cujo projeto é bonito de ver. Uma proposta fantasiosa, no deserto". Depoimento do arquiteto a Gabriel Rodrigues da Cunha. CUNHA, Gabriel Rodrigues. Uma análise da produção de Vilanova Artigas entre 1967 a 1976. Dissertação (mestrado). Escola de Engenharia de São Carlos da Universidade de São Paulo, 2009. p.192 
arquitetos depreciavam o estatuto técnico da profissão. Permaneciam, sobretudo, com uma visão idealista e heroica do ofício, que os deixava alheios às instâncias decisórias. Autonomizados no debate do campo da arquitetura, as propostas que defendiam estavam estritamente vinculadas ao repertório moderno, concepção em que o arquiteto assumiria um papel demiúrgico. Sem forças políticas para impor suas diretrizes aos grupos dirigentes, eles não conseguiram se fincar na máquina estatal a ponto de influenciar o processo político e intervir na elaboração de planos para a habitação moradia com um saber especializado.

Nô âmbito federal, a questão habitacional foi assumida como um problema econômico e não arquitetônico, a ser resolvido prioritariamente por um sistema de financiamento público. Durante o regime militar, foi criado o Banco Nacional de Habitação (BNH), que, no entanto, não conseguiu validar uma política habitacional destinadas às classes baixas. Uma das críticas centrais a essas ações foi o beneficiamento de famílias de classes médias e altas em detrimento às camadas populares. Com financiamento barato, os recursos empregados favoreceram grupos já privilegiados, que adquiriram um "verdadeiro patrimônio imobiliário, especulativo e lucrativo"16, em muitos casos, imóveis de veraneio e de aplicação rentista. O fracasso na generalização de um programa de habitação popular se deu pela dificuldade dos arquitetos de atuarem junto aos círculos dirigentes e se instituírem como mentores de um efetivo plano de produção e financiamento de moradia.

O golpe de 1964 colocaria em xeque a atuação dos arquitetos na esfera pública e abalaria o pretendido ideal de modernização das estruturas sociais. O dilema se estabeleceria entre trabalhar para o estado ou direcionar para atuação no mercado privado. Constrangidos pelos limites que a pauta modernizadora impunha, os arquitetos tiveram de se contentar com o apadrinhamento de uma fração de classe interessada em moldar seu habitat na linguagem dos movimentos estéticos. Em experiências individuais e pontuais, estariam desobrigados a pautar seus desenhos por

16 Cf. BOLAFFI, Gabriel e CHERKEZIAN. Henry. BNH, bode expiatório. Novos Estudos, nํ13, outubro, 1985. p. 47. 
um processo industrializado, condição essencial à produção da habitação popular.

Nesse desalinho, não é casual que nos discursos forjados pelos arquitetos e reforçados pelas interpretações historiográficas, o sentido privado da casa foi mitigado com a construção de formulações que sobrecarregaram o programa residencial de um valor coletivo e urbano, em detrimento do uso individual que o espaço representava. Em vez de expor a constrição dos arquitetos às determinações espaciais e materiais do projeto do edifício privado, procurou-se tomar essas limitações como índice de uma postura engajada e uma atitude vanguardista, reforçando um suposto papel social do arquiteto. Uma frase de Artigas que ficou célebre, "A casa é uma cidade, a cidade é uma casa", dá mostras do valor grandioso que se pretendia conferir ao projeto da moradia individual.

Sob o mesmo pressuposto de que o projeto residencial aviltaria a profissão, Lina Bo Bardi, por outro lado, expressou sua recusa em prestar esse serviço, com a justificativa de que não queria submeter suas ideias ao gosto de uma clientela burguesa. Além de sua própria casa no Morumbi, projetou apenas outras duas residências, uma em 1958, vizinha à sua moradia, e outra em Salvador, em 1964. Em São Paulo, o casal de encomendantes Valéria Piacentini Cirell, antiquária, e Renato Cirell, professor da Faculdade de Direito da Universidade de São Paulo, revela os círculos de sociabilidade da arquiteta no reduto de imigrantes italianos, do qual participavam famílias bem-postas na cidade. Na Bahia, o encomendante foi Rubem Rodrigues Nogueira ${ }^{17}$, advogado que ocupou cargos de deputado estadual, federal e procurador-geral de Justiça, o que mostra as relações que a arquiteta estabeleceu, quando trabalhou na Bahia, com a elite política local.

Ao se referir às casas projetadas por esses arquitetos, os historiadores e críticos procuraram minorizar a destinação individual das residências, abonando-as com interpretações que expurgassem a condição

17 Informações sobre Rubem Rodrigues Nogueira foram encontradas nos verbetes biográficos do arquivo do CPDOC. Disponível em: http://www.fgv.br/cpdoc/acervo/dicionarios/verbetebiografico/rubem-rodrigues-nogueira. Consulta em: 07/02/2016. 
de uso restrito que a dimensão privada impunha. Ora escusando o caráter limitado dos projetos isolados, ora valorizando-os como anúncio da totalidade da obra, essa dupla justificativa, inseparavelmente estética e ética, foi articulada a fim de conferir às residências o status de objeto legítimo da cultura. "Campo de prova", "laboratório formal", "espaço de experimentação", "narrativa sintética", "manifesto ético e estético", "profissão de fé", "documento extraordinário de suas aspirações" são algumas das expressões utilizadas nas instâncias de consagração, infundindo leituras orientadas a fixar um significado elevado a esses edifícios.

O projeto da moradia concentrou o compromisso moral dos arquitetos, que se pretendiam deflagradores de novas relações sociais. Essa narrativa mítica se apresenta de modo exemplar na definição de Marlene Acayaba, umas das principais propagadoras dos princípios do grupo, que contribuiu para conferir sentido transcendente aos projetos residenciais. Filha de uma família bem-estabelecida de imigrantes libaneses, a arquiteta formou-se na FAU-USP nos anos 1970. Em seu mestrado, selecionou as moradias paulistas de referência, coletânea que funcionou como guia estético para estudantes e profissionais ${ }^{18}$. Formada em um ambiente universitário, como explicitou, "essencialmente masculino", Acayaba direcionou a atividade prática de arquiteta para exercer o trabalho simbólico de propagadora das ideias do grupo. Não deixa de ser alusivo que nessa conversão, tenha conferido um significado particular à escolha do estudo da casa, invocando os papéis de gênero: "Estudar a casa foi a maneira que encontrei de exercer a minha feminilidade" (ACAYABA, 2011. p.31.). A experiência de estudante próxima aos mentores paulistas evidencia a inculcação dos esquemas interpretativos formulados no interior da "Escola". Segundo a afirmação da historiadora:

"[...] como alunos da FAU-USP, nós tínhamos a obrigação de superar a alienação desse modelo hierarquizado e estabelecer a partir dos nossos

18 Publicado em meados dos 1980, o material teve prefácio de Gilberto Freyre. O caráter sistematizador da estética paulista contribuiu para que o livro fosse adotado como material didático nas escolas de arquitetura, Cf. ACAYABA, Marlene Milan. Residências em São Paulo. São Paulo: Romano Guerra Editora, 2011. 
projetos um novo tipo de vida [...] tínhamos em mente que habitar é uma atividade".

Sob o título de "10 mandamentos da arquitetura residencial paulista", registrou os preceitos ideológicos e exigências estéticas que comandariam uma espécie de poética construtiva. 0 tom de sacralidade e adoração incutidos no exercício do projeto evidencia a aura que se constituiu em torno do programa da moradia:

"1. As casas serão objetos singulares na paisagem

2. A lógica da implantação será determinada pela situação geográfica

3. O programa será resolvido num único bloco

4. A casa se pretende modelo ordenador para a cidade

5. A casa será uma máquina de habitar

6. A casa será resolvida em função de um espaço interno próprio: o pátio, o jardim interno ou o vazio central

7. Volumes independentes conterão os espaços necessariamente fechados e definirão os espaços abertos

8. Internos ou externos, os espaços evoluirão um do outro

9. Os materiais serão genéricos e, se possível, industrializados

10. As relações sociais se darão sob uma nova ética"19.

Pode-se dizer que o apelo ético-político se apresentou como tentativa de blindagem contra a crítica do esteticismo e o formalismo da arquitetura paulista. É o que observa o crítico Roberto Schwarz, ao apontar as limitações do projeto moderno para a arquitetura:

"Ora, para quem pensara na construção racional e barata, em grande escala, no interior de um movimento de democratização nacional, para quem pensara no labirinto das implicações econômico-políticas entre tecnologia e imperialismo, o projeto para uma casa burguesa é inevitavelmente um anticlímax. Cortada a perspectiva política da arquitetura, restava entretanto a formação intelectual que ela dera aos arquitetos, que iriam torturar o espaço, sobrecarregar de intenções e experimentos as casinhas que os amigos recém-casados, com algum dinheiro, às vezes Ihes encomendavam. Fora de seu contexto adequado, realizando-se em esfera restrita e na forma de mercadoria, o racionalismo transforma-se em ostentação de bom gosto - incompatível

19 ACAYABA, Marlene. Brutalismo Caboclo e as residências paulistas. Projeto, São Paulo, n.73, mar, 1985, p.46-48. 
com sua orientação profunda - ou em símbolo moralista e inconfortável da revolução que não houve". (SCHWARZ, 2008, p. 93, grifos meus).

De acordo com os intérpretes, o programa da moradia que serve de guia para as apostas estéticas e políticas dos arquitetos estaria orientado, no âmbito individual, para emancipação dos moradores. No âmbito da sociedade, as formulações mobilizadas buscaram situar a casa como expressão formal da modernização brasileira, em que a dureza e a austeridade do material representariam a convivência entre o moderno e o arcaico. O processo artesanal de execução da moradia foi interpretado como a impossibilidade de efetivar a industrialização brasileira. No entanto, ao mesmo tempo em que o discurso passa a reiterar os dilemas do país, os traços sociais dos encomendantes são apagados. A despeito do caráter singular do edifício, a casa foi defendida como tentativa de resolver, em termos de linguagem formal, o problema estrutural do país, justificativa que a alçou à condição de manifesto artístico. Esse nó entre contemplação estética e engajamento político é inseparável do processo de autonomização e consagração da arquitetura paulista.

\section{Habitat e Habitus: alguns apontamentos}

Reconstituir o espaço social em que as encomendas de casas e mobiliários foram produzidas é, pois, uma forma de povoar a história da arquitetura moderna com os agentes que deram voz a essa demanda. Nessas balizas, o enfoque é a caracterização social de uma clientela de gosto cultivado, bem delimitada no espaço social, que desejou morar em casas atualizadas com as vanguardas arquitetônicas. As questões que emergem são: quais grupos sociais e frações de classe estiveram dispostos a modelar seus espaços de moradia afinados com as tendências de vanguarda? Quem foram os clientes que, por iniciativa própria, investiram 
financeira e simbolicamente na aquisição de artefatos modernos? Quais aquisições culturais, repertórios estéticos, sistemas de preferências e valores mobilizados, de um lado, na escolha do arquiteto, e, de outro, no programa de uso e nos arranjos da moradia? Essas perguntas evidenciam uma articulação entre os estilos de vida e as predileções estéticas, que podem ser mediadas pela noção de gosto, marcador expressivo das posições dos indivíduos.

Para entender essas dinâmicas sociais, a pesquisa assume como ponto de apoio um tripé caro a uma sociologia da cultura, que poderia ser nomeado pela articulação autor-público-obra, ou, no caso em questão, arquitetos, encomendantes e residências. Entrecruzando as esferas de produção e consumo, a se levar em conta o lugar social de produção dos criadores, dos objetos e dos encomendantes, a investigação buscou localizar o ambiente social que conferiu afinidades de gostos e estilos de vida. Nesses termos, a encomenda de residências e objetos de decoração passa a ser enfrentada como prática social. São condutas que revelam as aquisições culturais, a rede de relações sociais e um conjunto de afirmações e recusas que expressam a posição social de seus proprietários. Além de marcadores de distinção, os investimentos nos arranjos da moradia podem ser vistos em seu sentido mais profundo de reprodução social, uma vez que a casa guarda um projeto de fixação da família, espaço por excelência de coesão dos seus membros, interiorização durável de um sistema de disposições que estão na origem da aquisição de uma herança econômica e cultural.

A ideia pressuposta é que, carregada de múltiplos significados, a residência unifamiliar é um registro valioso dos modos de pensar e agir, maneiras de ser, ter e aparecer, ou seja, um conjunto expressivo de condutas que compõem as escolhas estéticas de seus proprietários. Nesse ponto, as formulações de Norbert Elias foram inspiradoras à pesquisa. Em Sociedade de Corte, o sociólogo recorre à arquitetura residencial para descrever os diferentes espaços de moradia na sociedade aristocrática francesa. Para o autor, a habitação de uma determinada sociedade oferece elementos para a compreensão das formas fundamentais das relações 
privadas (internas à família) e das relações sociais (constituídas no espaço coletivo da casa). A configuração do espaço é tomada como expressão concreta das inter-relações sociais, levando Elias a defender as "estruturas de habitação como indicadores de estruturas sociais" (ELIAS, 2001, p. 66).

Na mesma direção, mas em uma formulação específica à ação do indivíduo, as casas podem ser vistas como insígnias materiais que objetificam propriedades sociais de seus encomendantes. Para Pierre Bourdieu, as casas são suporte material de um projeto de reprodução dos valores familiares, no sentido de entesourar uma herança econômica e legar uma herança cultural ${ }^{20}$. Trata-se, pois, de um modo específico de modelagem de estilos de vida nos modos de morar, processo de via dupla que aqui é tomado como transfiguração do habitus em habitat. Como base fundamental da organização familiar, a casa e, por consequência, o ambiente físico e seus arranjos espaciais dão forma a esse propósito. Como nos mostra Pierre Bourdieu em seu artigo sobre os cabilas, população do norte da Argélia, a moradia é um território de clivagens sociais e expressão material da organização do grupo ${ }^{21}$. Em As estruturas Sociais da Economia, pesquisa sobre as estratégias de financiamento da casa própria entre os franceses, a residência é vista como elemento central de fixação dos membros da família, formando um espaço por excelência de coesão e

20 Pierre Bourdieu, em artigo de 1990, especifica que a moradia unifamiliar, além, é claro, de seu papel estratégico como reserva de valor econômico, no sentido estrito do termo, possui um forte componente simbólico. Ela é forma de entesouramento, investimento de dinheiro, mas também define um projeto de reprodução biológica e social, assegurando a acumulação e transmissão do patrimônio familiar: "En tant que bien matériel qui est exposé à la perception de tous (comme le vêtement), et cela durablement, cette propriété exprime ou trahit, de manière plus décisive que d'autres, l'être social de son propriétaire, ses 'moyens', comme on dit, mais aussi ses goûts, le système de classement qu'il engage dans ses actes d'appropriation et qui, e, s'objectivant dans des propriétés visibles, donne prise à l'appropriation symbolique opérée par les autres, ainsi en mesure de le situer dans l'espace social des goûts [...] La maison est indissociable de la maisonnée comme groupe social durable et du projet collectif de la perpétuer [...] Ce qui s'affirme tacitement à travers la création d'une maison, c'est la volonté de créer un groupe permanent, uni par des relations sociales stables, une lignée capable de se perpétuer durablement, à la façon de la demeure, durable et stable, immuable ; c'est un projet ou un pari collectif sur l'avenir de l'unite' domestique, c'est-à-dire, sur sa cohésion, son intégration [...]" Actes de la Recherche, n.81/82, mars, 1990. p.6-9. Essas ideias estão aprofundadas e ganham desenvolvimento teórico em Les Structures Sociales de l'economie (2000), quando o autor toma o mercado da produção de moradias como objeto de estudo empírico, em uma abordagem em que os significados sociais e antropológicos da casa, em contraponto com a economia racionalista, ganham centralidade explicativa.

21 BOURDIEU, Pierre. "A casa kabyle ou o mundo às avessas". Cadernos de Campo, São Paulo, noo8, 1999. 
interiorização de disposições de um grupo ligados por fortes laços. Nesse sentido, a moradia é tomada como matriz de um sistema durável que está na origem da aquisição de um patrimônio tanto econômico e quanto cultural. Nos termos do sociólogo, "se o habitat contribui para fazer o habitus, o habitus contribui para fazer o habitat, através dos usos sociais, mais ou menos adequados, que ele inclina os agentes a fazer desse mesmo habitat"22.

Ainda que a existência de um destinatário seja evidente no projeto da casa, a linha dominante de interpretação da arquitetura moderna brasileira apagou os traços da encomenda, silenciando sobre as relações sociais que dariam sentido a essa experiência. Faço alusão aqui ao fato de ser naturalizada nos livros de arquitetura a designação do projeto arquitetônico a partir do nome do encomendante, sem informar, no entanto, qualquer dado social do proprietário. Na maioria das abordagens que se consagraram na história da arquitetura moderna, essas casas foram assumidas como pequenos laboratórios estéticos, pelos quais os arquitetos testaram inventivas soluções espaciais, técnicas e construtivas. As residências foram descritas em seu partido arquitetônico, em suas soluções estruturais, na implantação no lote, na escolha dos materiais, ou seja, foram tratadas como objetos isolados.

Com efeito, de um lado, são evidenciadas as características formais, construtivas, estéticas da casa, e, de outro, são obliteradas as características sociais do cliente, as condições que viabilizaram a encomenda e as formas de apropriação cultural do espaço habitado. Por exemplo: fala-se em "Casa Elza Berquó", "Casa Czapski", "Casa Oduvaldo Vianna", "Casa Mário Masetti", "Casa Millan" etc. sem ser revelado qualquer informação social dos consumidores. O nome do cliente é revelado tão somente como título da edificação e não como sujeito ativo da encomenda. Nesse modus operandi, o nome do proprietário aparece metonimicamente como denominação da moradia, ou seja, a figura do encomendante é

22 Bourdieu explicitou as relações entre espaço físico e o espaço social na comunicação "Espace physique, espace social et espace physique approprié", apresentada no Colóquio "Poverty, Immigration and Urban Marginality in Advanced Societies", em 1991. O material foi traduzido e publicado no Brasil: "Espaço físico, espaço social e espaço físico apropriado", Estudos Avançados, n27, (79), 2013. pp.133-144. 
coisificada na obra física, e a moradia é personificada. Nesse arranjo narrativo, quem ganha centralidade é a residência, apresentada em si mesma como agente da renovação estética. Ao se levantar os dados biográficos desse seleto grupo de encomendantes, nota-se que eles formavam um corpo de intelectuais, artistas, profissionais liberais, empresários, muitos de origem imigrante, engajados em manifestações artísticas e culturais da cidade de São Paulo.

Essa lacuna na historiografia da arquitetura pode ser pensada em termos sociológicos. A despeito da condição sine qua non do encomendante para a efetivação de um projeto de arquitetura, a notabilidade artística concedida ao arquiteto e às suas invenções tirou de cena os destinatários da obra. Apenas mencionada no título da casa, a presença desencarnada da figura do cliente possivelmente resguarda a condição de heteronomia da arquitetura moderna. Produção que se quer insubmissa às vontades e aos desejos de um encomendante, a arquitetura de autor aparece, na narrativa historiográfica, como invenção singular de um criador, sem espaço para os condicionantes sociais da encomenda. Quando se oculta a localização social do cliente, apagam-se as amarras que unem o arquiteto a esse mundo social, a ponto de se prescindir das famílias que deram forma ao mecenato. Mais do que isso: a denegação do social - o velamento das propriedades, atributos, laços, cumplicidades entre arquiteto e cliente - reitera uma suposta universalização do consumo desses objetos. O que se vê é uma exposição que, ao apresentar o destinatário como um ser social abstraído das suas condições de existência, acaba por ratificar que a arquitetura moderna estaria disponível ao alcance de todos e que o gosto pela estética de vanguarda é universal e não distintivo.

Com isso, cumpre sinalizar o pressuposto que fundamenta esta pesquisa, segundo o qual a produção do valor artístico de uma obra de arquitetura não se reduz à fabricação material do edifício, ou seja, ao objeto em si, isolado de uma teia de relações sociais. Esta investigação se apoia em uma contribuição decisiva ao entendimento da dimensão social da arte, tal como formulada por Pierre Bourdieu - mas não se restringindo a ele $^{23}$,

23 O trabalho de Enrico Castelnuovo nos ajuda a pensar as balizas de uma história social da arte 
que inseriu os bens culturais em um espaço social marcado por relações de concorrência em que atuam instituições e indivíduos. De acordo com o sociólogo, para apreender a lógica de funcionamento das obras de arte é preciso considerar o amplo trabalho de produção simbólica em torno do produtor e do produto. Com isso, é preciso assinalar que os fenômenos artísticos e culturais, entendidos como produções simbólicas, não ocorrem de modo autônomo, isolado do mundo social. Nesses artefatos estão sedimentados processos sociais concretos, sem os quais se perde a materialidade da experiência social. Livre de uma associação unidirecional de causa/efeito, os artefatos modernos devem ser vistos tanto no atendimento ao gosto de um público como também contribuindo para produzir o gosto e o público. Abarcá-los em sua materialidade exige circunscrever essa produção nas negociações entre o produtor e o consumidor no campo artístico e cultural, espaço que delimita e tonifica as tomadas de posição dos agentes.

Destacados pela ideia de singularidade do autor, os arquitetos foram glorificados como artistas, pela liberdade formal que aplicaram às suas criações. As residências foram alçadas à condição de obras de arte, sacralizadas em seus espaços, cultuadas em sua originalidade. Essas abordagens canonizaram nomes e obras em tradições estéticas que foram validadas a partir do ponto de vista formado no interior do domínio da arquitetura, desviando-se dos compromissos de reconstituir a origem dos sistemas de hierarquização e classificação da produção arquitetônica. Sem situar as raízes sociais e as negociações entre arquiteto e cliente, as pesquisas hoje existentes na historiografia retiram o arquiteto de seu mundo social: ele aparece como um "criador incriado" ${ }^{24}$ e as obras como um

atenta à obra, ao artista e ao consumidor. Como nos mostram seus estudos, a figura do encomendante coloca o desafio de entender as "estratégias de imagens" pretendidas, tendo em vista que a emergência de um estilo está associada, em alguma medida, ao atendimento das necessidades práticas e simbólicas de um grupo social. Cf. CASTELNUOVO, Enrico. Retrato e Sociedade na Arte Italiana: ensaios de História Social da Arte. São Paulo: Companhia das Letras, 2006. Nessa mesma direção, dois trabalhos de Sergio Miceli exploram as relações de mão dupla entre mecenas e encomendantes: MICELI, Sérgio. Imagens negociadas: retratos da elite brasileira. São Paulo: Companhia das Letras, 1996. MICELI, Sergio. Nacional Estrangeiro: história social e cultural do modernismo artístico em São Paulo. São Paulo: Companhia das Letras, 2003.

24 BOURDIEU, Pierre. As regras da arte. op.cit. e "Mais qui a crée les créateurs" In Questions de sociologie. 
fetiche a ser cultuado, reforçando o universo da crença no dom do artista e no caráter demiúrgico do arquiteto moderno.

Escapar à ideologia carismática da "criação" - crença arraigada no mundo da arte que concede ao artista a responsabilidade total pela criação do valor de sua obra - é um desafio para os sociólogos que pretendem analisar o universo artístico. Dessa illusio, como diria Pierre Bourdieu, participam não apenas os criadores, mas também os comentadores e intérpretes, que atuam como porta-vozes autorizados a produzir um discurso de classificação e validação da obra. Todos esses agentes de diferentes extrações e cacifes contribuíram para a construção das representações em torno da "Escola Paulista", assegurando a estabilização de sentidos e ratificando os princípios doutrinários do grupo. De um ponto de vista externo a essas contendas, a não existência de consenso nas classificações mostra o dinamismo das disputas, que podem ser entendidas como expressivas da busca por legitimidade. Desse modo, se a classificação dos arquitetos em escolas, estilos e influências desafia os agentes do campo e os próprios interessados, é porque ela faz existir grupos, nomear diferenças, etiquetar tradições, designar herdeiros, apontar epígonos efetivando um jogo de disputas pela construção do reconhecimento dos arquitetos e dos críticos oficiais (também participantes do jogo) que se esforçam para estabelecer marcas distintivas.

Valendo-se dos referenciais teóricos brevemente apresentados, é no cruzamento entre produção e consumo que se vislumbrou dar inteligibilidade às experiências sociais em torno da arquitetura moderna, que passam pela formação do campo arquitetônico brasileiro, a emergência do gosto moderno e a constituição de uma fração de classe (com capitais culturais e econômicos), disposta a ratificar sua posição social nessa modalidade de consumo cultural. Sob essa ótica, coube explicitar os condicionantes sociais, expressivos da posição de seus proprietários, que estão na base da constituição de um conjunto de afirmações e recusas em relação à estética moderna.

Entra em cena a formação do gosto moderno, entendido como 
preferências que corresponderam às disposições estéticas produzidas em um contexto de emergência das instituições-chave no campo da cultura e da formação de novos arquitetos, no qual o apreço pela linguagem racionalizada parece funcionar como espécie distinta e distintiva de capital cultural. Isso significa dizer que esse sistema de predileções é resultado de aquisições escolares, de competências artísticas, de aprendizagens estéticas e de redes de relações sociais que unem produtores e consumidores. É na acomodação entre o fornecimento de representações simbólicas dos ofertantes e as reivindicações de distinção dos demandantes que se pretendeu compreender a conformação de uma modernidade limitada.

\section{Materiais e métodos}

Uma nota sobre os diversos materiais utilizados como fonte de pesquisa merece ser elaborada. As análises empíricas se debruçaram sobre diversas fontes primárias. Esses registros foram sistematizados tendo em vista três eixos: (A) Residências e Mobiliários (visita, material fotográfico, projeto arquitetônico, localização geográfica, programa de necessidades, linguagem arquitetônica); (B) Encomendantes (localização social, profissão, círculos de sociabilidade, engajamento político); (C) Arquitetos (origem familiar, formação escolar, trajetória profissional, parcerias, premiações, espaços de consagração).

O conjunto dos dados relativos às residências e mobiliários foram extraídos de diversas fontes, entre elas, as revistas especializadas de arquitetura (Habitat, Acrópole, Módulo) cuja emergência nos anos 1950 também é indicativa da dinamização do debate arquitetônico, em que os arquitetos estão à procura de registrar conteúdos, disseminar suas ideias e marcar suas posições. Não por acaso passa a ser fundamental para a formação do domínio arquitetônico o estabelecimento de um espaço de divulgação e de uma crítica especializada, através dos quais se disputam a definição da arquitetura legítima. Esses materiais divulgavam os novos 
arquitetos e seus projetos, constando memoriais descritivos, o partido arquitetônico adotado e informações gerais acerca das residências (custo, material e técnica empregados, área construída, programa de necessidades, localização urbana, construtora contratada etc). Deve-se enfatizar que nesta pesquisa esse material ganha o estatuto especial de fonte primária uma vez que os conflitos e as tomadas de posições estabelecidas entre os arquitetos se materializaram também nessas edições impressas. Jornais e revistas de circulação ampliada também foram consultados, como Estado de São Paulo, Diário da Manhã, O Cruzeiro, uma vez que também fornecem material iconográfico, como propaganda de mobiliário e de artefatos a serem comercializados em larga escala. O caderno localizado ao final da tese reúne imagens expressivas das apostas estéticas dos arquitetos.

Os dados sobre esses clientes foram coletados em entrevistas com os herdeiros e partir do levantamento das histórias pessoais, por meio de biografias publicadas e artigos em jornais. Essas fontes diversificadas permitiram reconstituir as trajetórias de vida dos clientes e coletar diversas narrativas sobre as residências. Com isso, o objetivo passou a ser a identificação dos padrões de apreciações estéticas, condicionamentos de gostos e redes de sociabilidade, ou seja, as condições sociais que permitem situar modos de existência e condutas de vida. A formulação do roteiro da entrevista (apêndice A) visou abarcar um conjunto de características sociais do encomendante e também de sua família, pois na maioria das vezes a demanda por uma residência coincide com a etapa da vida em que o encomendante estabelece laços conjugais e planeja a chegada de seus descendentes. As questões consideradas importantes para o entendimento das dinâmicas em torno do projeto da casa foram organizadas em blocos de modo a extrair informações sobre a constituição da família, a organização da casa, os gostos e as práticas culturais dos moradores.

Acessar o perfil da clientela a partir de biografias permitiu nuançar os discursos sobre as práticas artísticas no conjunto da trajetória desses indivíduos. Posto que muitos se notabilizaram em alguma área específica, seja intelectual ou artística como universidade, teatro, direito, medicina, fotografia etc, esses livros forneceram dados mais amplos sobre o consumo 
cultural. Além de se constituírem como fonte de informação do encomendante e da família, revelam em sua estrutura discursiva uma narrativa em que a encomenda aparece como marco na vida do biografado. O relato da construção da moradia se constitui, muitas vezes, oscilando entre a apologia do vanguardismo e sua qualidade em apreciar obras modernas, a ousadia de assumi-las enquanto moradia e os infortúnios do dia a dia de se habitar uma casa fora dos padrões convencionais, seja pelo olhar depreciativo dos vizinhos, que não partilham do mesmo projeto, seja pela dificuldade em se adaptar a essa forma de morar.

Foram cinco materiais biográficos utilizados para recompor o imaginário social dos familiares que se dispuseram a construir e a viver nesse experimento de vanguarda. Sobre Alfredo Mesquita (1907-1986) há o livro Um grã-fino na contramão, em que a biógrafa apresenta episódios sobre a construção do edifício Louveira, projeto de Vilanova Artigas de 1945. Sobre Yolanda Penteado (1903-1983) e Ciccilo Matarazzo (18981977), que encomendaram serviços de decoração com Lina Bo Bardi para a residência do casal, me vali da autobiografia Tudo em cor de rosa, material expressivo dos deslocamentos do mecenas no mundo da arte brasileiro e europeu. Ainda que haja o empenho em dignificar as atuações de Juljan Czapski (1925-2010) na área médica, a biografia O cavalheiro da saúde também apresenta relatos sobre a construção da casa no Sumaré, projeto de Vilanova Artigas. No livro, são exaltadas as relações de amizade da família com o arquiteto e a esposa, Virgínia Artigas, que passam pela esfera da política, das artes e da vida privada. Em Companheiros de Viagem, as peripécias da negociação do projeto da residência com Artigas foram registradas por Deocélia Vianna (1914-1987). A casa foi construída no Sumaré para ela, o marido - o diretor e dramaturgo Oduvaldo Vianna (1892-1972) - e o filho, o dramaturgo Vianinha (1936-1974), que na época da construção tinha 13 anos de idade. A amizade com Artigas vinha da militância no Partido Comunista, engajamento modelador das condutas e visões de mundo da família. Heloísa Alves de Lima e Motta (1904-?) narrou a sua vida em Uma menina paulista, biografia que conta o gosto sofisticado herdado da família aristocrática e o desejo de ter uma casa bandeirista de Paulo Mendes da Rocha. 
Sobre esses materiais, que variam entre biografia escrita por jornalistas, familiares ou relatos autobiográficos, o que vale deixar indicado é que apresentam o imaginário de ambições dos encomendantes, as motivações que levaram a empreender esse projeto, as decepções ou os triunfos angariados na convivência social e também observações cotidianas da vivência nesses espaços. De modo geral, as narrativas sobre o projeto da casa podem ser pensadas como a materialização de um caminho de ascensão social, em que a escolha do estilo e do arquiteto expõem cumplicidade de posições éticas e estéticas. As condições sociais do encomendante e a rede de relações da qual ele faz parte ficam explícitas na encomenda da mobília, no projeto paisagístico, nas telas exibidas nas paredes, negociadas com os próprios pintores, nas pessoas ilustres que frequentam a casa, na contratação dos empregados domésticos etc. Já a frustração com o projeto e mudança da casa se expressam como inadaptação ao ambiente moderno, falência financeira ou desagregação da família. Esses relatos biográficos, por encarnarem uma experiência social mais ampla do que apenas a relação objetiva e mecânica da família com a residência, nutriram várias questões que foram incorporadas às entrevistas que realizei com encomendantes e herdeiros. Realizei onze longas entrevistas, a maioria com filhos dos encomendantes, coleta de informações que permitiu especificar a experiência familiar de aquisição de projetos modernos. Os apêndices B e C condensam em quadros o perfil social dos encomendantes de Vilanova Artigas, Paulo Mendes da Rocha e Lina Bo Bardi. 


\title{
CAPÍTULO 01
}

\section{Moderno sob encomenda: produtores e consumidores do mobiliário nos anos 1950}

\begin{abstract}
"Decoração. Com essa palavra maltrata-se uma das mais sérias responsabilidades de hoje: o arranjo interno da casa, a formação do habitat, no verdadeiro sentido da palavra, onde os homens se desenvolvem, onde formam suas mentalidades, [...] Esta palavra desventurada (que logo nós substituímos por "arquitetura interna") apropria-se especialmente às senhoras e cavalheiros distintos, que a ela se dedicam, nos momentos livres, entre um coquetel e um jogo. Os arquitetos modernos, os intransigentes, dizíamos, aqueles que trabalham em silêncio e vêm na nova arquitetura o caminho à decência e à salvação para a humanidade, estes arquitetos pois, deveriam ser retratados como alguns santos antigos de couraça e espada flamejante; a espada para combater a vasta multidão de incompetentes e ignorantes que avança com falsos cristais, falsos ouros, pernas retorcidas de cão ou leão, cortinas de cetim e de tafetá, franjas e adejos, mouros e mourinhos, estuques e estuquesinhos, armas e lustres de verdadeiro ou falso Baccaratt [...].
\end{abstract}

Lina Bo Bardi ${ }^{25}$

\section{Novos produtores em cena}

$\mathrm{Na}$ área do design de mobiliário e da decoração de interiores, a entrada no meio do século $X X$ se apresentou como ruptura em relação ao gosto do passado. Na metrópole que se expandia, urbanizava e verticalizava, construíam-se novos prédios de apartamentos e casas, projetados pelos arquitetos atuantes em São Paulo, principalmente nos espaços apropriados pelas classes de alto poder aquisitivo, como em Higienópolis e nos recém-loteados, pela companhia inglesa City, bairros dos

25 Crônicas de Alencastro, Revista Habitat, no2, 1951. p. 91. 
Jardins. Para o interior dos espaços domésticos, os "intransigentes" arquitetos modernos, como "santos antigos de couraça e espada flamejante", nas expressões de devoção e encorajamento de Lina Bo Bardi, conclamavam as linhas livres de ornamentos. Desejavam produzir um ambiente em diálogo com o estilo arrojado da arquitetura nascente. Novos móveis seriam desenhados para equipar o ambiente residencial: cadeiras, poltronas, sofás, mesas, aparadores, camas, escrivaninhas, estantes para os equipamentos modernos (televisão, rádio), suporte para livros, revisteiros, carrinhos de chá e luminárias. [fig. 05 a 09] Esses móveis teriam suas funções e formas remodeladas pelos designers, servindo ao arranjo das atividades nos diversos cômodos. Na intenção dos arquitetos, sala de estar, sala de jantar, biblioteca, escritório e quartos deveriam despir-se do ar pomposo e da ostentação decorativa da arquitetura eclética, a forma de morar da elite cafeeira e da burguesia nascente.

Período de ebulição cultural e de complexificação do tecido social, a São Paulo de meados do século XX abriu espaço para a atuação de novos produtores motivados a absorver um arrojado repertório estético. Os agentes que entravam em cena tinham tarefa de dupla mão: promover estilo moderno e detratar o gosto hegemônico, principalmente mirando os modelos tradicionais [fig. 29]. O neoclássico, o neobarroco e os estilos Luís $\mathrm{XV}$, cornijas, estuques, matelassés, pompons e franjas foram combatidos pelos novos prescritores do gosto. Essas formas foram acusadas de pesadas, afetadas, superadas, obscuras e passadistas. Formava-se um novo mercado de bens simbólicos em que produtores ofertavam mercadorias modernas a um público em ascensão, muitos descendentes de famílias imigrantes que buscavam legitimidade nos grupos cultivados ${ }^{26}$.

Participantes engajados nas transformações culturais, criadores e consumidores faziam parte de uma geração reunidas em torno das atividades que fervilhavam na metrópole paulistana, prestes a comemorar o

26 Sobre a reestruturação da composição social nos anos 1930-1960, Sergio Miceli mostra que em São Paulo a mobilidade passava pela entrada no sistema de ensino universitário, que absorvia jovens principalmente oriundos de famílias imigrantes, atraídos pela oportunidade de formação cultural e atuar em uma profissão intelectual. Cf. MICELI, Sergio (org). História das ciências sociais no Brasil. São Paulo: Vértice/Idesp/FINEP, 1989. vol 1., notadamente o capítulo "Condicionantes do desenvolvimento das ciências sociais". 
IV Centenário. Tal como sintetiza Maria Arminda do Nascimento Arruda, em Metrópole e Cultura: São Paulo no meio século $X X$, nesse momento a capital paulistana caracterizava-se "pela absorção do progresso, da modernização, da racionalidade, da linguagem especializada". Essas mudanças estavam diretamente ligadas a "uma cultura invadida pelas promessas do presente que moldavam as atitudes de desprendimento do passado" (ARRUDA, 2001, p.424).

Quanto aos estilos de morar e os artefatos de decoração, é a linguagem especializada do design que dará expressão formal ao ambiente modernizador nascente. Atuando em diferentes firmas de desenho de móveis, alguns desses profissionais produziram um mobiliário de linhas inovadoras, livre de enfeites e retorcimentos, cuja "limpeza" e padronização pressuporia a produção em larga escala e a disseminação do produto. No panorama renovador do meio do século $X X$, o desenho industrial emerge como síntese entre arte, técnica e função social. O objetivo seria a democratização de produtos utilitários, esteticamente bem planejados, ampliando o acesso a uma linguagem racionalizada.

Os arquitetos ingressantes, desejosos de fixar uma nova ortodoxia estética, assumiram em seus projetos o trabalho pedagógico de formação do gosto moderno. Convicta de sua missão de "salvação da humanidade", Lina Bo Bardi, arquiteta italiana recém-estabelecida em São Paulo, e com grande acesso aos grupos de elite, declara seu programa modernizador orientado para formar a nova geração de consumidores da arquitetura moderna:

"Queremos ser claros: respeitamos profundamente as coisas antigas, as verdadeiras (...). Mas profanar uma época com cacarecos de estuque e papelão, é desconhecer o progresso trabalhoso, dolorido da humanidade (...). O Brasil há uma matéria-prima, o público, de primeira ordem, ainda não estragada; é dever dos arquitetos competentes defendê-la, combater o diletantismo, formando no público uma convicção firme para poder selecionar."27

27 Crônicas de Alencastro, Revista Habitat, ํํ2, 1951. p. 91. 
As práticas de decoração que até então serviam aos gostos dos grupos dominantes seriam tachadas de regressivas e decadentes. Desaprovados por serem clássicos, convencionais, conservadores, academicistas ou antimodernistas, os juízos eram direcionados tanto às frações de uma oligarquia rural quanto as de uma burguesia abastada, que desde o início do século XX havia manifestado seu desinteresse pelos movimentos de vanguarda ${ }^{28}$. Essa postura de depreciação e difamação impunha-se como estratégia dos ingressantes, interessados em destronar a legitimidade daqueles que controlavam as definições de "bom gosto".

O refinamento das formas livres, leves e despretensiosas seria, então, defendido como baluarte da modernização, do louvor ao novo e da adesão ao progresso. É possível notar entre os recém-chegados - novos produtores das feições modernizantes e novos públicos de consumidores uma conexão em suas proposições e escolhas. A proximidade social entre aqueles que se ocupam da oferta e os que encarnam a demanda são reveladoras das segmentações e afinidades quanto aos padrões de gosto.

\section{Promessas de democratização e marcadores de distinção}

Comprometidos com o espírito progressista daquele tempo e dispostos a defender a nova profissão em vias de institucionalização ${ }^{29}$, os arquitetos e designers despontariam na cena cultural sobrecarregados de intenções: a arquitetura e o desenho industrial moderno passam a ser apreendidos na união entre beleza e função. $O$ arranjo entre utilidade, qualidade estética e produção serializada assentava-se na preocupação

28 Sobre colecionismo e mecenato artístico das elites dirigentes em São Paulo no início do século XX, cf. MICELI, 2003.

29 Em 1947, foi criado o curso de arquitetura do Mackenzie College e, no ano seguinte, o curso da Universidade de São Paulo, ambos dissociados da formação politécnica a que até então estavam vinculados. Tanto na formação escolar e na prática profissional quanto na organização da profissão de arquiteto, o período entre o final dos anos 1940 e o início dos anos 1950 pode ser localizado como um momento decisivo de institucionalização da profissão. 
mais ampla de produzir objetos a públicos variados, realizando as promessas sociais da modernidade ${ }^{30}$.

Esses artefatos de decoração devem ser vistos tanto no atendimento ao gosto de um público como também contribuindo para produzir prescrições de gosto. Com isso, a imposição de uma linguagem de feições modernas firma-se como luta também travada na escolha de uma forma legítima de viver, de um modo de existência social revestido por uma estética vivida como fruição desinteressada. Não se trata, portanto, apenas da indicação de novas diretrizes formais para os espaços residenciais. Nas escolhas pelo mobiliário moderno, a estilização dos ambientes de moradia, criados com primazia da forma sobre a função, pressupõe uma capacidade de aplicar os valores da estética pura e despojada aos domínios mais comuns da existência cotidiana, por exemplo, a habitação, que é um dos espaços mais modelares de expressão das heranças culturais e das visões de mundo do indivíduo e sua família. Como expressão dos grupos culturalmente dominantes, que podem se situar distantes das urgências e necessidades imediatas, a apropriação simbólica diferenciada de uma estética livre de adornos, requintada e depurada corresponde às disposições dos eruditos e dos cultivados, frações sociais que tem a possibilidade de estabelecer uma relação estilizada, contemplativa e desinteressada com o mundo da arte e o mundo da vida (BOURDIEU, 2007).

É nesse contexto de renovação do tecido social, em grande parte marcado pela chegada de levas de imigrantes europeus, que emergirá uma clientela propensa a empregar seus recursos econômicos para certificar uma posição cultural arrojada, um grupo social bem-dotado de capitais culturais e competências artísticas para se valer das vanguardas estéticas, transformando seus gostos em estilos de vida, materializando seu habitus moderno em habitações modeladas nas linguagens formais de seu tempo.

30 Sobre os impasses da modernização brasileira, este capítulo o retoma uma parte da pesquisa que foi publicada em. Cf. ROSATTI, Camila Gui. "Lina, Ruchti e Zanine: três modernos na encruzilhada dos anos 1950". In: CALHEIROS, Alex. MARI, Marcelo, RUFINONI, Priscila R. Mobiliário Moderno: das pequenas fábricas ao projeto da UnB. Brasília, Editora da Universidade de Brasília, 2014. 


\section{Expectativas em curso}

Em agosto de 1948, os arquitetos Lina Bo Bardi e Jacob Ruchti seriam interpelados pelo Diário de São Paulo, publicação do grupo dos Diários Associados, a fim de responder a uma pergunta sobre decoração de interiores. Os jornalistas estavam interessados em abrir um debate para a questão, não fortuitamente, assim colocada: "Que influência exerce na dona de casa a decoração do lar?"31. Assumindo toada panfletária, os escolhidos para compor a matéria deram respostas nas quais vinculam modernidade estética a avanços sociais, ao estabelecer relações entre a adoção de linguagem livre de ornamentos e modernização das relações entre os indivíduos. Enquanto Ruchti destacou a interação entre mobiliário e arquitetura para compor um ambiente moderno integrado, Lina Bo Bardi, ecoando sua presença singular em uma profissão marcadamente masculina, criava expectativas em relação às mudanças da condição feminina. Os dois arquitetos estrangeiros pretendiam sintonizar o ambiente local com os temas debatidos nos países europeus. Era final dos anos 1940 e a pauta sobre a liberação da mulher das tarefas domésticas e sua presença no espaço público começa a ganhar atenção no meio brasileiro ${ }^{32}$.

Se até então, entre o final do século $\mathrm{XIX}$ e início do século $X X$, as moradias tradicionais das classes médias e altas codificariam marcações de gênero nos padrões de distribuição dos espaços e nas orientações de decoração, exercendo imposições rígidas de divisão entre espaços masculinos e femininos ${ }^{33}$, a euforia dos modernos prometia uma nova forma

31 Diário de São Paulo, 22 de agosto de 1948.

32 Silvana Rubino assinala que, já antes de vir para o Brasil, Lina Bo Bardi havia também se dedicado a pensar a organização da casa moderna a partir das distinções de gênero. Em artigos publicados no periódico A - Cultura della Vitta, por ela editado juntamente com Bruno Zevi, defendia que a liberdade da mulher no século XX poderia ser resolvida equipando a casa com as novidades tecnológicas surgidas com a industrialização, aparelhos que a arquiteta implementou em sua moradia construída em 1951 no Morumbi, a Casa de Vidro. (RUBINO, 2002, 2009)

33 Ao analisar os repertórios femininos mobilizados no espaço doméstico no início do século XX, Vânia Carneiro de Carvalho observa que, nos manuais de conduta, revistas, catálogos e materiais literários, os espaços e objetos da casa são tratados em simbiose com o corpo da mulher. A autora mostra uma aproximação entre os papéis e posturas a serem desempenhadas pelas mulheres - relacionados à organização das atividades domésticas, manutenção da vida familiar, preparação de refeições, incorporação de códigos de etiqueta para servir à mesa e 
de morar cujos valores e funções não estariam associados a essas hierarquizações. O espaço privado da casa, locus da manutenção dos papéis da mulher como esposa, mãe e dona de casa, era posto em questão, vislumbrando a possibilidade de se abrir como um lugar de transformação dos estatutos de gênero, motivada por mudanças técnicas e sociais como uso da eletricidade, disseminação de eletrodomésticos e ingresso feminino no mercado de trabalho.

O tom discursivo dos arquitetos registra as expectativas que a modernização de formas, materiais, desenhos e processos produtivos poderia trazer ao desencadeamento de novas relações sociais. Também flagra o fervor na promoção da cultura moderna que irrompia naquele momento e que iria se fortalecer a partir dos anos $1950^{34}$. Extrapolando a questão de gênero, na visão desses profissionais da área, as novas tendências de mobiliário, a decoração funcional dos ambientes e o arranjo adequado dos espaços da casa possibilitariam instituir novas maneiras de morar e novos modos de se comportar, oferecendo ampla satisfação às necessidades dos moradores.

Essas pequenas transformações na ambientação do cotidiano, prontas para ordenar esteticamente a vida prática, vinham vinculadas com a recusa dos paradigmas antigos de moradia, celebradas pela aposta decisiva no progresso. Tanto os jornais e revistas de divulgação ampliada, quanto os impressos destinados a um público restrito - como a revista Habitat, publicação realizada sob auspícios do Masp, dedicada a artes, cultura, arquitetura e interiores - , esmeram-se em difundir práticas atualizadas à

receber visitas, preparação do corpo e adequação às vestimentas - em concomitância com a elaboração dos modelos da residência burguesa difundidos pelos arquitetos do ecletismo. CARVALHO, Vânia Carneiro de. Gênero e Artefato: o sistema doméstico da perspectiva da cultura material - São Paulo, 1870-1920. São Paulo: EDUSP/FAPESP, 2008.

34 Em que pese o lugar de "pioneiro" em que foi, pela historiografia da arquitetura, entronado Gregori Warchavchik, sinaliza-se que as inovações arrojadas propostas pelo arquiteto ucraniano emigrado para o Brasil em 1923 não consolidaram na São Paulo dos anos 1920 e 1930 uma continuidade de práticas modernas em relação à estética dos edifícios. Foi só no final dos anos 1940, com as escolas de arquitetura separadas da engenharia e regulamentação da atividade profissional do arquiteto, que se adensou a produção arquitetônica marcadamente moderna, dinamismo propiciado também pela reconfiguração social dos grupos dirigentes, não mais extraídos somente dos setores oligárquicos (ainda que ligado a eles), mas também tributário da ascensão de novas classes médias intelectualizadas, alicerçadas pela aposta prioritária na cultura. 
modernização. No começo dos anos 1950, a publicidade anunciada em revistas de grande circulação, como O Cruzeiro e A Cigarra, reforçam a praticidade do dia a dia com liquidificadores, enceradeiras, panelas de pressão, ferros de passar roupa, sardinhas e feijoada em lata e também móveis modernos, prontos a oferecer funcionalidade à vida da mulher e ao ambiente doméstico. Nesse sentido, as propagandas podem ser vistas como expressão de mudanças nas práticas culturais, e ainda que não incorporadas pela maioria da população, são registros do imaginário coletivo formado com a disseminação de "dispositivos modernizadores"35.

No que concerne ao métier dos arquitetos, a se notabilizar pelo pequeno depoimento do jornal, as casas modernas são propagandeadas como a face privada de um programa civilizatório. As moradias livres de ornamentos e austeramente decoradas são defendidas como um modelo capaz de instituir um novo homem e uma nova mulher. As metáforas acionadas, no jogo de oposição entre o antigo e o moderno, pretendem dar ao "novo" um sentido de processo evolutivo espiritual e moral. É com essa carga simbólica que Lina Bo Bardi expõe suas ideias ao jornal:

"A casa, para a mulher, foi sempre uma prisão. A mulher necessita porém de participar da vida social, contribuindo para o progresso da comunidade em que vive. Eis porque, nos tempos modernos, tudo se tem feito para libertá-la da opressão puramente doméstica. Nesse sentido, uma casa deve ser como uma alma aberta às coisas da vida e não uma casa-caverna, uma furna de onça. Uma decoração interna, pesada e cheia de enfeites, além de ser uma extravagância, exerce influência esmagadora na dona de casa. É como se alguém, hoje em dia, fosse para o trabalho utilizando-se de uma carruagem. Acrescenta-se ainda que, uma criança, vivendo em um ambiente de veludo e cetim, pode crescer enfermiço. A decoração simples dá liberdade e independência à mulher. Além de facilitar a limpeza do lar, sugere tranquilidade. Mais do que tudo, a casa deve ser uma entidade espiritual

35 A expressão é de Beatriz Sarlo, referindo-se à ampliação das mídias impressas na Buenos Aires dos anos 1920. Guardadas especificidades dos distintos contextos sócio-históricos, a disseminação desses dispositivos também pode ser verificada nos meios de comunicação da São Paulo dos anos 1950. SARLO, Beatriz. Modernidade Periférica. Buenos Aires 1920 e 1930. São Paulo: Cosac Naify, 2010. p.45 
e moral, sem oferecer a aparência cenográfica teatral" ${ }^{\prime 36}$.

Já Jacob Ruchti manifesta-se em defesa da profissão de decorador. Para evitar que essa especialidade fosse tomada apenas como maquiagem do ambiente, o recurso utilizado é renomear a profissão para "design de interiores", evitando assim que fosse vista como uma atividade supérflua, ou fútil, previamente associada a atividades de "madames". Para defender seu quinhão, declara de antemão o vínculo entre decoração dos espaços e o projeto moderno de arquitetura. Tal como a colega, sobrevaloriza a influência do ambiente físico no comportamento das pessoas e na elevação do nível cultural dos moradores, sem, no entanto, entrever o contrário, ou seja, que seria o espírito esclarecido e cultivado um antecedente necessário para a formação de disposições estéticas para apreciar as linhas leves e ousadas da arquitetura moderna:

"A decoração interna de um lar na concepção moderna está essencialmente ligada à arquitetura. É mesmo uma resultante desta. Estabelecido esse princípio, penso que uma das funções da decoração é de proporcionar ambientes leves e intimamente ligados à natureza, a fim de estimular a imaginação e ter, como resultado, a elevação do nível cultural dos habitantes da casa. Como a mulher vive a maior parte do tempo no lar, ela é mais influenciada do que o homem. Uma decoração que obedece ao princípio das linhas simples e livres, exerce influência benéfica na dona de casa, o que se transmite aos demais moradores. A arquitetura tradicional, pesada - e o mesmo pode ser dito da decoração interna - prende, confunde e oprime o espírito das pessoas. É claro que sou favorável à arquitetura moderna, que permite à decoração interna uma situação mais relacionada à época que vivemos. $E$, frisando, linhas leves e livres, na decoração interna de um lar, dão à dona de casa mais espírito de iniciativa" ${ }^{37}$.

A bandeira empunhada pelos arquitetos modernos buscava instaurar

36 Diário de São Paulo, agosto, 1948.

37 Idem. 
relações entre a organização dos espaços internos das residências e o desenvolvimento moral de seus proprietários, impregnando-a com expectativas de mudanças sociais. Dissolver as coerções do espaço doméstico, transformar os costumes e instaurar novas relações entre as pessoas: o rol de promessas envolvia orientações de gosto, sistemas de valores e estilos de vida. Colocavam-se, assim, contra a profusão de ornamentos da arquitetura corrente, identificada com mobiliário pesado ou linhas afetadas, formas que, em um passado não tão distante, ganharam espaço no interior dos palacetes aristocráticos paulistanos ${ }^{38}$. À robustez era imputada a conformação de um ambiente opressor, que aprisiona e tolhe o espírito. Por outro lado, a defesa do estilo moderno vinculava o lar a um ideal de eficiência ${ }^{39}$, valor moral em que as linhas leves, esguias e sinuosas do mobiliário são associadas a liberdade e autonomia, a ponto de conferir "à dona de casa mais espírito de iniciativa".

A aproximação entre modernização da arquitetura, atualização da decoração dos espaços privados das residências e mudanças nas relações sociais davam a tônica das expectativas de um período que se declarava ávido por rupturas. Mais do que expressão ou imagem da personalidade e do caráter de seus moradores, a casa é pleiteada a partir de uma função modeladora de novos indivíduos, pretensão que aproxima os interesses de inovação dos proponentes dessa estética aos grupos sociais cujas casas se destinavam, também investidos do desejo de romper com os moldes estabelecidos. De onde se vê que, embora a prescrição procurasse receitar novos padrões de moradia para a ampla sociedade, o alvo é delimitado. 0 sujeito moderno que se avista nas entrelinhas é ali entendido como um ser abstrato e desreferenciado das suas aquisições culturais e condições de classe. Desistir dos móveis com patas de leão, abrir mão dos estuques falsos e das cornijas, abdicar dos frontões e colunatas da arquitetura grego-

38 HOMEM, Maria Cecília Naclério. O palacete paulistano e outras formas urbanas de morar da elite cafeeira: 1867-1918. São Paulo: Editora Martins Fontes, 2010.

39 Adrian Forty reconstrói algumas balizas das ideias sobre o que constituía um lar no período vitoriano e na modernização do XX, apontando que "a visão do século XIX de que o lar era um baluarte da beleza e da virtude espiritual foi substituída pela ideia de que a principal função da casa era ser uma fonte de bem-estar físico e de saúde", onde se nota que a postura de Lina Bo Bardi e Jacob Ruchti acrescentam um conteúdo de politização aos sentidos da casa. FORTY, Adrian. Objeto de desejo - design e sociedade desde 1750. São Paulo: Cosac Naify, 2007. p. 156 
latina ou dos telhados de mansarda: era essa a proposta que a linguagem moderna traria às famílias que haviam amealhado algum capital nas décadas de crescimento econômico da cidade, também desejosas de se mostrarem conectadas às novidades artísticas.

Plasmando as diretivas do movimento moderno internacional, que fixava a casa como uma máquina de morar, imbricando beleza a eficiência, o tom entusiástico dos depoimentos desses arquitetos revela também que promessas quanto às transformações culturais que rondavam São Paulo no alvorecer dos anos 1950 estavam em jogo. Os dois arquitetos almejavam marcar sua posição como modernos e dar legitimidade a essa arquitetura nascente, manifestando uma postura em oposição à arquitetura tradicional. Para ganhar simpatizantes, o discurso não se restringia ao embelezamento estético. Ocupantes de posições dominadas, dada a recente entrada no meio profissional, as críticas desses arquitetos podem ser vistas como uma tentativa de emplacar um lugar de vanguarda, ação articulada a um trabalho pedagógico de formação do gosto dos grupos sociais que tomavam a cena cultural nos anos 1950 .

Aspirantes à posição cultural dominante, a luta se fazia em duas frentes: detratar o gosto hegemônico, que associavam tanto à aristocracia decadente quanto à burguesia endinheirada e atuar didaticamente na formação do gosto moderno junto aos grupos que concentravam capital cultural. Para tanto, seria preciso constituir uma clientela apta a consumir essa estética, propensa a se apropriar simbólica e materialmente desses objetos, ou seja, com competência artística para valorizar as heresias vanguardistas de modo a transfigurar seu habitus moderno em habitat ${ }^{40}$. Estrangeiros que se fixaram no país pelo flanco da cultura, Lina Bo Bardi e Jacob Ruchti encontrarão nos círculos de imigrantes de boa estirpe, muitos deles judeus e italianos que se deslocaram por conta da Segunda Guerra Mundial, e nas frações ilustradas da elite local um mercado consumidor para seus produtos com apelo cosmopolita.

Esses circuitos culturais eram alimentados por várias iniciativas. A

40 Faço referência aos trabalhos de Pierre Bourdieu $(1983,1996,2003,2006)$. 
São Paulo dos anos 1950, no carrefour das transformações políticas e econômicas do país, estava em um momento decisivo de adensamento das instituições modernas direcionadas a encorporar a cena cultural e artística da cidade, nas artes plásticas, teatro e cinema. Patrocinadas por empresários culturais, essas ações de institucionalização se mostraram delineadoras da experiência social e artística que se fomentou na metrópole paulista, na qual emergiram grandes "homens da cultura", como Francisco "Ciccilo" Matarazzo (MAM e Bienais) e Assis Chateubriand (Masp e meios de comunicação), dando concretude à demanda de acolher e salvaguardar as obras modernas (ARRUDA, 2001).

A dinâmica das atividades culturais nessa cidade, onde passaram a se constituir as principais instituições artísticas e os espaços expositivos do Museu de Arte de São Paulo (1947), do Museu de Arte Moderna (1948) e das primeiras Bienais de Arte de São Paulo (1951), está em convergência com a formação de um público apreciador das artes visuais e das linguagens modernas. As ações culturais se adensavam com a dedicação de outros entusiastas, também provenientes de famílias bem estabelecidas, que passaram a investir na dramaturgia e no cinema. No teatro, Alfredo Mesquita empenhou-se na fundação da Escola de Arte Dramática (EAD), em 1948. Dois anos depois, vem a inauguração do novo edifício-sede do Teatro Cultura Artística. No cinema, a parceria dos industriais Franco Zampari e Francisco Matarazzo Sobrinho resultou na criação da Companhia de Cinema Vera Cruz (1949).

Todas essas ações culturais seriam estribadas por um mecenato proveniente das novas camadas em ascensão, empenhado em aplicar no fomento cultural o acúmulo material originado de setores industriais e das organizações de imprensa, do jornal Estado de São Paulo, dos Mesquitas, família que também havia aberto como frente de investimento simbólico o empenho na fundação da Universidade de São Paulo e dos Diários Associados, propriedade de Assis Chateubriand ${ }^{41}$.

41 Diferentemente do Rio de Janeiro, que se apoiava no mecenato estatal, as duas grandes figuras de destaque de São Paulo são do mecenato privado, que disputavam os investimentos nos meios intelectuais, nas artes e na cultura. ARRUDA, Maria Arminda do Nascimento. Metrópole e Cultura: São Paulo no meio do século. Bauru, SP: EDUSC, 2001. Sobre a concertação em torno da Universidade de São Paulo, ver CARDOSO, Irene. A universidade da comunhão paulista. São 
Cumpre destacar o papel amplificador dessas iniciativas, que mobilizavam convites a estrangeiros. Um deles é a vinda de Pietro Maria Bardi ao Brasil, em 1947, convidado por Chateubriand para ser formulador intelectual do acervo do Museu de Arte de São Paulo. Galerista e jornalista na Itália saída da Segunda Guerra, Bardi havia recém casado com Lina Bo e ambos estavam à espreita de novas oportunidades de atuação profissional $^{42}$. Ainda que ela tivesse atuado como editora em revistas de arquitetura, o casamento e a vinda ao Brasil representaram à arquiteta o início de suas experiências na área de projeto, muito em razão da condição de esposa, título que Ihe facultava acesso privilegiado às atividades do Masp (RUBINO, 2009). Logo que chegou, ela seria encarregada da adaptação do espaço expositivo da nova instituição, a princípio localizada em dois andares do prédio dos Diários Associados; e, anos depois, a sede definitiva do museu, na avenida Paulista. Nesses primeiros anos, ampliou sua participação nas atividades do museu oferecendo-se para projetar as novas cadeiras do auditório do museu e também assumindo a direção da revista Habitat, logo em 1950. [fig. 04]

A Habitat seria uma dessas iniciativas de produção editorial do Masp como estratégia de divulgação do repertório moderno com a difusão de uma publicação que se apresentava com o slogan "A Revista das Artes no Brasil". Desde sua criação, Lina Bo Bardi contribuiria na exposição da agenda artística de vanguarda antenada em temas nacionais e cosmopolitas. Ali, a arquiteta italiana, então recentemente radicada no Brasil, retomava sua empreitada no domínio da produção editorial. No plano institucional, a revista se oferecia como espaço de divulgação das atividades do museu, coadunando-se ao conjunto de valores artísticos que o espaço colocava em tela. No plano pessoal, o empreendimento se abria como oportunidade para a estrangeira recém-chegada vincular-se aos grupos culturais em formação

Paulo, Cortez, 1982.

42 Lina Bo Bardi assim narrou de forma mítica o interesse pelo Brasil, tentando imprimir retrospectivamente um tom de acaso: "Nós nunca fomos emigrantes, chegamos ao Brasil por acaso, em fim de 1946, logo depois da Segunda Guerra Mundial numa viagem de nupcias e ficamos aqui, eu, por causa da arquitetura moderna: Lúcio e Oscar [...] Pietro por causa de um alguém genial (nome Assis Chateubriand) que o convidou para arrumar o maior museu da América Latina." Caderno de notas, com datas de 19 de outubro de 1988. Acervo pessoal da arquiteta pertencente ao Instituto Lina Bo Bardi. 
na cidade, fazendo coro com as vozes de modernização artística que dariam a tônica dos anos 1950.

$\mathrm{Na}$ atmosfera moderna de síntese das artes, a proposta da revista era integrar os vários domínios estéticos, seja erudito, industrial ou popular, divulgando matérias sobre artes plásticas, música, fotografia, cerâmica, tecelagem, dança, arquitetura, design gráfico, decoração, mobiliário etc. 0 nome da revista abonava a proposta, não sem colocar uma sobrecarga aos modos de ser e modos de morar modernos. Logo no prefácio da primeira edição, Lina Bo Bardi esmera-se em justificar o título:

'Habitat' significa ambiente, dignidade, conveniência, moralidade de vida, e portanto espiritualidade e cultura: é por isso que escolhemos para título dessa nossa revista uma palavra intimamente ligada à arquitetura, à qual damos um valor e uma interpretação não apenas artística, mas uma função artisticamente social ${ }^{43}$.

Se cada uma área das artísticas, culturais e intelectuais declaravam inovações nos temas, formas e conteúdos, instaurando diversos matizes da linguagem moderna, não poderiam ficar de fora a arquitetura, o desenho de mobiliário e o design de interiores. Ao se justificarem como artes aplicadas, chamavam para si a missão revolucionária de superposição entre forma e função, belo e útil, desenho e desígnio, articulando ideais de preenchimento dos espaços comuns da vida com arte.

Nas mãos de Pietro Maria Bardi e Lina Bo Bardi, o Masp teve a iniciativa de fundar o Instituto de Arte Contemporânea - IAC (1951), reconhecido como o primeiro curso no país voltado para o desenho industrial, com inspiração na escola de design alemã Bauhaus. O recrutamento de jovens de várias regiões do país, - homens e mulheres sobretudo aqueles afinados com percepções estéticas, vinha com o objetivo de formar profissionais para resolver problemas técnico-artísticos da vida moderna. Defendiam que a importância e legitimidade dessa área seria

43 Habitat, outubro-dezembro de 1950. 
conectar arte e indústria. Na edição de 1951 da revista Habitat, celebrando $^{44}$ a abertura da primeira turma do IAC, Jacob Ruchti, também convidado para ser professor do curso, assim define o papel e a missão civilizatória desse profissional:

"O desenhista industrial é responsável pelo projeto de todos os objetos - utensílios, móveis, etc, que nos cercam - que são produzidos industrialmente e que formam o ambiente em que vivemos diariamente, seja em casa, na rua ou no local de trabalho. Não é portanto um exagero afirmar que o desenhista industrial é uma das personalidades mais importantes da vida moderna (...) O desenhista industrial é o artesão do século XX. Porém, enquanto o artesão do passado trabalhava com as mãos, e com ferramentas manuais, produzindo ele próprio o objeto que imaginava - 0 artesão do século $X X$ tem por ferramentas as máquinas da indústria moderna, baseado nas possibilidades técnicas das quais precisa imaginar seus produtos". ${ }^{45}$

A difusão e aceitação do movimento estético para além de uma vaga modernizante são inseparáveis das condições de emergência de um campo cultural nos anos 1950, impulso incentivado pela intensificação das dinâmicas sociais, em que se misturam imigrantes imbuídos de referências europeias, novas camadas ascendentes do setor industrial e profissionais liberais, compondo um público cultivado destinatário da nova estética. A emergência de instituições de ensino e fomento da arquitetura e design modernos, a constituição de um mercado de profissionais especializados e gabaritados para exercer a atividade, bem como o espraiamento das novas tendências em mídias de difusão ampla ou especializada, configuram instâncias de produção e circulação de formas e ideais, valores éticos e

44 Como era de se esperar em um material que também encarna o papel de promotor das próprias iniciativas, a apresentação do curso vem carregada de apologias e bairrismo, "mais uma iniciativa de gente paulista que está sendo realizada pela primeira vez no Brasil". Assim como de acesso e conversão de possíveis parcerias e patrocinadores, direcionadas a sensibilizar o empresariado industrial paulista: "numa cidade de enorme desenvolvimento industrial como São Paulo, onde milhares e milhares de produtos são manufaturados diariamente, e onde a profissão difundida, sendo exercida principalmente por amadores e autodidatas - uma escola como o Instituo de Arte Contemporânea representava uma necessidade premente". Habitat $\mathrm{n}^{\mathrm{0}}$ 3, de abril/junho de 1951, p. 62.

45 Idem. 
estéticos, sem as quais a linguagem moderna não lograria operar e impor suas visões de mundo.

No alastramento dessas tendências, os espaços domésticos se apresentariam como o local em que seus moradores se mostrariam predispostos a comunicar o engajamento na linguagem artística da época, certificando sua participação na modernidade. O surgimento de diversas firmas de móveis modernos no início dos anos 1950, entre elas Studio Palma, Branco\&Preto e Móveis $Z$, vincula-se ao fomento da nova linguagem, abrindo novas possibilidades de ambientar as residências e organizar a vida doméstica de acordo com os gostos e investimentos de seus moradores.

\section{Arquitetos, firmas e clientes: produção e consumo do mobiliário moderno}

O começo dos anos 1950 viu despontar a constituição de estúdios e empresas voltadas para o provimento de equipamentos modernos direcionados a suprir uma lacuna no mercado moveleiro. Criadas no início dos anos 1950, as três principais firmas desse período são aqui examinadas na sua formação, oferta de produtos e público consumidor. A arquiteta italiana Lina Bo Bardi (1914-1992) esteve à frente da criação do Studio Palma, o arquiteto suiço Jacob Ruchti (1917-1974), junto a colegas do Mackenzie, fez parte da formação da Branco\&Preto e o autodidata baiano Zanine Caldas (1919-2001) foi o responsável pelo design dos produtos da Móveis Artísticos $Z^{46}$.

Consagrados como os principais arquitetos propulsores da linguagem moderna em São Paulo, as trajetórias dos três são representativas do empenho modernizador que a capital paulista congregou e do espaço heterogêneo que abriu para novas carreiras. O percurso profissional dos

46 Os dados biográficos e as informações sobre as firmas de design foram coletadas a partir dos trabalhos de historiografia da arquitetura, entre os quais a principal referência para uma história geral do móvel moderno brasileiro é SANTOS $(1989,1995,1993)$. Sobre Zanine Caldas e a Móveis Artísticos Z, cf. MELO (2001). Sobre Jacob Ruchti e a Branco\&Preto, cf. ACAYABA (1994) e RUCHTI (2011). Sobre Lina Bo Bardi: RUBINO $(2002,2010)$. 
dois estrangeiros - Jacob Ruchti veio com a família aos dois anos de idade e Lina Bo Bardi mudou para o Brasil acompanhando o marido Pietro Bardi aponta elementos da experiência social de famílias imigrantes na cidade, ambas escapando das constrições que as duas Grandes Guerras impunham à vida na Europa. No entanto, eles não entraram no país na condição de imigrantes destituídos de capital cultural e escolar. Pertencentes a círculos de elite, puderam desempenhar funções de produtores de gosto. A possibilidade de enraizamento nas atividades culturais da cidade os motivou a participar de diversas instâncias artísticas, entre elas, a criação do Instituto de Arte Contemporânea ${ }^{47}$ e a revista Habitat, ambas ligadas às promoções artísticas do Masp, fundado em 1947. Na condição de promotores culturais, Lina Bo Bardi e Jacob Ruchti foram responsáveis por articular a criação do curso de desenho industrial e lecionar disciplinas, preconizando as intenções de um desenho a serviço das mudanças sociais. Além da aposta em formar novas gerações e institucionalizar a profissão, os arquitetos exerceram a atividade de designers visando estruturar o mercado de móveis modernos.

Por outro lado, o percurso de ascensão de Zanine Caldas dá indícios da configuração do campo da arquitetura do período. Mesmo sem dispor do diploma de arquiteto, iniciou-se como maquetista dos grandes arquitetos modernistas e, com isso, firmou um lugar em contato com a tradição moderna, o que lhe garantiu a possibilidade de se integrar ao movimento estético emergente. No entanto, diferente dos outros dois, que se formaram em escolas de arquitetura, Caldas teve seu aprendizado profissional constituído na prática de fazer maquetes para arquitetos já reconhecidos no campo da arquitetura, como Lúcio Costa e Oscar Niemeyer. A experiência no desenho arquitetônico e recorte de madeiras foi direcionada para a elaboração de peças de mobiliário.

Se Lina Bo Bardi e Jacob Ruchti ficaram presos a seus círculos de encomendas pessoais, produzindo artefatos semiartesanais, a forma de produção adotada por Zanine Caldas, no início de carreira, distinguiu-se dos colegas, por tentar disseminar um produto industrial na lógica do consumo

47 Sobre o papel do IAC na formação do design brasileiro, cf: LEON (2006) e SOUZA (2011). 
de massa. Objetivava alcançar uma produção racionalizada e em larga escala, com a distribuição de produtos em grandes magazines espalhados por diversas cidades do estado de São Paulo. Seria, no entanto, acusado de diluir o repertório moderno e difundir uma linguagem que se pretendia elevada e vanguardista.

Em diversos planos de abordagem, a comparação entre as três firmas se mostra frutífera para apresentar a constituição da oferta e da demanda de um bem artístico carregado de injunções sociais. Os três arquitetos encamparam suas propostas estéticas de modo autoral, tomaram a frente na produção dos móveis, assumindo-se como empreendedores e arriscando-se nas diversas etapas que envolvem a produção e a circulação desses artefatos: concepção, desenho, fabricação e vendas dos produtos. Tanto a trajetória dos arquitetos, a inserção na área profissional, quanto a forma de produção, distribuição e consumo dos mobiliários expõem algumas linhas para se pensar os impasses do período, tendo em vista a hierarquização dos públicos que acessaram os diferentes tipos de mobiliários nos anos $1950^{48}$.

\section{Lina Bo Bardi e o Studio Palma}

Dois anos após chegar da Itália, Lina Bo Bardi inaugurou em 1948, em parceria com seu marido Pietro Maria Bardi e o arquiteto Giancarlo Palanti (1906-1977), amigo da Itália também imigrante no Brasil, o Studio Palma. Formada na Universidade de Roma em 1939, a arquiteta exerceu o

48 Cabe destacar que, embora nos anos 1950 tenham surgido outras firmas de móveis modernos para residências, nesta pesquisa optou-se por tratar apenas das experiências do Studio Palma, Branco\&Preto e Móveis Artísticos Z. Essa limitação justifica-se em razão da dificuldade de encontrar dados e registros sobre encomendas e consumidores das outras empresas, sem os quais não se consegue mapear de forma sistemática as propriedades sociais do público destinatário. Como informação esparsa, registra-se, por exemplo, fotos internas da casa do crítico de cinema Paulo Emílio Salles Gomes nas quais informa-se que os móveis foram fabricados pela Unilabor, empresa que se diferenciava das demais no método de produção ao instituir um modo cooperativo coordenado por religiosos católicos. 
início de sua carreira profissional em uma Itália convulsionada pela Segunda Guerra Mundial, o que a impeliu a exercer atividades sobretudo na imprensa escrita, editando revistas de arquitetura e design. A vinda para o Brasil e o contato direto com as instituições culturais em desenvolvimento na cidade de São Paulo Ihe possibilitaram atuações em projeto e desenho industrial.

A abertura do Studio Palma é expressiva da vinculação de Lina Bo Bardi ao espaço artístico paulistano. A arquiteta foi chamada para projetar a reforma e os arranjos dos espaços internos do Masp, espaço expositivo então sediado na rua Sete de Abril, instituição na qual o marido foi responsável pela criação e ficou na função de diretor por 45 anos. Lina Bo Bardi desenhou novas cadeiras para o auditório, uma vez que não encontrou poltronas prontas no mercado moveleiro que atendessem às exigências de flexibilidade do local. O pequeno espaço para apresentações e conferências necessitava de cadeiras leves e dobráveis. A arquiteta produziu um modelo em couro e madeira nacional compensada, combinação inédita na época. Os móveis foram produzidos em uma marcenaria de um artesão italiano, o que explicita a presença de mão de obra imigrante especializada no trabalho artesanal ${ }^{49}$. Esse início profissional impulsionou Lina a se estabelecer em uma firma, ampliando o leque de ofertas de produtos. 0 objetivo era oferecer móveis de linhas modernas, desenhados pelos dois arquitetos italianos, e produzidos a partir de um processo manufaturado pela marcenaria Pau Brasil, também de propriedade do trio, local onde os modelos seriam executados em maior escala e com portfólio ampliado de produtos.

Realizados sob a forma de encomendas, os móveis projetados pelo Studio Palma estenderam-se a diversas versões de poltronas e cadeiras, carrinhos de chá, móveis-bar, estantes para livros, móveis para discos, constituindo um mobiliário personalizado, adequado aos espaços de moradia dos clientes. Além de destinados a residências particulares, o Studio Palma forneceu mobiliário e artigos de decoração para diversos espaços artísticos e culturais em constituição na cidade. Os documentos

49 Sobre o mobiliário de Lina Bo Bardi, cf. SANTOS, 1985. 
relativos aos orçamentos elaborados pelos arquitetos do Palma ${ }^{50}$ nos permitem ter acesso aos nomes dos clientes e tipo de produtos especificados, registros altamente significativos do caráter individualizado desses produtos.

Nessas planilhas de encomenda, os móveis estão detalhados em relação ao material (por exemplo, madeira de lei, guaiçara, jacarandá-dabahia, pau-marfim ou madeirite), ao revestimento do estofado (tecido pintado a mão, seda, cetim, couro, plavinil) e ao modelo desejado (poltrona P4, mesa M2 etc). Tais pormenores evidenciam a personalização do pedido. As especificações da encomenda, feita de acordo com as exigências do interessado, mostra o cuidado na escolha dos materiais, entre os quais madeiras nobres e tecidos sofisticados, com padronagens diferenciadas, alguns importados. Também constam os valores de cada produto e as quantidades solicitadas, às vezes corrigidas com um risco, pela mudança de algum detalhe do pedido ou desconto em relação ao valor do produto.

A partir dos orçamentos dos móveis do Studio Palma, entre 1949 e 1950, foi possível localizar parte desse grupo de consumidores, pelo menos aqueles dos quais se guardou a documentação. Nessas planilhas constam o nome dos destinatários do pedido, às vezes apenas indicando o sobrenome, a data, e, em alguns casos, o endereço de residência. Os registros contêm a lista dos móveis solicitados ou, possivelmente, especificados pela arquiteta para compor a decoração dos cômodos da casa. A partir da coleta dos nomes de encomendantes, foram buscadas as localizações sociais dessas pessoas em arquivos de jornais e revistas, principalmente no acervo on-line do estado de São Paulo e da Hemeroteca da Biblioteca Nacional. Com o cruzamento dessas informações, foi possível caracterizar o público e as instituições culturais que se valeram desses móveis para arranjar os interiores de seus edifícios. Vale ainda destacar que o documento registrado como "orçamento" expressa o rol de pessoas e instituições que entraram em contato com o Studio Palma, para os quais Lina Bo Bardi fez a definição e a avaliação do custo dos móveis solicitados, sem a possibilidade de

50 Essa documentação original foi consultada no Instituto Lina Bo Bardi, localizado na Casa de Vidro, instituição que abriga o arquivo documental da arquiteta, e que reúne diversos outros materiais que aqui foram usados como fonte de pesquisa primária. 
confirmar se tais solicitações geraram efetiva realização e compra do mobiliário. Em alguns casos, foi possível confirmar a encomenda por fotografias e reportagens de época, como a cliente Helena Sangirardi, cuja residência foi anunciada em jornal; o cliente Alberto Mortara, cujos netos cederam à pesquisadora imagens do álbum de família e do Teatro Cultura Artística, com foyer mobiliado. No entanto, em termos empíricos, a existência desses orçamentos sinaliza as redes de sociabilidade que unem clientela e arquiteto, bem como as possibilidades imaginadas em torno da constituição de ambientes modernos.

Cumpre salientar que alguns nomes de fregueses, facilmente identificáveis, são figuras conhecidas do ambiente cultural e artístico dos anos 1950: os empresários e incentivadores da arte Alfredo Mesquita, Iolanda Penteado e Francisco Matarazzo Sobrinho, o fotógrafo Thomaz Farkas e o artista plástico Fúlvio Penacchi. Foi possível encontrar alguma informação sobre outros nomes em jornais do período, com notas que indicam profissão, publicação de um livro ou artigo, naturalização da situação de imigrante, aviso de casamento, abertura de empresa, falecimento, ou mesmo, frequentação de eventos mundanos, relatados pelas colunas sociais. O fato desses nomes serem de pessoas conhecidas, com presença na mídia impressa, demonstram que, no pequeno ambiente paulistano dos anos 1950, os encomendantes estão fixados a um grupo com expressão e destaque social, principalmente, no campo cultural.

Além da destinação para uso residencial, aparecem as instituições artísticas que se dinamizavam no início dos anos 1950, cobrindo diversos domínios das artes, cinema, teatro, museu e hotelaria. Os espaços cênicos e de exibição de filmes Cine Art Palácio e Teatro Cultura Artística, ambos projetados pelo arquiteto italiano Rino Levi (1901-1965), pediram orçamentos para mobiliar seu interior. Em 1949, para o Art Palácio, cinema que figurava como um dos primeiros espaços de exibição de filmes na região conhecida como "cinelândia paulistana", novas poltronas em couro e divãs estofados em tecido foram orçados para a sala de espera.

Já para o Teatro Cultura Artística, em agosto de 1949, a pedido do arquiteto, foram solicitados diversos móveis para a nova sede, cuja 
inauguração seria realizada em março de 1950. Os itens elencados referemse a mobiliário para o foyer, com quatro conjuntos compostos por um sofá, duas poltronas cobertas com cetim e mesa baixa; e para o "toilete das senhoras", sofá para quatro pessoas, três poltronas, uma mesinha e três cadeiras em cetim-seda. [fig. 11] A ambientação dos espaços internos com móveis de linhas modernas certificava os ares de modernidade que o teatro fazia valer, materializado tanto pelo próprio projeto arquitetônico inovador de Rino Levi, como também pelo monumental afresco exibido na fachada semicircular do edifício, em homenagem às musas das artes, painel em mosaicos de vidros elaborado por Di Cavalcanti e que reafirmava a proposta de síntese das artes, tão cara ao movimento moderno. [fig. 10]

No fervilhante espírito do IV Centenário, o Hotel Comodoro ${ }^{51}$ viria a preencher uma lacuna no mercado hoteleiro, com disponibilização de 132 apartamentos, fomentado por leis de incentivo da prefeitura, grande interessada em se adequar ao caráter metropolitano que despontava na cidade. [fig. 12] Quanto ao arranjo dos espaços internos, a ambientação proposta por Lina Bo Bardi destinava-se à decoração dos quartos, revestidos com armação de madeira e com móveis que incluíam estante para livros, camiseira e penteadeira com espelho e luz interna, cadeiras e poltronas estofadas, além de tecidos para cortina e para o colchão. Design de interiores e artes criavam um clima estiloso para recepção de políticos, diplomatas, artistas, músicos.

Um dado interessante sobre a construção desse hotel revela o ímpeto de modernização e valorização econômica de São Paulo, com a criação de espaços para hospedar as pessoas em trânsito pela capital. Localizado no centro da cidade, também em proximidade com a cena cultural que ali se concentrava, o edifício foi construído na esquina da avenida Duque de

51 No estado de São Paulo, em 25 de janeiro de 1952, o anúncio de inauguração assim divulga o hotel: "Supremo na arte de hospedar. Agora São Paulo pode orgulhar-se de possuir um hotel igual aos melhores do mundo! Como presente de aniversário à ciclópica cidade de São Paulo, inaugura-se amanhã o magnífico Hotel Comodoro, mais uma iniciativa da firma F. R. de Aquino S.A., no setor de seus empreendimentos imobiliários na Capital. Dotado do que há de mais moderno na indústria hoteleira, e pelo serviço ímpar que oferece, o Hotel Comodoro coloca São Paulo a par com os maiores centros mundiais na difícil arte de bem hospedar. O Hotel Comodoro é, igualmente, o primeiro marco da iniciativa particular, nos preparativos que se projetam para festejar condignamente o $4^{\circ}$ Centenário da fundação da cidade mais dinâmica do mundo". 
Caxias com a rua Conselheiro Nébias, em terreno ${ }^{52}$ onde antes estava situado o célebre palacete da aristocrata Olívia Guedes Penteado. A demolição do antigo casarão para instalação de um grande hotel é simbólica: transformação na paisagem que se afina com a rapidez das mudanças da estrutura social de São Paulo. A modernização e verticalização em curso alterava o perfil marcadamente residencial e aristocrático do bairro Campos Elísios, que até então havia se imposto como espaço privilegiado de acolhimento de inúmeras famílias produtoras do café ${ }^{53}$. Ao erguer-se no local um grande edifício de 19 andares, a demolição do casarão tirava de cena um projeto do arquiteto Ramos de Azevedo ${ }^{54}$, mudando a paisagem da cidade na cadência da verticalização. No novo edifício hoteleiro, além do mobiliário depurado de Lina Bo Bardi, a reafirmação da linguagem moderna se faria com a contratação do artista plástico Cândido Portinari para execução, no saguão do restaurante, de um amplo painel em mosaico representando os bandeirantes, tema de orgulho paulista amplamente reavivado nas comemorações de 1954, no IV Centenário.

Para a sede dos Diários Associados, no edifício Guilherme Guinle, rua 7 de Abril, os orçamentos do Studio Palma previam a execução de lambris no hall de entrada, especificação de encomenda feita em setembro de 1949 por mais um estrangeiro, o arquiteto francês Jacques Pilon ${ }^{55}$, responsável pelo projeto do edifício. O prédio reunia importantes iniciativas culturais e artísticas, ainda concentradas no centro da cidade: no primeiro andar ficava

52 Sobre a produção hoteleira entre os anos 1940 e 1960, cf. MONTEIRO, 2006.

53 "Na década de 1880, Campos Elísios (a oeste) representou o primeiro loteamento aristocrático e 'moderno' feito nos moldes de um empreendimento imobiliário capitalista, para a aristocracia paulistana. Seu projeto era moderno, com ruas retas, largas para a época, cruzando-se em ângulo reto e - grande novidade - uma praça, como parte integrante do loteamento (...)" VILLAÇA, Flávio. Espaço intra-urbano no Brasil. São Paulo: Studio Nobel, FAPESP, 2001. p.194.

54 A residência de Ignácio e Olívia Guedes Penteado foi edificada em 1899 a pedido do casal, com planta que organiza a profusão de cômodos da casa, tão aos modos de morar materializados na forma palacete, que serviu-se ao gosto e às necessidades materiais da aristocracia cafeeira paulistana. CARVALHO, Maria Cristina Wolff de. Ramos de Azevedo. São Paulo: Editora da Universidade de São Paulo, 2000.

55 Sobre a trajetória de Jaques Pilon, cf. SILVA, Joana Mello de Carvalho e. O arquiteto e a produção da cidade : a experiência de Jacques Pilon em perspectiva (1930-1960). São Paulo. Faculdade de Arquitetura e Urbanismo, Universidade de São Paulo, 2010. Tese de Doutorado. 
o Masp, no segundo andar, o MAM, e no oitavo andar, o Comitê Editorial da Revista Habitat, da qual Lina Bo Bardi era a editora-chefe. Parece ser possível afirmar que a contiguidade física entre essas atividades facilitou as redes de colaboração entre esses artistas, arquitetos e intermediários culturais. O vínculo profissional de Pietro Bardi com Assis Chateubriand também garantiria a contratação do Studio Palma para a execução dos mobiliários do Museu de Arte de São Paulo. Para os espaços de palestras e conferências, foram desenhadas as cadeiras para o auditório, que deram ensejo à criação da firma. Os orçamentos também registram a entrega no mês de junho de 1950 de escrivaninhas, mesa para telefone, mesa para máquina de escrever, cadeira em estofado em couro e diversas poltronas em ferro esmaltado, integrando a decoração das áreas administrativas da instituição.

Se os espaços culturais, tão ao sabor do espírito progressista, tornaram-se um canal possível de escoamento da produção desse mobiliário, as encomendas para residências unifamiliares, onde se registra a maioria dos pedidos, mostram-se como um significativo indicador das práticas culturais e estilos de vidas de determinadas frações sociais. São 26 nomes que compõem essa clientela que acessou o Studio Palma, conjunto que abre pistas para o entendimento das condições de produção do gosto moderno, em suas vinculações entre percepção estética e as propriedades sociais do consumidor. Cruzando os dados de preferências estéticas com o perfil do grupo destinatário, é possível sinalizar condicionantes sociais na definição da demanda por esses objetos simbólicos e econômicos, demarcando o vínculo entre a posição social dos encomendantes e estilos de vida por eles propagados.

Os orçamentos disponíveis, entre maio de 1949 e agosto de 1950, contêm em sua maioria encomendas privadas feitas por uma clientela reduzida. São, basicamente, dois grupos sociais que dão sustentação a esse gosto: artistas e frações ligadas ao patrocínio cultural na cidade.

As frações de artistas, produtores de vanguarda, pertencentes às camadas médias escolarizadas em emergência na cidade, ligadas principalmente aos redutos culturais dos quais a arquiteta também fazia 
parte. Profissionais liberais, jornalistas e artistas. Entre eles, a presença de estrangeiros é reveladora da participação de novos grupos na produção artística e intelectual paulistana. Por exemplo, o artista plástico italiano Fúlvio Pennachi (1905-1992), muralista e ceramista, que chegou ao Brasil em 1929 e fez parte do grupo Família Artística. Nos primeiros anos de sua chegada ao Brasil, também foi professor de artes no Colégio Dante Alighieri, instituição de ensino fundada em 1911 por imigrantes italianos interessados em manter a identidade cultural. Outro imigrante é o fotógrafo húngaro Thomaz Farkas (1924-2011), vindo com a família aos seis anos. Filho do fundador da Fotoptica, empresa de equipamentos fotográficos, logo se dirigiu para a área. Em 1949, aos 23 anos, fez sua primeira exposição no Masp e, no ano seguinte, foi convidado para coordenar o laboratório de fotografia do museu, junto com Geraldo de Barros (1923-1998), fotógrafo e artista gráfico que também atuaria no design de móveis. A ligação com Lina Bo Bardi se explica pela vinculação de ambos às atividades do Masp, onde ofereceram cursos de pintura e fotografia. Pelo caráter da instituição, que também organizava atividades didáticas e promovia nomes na arte, constelava uma geração de artistas que ofereciam cursos, faziam monitorias e eram incorporados às redes de sociabilidade do museu.

Esses móveis foram também encomendados por frações culturais endinheiradas da burguesia paulista, grupos interessados em patrocinar o circuito das artes e as novas linguagens estéticas, como Francisco Matarazzo Sobrinho, Yolanda Penteado, Alfredo Mesquita e Ambrógio Bonomi. Desse modo, serviram a um grupo de pares artistas, já convertidos por escolha profissional à expressão moderna, e a uma burguesia ilustrada, em grande parte atuante no mecenato das novas linguagens, que convertia em emblemas da modernidade seus capitais econômicos provenientes dos setores de produção imobiliária, industrial e dos meios de comunicação.

Para Francisco Matarazzo e Yolanda Penteado, as encomendas concentraram nos espaços de intimidade, com a decoração do quarto do casal. Previa-se o revestimento das paredes com listras de pau-marfim, prateleiras para livros, mesa curva com gaveta, camiseira, almofadas em couro e algumas poltronas laqueadas. Diretamente em seu nome, dona 
Yolanda contratou serviço de tapeçaria, com a instalação de cortinas em abril de 1950, para a residência recém-aberta na rua Estados Unidos, número 1093, no bairro dos Jardins. Nesse momento, a mecenas estava com 47 anos, há três casada com Ciccilo, uma parceria afetiva, artística e empresarial que imantava os investimentos no cenário cultural de São Paulo. A fundação do MAM, a organização das Bienais de Arte, as compras de coleções de obras de arte, os preparativos para a comemoração do IV Centenário da cidade, entre outras iniciativas que passavam por seu crivo, foram resultado de sua articulação ${ }^{56}$.

Já Alfredo Mesquita ${ }^{57}$, filho caçula de Júlio Mesquita, ao ser excluído dos negócios familiares ligados ao jornal Estado de São Paulo, dedicou-se ao patrocínio de experiências culturais na cidade e a investimentos imobiliários para empregar a cota da herança que recebeu. Nos anos 1940, o "grã-fino" incentivador da cultura se ocupava com a organização dos espaços ligados à cena literária e teatral, para os quais iria contribuir com a escrita de peças e os incentivos à publicação da revista Clima. Desde 1942, tocava a livraria Jaraguá, localizada na mesma quadra do prédio dos Diários Associados, ponto de encontro de intelectuais e artistas. No final da década, esteve ligado à fundação da Escola de Arte Dramática e do Teatro Brasileiro de Comédia. Em 1945, já tinha encomendado a Vilanova Artigas um edifício residencial, empreendimento para investimento imobiliário. Para Lina Bo Bardi, as encomendas do mobiliário, no entanto, também viriam a se ajustar a seus espaços privados, revelando, no pedido para decoração do terraço de sua residência, as atividades que preenchiam seu tempo de lazer com a recepção de amigos, a jogar cartas na mesa de jogo com tampa de camurça verde.

Para além dos círculos de alto poder aquisitivo, aqueles direcionados ao incentivo da cultura nas esferas institucionais, um contingente de clientes do Studio Palma reúne indivíduos com trajetórias de ascensão

56 Os arranjos mobilizados em torno da dinamização da cena cultural e artística da cidade foram relatados na autobiografia de Yolanda Penteado, descrita no prefácio de Gilberto Freyre como "protetora de artes e admiradora de artistas e amiga de escritores". PENTEADO, Yolanda. Tudo em Cor de Rosa. São Paulo: Edição da Autora, 1977, p.27.

57 Para biografia de Alfredo Mesquita, cf.: GÓES, Marta. Alfredo Mesquita: um grã-fino na contramão. São Paulo: Editora Terceiro Nome, 2007. 
profissional, especialmente em atividades liberais, artísticas e intelectualizadas, grupos que se mostraram mais devotos ao espírito cultural moderno. Jornalista, escritor, radialista, cantora lírica, fotógrafo e artista plástico são algumas profissões identificadas entre os clientes, configurando um perfil cultivado. A adesão ao gosto moderno se deu prioritariamente entre indivíduos dotados de competências estéticas e inseridos nos círculos sociais dos produtores, em outros termos, um grupo de já convertidos.

Entre eles, destaca-se a presença da freguesa e amiga paulista residente no Rio de Janeiro Helena Sangirardi, de quem Lina Bo Bardi deixou guardado um recado escrito em um pequeno pedaço de papel. Os dizeres põem à mostra as negociações em torno da compra dos móveis, os esforços para transportar a mercadoria para a moradia carioca e os vínculos de amizade, coroados pela promessa de troca de favores:

"Lina, acabo de saber, por um vizinho, que a 'Itaú', uma companhia de aviação, faz transporte de móveis por CR\$1,20 o quilo, sem ser preciso engradado. A "Ser" cobra 1,80 e é indispensável o engradado. Se você quiser se informar aí, será favor. Se achar conveniente, pode mandar os móveis, mas telegrafe antes para meu mano: Sr Jorge Bechuat, rua Santa Clara, 36, apto 1001, Copacabana, Rio de Janeiro. Avise data da chegada, de acordo com informação da Companhia. E muito obrigada, desde já. Vamos depois de amanhã para Cambuquira, onde Girardi vai terminar seu restabelecimento, fazendo uma estação de águas. Lá nosso endereço é Hotel Empreza e o telefone é 25, caso haja alguma necessidade de falar com a gente, o que não acredito. Se não houver censura, talvez $O$ Cruzeiro publique umas linhazinhas a seu respeito, no dia 22-04-1950, nas minhas páginas. Estou escrevendo pessimamente, hoje, não sei porque [sic]. Helena B. Sangirardi (data 16-03-1950)"158

Nos anos 1950, Helena Sangirardi ocupava um lugar proeminente na cena midiática brasileira, como locutora na Rádio Nacional, articulista na revista $O$ Cruzeiro (pertencente ao grupo Diários Associados) e

58 Documento consultado no acervo pessoal da arquiteta pertencente ao Instituto Lina Bo Bardi. 
apresentadora na TV Tupi. Trabalhava em diversos programas ${ }^{59}$ voltados para os temas femininos (economia doméstica, conselhos sentimentais, regras de etiqueta, entrevistas com personalidades), e tinha publicado $A$ alegria de cozinhar, livro de receitas que tornou um best-seller. Também figurava como garota-propaganda em diversos anúncios para o mesmo público, divulgando panelas de pressão, sardinha e feijoadas enlatadas, achocolatado em pó, margarina vegetal, liquidificador, dedetizador de baratas, sabonete, de marcas até hoje conhecidas (Panex, Toddy, Claybon, Nestlé e Walita), participação que acena para o vigoroso mercado de produtos industrializados. Não se descuidou também das atividades políticas em defesa da mulher, assinando petições de apoio e atuando como primeira secretária eleita em uma entidade da classe, a Federação das Mulheres do Brasil, frente de ação do movimento feminista ${ }^{60}$. No auge do sucesso, com o lucro da venda dos livros de culinária, ela "comprou um apartamento" ${ }^{61} \mathrm{em}$ Copacabana e encomendou os artigos de decoração à amiga arquiteta. Os jornais anunciaram a nova mobília: cadeira de balanço e espreguiçadeira amarelas, sofás, diversas poltronas em pau-marfim e imbuia, bergères, cadeiras para a mesa da sala de jantar e diversas mesinhas laterais, um conjunto de móveis de "linhas retas" para equipar a sala de visitas.

Embora Lina Bo Bardi não tivesse conseguido ganhar a divulgação prometida por Helena Sangirardi, a mobília de feição moderna foi digna de nota no Diário de Notícias. A jornalista que visitou a residência assim a descreveu:

"Estou hoje num apartamento realmente bonito e agradabilíssimo, desses em que a gente sente logo vontade de ficar morando. Lina Bardi,

59 Na Rádio Nacional, comandava como radialista o programa Conselho Sentimental; na revista $O$ Cruzeiro, era responsável pela seção de culinária, editando uma coluna semanal; na TV Tupi, apresentou Cartazes Luminosos, programa com entrevistas, Doce Lar e Bazar Feminino. A fama no universo feminino até lhe rendeu homenagem de Vinicius de Moraes, que em referência aos dotes culinários da apresentadora, dedicou o poema "Feijoada à minha Moda", uma "receita poética de sua feijoada completa": "Amiga Helena Sangirardi /Conforme um dia prometi / Onde, confesso que esqueci / E embora - perdoe - tão tarde/ (Melhor do que nunca!) este poeta/ Segundo manda a boa ética / Envia-lhe a receita (poética)/ De sua feijoada completa. MORAES, Vinícius. Para viver um grande amor. São Paulo: Companhia das Letras, 2010. p.96.

60 Revista $O$ movimento Feminino, dezembro de 1951, p.2.

61 “Consultora Sentimental e culinária”. Diário de Notícias, 27 de dezembro de 1951. 
a arquiteta paulista, traçou os móveis, e a dona da casa desenhou a decoração. São sempre linhas retas. É acolhedor, elegante, esportivo aquele apartamento da rua Sá Ferreira, em Copacabana"62.

Por vezes, os laços de ligação de Lina Bo Bardi com sua clientela se ancoraram em redes de sociabilidade de imigrantes italianos, muitos em situação de exílio político. No final dos anos 1940, a arquiteta realizou serviços de marcenaria para Paulo Matarazzo, Luciano Falzoni e Ambrógio Bonomi ${ }^{63}$. Os trabalhos consistiram na execução de porta e janelas, encomenda destoante das atividades comumente exercidas pelo Studio Palma. Esses clientes foram encaminhados pelo arquiteto também italiano Danielle Calabi (1906-1964), então responsável pela reforma e construção das moradias desses proprietários. Aí se sobrepõem relações profissionais, de apoio e camaradagem que atravessaram um círculo de italianos ricos, uma nova elite estrangeira que, articulada a uma rede de negócios artísticos e imobiliários, fixava-se na cidade de São Paulo.

No conjunto dos encomendantes italianos também figuram o escritor e jornalista Adriano Grego, que em 1941 asilou-se no Brasil em decorrência de embates contra o fascismo, tendo aqui colaborado em jornais e revistas com reportagens sobre guerra, gueto dos judeus e espionagem, e o cliente Alberto Mortara (1920-1996), filho de Giorgio Mortara (1885-1967) e Laura Ottolenghi (1893-1971). No caso, pai, mãe e irmãos (Alberto com 18 anos, Marcella com 16, Guido com 15 e Valério com sete) vieram para o Brasil em janeiro de 1938 escapando das coerções políticas e das leis raciais impostas

62 “Consultora Sentimental e culinária”. Diário de Notícias, 27 de dezembro de 1951.

63 Fugindo dos ataques da Segunda Guerra Mundial, Ambrógio Bonomi, engenheiro militar, veio para o Brasil e fixou-se com a família em São Paulo em 1947, quando a filha Maria Bonomi, hoje reconhecida artista plástica, estava com 12 anos. A facilidade de entrada no país se deu devido à cidadania brasileira da esposa, Georgina Martinelli, filha do abastado empresário Giuseppi Martinelli, que construiu em 1922, o primeiro arranha-céu da cidade. Desde cedo, a frequentação dos círculos culturais da cidade, entre eles de Segall, Matarazzo e dos Bardi, rendeu a então jovem Maria Bonomi, nos anos 1950, matérias publicadas em jornais e revistas, como na própria Habitat, n. 7, de abril/junho de 1952, em texto escrito por Lina Bo Bardi com o título "Mais uma amadora", em que apresenta uma tela da emergente pintora, expondo a obra "Paisagem urbana de São Paulo", p.40-41. Para alguns dados biográficos de Ambrógio Bonomi e a trajetória artística de sua filha, Maria Bonomi, cf. LAUDANNA, Mayra. Maria Bonomi da gravura à arte pública. São Paulo: Editora da Universidade de São Paulo, Imprensa Oficial, São Paulo, 2007. 
aos judeus italianos ${ }^{64}$. Economista e professor de Estatística na Universidade de Milão, Giorgio Mortara conseguiu o visto de entrada no Brasil em um momento em que a autorização para recebimento de judeus no Estado Novo era dificultada. No entanto, para o renomado estatístico, os convites da Universidade do Brasil e para trabalho no IBGE garantiram a fixação da família no país (BIGAZZI, 2007). Alberto Mortara chegou no Brasil com 18 anos, e logo em seguida, mudou-se para São Paulo para cursar Economia na Fundação Álvares Penteado, formação que possibilitou galgar cargos executivos em empresas nacionais e multinacionais, entre elas, a Indústria Reunidas Matarazzo e a Ford. A encomenda de mobiliário em 1950 também coincide com a construção de uma residência no Brooklin, fruto dos recursos garantidos pela boa posição econômica, logo seguido do casamento e constituição de sua família em São Paulo. Dos móveis listados no orçamento - cadeiras em pau-marfim, mesa de abrir, móvel estante para livro, mesa em pau-marfim, sofá com tiras de lona e almofadas soltas, bergère grande, duas poltronas, floreira, móvel com quatro gavetas e duas prateleiras - foi possível localizar no álbum da família duas fotos de momentos íntimos reunidos na sala de estar, em que aparece a mesa de centro, o sofá e a bergère. [fig. 13 e 14]

Elphy Rosenthal, colecionador de obras de arte e atuante na área de corretagem financeira, e José Mário Taques Bitencourt, médico e também vinculado a outras iniciativas culturais, como a revista Clima, valeram-se das linhas inovadoras do Studio Palma para decorar suas residências recémconstruídas, no Pacaembu e no Sumaré, respectivamente, novo vetor residencial de fixação das ascendentes camadas médias e altas ${ }^{65}$. Os dois clientes do Studio Palma têm em comum o fato de suas casas terem sido

64 A família veio para o Brasil devido às imposições religiosas impostas pelo fascismo. Em 1938. Giorgio Mortara foi demitido do cargo de professor e seus filhos impedidos de frequentar as escolas públicas. Giorgio buscou então possibilidades de trabalho em outros países, e tendo recebido convite do IBGE para vir colaborar no recenseamento de 1940, o aceitou. Agradeço à família Mortara - Valério, Fábio, Adriana, Maria Luísa - pelas informações transmitidas, assim como pela busca de fotos antigas no álbum da família, à procura dos móveis encomendados a Lina Bo Bardi.

65 Para as dinâmicas de deslocamentos espaciais e os processos históricos de formação dos bairros residenciais de alta renda, cuja ocupação concentrou-se sobretudo no vetor sudoeste cf: VILLAÇA, 2001, principalmente capítulo 8. 
projetadas, em 1949, por Vilanova Artigas, em um momento em que o arquiteto ganhava proeminência no cenário paulistano, evidenciando a reafirmação de uma aposta estética com o acúmulo de várias formas de capitais. Retesada na prática política, a encomenda da moradia viria como preito de amizade entre os simpatizantes do Partido Comunista, possivelmente um índice para a aceitação de um habitat pouco convencional, com ambientes abertos, não compartimentados. [fig. 15 e 16]

É possível dizer que, quanto ao projeto formal, os móveis projetados por Lina Bo Bardi sintonizam-se com as experiências estéticas propaladas por Vilanova Artigas. Não é à toa que ambos também serviram a uma fração de classe cultivada, engajada nos movimentos artísticos, cuja posse de capitais culturais os impulsiona a interiorizar os sinais distintivos da modernização em forma de habitação. A própria arquiteta encarregará de difundir os projetos do colega com um artigo tecendo elogios ao arquiteto curitibano radicado em São Paulo. Em 1950, na primeira edição de sua revista Habitat, a arquiteta publica longo ensaio, com fotografias e desenhos arquitetônicos, em que avalia com entusiasmo a atividade projetual do colega. Para ela, Artigas, com seus projetos de casas, expressa uma radicalidade estética que se contrapõe à da moral burguesa.

Em "Casas de Artigas", a italiana marca sua estreia na crítica de arquitetura no Brasil, louvando os projetos residenciais do arquiteto, nos quais reconhece força e engajamento das propostas modernas. Os espaços fluidos, os grandes volumes em concreto, as amplas janelas de vidro que iluminavam e integravam o interior ao jardim arrancaram seus elogios. De acordo com Lina, as residências com formas leves e despojadas, os espaços abertos, que tanto integram ambientes internos e externos, e que também conectam sala e cozinha, ambientes usualmente separados, modificam os tradicionais projetos residenciais dos grupos dominantes. Com esses espaços austeros, o arquiteto brasileiro dotaria a casa de leveza poética e radicalidade política. A arquiteta vê na obra de Artigas "uma moral de vida" que questiona o modo de morar do burguês, conservador e preso às representações da arquitetura neoclássica. Com essa condenação, Lina Bo Bardi sinaliza a localização social dessa clientela abonada. Trata-se de uma 
fração da classe dominante intelectualizada para quem os símbolos tradicionais de luxo, riqueza e ostentação não oferecem os mesmos ganhos simbólicos que desempenharam uma aristocracia e uma burguesia tradicionais, parcelas altamente dotadas de capital econômico, mas esteticamente antimodernas.

Cabe considerar também que, ao dar grande destaque a Vilanova Artigas, arquiteto em ascensão e docente da recém-criada Faculdade de Arquitetura da Universidade de São Paulo, Lina Bo Bardi ratificava suas posições em defesa da arquitetura e mobiliários modernos, em um investimento que explicita seu interesse de reconhecimento e integração no meio local. Três meses antes da publicação dessa edição da revista Habitat, o Studio Palma executava as encomendas dos móveis da casa de Mário Taques Bitencourt, revelando a convergência entre arquiteto, designer e cliente ilustrado. Nos orçamentos, constam duas poltronas estofadas com fazenda feita a mão, uma mesa de pau-marfim extensível, uma espreguiçadeira estofada em branco e preto, oito cadeiras de madeirite, um carrinho de chá e um móvel com estantes para bar e biblioteca, artefatos que organizam os espaços integrados da casa. As imagens da matéria na revista Habitat, feitas pelo reconhecido fotógrafo Francisco Albuquerque (1917-2000) especialmente para essa edição, mostram o arranjo moderno da sala de estar, do terraço e dos móveis. A disposição das poltronas em formato bumerangue e a mesa de centro na sala de estar; a espreguiçadeira bicolor, com poltrona e mesinha lateral, no terraço, compõem, junto com as formas amplas da casa um ambiente fluido, entendido como efetivamente moderno, condição que impeliu Lina Bo Bardi a escrever acalentado ensaio elogiando os projetos do arquiteto.

O mapeamento detalhado dos comitentes revela o quanto tais encomendas ficaram circunscritas às redes de relações primárias, contatos diretos decorrentes da posição do casal Bardi no meio cultural. Ainda que o casal Bardi tivesse acesso a grupos dirigentes e empresários, não conseguiram convencer esses grupos a investir na industrialização dos produtos, tal como era a aposta moderna de disseminação.

Tomando por base os nomes citados nos orçamentos, a irradiação 
não passou para além dos grupos cultivados em torno de instituições culturais, como o Masp, das indicações dos amigos arquitetos e dos círculos de imigrantes italianos que no Brasil conseguiram se estabelecer financeiramente. Os grupos sociais com acesso ao mobiliário do Studio Palma pertencem às mesmas rodas dos produtores, reafirmando e sobrepondo a inserção cultural, profissional e étnica dessas redes de sociabilidade. Em que pese todo esforço dos arquitetos para a disseminação das formas modernas, a produção permaneceu semiartesanal. Essa mobília, artefato cuja legitimidade estética derivava da atmosfera modernizante dos anos 1950, caía no gosto de reduzidas frações sociais, conformando uma modernidade limitada. O retraimento da produção e do consumo talvez explique o curto período de funcionamento da firma e o insucesso da experiência. Sem possibilidade de escoamento dos artefatos para além dao grupo de amigos, colegas da colônia e parceiros profissionais, o Palma fechou em três anos.

\section{Jacob Ruchti e a Branco\&Preto}

"Em São Paulo, à rua Vieira de Carvalho, 99, abriu uma nova casa de decoração e de objetos de artesanato, Branco e Preto, organizada por um grupo de seis arquitetos: Carlos Millan, Chen Y. S. Hwa, Jacob Maurício Ruchti, Miguel Forte, Plinio Croce e Roberto Claudio Aflalo. Essa notícia merece realmente ser sublinhada. Numa cidade em que a arquitetura de interiores está praticamente monopolizada por simpáticas senhoras, as quais porém não conhecem a arte do desenho e ainda, por fabricantes de móveis, ótimos em sua profissão, mas que não sabem por onde se começa um trabalho de arquitetura, nessa situação, a iniciativa dos seis arquitetos é um elemento para o progresso do gosto [...] Agora com a participação de seis arquitetos jovens e conhecidos por suas preferências modernas, o melhoramento será sem dúvida notável. Sua tarefa, pois, como aliás a de todos os arquitetos que se dedicam à arquitetura de interiores será dupla: por um lado demonstrar que todos os estilos, digamos tipo "Liberal", são anacrônicos, e por outro lado, que o falso, mal entendido moderno, copiado de várias fontes, tipo "São José dos 
Campos", é uma ofensa ao bom gosto e ao senso comum"66.

Em 1951, com essa nota informativa e provocativa, Lina Bo Bardi anunciava na revista Habitat a abertura de uma nova loja de decoração de seus colegas arquitetos. As posições expressas sintetizam, a partir do olhar da arquiteta, as tensões em jogo nas definições das práticas e dos praticantes da profissão. Decoradores, moveleiros, arquitetos e designers competiam por uma fatia do mercado. Ao marcar seu ponto de vista, utilizando a revista como porta-voz de suas posições, o campo de batalhas desenhado pela arquiteta sinaliza os enfrentamentos internos e externos ao exercício da profissão.

Dois tipos de designers são acusados de praticar a profissão de forma ilegítima. De um lado, as "madames" aparecem como representantes dos leigos que não dispõem das credenciais formais e nem competências estéticas. São acusadas de valerem de suas redes de relações sociais para validar sua entrada no mercado. De outro lado, os "falsificadores" do moderno aparecem como aqueles que reproduzem com mediocridade um estilo que se pretendeu exclusivo. A crítica indireta era destinada à empresa de Zanine Caldas, a Móveis Z, instalada em São José dos Campos, que fazia móveis em escala industrial. Estabelecendo um corte entre os profissionais e os profanos, os autorizados e os não autorizados, Lina Bo Bardi aposta na atuação da Branco\&Preto para o "progresso do gosto", colocando-os na posição de detentores oficiais dos padrões de sensibilidade.

Inaugurada no começo dos anos 1950 por um conjunto de arquitetos que se tornaram amigos durante o curso de arquitetura no Mackenzie, a Branco\&Preto atenderia a um nicho de consumidores cultivados, muito próximo do espaço social daqueles que acessaram o Studio Palma. Foram encomendantes sobretudo recrutados nos círculos sociais de elite construídos nas relações de amizade dos donos da loja. A abertura da loja de móveis foi um investimento de um conjunto de arquitetos que, além dos serviços de arquitetura, queriam oferecer móveis, objetos de arte e itens de decoração. Desse modo, além do desenho das novas residências, os

66 Habitat $\mathrm{n}^{\mathrm{0}}$ 9, de abril/junho de 1951, p. 89 (grifos meus) 
serviços contratados se estendiam à decoração, o que incluía a execução de mobília personalizada e a prescrição dos arranjos dos espaços.

Localizada na arborizada rua Vieira de Carvalho, local favorável por ser perto dos escritórios de arquitetura dos proprietários, a loja também se aproximava do refinamento de outras atividades que ali se encontravam, como galerias de arte, antiquários e empórios de produtos finos, compondo o que poderia se nomear como o "circuito da elegância" na capital paulista dos anos 1950. O próprio nome da loja e a logomarca criada para representá-la foram apontadas como "bastante sugestiva do requinte e da originalidade das peças" (SANTOS, 2015, p.155). A distribuição das tipografias clássicas nas iniciais do nome ("B \& $\mathrm{P}^{\prime}$ ) em seis quadrados alternados pelas cores branca e preta formavam a partir dos espaços cheios e vazios uma imagem geométrica leve e impactante, e, ao mesmo tempo, moderna e clássica. [fig. 17]

Além de Jacob Ruchti, participaram da fundação da Branco\&Preto outros arquitetos, como Miguel Forte (1915-2002), Plínio Croce (19211984), Roberto Aflalo (1926-1992), Carlos Millan ((1927-1964) e o chinês Chen $Y$ Hwa, amigos que se aventuraram na empreitada em nome do design moderno por avaliar que não havia oferta de móveis modernos, elegantes e finos. A parceria dos amigos se deu logo depois que terminaram a faculdade do Mackenzie, um ambiente de formação que, embora refratário às tendências modernas, abriu brecha para que esses alunos questionassem as imposições do diretor Christiano Stockler das Neves, afeito ao ecletismo.

O empenho na defesa das linhas modernas levou-os, depois de formados, a se associar para desenvolver projetos residenciais e de mobiliário na linha racionalista, com desenho sóbrio, materiais nobres e execução apurada [fig. 18 e 19]. A avaliação era de que não havia no mercado empresas que fornecessem um móvel "de bom gosto, contemporâneo e que pudesse ser utilizado nos projetos que os próprios integrantes da equipe executavam" (SANTOS, 1995, p.155). Para satisfazer os padrões de requinte dessa clientela, a loja também comercializava outros produtos exclusivos, como cerâmicas, objetos de arte, luminárias e tecidos importados, artigos que podem ser classificados como representativos de 
um consumo conspícuo.

A formação de Miguel Forte e Jacob Ruchti, sobretudo acumulada no ambiente familiar com concentração de capital econômico e cultural, foi apontada por um arquiteto amigo do grupo como elemento distintivo para elaboração de propostas "de bom gosto incrível". Ruchti é lembrado como "sujeito requintado", o "rei do bom gosto", ao produzir móveis com tecidos em tonalidades variadas, tendo inventado "para as cores nomes associados com a arquitetura, cidades italianas, estações do ano etc" ${ }^{\prime \prime 67}$. Tal familiaridade com o universo artístico paulistano de vanguarda fez com que os amigos de faculdade o identificassem como um estudante de arquitetura de afinado com a modernidade. E mesmo essa socialização o encaminhou para diversas atividades profissionais junto ao Masp, na organização de exposições, no desenho industrial, participação no corpo docente do IAC, e na revista Habitat, escrevendo artigos.

Nascido em 1917, na Suíça, Ruchti veio para o Brasil ainda pequeno, em 1919, com a família que escapava das atribulações da Primeira Guerra Mundial. Tanto do lado materno (judeus russos) quanto paterno (suíço protestante), a socialização se deu em um ambiente com altos recursos econômicos e com acesso à arte. O pai, que havia se formado em arquitetura na Universidade Técnica de Munique, imigrou-se para o Brasil com o convite para trabalhar nas empresas da família Klabin, o que possibilitou que a família entrosasse nos círculos culturais dos anos 1920. Faziam parte de suas relações sociais Gregori Warchavchik (1896-1972) e Lasar Segall (1891-1957), ambos casados com filhas da família Klabin, e também outros arquitetos, entre eles, Rino Levi, além de poetas e escritores ligados à Semana de 22, como Guilherme e Tácito de Almeida, e pintores, como Mucia Pinto Alves. Jacob Ruchti conviveu, desde pequeno, num ambiente de vanguarda (RUCHTI, 2011).

Com essa socialização, a presença de Jacob Ruchti na Branco\&Preto contribuía para dar esse espírito refinado aos produtos comercializados e atrair a clientela abastada. As criações dos móveis mantinham um padrão

67 Depoimento de Salvador Candia em ACAYABA, 1994. p. 66 
sóbrio e bem-acabado, executado com materiais sofisticados, qualidade que dependia de produção rigorosa e especializada. Com tiragem limitada, produzida sem mecanização, o trabalho era realizado por marceneiros alemães. Os desenhos bem cuidados e detalhados deixavam transparecer que o grupo se propôs a desenvolver um mobiliário elegante inspirado nos padrões estéticos dos arquitetos norte-americanos e alemães.

O repertório criativo foi guarnecido pelas revistas estrangeiras que assinavam e pelas viagens de formação que fizeram, nas quais conheceram pessoalmente figuras de proa do modernismo internacional, como Frank Lloyd Wright (ACAYABA, 1994). Em 1947, para complementar sua formação estética e cultural, Miguel Forte e Jacob Ruchti fizeram juntos uma viagem de seis meses aos Estados Unidos, onde entraram em contato com a produção moderna do país (FORTE, 2011). Antenados na produção estrangeira, esses investimentos de início de carreira podem ser vistos como estratégias de acúmulo de referências internacionais, possibilitados pelo capital financeiro amealhado por suas famílias. Inspirados pela experiência internacional, produziram móveis com linhas retas e elegantes tal como faziam os designers norte-americanos e europeus. O apuro na escolha dos materiais e as combinações de cores conferiam às linhas modernas um caráter requintado, refinamento que se mostrava adequado ao perfil de maior poder aquisitivo das frações de classe dominante que se valeram de tais produtos.

A partir de plantas e perspectivas em que aparece o nome do encomendante do projeto de design de interiores, é possível identificar, entre 1952 e 1958, 21 destinatários para os quais foram desenvolvidos projetos $^{68}$. O recrutamento desse público se deu em grande medida a partir dos escritórios de cada um. São clientes que buscavam esses arquitetos para encomendar um projeto de residência, ou chegaram por indicação de outros arquitetos próximos aos círculos dos mackenzistas. Entre eles, reconhecidos escritórios da capital paulista: Rino Levi, Oswaldo Bratke

68 As plantas arquitetônicas, perspectivas e vistas frontais do conjunto de desenho realizados pelos arquitetos da Branco\&Preto, bem como fotografias internas dos arranjos de mobiliários da casa foram publicadas no livro de Marlene Acayaba sobre a Branco\&Preto: uma história de design brasileiro nos anos 1950. Ali constam os desenhos e os nomes dos encomendantes, único material encontrado em que foi possível acessar parte dos destinatários desses produtos. 
(1907-1997) e Rodolfo Ortenblad (1927-?). Outra parte desses projetos destinou-se ao consumo dos próprios proprietários da Branco\&Preto e a uma parentela imediada, irmãos e cunhados. Entre eles, citam-se os projetos de decoração desenhados para o médico Roberto Millan, irmão do arquiteto Carlos Millan, e Luiz Forte, irmão de Miguel Forte, o que demonstra tratar-se de uma produção orientada para consumo entre pares e parentes.

Verificando a posição social de outros fregueses, a partir da coleta de dados de inserção profissional, nota-se que alguns destes, como Oswaldo Mitsuo Fujiwara, Carlos Schmuzigner e Enzo Segri, atuaram como empresários na cidade, principalmente com investimentos em setores industriais. Em 1953, o industrial Enzo Segri contratou os serviços de Miguel Forte e Gagliano Ciampaglia para o projeto de sua residência, localizada no Pacaembu. Em seguida, encomendou a mesa de jantar, cadeiras de palhinha, móveis para escritório, estantes, biombo, poltronas e sofá para sala de estar. Oswaldo Mitsuo Fujiwara teve sua casa projetada por Carlos Millan, assim como os móveis. Os sobrenomes estrangeiros confirmam as trajetórias de ascensão social de famílias imigrantes, para os quais o sucesso financeiro e o acesso à cultura moderna lhes proporcionariam expressão de seus critérios de apreciação estética no depuramento dos espaços de habitação.

Ruchti também desenvolveu inúmeros trabalhos para uma clientela mobilizada nas redes de relações pessoais, muitos pertencentes à comunidade judaica. Embora pela transmissão matrilinear Ruchti pudesse ser considerado judeu, não era seguidor da religião. No Brasil, a família de seus pais adotou a religião protestante e o casamento com Irene Ivanovsky ${ }^{69}$, aluna do curso de composição do IAC, no início dos anos 1950,

69 Irene era formada pelo Instituto de Belas Artes da Universidade de Porto Alegre e tinha ganhado bolsa de estudo de Assis Chateubriand para frequentar o curso do IAC, onde conheceu o futuro esposo. Em 1953, o casal foi morar em um prédio em Higienópolis, projetado pelo arquiteto judeu polonês Lucjan Korngold (1897-1963), onde era vizinho de porta de Fernando Henrique Cardoso e Ruth Cardoso. Em 1955, o casal já tinha 4 filhas (duas gêmeas), o que dificultou a fixação de Irene no trabalho de decoração de interiores. No entanto, com em parceria com marido, realizou desenhos e perspectivas para decoração de interiores. Utilizava em seus trabalhos o carimbo "IIR", de Irene Ivanovsky Ruchti, marca presente tanto nos estudos detalhados de ambientação quanto nas toalhas bordadas no toalhete social de sua residência, $o$ que não passou despercebido pelo artista e designer suiço Max Bill, quando foi recebido na 
o aproximou da Igreja Episcopal, relação que levou a vários trabalhos de adaptação de capelas da congregação e construção de igrejas ${ }^{70}$. No entanto, os vínculos com a comunidade de imigrantes judeus deram a tônica das encomendas que recebeu, estrangeiros e descendentes "afoitos por se aproximar do 'estilo moderno', naquilo que o meio cultural paulista apresentava de mais avançado" (RUCHTI, 2011, p.194).

Grande parte dos trabalhos foram realizados para amigos e conhecidos residentes em casas nos Jardins e apartamentos em Higienópolis, principalmente dos grandes e luxuosos edifícios projetados por arquitetos modernos, como Jacques Pilon, Rino Levi, Lucjan Korngold, Franz Heep, também estrangeiros que contribuíam para a fixação dos modos de morar modernos na capital. Jacob Ruchti desenvolveu projetos, em sua maioria para uma freguesia de industriais, profissionais liberais, artistas e engajados nas artes. Esses grupos estavam ligados a uma cultura urbana e cosmopolita e demonstravam interesse em se manter atualizados na mentalidade artística da época. Por vezes, a pedido do cliente, o arquiteto foi convidado a viajar para Europa a fim de adquirir novos materiais, tecidos, molduras de quadros e objetos de decoração que pudessem preencher o ambiente doméstico com referências artísticas nobres e atualizadas.

Essa freguesia emergente tanto demandou a ambientação dos espaços residenciais, em São Paulo e nas casas de praia, quanto nos espaços de lazer e trabalho, como, por exemplo, escritório e salas das empresas, consultório médico, restaurante, loja e o clube de golfe. Entre as famílias de seu convívio social, Ruchti prestou serviços para os Kablin e os Feffer, empresários lituanos e ucranianos da indústria de celulose e papéis; Thomaz Farkas, empresário húngaro do setor de equipamentos fotográficos; Adolpho Leirner ${ }^{71}$, de família polonesa, industrial do setor de malhas e um

residência do casal, por ocasião da I Bienal de São Paulo. Cf. RUCHTI, 2011, p. 183.

70 Ruchti foi responsável pelo projeto da igreja Santíssima Trindade, localizada no bairro de Campos Elíseos, projeto de 1951, em 1952, para Igreja Episcopal da Vila Maria, no final dos anos 1950, o Seminário Teológico da Igreja Episcopal Brasileira, em Santo Amaro e em 1962, apartamentos para seminaristas e casa de hospedagem para moças, no mesmo bairro.

71 Adolpho Leiner era primo do artista plástico Nelson Leiner, também de família artística, como sua mãe, Fúlvia Leirner, escultora. Os pais de Adolpho tinham decorado a residência da família 
dos principais colecionadores de arte construtivista brasileira; Simão Waissman, engenheiro civil, empresário e patrocinador da revista Senhor ${ }^{72}$; Jacques Rabinovich, judeu de origem russa, proprietário de indústria têxtil; Carlos Taub, de origem judaica, dono da Eletroradiobraz, grande magazine de venda de eletrodomésticos e produtos de departamento e Milton Guper, médico-ortopedista, amante de música clássica.

Além de servir a um restrito círculo da comunidade judaica, desenvolveu trabalhos para outras famílias de grande poder aquisitivo e interesse pela cultura, como Baby Pignatari, rico descendente da família Matarazzo, para quem fez o projeto de interiores residenciais e dos escritórios das minas de extração de metais; para a família e a sede das agências de banqueiros como Eudoro Libânio Vilela e Olavo Setúbal, proprietários do Banco Federal de Crédito e, posteriormente, do grupo Itaú, e também para Armando Conde, do Banco de Crédito Nacional. A frequentação dos circuitos das elites econômicas do país resultava na captação de clientes de alto poder aquisitivo, o que levava à afirmação em tom de brincadeira dos colegas arquitetos: "a maior parte do PIB brasileiro era cliente de Jacob" (RUCHTI, 2009, p.209).

Essa clientela traz um novo componente em relação aos segmentos de elite que se constituía em São Paulo, um circuito que concentrou alto capital econômico. Articulada a uma rede de negócios e oportunidades, mostra que a imigração se fez por diversos flancos, formando uma elite rica e disposta a patrocinar iniciativas culturais. Essas famílias tinham acumulado riqueza no Brasil com atividades produtivas e frequentavam os espaços artísticos metropolitanos. Movimentavam galerias de arte e antiquários, tanto no Brasil quanto no exterior, onde compravam obras de arte, pratarias, cerâmicas, peças do barroco.

Um desses projetos significativos é a proposta de decoração e design de interiores efetuada para a grandiosa residência, um palacete moderno,

com móveis de John Graz, o que atesta a imersão dessa comunidade de estrangeiros no mundo das artes.

72 Revista de política, artes e comportamento criada no final dos anos 1950, que publicou grandes nomes da literatura brasileira, como Clarice Lispector e Guimarães Rosa, e lançou nomes como Paulo Francis, Carlos Scliar. 
de um casal de mecenas das artes, Maria Luíza Ferraz Americano (19171972) e o engenheiro Oscar Americano de Caldas Filho (1908-1974). Os detalhados desenhos e perspectivas efetuados pelos arquitetos da Branco\&Preto, em 1956, dão mostras do rigor no projeto de design de interiores, em que utilizam armários embutidos retilíneos, estantes com nichos variando entre cheios e vazios, em assonância com os longos bancos que compuseram a demarcação dos espaçosos ambientes. [fig. 19 a 21] As poltronas de palhinha e sofás de linhas leves e retas, revestidos de seda natural nas cores peroladas e acinzentadas, garantiriam centralidade visual às obras de arte dispostas nos vários espaços, telas e esculturas que compunham o acervo artístico do casal, empenhado em colecionar obras de arte. A própria casa é a materialização plena do gosto moderno. A residência foi projetada em 1950 por Oswaldo Bratke, arquiteto-engenheiro amigo do proprietário, ambos formados na Escola de Engenharia do Mackenzie em 1931, e está localizada na chácara de recreio da família, no então distante Morumbi está entre as mais suntuosas residências modernas.

Essa clientela de gosto refinado e seduzida pelas tendências inovadoras da época provinha de setores empresariais não por acaso ligados à "construção do Brasil moderno"73. A riqueza de Oscar Americano se acumulou com negócios na área de construção civil obtidos com a fundação, logo após sua formatura, da Companhia Brasileira de Pavimentação e Obras (CBPO). A empreiteira atuou em grandes serviços de infraestrutura em todo território nacional entre os anos 1930 e 1970, por exemplo, o consórcio da Usina Hidrelétrica de Itaipu, a construção de rodovias Imigrantes, Castelo Branco, Trabalhadores e do metrô do Rio de Janeiro. Tal portfólio de peso a colocou, nos anos 1970, entre as empreiteiras com maior faturamento do país, quando foi anexada ao grupo Odebrecht. Nesse mesmo momento, em um ato característico de grupos de elite que querem fixar o nome na cultura, a família doou para a cidade de São Paulo parte da coleção de obras de arte, mobiliários, documentos históricos e a chácara da residência moderna, espaço que foi transformado na Fundação Maria Luísa e Oscar Americano.

73 "Quem construiu o Brasil Moderno". Jornal 0 empreiteiro, 31/05/2012. 


\section{Zanine Caldas e a Móveis Artísticos Z}

Além do Studio Palma e da Branco\&Preto, a década de 1950 também instigou a realização de outras experiências para a formação do design moderno brasileiro e que dão a medida do ímpeto modernizador em curso. Naqueles anos, participam dessas investidas diversos empreendimentos que expressaram tentativas de coordenar a produção industrial do mobiliário, entre elas, por exemplo, a Unilabor, a L'Atelier e a Móveis Artísticos $Z^{74}$.

Interessa aqui analisar a Móveis Artísticos $Z$, pois se trata de uma empresa que conseguiu realizar uma produção em escala industrial, com peças modernas serializadas, prontas a atender um mercado mais amplo. A empresa foi implementada por Zanine Caldas e Sebastião Pontes, em 1950, no parque industrial de São José dos Campos. O empenho em realizar uma produção de móveis em larga escala, e, assim, liberada das constrições da encomenda, é a marca distintiva dessa experiência.

Tal horizonte de produção e distribuição não escapou às críticas furiosas de Lina Bo Bardi, que, como se mostrou acima, valeu-se da condição de detentora dos canais de consagração para validar suas posições e buscar o monopólio da definição legítima do bom gosto, depreciando outras iniciativas. Utilizando a expressão "tipo 'São José dos Campos", de forma implícita e não nominável, acusou Zanine Caldas de produzir um móvel "falso, mal entendido moderno, copiado de várias fontes", e assim expressou sua posição considerando o mobiliário da Z uma "ofensa ao bom gosto e ao senso comum". A proximidade dos desenhos dos móveis de ambos designers, em formas curvas recortadas em placas de madeira

74 A Unilabor foi fundada em 1954 tendo como proposta política a elaboração de móveis a partir de uma dinâmica cooperativa, experiência que previa produção participativa e igualitária. Coordenada pelo Frei Dominicano João Batista Ferreira dos Santos e pelo artista plástico do grupo concretista Geraldo de Barros, responsável pelo design do mobiliário, a firma esteve direcionada para a fabricação de móveis de madeira e ferro, em um primeiro momento sob encomenda. Esses artefatos serviram a uma clientela provinda da intelectualidade paulistana, artisticamente formada e simpatizante de propostas cooperativas, entre eles, o crítico de cinema Paulo Emílio Salles Gomes. A L'Atelier, criada pelo arquiteto polonês Jorge Zalszupin, no final dos anos 1950, concentrou a produção na industrialização de móveis para escritórios e ambientes de trabalho, nicho menos constrangido às variações de moda e imposições de gosto de uma clientela interessada em modelar seus espaços residenciais (SANTOS, 1995). 
compensada, levou Lina a tachar a Móveis $Z$ de produzir uma cópia malfeita, sem o apuro do acabamento e refinamentos dos materiais. Segundo Zanine, a arquiteta italiana Ihe atribuía a falta de cuidado na execução do produto, em que os parafusos das poltronas expostos poderiam "rasgar as meias-calças das mulheres"75.

O que se vê é que no esquema de classificação da arquiteta, a Branco\&Preto é elogiada pela sofisticação e finura e a Móveis $Z$ ocupa uma posição rebaixada, criticada pela baixa qualidade, falsificação e inautenticidade. Ao recriminar o colega pela má execução dos móveis, a crítica se desliza para os efeitos da difusão de uma mercadoria cultural, em que valores como originalidade e autoria entram como medida da discussão. Em termos mais amplos, os posicionamentos de Lina Bo Bardi expressam tensões inerentes aos processos de modernização, quando a rotinização dos produtos culturais vai resultar em diluição das formas estéticas.

Entre todas essas firmas que despontaram na década de 1950 advogando em nome da atualização estética e da produção em série do mobiliário moderno, a Móveis $Z$ é paradigmática na implementação de um projeto de distribuição ampliada do móvel moderno, empreendimento que se realiza após início profissional de Zanine Caldas, que até então havia trabalhado na produção de móveis sob encomenda, principalmente destinados a colegas de profissão e círculos sociais próximos. Com isso, vale a pena confrontar a trajetória do designer, o modo de produção dos produtos e a dinâmica de consumo dessa firma com as duas antes analisadas.

Tendo em vista que o final da década de 1940 representou um momento de institucionalização das faculdades de Arquitetura, a trajetória de Zanine Caldas pode ser vista como uma exceção, uma vez que o designer conseguiu se instalar no meio profissional sem as certificações oficiais de formação educacional universitária. Diferente do percurso dos

75 Em depoimento a Maria Cecília Loschiavo dos Santos, Zanine Caldas sinalizou: "A Lina Bardi também fez móveis em compensado, mas ela criticou o meu móvel porque tinha parafusos, rasgava as meias das mulheres". SANTOS, Maria Cecília Loschiavo. Tradição e Modernidade no Móvel Brasileiro: visões de utopia na obra de Carrera, Tenreiro, Zanine e Sérgio Rodrigues. Tese de Doutorado, São Paulo, FFLCH USP, 1993. p.163. 
dois concorrentes, que passaram por instituições oficiais e altamente reconhecidas, o ingresso de Zanine deveu-se a uma competência adquirida no trabalho prático, como obreiro e maquetista de arquitetos modernistas cariocas e paulistas. O exercício de execução de maquetes em madeira compensada, que exige a habilidade de trabalhar com miniaturas, resultou em um aprendizado repetitivo de técnicas, uso de materiais, modelagem de formas, além de colocá-lo em contato com as dinâmicas criativas de uma geração de arquitetos modernos. Esse contato favoreceu a inculcação de um repertório moderno, dos valores missionários dessa linguagem e da experiência de pertencimento ao mundo dos arquitetos.

Filho de médico em Belmonte, na Bahia, Zanine Caldas cursou a escola apenas até o ginásio, partindo para um percurso de formação prática. Entrou em contato com Lúcio Costa, no Iphan, onde trabalhou como obreiro na conservação de edifícios históricos de Minas Gerais e Bahia. Também trabalhou em escritórios de arquitetura, com Oscar Niemeyer, no Rio de Janeiro, e Oswaldo Bratke, em São Paulo. Foi recuperando portas de casarões coloniais e executando maquetes, entre elas, a do Ministério da Educação e Saúde e do Estádio do Maracanã, no Rio de Janeiro, e do Edifício Copan, em São Paulo, que Zanine treinou suas competências técnicas de desenho e manejo de materiais. Em meio ao trabalho dos modelos em miniatura, propôs maquetes inicialmente em gesso e depois executadas em madeira compensada. Esse trabalho de pesquisa de materiais possibilitou a aquisição de habilidades e domínio técnico sobre o talhe da madeira e a modelagem de formas em escala reduzida.

Inscrito nessas redes de relações sociais, o contato com ícones do modernismo arquitetônico foi favorável para aproximá-lo dos valores e traços dessa vertente, bem como a iniciá-lo em um círculo restrito de profissionais, a ponto de ser convidado, em 1951, por Alcides Rocha Miranda, então diretor da Faculdade de Arquitetura da Universidade de São Paulo, para implementar uma oficina de maquetes, curso que havia sido fundado há três anos. Naquele momento, desenho industrial ainda não constituía um grupo de disciplinas oferecidas nas grades curriculares da faculdade, isso só viria ocorrer em 1962, com uma reforma do ensino. A 
contratação de Zanine, que não tinha as credenciais formais para ocupar a posição prestigiosa de docente, visava oferecer aos estudantes formação técnica e prática para elaboração de seus projetos a partir da representação tridimensional, que os ajudaria a se distanciarem da formação academicista e baseada na composição de estilos da Escola Politécnica.

A amizade com Vilanova Artigas, docente na FAU-USP, vinha da militância no comunismo, o que também lhe rendeu a execução dos móveis da casa do arquiteto e de amigos dos mesmos círculos. Essas relações de amizade e engajamento de esquerda e de convivência com artistas e intelectuais funcionaram como redes de apoio que fomentavam as parcerias profissionais e o acesso a uma freguesia interessada em equipar suas moradias com a linguagem moderna. [fig. 22]

Na trajetória de Zanine, a passagem da escala reduzida da maquete para escala 1:1 do mobiliário ganhou força no final dos anos 1940 e início dos anos 1950, com experimentações para arquitetos, entre eles, Vilanova Artigas, com a execução de mobiliário para sua residência no Campo Belo, montando os móveis embutidos dos quartos, poltronas e cadeiras. No trabalho de marcenaria, seria também responsável por produzir um dos únicos desenhos de mobiliário projetados por Artigas, as poltronas da sala de espera da secretaria, destinados à empresa de seguros de vida A Equitativa, cujo proprietário era o português e simpatizante comunista Manuel Mendes André, cliente de Artigas em outros projetos residenciais. [fig. 23] Nesse projeto destinado a áreas administrativas, Artigas foi responsável pela modernização das instalações de dois andares do escritório, onde desenhou as divisões internas das salas de atendimento, arquivo, expediente, secretaria etc., espaços que contaram com trabalhos de pessoas ligadas a seu círculo de amizade e inclinações políticas de esquerda, como Rebollo Gonçalvez, que atuou na pintura, e Candido Portinari, a quem foi encomendado três grandes painéis representando ciclos econômicos brasileiros. A escolha desses artistas, todos com passagem pela militância, manifestam os interesses coadunados entre proprietário, seus artífices, arquitetos e colaboradores estéticos para atualizar a imagem da empresa. 
Outros encomendantes dos móveis de Zanine ratificam os vínculos e as parcerias que o designer estabeleceu com clientes comunistas e Vilanova Artigas. Por exemplo, no início dos anos 1950, o casal de diretores e roteirista de teatro Oduvaldo Vianna e Deocélia Vianna, pais do dramaturgo Vianinha, acionaram Artigas para o projeto de sua casa em São Paulo, localizada no bairro Sumaré. Além de contratar Zanine para executar o mobiliário, convidaram o muralista Clóvis Graciano para desenvolver o painel de mosaicos na entrada da casa e negociaram com Portinari a compra de quadros para decoração dos interiores. Deocélia Vianna deixa registrado na biografia da família os investimentos afetivos e artísticos direcionados na realização da casa da família, a partir do qual sobressai o circuito de relações com militantes, as apostas revolucionárias e diretrizes estéticas. Os laços entre Artigas, família Vianna, Zanine e todo um conjunto de artistas foram alimentados na simpatia com as ideias do Partido Comunista, conformando um conjunto de relações acionáveis na amizade, em que se cruzam engajamento político, amor pela arte e camaradagem profissional.

Após executar móveis sob medida, a criação da Móveis Artísticos Z, em 1950, foi um investimento evidente na tentativa de superar a produção personalizada e produzir móveis de linhas modernas em escala industrial. Os móveis desenhados por Zanine procuraram dinamizar o processo produtivo com a escolha de materiais e processos de execução que não exigissem a mão de obra especializada, tal como se fazia nas marcenarias voltadas para produção exclusiva. O contraplacado - finas placas de madeira coladas, um material não nobre quando comparado ao uso de madeira maciça - foi utilizado como insumo de suas criações. As formas bumerangues dos móveis eram recortadas a partir dessas pranchas planas de madeira, elementos bidimensionais utilizados na montagem do produto. Para evitar a complexificação do processo e o encarecimento dos custos, a execução foi planejada para ser a mais simples possível, com emparafusamento manual das partes e estofamento feito por grampos, sem necessidade de costuras ou arremates especiais.

Os procedimentos de barateamento da produção e racionalização da 
realização das peças procuravam se adequar às dinâmicas do processo industrial, evitando o emprego de trabalho artesanal ou mão de obra especializada, tais como serviços onerosos de tapeçaria e marcenaria personalizados. Na lógica do desenho industrial, a serialização do produto teve como meta a redução dos custos e do tempo de produção a partir de uma cadeia produtiva racionalizada. Tais arranjos na organização do processo produtivo foram pensados como estratégia para alargamento da difusão dos móveis modernos, atingindo um público mais amplo, para além dos pares arquitetos e dos grupos já identificados com as diretrizes modernas. Trata-se, então, de uma tentativa de abastecer o mercado moveleiro com produtos de menor preço, o que possibilitaria estender 0 mobiliário de linhas arrojadas para grupos sociais mais diversificados, como as classes médias urbanas, ou seja, para segmentos sociais além dos círculos de elite em proximidade com os agentes do mundo das artes.

A redução na qualidade de execução e o emprego de materiais simples reforçam a destinação a um público de extrações mais modestas, que não tem condições financeiras para escolhas mais exigentes. Os revestimentos dos assentos eram feitos de lona, material sintético mais rústico e menos sofisticado que os tecidos finos, acetinados e com padrões exclusivos usados nos móveis modernos refinados. As cores primárias e secundárias dos estofamentos em tonalidades intensas (vermelho, azul, amarelo, verde) reforçam as correlações aos padrões de gosto de grupos populares, em oposição àqueles que se valem de cores sóbrias e nobres como gosto distinto (bege claro, pied de poule, risca de giz - padrões de alfaiataria usados de forma ousada nas tapeçarias de Ruchti). Ainda que no plano estético e formal esses móveis se aproximassem da linguagem de alguns dos projetos de mobiliário de Lina Bo Bardi, que também fez uso de formas pontiagudas, linha angulosa e madeira compensada, o acabamento e a qualidade dos materiais se diferenciavam, assim como os discursos e as práticas em torno dos produtos. O conteúdo expresso no anúncio de venda é um exemplo evidente.

Do mesmo modo que as estratégias de produção se basearam no desenho simplificado, na racionalização do processo produtivo e na 
diminuição dos custos com a utilização de matérias-primas de menor valor agregado, as estratégias de distribuição e vendas reiteram o esforço de espraiamento e popularização dessas peças. A disseminação das manufaturas modernas se deu com a revenda autorizada em diversas lojas e grandes magazines tanto em São Paulo quanto em outras cidades. Para acelerar a difusão, valeram-se também dos mecanismos sedutores de divulgação da propaganda moderna, com slogans no imperativo ("Renove", "Peça", "Insista"), fotografias e desenhos ilustrativos propondo uma nova forma de organização do espaço doméstico. [fig. 24 a 28]

O material publicitário da Móveis Artísticos $Z$ foi veiculado nos mais variados meios de comunicação, mostra do esforço de difusão de seus produtos visando abarcar um mercado de consumidores ampliado. Eram cartazes criativos e arrojados, com informações sobre os móveis, indicações de modos de uso e sugestões de decoração. Ao longo dos anos 1950, foram encontrados anúncios nos jornais Estado de S. Paulo, Diário de Notícias, Diário Carioca, e nas revistas O Cruzeiro, Readers Digest e Casa e Jardim, revelando o interesse dos proprietários da empresa em alargar a circulação de seus produtos, na expectativa de atingir camadas sociais diversificadas. Os títulos indicam que são revistas e jornais de acesso a um público ampliado de consumidores, que adquire suas peças sem intermediário. Não se trata, portanto, de revistas especializadas, como Acrópole, Habitat, Módulo, onde apareciam os anúncios do Studio Palma e Branco\&Preto. Neste caso, a estratégia de divulgação era atingir os arquitetos, que seriam os orientadores do gosto de seus clientes.

De outro modo, a dinâmica de distribuição ampliada e as estratégias publicitárias da Móveis $Z$ se combinaram na tentativa de propagar o estilo moderno e vulgarizar seu consumo. As propagandas divulgadas na mídia da época são explícitas desse interesse e serão analisadas aqui tendo em vista a projeção do perfil social do público recrutado para o consumo desses artigos domésticos. Em outros termos, na impossibilidade empírica de se levantar os nomes dos clientes que acessaram esse mobiliário, optou-se por fazer uma análise detida desses anúncios, buscando extrair algumas das propriedades sociais dos destinatários. Uma vez que esses produtos não 
foram feitos sob encomenda, isto é, projetados a um cliente individualizado (nomeável), a linguagem dos reclames nos permitem localizar, em plano mais amplo, o alvo dessas ações de comunicação, público provável, possível ou desejável.

Nesse sentido, é possível afirmar que o arranjo gráfico dessas peças de propaganda é expressivo das estratégias de convencimento orientadas a um público específico. O conjunto de elementos visuais e discursivos empregados, tais como slogans e palavras de ordem, desenhos e fotografias, pontos de distribuição elencados e opções de pagamento são sinais dos modos de aquisição cultural e visões de mundo materializadas. Os cartazes, em sua maioria carregados de informação, apresentavam desenhos e fotografias dos móveis, que se misturavam a slogans, preços, formas de parcelamento, em imagens sobrepostas. Um dos anúncios encontrados, de 1953, passa a ideia de leveza e apuro estético, os demais possuem uma linguagem sobrecarrega de elementos visuais e textuais. Quanto ao conteúdo, a propaganda procurou vincular de maneira explícita o bom gosto ao bom preço, reiterando que os produtos estariam "ao alcance da maioria":
"Custam bem menos do que você pensa"76
"Novos modelos, Novos Conjuntos, Preços mais acessíveis"
"Renove de uma só vez, ou parceladamente, o mobiliário de seu lar com os legítimos móveis modernos, ao alcance da maioria"
"Móveis Z custam menos, graças a seus aperfeiçoados métodos de produção. Insista sempre nos legítimos Móveis $Z^{\prime \prime}$

Os anúncios são persistentes em convocar um mercado expandido de consumidores, acessando as camadas sociais embaladas pelo boom de modernização dos anos 1950, mas sem condições de arcar financeiramente com essas novidades. Para tanto, se valem da divulgação ostensiva do parcelamento no pagamento dos produtos, com apelo ao crediário:

76 Todas essas frases foram extraídas das propagandas encontradas. Esse material foi reproduzido no Caderno de Imagens. 
"Mobília de quarto para solteiro. Cama com mesa de cabeceira, guardaroupa, camiseiro: 600 , mensais"

"Bar revestido em plástico de várias cores, com armários, 340 mensais" "Poltrona estofada em plástico de várias cores, com molas-no-sag, 95 mensais"

Dirigindo-se a uma clientela que não teria acesso à contratação de arquiteto-decorador, ou seja, sem condições para bancar um serviço personalizado de orientação de gosto, o oferecimento de um catálogo com sugestões de uso dos produtos pressupõe que o encargo da decoração seria do próprio cliente. Esses encartes ofereciam prescrições de uso e modelos de decoração:

"Veja como é fácil decorar livings, salas de jantar e estar, dormitórios, jardins de inverno, e qualquer ambiente com os magníficos móveis funcionais Z. Nossos revendedores distribuem (gratuitamente) esse álbum com belíssimas sugestões para o seu lar. Não o encontrando peça-nos diretamente"

Para adequar-se aos espaços menores das residências desses grupos sociais, aparece o apelo a propostas de móveis flexíveis, que reúnem várias funções como "bar, discoteca, estante e divisão de ambiente", nos termos do anúncio denominado como "double-face". Trata-se de uma estante vazada instalada do teto ao chão, que reúne prateleiras usadas para o arranjo das garrafas do bar, de livros e discos, e funciona como divisória da sala de estar com a sala de jantar. O móvel prometia se adequar aos novos modos de apropriação dos espaços domésticos, mobiliando cômodos que servem ao lazer, recepção de amigos e organização das aquisições culturais e das memórias familiares, com espaços planejados para vinis, livros, fotografias. O imperativo de "aproveitamento total do espaço" é justificado por móveis e sofás arredondados, que ocupam melhor os cantos da sala ou na sala de jantar, cadeiras cujos pés não coincidem com a mesa, "sem estorvar os que sentam". 
Nos cartazes de anúncio, as frases sintéticas apresentadas com variação de tipologias e cores, tamanhos e volumes, dão um perfil descontraído ao material. Quanto ao conteúdo, se por um lado fundem a imagem de modernidade à economia, também procuram assegurar que o barateamento do produto não comprometeria, no requisito estético, os padrões de bom gosto e vanguardismo, e, no requisito funcional, o compromisso com qualidade e conforto:

"Cada novo móvel é um padrão de bom gosto, conforto, atualidade, originalidade"

"Para dar a seu lar todo aquele encanto que você sonhou"

"Moderno, funcional, proporciona o máximo de aproveitamento do espaço"

A maneira detalhada de anunciar os materiais e revestimentos é indício de uma postura com teor didático, preocupada em fornecer informações técnicas e práticas sobre o produto. Essas prescrições se propõem a informar tecnicamente sobre o produto, mas também cumprem funções quanto à educação do gosto e à modelação do corpo, ampliando a disseminação do estilo moderno como um modo de vida. Quanto ao uso dos móveis, por exemplo, as recomendações deixam entrever uma oposição às exigências de compostura e rigidez corporal, orientando os usuários a assumir posições confortáveis e relaxadas. As propagandas validam ideias de facilidade, limpeza, conforto, não desperdício, economia e conservação, valores que podem ser associados aos grupos sociais circunscritos às necessidades cotidianas e imediatas:

"Compensados feitos com cola de avião", "tecidos indesbotáveis", "plásticos extrafortes, laváveis, "madeiras e compensados extrafortes impermeabilizadas contra cupim e à prova d'água".

"Z - significa o famoso molejo "no-sag", indeformável e eterno"

"Z - significa estofamento plástico colorido, lavável com água e sabão, conservando por muito tempo seu aspecto de novo" 
"Z - significa o corte moderno da madeira que se curva ou se alonga para formar um conjunto harmonioso"

Como se observa, para além das rodas sociais já familiarizadas e ajustadas ao gosto moderno, tal como se fez nas outras iniciativas do desenho de mobiliário, o desafio da Móveis $Z$ foi persuadir em termos de linguagem formal, custos, estilos de vidas e visões de mundo de outras camadas sociais a aderir às linhas arrojadas, oferecendo, a preços reduzidos, produtos de cores fortes, design prático, descontraído e impactante.

Em meados da década de 1950, a fábrica matriz de São José dos Campos chegou a contar com mais de 150 funcionários e uma dinâmica de distribuição e comercialização em inúmeras lojas autorizadas. Somente na cidade de São Paulo, conforme consta nas indicações de endereço das propagandas, mais de 20 lojas ofereciam esses produtos, em bairros como Centro, Brás, Santa Cecília, Liberdade, Consolação, Pinheiros, Vila Mariana, Tucuruvi, Ipiranga, bem como em cidades do entorno paulistano, dentre elas Santo André e São Bernardo do Campo. Ainda que centrais e diversificadas, essas regiões demarcam um perfil de consumo entre classes médias e populares. Esse mobiliário também foi disseminado para além da cidade de São Paulo. As propagandas indicam a revenda autorizada em quatro lojas em Santos, além de lojas em Campinas e em cidades de outros estados da região sudeste e sul, como Rio de Janeiro, Petrópolis, Belo Horizonte e Londrina, centros urbanos que se adensavam e diferenciavam.

Uma nota sobre o malogro da experiência, com a saída de Zanine Caldas e a orientação de seu percurso profissional, pode ser aqui mencionada para o entendimento da limitação da oferta desses artigos, dos impasses em relação ao campo da arquitetura e das contradições em relação a um programa estético carregado de intenções. A Móveis Artísticos $Z$ esteve em atividade por 12 anos, entre 1948 e 1960; o afastamento de Zanine Caldas como designer do mobiliário moderno ocorreu ainda em meados dos anos 1950 (LEON, 2009). A saída foi explicada pelo desentendimento com os sócios empreendedores que, convencidos do 
sucesso comercial do produto, demonstraram desinteresse em investir no desenvolvimento de novas peças e na renovação estética. Segundo Zanine, os empresários trabalhavam de forma mecânica na repetição dos mesmos desenhos, sem dar espaço para novas criações.

Sob justificativa de cerceamento de liberdade ${ }^{77}$, Zanine Caldas reconduziu sua carreira na década seguinte para a produção de móveis sob encomenda, com o desenvolvimento de peças únicas, de talhe artesanal a partir de grandes toras de madeira (SANTOS, 1993). Tal reconfiguração o levou a ocupar, no mercado internacional do mobiliário, um lugar de artista, "escultor" de peças utilitárias, móveis únicos e assinados que são difundidos sob os mesmos padrões de autenticidade e singularidade conferidos a uma obra de arte. O que se constata é que no enfrentamento entre o desenhista industrial e o artista, entre o produto serializado e a obra autoral, malgrado a limitação do produto a segmentos privilegiados, Zanine foi levado a ocupar uma posição que reiterou o mito do artista criador, condição reveladora dos valores de reconhecimento e consagração no campo arquitetônico.

\section{Formação do gosto moderno e detração do gosto hegemônico}

O discurso em defesa de uma produção autônoma, não subordinada às imposições do mercado ou de sua clientela, tem a presunção de garantir uma posição de maior prestígio no campo arquitetônico, decorrente da vinculação da arquitetura a uma arte pura, desinteressada e afastada das injunções comerciais. Estrangeira em um país que se queria radicalmente moderno, Lina Bo Bardi procurou, de corpo e alma, ocupar posições incisivas na configuração do campo artístico e cultural. Na distinção entre "obras feitas para o público e as que devem fazer seu público" (BOURDIEU,

77 De acordo com Maria Cecília Loschiavo dos Santos: "ateando fogo aos próprios desenhos, na década de 1950, para marcar o encerramento de sua participação na Fábrica de Móveis Z”. (SANTOS, 2015, p.153) 
1996, p. 247), as apostas da arquiteta mostram que ela tomou partido pela fomentação do gosto moderno. Para produzir essa legitimidade, atuou na detração dos gostos que ela julga espúrios, ora associando-os ao ecletismo dos estilos passadistas, aos usos ostensivos da estética burguesa ou às combinações estridentes dos que se pretendem modernos. Esses ataques são marcadores explícitos de suas posições e suas práticas:

"Eu tenho projetado algumas casas mas só para pessoas que eu conheço, por quem eu tenho estima. Tenho horror em projetar casas para madames, onde entra aquela conversa insípida em torno da discussão de como vai ser a piscina, as cortinas[... $]^{\prime 78}$.

Com esse depoimento, Lina Bo Bardi explicíta uma recusa e demarca seu ponto de vista em relação ao desafio do arquiteto em servir como educador do gosto de grupos distantes de suas orientações estéticas e desajustados em relação às suas disposições políticas. O uso do termo "insípido", adjetivo marcadamente vinculado às noções de gosto, e, nesse caso, à acusação de "ausência de gosto", está carregado de significação. A metáfora utilizada postula sobre algo ao mesmo tempo desprovido de interesse, de elegância, de sabor e de classe. E não é casual que a referência ao caráter fútil da decoração do espaço doméstico esteja direcionada às "madames", as mulheres de classes abastadas, frequentemente associadas à função de dona de casa, sem atividade no mercado de trabalho e que não incorporaram formalmente disposições culturais e estéticas. A declaração da arquiteta expõe sua ojeriza a clientes que, em seu ponto de vista, estão presas na levianidade de suas aspirações, que não incorporaram nos modos de morar o paradigma moderno (que se pressupõe esteticamente depurado, politicamente engajado e moralmente independente). Por outro lado, sua fala também expõe as ambições e os caprichos de quem pretendeu assumir uma postura autoral, de arquitetura criadora, para qual a exigência radical é a não concessão aos gostos dos clientes.

78 Entrevista de Lina Bo Bardi reunida em FERRAZ, Marcelo Carvalho (org). Lina Bo Bardi. São Paulo: Empresa das Artes, 1993. 
Em um momento de constituição da autonomia do campo arquitetônico, ficar sujeito às necessidades da clientela ou se curvar servilmente ao gosto da demanda se manifesta como um ponto constante de temor dos arquitetos. Sob risco de ferir sua liberdade de criação, a ameaça é percebida como heteronomia, quando o arquiteto perderia a capacidade de impor seu projeto ao cliente. Tal risco aparece quando o encomendante destoa das expectativas do arquiteto, critica o projeto ou discorda das soluções formais, situação que traz à tona assimetrias entre arquitetos e clientes na adoção de estilos de vida e na afirmação de valores estéticos, expressão também de posições distantes no espaço social.

A rejeição em projetar para um público vinculado ao modo de vida pejorativamente tachado como "burguês", cujas preferências não estariam apuradas nos valores vanguardistas, expressa o desejo dos modernistas em garantir sua autonomia na definição do partido arquitetônico, ou seja, de manter certo grau de independência em relação às sanções que as demandas dos clientes impõem ${ }^{79}$. Por outro lado, projetar novos espaços de morar para amigos e estimados significa pregar para convertidos, ou para grupos que, próximos dos ambientes dos produtores, apresentam adesão aos mesmos estilos de vida.

Uma vez que ambos estavam dotados de disposições estéticas adquiridas nos mesmos espaços de fruição, formação e julgamento de gosto, as ligações permanentes entre arquitetos e certas frações de classes em ascensão no panorama das artes é condição para validar o sentimento de independência desses profissionais, ou seja, a percepção de que estariam produzindo artefatos sem intervenção, corroborando para a ilusão cultivada no mundo das artes de se produzir uma forma livre de coerções. Tal convicção é vivenciada pelo arquiteto como maior autonomia na definição das formas e propostas artísticas.

A proximidade social parece contribuir para aliviar a relação tensa materializada nas disparidades de expectativas sociais e visões de mundo

79 Conforme explicita Jose' Carlos Durand: “clientela, bem dotada de trunfos culturais e cumplicidade bastante para conceder ao arquiteto a autonomia que ele julga necessária para produzir a sua arte" (DURAND, 1989, p.282) 
entre cliente e arquiteto. A situação ganha evidência quando Lina se refere ao projeto da residência que fez para si, celebrada como uma oportunidade de defender exemplarmente a radicalidade de suas tomadas estéticas. É assim que a arquiteta descreve o projeto, pelo qual se observa que tanto o edifício quanto o discurso sobre ele são modelares da pretensão de posicionamento no campo artístico e arquitetônico em formação:

"Esta casa é, num certo sentido, polêmica, como aliás deveriam ser todas as construções de arquitetos de responsabilidade, especialmente se não existem compromissos com o comitente. Quase a totalidade da arquitetura contemporânea, mesmo quando executada por arquitetos de responsabilidade, denuncia 'ideias' e 'gostos' dos proprietários que carecem, na maioria dos casos, de base. Se um arquiteto da nova geração erra, isso se deve quase sempre à interferência do comitente. Neste caso, a situação foi outra: o comitente era o próprio arquiteto" ${ }^{80}$.

Como ela mesmo argumenta, uma vez que arquiteto e encomendante sobrepõem-se na mesma pessoa, a distância entre as duas figuras centrais na prestação do serviço é eliminada. Não por acaso que o projeto da casa do próprio arquiteto, tendo em vista a atuação dos vanguardistas, revela-se como ocasião decisiva de engrandecer seu portfólio, materializar suas escolhas estéticas e afirmar sua posição. Na perspectiva dos arquitetos que reivindicam o estatuto autoral, a situação ideal de exercício profissional é projetar para um cliente à sua "imagem e semelhança", condição em que estaria livre para produzir uma casa-manifesto ou reafirmar seus princípios estéticos construindo um edifício que lhe sirva de cartão de visitas.

A residência dos Bardi, chamada "Casa de Vidro", foi construída em 1950, poucos anos após a fixação do casal em São Paulo, e pode ser vista como uma clara estratégia de investimento para garantia de posição legítima. O projeto da casa é um bloco suspenso por pilotis, caixa de concreto vedada por amplos painéis de vidro [fig. 01 e 02]. O volume transparente, como uma vitrine exibindo a coleção de objetos de arte do casal, foi a primeira casa implantada no Morumbi, bairro para as classes

80 Habitat, no 10, 1953, p.38. (grifos meus) 
abastadas recém-loteado. O conjunto arquitetônico é uma exposição eloquente dos gostos e estilo de vida de um casal afinado com as dinâmicas culturais da cidade. A semelhança da sala de estar da casa a um salão de exposição de artes, um "museu", como se comentava, chegou a levantar hipóteses, na época, de que ali seria construída a sede do Masp, instituição até então localizada improvisadamente no prédio dos Diários Associados, no centro de São Paulo.

Reafirmando a função de residência, na Habitat de 1953, décima edição da revista que coordena e que the serve de palanque, a arquiteta põe em evidência as responsabilidades e as vantagens advindas de produzir para si mesmo e em contrapartida o risco de servir a um cliente não cultivado. Na matéria intitulada de "Residência no Morumbi", com dez páginas ricamente ilustradas com fotos dos espaços internos e externos da casa, Lina Bo Bardi apresenta suas opções de projeto, a implantação no bairro, os detalhes construtivos, a integração com a natureza tropical, os materiais utilizados, a adequação à iluminação, o sistema de ventilação, os arranjos da decoração, as obras de arte etc. Justificando as suas preferências na decoração, a arquiteta sai em defesa de estilo de vida erudito, que se expressa nas prescrições de refinamento daqueles que sabem combinar peças do passado e do presente:

"Existe uma tendência, embora modesta, de eliminar da casa os objetos antigos. Aliás, no caso desta residência, a observação mais comum é que parece um 'museu'. Ter sobre um móvel um vaso de Orvieto do Quatrocentos é talvez mais confortante para quem gosta de Renascimento e portanto, da história, do que possuir um objeto qualquer encontrado na Rua Barão de Itapetininga. Ao lado da cerâmica de Orvieto, pode-se ver outra, não de Picasso como nas casas dos 'petits bourgeois' de regresso de Paris, mas de Melotti. Apreciar o antigo, o passado, a história, é o único índice cultural que diferencia o homem moderno dos visitantes de estádios e hipódromos" ${ }^{\prime \prime 1}$.

As oposições que a arquiteta emprega parecem trazer imagens

81 Habitat, $\mathrm{n}^{\mathrm{o}}$ 10, 1953, p.38. (grifos meus) 
alusivas dos embates entre frações sociais: apreciar obras de arte do passado X valorizar obras de arte modernas; Orvietto/Melotti X Picasso; objetos de herança $X$ peças de recente aquisição; apreciar a história $X$ desconhecer o passado; frequentadores de museus $X$ visitantes de estádios/hipódromos. Nesse trecho contundente, são alvos de sua crítica as práticas culturais dos novos-ricos, que adquirem peças pelo modismo, deslumbrados com suas recentes viagens à Europa. Por outro lado, ao referir a suas aquisições, a posse de peças de antiquário, que poderia ser uma aparente contradição, é apresentada como "índice cultural" do proprietário. No entanto, não basta qualquer peça comprada no comércio local, nas casas do ramo que se disseminavam pelas ruas do centro. Lina Bo Bardi é expressiva ao demarcar os mecanismos de distinção entre os modernos de boa cepa e os modernos sem estirpe, entre aqueles que sabem apreciar o passado e aqueles que usam, tropegamente, o passado, aspirando à tradição. Os "modernos de origem", na definição que emprega, dispensam adjetivos: esses são herdeiros de móveis com passado digno. Já os "modernos recém-chegados", aqueles que não herdaram móveis de família, são os provenientes de camadas sociais em ascensão.

Nesse jogo de oposição, aqueles que podem exibir conhecimento, refinamento e sofisticação se demarcam contra aqueles cujas escolhas caem no gosto novidadeiro, ostentatório e desarrazoado. Desprovidos de herança cultural adquiridas na antiguidade de suas posições e desapegados do vanguardismo, guiam-se pelas tendências e adquirem um "Picasso", sem se darem conta, na visão da crítica, que se trata de uma preferência já vulgarizada, "batida", uma vez que caiu no gosto do "grande público". Na alegação da arquiteta, escorregam, assim, para a adoção de um gosto moderno espalhafatoso, daqueles que frequentam os espaços mais imediatos de ostentação de riqueza.

Em sua categorização, o que a arquiteta nomeia de "petits bourgeois" parece ser um modo de indicar a caracterização de um gosto medíocre, tradicional, sem pretensões de subversão. A se tomar seu ponto de vista, esses grupos recém-dotados de capital econômico, mas sem acúmulo de competência artística e intelectual para sustentar suas aquisições estéticas, 
não se aventurariam nas escolhas do gosto valioso, raro e ousado, considerado distintivo e distinto. Abalizar as mais valorosas e representativas peças de arte e saber fazer a boa sintonia entre objetos modernos e antigos são apresentados como expressão de bom gosto e bom senso, portanto, mobilizam tanto uma categoria estética quanto moral. Sua maneira de preceituar as normas de elegância designa, no entanto, seu modo específico de aquisição cultural, de uma elite intelectualmente dominante, que concentra conhecimentos prolongados em história e mercado da arte, além de convívio nos círculos do colecionismo artístico internacional.

Classificando e desclassificando grupos a partir dos gostos e das aquisições culturais, Lina Bo Bardi se vale da atuação como crítica na revista Habitat e da inserção nas instituições culturais para irradiar suas posições e buscar o monopólio das definições legítimas em matéria de habitação. Além de retraduzir suas preferências, as expressões de recusa, desgosto e aversão da arquiteta a localizam no espaço social. É assim que se pode entender seu esforço constante em louvar certas práticas e recusar outras, cavando para si uma posição de árbitro do cânone estético. Não é à toa também que são constantes suas investidas satíricas contra "o mau gosto consagrado", identificado pelo excesso de ornamentos e pela exibição de opulência daqueles que precisariam do rebuscamento para aparecer.

Prontos a classificar o jeito digno e o inadequado de morar ou se comportar, em que as escolhas pela decoração também passam pela afirmação de decoro e elegância, os ataques ao "mau gosto" se expressam em um conjunto amplo de ações: no tom dos discursos, em desenhos, em notas na imprensa escrita e nos eventos mundanos, divulgados nas seções de colunismo social dos jornais. Uma dessas situações de evidente rentabilidade simbólica e midiática é a festa pré-carnavalesca organizada em fevereiro de 1950 pelo Instituto dos Arquitetos e pelo Museu de Arte Moderna, na qual as diversas frações dominantes, tanto dos meios culturais quanto econômicos, participam de um ritual contra o mau gosto, ou o gosto considerado ilegítimo. Conforme registra a cobertura jornalística de 1950, esses eventos congraçavam os círculos artísticos com figuras da alta 
sociedade, alguns propensos a ocupar o papel de mecenas [fig. 30]. Na reportagem, aparecem os nomes de alguns frequentadores da festa, entre eles pessoas das artes plásticas, arquitetura, crítica de arte, universidade e setores industriais associados ao patrocínio dos artistas: Francisco Matarazzo Sobrinho, Lasar Segall, Gregori Warchavchik e sua esposa Mina Klabin, Flávio de Carvalho, Quirino da Silva, Lourival Gomes Machado, Oswald de Andrade, Helena Silveira, além do casal Pietro e Lina.

A nota da coluna "Sociedade" do Jornal de Notícias de 02 de fevereiro de 1950 assim divulga os preparativos da festa, organizada pelas mulheres dos grupos de prestígio da alta sociedade, responsáveis pelo trabalho de coleta financeira, em parceria com os artistas modernos, a quem confiaram o embelezamento do espaço:

"Conforme tem sido noticiado, um grupo de senhoras da nossa sociedade resolveu organizar, em benefício do Museu de Arte Moderna, um baile pré-carvanalesco, nos salões do Trianon. Para essa festa, que se realizará no dia 11 de fevereiro, foi tomado como tema da decoração e das fantasias, a ridicularização do mau-gosto. Por isso, o baile recebeu o nome 'Triunfo do Mau Gosto'. Já se iniciaram as decorações do Trianon, confiadas aos artistas modernos de São Paulo, desejosos de exprimir seu desagrado pelas formas anti-estéticas e imperdoáveis, deste e de outros séculos. São os seguintes artistas que se dispuseram a colaborar: Aldemir Martins, Aldo Bonadei, Di Pretti, Flexor, Nelson Nóbrega, Noemia, Oswaldo de Andrade Filho, Penachi, Rebolo, Volpi e Zanini. A comissão organizadora está constituída das senhoras Alice Maluf, marquesa Cornaggia Medici Castiglioni, Bia Coutinho, Eva Ditchmor, Elisabeth Magnelli, Irene Giorgi, Jeanine F. Schulmann, Jani Segall, Lourdes Gomes Machado, Maria H. da Silva Barros, Maria Penteado Carmargo, Mussia Pinto Alves, Marcela Ascarelli, Maria Pia Mombelli, Marjorie Prado, Mina Warchavichik, Rose Borba, Raci Karan Latiffe, Renata da Silva Prado, Violeta Jaffet, Iolanda Penteado Matarazzo e senhora William Lee. Os bilhetes de ingresso serão postos a venda no Museu de Arte Moderna, à rua 7 de Abril $[\ldots]^{182}$

82 Jornal de Notícias, 02 de fevereiro de 1950 (grifos meus). 
Por meio do deboche, a explicitação das posições de recusa ganha significação quando o mau gosto é elevado a tema oficial do baile de fantasia. O nome "Triunfo ao Mau Gosto" convoca os convidados a expressar seu desprezo pelos estilos de vida que consideram não dignos de valor, ou, nos termos do anúncio, as eleições estéticas "imperdoáveis". Vestiram-se espalhafatosamente, de modo a zombar do gosto tido como vulgar, deselegante, não sofisticado e, também, os não modernos, a se contar pelos convidados a decorar a festa. A fotografia do evento de 1950 mostra Lina Bo Bardi trajada com um figurino cheio de ornamentos, um longo vestido de tecido brilhante, acetinado e decorado com tassel, e um enorme chapéu, enfeitado com argolas e cristais; a seu lado está o arquiteto Warchavichik, com um terno largo acinzentado de tecido com padrão de linhas quadradas, flor na lapela, barba e bigodes falsos, chapéu panamá e uma máquina fotográfica a tiracolo. A posição de destaque e o esmero na galhofa rendeu a Lina Bo Bardi o título da melhor fantasia cafona daquele ano de 1950 [fig. 03]. Após o evento, a manchete do jornal Diário da Noite, de 13 de fevereiro de 1950, é expressiva em nomear a consagração do "museu vivo de horrores", na qual se anuncia a "Definitiva consagração do mau-gosto. Transformado ontem o Trianon em um museu vivo de horrores. Decorreu muito animado o baile em benefício ao Museu de Arte Moderna"83

A despeito da ritualização em torno do mau gosto, tais práticas não comprometem os repertórios modernizantes aos quais os participantes buscam se vincular. Ao contrário, os deslizamentos entre o gosto legítimo e o gosto desclassificado se destinam a reafirmar o lugar de vanguarda que estão em vias de ocupar, a ponto de se poder anunciar: "o mau gosto assim já é arte" ou "o resultado de tanto mau gosto vai redundar, de certo, no engrandecimento de uma casa de bom gosto e de beleza, o Museu de Arte Moderna de São Paulo"84. Frequentado por aqueles que visam controlar os códigos de definição do que é bom gosto, moderno e legítimo, esses eventos mundanos abrem a possibilidade de encontro entre arquitetos, artistas, empresários e clientes, estabelecendo trocas materiais e

83 Jornal Diário da Noite, 13 de fevereiro de 1950.

84 Jornal Diário da Noite, do dia 13 de fevereiro de 1950. As legendas das fotografias indicam que Lina Bo Bardi foi campeã do baile naquele ano. 
gratificações simbólicas nas quais os produtores do mundo da arte, patronos e intermediários conferem uns aos outros o poder de consagração dos seus estilos de vida.

\section{Gostos e estilos de vida sob medida}

A proposta de investigar o público destinatário dos móveis produzidos por três empresas parte do pressuposto de que a apropriação de bens culturais é reveladora das sociais dos indivíduos e dos conflitos estabelecidos no campo de produção e consumo. O domínio do desenho industrial, linguagem especializada cuja emergência ocorre nos anos 1950, mostrou-se propício à compreensão dos embates entre valores dos arquitetos, proposições estéticas, modos de produção e apropriação dos objetos de design e lógicas de consumo. Nesse sentido, além das disputas travadas pelos produtores, por agentes que carregam seus diferentes capitais, redes de sociabilidade e visões de mundo, caucionando distintas propostas formais, entre os consumidores, a comparação das três firmas se mostra expressiva das preferências estéticas que impactam a diferenciação dos gostos e os estilos de vida.

Por meio dos orçamentos que registram a encomenda e dos desenhos de projetos de design de interiores do Studio Palma e da Branco\&Preto foi possível apontar os destinatários privilegiados desses objetos: camadas intelectualizadas e artísticas em ascensão no panorama cultural paulistano, atuantes em profissões liberais e/ou de orientação estética, como médico, jornalista, radialista, artista plástico, músico, fotógrafo; e uma burguesia industrial com concentração de capital econômico e cultural, frequentadora de espaços artísticos e eventos sociais mundanos da cidade. O levantamento da clientela dessas duas firmas foi necessário para apreender a emergência do gosto moderno entre as frações de classe ilustradas, grupos sociais que têm como diferencial o acúmulo de capitais de todas as espécies. Dentro dessas frações de classes dominantes e esclarecidas, 
muito deles, tal como Lina Bo Bardi e Jacob Ruchti, estrangeiros abastados conectados ao gosto internacional, procuraram se separar das frações dominantes dotadas de alto capital econômico assumindo, principalmente, a estética moderna como elemento de diferenciação.

A atuação programática desses profissionais instigou a conversão dos modos de percepção dos consumidores, com a intenção de torná-los aptos a apreciar as novas formas de morar. Todavia, no ordenamento dos espaços privados de uso residencial, a aceitação e o espraiamento da estética moderna estiveram alicerçados em mudanças na composição da sociedade paulistana dos anos 1950, cujo reordenamento levou à constituição de uma clientela dotada de condições para apostar no valor estético desses objetos.

Ainda que as amplas promessas de transformação das relações sociais pelas mudanças espaciais e estéticas encampadas pelo discurso arquitetônico moderno não pudessem ser garantidas, coube aos arquitetos o papel de fomentar a formação de um gosto refinado e ousado em matéria de decoração e mobiliário. Em que pese o empenho discursivo e programático dos arquitetos modernos na defesa da democratização do design, a forma de produção dos móveis em questão não atingiu um mercado ampliado de consumidores anônimos, que seriam contemplados com a disseminação do produto a partir da tiragem em escala industrial. Ao contrário: a feitura do mobiliário moderno ocorreu, em sua maioria, a partir de uma lógica artesanal, tendo como destinatário o cliente exclusivo.

Embora o elã progressista do período instigasse a utopia de desenhar móveis para serem produzidos em processo industrial, esses objetos de decoração tiveram uma clientela restrita, frustrando as expectativas de seus criadores. Não por acaso a maioria desses artefatos realizou-se sob a forma de encomenda, ou seja, um produto personalizado para um cliente individualizado e nominável, calibrado ao gosto de um público cultivado e ávido por adquirir as insígnias da modernidade. O desalinho entre o desejo de disseminação irrestrita e realização para uma clientela recolhida pode ser entendido a partir de um olhar sociológico orientado a compreender as práticas que caracterizam os estilos de vidas de determinados grupos sociais. 
Sem se atentar para as especificidades da localização social do público que encampou esses produtos simbólicos, o que se depreende é um sujeito abstrato, ou supõe-se que o gosto moderno estaria disponível a todos, universalizando uma escolha estética que, na verdade, esteve circunscrita a um pequeno grupo social com gosto apurado nas suas aquisições familiares, escolares e em suas redes de convívio ${ }^{85}$. A ausência do destinatário fica visível nas fotografias desses objetos: os móveis, cadeiras e poltronas permanecem desocupados, as casas, em suas salas de estar e jantar, são esvaziadas, sem rastros mais evidentes da presença dos moradores da casa. São formas de apresentação e exposição que dão centralidade à forma em detrimento ao uso, contrariando, diga-se de passagem, um dos mitos da arquitetura moderna repetido na frase "a forma segue a função" ${ }^{\prime 86}$.

Com o destacamento de uma nova elite cultural, novas organizações, formações acadêmicas, instituições artísticas e instâncias de divulgação se dinamizaram, fomentando expectativas de mudança dos padrões de sociabilidade e sensibilidade. Nesse arranjo, os arquitetos colocariam na prancheta linhas, formas e volumes dos artefatos materiais e simbólicos a preencher as casas, as vidas e as almas de seus moradores. Colaborando para certificar a legitimidade da estética moderna, algumas das figuras de proa das instituições culturais do período, como os empresários Cicciolo Matarazzo, Yolanda Penteado, Alfredo Mesquita, Maria Luíza e Oscar Americano, não se furtaram a incentivar e consumir o gosto moderno. As instituições culturais em emergência no período - Masp, Teatro Cultura Artística, Cinema Art Palácio, entre outras - também deram impulso ao estilo, mobiliando seus espaços nessas tendências estéticas.

Por outro lado, a distância entre os clientes nomináveis (Studio Palma

85 Uma sociologia do gosto, atenta para as legitimidades e hierarquizações no consumo de bens simbólicos, é uma das portas de entrada para se contrapor a versão oficial da história da arquitetura moderna.

86 É de Panofsky a precisa observação: "O gosto clássico exigia que as cartas particulares, discursos legais e escudos de heróis fossem 'artísticos' (resultando, possivelmente, no que se poderia denominar de 'falsa beleza'), enquanto que o gosto moderno exige que a arquitetura e os cinzeiros sejam 'funcionais' (resultando, possivelmente, no que se poderia denominar de 'falsa eficiência')". PANOFSKY, Erwin. "A história da arte como uma disciplina humanística”. In $O$ significado nas artes visuais. São Paulo, Perspectiva, 2012. p.32. 
e Branco\&Preto) e os anônimos (Móveis Artísticos Z) explicita diferenças na produção e no consumo desses artefatos. Decorrentes da disseminação e rotinização das formas modernas, essas hierarquizações na constituição do gosto são inerentes à dinâmica de distinções das práticas culturais. Servindo às necessidades simbólicas e materiais de grupos bem delimitados no ambiente cultural paulistano, pode-se afirmar que as práticas e preferências em relação ao consumo do mobiliário moderno opõem grupos com diferente estrutura e volume de capital, não apenas em relação aos objetos adquiridos, mas em relação aos modos de apropriação e aos discursos proferidos pelos produtores. É o que se pode extrair a partir dos embates entre Lina Bo Bardi e Zanine Caldas, em relação à legitimidade das formas modernas.

Assim, foi possível verificar que a hierarquia dos produtos corresponde a uma hierarquia dos consumidores. No polo de produção restrita, mais autônomo e produzindo objetos exclusivos, de desenho sóbrio, com madeiras e tecidos nobres estão a Branco \& Preto e o Studio Palma. No polo mais comercial e com produção em larga escala voltada à disseminação do mobiliário moderno em diversas regiões do país, está a Móveis Z, com objetos de linhas ousadas produzidos com madeira compensada, material não nobre, estofamento de tecido sintético e acabamento rústico. As distinções entre os dois polos se expressam na forma de produção. O objeto único, o artefato personalizado, se opõe ao produto genérico, à mercadoria industrial. De um lado, a encomenda sob medida, com processo artesanal, restrição que se apresenta também como garantia de qualidade e distinção. De outro, a produção na linha de montagem, industrializada, padronizada, gerando aumento da quantidade, o que, como consequência, interferiu na qualidade do acabamento dos produtos e provocou vulgarização.

Quanto aos consumidores dos móveis, contrapõem-se de um lado, encomendas que se restringem à rede de sociabilidade dos círculos próximos aos arquitetos; de outro, peças que, devido ao barateamento da produção, atingem um público ampliado, em estratégia de espraiamento que se dá com a divulgação de anúncios em revistas e jornais de grande 
circulação. A ampliação desses móveis modernos para além das camadas sociais a que estavam restritos também contribuiu para disseminar o estilo moderno, ainda que, na maioria das vezes, a escolha pelo racionalismo e a "limpeza" das formas seja uma justificativa para economia de material, tendo em vista maiores lucros no processo produtivo.

Quando se traz a relação de consumo, diretriz pouco trabalhada na historiografia do desenho industrial, o perfil da clientela que teve acesso a esse mobiliário explicita que o gosto moderno esteve submetido às posições na estrutura social e às competências adquiridas em círculos sociais cultivados, relação que se formaliza na dinâmica de produção sob encomenda desses objetos. Sob medida, a oferta desses produtos serviu às frações de classe alta em afinidades com os campos das artes que, em busca de figurar na dianteira dos empreendimentos de vanguarda, investiram em um projeto estético modelador da vida cotidiana, ambientando os espaços domésticos com novidades em matéria de decoração.

Ainda que a produção de móveis modernos na década de 1950 tivesse como horizonte mais amplo a industrialização e universalização dos componentes, com vistas a engendrar um novo homem modernizado, observa-se um impasse. Ao fracassar a mecanização ampliada do processo produtivo e a sequente diminuição do preço do produto, grande parte dessa produção realizou-se de forma artesanal, personalizada, qualificando-se com as funções sacralizadoras emprestadas da obra de arte. A criação de um objeto artístico, marcado pela ideia de autoria, além de impor a necessidade de mão de obra especializada, limitaria a produção a uma pequena tiragem, fatores que, colocados na ponta do lápis, causavam prejuízos aos proprietários. Somado a esse arranjo difícil, as criações eram alvo de cópias e adaptações, jogando no mercado peças parecidas que, com preços menores, desbancavam o concorrente. Sintoma disso são os debates sobre a defesa dos designers e a luta pela definição de "direitos autorais" em relação a seus projetos.

Ao visar a disseminação de produtos arrojados para amplos setores da população, essa mobília expõe uma relação contraditória do processo de 
modernização das formas e revela uma tensão em relação ao projeto estético moderno. O barateamento dos custos dos produtos traria as queixas de outros agentes do campo, insatisfeitos com a falsificação e a perda da aura das mercadorias exclusivas. Endereçados a um público maior, ocorria a diluição de um repertório elevado, antes circunscrito aos segmentos de elite. Os industriais detentores dos meios de produção também se mostravam pouco interessados a incorporar a inovação estética na feitura dessas mobílias.

Vistas como acúmulo de um projeto modernizador ou como impasse histórico, ao expor um baixo grau de andamento das condições produtivas do país naquele momento, as tentativas frustradas de modernização podem ser tomadas como reveladoras das peculiaridades da industrialização em um país periférico, dando forma a injunções estéticas, políticas e sociais que atravessaram o design brasileiro ${ }^{87}$. No entanto, tomado o ponto de vista do consumo, ao se examinar a relação de afinidades na produção do gosto, observa-se que esses artefatos serviram prioritariamente às exigências simbólicas de uma restrita fração social, clientela culturalmente esclarecida e economicamente estabelecida, possivelmente os mais convencidos das razões e mais apegados às paixões de se habitar na modernidade.

Para essas frações, a linguagem moderna ofereceu, sobretudo, um mote para seus estilos de vida, uma plataforma de inserção no processo de transformações em curso, um recurso de exibição de seus engajamentos artísticos e, também, um instrumento de vocalização de suas aversões. O gosto moderno arrojado e refinado lhes permitiu distinguir-se do gosto comum, dos móveis "sem estilo", ou do gosto do passado, dos móveis do "estilo superado" ou ainda, do gosto popular, dos móveis modernos vulgarizados. Nos anos 1950, um momento de efetiva renovação de linguagens e fixação de uma nova ortodoxia arquitetônica, os grupos

87 Sobre forma estética e conteúdo social, inspiro-me nas reflexões mais amplas desenvolvidas pelo crítico literário Roberto Schwarz, principalmente em dois trabalhos: SCHWARZ, Roberto. Um mestre na periferia do capitalismo: Machado de Assis. São Paulo: Duas Cidades; Ed.34, 2000. SCHWARZ, Roberto. “Cultura e política, 1964-1969”. In: O pai de família e outros estudos. Rio de Janeiro: Paz e Terra, 1978. Sobre as ideias de Schwarz na crítica à arquitetura moderna brasileira, cf. ROSATTI, Camila Gui. Roberto Schwarz: Arquitetura e Crítica. Dissertação de Mestrado, São Paulo: FAU USP, 2010. 
detentores de capitais culturais rentabilizaram os lucros simbólicos de figurar na comissão de frente dessas transformações.

A cumplicidade entre comitentes e arquitetos foi assegurada na participação dos mesmos círculos sociais, momento de afinamento de suas visões de mundo e valores estéticos. Essa seria uma condição para a formação de percepções e apreciações estéticas em convergência, a ponto de os atrevimentos formais projetados pelos arquitetos não lhes causar estranhamentos. É nesse sentido que o ponto de vista da clientela aqui empreendido contribui também para revelar o caráter exclusivo e limitado dessa modernização. Inicialmente prerrogativa das frações dominantes ilustradas, o consumo do mobiliário moderno sob forma de encomenda mostraria os impasses da universalização dos modos de morar e o caráter quimérico da aposta emancipadora apregoada pelos arquitetos modernos. 


\section{CAPÍTULO 02}

\section{Prática profissional e engajamento: projeto modernizador de Vilanova Artigas}

"Na década de 1950, achei que era necessário mudar a tipologia
da casa paulistana. Tratava-se de mudar a divisão espacial da
casa da classe média paulistana, que necessitava se atualizar em
relação às modificações sociais que se processavam em nosso
país. Ela já não podia continuar imitando a casa tradicional,
influenciada pela vida no campo. Nessa época, por exemplo, era
comum as casas manterem a entrada de carro como uma
reminiscência da antiga cocheira, com os quartos de criados e o
tanque de lavar nos fundos da casa. As casas deveriam ser
pensadas enquanto um objeto de quatro fachadas, mais ou
menos iguais, ajustando-se à paisagem, como uma unidade.
Assim, tanto a garagem quanto o quarto de empregados e
lavanderia estavam incluídos na unidade"

Vilanova Artigas ${ }^{88}$

\section{Centralidade de um mestre}

A despeito da presença de outros arquitetos modernos, coube a João Batista Vilanova Artigas (1915-1985) projetar uma grande quantidade de programas representativos da modernização paulista: ginásios, escolas estaduais e privadas, faculdade, clubes de elite, sedes de sindicatos, estádio de futebol, hospitais, rodoviárias, conjuntos habitacionais etc. Esse amplo portfólio de mais de quatrocentos projetos $^{89}$ Ihe conferiu, em volume e

88 Depoimento In. Construção em São Paulo, setembro de 1984.

89 Os pesquisadores do laboratório Lab Arq-FAU, coordenado por Marlene Yurgel e Eunice Barbosa, reuniram grande listagem com todos projetos atribuídos a Vilanova Artigas. 
qualidade, reconhecimento e legitimidade como representante da nova linguagem arquitetônica.

Isso não quer dizer que outros agentes não atuaram naquele momento, mas a combinação de desempenho profissional, docente e militante deu vazão ao processo de consolidação de um lugar aurático na historiografia da arquitetura. O percurso de Artigas passou a ser visto como condensador dos processos de modernização. Tendo em vista a trajetória do arquiteto, é possível levantar questões sobre a organização do campo da arquitetura em São Paulo, nos anos 1950, momento de fixação de um padrão de atuação da profissão e de florescimento do repertório estético que irá orientar futuros aspirantes a ingressar no campo da arquitetura. A trajetória de Artigas (1915-1985) é exemplar para a compreensão da formação da arquitetura moderna em São Paulo a partir dos anos 1940. Sua participação engajada na produção e no debate arquitetônico explicita os arranjos institucionais levados a cabo tanto em relação à profissão quanto em relação à formação educacional no sistema universitário.

A dupla atuação na universidade e em escritório próprio contribuiu para que Vilanova Artigas conseguisse firmar uma linguagem que passou a ser reverenciada como base formal de um movimento artístico. A linguagem de seus projetos - grandes espaços fluidos no interior do edifício, relação dissolvida entre ambiente interno e externo, a força dos elementos estruturais, colunas, pilastras e pontos de apoio esculturais, rampas interligando os edifícios, grandes lajes planas de cobertura, volumes geométricos suspendidos, espaços arrojados com a proposição de novas formas de morar, aspereza do uso do concreto armado sem revestimento foram exaltados como projeto estético de máxima elevação moral. Estribado na ideia de "moralidade construtiva", a arquitetura moderna, em seu discurso, foi investida da condição de agente transformação social. Ainda que se reconhecesse como "enciclopedista", "comunista" e "sonhador", o arquiteto se incluiu como parte da geração "que procurou soluções para todos os problemas", e que almejou, com sua arquitetura, "fazer poesia desse processo todo"90. Entre a arte e a técnica, a arquitetura deveria ser

90 Depoimento de Artigas publicado em: FERRAZ, Marcelo Carvalho. Vilanova Artigas. São 
aparato material para o avanço do país. Com esse propósito, o repertório formal foi justificado como encarnação de um ideal sobre o desenvolvimento e a industrialização brasileira. Conforme declarou:

"Aconteceu que toda essa ética [refere-se à arquitetura de Frank Lloyd Wright vinculada à cultura norte-americana], me levou a compreender também, pelos cantos, a problemática do povo brasileiro, da nossa condição de subdesenvolvidos. Percebi que a arquitetura estava ligada a uma problemática nacional e popular e que era preciso arranjar uma ética que me reconciliasse com os ideais do povo brasileiro"91

Nesse sentido, é possível fazer uma breve aproximação ${ }^{92}$ com a figura paradigmática de Florestan Fernandes (1920-1995), personagem que se instituiu e foi instituído na condição de autoridade científico-acadêmica em uma disciplina especializada, ocupando posição central do desenvolvimento das Ciências Sociais em São Paulo, e também no Brasil (ARRUDA, 1995; GARCIA, 2002; PULICI, 2008). As duas personalidades carismáticas fazem parte de um grupo que, atravessando constrições sociais, teve acesso às primeiras gerações de ingressantes na Universidade de São Paulo, obtiveram suas credenciais acadêmicas e encontraram condições institucionais para conduzir carreira na atividade docente. Tal como Florestan Fernandes atuou na consolidação da Sociologia como disciplina universitária, Vilanova Artigas contribuiu para que a Arquitetura fosse incorporada como formação profissional oferecida no sistema de ensino superior, apartada das engenharias ou das belas-artes.

A criação da Universidade de São Paulo é um condensador das transformações que se operavam no âmbito cultural e de estruturação dos novos segmentos sociais. Em um momento de adensamento e complexificação dos arranjos societários do país, no qual a cidade de São

Paulo:São Paulo: Inst. Lina Bo \& Fundação Vilanova Artigas, 1997.p.33

91 Depoimento de Artigas publicado em: FERRAZ, Marcelo Carvalho. Vilanova Artigas. São Paulo:São Paulo: Inst. Lina Bo \& Fundação Vilanova Artigas, 1997 .p.24

92 A convergência de uma concepção sobre o papel da cultura é também sugerida por Carolina Pulici em Entre Sociólogos: versões conflitantes da "condição de sociólogo" na USP dos anos 19501960. São Paulo, Edusp, 2008. p.207. 
Paulo assume papel de ponta de lança nos rumos econômicos e culturais, a universidade fundada no início dos anos 1930 permitiria formar e acolher dentro da instituição trajetórias, por vezes díspares, imbuídas dos valores de mudança social, produção e transmissão de conhecimento. Florestan Fernandes, filho de empregada doméstica solteira, e Vilanova Artigas, filho de professora do ensino infantil no interior do Paraná que ficou viúva com três crianças pequenas, encontraram na universidade espaço para fazer valer suas disposições individuais de dedicação e compromisso social. Percursos singulares, conseguiram se destacar dos demais colegas de geração das suas respectivas escolas, a Faculdade de Filosofia, Letras e Ciências e a Escola Politécnica.

Passando da condição de alunos a docentes, Florestan Fernandes e Vilanova Artigas tiveram suas trajetórias talhadas no seio da Universidade de São Paulo. O engajamento acadêmico no ensino superior abriria espaço para a profissionalização e a rotinização de novas gerações de grupos sociais com acesso à universidade. Os dois personagens tiveram a academia como centro da carreira docente, espaço que lhes permitiu angariar legitimidade entre seus pares, formar novos quadros e firmar nova linguagem, em ruptura com às gerações passadas. Os dois professores, com as especificidades científicas e práticas de cada domínio de atuação, foram portadores de um discurso de inovação acadêmica, transformação social e confiança na modernização. Ambos respondem a um momento em que o discurso civilizatório organiza a prática profissional e serve de ancoragem ideológica ao grupo. As linguagens especializadas - científica e estética - são concebidas como ideal de emancipação social, que orientaria a intervenção na sociedade brasileira. Aí ficam evidentes o grau de autonomia e heteronomia de cada campo disciplinar e os sentidos do engajamento. Enquanto Florestan Fernandes, no campo acadêmico, defendia a cientificidade e travava disputa contra a linguagem "amadora" e ensaística da geração anterior, Vilanova Artigas, no campo da arquitetura, empenhava-se em validar uma inovação estética contra os valores do ecletismo e neoclassicismo dos palacetes e a importação irrefletida da arquitetura moderna norte-americana e europeia. Desejosos de construir uma resposta nacional, Sociologia e Arquitetura moderna são pensadas 
como base ideológica e material para transformação da sociedade brasileira, missão civilizatória que foi a raiz do carisma desses intelectuais ${ }^{93}$.

Amparados por esse projeto modernizador, as duas disciplinas seriam, em um horizonte mais amplo, erigidas como instrumento potencializador do desenvolvimento da nação. Tem-se aí uma aposta social. A luta simbólica entabulada pelos dois artífices da modernização se deu contra os entraves de um Brasil atrasado, seja por formular interpretação para os limites da revolução burguesa no país, seja por oferecer propostas de novas formas de morar para uma burguesia, na expectativa de superar o arcaísmo da sociedade, educar uma fração social e dotá-la de repertório ético e estético. Em relação ao encaminhamento e ao desenlace desse projeto, há que se sinalizar que ambos foram aposentados compulsoriamente pelo mesmo decreto, em 1969, sendo obrigados a deixar abruptamente seus postos de trabalho na USP.

Sendo assim, se é possível falar em uma "Escola Paulista" no âmbito da Arquitetura, tal como certificada e vangloriada pela tradição historiográfica da disciplina, seria preciso acrescentar, para além do debate estético e formalista que dá o tom dessas abordagens, o chão social que alicerçou tais transformações. Isso porque essa atualização da arquitetura paulista não irrompeu repentinamente, a partir de transformações estéticas limitadas a propiciar roupagem moderna aos novos prédios da cidade. As mudanças sociais encetadas nas décadas anteriores, cujo saldo positivo foi a fundação da universidade, consolidaram novos parâmetros no ensino, na prática e no horizonte de atuação, que se estenderam à renovação de uma profissão liberal.

Com isso, cabe observar que a formação de uma "escola", no sentido de identidade entre o conjunto dos participantes, passa pelo entendimento das condições sociais de formação do ensino, em seu sentido institucional, das condições sociais de produção de seus agentes, no sentido das disposições e competências exigidas àqueles que serão convocados a

93 Sobre o papel de Florestan Fernandes para a geração de cientistas sociais, Cf. KEINERT, Fábio Cardoso. Cientistas sociais entre a ciência e política (Brasil, 1968-1985). Tese (Doutorado em Sociologia). Faculdade de Filosofia, Letras e Ciências Humanas, Universidade de São Paulo, São Paulo, 2011. 
praticar uma arquitetura de autor e, as condições sociais de formação de uma clientela disposta a adquirir esses bens simbólicos.

É no entrelaçamento desses arranjos e disputas que se pretende focalizar a trajetória de Vilanova Artigas. Se a análise propõe a assumir a atuação do arquiteto como um fio condutor para compreensão desses processos formativos, mesmo sabendo das limitações que isso impõe, é porque a figura de Artigas deixou marcas na organização da profissão e do ensino ${ }^{94}$. A posição central que ocupou na definição do ofício de arquiteto se deu com sua participação na criação do IAB (Instituto dos Arquitetos do Brasil), em seu núcleo paulista, fundado em 1943. No ensino, teve forte atuação na institucionalização da Faculdade de Arquitetura e Urbanismo, a FAU-USP, separada da Escola Politécnica, que culminou em 1948 na criação do novo curso. Até então, na Universidade de São Paulo, a formação existente era de engenheiro-arquiteto, sendo que a concepção arquitetônica praticada estava vinculada ao paradigma beaux-arts, ou seja, voltada para a aprendizagem e a inculcação dos modelos neoclássicos. Esses novos espaços de afirmação corporativa e formação educacional deram vazão às perspectivas de um grupo dominado no campo, agentes interessados em modernizar a prática profissional e escolar e que atuaram de modo a recrutar seguidores, contribuindo para polarizar as tomadas de posição no campo da arquitetura brasileira.

O final dos anos 1940, em São Paulo, é o momento da institucionalização do ensino de arquitetura. Foram criados dois cursos: em 1947, a Faculdade de Arquitetura do Mackenzie, e em 1948, a Faculdade de Arquitetura da Universidade de São Paulo. Esse período se apresenta, assim, como de alianças para a reformulação da formação escolar, principalmente na capital paulista. Tanto na luta corporativa pela profissão do arquiteto, quanto na formulação do ensino, a tarefa que se impunha era a defesa das especificidades da nova profissão em relação à engenharia, com o desafio de sustentar a dimensão estética e artística da arquitetura. Fazer arquitetura seria se distinguir de outras atividades da construção,

94 Cf. FICHER, Sylvia. Ensino e profissão: o curso de engenheiro-arquiteto da Politécnica de São Paulo. São Paulo: Edusp, 2005. 
como engenheiros civis, mestres de obras e técnicos não diplomados no ensino superior.

O arquiteto passa a ser defendido como o profissional que oferece algo a mais que o "mero" projeto técnico, um ofício que se ocupa para além da execução. Impõe-se distinção entre construção e arquitetura: enquanto a primeira é vista como desprovida de senso estético, a segunda é sustentada em nome de uma intenção plástica ${ }^{95}$. Tais investidas resultaram na aglutinação dos arquitetos paulistas em torno de um projeto comum, obstinados a se organizar em torno das instituições essenciais à formulação de um programa com matizes próprias. Ainda que não diretamente voltados a assumir bandeira regionalista, de defesa de uma arquitetura declaradamente paulista, a emergência de instituições locais mobilizadas em torno da organização do ensino e da profissão garantiram coesão interna ao grupo e repertório comum que estimulou a emergência de especificidades dessa arquitetura paulista. Em relação à atuação do arquiteto, a principal mudança foi a constituição da atividade como profissão liberal. Ele passa a trabalhar em escritório próprio, em detrimento do contrato assalariado em construtoras. Em relação à implementação das escolas, a separação do ensino de arquitetura da formação politécnica contribuiu para o processo de autonomização do campo arquitetônico. Essas mudanças institucionais e profissionais estiveram atreladas à emergência da estética moderna.

Nos anos 1940 e 1950, as proposições estéticas de Vilanova Artigas estão amparadas nas ideias e utopias que circulavam pelos grupos da intelectualidade engajada nas manifestações culturais, alguns de esquerda e com militância política. Nesse período, artistas como o escultor Vitor Brecheret, o incentivador da cultura Alfredo Mesquita, os advogados trabalhistas Rio Branco Paranhos e Rivadávia Mendonça, o médico Juljan

95 É preciso salientar o papel fundador assumido por Lúcio Costa na definição da especifidade da arquitetura, que angariou o consenso dos arquitetos em torno da questão plástica, ao aproximar o trabalho do arquiteto ao do artista. "Arquitetura é, antes de mais nada, construção; mas, construção concebida com o propósito primordial de ordenar o espaço para determinada finalidade e visando a determinada intenção. É nesse processo fundamental de ordenar e expressar-se ela se revela igualmente arte plástica". Lúcio Costa: Registro de uma vivência. São Paulo: Empresa das Artes, 1995. 
Czapski, casado com a fotógrafa Alice Brill, o médico simpatizante do Partido Comunista David Rosemberg, o médico trotskista Febus Gikovate e o escritor e dramaturgo Oduvaldo Vianna, casado com a jornalista Deocélia Vianna, fazem parte do conjunto de encomendantes cujas residências deixam indícios dos círculos de sociabilidade em torno do arquiteto. Referendada por uma clientela apta a consumir uma estética de vanguarda, essas residências são linha de força da experiência social de renovação dos modos de habitar. O exame da trajetória do arquiteto e de sua prática profissional permite matizar um olhar sobre as oportunidades de carreira proporcionadas pelo processo de modernização da capital paulista em meados do século $\mathrm{XX}$.

\section{Anos de formação: arquitetura e engenharia}

Nascido em Curitiba, em 1915, João Batista Vilanova Artigas mudou com a mãe e os dois irmãos para o interior do estado do Paraná, na pequena cidade de Teixeira Soares, quando tinha seis anos. Primogênito de uma família de três filhos homens, tinha cinco anos perdeu o pai, situação que provocou a mudança de cidade. Brasílio Artigas, então comerciante de tecidos, sofreu acidente em uma de suas viagens para o Rio de Janeiro, pondo fim aos negócios familiares e obrigando a mãe a buscar outras fontes de renda. Sem esteio financeiro do cônjuge e na ausência de garantias familiares que assegurassem a sobrevivência da família, a viuvez precoce impôs aceitar, em 1922, uma oportunidade de emprego. Bacharel em Letras e Ciências, Alda conseguira uma vaga de professora normalista em uma escola pública no interior do Paraná, para onde se mudou com os três filhos pequenos $^{96}$. Somente em 1926, aos 11 anos, quando ingressou no ginásio,

96 Alda Vilanova Artigas teve três filhos: o primogênito João Batista; o segundo, Giocondo, nascido em 1916, e o caçula, Joel, nascido em 1918. Os dados biográficos da família Artigas foram extraídos do material biográfico do irmão de Vilanova Artigas, Giocondo. COELHO, Julio; CAMPOS, Antonio Carlos (org.) Giocondo Vilanova Artigas: o formador de cirurgiões. Curitiba: Relisul: 1991. 
Vilanova Artigas voltaria a residir em Curitiba, onde morou junto com os avós. Terminada a formação escolar básica, foi admitido, em 1932, no curso de Engenharia Civil na Faculdade de Engenharia do Paraná. Dois anos depois, migraria para a cidade de São Paulo, em busca de uma formação mais voltada para a arquitetura, uma vez que a politécnica paulista oferecia o curso de engenheiro-arquiteto. Vislumbrava também melhores oportunidades profissionais em uma cidade que empunhava a bandeira do crescimento urbano e do progresso econômico. O ano era 1934, não por acaso a data de fundação da Universidade de São Paulo, em que a tradicional Escola Politécnica foi incorporada à instituição.

Desde os anos iniciais de formação universitária, Artigas teve que se defrontar com os constrangimentos que a escolha pela arquitetura impunha em um meio familiar conservador, no qual a origem modesta da família era reforçada pelo ambiente provinciano de Curitiba. A saída da Faculdade de Engenharia do Paraná para o curso de engenheiro-arquiteto da Escola Politécnica é um marco desse confronto. Em tom de humor, o deslocamento na trajetória é analisado pelo próprio arquiteto como uma dissonância na rota almejada pela família, principalmente em relação às expectativas do avô durão, que possivelmente passou a ser a referência masculina de Artigas após a morte do pai. Em depoimento, fica visível a imagem subalterna ocupada pela arquitetura. Na disputa entre uma área de exatas e outra artística, vem à tona os polos em oposição: "engenharia" versus "arquitetura", "cálculo matemático" versus "desenho artístico", "formação prestigiosa" versus "formação vergonhosa":

"Entrei para a Escola de Engenharia do Paraná porque era moço e tinha facilidade para a Matemática. Os arquitetos, hoje, entram para Arquitetura porque têm facilidade para o desenho. Desenhar a gente desenhava mas, se eu dissesse para meu avô Artigas, que era severo e que me parece, hoje, uma figura do Garcia Marques, que eu gostava de desenho, ele acharia, um pouco desconfiado, que eu não tinha a machidão necessária para ser descendente dele. Por que o desenho era tido como exercício feminino, de fundo de quintal, escondido. Desenhar? - Isso não era coisa de homem, deixa de besteira. Mas a matemática era masculino. Esse foi o interstício dentro do qual eu entrei para 
Engenharia, para depois descambar para a Arquitetura." (Depoimento de Artigas em FERRAZ, 1997, p. 15)

As oposições entre as escolhas profissionais também acionam relações antagônicas entre "masculino" e feminino", apreendidos por esquemas de percepção que ora repõem uma ambivalência entre "viril" e "efeminado" ora afirmam contraposição entre "sério" e "fútil", na qual a arquitetura é posicionada em polo rebaixado ${ }^{97}$. Em sentido mais abrangente, a denegação do supérfluo e do excesso passa também pela linguagem estética moderna (racional, sem ornamentos, sisuda), elevada à condição de prestígio em disputa com os estilos passadistas (ecléticos, rebuscados, decorativos, retorcidos), tratados como levianos, frívolos, enganadores, criminosos $^{98}$.

Se a saída de Curitiba representaria o desafio de enfrentar a posição inferiorizada e feminina que as habilidades artísticas evocavam, a fixação na cidade de São Paulo traria como obstáculo a inserção em uma capital em processo de modernização, na qual o arquiteto não possuía vínculos prévios com grupos dirigentes nem acesso aos circuitos de elites, frações mais propensas a investir na encomenda de projetos arquitetônicos. Sem familiares na cidade, nos anos iniciais, Vilanova Artigas dividiu república estudantil, próxima à avenida São João, com outros colegas do curso, entre eles Luís Saia ${ }^{99}$, que nesse período colaborava com Mário de Andrade no debate sobre patrimônio histórico (FICHER, 2005, p.338).

Ser bem-sucedido nos exames e garantir boas notas eram os pedágios a se pagar para transitar na Politécnica, que ele definia como "escola de burgueses competentes". O relato expõe as tensões em ser

97 Cf. BOURDIEU, Pierre. A dominação masculina. Rio de Janeiro: Bertrand Brasil, 2007

98 Refiro-me a` célebre expressão de Adolf Loos, título do manifesto publicado em 1908, "Ornamento e crime", no qual o arquiteto condena as insígnias historicistas usadas de decoração nos edifícios.

99 Com relação à dedicação ao curso, a trajetória de Luís Saia parece ter sido o oposto da trajetória de Artigas. Saia entrou na Politécnica em 1931 e diplomou-se apenas em 1948. Marcada pela longa permanência na instituição e pela desavença com professores, como Prestes Maia, "sua longa vida estudantil foi extremamente conturbada, tendo abandonado várias vezes a frequência à escola. E assim se tornou parte do folclore politécnico." (FICHER, 2005, p. 337) 
aceito como paulista ${ }^{100}$, desejo que revela o embaraço de frequentar um ambiente cujos ingressantes eram, em sua maioria, provenientes de famílias das classes abastadas da capital ou do interior de São Paulo:

"Passei. Em algumas matérias com notas razoáveis. E foi o jeito que me tornei paulista. E me formei arquiteto por volta de 1937 [...] Como a Escola Politécnica era uma escola de burgueses competentes, pegavam os quadros da escola e diziam: esse vai ser isso, esse vai ser aquilo". Depoimento de Artigas, (FERRAZ, 1997, p. 17).

Artigas ingressa na faculdade em 1934, ano em que o tradicional curso de Engenharia, espaço de formação das elites dirigentes desde sua fundação, em 1893, é incorporado à Universidade de São Paulo. Ambiente restrito e de poucos profissionais disponíveis, as oportunidades de estágio e emprego passavam pelo controle dos professores, que selecionavam os estudantes e encaminhavam para as vagas que acreditavam se encaixar no perfil do aluno. Durante a graduação, Artigas recebeu proposta de um ano de estágio na Secretaria de Viação, arranjo feito pelo então diretor da Politécnica, Alexandre Albuquerque, figura de destaque no cenário político e institucional da Escola, o que poderia significar a fixação em posto estatal. A despeito das portas que esse emprego poderia Ihe abrir, Artigas abdicou da vaga em pouco tempo de trabalho.

A desistência foi posteriormente justificada sob alegação de que poderia seguir uma carreira própria, atuando fora do funcionalismo público, atividade de exigências mais modestas. Rejeitando curvar-se a uma figura de autoridade, o arquiteto quis se arriscar em um escritório próprio, o que Ihe permitiria assumir a prática autoral, portanto ligada às pretensões artísticas. Ao comentar suas escolhas e seu destino profissional, fez alusão à sua vinda a São Paulo, reiterando a condição do forasteiro, o aventureiro que, sem muito a perder, tem o atrevimento de atravessar os espaços

100 Cabe alertar que os depoimentos sobre sua vida e atuação profissional aos quais aqui faço referência foram organizados por Marcelo Ferraz no livro Vilanova Artigas, a partir de testemunhos dados por Artigas a diferentes pessoas, entre 1962 e 1984. A forma da edição de diferentes entrevistas compondo um texto único não permite identificar as datas nem o interlocutor de tais relatos de vida. 
sociais, mesmo se as vantagens não estivessem asseguradas:

"Mas esse emprego logo entrou em conflito com meu voluntarismo e durou mais ou menos seis meses. Achava que, como tinha vindo audaciosamente do Paraná, ia fazer minha carreira profissional audaciosamente também." (Depoimento de Artigas em FERRAZ, 1997, p. 20)

Nesses anos de formação, se o trabalho estável de arquiteto no setor público é rejeitado, abrem-se as portas dos escritórios de arquitetos que despontavam na prática moderna, atividade em expansão em uma cidade que rapidamente se urbanizava e expandia seus loteamentos de alta renda. Entre 1936 e 1937, Artigas trabalhou como estagiário de Oswaldo Bratke (1907-1997) e Carlos Botti (?-1942), escritório que havia sido aberto em 1933, responsável por dezenas de projetos residenciais na cidade. Em seguida, no primeiro ano de formado, em 1938, Artigas trabalhou com Gregório Warchavchik ${ }^{101}$, arquiteto russo cuja clientela de alta renda era formada por grupos da elite dirigente e empresários, entre eles, integrantes das famílias Prado, Klabin, Crespi e Segall. A relação com o arquiteto se iniciara anos antes, ainda quando Artigas era estudante e havia participado do concurso para o Paço Municipal de São Paulo, aos 23 anos, em parceria com Warchavchik.

Essas relações profissionais durante a graduação e no início de formação contribuiriam para o arquiteto se entrosar no meio local, entrando em contato com diferentes frações dos grupos dirigentes, inscrição marcada pela tensão e crítica. Além da experiência profissional junto aos núcleos do poder, ele havia incursionado pelas atividades culturais, em proximidade com os artistas que mais tarde ficariam conhecidos como Grupo Santa Helena, em sua maioria profissionais de origem modesta, operários e imigrantes, que ocupavam posição rebaixada em relação ao sistema de arte dominante. O grupo se reunia no palacete que deu nome ao grupo, próximo à Praça da Sé. Naquele momento, Alfredo Volpi, Aldo Bonadei, Francisco

101 Cf. LIRA, José Tavares Correira de. Warchavchik: fraturas da vanguarda. São Paulo: Cosac Naify, 2011. 
Rebolo Gonzales, Clóvis Graciano, Tereza Damico, todos novatos, arriscavam-se no mundo da arte, na tentativa de converter a subsistência do trabalho manual e artesanal em trabalho com valor artístico. Os encontros para a prática do desenho do modelo-vivo propiciaram laços afetivos - casamento com a artista e gravurista de origem modesta Virgínia Camargo, depois Virgínia Artigas, e a camaradagem, expressa também na parceria profissional, com vários integrantes do grupo:

"Veja quem eu encontrei tendo descoberto esse curso: passei a conviver em frente desse modelo vivo que lá se oferecia aos jovens ansiosos pela arte de São Paulo, nada menos que Alfredo Volpi, Aldo Bonadei, Francisco Rebolo Gonzales, Clóvis Graciano, Tereza Damico e minha mulher Virgínia Artigas"102.

No embate entre a formação na Politécnica e a prática do desenho, o contato com os integrantes do grupo Grupo Santa Helena e a imersão nas aulas de modelo-vivo o aproximou das artes plásticas, convivência modeladora de sua formação. O entrosamento no grupo de amigos pintores e artistas de formação simples facultaria amizade e vínculo amoroso, travados no reconhecimento de posições semelhantes no espaço social. A origem de social em comum também seria fermento para uma postura crítica e engajada, que os moveria para a atuação política na militância comunista. Experiência de classe e, ao mesmo tempo, experiência artística, os encontros possibilitariam o desenvolvimento do traquejo necessário para o traço limpo e ágil e para a fala expressiva, treinamento de base para a elaboração da forma arquitetônica e ampliação da consciência social:

"Três horas todas as noites, de modelo exposto para nós, inclusive no sábado. Nós íamos lá sem ter jantado: um pão com alguma coisa dentro do bolso. Imagine, Volpi era pintor de paredes; Rebolo, jogador de futebol do Corinthians; Clóvis Graciano se iniciava, era fiscal de consumo, e o Bonadei era um costureiro. Fúlvio Penacchi também estudava lá, também ia fazer desenho vivo. Vinha da Itália, também

102 Depoimentos de Artigas concedidos entre 1983 e 1984, material que compõe a dissertação: JUCÁ, Christina Bezerra de Mello. João Batista Vilanova Artigas, arquiteto: a gênese de uma obra (1934-1941). Brasília: UnB, 2006. (dissertação de mestrado). 
tinha convivência com a arte italiana dessa época [...] Essa nossa convivência acabou nos levando a sermos conhecidos nas pequenas exposições de arte coletiva que aconteciam, ou na convivência com Paulo Rossi Osir e com outros paulistas". ${ }^{103}$

A amizade intensificada nos anos de convivência no período de faculdade e início de carreira de arquiteto se converteria na participação de alguns desses artistas nos projetos arquitetônicos de Artigas, seja na formulação das cores e execução das pinturas das paredes, seja no desenho de painéis ou afrescos a decorar empenas de suas casas modernas, colocando assim em prática o ideário moderno de integração das artes plásticas com a arquitetura. A camaradagem com os artistas plásticos do Grupo Santa Helena resultou no convite a Rebolo e Graciano para colaborar na realização de painéis artísticos nas residências em que projetou, consolidando um dos motes do programa moderno: integração da arquitetura à arte. O apreço entre o arquiteto e os artistas plásticos também aspergia na clientela, que chegava a adquirir telas para decorar os cômodos, completando um arranjo que unia arquiteto, encomendante e artistas plásticos ${ }^{104}$. Além de participação em exposições junto ao grupo, os laços com os artistas convergiriam para outras ações, como a participação na fundação do Museu de Arte Moderna, em 1948, no qual integrou sua primeira diretoria e também fez o projeto para ocupação da primeira sede do museu, instalada dentro do prédio dos Diários Associados.

103 Depoimento a Christina Bezerra de Mello Jucá em 1983, extraído de sua dissertação de mestrado.

104 Sobre o convívio entre artistas, arquitetos e intelectuais, Luís Saia em "Arquitetura Paulista" adverte que "a frequentação dos artistas pelos arquitetos e dos escritórios dos arquitetos pelos artistas se tornou um fato corriqueiro e, por isso mesmo, pouco percebido, em que pese a enorme importância de tal acontecimento". A despeito do arrebatamento, ele credita tais afinidades a um horizonte mais amplo, de "existência de uma área comum de sentimento dos problemas nacionais e dos problemas da arte, capaz de conduzir a uma unidade da inteligência paulista”. SAIA, Luís. "Arquitetura Paulista" (in Xavier, 2003, p.111). 


\section{Construtora Marone e Artigas (1937-1944)}

Após as duas experiências de familiaridade com o trabalho em escritório particular como estagiário, com Oswaldo Bratke e Gregori Warchavchik, Artigas investiu na abertura de uma firma construtora com o colega da faculdade Duílio Marone, formado na Politécnica em 1936. Surgia a firma Marone e Artigas. Paulista, filho de comerciantes proprietários de uma pequena empresa de produção de perfume, Marone possuía postura mais comercial e tino para negócios e contatos sociais. Na sociedade, Artigas ficaria voltado para o desenho dos projetos e Marone seria o responsável pelos cálculos de engenharia, assumiria a parte administrativa do escritório, compra de materiais, processos de legalização das obras na prefeitura e a captação de clientes. A parceria possibilitaria expandir as encomendas, uma vez que o paulista possuía na cidade uma rede cristalizada de relações sociais.

Com sede na rua São Bento, a empresa cobria tanto a área de projeto quanto a de construção, fazendo orçamentos, acompanhando obras, formato no qual até então a maioria dos escritórios de arquitetura estava organizado. A sociedade iniciou-se em novembro de 1937 e permaneceu até junho de 1944, prioritariamente desenvolvendo projetos residenciais ao gosto das classes média e alta paulistanas, grupos em grande parte de profissionais liberais e rentistas que dispunham de condições financeiras para investir em moradia particular. Em seus sete anos de atuação, totalizou cerca de 64 projetos, dos quais 62 foram construídos, um índice elevado se comparado ao período posterior, em que a linguagem estética é arrojadamente moderna ${ }^{105}$.

Sobretudo, Pacaembu, Jardim América, Jardim Europa, Jardim Paulista, Ibirapuera, Vila Nova Conceição e Cerqueira César foram os bairros cuja clientela mobilizou seus recursos na fixação de espaços de moradia, locais onde se concentrou mais da metade das casas produzidas pela dupla

105 A elaboração dessas informações se deu a partir de uma planilha organizada pelo Lab Arq-FAU, documento que reúne listagem de todos projetos atribuídos a Vilanova Artigas. 
nesse período ${ }^{106}$. São bairros que se desenvolveram com uma legislação especial, que os definia como zona de uso estritamente residencial de baixa densidade (Zona 1), tal como previsto pelo Zoneamento da Cidade de São Paulo, regulamentado em 1934. No Pacaembu e Jardim América, implementados pela Companhia City ${ }^{107}$, o traçado urbano privilegiava-se das ideias vindas do exterior, como as cidades-jardins inglesas ${ }^{108}$, com seu desenho de ruas sinuosas, arborizadas, em grandes lotes com recuos laterais e frontais. Propalados como "a nova maravilha urbana", foram projetados como bairro-modelo, respondendo aos desejos europeizados de seus futuros moradores.

O padrão de ocupação urbana desses bairros-jardins - fusão do "pitoresco, salubre e sossegado" - esteve fixado ao estilo de vida de sua

106 É possível avaliar a relação entre os preços dos terrenos dos diferentes bairros da cidade de São Paulo a partir da Planta Genérica de Valores de 1938 e 1958, onde se verifica que, em um primeiro momento, os terrenos nas áreas do núcleo central da cidade (Centro, Santa Efigênia, Consolação, e Luz) eram os de maior valor por $\mathrm{m}^{2}$. Também, nos anos 1940, o caderno de Imóveis e Terrenos do jornal $O$ Estado de São Paulo registra, nos anúncios imobiliários, o caráter "aristocrático" e "elegante" a que eram atribuídos os bairros recém-loteados.

107 A Cia City - oficialmente City of São Paulo Improvements and Freehold Land Company Ltd —, organização estrangeira com sede na Inglaterra, elegera desde 1911 a cidade de São Paulo para seus investimentos nos setores imobiliários e urbanísticos. Inicialmente, a região do Pacaembu foi escolhida para aplicação dos investimentos com o desenho de um loteamento com mil lotes. No entanto, entraves na aprovação do projeto pela prefeitura, devido ao traçado inovador e as exigências legais ocasionadas pelas características topográficas do local, emperraram a efetivação do empreendimento. Posteriormente as obras foram retomadas e postas em comercialização somente em 1925, quando praticamente concluíram as obras de drenagem, galerias pluviais e de esgoto, rede de água e iluminação, arruamentos e construção de praças. Cf: BACELLI, Ronei. A presença da Cia. City em São Paulo e a implantação do $1^{\circ}$ bairro-jardim 1915-1940. São Paulo: FFLCH (dissertação de mestrado), 1982. WOLF, Silvia Ferreira Santos. Jardim América: o primeiro bairro-jardim de São Paulo e sua arquitetura. São Paulo: Edusp, Fapesp, Imprensa Oficial, 2001.

108 A concepção das cidades-jardins faz parte da história do pensamento do planejamento urbano do início do século XX, movimento que tem suas raízes mais amplas nas tradições utopistas que impactaram a Inglaterra em meados do século XIX, em autores como Owen, Morris e Ruskin, que evocariam a retomada dos valores e modos de vida tradicionais como crítica à industrialização. Em seguida, passa por uma formulação mais concreta e realizável, com Ebenezer Howard, que propõe a união dos benefícios da cidade com a vida no campo em Cidades-jardins do amanhã, publicado em 1898. Sob esse paradigma, em 1903, uma cidadejardin próxima a Londres, Letchwork, e um bairro no subúrbio da capital inglesa são construídos, em planos desenhados por Raymond Unwin e Barry Parker. Foram esses mesmos arquitetos que desenharam, em 1910, uma primeira proposta para o Jardim América, em São Paulo, posteriormente levada a cabo por Parker, que aqui esteve entre 1917 e 1919. Cf. BENEVOLO, Leonardo. História da Arquitetura Moderna. São Paulo: Perspectiva, 1998. CHOAY, Françoise. L'urbanisme, utopies et réalités: une anthologie. Paris: Seuil, 1965. HALL, Peter. Cidades do amanhã: uma história intelectual do planejamento e do projeto urbano no século XX. São Paulo: Perspectiva, 2002. 
clientela abastada, expressando no setor imobiliário as aspirações de novas frações de classe, a convergência entre antiga aristocracia agrária e nova burguesia urbana. Se a região do Centro de São Paulo, nos arredores da Vila Buarque - nosso "Quartier Latin" - concentrava-se o reduto boêmio, de intelectuais e artistas paulistanos ${ }^{109}$, nesses bairros afastados se concentravam os grupos endinheirados, ratificando na exclusividade dos espaços os estilos de vida dos moradores. Conforme atestam as peças de propaganda publicitária veiculadas nos jornais do período, a restrição a uso estritamente residencial é apresentada como garantia de "uma boa vizinhança", caucionando a convivência entre pares, e também como promessa de valorização imobiliária, ao afastar "surpresas desagradáveis", ilustradas por uma serraria ou um mercado de "secos e molhados". O plano urbanístico do loteamento - grandes lotes integrados a áreas verdes, onde a casa fica isolada no terreno - buscava atrair clientela cobiçosa por usufruir "plenamente das delícias da vida de campo, tranquila e sadia, em plena capital, e com todo conforto das grandes metrópoles". [fig. 31 a 34]

No despontar do processo de urbanização e industrialização da capital paulista, não é possível deixar de notar a retomada do bucólico, anexado aos melhoramentos da vida urbana (rede de esgoto, rede de água, eletricidade, gás e telefone) como modelo idealizado da paisagem rural em um refúgio para enfrentar o processo de modernização. O enaltecimento da natureza ${ }^{110}$, com o redesenho da paisagem campestre em local próximo ao centro agitado da cidade, apresenta-se como antídoto à aglomeração urbana, à insalubridade da cidade encortiçada, à desordem da ocupação proletária, que marcava o processo de desenvolvimento de São Paulo nessas primeiras décadas do século $X X$. Em seus espaços verdejantes e labirínticos, os bairros-jardins surgem como barreira artificialmente projetada para nublar a realidade miserável dos trabalhadores, orientando para o vetor sudoeste os locais residenciais dos moradores de alto poder aquisitivo, em contraponto aos bairros centrais, antigos redutos da elite e

109 GAMA, Lúcia Helena. Nos bares da vida: produção cultural e sociabilidade em São Paulo,19401950. São Paulo: Editora Senac, 1998.

110 Sobre as interações entre campo e cidade através da história e da literatura inglesas, ver o livro inspirador de WILLIAMS, Raymond. O campo e a cidade. São Paulo: Cia das Letras, 2011. 
espaços sem planejamento, em direção à zona leste, relegados à massa de trabalhadores pobres.

Como contraponto a tantos projetos para usufruto familiar e encenação da vida social de seus encomendantes nas áreas nobres da cidade, há algumas solicitações cuja finalidade era renda imobiliária, imprimindo diferenciação na escolha entre os bairros residenciais das camadas de alta renda e os bairros residenciais destinados às camadas populares. Na Barra Funda, por exemplo, Artigas e Marone construíram em 1942 dois conjuntos de habitações em uma mesma quadra, para os jovens irmãos José Coelho Pamplona (1920-1964) e Maria Risoleta Bueno Pamplona $(s / d)$, clientes cujos ascendentes possuíam tradição na produção imobiliária, tanto em edificações quanto em loteamentos. O pai deles fora Luiz Coelho Pamplona e o avô, o visconde José Coelho Pamplona, imigrante açoriano que enriqueceu em São Paulo, um dos proprietários de grandes áreas em torno da avenida Paulista no momento de sua abertura ${ }^{111}$. Para eles, o investimento financeiro nesse empreendimento representaria grande possibilidade de retorno uma vez que a família já atuava como rentista, em bairros como Lapa e em municípios próximos a São Paulo. Com o menor preço de terra no mercado, já desde os anos 1920, o bairro da Barra Funda registra sua desvalorização, ratificando a destinação social dessas moradias para a classe trabalhadora de baixo poder aquisitivo.

Nesse período, o perfil operário do bairro consolidava-se com a instalação de depósitos e conjuntos fabris, em razão da proximidade com a linha férrea da São Paulo Railway ${ }^{112}$, o que atraía mão de obra interessada em se fixar próximo ao local de trabalho. Um dos conjuntos projetados por Artigas, já demolido, se organizava com quatro casas geminadas

111 MOTA, Valdemar. Visconde de Porto Martim: Um benemérito açoriano no Brasil, Instituto Açoriano de Cultura, Angra do Heroísmo, 1978. A rua Pamplona e a rua Luis Coelho foram assim nomeadas em homenagem aos proprietários. José Coelho Pamplona também foi retratado pelo pintor Oscar Pereira da Silva.

112 Ligando Santos a Jundiaí, a estrada de ferro foi inaugurada em 1967. Essas intervenções no espaço urbano, junto às características geográficas, representaram condicionantes que estruturaram o espaço da cidade, contribuindo para a estratificação entre os grupos de maior poder aquisitivo e as classes trabalhadoras. Isto é, estabeleceu-se uma "divisão da cidade em 'lado de cá' e 'lado de lá' dos trilhos", a partir de um percurso de fixação das camadas de alta renda que se estabeleceu em direção ao quadrante sudoeste da cidade. (VILLAÇA, 2001, p. 193) 
sobrepostas, duas no piso térreo e duas no superior, solução que ainda privilegiava o acesso distinto para cada uma das unidades. Com parca ornamentação na fachada, as modestas casas situavam-se em quadra contígua à linha férrea, em local onde hoje passa o Viaduto Pacaembu. Como programa, as casas tinham dois dormitórios, sala de estar, cozinha e sanitário. O outro conjunto, existente ainda hoje, compõe-se de doze unidades de casas justapostas, sem recuos laterais e frontais, sendo que sete têm acesso pela rua principal e as demais estão implantadas no interior do lote, cujo acesso se dá por meio de vila interna. [fig. 35] São casas de três dormitórios, com sala de estar, copa, cozinha e sanitário, tal como a da maioria das casas projetadas por Artigas para os demais clientes abastados dos bairros nobres. Se o desenho arquitetônico e o programa de necessidades aparentemente apresentam semelhanças, as distinções ficam bem demarcadas quando se leva em conta a ornamentação da fachada, a tipologia da moradia, a área construída e a localização urbana e sobretudo ausência de quartos de empregada e quintal ajardinado. Sem recuos laterais, as habitações apresentam em torno de $75 \mathrm{~m}^{2}$, agrupadas em pátio interno coletivizado por todos os moradores do conjunto, impondo compartilhamento dos espaços de lazer e instaurando forma de sociabilidade definidora de uma pequena comunidade.

Nesse início profissional, as residências encomendadas pelas famílias de classe média e alta para acomodação particular se distinguem pelo uso do ornamento, escolha dos estilos arquitetônicos, decoração dos espaços internos, mobiliários, assim como pelo tamanho do terreno e pela localização urbana, conteúdos estéticos e materiais definidores da imagem pública e doméstica a ser representada por esses grupos. A configuração arquitetônica das moradias oferece material tangível para investigação das relações sociais, fornecendo acesso privilegiado para entendimento dos valores e investimentos sociais fixados no espaço doméstico. Formas de afirmação social, as residências acumulam múltiplos significados: marcadores de gosto e estilos de vida, revelam sistemas de classificação e hierarquia de seus proprietários.

Entre os encomendantes de moradia unifamiliar estão Henrique 
Arouche de Toledo, Otoni de Arruda Castanho, Fernando Bebiano Barreto Henriques e Nicolau Scarpa Jr, entre outros clientes pertencentes a grupos sociais de alto poder aquisitivo. É notável que nesse momento de ingresso profissional o escritório precisasse responder de forma pragmática ao mercado da construção civil, em que o critério de atuação não é a originalidade. Grande parte das casas é marcada pelo estilo eclético, em suas diversas variações, com a aplicação dos modelos neocolonial, chalé suíço, normando, mexicano. O programa arquitetônico é convencional em relação aos espaços domésticos, ainda nos moldes das lições aprendidas no curso de engenheiro-arquiteto da Politécnica ${ }^{113}$. Regido pela rentabilidade econômica, trata-se de um mercado ampliado de clientes de classe média, cujas construções "apresentam feições comuns ao gosto paulistano e filiadas a um ecletismo re-interpretado pelas limitações das condições financeiras dos futuros moradores"114.

No entanto, o escritório também começava a se ocupar de encomendas que privilegiavam a intenção estética. As solicitações de clientes pertencentes ao núcleo mais próximo do círculo de amizade do arquiteto permitiram soluções mais arrojadas, nas quais era possível aplicar padrões da arquitetura moderna internacional. Exemplos disso são as casas de "Giulio Pasquale, projeto de 1939, ou outra para Luís Gonzaga Leme Monteiro, de 1941, que o próprio Artigas reconhecia terem sido inspiradas em Walter Gropius"115, arquiteto alemão que dirigiu a Bauhaus. A liberdade para impor um estilo arquitetônico moderno estaria garantida quando demandada por uma clientela em afinidade com o círculo social de Artigas. A proximidade com o Partido Comunista contribuiria para atrair um grupo de pessoas com abertura para assumir estilo de vida moderno, cuja moradia seria a coadunação de posturas estéticas e ambições políticas.

113 Em sua pesquisa, Ficher apresenta os trabalhos escolares entregues pelos estudantes do curso de engenheiro-arquiteto da Escola Politécnica, em sua maioria exercícios de aplicação dos estilos estéticos em voga: renascimento, gótico, neocolonial, art déco, entre outros.

114 ARTIGAS, Rosa. “Por enquanto, João Batista”. In . Vilanova Artigas. Instituto Tomie Ohtake, 2003, p. 245.

115 Idem. p.245 


\section{Causas operárias: os advogados Rio Branco Paranhos, Rivadávia Mendonça e Rubens Mendonça}

$\mathrm{Na}$ historiografia da arquitetura, tornaram-se célebres as casas que Vilanova Artigas projetou para Rio Branco Paranhos, Rivadávia Mendonça e Rubens Mendonça. [fig. 36 e 37] Esses trabalhos destacaram apenas as inovações formais das residências, mas silenciaram em relação às circunstâncias sociais da encomenda. Os três clientes, que são irmãos, nos permitem localizar o surgimento de uma nova demanda de consumidores dos projetos modernos: frações de profissionais liberais com exigências estéticas e comprometidas com causas sociais.

Rio Branco Paranhos, Rivadávia Mendonça e Rubens Mendonça, em diferentes anos, 1943, 1944 e 1958, respectivamente, encomendaram projeto de residência a Vilanova Artigas. Todos advogados, eles foram reconhecidos nos anos 1940 por fundar o primeiro escritório de advocacia especializado na defesa de causas trabalhistas. A amizade com Artigas teve origem na militância de esquerda, próxima ao Partido Comunista. Eles passaram a colaborar com sindicatos em defesa dos empregados, principalmente após a aprovação da CLT, em 1943, que conferia um recurso jurídico aos direitos trabalhistas. A proximidade com as causas operárias deu-se quando o primogênito, Rio Branco Paranhos (1913-?) se tornou juiz do trabalho ${ }^{116}$. Em pouco tempo, largou a carreira na magistratura para se envolver na luta sindical, especializando-se em direito trabalhista. Nesse momento, abriu escritório voltado para atuação junto ao movimento sindicalista e dedicou-se ao apoio das atividades institucionais do Partido. 0 objetivo era atuar em contato direto com os operários, e tornar a linguagem jurídica mais acessível. Rio Branco Paranhos ajudou a criar o departamento jurídico do $\mathrm{PCB}$, oferecendo plantão aos trabalhadores sindicalizados que entravam com processos judiciais na Justiça do Trabalho. Essa militância

116 Para a atuação de Paranhos no PCB, cf. CORREA, Marissa Rosa. Trabalhadores têxteis e metalúrgicos a caminho da Justiça do Trabalho: leis e direitos na cidade de São Paulo, 1953 a 1964. Campinas: Unicamp, 2007. (dissertação de mestrado). 
contribuiu para ingressar nos quadros políticos do Partido, e concorrer como candidato a deputado estadual.

As duas residências dos anos 1940, localizadas no Pacaembu, foram feitas quando Artigas ainda possuía a parceria profissional com Marone. A casa de 1958, localizada no Sumaré, já pertence à fase em que o arquiteto está estabelecido em seu escritório próprio. Embora as residências possuam diferenças no partido estético adotado, do ponto de vista da efetivação da encomenda, sinalizam as pretensões estéticas e políticas de três advogados enredados na militância. As atividades em conjunto se espraiavam na articulação junto aos sindicatos e em parcerias nas revistas culturais ligadas ao Partido. Traço dessa comunhão de interesses é a participação de Artigas e Rivadávia Mendonça na revista Fundamentos ${ }^{117}$, publicação sobre cultura e política ligada às ideias do Partido Comunista, em que Artigas ocupou o cargo de editor. A materialização dos projetos residenciais é, pois, representativa do estreitamento das relações sociais com os irmãos, conformando círculo de militantes e simpatizantes comunistas. Marcados pela atuação junto ao Partido, o vínculo contribuiu para conformar uma rede de amigos com posturas políticas e valores de esquerda, que se interessavam por referências estéticas internacionais, tal como as casas de Frank Lloyd Wright e Le Corbusier, inspirações de Artigas naquele momento.

Mesmo antes de sua filiação, que só ocorreria em 1945, era com esse grupo de amigos que Artigas estabelecia relações profissionais e de luta política. Com o ingresso oficial no PCB, o arquiteto passou a frequentar com

117 Em 1948, foi lançada a revista Fundamentos, publicação fundada por Monteiro Lobato, que teve como colaboradores Caio Prado Jr, Astrojildo Pereira, Graciliano Ramos, Barão de Itararé, Cândido Portinari, entre outros. Artigas publicou vários textos na revista, nos anos 1950, período de acirramento da Guerra Fria, tomando uma postura combativa contra a arquitetura norte-americanas e francesa. Em nome de uma arquitetura nacional, nomes como Le Corbusier e Frank Lloyde Wright, influências caras ao arquiteto, foram fortemente criticados, devido à dominação imperialista. Rivadávia Mendonça publicou artigos criticando os intelectuais e críticos de arte paulistas, entre eles, Sergio Milliet e Lourival Gomes Machado, Luís Coelho, que, de acordo com ele, formava " o conhecido grupinho desagregador que muito bem traduz os interesses da classe dominante dos latifundiários [...]”. 0 tom de violento e panfletário de parte os textos publicados na revista é expressivo da posição radical que ela ocupava no jornalismo intelectual de esquerda. Quanto ao debate estético, a revista se orientava pelo realismo socialista: assumia pautas contra a linguagem formalista, criticava a degeneração artística produzida no capitalismo e se posicionava em combate à cultura cosmopolita burguesa. Cf. MENDONÇA, Rivadávia. "Pelegos a serviço da reação". Fundamentos, abril, 1950. GUIOLDI, Rodolfo. "A estética à luz do marxismo". Fundamentos, janeiro, 1951. 
assiduidade as rodas de esquerda, espaço que permitiria consolidar uma redes de amizades acionadas para garimpo de clientela. O capital de relações sociais estabelecido com o engajamento político renderia, nas décadas seguintes, além de diversas moradias, vários projetos de edifícios para sede de sindicatos e colônias de férias. Os encomendantes eram categorias de trabalhadores, alguns deles atendidos pelo escritório de Rio Branco Paranhos ${ }^{118}$.

A casa projetada para o advogado Rio Branco Paranhos foi amplamente divulgada nos trabalhos de história de arquitetura, valorizadas pela influência das ideias do arquiteto norte-americano Frank Lloyd Wright. A inspiração declarada nas praries houses se expressa na volumetria horizontalizada, com telhados em grandes beirais em sobreposição, janelas amplas, ambientes internos fluidos, assim como pelo uso diverso de materiais, como madeira, tijolo e pedra. O grande volume em balanço, calculado pelo próprio arquiteto ${ }^{119}$, foi feito para acolher o escritório particular do advogado. A casa, com aproximadamente $240 \mathrm{~m}^{2}$ acomodados em terreno de grande aclive no Pacaembu, tinha três dormitórios no nível superior, ambos dividindo um único sanitário, e no primeiro pavimento, dormitório e banheiro de empregada, com acesso à área de serviços.

Ainda que nesse momento inicial da carreira o arquiteto tivesse se valido de outros estilos associados ao ecletismo no projeto de inúmeras residências, foi a fase wrightiana, restrita a algumas casas, que teve eco nas publicações, sendo aceita e legitimada como a principal influência na

118 Entre 1958 e 1970, Artigas foi chamado a reformar ou desenvolver projetos para diversos sindicatos em São Paulo e cidades do interior, entre eles, marceneiros, têxteis, carris urbanos, ferroviários, metalúrgicos, rodoviários, químicos, gráficos, bancários, servidores públicos, químicos e farmacêuticos. Entre os projetos para sede de sindicato, ao todo, são 15 desenhos, dos quais oito foram construídos. Os sindicatos também encomendaram outros programas, como escola, quadra esportiva, centro educacional. Também foram solicitadas cinco colônias de férias, todas a princípio localizadas em Praia Grande, das quais apenas uma foi construída.

119 As palavras de Artigas sinalizam a atuação do arquiteto-engenheiro em início de carreira, ainda responsável pelo desenho da forma e cálculo da estrutura: "Esse terraço foi feito de tijolo prensado com estrutura de ferro dentro e fui eu mesmo que calculei a partir de um estudo do teorema de Langendonck, publicado na revista do Instituto de Engenharia, um estudo sobre vigas-balcão. Nessa época, eu era um arquiteto meio vitruviano: calculava minhas próprias obras e passava sábados e domingos inteiros a ver de que maneira era possível fazer balanços desse tipo com telhados de madeira, a partir da tradição brasileira de construção de telhados". (FERRAZ, 1997, p. 40) 
produção de Artigas desse período. Isso ocorreu possivelmente porque a tomada de Wright como modelo inspirador marcaria um contraponto à influência corbusiana na arquitetura carioca, já reconhecida com a atuação de Oscar Niemeyer e Lúcio Costa. Além disso, com relação ao gosto dos clientes, como aponta Bruand, a aceitação do estilo moderno não radicalizado de Wright seria, em São Paulo, "menos suscetível de espantar clientela particular (que ainda era a única que contava, face à falta total de interesse dos poderes públicos)", e assim o arquiteto "oferecia em contrapartida uma solução mista, ao mesmo tempo moderna e tranquilizante, apresentando várias vantagens" (BRUAND, 1981, p. 271).

Anos depois, em 1958, Artigas projetaria a casa para o irmão mais novo entre os advogados, Rubens Mendonça. Essa residência, localizada no Sumaré, já exibiria uma proposta estética mais radicalizada, com o emprego do concreto aparente, a volumetria concisa e a fluidez dos espaços internos, elementos com os quais sua linguagem brutalista seria identificada. Conhecida como "Casa dos Triângulos", a empena de concreto da fachada principal contava com grande painel demarcado com planos geométricos azul e branco, cujo desenho foi feito por Mário Gruber, e a pintura executada por Francisco Rebolo, artistas cujo companheirismo entrelaçava-se na militância política. O jardim da residência, cuja disposição de palmeiras marcaria uma geometria rigorosa, foi assinado por Waldemar Cordeiro (1925-1973), artista também engajado no PCB. [fig. 37] Artista plástico e designer, Cordeiro foi líder do movimento concretista em São Paulo, quando participou ativamente do Grupo Ruptura, que reunia artistas interessados pela arte abstrata. Ele atuou em diversos projetos na área de paisagismo em São Paulo, tendo como prerrogativa uma postura que aliasse a organização estética dos espaços da vida cotidiana.

A moradia de Rubens Mendonça representa com força o projeto de integração das artes, preconizado pelos arquitetos e artistas modernos. Arquitetura de Artigas, paisagismo de Cordeiro, mural na fachada de Gruber e Rebolo e tela de Portinari no interior da moradia conformam um ambiente em que se misturam as principais ofertas artísticas que comandavam a cena cultural da cidade. É também um ambiente travejado pelo rol de amizades 
postas em ação nas utopias políticas e ousadias estéticas que marcaram o período. A posição bem-sucedida do advogado, já estabelecido economicamente, facultava o convite de trabalho para os amigos artistas, arquitetos e paisagistas, muitas vezes vivendo com poucos recursos vindos da atividade intermitente. Em troca, o corpo de produtores estéticos colocava o advogado em sintonia com as manifestações artísticas, em um entrelaçamento de financiamento econômico com prestígio social.

\section{Artigas em escritório próprio}

As casas de Rio Branco Paranhos e Rivadávia Mendonça foram uns dos últimos projetos que o arquiteto realizou com a construtora, modelo de prática profissional em que eram responsáveis por fornecer tanto o desenho técnico quanto a construção da obra. Para o arquiteto, a década de 1940 é um momento de reconfiguração da prática profissional. Deve ser considerado, no entanto, que já desde a década de 1930, em São Paulo, alguns arquitetos abriam escritórios com a finalidade de vender apenas o projeto do edifício. Até então, a maioria desses profissionais, tal como Artigas, estavam atrelados a firmas de construção, nas quais o cliente procurava tendo como objetivo o produto final, ou seja, a execução da obra. O projeto arquitetônico não era vendido como um produto em si. Contido no pacote da construtora, "não se caracterizava como mercadoria para o proprietário do empreendimento imobiliário, para quem ficava, aparentemente, de graça"120.

Para Artigas, essa mudança no modelo de atuação profissional ocorre em 1944, quando o arquiteto encerra a sociedade com Marone. A partir de então, deixa de atuar como empreiteiro e se envereda para prática como profissional liberal. Na trajetória do arquiteto, essa passagem para escritório

120 FICHER, p.241. O trabalho destaca que um dos pioneiros na venda do projeto separadamente à construção foi Rino Levi, em 1936, quando o arquiteto registrou um edifício constando de seu trabalho apenas o projeto e fiscalização da obra. 
próprio representa uma mudança profissional e estética. O voo solo pode ser entendido pelas oportunidades que se abriram em sua carreira, muitas advindas do cultivo de relações na militância política.

A orientação da carreira para atuação exclusiva na elaboração de projeto em escritório próprio responde, em um plano mais amplo, às mudanças no estatuto da organização profissional que se consolidava no período. Para ratificar a separação, os arquitetos procuravam se distanciar dos engenheiros apresentando-se, de um lado, como os responsáveis pelo projeto, ou seja, pela concepção do desenho arquitetônico e, por outro lado, atribuíram aos engenheiros a tarefa de execução, deixando-os como responsáveis pela construção da obra.

Chancelando a cisão entre projeto e construção, os arquitetos garantiam a si mesmos o status de criadores, os inventores da forma, relegando aos engenheiros o papel de "calculadores" do projeto, aqueles que seriam prestigiados pela recompensa financeira ${ }^{121}$. Desse embate sobressai a dinâmica assentada na oposição entre arte e negócio, em que os arquitetos estão vinculados à arte e os engenheiros associados ao lucro financeiro. Tal passo seria importante em direção à autonomização do campo da arquitetura em relação à construção. Se, por um lado, esse processo para Artigas significou uma redução do volume da clientela, por outro, resultou em maior liberdade formal, pois os clientes seriam recrutados pela afinidade com as práticas culturais do arquiteto. Em outros termos, a mudança operada no âmbito dessa reestruturação profissional se complementa com a alteração no agenciamento dos encomendantes, rebatimento que incide nas características sociais, nas expectativas políticas

121 Essa ambivalência está na constituição da profissão, não apenas no Brasil, como também nos países europeus. Retomando historicamente a profissão na França, Florent Champy nos mostra que primeiramente o processo de autonomização se deu em relação aos carpinteiros e pedreiros, no Renascimento, momento em que a arquitetura nasce como atividade projetual. É também quando ganha destaque a "assinatura" como marca de quem concebe o edifício, abrindo espaço de valorização da autoria. Com as escolas de Beaux-Arts, no século XIX, a instituição de formação mantém a identidade de artista, como forma de preservar o status da profissão, separando-a das atividades dos engenheiros, que se ocupam de um espectro mais largo das construções e do público consumidor. Na divisão das funções, eles deixam a obra e a construção, partes menos nobres, aos engenheiros, ficando aos arquitetos a parte mais prestigiosa do projeto, o que contribuiu para formar a aura e o status dessa atividade. CHAMPY, Florent. Sociologie de l'architecture. Paris: La Découverte, 2001. (p.29-32) 
e no gosto estético dos mesmos.

O que se pretende salientar é que a passagem de uma firma de construção para escritório de arquitetura está diretamente vinculada ao recrutamento da clientela. Quando se tratava de um empreendimento comercial, os encomendantes que acessavam a firma de Artigas e Marone pertenciam a um grupo mais disperso no espaço social, muitos dos quais sem vínculos diretos com a trajetória do arquiteto. Já aqueles que passaram a encomendar projetos quando Artigas se estabeleceu em escritório próprio foram, em sua maioria, captados de relações pessoais.

Nos anos iniciais de sua carreira, entre 1937 e 1944, os clientes que acessam a Marone \& Artigas buscavam, prioritariamente, um projeto convencional. Eram encomendantes menos interessados em pagar por um projeto arquitetônico com marca de autoria e com signos declarados de uma postura estética. A atuação em escritório próprio representou, pois, motivação para assumir projetos autorais, em que poderia propor soluções arquitetônicas mais arrojadas, uma vez que as posturas estéticas e políticas do público destinatário coincidia com as dele. Tem-se aí dois modelos de produção arquitetônica: um apoiado na lógica de mercado, que atende uma clientela dispersa, sem pretensões de inovação artística; e outro que se orienta pelo juízo estético, postura de valorização da liberdade formal, que seleciona um público restrito.

O investimento em escritório de arquitetura apartado da execução da obra consagra a prática projetual produtora de um objeto de valor único. Ou seja, ao se estabelecer como profissional liberal, o que está em questão também é a possibilidade de se elevar à condição de criador, produzindo um artefato artístico que, pelo menos em primeira instância, responderia às intenções estéticas do arquiteto. Amarrado à construção, o profissional teria menos autonomia para propor suas formas, definir seu estilo, impor sua identidade projetual, assinar seu desenho e vendê-lo como mercadoria. Já o escritório exclusivamente de projetos possibilitaria assumir postura autoral, atraindo clientela desejosa de investir em edifícios com estética renovada.

Essa passagem parece indissociável da atuação política de Artigas, em que a filiação ao Partido Comunista e a militância junto aos círculos de 
esquerda contribuiriam para fixar amizades, garantindo clientela intelectualizada e comprometida socialmente, possivelmente os mais habilitados a legitimar, como espaço de moradia, uma casa com linguagem moderna.

\section{Em defesa da profissão}

O ano de 1945 parece aflorar as razões do investimento em escritório próprio. Em julho, Artigas redigiu uma carta a um cliente ${ }^{122}$, reiterando a importância de se contratar um arquiteto para elaboração do pretendido edifício. A demanda em questão era uma casa de saúde em Curitiba, e a carta de Artigas foi formulada de modo a convencer o encomendante a chamar um arquiteto, quando ele estava decidido a contratar engenheiros de uma construtora.

Após receber informação de que o cliente não se valeria de seus trabalhos, Artigas enfaticamente escreveu esse documento, que até hoje é tomado como bandeira em defesa da profissão do arquiteto, a justificar a necessidade do projeto. Artigas argumenta em números, valores e cifras o quão vantajoso seria ao proprietário ter um estudo prévio, um plano minuciosamente elaborado, um desenho garantindo eficiência, funcionalidade, adequação ao terreno, economia e beleza. Nessa carta, põese a defender seus atributos profissionais, questionando então, se o proprietário estaria de acordo que projeto do edifício fosse relegado a técnicos e construtores, sem formação suficiente para planejar a obra em sua totalidade.

O tom persuasivo de Artigas se munia de argumentos estabelecendo diferenças entre construção e arquitetura, deixando claros os dois polos em oposição. De um lado, Artigas criticava a falta de planejamento da construção, julgando-a problemática por se realizar como uma prática

122 ARTIGAS, Vilanova. “Carta ao cliente”. In. FERRAZ, 49-52. 
construtiva in loco, isto é, definida apenas no canteiro, desprezando a necessidade de desenho. Esse modo de produção da construção civil é colocado como representativo do "vezo brasileiro [de] fazer as coisas sem plano inicial perfeitamente elaborado", sem método, sem planejamento, sem racionalidade, com as decisões tomadas no momento de execução, sob risco de imprevistos e adaptações. De outro lado, o arquiteto exaltava o caráter espiritual do projeto, "valor perene, enorme, inestimável", chancelando à arquitetura a condição de obra de arte. Nessa aproximação, ele se coloca na posição de artista, cuja "arte não tem livro de regulamento que ensine. Nasce dentro de cada um e desenvolve-se como conjunto de experiências". Além da garantia de melhor solução técnica, planejamento e eficiência, a escolha da arquitetura feita por arquiteto, em detrimento da construção feita por engenheiros-construtores, endossaria um valor estético indubitável ao edifício. Por fim, deixa a deliberação ao proprietário:

"Com a consciência limpa termino minha proposta. Está em suas mãos a responsabilidade de decidir entre os caminhos. De um lado eu me coloco, não só, como representante dos arquitetos brasileiros, defendendo economia, a ordem, e acima de tudo, o futuro. De outro lado, o empirismo, a reação, a imprevisão". (In FERRAZ, 1997, p.52)

Em que pese o interesse pessoal no trabalho, declarado no início e no fim da missiva ("Pague pois o que eu pedi. É pouco em relação às vantagens futuras"), a investida pode ser interpretada como uma peça movida com a intenção de valorização da profissão. A atitude soma-se a outras ações que confluíram para a afirmação da arquitetura como disciplina técnica e intelectual, em momento de institucionalização dos cursos e de reconfiguração da definição da profissão, em um ciclo de autonomização em relação à prática construtiva.

Há que se considerar também o tom panfletário da carta. Nesse mesmo período, entre 1943 e 1946, Artigas ajudou a fundar e assumiu funções de tesoureiro na primeira diretoria do IAB, no departamento de São Paulo. A articulação regional de uma organização em defesa dos arquitetos 
cumpriria a função de espaço de debate, reivindicação e socialização, permitindo a formulação e disseminação entre os participantes de discursos e práticas afinadas em defesa da profissão. A aglutinação em torno do IAB é sintomática da situação legal em que se encontrava o profissional de arquitetura. Desde 1933, os arquitetos estavam organizados no Crea, Conselho Regional de Engenheiros e Arquitetos, um órgão fiscalizador que dividia com outras áreas as atribuições, recaindo em disputas profissionais. Tratava-se, pois, de uma entidade compartilhada com profissionais que não tinham "estreitas afinidades em termos de visão de mundo". (DURAND, 1972 , p. 44). Tendo em vista as revindicações encampadas pelo IAB, carta de Artigas emblematiza o anseio dos arquitetos na conformação de seus interesses. Com a regularização e proteção da profissão, buscava-se garantir uma reserva de mercado, distinguindo-se das atribuições profissionais dos competidores mais próximos, entre eles, os engenheiros e construtores.

O ano de 1945 foi também quando o arquiteto se filiou oficialmente ao $\mathrm{PCB}$, uma vez que o partido voltava à legalidade. Além da afirmação de suas convicções políticas, a participação na militância se tornaria também um espaço de construção de amizades e vínculos, aproximando-o de pessoas com estilos de vida e visões de mundo em convergência. Grande parte da clientela que acessa o escritório de Artigas nesse momento está relacionada aos quadros do Partido Comunista, intelectuais e profissionais liberais com militância de esquerda, grupos ligados às manifestações artísticas da cidade. Soma-se a isso o início da carreira acadêmica na Universidade de São Paulo, consolidando os nexos de sociabilidade com clientela intelectualizada.

Participando dos redutos de esquerda, e atuando dentro da universidade, Artigas circulou entre intelectuais militantes e a burguesia engajada. A participação no conselho da revista Fundamentos, junto com Caio Prado Jr., Mário Schenberg, as viagens a Varsóvia, China e Rússia, com intelectuais, entre eles, Jacob Gorender, demarcam alguns pontos da trajetória do arquiteto junto a intelectuais com atuação política. Em 1950, por exemplo, fazia parte do conselho de redação artistas, escritores e 
jornalistas, entre eles, Astrogildo Pereira, Anibal Machado, Graciliano Ramos, Cândido Portinari, Mário Schenberg, Oscar Niemeyer, Moacir Werneck de Castro, grupo de intelectuais que compartilhava posições socialistas em defesa das democracias populares.

Quanto às trajetórias possíveis, aqui é possível estabelecer uma comparação com o arquiteto Oscar Niemeyer, também filiado ao comunismo. Membros do Partido Comunista na conjuntura da redemocratização de 1945, tanto Artigas quanto Niemeyer arrogavam para si a condição de militantes de esquerda; no entanto, a maneira como cada um assumiu as diretivas do partido e incorporou esses preceitos políticos na prática projetual apresenta divergências. As clivagens entre eles correspondem a diferenças nas posições que cada um ocupava no campo da arquitetura brasileira e no interior do Partido ${ }^{123}$. Enquanto Niemeyer entrou para o PCB quando já estava consagrado com projeção nacional e internacional, dando a possibilidade de exercer a arquitetura de modo mais autônomo, Artigas esteve mais proximamente alinhado às teses do Partido, uma vez que sua filiação se deu nos anos iniciais de sua carreira como arquiteto.

Para Artigas, a militância no Partido permitiu a consolidação de uma rede de sociabilidade a partir do aparato organizativo, congregando pessoas com mesmas perspectivas políticas e afinidades estéticas, portanto, chance de formar uma clientela desejosa de encomendar um projeto residencial. Já para Niemeyer, é ele que transfere ao Partido Comunista seu capital simbólico, uma vez que seu prestígio nacional e internacional contribuiu para validar e disseminar as ideias e visões de mundo defendidas pelo grupo. Disso resulta relações diferentes quanto à submissão e à estrutura partidária e empenho ao abraçar as causas. Um exemplo de obediência às teses do Partido se dá com a atuação na Fundamentos, da qual Artigas fez parte da direção a partir de 1949. Ainda que sem fazer referência a Oscar Niemeyer, em 1951 escreveu "Le Corbusier e o Imperialismo", texto em que

123 Sobre a relação de artistas com o realismo socialista cf. Paul ARON, Frédérique MATONTI, Gisèle SAPIRO, eds., «Le réalisme socialiste en France ».Sociétés \& Représentations, 15, 2002. Sobre o campo literário francês e o embate entre colaboracionistas e resistentes, ver. SAPIRO, Gisele. La guerre des écrivains 1940-1953, Paris, Fayard, 1999 . 
fez críticas à linguagem corbusiana, cujo empréstimo servil foi tachado como produto da dominação de imperialista. No plano discursivo e doutrinário, Artigas seguiu o receituário do Partido contra a dominação das potências mundiais e em defesa de um projeto de emancipação nacional, ainda que, no plano estético, não havia as diretrizes específicas para uma arquitetura partidarizada que pudesse definir um cânone para a orientação dos arquitetos. Mesmo que o arquiteto estivesse mobilizado no debate do realismo socialista, para Artigas, seria impossível rejeitar completamente a estética moderna, consagrada na difusão do Estilo Internacional.

Para Niemeyer, a relação com o Partido Comunista ficou constrangida aos vínculos que ele estabeleceu com as camadas de alto comando dos governos instalados no poder, para os quais realizou inúmeras obras monumentais. Na encruzilhada entre apregoar a defesa aos oprimidos e servir ao Estado, a bandeira empunhada pelos comunistas de que arquitetura deveria estar a serviço da revolução social ficaria apaziguada e assim emerge uma justificação em que arquitetura aparece como liberdade plástica e, portanto, apenas submetida ao discurso das formas.

Nas lutas para ocupar a posição legítima, é significativo o teor com que Artigas explicita suas divergências em relação à arquitetura de Niemeyer, em depoimento a Yves Bruand:

"Oscar e eu temos as mesmas preocupações e encontramos os mesmos problemas, mas enquanto ele sempre se esforça para resolver as contradições numa síntese harmoniosa, eu as exponho claramente. Em minha opinião, o papel do arquiteto não consiste numa acomodação; não se deve cobrir com uma máscara elegante as lutas existentes, é preciso revê-las sem temor"124.

Tais oposições declaradas podem indicar caminhos para se compreender os vínculos que cada um estabeleceu com as ideias comunistas, em relação à entrega política e à prática arquitetônica

124 BRUAND, Yves. Arquitetura Contemporânea no Brasil. São Paulo, Perspectiva, 1999. p.302. 
engajada, bem como aos mecanismos de submissão às diretrizes do partido ${ }^{125}$. Artigas acusa Niemeyer de abrandar os conflitos sociais. A produção arquitetônica formalista seria o resultado disso: exuberância das formas, plasticidade do concreto e leveza da linha curva escamoteariam a luta de classe. Contra o formalismo de Niemeyer, Artigas associa o peso do concreto em estado bruto, o uso da estrutura como elemento plástico e a austeridade do caixote sem revestimentos a uma postura de confronto político. Em sua visão, ele seria o arquiteto radical, genuinamente compromissado com as bandeiras da esquerda. Estabelece-se, assim, no plano discursivo, uma polaridade entre, de um lado, harmonia, acomodação e resignação, e de outro, desobediência, denúncia, inconformidade. São oposições que transmutam as próprias disputas em jogo no campo da arquitetura: de um lado, formalismo puro e de outro, arquitetura engajada. Pelo menos é assim que os arquitetos e críticos vão vir a campo para defender suas especificidades, semantizando na linguagem estética, matizes políticos e formas de atuação do arquiteto em relação à sociedade.

Mudanças profissionais e institucionais, engamento político e atuação como docente: o final da década de 1940 se apresenta para Artigas como período de alianças empenhadas em reformular as condições de realização da prática arquitetônica. Tanto na luta corporativa pela profissão, quanto na formulação do ensino, a tarefa que se impunha era a defesa das especificidades da nova profissão em relação à engenharia, com o desafio de sustentar a dimensão estética e ética da arquitetura, para além de uma mera construção desprovida de intenção plástica e compromisso social ${ }^{126}$. Tais investidas sinalizam a aglutinação dos arquitetos paulistas e a

125 A referência para análise da relação da intelligentsia brasileira com o Partido Comunista está inspirada na análise de Frédérique Matonti sobre os intelectuais franceses no período da Guerra Fria, material que permite pensar um modelo de atuação dos agentes sob constrição da obediência política às diretrizes do Partido Comunista. MATONTI, Frédérique. Intellectuels Comunistes. Essai sur l'obéissance politique. La Nouvelle Critique (1967-1980). Paris: La Découverte, 2005.

126 É preciso salientar o papel fundador assumido por Lúcio Costa na definição da especifidade da arquitetura, que angariou o consenso dos arquitetos em torno da questão plástica, ao aproximar o trabalho do arquiteto ao do artista. "Arquitetura é, antes de mais nada, construção; mas, construção concebida com o propósito primordial de ordenar o espaço para determinada finalidade e visando a determinada intenção. É nesse processo fundamental de ordenar e expressar-se ela se revela igualmente arte plástica". Lúcio Costa: Registro de uma vivência. São Paulo: Empresa das Artes, 1995. 
obstinação em se organizar em torno das instituições essenciais à formulação de um projeto com matizes próprias, com vistas a afirmar, ainda que não diretamente, as especificidades de uma arquitetura paulista.

\section{A fundação da FAU-USP}

No início dos anos 1940, quanto à disseminação do ensino de arquitetura, havia em São Paulo os cursos oferecidos pela Escola Politécnica e pelo Mackenzie College, que conferiam o título de engenheiro-arquiteto. No Rio de Janeiro, centrada em uma abordagem de cunho artístico, havia a Escola Nacional de Belas Artes (ENBA), cuja origem remonta à instituição de ensino das artes no império. Enquanto Lúcio Costa e Oscar Niemeyer se formaram nessa tradição associada às artes, respectivamente em 1924 e 1934, Vilanova Artigas se formou, em 1937, na Escola Politécnica, vertente ligada à engenharia.

É somente na segunda metade dos anos 1940 que os cursos de Arquitetura ganham autonomia em relação às artes e às exatas. No Rio de Janeiro, em 1945, cria-se a Faculdade Nacional de Arquitetura da Universidade do Brasil, e em São Paulo, em 1947, a Faculdade de Arquitetura do Mackenzie torna-se independente do curso de Engenharia, bem como, no ano seguinte, funda-se a Faculdade de Arquitetura e Urbanismo da Universidade de São Paulo, separada da Escola Politécnica. Tais origens, ora vinculadas com a matriz artística, no caso do Rio de Janeiro, ora assentadas na técnica e no cálculo, no caso da ligação com os cursos de Engenharia em São Paulo, são centrais para entender as diferenças técnicas e estéticas assumidas pelas duas vertentes arquitetônicas em questão.

As transformações do estatuto da prática profissional e o debate concernente ao ensino caminhavam na mesma direção, ecoando uma crescente demanda pela autonomia em relação à Politécnica. Comprometido 
com a institucionalização de ensino liderada por Luís Inácio de Anhaia Melo, Artigas foi um dos que colaboraram com a fundação, em 1948, do curso de Arquitetura e Urbanismo na Universidade de São Paulo, quando este ganha independência das engenharias. A experiência dentro da universidade como professor vinha desde 1940, quando Artigas aceitou o convite para ser assistente de Anhaia Melo, nas disciplinas de "Estética e Composição Geral", no curso de engenheiro-arquiteto da Politécnica.

O estabelecimento de relações com a Universidade de São Paulo Ihe propiciou em 1946 uma bolsa de viagem aos Estados Unidos, patrocinada pela Fundação Guggenheim, cujo objetivo era o estudo dos cursos de arquitetura norte-americanos. No momento em que a Universidade de São Paulo constituiria uma Faculdade de Arquitetura e Urbanismo, a ida para os Estados Unidos se abriria como possibilidade para efetivação na carreira docente. No novo arranjo institucional, a disposição em ficar de setembro de 1946 a novembro de 1947 nos Estados Unidos, circulando entre diferentes faculdades ${ }^{127}$ Ihe rendeu a contratação, no mesmo ano, para o cargo de professor na cadeira de "Composição de Arquitetura e Pequenas Composições" na nova faculdade.

No plano de trabalho que entregou para conseguir a bolsa de estudos da Fundação Guggenheim, Artigas deixa explícito que a ida aos Estados Unidos poderia representar um avanço na ventilação de ideias arquitetônicas em São Paulo:

"Os Estados Unidos representam no momento uma grande fonte para estudo e investigação em arquitetura, não só pelo que alguns de seus arquitetos já fizeram, como também porque tem atualmente quase que o monopólio dos grandes arquitetos do mundo. F. L. Wright, Walter Gropius, R. Neutra, somente para começar uma grade lista. A influência que estes mestres podem ter no desenvolvimento da arquitetura americana, nós, brasileiros podemos julgar bem, lembrando como

127 As instituições com as quais Artigas teve contato foram Massachusetts Institute of Technology, Columbia University, em Nova Iorque, Black Mountain College, na Carolina do Norte, Florida Southern College, em Lakeland. Entre as cidades, o roteiro de viagem de leste a oeste do país, visitou Boston, Cambrigde, Lincoln, Nova Iorque, Washington, Black Mountain, Knoxville, Atlanta, Lakeland, Nova Orleans, Dallas-Forth Worth, Oklahoma City, Albuquerque, Grand Canyon, Phoenix, Scottsdale, Los Angeles, San Francisco, Portland e Chicago. IRIGOYEN, Adriana. Wright e Artigas: duas viagens. São Paulo: Ateliê Editorial/Fapesp, 2002. 
frequentemente fizemos, o efeito no Rio de Janeiro da visita de Le Corbusier. Já em São Paulo, a minha cidade, as coisas tem-se passado de maneira bem diferente. Condições locais especiais têm dificultado maiores raízes para a arquitetura moderna. O que nos tem faltado, pretendo trazer da América". ${ }^{128}$

A motivação institucional de abertura do curso de Arquitetura na Universidade de São Paulo ganhou apadrinhamento da família Álvares Penteado, que doou, em 1946, seu palacete em estilo art nouveau, localizado em Higienópolis. A condição imposta era que o edifício fosse destinado à abertura do curso. Em contraposição à orientação artística das belas-artes e da matriz técnica da formação de engenheiro-arquiteto da Politécnica, a institucionalização do curso de Arquitetura e Urbanismo respondia às reivindicações dos profissionais da área, interessados em uma formação específica, de cunho humanista e artístico. Institucionalizar o ensino em São Paulo seria importante passo para se contrapor à hegemonia estabelecida no Rio de Janeiro.

O investimento na carreira de docente é um ponto central na trajetória de Artigas, que se diferencia de outros arquitetos consagrados na linguagem carioca. Lúcio Costa, com exceção da pequena passagem na ENBA e Oscar Niemeyer, em pequeno período de aula na Universidade de Brasília, não se dedicaram a formar discípulos por via do sistema de ensino. Já Vilanova Artigas, ao se engajar na tarefa de institucionalização do curso de Arquitetura na Universidade de São Paulo atuou mobilizando investimentos de forma a difundir sua liderança, o que contribuiu para recrutar arquitetos com afinidades e promover discípulos a partir das gerações sequentes ${ }^{129}$. Tais herdeiros empenhados em desenvolver uma linguagem arquitetônica a partir do léxico comum atuariam como quadros reprodutores da arquitetura paulista, com vantagem de serem subvencionados pelo salário de docente da Universidade de São Paulo,

128 IRIGOYEN, Adriana. Wright e Artigas: duas viagens. São Paulo: Ateliê Editorial/Fapesp, 2002. p. 148

129 Refiro-me a Paulo Mendes da Rocha, Carlos Milan, Joaquim Guedes, Sérgio Ferro, Rodrigo Lefèvre, arquitetos que assumirão cadeiras como docentes na FAU-USP a partir de 1954. 
segurança material que possibilitaria a proposição de uma estética mais radicalizada e apartada do mecenato estatal.

A virada dos anos 1940 para os 1950 é significativa para a reformulação estética pela qual passaria a produção de Artigas. A novidade não passou despercebida pelas instâncias de consagração, como a revista Habitat, organizada por Lina Bo Bardi sob auspícios do Masp. A edição inaugural da revista, em outubro de 1950, abria com uma matéria especial dedicada às residências de Vilanova Artigas. Para Lina, Artigas, ao eliminar o elemento decorativo, impunha uma moral severa que questionava a ordem burguesa:

"Cada casa de Artigas quebra todos os espelhos do salão burguês. Nas casas de Artigas que se veem, dentro tudo é aberto, por toda a parte o vidro, e os tetos baixos, muitas vezes a cozinha não é separada, e o burguês que se deixasse levar pela novidade e pedisse uma casa a Artigas, chocado com 'tão intimidade', cego por tanta claridade, se apressaria em fechar com pesadas cortinas as vidraças, a fazer crescer sebes, a reforçar as portas, para continuar, bem defendido, a sua vida despreocupada entre os móveis chippendale e os abat-jours pintados à mão."130

Se de um lado estava em questão, nos discursos dos arquitetos, o desejo de transformação social e o questionamento dos padrões burgueses, na aplicação prática, as inovações nas formas de morar encontrariam dificuldades e resistências nos habitantes da casa. Algumas biografias de clientes relatam a novidade e o encantamento de se morar em uma residência moderna - signo de admiração e status entre amigos, e os obstáculos da efetivação do projeto e constrangimentos da vida cotidiana, seja pela pouca funcionalidade de algumas soluções ousadas, seja pela dificuldade de se acostumar com uma moradia "fora dos padrões". A encomenda de Alfredo Mesquita para a construção do Edifício Louveira, empreendimento com 30 apartamentos, sinaliza os investimentos financeiros dos irmãos Mesquita na área imobiliária. Já as residências 
projetadas para os casais Alice Brill e Juljan Czapski, no Sumaré, e Deocélia Vianna e Oduvaldo Vianna, anunciam fraturas e revelam os grupos sociais (artistas e intelectuais) que estavam dispostos a arcar com esses caprichos para ratificar seus estilos de vida.

\section{Edifício Louveira para os irmãos Alfredo, Esther e Lia Mesquita}

Entre vários os projetos de moradias unifamiliares até então, em 1946, Artigas é convidado por Alfredo Mesquita para projetar um edifício residencial em terreno de propriedade da família, em frente à Praça Vilaboim. [fig. 38] Alfredo Mesquita, filho caçula dos proprietários do jornal Estado de São Paulo, esteve sempre ligado às manifestações artísticas da cidade, investindo prioritariamente em práticas culturais, como teatro e literatura. A encomenda a Artigas foi feita em nome de Alfredo e suas duas outras irmãs, Esther e Lia, também solteiras, como ele. Os demais irmãos casados já estavam empregados nos negócios familiares, dando continuidade aos empreendimentos dos Mesquita. Possivelmente vislumbrando uma chance de futura estabilidade financeira, o trio de irmãos solteiros resolvera investir no mercado imobiliário, garantia de esteio econômico quando da ausência de bom casamento.

Pertencente a uma família de nove irmãos, sendo seis mulheres, Alfredo, diferentemente dos outros dois "homens da casa" - Júlio Mesquita Filho e Francisco Mesquita - foi excluído dos negócios familiares, pouco se envolvendo com a manutenção do jornal. Irmão caçula acobertado pela ala feminina da família, Alfredo pouco trabalhou até os 40 anos de idade, integralmente se dedicando aos estudos, cursos, acumulando formação intelectual e estética ${ }^{131}$. Era visto como frágil e sua inclinação para a arte era encarada com suspeita. Aos 39 anos, o investimento na construção do prédio de apartamentos antecede em um ano as preparações em torno da

131 GÓES, Marta. Alfredo Mesquita: um grã-fino na contramão. São Paulo: Editora Terceiro Nome, 2007. p.41 
fundação da EAD, Escola de Arte Dramática, que dirigiu até 1968, criação artística contribuidora para a formação do teatro em São Paulo.

Ainda que fixado na cidade de São Paulo e enraizado na dimensão cultural da metrópole, Alfredo frequentava com assiduidade a fazenda da família em Louveira, da qual era responsável pela administração. De lá sempre trazia verduras, queijos e doce de leite para abastecer a casa na cidade e era para lá que levava amigos artistas, poetas, intelectuais e atores do teatro para momentos de convívio. Em sua biografia, percebe-se que a fazenda ocupa um espaço de respiro em relação às pressões da vida na capital, espaço de consolidação de sua rede de amizades e experiências pessoais. Como contraponto, o prédio moderno projetado por Artigas levou o nome "Louveira", em homenagem ao vínculo sentimental que tinha com a fazenda.

Ainda que a reminiscência seja à propriedade agrária da família Mesquita, o edifício Louveira se impõe à cidade de São Paulo como símbolo de modernidade. No partido arquitetônico, Artigas propõe dois edifícios interligados por um grande jardim com rampa de acesso sinuosa. 0 programa moderno corbusiano das grandes janelas em fita percorrendo toda a fachada, os pilotis, a integração com a escala urbana e a síntese com as artes atestam a conexão aos paradigmas internacionais da arquitetura moderna. A novidade da proposta foi tão grande que o código de obras da cidade não estava preparado para aprovar tais ideias. Com grandes janelas envidraçadas em duas faces do edifício visualizando a área arborizada, Artigas desenha uma empena cega (face sem janelas) voltada para a rua, solução que foi criticada pelo departamento de aprovação de projeto da prefeitura. Mesmo assim, o projeto foi executado e "ninguém teve coragem de dizer que eu tinha que abrir as janelas na empena"132.

Se do ponto de vista do arquiteto, o rompimento a ser feito era com a estética convencional disseminada na cidade de São Paulo, do ponto de vista do encomendante, o investimento na inovação Ihe colaria a pecha, no ambiente familiar, de mal investidor. A biógrafa de Alfredo Mesquita relata

132 Depoimento de Artigas, in FERRAZ, 1997, p.55. 
algumas agruras que o mecenas sofreu ao bancar a contratação do arquiteto ousado:

"A propósito do empreendimento, ele resmungava. 'Convidei esse rapaz e quase ele me deixou maluco'. Referia-se aos inevitáveis prazos vencidos e à maneira de o arquiteto lidar com os mestres de obras, que ele julgava demasiado democrática. Na família, o edifício ficou famoso como exemplo da vocação de Alfredo para perder dinheiro"133.

\section{Casal Alice Brill e Juljan Czapski}

As relações de encomenda da casa não se dão pelas contingências, mas pelas afinidades que ligavam cliente a arquiteto, identificação que pressupõe preferências, gostos e práticas sociais em comum, que se ajustam em disposições estéticas e éticas. A fotógrafa Alice Brill conheceu o casal Artigas e Virgínia no Grupo Santa Helena, onde frequentaram aulas de desenho. Imigrante alemã judia, em 1934, Alice veio para o Brasil com 13 anos, junto com a mãe, fugidas com a ascensão do nazismo na Europa. O pai, Erich Brill, pintor de paisagens conhecido na Europa, ficara para continuar seus trabalhos. Ainda que na Alemanha a mãe de Alice trabalhasse como repórter, no Brasil, elas tiveram que tentar a vida em diferentes trabalhos. Em um desses empregos, Alice conheceu o futuro marido, Juljan Czapaski, seis anos mais novo, quando ela havia sido contratada para trabalhar como secretária de negócios da família. Em emprego anterior, na livraria Guatapará, conheceu vários intelectuais e artistas, como Paulo Rossi Osir, que a colocou em contato com o grupo de artistas do Santa Helena, quase todos eles vindos da Itália, Espanha e Portugal ou descendentes desses países:

"Pessoas de origem humilde que não deixavam suas profissões artesanais, como a decoração de paredes, a ourivesaria, o bordado, para fazerem arte. Eles trocavam conhecimentos, promoviam sessões de

133 GÓES, Marta. Alfredo Mesquita: um grã-fino na contramão. São Paulo: Editora Terceiro Nome, 2007. 
modelo-vivo durante a semana e, nos fins de semana, faziam excursões aos arredores da cidade para exercitar a pintura de cavalete ao ar livre. Tinham um estilo próprio com que Alice se identificou, pois não se prendiam ao classicismo, nem ao jeito dos modernistas de $1922^{\prime \prime 34}$.

A amizade com o casal Artigas teve início nessas atividades artísticas, demarcando relações estreitas e interesses em comum. Ao receber uma bolsa de estudos da Arts Students League, Alice Brill foi morar nos Estados Unidos e reencontrou com o casal em 1948, época em que Artigas também tinha viajado com a bolsa da Fundação Guggenheim. De volta ao Brasil, a amizade rendeu o convite para Artigas projetar a morada do casal.

Ainda que nesse período Artigas e Virgínia estivessem diretamente vinculados à militância do Partido Comunista, a amizade não levou ao convencimento para participarem das atividades políticas, principalmente por conta do marido, Juljan Czapski, que discordava das ideias de esquerda. Fugido da Polônia com a família por conta da perseguição nazista, ele não concordava com o sistema comunista, pois, acabada a guerra, o regime se implantou no país, ocupando terras e gados que a família havia deixado. No entanto, a convivência entre os casais permaneceu constante, como atestam o projeto da residência e a participação na fundação do Museu de Arte Moderna de São Paulo, em 1947, da qual foram signatários a convite de Artigas. Para além das preferências em matéria artística, as afinidades entre as duas famílias transpassaram em relações afetivas: uma das filhas do casal - Sílvia Virgínia Czapski - recebeu segundo nome em homenagem à esposa de Artigas.

O projeto de Artigas para o casal foi encomendado em 1949, quando Alice e Juljan tinham acabado de casar. [fig. 39] Naquele momento, com recursos parcos, ela trabalhava como fotógrafa para várias revistas, entre elas a Habitat, e ele, estava terminando a faculdade de Medicina. Ganhavam pouco, mas conseguiram poupar algum dinheiro para realizar o sonho de uma casa própria, que contaria com um pequeno estúdio

134 CZAPSKI, Silvia. O cavaleiro da saúde: a saga de Juljan Czapski, criador dos planos de saúde no Brasil. Osasco: Novo Século, 2011. p. 80 
fotográfico para Alice trabalhar:

"Juljan soube de um loteamento no bairro do Sumaré, em que os compradores recebiam o terreno por meio de uma hipoteca na Caixa Econômica e logo conseguiam a escritura definitiva, para viabilizar o financiamento da construção da casa. O jovem perguntou ao amigo Vilanova Artigas se o valor ofertado bastaria para erguer uma residência. Ele disse que sim. Confiaram e deram carta branca ao arquiteto, que só mais tarde ficaria famoso. Ele escolheu um terreno em declive e as obras começaram. Como não é raro acontecer, a construção estava pela metade quando o dinheiro acabou". (Czapski, 2011, p.98)

Juntando outros recursos por meio das relações familiares, o casal conseguiu concluir a casa. [fig. 39] A descrição dos espaços deixa à mostra a irreverência do projeto, abrindo brechas para revelar o desconforto entre a funcionalidade aparente da casa moderna:

"Por fim, a Casa Czapski ficou pronta. Era uma jóia da arquitetura moderna, diferente de todas as outras. Para compensar o terreno inclinado, fora construída sobre pilotis. $\mathrm{O}$ telhado tinha formato em ' $\mathrm{V}$ ', dando à casa uma forma que alguns chamariam de asa de borboleta. Sua frente fora feita com grandes placas de vidro transparente. Se a transparência tirava a privacidade da família, isso era um pequeno incômodo ao qual teriam de se acostumar. O laboratório fotográfico ficava na entrada. Para alegria das crianças, uma rampa substituía a escada de acesso às demais dependências. Instalada para facilitar a placa de linóleo no chão foi certa vez encerada: tornou-se o escorregador de estimação dos mais novos, e até de algum adulto que quisesse aderir à brincadeira [...] Profissional e mãe, Alice preparava tudo sozinha, pois nessa hora, a 'secretaria do lar' já tinha ido embora. Por achar socialmente incorreto, o arquiteto não previa um quarto de empregada. [...] Como na casa só se saía pela sala, era preciso atravessá-la com o lixo para levá-lo à rua. Mais um preço da arquitetura moderna, que colocava a beleza acima da praticidade. Mas nada disso tirava a atração que a casa exercia sobre os amigos, que fizeram dela ponto de encontro". (Czapski, 2011, p.98) 
Compacta, a casa contava apenas com dois quartos, espaço que se tornou pequeno com a chegada do quarto filho do casal, em 1960, quando os moradores deixaram o imóvel. O período coincide com a ascensão financeira da família e a inscrição em outros círculos sociais, com recursos provenientes da atuação de Juljan na área médica. No entanto, o momento inicial de adesão aos preceitos modernistas e o período de dez anos em que residiram na casa reafirmam disposições estéticas que só puderam ser adquiridas em condições específicas, afinadas com grupos de vanguarda e de posse de algum recurso material passível a transformar esses estilos de vida em moradia.

A narrativa da família, se por um lado anuncia as veleidades que os arroubos modernos impunham, por outro, revela os grupos sociais (artistas e intelectuais) que estavam animados a arcar com os caprichos para ratificar seus estilos de vida e "pagar o preço" simbólico e material desse modo de morar moderno.

\section{Deocélia Vianna e Oduvaldo Vianna: militância comunista e estética}

As expectativas e limitações em torno da casa projetada para o casal Oduvaldo Vianna, escritor, dramaturgo e Deocélia Vianna são representativas das afinidades e negociações entre arquitetos e clientes. Grandes amigos de Artigas por conta da militância no PCB, o casal planejou a compra de um terreno no Sumaré, na avenida Dr. Arnaldo, para construção da casa, em um momento no qual a venda de textos dramatúrgicos e o trabalho nos Diários Associados e agências de publicidade possibilitaram amealhar boa quantidade de recursos financeiros. No ano da encomenda, em 1950, Oduvaldo Vianna já usufruía de certo prestígio com a venda de novelas para rádio e teatro. Vianninha, filho do casal, estava então com 14 anos, e a casa representaria essa nova fase da vida da família, de militância política e êxito material. 
A casa projetada por Artigas se valia do terreno íngreme para implantar um bloco prismático sob pilotis, com estrutura de concreto armado. Essa casa seria a primeira a fazer uso das rampas para ligação dos blocos. Ela possuía quatro pavimentos alternados e interligados pelos espaços de circulação, modelo que depois foi aproveitado no projeto da Faculdade de Arquitetura e Urbanismo. No andar mais baixo, estavam os dois quartos com banheiro, um para o casal e outro para o filho. Em seguida, subindo um lance de rampa, localizavam-se as dependências de empregada, com acesso externo à cozinha por escada em caracol. Mais um lance e se acessavam o estúdio e o terraço. Por fim, no último pavimento, situavam-se sala de jantar, sala de estar e pequena cozinha. [fig. 40]

Além do arrojado projeto arquitetônico, no qual se pode verificar influência de Le Corbusier no uso dos pilotis, a família contratou Clóvis Graciano para pintar um painel no salão principal da casa cuja imagem representava mulheres catadeiras de café, e para decorar a sala, o casal também planejou a compra de uma pintura de Cândido Portinari, artista também pertencente aos círculos de amizades de esquerda. Quanto à mobília da casa, fora projetada sob medida pelo designer de móveis modernos Zanine Caldas ${ }^{135}$. Ainda que a amizade com Artigas tenha rendido a elaboração de um projeto gratuito, os gastos para a construção se avolumaram, devido a imprevistos, como a reconstrução do muro do vizinho, que ficou abalado ${ }^{136}$. Apesar de o projeto da moderna residência parecer reunir grandes expectativas e desejos, a efetivação da construção frustrou as aspirações iniciais.

O longo trecho do depoimento vale o interesse pelas viravoltas em jogo, pela forma humorada com que Deocélia narra os conflitos que o projeto acabou por trazer, em que se cruzam desacordos com relação aos arroubos modernos, conflitos ligados à posição feminina, o malogro da empreitada e o desmanche das pretensões.

135 SANTOS, Maria Cecília Loschiavo. Móvel Moderno no Brasil. São Paulo: Studio Nobel/Fapesp/ Edusp, 1995.

136 Além do muro, "O roseiral do vizinho dos fundos foi destruído e meu marido pagou o prejuízo." VIANNA, Deocélia. Companheiros de Viagem. São Paulo: Brasiliense, 1984. p. 121. 
"E aí começou o nosso, nosso não, meu drama. Por causa da casa, tive várias discussões com meu marido. Ele procurou o Vilanova Artigas, professor de Arquitetura, criatura maravilhosa. Seguindo a vontade de Oduvaldo, ele fez a planta mais maluca que já vi na minha vida. Talvez mais maluca do que a casa em que ele e a Virgínia moravam. Ela me contava que tocavam a campainha de sua casa, lá pros lados de Santo Amaro e perguntavam:

- Aí é que é a granja?

- É a fábrica de botões?

- Aí é o Hospital Veterinário que interna animais?

Achavam a casa com jeito de tudo, menos de uma casa familiar... Pois a nossa tinha $500 \mathrm{~m}^{2}$ de área construída e apenas dois quartinhos pequenininhos, que mal davam para nós. O meu só daria para a cama de casal com as duas mesinhas de cabeceira, com armários embutidos, claro, e banheiro completo, porém pequeno, e o quarto do Vianinha comportava a cama e uma estante que se transformava em mesa de estudo, e um banheiro com chuveiro. Metade da construção era em rampas, um salão de $8 \times 6 \mathrm{~m}$, outro de $5 \times 4 \mathrm{~m}$, áreas lajotadas, a cozinha, mirradinha também, era na frente da casa, dando para a rua. Para uma dona de casa, um horror! Artigas acabou brigando comigo, eu não tinha que dar palpites, eu não entendia de construção, eu era burra. E haja dinheiro para os empreiteiros [...] Eu já me recusava a morar na casa, onde seria preciso um mordomo de luvas e tudo, coisa que não coincidia com a nossa maneira de pensar. Para encurtar a história, uma parede externa junto à primeira rampa era de vidro, três metros de altura na parte mais baixa e nove metros na parte mais alta. Como lavar aqueles vidros? Teríamos que contratar uma empresa que colocasse Jaú para limpar aquilo tudo. Vai daí o dinheiro acabou, a casa foi hipotecada à Caixa Econômica e para encerrar a confusão, os Associadas despediram Oduvaldo. Bilhete azul sem mais sem menos, isto é, devido, é claro, à sua posição política[...]"137

Como visto, se os primeiros anos de formado lhe renderam projetos

137 Idem p.121-122. 
para uma elite prioritariamente de domínio econômico, a partir de 1945, os novos espaços institucionais que estava engajado propiciaram contato com novos grupos sociais. Essa arquitetura vai dar respostas às ambições das frações de uma elite intelectualizada e politizada. Nesse momento, sob orientação do PCB, Artigas recusa participar do projeto de conjuntos habitacionais em grande escala no governo de Getúlio Vargas, para os Institutos de Aposentadoria (IAPs), e passa a defender a moradia moderna como espaço para educar a burguesia nacional. Tal como as diretrizes defendidas pelo partido com relação às etapas de desenvolvimento do país, para o arquiteto, o projeto da casa adquiria o papel de formar a classe burguesa como sujeito histórico apto a assumir o desenvolvimento nacional. Essa visão das classes dominantes estava forjada nas doutrinas do PCB, que defendia interpretação etapista da história e apostava na superação das características feudais do país aliando-se à burguesia nacional com o objetivo de promover a industrialização brasileira ${ }^{138}$. Tal postura se expressa nos projetos residenciais:

\footnotetext{
"Na década de 50, achei necessário mudar a tipologia da casa paulistana. Tratava-se de modificar a divisão interna espacial da casa da classe média paulistana, que necessitava se atualizar em relação às modificações sociais que se processavam em nosso país"139.
}

Se a casa moderna propõe inculcar uma expectativa de consciência social na burguesia, logo se percebe que um projeto desse porte na escala tão reduzida da moradia estaria frustrado. Os grupos potencialmente aptos a aceitar morar em uma residência moderna já estavam convertidos aos estilos de vida ensejados, como se expressa pela homologia social entre clientela e arquitetos. Nos termos de José Carlos Durand, "as soluções típicas dessa arquitetura supõem uma clientela cultivada e cúmplice, social e culturalmente próxima do arquiteto, para identificar-se com ele, expor-lhe suas necessidades e estilo de vida e conceder-Ihes a autonomia pretendida

138 RIDENTI, Marcelo. Em busca do povo brasileiro. Rio de Janeiro: Record, 2000.

139 ARTIGAS, Vilanova. "Depoimento". In XAVIER, Alberto. Depoimento de uma geração arquitetura moderna brasileira. (p.217) 
para uma proposta 'ousada'"140. E enquanto a moradia burguesa tradicional, com sua exibição de ornamentos e adornos, cumpre claro papel social de alardeamento do capital econômico de seu proprietário, a proposta moderna, despida desses elementos, ostenta uma visão de mundo, daqueles que "não precisam aparecer" ou que "aparecem sem denunciar que querem aparecer"141.

No plano cultural, essas residências estão alicerçadas em projeto modernizador mais amplo, atravessado por renovações na prática profissional, no ensino de arquitetura e na concepção de função social para a atuação do arquiteto. Se por um lado podem ser vistas como expressão de desejos de distinção social com ambições estéticas, por outro, estão revestidas de utopias políticas em um projeto de desenvolvimento nacional cujas expectativas foram frustradas.

Ainda que o foco deste capítulo seja os anos 1940 e as condições de ingresso profissional, vale explicitar que nas décadas seguintes, período de exacerbação e consagração de sua linguagem moderna, o arquiteto passa a produzir algumas casas para pessoas ligadas à intelectualidade universitária e vinculadas aos círculos de esquerda: o médico judeu David Rosemberg ${ }^{142}$, docente da Escola Paulista de Medicina; Febus Gikovate, médico e militante trotskista; os biólogos Olga Henriques Baeta e Sebastião Baeta, em 1956, vinculados à pesquisa do Instituto Butantã; a professora e demógrafa Elza Berquó, amiga que Ihe encomendou uma residência no momento em que Artigas estava preso, em 1969. Ele também serviu aos anseios estéticos da burguesia politizada e ilustrada, como o empresário da companhia de seguros Equitativa, o português Manuel Antônio Mendes André ${ }^{143}$, em

140 DURAND, José Carlos. Arte, privilégio e distinção. Artes Plásticas, Arquitetura e Classe Dirigente no Brasil, 1855/1985. São Paulo: Perspectiva/EDUSP, 1989 p.280.

141 Idem. p.277.

142 Atuante na militância comunista, David Rosemberg foi afastado da carreira docente pela perseguição instaurada pelo regime militar. Agradeço a Lia Rosemberg, filha de David, pelas informações fornecidas.

143 Sobre Manuel Mendes André, o laboratório de vídeo da FAU-USP realizou gravações com o encomendante, material não editado e não publicado que revela o engajamento nas manifestações estéticas e políticas dos anos 1950 e 1960. Agradeço a José Mendes André, neto de Manuel, por fornecer em entrevista informações sobre o avô. 
projeto de 1966, também simpatizante do Partido Comunista. Seja pelos espaços amplos, interligando os vários ambientes da casa, pela redução dos espaços individuais (quartos) e ampliação dos espaços de uso coletivo, pelo arrojo estrutural, pelo uso do concreto sem revestimento, essas moradias materializam na linguagem estética e na concepção do espaço doméstico algumas das representações políticas que mobilizavam esses grupos.

Logo no início profissional, seus projetos residenciais foram tomadas como um modelo exemplar da casa moderna, valorizado nas revistas especializadas por sua radicalidade e moral construtiva e elogiado por críticos do porte de Mário de Andrade. Reconhecido pelos colegas por ser uma figura cativante e enérgica, Artigas conseguiu reunir em torno de seu projeto modernizador arquitetos e clientes que partilhavam a dimensão estética e política do projeto. Essa capacidade de liderança e engajamento, combinação de origem social modesta, socialização escolar em uma escola de elite e ambição transformadora, contribuiu para que disseminasse suas ideias e controlasse a interpretação de sua obra. A habilidade de orador e a experiência política ajustada na militância comunista deram corpo a uma prática missionária. Tais atributos de uma personalidade envolvente desempenharam papel efetivo na aglutinação de uma geração de jovens arquitetos, assim como contribuiu para que influenciasse aqueles que assumiriam a função de comentadores teóricos do grupo.

\section{O trabalho simbólico dos mentores e divulgadores}

"Faz parte essencial da condição humana viver em beleza também. E nisso deriva o valor, a necessidade decorativa implícita nos mil e um elementos, não da máquina de fazer tecidos, mas da máquina de morar [...] as arquiteturas mais sublimes as quais para meu gosto e raciocínio são o egípcio, o renascimento florentino e a casa moderna. A casa moderna legítima, entenda-se: o Ministério da Educação e jamais o Ministério da Guerra; o Edifício Esther e jamais a Faculdade de Direito; uma morada de Artigas e jamais uma moradia neocolonial." 
Mário de Andrade, "Brazil Builds"144

Com essas palavras publicadas no jornal Folha da Manhã, Mário de Andrade teceu comentários ao catálogo da exposição realizada no MoMa, Museu de Arte Moderna de Nova York, em 1943. Intitulado Brazil Builds, o material norte-americano reunia diversas obras que foram selecionadas pelo curador da exposição, Philip Goodwin, também responsável pelas relações internacionais do museu. A escolha dos edifícios para compor a publicação contou com a indicação de Gustavo Capanema e Rodrigo Mello Franco de Andrade, mentores do Ministério da Educação e Saúde e do SPHAN, órgão responsável por valorizar o patrimônio nacional. Sob tutela do Estado, a arquitetura moderna brasileira dos anos 1930 e início de 1940 ganhava destaque internacional e orgulhava os intelectuais engajados na institucionalização do patrimônio nacional.

A organização do catálogo com edifícios representativos da cultura brasileira viria articulada com um trabalho político, fruto do empenho institucional do Estado varguista, que se aproximava dos Estados Unidos na Segunda Guerra Mundial ${ }^{145}$. O Brazil Builds se apresentou como uma vitrine na circulação internacional da arquitetura brasileira, que deu visibilidade ao que se produzia no país, contribuindo para aumentar a reputação dos arquitetos, eleger obras paradigmáticas e valorizar nossa identidade cultural no exterior. Comentando o sucesso com que o material foi recebido, e entusiasmado com a exaltação da produção brasileira, Mário de Andrade se mostrava confiante na superação de nosso "complexo de inferioridade". A arquitetura moderna seria uma oportunidade para um "país de mestiços" ter reconhecida sua capacidade criativa. Ou seja, em suas ideias, arquitetura

144 Folha da Manhã, São Paulo, 23 de março de 1944. (grifos meus) In. XAVIER, Alberto (org). Depoimento de uma geração. São Paulo: Cosac \& Naif, 2003.

145 Escrito pelo norte-americano Philippe Goodwin, o prefácio de Brazil Builds inicia justificando o interesse em se aproximar do Brasil em razão do país se tornar um futuro aliado dos Estados Unidos: "The Museum of Modern Art, New York, and the American Institute of Architects in the spring of 1942 were both anxious to have closer relations with Brazil, a country which was to be our future ally. With this motive and with a keen desire to know more about Brazilian architeture, especially their solutions for the problem of controlling heat and light on large exterior glass surfaces, a flying trip was undertaken". GOODWIN, P. Brazil Builds. Architecture New and Old. 1952-1942. THE MUSEUM OF MODERN ART, NEW YORK, 1943 
moderna e autoestima nacional andariam juntas para a construção da identidade de um país que se pretendia moderno e avançado.

Nesse mesmo artigo, os comentários de Mário de Andrade também deram alento à polêmica sobre o local de origem da arquitetura moderna no Brasil, em meio à rivalidade entre cariocas e paulistas. O crítico enaltecia a arquitetura então produzida no Rio de Janeiro, enfocando o protagonismo da figura de Lúcio Costa, e atribuindo a essa tradição o germe de uma genuína "escola de arquitetura moderna". Os cariocas ficam com o título garboso de consolidação em uma linhagem, com o mérito de formar uma "escola", índice de renovação e coesão estética entre membros de um grupo. Aos paulistas, na visão de Mário de Andrade, como consolo, caberia o prêmio de estreia, por ter inaugurado a modernidade. O arquiteto judeu de origem russa Gregori Warchavchik, que chegou ao Brasil em 1923, com 27 anos, que é lançado como o pioneiro da arquitetura moderna brasileira. Pelo menos é essa a avaliação de um modernista inveterado:

"A primeira manifestação da arquitetura moderna no Brasil, como a das outras artes, também se deu em São Paulo. Foi uma casa do arquiteto Warchavchik, muito comentada pelas nossas revistas de então. Mas o moderno de arquitetura teve de ceder aqui. A primeira escola, o que se pode chamar legitimamente de 'escola' de arquitetura moderna no Brasil, foi a do Rio, com Lúcio Costa a sua frente, e ainda inigualado até hoje. ${ }^{\prime 146}$

Ainda que a tendência carioca, que vinha se encorpando desde os anos 1930, tenha levado a condecoração de modernista-mor, a arquitetura paulista também é contemplada, com a defesa do pioneirismo de Warchavchik e da autenticidade do modernismo de Artigas. O cotejo entre a produção das duas regiões abriria flanco para avaliações posteriores de historiadores, que se enfrentariam em nome da separação em duas linhagens, argumentando características singulares de cada vertente ou se uniriam defendendo as similitudes, em busca da construção de uma identidade nacional. Nesse confronto, os elogios às casas projetadas pelo 
jovem Artigas, que naquele momento acabara de abrir escritório próprio na capital, seriam um modo triunfalista de apresentar o arquiteto como promessa de consolidação de uma vertente da arquitetura brasileira, estreando com suas "máquinas de morar modernas".

Foi, no entanto, somente nos anos 1960 que Artigas passou a ser apontado mais claramente como figura central da "Escola Paulista", denominação retrospectiva utilizada pela historiografia para agrupar um conjunto de arquitetos que nos anos 1950 e 1960 representou uma ampla modernização da arquitetura em São Paulo ao fazer uso do concreto aparente e da estrutura do edifício como elemento plástico. Nessas leituras, o material historiográfico sobre a produção arquitetônica moderna em São Paulo seguiu, em grande parte, as diretrizes interpretativas reorganizadas pelo francês Yves Bruand, que se valeu do termo "brutalismo paulista".

Ao se reconstituir as linhas de força da interpretação de Bruand, é possível afirmar que o trabalho, que se tornou referência primeira da produção historiográfica no país, recuperava em grande medida as próprias interpretações que os arquitetos modernistas e os intelectuais atuantes no Estado aplicaram sobre suas produções, entronizando uma leitura na qual a arquitetura moderna se institui, ao mesmo tempo, como ruptura e continuidade com o passado. No entanto, o que retomou do passado foi uma reinvenção elaborada pelos próprios arquitetos. Cumpre lembrar que um dos principais instrumentos intelectuais e burocráticos de edição da história da arquitetura se fez com a criação do Serviço do Patrimônio Histórico e Artístico Nacional (SPHAN), projeto de início concebido por Mário de Andrade e, em seguida, reformulado por Rodrigo Mello Franco de Andrade. O órgão federal conseguiu imprimir uma política de classificação e preservação dos bens nacionais organizada pela classe dirigente sob auxílio dos intelectuais modernistas, com ênfase nas manifestações do barroco, entronizando-o como ponte de ligação entre o passado e o presente modernista ${ }^{147}$. O passado colonial se apresentaria como emblema para a

147 Cf. MICELI, Sérgio. SPHAN: refrigério da cultura oficial. In: Intelectuais à brasileira. São Paulo: Companhia das Letras, 2001. RUBINO, Silvana. 0 mapa do Brasil passado. Revista do IPHAN, n. 24. 1996. CODATO, Adriano e BONAMIN, Giovana. Patrimônio Histórico e dominação simbólica. 34을 Encontro Anual da Anpocs, 2010. 
invenção de uma memória coletiva, ancorada em um projeto estético que seria recuperado a partir de uma leitura moderna. Lastreada na tradição brasileira, a arquitetura moderna seria valorizada como um lugar privilegiado de construção da identidade nacional.

O trabalho elaborado por Yves Bruand pode ser visto como uma narrativa sobre a história da arquitetura brasileira que vocalizou os anseios de valorização da produção nacional, somado a um esforço de distinguir vertentes regionais. Essa visão contribuiu para disseminar a ideia de que Vilanova Artigas se diferenciaria da sedimentada tradição carioca. Ele seria o protagonista da renovação formal em São Paulo formulando um projeto estético vinculado a um programa ideológico de esquerda.

Diplomado na Escola de Chartes em 1951, com formação de arquivista e paleógrafo, Yves Bruand havia iniciado a trajetória de pesquisador com o tema da arquitetura militar entre os séculosXIII e XV, seguindo o enfoque do grupo a que estava ligado na França, cuja área era história da arte medieval e renascentista. Mirando a possibilidade de ingresso em outros mercados intelectuais, as manifestações da arquitetura brasileira passaram a Ihe interessar. Em 1961, Bruand publicou um balanço sobre a experiência de Brasília, pauta de grande repercussão internacional, o que mostrava seu interesse pelas manifestações arquitetônicas contemporâneas $^{148}$. Em 1962, o historiador foi nomeado professor no departamento de História da Faculdade de Filosofia, Letras e Ciências (FFCL) da Universidade de São Paulo ${ }^{149}$, oportunidade direcionada em benefício de uma tese que focalizava as recentes produções arquitetônicas no país. Bruand foi professor visitante na FFCL, entre 1962 e 1969, sendo responsável pelas disciplinas obrigatórias de "Paleografia, Teoria e Metodologia da História" e um curso optativo em História da Arte, que focalizou sobretudo a arte barroca europeia na arquitetura e escultura.

148 BRUAND, Yves, «L'expérience de Brasília : essai de synthèse des principales critiques concernant la nouvelle capitale du Brésil ", in : L'information de l'histoire de l'art, sept.-oct. 1961, pp. 111-120, nov.-déc. 1961, pp. 142-152.

149 Segundo o relato de Walter Zanini, Yves Bruand contribuiu para trazer maior aprofundamento ao ensino de história da arte, antes pouco incorporado os cursos de humanidades da Universidade de São Paulo. ZANINI, Walter. Arte e História da arte. Estud. av., São Paulo, v. 8, n. 22, Dec. 1994. 
Próximo aos debates travados no meio intelectual brasileiro e influenciado pelo historiador francês Germain Bazin (1901-1990), especialista na obra de Aleijadinho, escreveu em 1966 um artigo sobre o barroco e o rococó na arquitetura de Minas Gerais ${ }^{150}$.

Na disciplina de "Metologia e Teoria da História e Paleografia" defendia a aproximação do estudante aos problemas práticos da pesquisa historiográfica, afastando-se de abordagens excessivamente filosóficas ou epistemológicas. Para o professor e pesquisador, o importante era que se formassem gerações que "devem antes de tudo fazer História"151. Aplicando essa concepção à sua pesquisa, Bruand travou contato direto com o ambiente da arquitetura paulistana, o que pode, por outro lado, ter contribuído para que ficasse refém das autoconstruções fornecidas pelo grupo. Em seu doutorado, as fontes orais foram essenciais para a reconstrução do período. Por se tratar de uma pesquisa sobre história recente, valeu-se de testemunhos de arquitetos, políticos e agentes do Estado, entre eles, Rodrigo Mello Franco de Andrade, que conforme afirmou, "foi um guia precioso"152.

A condição de estrangeiro e historiador da arte franqueou acesso aos arquitetos e a alguns personagens da classe dirigente, que se sentiram envaidecidos com a possibilidade de terem seus nomes registrados na história da arquitetura ${ }^{153}$. Em proximidade com a produção local, Bruand

150 BRUAND, Yves. "Baroque et rococo dans l'architecture de Minas Gerais". Extrait de la Gazette des Beaux-Arts, mai 1966, pp. 321-338.

151 Cf. "Mas voltemos ao nosso assunto e limitemo-nos às questões que dizem respeito à Metodologia e à Teoria da História. Pensamos que para a formação dos estudantes em História, o trabalho prático e efetivo do aluno é muito mais importante que o conhecimento de todas as teorias que se apresentam já elaboradas. Entre estas, somente as que tiveram uma influência direta sobre o desenvolvimento da historiografia nos interessam, porque nunca se deve perder de vista que os estudantes de História devem fazer antes de tudo História". BRUAND, Yves. Questões pedagógicas. Metologia da História, Teoria da História e História da Historiografia. Revista de História. no54, 2o trimestre, 1963. p.516.

152 Segundo Bruand, "O ex-diretor do serviço de monumentos históricos brasileiros, Rodrigo Mello Franco de Andrade: advogado, depois de alto funcionário e fundador do serviço em questão, foi para nós um guia precioso; as conversas que tivemos com esse homem muito fino, dotado de espírito ordenado e excelente memória, ao mesmo tempo participante ativo e espectador privilegiado do movimento de renovação da arquitetura no Brasil, foram muito frutíferas". BRUAND, 1999, p. 385.

153 Quanto às fontes orais, o historiador esclareceu que teve longas conversas com os arquitetos: "Sempre fomos acolhidos com grande amabilidade, os arquitetos falaram de modo muito livre 
acompanhou os arquitetos em seus escritórios e obras, registrando suas ambições, acompanhando seus investimentos e levantando os discursos por eles expressados. A afeição pela produção paulista levou o pesquisador a enfatizar o caráter inovador da produção estética realizada na capital, sugerindo que ela representaria os novos rumos da arquitetura nacional, com chance de desbancar a rival carioca. Cabe lembrar que estávamos no pós-Brasília e em meio ao regime militar, momento marcado pela reavaliação da produção moderna brasileira e, sobretudo, pela tentativa de estabelecer nexos, continuidades e rupturas.

Em 1973, Yves Bruand apresentou o resultado de sua pesquisa de doutorado ${ }^{154}$ sob título "L'architecture contemporaine au Brésil". A tese foi traduzida e publicada em português pela editora Perspectiva somente em 1981, no entanto, a versão francesa já circulava entre os arquitetos nos anos 1970, momento em que Vilanova Artigas estava afastado da Faculdade de Arquitetura e Urbanismo devido à aposentadoria compulsória. O material, uma das principais narrativas de grande envergadura sobre a arquitetura moderna brasileira, abarcou um grande período, entre 1900 e 1969, ano de retorno do pesquisador à França, e propunha uma leitura sobre as escolas e as filiações, apontando os principais responsáveis por edificar o legado moderno brasileiro e, sobretudo, paulista, que até então, diferentemente da arquitetura carioca, não havia sido tratado de modo sistemático.

Na recomposição da arquitetura do século $X X$, Bruand iniciou sua narrativa com a passagem do ecletismo "sem originalidade" para a afirmação de uma escola internacional, reafirmando o "marco da transformação decisiva" com a construção do Ministério da Educação e

de seus objetivos, suas dificuldades, suas esperanças e suas decepções; ficaram ainda mais à vontade porque se tratava de um estrangeiro e um historiador de arte; de fato, eles ficaram lisonjeados por alguém se interessar por seu trabalho no plano histórico, sem segundas intenções (pois não se tratava de um colega que poderia aproveitar as informações obtidas para sua obra pessoal)" BRUAND, 1999. p.385

154 BRUAND, Yves. L'architecture contemporaine au Brésil. sous la direction d'André Chastel] / Lille: Service de reproduction des thèses de l'universite' de Lille III, 1973. A pesquisa foi sob orientação do francês André Chastel (1912-1990), reconhecido historiador da arte especialista do renascimento italiano, que alguns anos antes havia sido eleito professor no Collège de France. 
Saúde, no Rio de Janeiro, sob patrocínio de Gustavo Capanema. Seguindo a visão assentada pelos seus criadores, o edifício seria o ponto de referência para a instauração de um movimento profundo de renovação, testemunhando "a profunda vitalidade da nova arquitetura no país" (BRUAND, 1999, p.93). Se no Rio de Janeiro a presença de Le Corbusier e a equipe formada em torno dele, entre eles Lúcio Costa e Oscar Niemeyer, foi fixada como a mudança definitiva da história da arquitetura brasileira em meados dos anos 1930, em São Paulo, demarcou Gregori Warchavchik como um dos precursores da modernidade paulista, em consonância programática com a atmosfera de Semana de 1922.

Na parte principal da tese, em que se dedica ao tratamento da "maturidade da nova arquitetura brasileira", Bruand apresenta as contribuições de Lúcio Costa, Oscar Niemeyer e Afonso Reidy, postura racionalista que triunfaria na primazia da liberdade plástica. Na sequência dessa produção, concede centralidade aos arquitetos modernos radicados em São Paulo. Quase como uma argumentação teleológica, insere o "brutalismo paulista" na sequência evolutiva, dando ênfase à produção de São Paulo como uma corrente estética de grande relevância nacional. Na sua visão, enquanto a corrente de Niemeyer instaura o interesse pela forma livre, valorizando a arquitetura "como arte plástica", concepção em que "o arquiteto é um artista e, portanto, antes de tudo, um criador de formas" (BRUAND, 1999, p.152), na arquitetura de Artigas "os fatores políticos desempenharam um papel de primeira linha" (BRUAND, 1999, p.295). Enquanto Oscar Niemeyer é apontado como arquiteto que "recusa se deixar prender por preocupações de ordem social", desobrigando-se da tarefa de "reformar a sociedade" (BRUAND, 1999, p.152). Artigas é apresentado como um "espírito combativo e comunitário", aquele que não dissocia "a arte, a sociedade e a ação individual" e cujas "soluções radicais" expressam "os conflitos existentes na sociedade capitalista" que irão no edifício "refletir por meio de oposições francas e pesadas" (BRUAND, 1999, p.295-296).

Em Arquitetura Contemporânea no Brasil, Bruand nomeia Artigas como "chef de file" da geração dos arquitetos modernos paulistas que unem projeto estético a compromisso social. O arquiteto é tomado como uma 
"espécie de profeta ouvido atentamente pela geração que seguia". Junto a essa figura inspirada, agrupou um conjunto de arquitetos atuantes nos anos 1960, que são posicionados como discípulos do mestre, entre eles, Paulo Mendes da Rocha (1928-), Carlos Millan (1927-1964), Joaquim Guedes (1932-2008), Sérgio Ferro (1938-). O autor declarava que esse grupo formava um movimento

"(...) indiscutivelmente original: constitui o primeiro questionamento de sua arquitetura pelos brasileiros depois do triunfo internacional obtido após a Segunda Guerra Mundial e merece grande respeito em razão de sua honestidade básica". (BRUAND, 1999, p.319)

No entanto, considerando a devoção ao programa estético moderno, acusou-os de "jovens fanáticos [...] convencidos de que são os donos da verdade". (BRUAND, 1999, p.319). A cada arquiteto são reservadas algumas páginas de análise, sob o ponto de vista estilístico, dos projetos mais significativos. O autor destaca o uso concreto armado, o peso das estruturas, o aspecto bruto do material e associa a esse fundamento estético uma expressão de engajamento ético. Cabe notar que a maioria dos projetos dos continuadores concentra-se em obras de arquitetura doméstica, e estas são vistas como expressão decantada de uma manifestação política. Na tentativa de abarcar uma "nova geração paulista", outros arquitetos, entre eles Ruy Ohtake e Siegbert Zanettini, tem apenas seus nomes citados, sem que suas obras sejam apresentadas.

Em relação à escolha dos legítimos sucessores registrados por Bruand, vale destacar que todos são arquitetos egressos das faculdades paulistanas Mackenzie e USP. São as primeiras levas formadas no curso de Arquitetura e Urbanismo que havia sido institucionalizado no final dos anos 1940, portanto, resultado geracional do processo de autonomização da carreira de arquiteto no sistema de ensino e sua decorrente inscrição no sistema universitário. Embora o que seja frequentemente apontado como base da coesão do grupo restrinja-se à expressão estética, ou seja, ao uso de um mesmo vocabulário formal, é fundamental enfatizar que a unidade do grupo era garantida pelo pertencimento a uma mesma instituição de 
ensino.

Os arquitetos selecionados para compor o conjunto de discípulos de Artigas eram todos docentes da Faculdade de Arquitetura da Universidade de São Paulo. Paulo Mendes da Rocha foi convidado por Vilanova em 1954 como seu assistente e ficou na instituição até 1969, quando ambos foram aposentados compulsoriamente pelo regime militar. Carlos Millan havia ocupado entre 1957 e 1964, quando faleceu, a cadeira de Composição, a convite dos arquitetos Roberto Cerqueira César e Luiz Roberto de Carvalho Franco. Joaquim Guedes entrou na FAU-USP em 1958 como assistente da cadeira de Materiais de Construção, cujo regente era Fernando José de Oliveira Escorel, docente da Escola Politécnica. Sérgio Ferro entrou como professor em 1962, no ano seguinte à conclusão da graduação, compartilhando a disciplina de "História da Arte e Estética" com o docente responsável, Flávio Lichtenfels Motta (1925-), historiador da arte egresso em 1946 do curso de Pedagogia da Faculdade de Filosofia, Ciências e Letras da Universidade de São Paulo.

A inserção na Universidade de São Paulo, uma instituição altamente singular, não é um dado irrelevante à legitimação do movimento paulista. Para além de uma "simples localidade", cabe assinalar o quanto foi significativo para os integrantes do grupo a reunião em torno de uma universidade pública de grande porte, principal aparato institucional a organizar a vida cultural da cidade a partir dos anos 1930, que absorveria tanto o projeto das oligarquias em decadência quanto abriria espaço para a incorporação de novas camadas em ascensão. Tomando como referência a análise que o sociólogo inglês Raymond Williams desenvolveu para o grupo de intelectuais e escritores do grupo Bloomsbury ${ }^{155}$, é possível destacar que o enraizamento na universidade representaria a modelagem de uma efetiva experiência de grupo, no sentido de orientar práticas culturais, ideias, valores e sentimentos que deram coesão a esses produtores culturais.

Sendo assim, as práticas desses arquitetos não podem ser separadas da experiência universitária paulista, da atmosfera intelectual por ela

155 WILLIAMS, Raymond. A fração Bloomsbury In: Plural; Sociologia, USP, São Paulo, 6: 139168, 1999. p.142 
propiciada, que atuou de modo a estabelecer um sistema de ensino e definir os círculos de intelectuais, estabilizando a presença de uma elite cultural no espaço institucional. Em relação ao métier do arquiteto, a participação desses profissionais nos quadros da universidade traria vantagens ao institucionalizar no meio universitário uma reflexão sobre arquitetura e urbanismo, o que levaria os arquitetos-docentes à posição prestigiosa de intelectuais. Vinculados ao sistema universitário, para além de simples formação técnica ou prática, os arquitetos pleiteavam a condição de uma profissão intelectual e engajada, carregada de sentido e orientada para pensar o destino do país. No discurso panfletário da disciplina, a Arquitetura é promovida a fato cultural e político de extrema relevância.

A convivência nos quadros acadêmicos da FAU contribuiu para definir uma agenda de temas e interesse comuns, pautas para a militância política e a defesa da função social do arquiteto. Desde o início dos anos 1950 e durante parte dos anos 1960, esses arquitetos estavam se socializando na mesma instituição, ocupando cadeiras nas disciplinas de "Composição Arquitetônica, Estética, Projeto e História", sobretudo a convite de Artigas, interessado em agrupar em torno de si um núcleo cujas tomadas de posição estéticas e políticas estivessem afinadas. $\mathrm{O}$ ambiente intelectual influenciaria as oportunidades de consagração de seus membros, os aproximaria de uma clientela cultivada e os permitiria inscrever seus valores e ideias como programa pedagógico. Em um meio politizado pelos ideais de esquerda, a relação a clientela endinheirada tornou-se móvel de denúncias de elitismo. Os arquitetos concorrentes, que não se enquadravam na doutrina militante do grupo, eram vistos como burgueses reacionários, destituídos de uma visão coletiva - ou até mesmo revolucionária - para a arquitetura. As acusações contra o grupo de arquitetos do Mackenzie, reunidos em torno da empresa de design Branco\&Preto, são reveladoras das tensões que constituíram as adesões e desfiliações à aquilo que consideravam ser uma arquitetura engajada. O depoimento de Joaquim Guedes explicita o confronto de posições políticas:

"o que acontecia era que [Carlos] Millan era um fino representante da burguesia paulista, amigo de industriais, de gente de mais alta educação, descendente do Colégio São Luís (...) o Millan teve uma 
prática social e profissional muito elitista no começo (...) ele expressava uma profissão de elite, que colidia com o discurso do Artigas. O Artigas não se deu com ninguém daquele grupo, nem com o Jacob Rutchi, nem com o Milan, nem com o [Salvador] Candia, nem com o Forte. Miguel Forte, então, nem se discute, porque o Miguel era um cara de família muita rica, enfim... e isso afastava. Eles vão fazer uma loja de decoração para riquíssimos (...) Então, acho que o afastava era a prática social e a prática profissional, eles trabalhavam em mundos diferentes. Um queria a revolução e o outro queria servir, fazer arquitetura para o mundo, para ser inclusive visto nas revistas internacionais" ${ }^{\prime 156}$

Ao mesmo tempo que a universidade possibilitou a acumulação do prestígio, a permanência no emprego público deu respaldo às condições materiais de existência. A docência na universidade serviu como opção de profissionalização, cargo que alguns assumiram logo depois de terminada a graduação, junto com o ingresso no mercado de trabalho. Se, por um lado, o posto acadêmico os predispõe a refletir sobre a prática, de outro, a garantia do salário favorece a atuação desinteressada, uma vez que estão desobrigados de ganhar a vida exclusivamente com a venda dos projetos em seus escritórios particulares.

A dupla atuação como arquiteto e docente livrou-os de ficar à mercê dos gostos estéticos de encomendantes pouco afinados com suas propostas arquitetônicas, assim como os aproximou de grupos intelectuais da universidade com disposições artísticas de vanguarda e engajamento político. Era de se esperar que essa segurança financeira facilitasse a abnegação em nome de uma radicalidade estética, cuja apropriação destinar-se-ia a alguns interessados em arcar com esses experimentos. Acrescente-se ainda que o vínculo institucional estabelecido com a universidade Ihes permitia disseminar suas posturas éticas e estéticas, as quais, uma vez encampadas por sucessores, facilitou o reconhecimento de suas atividades, processo cujo resultado não tardou a inscrevê-los com legitimidade na história da arquitetura.

156 Depoimento de Guedes a Sergio Matera. MATERA, Sergio. Carlos Millan: um estudo sobre produção em arquitetura. São Paulo, FAU USP, 2005. (dissertação de mestrado) p.68-69. 
A especificidade da "Escola Paulista", com a presença de arquitetos no sistema de ensino universitário, fica evidente quando se toma, a título de comparação, a experiência carioca. No Rio de Janeiro, ainda que tivesse a intenção de implementar o ensino moderno de arquitetura na Escola Nacional de Belas Artes (ENBA), Lúcio Costa ficou apenas sete meses no cargo de diretor de ensino, sem condições de atualizar o modelo acadêmico beaux-arts que ele combatia. No entanto, distantes do ensino, os arquitetos da nomeada "Escola Carioca" conseguiram legitimar sua atuação beneficiando-se diretamente dos projetos públicos encomendados pelo Estado $^{157}$. Já os arquitetos paulistas, sem acesso direto ao patronato estatal, entrincheiraram-se na universidade, e foi nessa instituição que construíram suas posições de destaque. Com a penetração efetiva no sistema de ensino, foi nesse espaço altamente específico que conseguiram se legitimar e modelar novas gerações de continuadores, o que se mostraria um instrumento potente para construir e disseminar a ideologia do grupo.

A presença de um agente comprometido a assumir função de autoridade intelectual e espiritual será central para a vocalização dos valores compartilhados e fixar as reivindicações intelectuais e políticoestéticas do grupo. Flávio Motta, além das aspirações artísticas, com produção de desenhos e pinturas, colaborou com a imprensa especializada (Habitat), instituições culturais, educacionais e profissionais (Masp, FAAP, Sindicato dos Artistas Plásticos), atuou no ensino e colaborou na definição das reformas curriculares da FAU-USP no início dos anos 1960. Inserido na instituição como docente de história da arte e estética, e próximo afetivamente desses arquitetos, Motta ocupou a posição de formulador teórico, qualificando a experiência no plano discursivo, nomeando as práticas, estabelecendo os critérios de apreensão, afinando as justificativas, em suma, fornecendo uma agenda intelectual afinada à prática

157 O representante máximo da tradição carioca, Oscar Niemeyer, oficializava por todo país sua arquitetura a partir de grandes obras públicas, tais como o Ministério da Educação e Saúde Pública, no Rio de Janeiro, em 1936; o Conjunto Pampulha, em Belo Horizonte, em 1942; Conjunto do Parque Ibirapuera, em São Paulo, em 1954, e os palácios de Brasília, no final dos anos 1950, triunfando na construção de uma imagem de modernidade para o país. A Escola Carioca se valeu do apoio de importantes figuras políticas, como o ministro de Getúlio Vargas, Gustavo Capanema, e o presidente Juscelino Kubitschek, mecenato estatal que a incorporou à máquina governamental para a produção de uma cultura moderna de feições nacionais. 
arquitetônica $^{158}$. Ele esteve, por exemplo, junto com Vilanova Artigas, Paulo de Camargo Almeida, Carlos Cascaldi e Mario Wagner da Cunha na elaboração do projeto para o concurso de Brasília, em 1956, contribuindo com a redação do memorial descritivo.

A habilidade com a escrita, o veio poético e a erudição lhe propiciaram efetiva parceria com os arquitetos e um entrosamento junto aos temas da comunidade arquitetônica. Na universidade, investiu-se do trabalho simbólico de representar o grupo paulista, inclusive em publicações e exposição internacionais. Em ensaios, parceria em projetos e cursos manifestou seu apoio à produção arquitetônica paulista, especificando as singularidades da nova geração. Escreveu sobre Vilanova Artigas, Paulo Mendes da Rocha e Sérgio Ferro, assim como procurou apresentar as especificidades do que seria a "Escola Paulista", definindo o caráter do movimento ${ }^{159}$. Quando apresentou Vilanova Artigas em revista italiana, em 1960, contexto da inauguração de Brasília, ou quando escreveu o memorial para o projeto do Pavilhão de Osaka, em 1973, e desenvolveu a curadoria da exposição, em parceria com Paulo Mendes da Rocha, inseriu a produção em uma perspectiva mais ampla da cultura brasileira, reconstituindo um sentido universal para a arte e a arquitetura. Com escrita inspirada, alusiva e cheia de imagens, procurou conferir à produção dos arquitetos um conteúdo transcendente que insistia na valorização das manifestações nacionais: "o Brasil fixa com Brasília e as novas cidades essa busca de um espaço e um tempo de constante significação humana. Esse trabalho traz a história para o presente e se afirma como projeto" ${ }^{160}$. Tal como no projeto

158 Segundo Juliana Braga: "Participou ativamente do processo de consolidação institucional e projeção nacional da escola, sendo até hoje lembrado por quase todos aqueles que foram seus alunos, independente de suas orientações ideológicas ou profissionais, como uma das figuras mais marcantes na formação de sucessivas gerações de arquitetos de São Paulo". (BRAGA, 2010, p.20).

159 Alguns de seus artigos são ensaios e homenagens direcionados a Vilanova Artigas, Sérgio Ferro e Paulo Mendes da Rocha: "João Vilanova Artigas e a escola de São Paulo". Módulo Especial Vilanova Artigas, 1985. "Paulo Mendes da Rocha". Acrópole, São Paulo, no343, p.17-18, set, 1967. "Sérgio Ferro". Projeto, São Paulo, v.32, ago, 1981. Outro material que inscreve a orientação dada ao grupo é "Desenho e emancipação". Desenho Industrial e comunicação visual, FAU/USP, 1970.

160 Texto escrito por Flávio Motta para justificar o projeto do Pavillhão do Brasil na exposição internacional em Osaka, no Japão. A equipe que ganhou o concurso para reprensentar o Brasil foi liderada por Paulo Mendes da Rocha e contou com os arquitetos Ruy Ohtake, Júlio Katinsky, 
do Pavilhão de Osaka, Motta foi responsável por traduzir em palavras as ideias do grupo. Defendeu que os arquitetos estavam comprometidos com uma missão humanista e transformadora, e com seu traço, ambicionavam unir o político e civilizador, em nome de um projeto emancipatório:

"Se coloca assim, na fase atual da vida brasileira, a figura do arquiteto como intelectual e artífice da nação. Cabe ao arquiteto contribuir do melhor modo na orientação dessa burguesia em sua fase de planejamento"161.

Flávio Motta entrou na FAU-USP em 1954 como assistente de Lourival Gomes Machado (1917-1967), figura de proa da crítica estética florescida no meio universitário nos anos 1940, estabelecendo um elo de ligação com uma geração empenhada em valorizar a vanguarda modernista e enraizá-la em nosso passado colonial. Próximo aos arquitetos, Motta incorporava esse repertório da tradição consagrada e aprofundava em relação aos temas da arquitetura moderna, inserindo a produção brasileira na dinâmica internacional. Dentro da FAU, a contratação de egressos da FFCL representaria a continuidade de uma matriz de pensamento sobre a arte brasileira que incorporou o legado da geração de 1920, em suas pautas estéticas e de política cultural.

Gomes Machado havia sido um dos participantes da revista Clima, experiência decisiva de um conjunto de amigos que deu forma a um novo padrão de autoridade na crítica de arte ${ }^{162}$. Graduado em Direito e Ciências Sociais, fez parte das primeiras turmas de universitários formadas junto à

Jorge Caron e os artistas plásticos Marcello Nistche e Carmela Gross. Acrópole, no61, 1969, p.15.

161 MOTTA, Flávio. "Introduzione al Brasile”. Zodiac, no, Milão, 1960". Tradução disponível em BRAGA, Juliana. Ver não é só ver: dois estudos a partir de Flávio Motta. FAU/USP, dissertação de mestrado, 2010. p.208.

162 Na revista Clima esteve junto com o que viria a ser a fina flor da crítica estética paulistana, uma nova geração abençoada por Mário de Andrade, entre eles, Paulo Emílio Salles Gomes, Antonio Candido, Gilda de Mello e Souza, Ruy Galvão Coelho e Décio de Almeida Prado. Entre o campo universitário e o cultural, essa geração tinha apostas intelectuais elevadas. Gomes Machado defendeu a livre-docência na FFCL em 1949, onde atuou como assistente e substituto do francês Paul Arbousse-Bastide na cadeira de Sociologia e, em seguida, Ciência Política, quando esta foi implantada em 1941 e ocupou a cátedra de Ciência Política, em 1954. Sobre a trajetória de Lourival Gomes Machado e a formação da geração de críticos egressos do meio universitário paulistano, cf. PONTES, Heloísa. Destinos Mistos. Os Críticos do Grupo Clima em São Paulo (1940 - 1968). São Paulo: Companhia das Letras, 1998. 
missão francesa uspiana, na FFCL, onde ingressou como assistente e depois docente na cadeira de ciência política. Quando contratado como docente de "História da arte e Estética", em 1952, já dispunha de reconhecimento no meio acadêmico e cultural paulistano: havia publicado Retrato da Arte Moderna do Brasil, era docente da FFCL e havia sido diretor artístico do MAM e da Bienal no início dos anos 1950, cargos que pavimentavam sua especialidade com crítico de artes plásticas e arquitetura. Em menos de dez anos, chegou a ocupar o posto de diretor da FAU entre 1961 e 1964, momento de crise no interior da faculdade. Na gestão, Gomes Machado foi responsável por ampla reforma no ensino da faculdade, mudanças que propiciaram o ingresso de uma nova geração de docentes afinados com o programa modernizador, entre eles, os arquitetos Sérgio Ferro, Flávio Império, Rodrigo Lefèvre, Júlio Katinsky. Esse conjunto de arquitetos e intelectuais se somava à geração antecedente, de Artigas, Paulo Mendes da Rocha e Flávio Motta, e conformaria uma linhagem prestigiosa, com trunfos e oportunidades para controlar sua reprodução institucional. Nesse espaço institucional, procurarão exercer a função de mentores espirituais e árbitros estéticos, agentes presumidos de um projeto moderno aliado ao desenvolvimento do país.

Ao se investigar a trajetória de Flávio Motta e às condições que possibilitaram que tomasse para si tal tarefa, chama a atenção a origem social privilegiada, certamente responsável por definir as inclinações intelectuais e artísticas. Descendente de uma família abastada com expressão na política e participação nas frações intelectuais desde o final do século XIX, Flávio Motta seguiria a genealogia e assumiria os encargos do trabalho intelectual. Seu pai fora Cândido Motta Filho, e seu avô, Cândido Nazianzeno Nogueira da Motta: ambos advogados, docentes da Faculdade de Direito da Universidade de São Paulo e que desempenharam carreira política notória, em altos cargos do poder (MICELI, 2001). Vinculado ao Partido Republicano Paulista, que representava os interesses dos proprietários de terra da oligarquia paulista, Cândido Motta Filho (18971977) construiu carreira política próximo ao grupo conservador, e mesmo com a reorganização política da década de 1930, que marcou o fim da "República Velha", continuou a ocupar postos de destaque, como deputado 
estadual e cargos de ministro do Trabalho, da Educação e do Supremo Tribunal Federal. A inserção nas frações dirigentes possibilitou ativo contato com artistas e escritores do modernismo, com os quais se engajou no movimento Verde-Amarelo, de matiz nacionalista, no qual desempenhou tarefa política e ideológica. Tamanha integração nas classes dominantes abriu espaço para a atuação no campo intelectual, assumindo diversas atribuições: jornalista, professor catedrático de "Direito Constitucional", crítico literário, ensaísta, memorialista, biógrafo.

Foi nesse ambiente intelectualizado das frações dominantes que Flávio Motta foi socializado. Nascido em 1925, penúltimo dos cinco filhos do casamento de Cândido Motta Filho com Elza Lichtenfels Motta (1898-1982), filha de uma família de industriais de Sorocaba, Flávio teve a oportunidade de conviver com os mais reputados círculos do poder e da intelectualidade, o que inclui os artistas modernistas, entre eles, Cassiano Ricardo e Menotti del Picchia, a fração mais à direita do espectro artístico, escritores aliados de seu pai no âmbito político. Herdeiro "da fração intelectual da classe dirigente em São Paulo em meio à conjuntura de crise do poder oligárquico"163, Flávio Motta ingressaria no mundo intelectual em um contexto diferente de seu pai e seu avô, quando as aristocracias rurais em decadência perdem espaço político e cultural. Novas demandas sociais, ativadas pela ascensão de imigrantes, pela emergência do proletariado e pelo processo de industrialização, se abrem, reconfigurando o jogo de força no campo do poder e no da cultura.

$\mathrm{Na}$ reorganização das forças sociais, Motta conduziria o cabedal social, intelectual e artístico que herdou para dar voz ao programa paulista, aproximando-se de início de grupos menos vanguardistas e mais tradicionais, como os despretensiosos pintores de origem proletária que se reuniam no Palacete Santa Helena e tentavam a profissionalização no mundo das artes, grupo que havia também despertado o interesse de Mário de Andrade. Interessado pelo fazer artístico, foi nesse círculo de artistas pobres, muitos de origem imigrante, que Flávio Motta, em início de carreira artística no qual pinta paisagens e temas campestres, conheceu Vilanova

163 MICELI, Sergio. Intelectuais à brasileira. São Paulo, Companhia das Letras, 2001. p.106 
Artigas. Ao assumir a função de docente na FAU em 1954, teria como modelo a crítica estética especializada e erudita produzida no meio universitário, que se distanciava do diletantismo dos escritores polígrafos ao qual pertenciam seus ascendentes. No entanto, teve uma atuação em parceria com os arquitetos. Próximo a Lourival Gomes Machado, incutiu os esquemas interpretativos que glorificaram o modernismo da Semana de 1922, o barroco brasileiro, prolongando a interpretação de uma renovação gloriosa para a arquitetura paulista. Flávio Motta, em um ensaio sintético sobre o Brasil divulgado em revista estrangeira, torna evidente a homenagem aos mitos nacionais:

"Em 1922, os intelectuais paulistas menos sujeitos ao paternalismo rigoroso e tenaz dos plantadores de café davam vida a um movimento semianárquico que ecoava por todo Brasil, como exigência de liberalização e convivência mútua. Surge a figura do escritor, poeta e crítico Mário de Andrade, e inúmeros outros intelectuais preocupados em realizar uma cultura brasileira, e ao mesmo tempo inquietos investigadores das mais avançadas realizações da arte europeia: amigos de Brancusi, Cendrars, Léger e Marinetti; colecionadores de obras de Lipchitz, Picasso, Dufy, Delaunay, De Chirico, Matisse, Modigliani. Todavia no terreno da arquitetura as manifestações são mais esporádicas. É só em 1925 que Gregori Warchavchik publica um "Manifesto da arquitetura funcional" e Rino Levi lança um apelo por uma política de urbanização. Em 1927, Flávio de Carvalho escandaliza o público com um projeto moderno para o palácio do governo. E em 1928, Warchavchik constrói a primeira residência moderna em São Paulo. Porém, essas propostas são apresentadas paralelamente ao Movimento Antropofágico. Oswald de Andrade e outros intelectuais de 22 buscam na lenda dos indígenas antropofágicos uma visão grandiosa e sincretizante do país. Por isso o Brasil era como a gigantesca figura do 'Abapuru antropófago' que tudo devora. Como os indígenas se alimentavam dos inimigos para apossar-se de sua força, assim também - Brasil possui essa divina capacidade digestiva. Nesse mesmo ano o escritor Mário de Andrade cria a figura pantagruélica de 'Macunaíma' o herói sem caráter, simbolizando a coexistência da mutabilidade indígena com a civilização. A partir desse momento, o movimento de 22 passa da esfera local àquela nacional. Era, no âmbito da cultura, quase 
uma antecipação da Revolução de 30, que sacudiu as fundações da República, em uma agitação provocada por aquilo que se chamou 'o general do café'." (In BRAGA, 2010, p. 205)

É esse percurso apoteótico que desenvolve em "Introduzione al Brasile" até apresentar a figura proclamada central da "Escola Paulista":

"Entretanto, se quisermos citar um exemplo entre os nomes menos conhecidos da crítica estrangeira, encontramos aquele do arquiteto Vilanova Artigas que realiza em São Paulo uma intensa atividade doutrinária, seguindo o exemplo de Lucio Costa no que diz respeito às exigências de uma posição teórica [...] As suas realizações revelaram o esforço de alcançar novas formas através de processos construtivos independentes da instabilidade da indústria da construção nascente. As suas casas de moradia, projetadas para intelectuais e profissionais liberais, são caracterizadas pela economia de recursos da construção, onde, às vezes, os arquitetos se mistura intimamente à atividade do mestre de obra e do operário. Hoje suas realizações vão amadurecendo em direção a um aparente 'brutalismo'. [...] Pensamos que isto é um exemplo que ilustra uma das tendências mais significativas da arquitetura brasileira nesta fase onde $o$ arquiteto se assemelha ao lendário 'bandeirante', que abatia a floresta e construía sólidas habitações." (In BRAGA, 2010, p. 208)

Ao refazer o percurso mítico do moderno brasileiro, Motta inscrevese, assim, na linhagem modernista de críticos que teve como liderança e inspiração a figura de Mário de Andrade para exercer uma crítica estética de reconhecimento do modernismo paulista. Também, tal como o célebre vanguardista, reatualizou temas como artesanato, técnica e saber o popular, sem perder de vista a grandiosidade do projeto moderno realizado em São Paulo. Ao mesmo tempo que procurou investigar o papel do imigrante, dos proletários, da arte anônima e popular, a fim de dar significação histórica a esses novos arranjos sociais na produção artística, Flávio Motta encampou o programa dos arquitetos e apostou no desenvolvimento das forças produtivas, concedendo aos colegas paulistas um lugar de excelência, como 
artífices de um projeto emancipatório.

Dando continuidade ao legado modernista glorificado por Mário de Andrade e Lourival Gomes Machado, Flávio Motta assumiu o lugar de enunciação do projeto estético e político do brutalismo, colocando-se como agente ativo na empreitada de legitimação da arquitetura da "Escola Paulista". O trabalho simbólico encontrou eco em outros historiadores externos ao meio, como Yves Bruand, que sistematizou e construiu uma narrativa coesa vocalizando as autoconstruções do grupo, o que amplificou o alcance da interpretação. Quando enuncia o papel de profeta a Vilanova Artigas e nomeia os seguidores, Paulo Mendes da Rocha, Joaquim Guedes, Carlos Millan, Sérgio Ferro, o historiador francês demarca uma geração que vinha sendo engendrada no interior da instituição. Apesar das divergências internas e disputas no choque do acirramento político, as dissensões em relação ao modelo de desenvolvimento do país ou as divergências quanto aos caminhos revolucionários a serem seguidos, foram os mais dispostos a se alinhar ao mestre, por razões místicas ou profanas, políticas ou morais, e, assim, assumir uma missão salvadora para a profissão, propensa a reproduzir o discurso de uma arquitetura carregada de potência transformadora. Os que ficaram de fora de tal percurso consagratório, expurgados pelo trabalho sedimentador da historiografia, foram os que se mostraram mais insubmissos à presilha política ou estética, entre eles, por exemplo, os já mencionados Ruy Othake e Siegbert Zanettini, que institucionalmente distantes do grupo, procuraram seguir uma postura menos dogmática quanto às diretrizes da esquerda ou da hegemonia do concreto bruto.

Cumpre frisar que os arquitetos diretamente próximos ao grupo de Artigas são todos homens, o que explicita um ambiente refratário à absorção de profissionais mulheres, tanto na escolha da formação escolar quanto na fixação da carreira. Mesmo em período de maior ingresso de mulheres nos cursos de Arquitetura, muitas foram constrangidas a assumir o papel de coadjuvante nos escritórios dos parceiros, em posições menos centrais, como decoração e paisagismo, ou abandonar a profissão. A única mulher que conseguiu firmar sua assinatura e garantir nome próprio foi Lina 
Bo Bardi, que como se mostrou, concentrou posições-chave pois beneficiouse da ligação estreita com a elite local e com os formuladores das políticas culturais na São Paulo dos anos 1950 e 1960, acesso que Ihe concedeu a oportunidade grandiosa de projetar, em 1962, umas das obras mais emblemáticas da capital paulista, a sede do Museu de Arte de São Paulo. Uma grande caixa suspensa de concreto aparente, envidraçada e apoiada sob quatro pontos de apoio Ihe concedeu a posteriori o rótulo de arquiteta do brutalismo paulista, quando a crítica de arquitetura procurou, sob o ponto de vista formal, sistematizar os exemplares que conformariam um movimento estético em São Paulo (ZEIN, 2002, 2005).

No entanto, do ponto de vista institucional, a arquiteta estrangeira não conseguiu se fixar como docente na FAU. Entre maio de 1955 e dezembro de 1956, ela havia sido professora na cadeira de "Composição Decorativa III", sob regência de José Maria da Silva Neves. O assistente da cátedra era o também estrangeiro Jacob Ruchti, que ficou na instituição entre 1954 e 1961, quando se demitiu, por descordar da "feroz onda socialista que dominava a FAU naquele momento"164. Menos afeito ao dogmatismo desenvolvimentista que marcava o discurso da faculdade e contrário ao radicalismo de esquerda, possivelmente tendo em vista a clientela que o rodeava, tenha soado aos arquitetos que dominavam a pauta arquitetônica um representante do gosto elitista. Lina Bo Bardi tentou ingressar como professora da cadeira de "Teoria da Arquitetura", em 1957, disputando a vaga com Eduardo Corona, Luiz Saia, Miguel Badra Junior e José Vicente Vicari. No entanto, o concurso não foi levado a cabo e, no mesmo ano, sem sucesso, tentou impetrar mandado de segurança para garantir a continuidade do processo ${ }^{165}$. Ainda que a arquiteta italiana não estivesse diretamente vinculada ao grupo de arquitetos paulistas, assumiu um discurso cerrado em relação à moral construtiva, identificando em Vilanova Artigas, logo em 1950, sua própria concepção de que a arquitetura moderna deveria se insurgir contra a moral burguesa. Contribuiu, assim, para organizar a narrativa em torno do papel heroico e contestador do

164 RUCHTI, Valéria. Jacob Ruchti e a modernidade paulista (1940-1970). São Paulo: Dissertação de Mestrado, FAU-USP, 2011. p. 372

165 Documento consultado no acervo do Instituto Lina Bo Bardi. 
arquiteto.

Entre aqueles apontados como discípulos, foi Paulo Mendes da Rocha quem conseguiu se inscrever como legítimo herdeiro. Joaquim Guedes, além da docência na FAU, conduziu o escritório na área de projeto, realizou várias residências e devido a sua experiência com o padre Louis-Joseph Lebret e a formação na Escola de Sociologia Política, orientou-se sobretudo para atividade urbanística. Sempre citado como polêmico e de personalidade marcante, "um pensador insurgente, avesso a consensos e adesões"166, optou por carreira solitária, o que "sobrou-lhe a alcunha perversa de alienígena"167. Carlos Millan faleceu aos 37 anos em acidente de carro, em 1964, interrompendo uma trajetória que os colegas previam como uma das mais promissora. Sérgio Ferro, no momento de radicalização política, deixou o Partido Comunista em 1967 e ingressou na Ação Libertadora Nacional (ALN), foi preso entre 1970 e 1971 pelo regime militar e, assim, impedido de lecionar na instituição. Logo em seguida, mudou-se para a França, onde atuou como docente na École d'Architecture de Grenoble, com pesquisas sobre o canteiro de obras. Quanto a prática profissional, direcionou-se, sobretudo, para atividades nas artes plásticas, realizando desenhos e pinturas figurativas, inspiradas no estudo da arte renascentista ${ }^{168}$.

Mendes da Rocha foi quem melhor conseguiu gerir a carreira e se manter fiel aos princípios da "Escola Paulista", construindo uma trajetória demiúrgica que se fez reconhecer pela austeridade. Logrou assimilar as lições do concreto, controlar o ímpeto inventivo para não desaguar em repertório formalista ou amaneirado, atualizar o discurso radical em versão abrandada e se firmar como continuador direto da linhagem de Vilanova

166 Reunião de depoimentos de ex-alunos e colegas. MATOS, Olgária. In Memorian, Pós, v.15, no24, São Paulo, dezembro, 2008. p.232-248. Sobre a produção arquitetônica do arquiteto, cf. CAMARGO, Mônica Junqueira. Joaquim Guedes. São Paulo: Cosac\&Naify, 2000.

167 PEREIRA, Miguel. Pós, v.15, nำ24, São Paulo, dezembro, 2008. p.245. Ainda segundo o depoimento: "Guedes não foi um 'campeão', porque, como os bons atletas, não teve sorte em alguns setores da frente de batalha, dentre eles, o da política profissional. Queria ser presidente do IAB de São Paulo, queria ser vereador, e, também, presidente do IAB nacional. Buscava, com isso, nessa faixa de poder, a democratização do mercado de trabalho para os arquitetos".

168 FERRO, Sérgio. Artes Plásticas e trabalho livre: de Dürer a Velázquez. São Paulo: Editora 34, 2015. 
Artigas. A socialização primária em uma família de engenheiros serviu de lastro para declarar seu apreço pela técnica no desejo explícito de afiançar uma experiência criativa caucionada pelo rigor construtivo. Reposicionando a radicalidade do discurso político no domínio da transformação da natureza, o arquiteto lapidou a matéria bruta que tomou como herança e construiu uma arquitetura depurada que conquistará reputação internacional. A investigação da trajetória do arquiteto e o processo de acúmulo de reconhecimento permitem explicitar as linhas de força dominantes na consagração da "Escola Paulista". 


\title{
CAPÍTULO 03
}

\section{Depuração estética e sublimação do social: Paulo Mendes da Rocha e sua clientela}

\begin{abstract}
"Nasci no porto de Vitória, Estado do Espírito Santo. Morei no Rio de Janeiro e em São Paulo, onde meu pai, engenheiro de portos e vias navegáveis, tornou-se professor da Escola Politécnica da USP. Por aí fui educado, um pouco no sertão, nas fazendas de cacau do Rio Doce e nas serrarias, junto às obras pesadas da engenharia, no mar. Habituei-me a contar com o poder da transformação da técnica, com a premeditação e o olhar que projeta manobras úteis, desejáveis, realizadoras de promessas e esperanças, com o trabalho festivo, apesar da miséria de meu país. Fui formado com a certeza de que os homens transformam a beleza original, a natureza, em virtudes desejadas e necessárias, para que a vida se instale nos recintos urbanos."
\end{abstract}

Paulo Mendes da Rocha, "Genealogia da imaginação"169

\section{Engenhosidade familiar}

Paulo Archias Mendes da Rocha nasceu em Vitória, em 1928, primogênito e único filho homem de uma família de três herdeiros, sendo as duas irmãs mais novas chamadas Lina e Ana Mendes da Rocha. Ingressou em 1950 e se formou em 1954 no curso de Arquitetura da Universidade Mackenzie, em São Paulo. Casou-se, logo após a conclusão da graduação, com Virgínia Ferraz Navarro, proveniente de família tradicional de

169 ARTIGAS, Rosa (org). Paulo Mendes da Rocha. São Paulo, CosacNaif, Associação Brasil 500 anos, Fundação Bienal de São Paulo, 2002. p.70. 
fundadores do município de Jaú, interior de estado de São Paulo. O casal, em 1955, teve o primeiro de seus cinco filhos, sendo que os três homens se tornariam arquitetos, seguindo a profissão do pai.

Em relação à escolha profissional, após ter cogitado formação na Escola Naval do Rio de Janeiro, nos meados dos anos 1940, Paulo Mendes da Rocha enveredou definitivamente para o curso de Arquitetura. Embora tenha desistido das atividades junto à engenharia, as frequentes referências à matriz técnica da profissão, o léxico construtivo e a recorrente comparação da arquitetura com a amplitude de transformar a natureza e construir o território aparecem nas falas de Mendes da Rocha e dão o tom de suas definições do ofício. Em seus depoimentos, o mister assume eminentemente uma ligação com a reinvenção da paisagem, com o domínio dos materiais e com o rigor estrutural. A engenharia é qualificada pela sua capacidade de produzir um raciocínio límpido, cuja clareza e retidão são evocadas como fundamento de sua linguagem arquitetônica.

Ao retornar às explicações para seu processo criativo, sua "genealogia da imaginação", é ao registro afetivo e familiar que o arquiteto reporta sua inspiração, nomeando a experiência doméstica como uma formação voltada para "engenhosidade do mundo". Para definir a especificidade de sua prática arquitetônica, ele reconstitui suas memórias de criança, empenhando-se em justificar sua inclinação para uma profissão de domínio construtivo e científico, garantida na linhagem de seus antepassados. Vale lembrar que Paulo Mendes da Rocha desde que nasceu esteve socializado em meio intelectual e construtivo pujante, propiciado pela atuação profissional e as altas posições administrativas que pai e avô ocuparam.

Do lado paterno, o arquiteto é filho de um mineiro, engenheiro civil, Paulo Menezes Mendes da Rocha (1887-1967) e neto de um baiano, engenheiro militar, Francisco Mendes da Rocha, que, entre 1892-1894, dirigiu a Biblioteca Nacional e, no início do século $X X$, assumiu os serviços de navegação do rio São Francisco. Do lado materno, também a engenharia. Seu pai casou-se com a filha de um empreiteiro italiano com quem trabalhou juntos nos anos 1920. O pai de Paulo Mendes da Rocha, 
após formado no curso de Engenharia do Rio de Janeiro, atuou na construção de açudes no Rio Grande do Norte e pontes no estado do Espírito Santo, onde então conheceu a esposa, Angelina Derenzi (19012006), filha do imigrante italiano responsável pelas obras de construção de estradas pelos estados do Nordeste ${ }^{170}$. Foi dessa união que nasceu Paulo Mendes da Rocha, no Espírito Santo, estado onde passou parte de sua infância até se deslocar inicialmente para o Rio de Janeiro, na casa do avô paterno, na Ilha de Paquetá, e depois para a cidade de São Paulo.

O ambiente culto e o contato empírico com as obras de grande porte permaneceram como legado de uma família de tradição na engenharia. É à infância, nas relações com seu pai, seu avô paterno e ao espaço familiar materno, que Paulo Mendes da Rocha faz alusão ao restituir a importância que a técnica e a construção assumiram em sua produção arquitetônica. Nesse período, viu serem construídas as "obras de arte" - estradas, pontes, projetos navais e de recursos hídricos, áreas técnico-científicas em que trabalhavam a maioria dos homens da família.

"A minha infância sempre foi muito rica, devo a ela a minha formação. Hoje sei disso, mas é uma coisa da qual você não tem consciência logo, pouco a pouco a infância surge com muita força na vida da gente. Nasci lá no Espírito Santo, na cidade de Vitória, que é um porto de mar, na casa da minha avó, mãe da minha mãe, casa do meu avô Serafim Derenzi, um construtor de estradas. Era uma família de dois homens e oito mulheres. Essas irmãs da minha mãe casaram e a família expandiu de aventuras, digamos assim, de notícias. Havia fazendeiros de cacau e havia um tio médico que teve uma importância muito grande na minha vida, um homem notável, um verdadeiro cientista [...] E meu pai era um grande engenheiro, de família baiana, formado no Rio de Janeiro. Portanto, fui criado vendo a engenhosidade do mundo, a possibilidade de transformação das coisas de uma maneira - hoje eu compreendo que alimentou a minha visão sobre a ideia de projeção, a relação entre ideia e coisa, 'você pode fazer coisas extraordinárias, um porto, um navio'. Isso, em poucas palavras, foi a minha infância. E vivi coisas

170 "Na casa do meu avô italiano, pai da minha mãe, sempre ouvi falar em muros de contenção, escoramentos, saneamento de áreas inundadas e mangues, já que a Vitória é território ganhado do mar.". ROCHA, Paulo Mendes da. América, natureza e cidade. São Paulo: Estação Liberdade, 2012. p.28-29. 
extraordinárias. Inclusive vivi coisas da história do Brasil necessariamente, porque nasci em 1928 - a crise de 1929, a revolução em São Paulo em 1932. Meu pai foi preso aqui em 1932, estivemos afastados quase cinco anos $[\ldots]^{\prime \prime 171}$

As condições de mudança para a capital paulista se deram por conta do emprego de seu pai, que depois de idas e vindas, fixou-se na cidade ao ser aprovado, em 1939, no concurso de professor da Escola Politécnica da Universidade de São Paulo ${ }^{172}$. Mudar de estado e ingressar na carreira universitária foi a alternativa encontrada depois da falência da empresa de engenharia e dos negócios familiares de exportação de café, com o colapso de 1929, crise que abateu a família no ano seguinte ao nascimento de Paulo. A estabilidade econômica foi retomanda quando o pai converteu sua ampla prática profissional em uma carreira no ensino, ao ser aprovado para o posto de docente e, em seguida, catedrático nos cursos de "Navegação Interior e Portos Marítimos" na tradicional Escola Politécnica. Na universidade, ascendeu ao prestigioso cargo de diretor da Politécnica, posição que ocupou entre 1943 e 1947, momento em que se gestou e aprovou a autonomização do curso de Arquitetura em faculdade separada à formação de Engenharia.

Quando chegou a São Paulo, Paulo Mendes da Rocha, então com cerca de 11 anos, morou em uma pensão na avenida Brigadeiro Luís Antônio e estudou no colégio Paes Leme. No ginásio, mudou-se para o tradicional colégio São Luís, instituição educacional que atendeu expressiva parcela de famílias da elite cultural paulistana. Após a experiência hesitante com a formação naval no Rio de Janeiro, optou definitivamente por São Paulo, pela arquitetura e pelo Mackenzie, distanciando-se da posição ocupada pelo pai no ambiente uspiano. Conforme declarou:

"Acontece que meu pai era diretor da Poli, que ainda abrigava os cursos

171 ROCHA, Paulo Mendes da. Entrevista “A natureza é um trambolho”. Caros Amigos, abril, 2002.

172 "Na casa do meu avô italiano, pai da minha mãe, sempre ouvi falar em muros de contenção, escoramentos, saneamento de áreas inundadas e mangues, já que a Vitória é território ganhado do mar.". ROCHA, Paulo Mendes da. América, natureza e cidade. p.28-29. 
de arquitetura - nessa época foi criada a Faculdade de Arquitetura da USP na rua Maranhão. Por que não fui para a Poli? Talvez porque tivesse pudor. Não quis me arriscar a fazer besteiras na casa de meu pai. Acabei indo estudar no Mackenzie, onde tinha de pagar"173.

Ao se formar no Mackenzie em 1954, Paulo Mendes da Rocha fez parte das primeiras turmas em São Paulo a receber um diploma superior com a designação de arquiteto em uma formação plenamente feita em uma faculdade de Arquitetura. De modo pioneiro, a autonomização do ensino de Arquitetura da escola de Engenharia ocorreu em 1947, quando se deu a criação da Faculdade de Arquitetura do Mackenzie, um ano antes da USP.

\section{A formação no Mackenzie e as possibilidades de renovação estética}

Ainda que tenha sido uma das primeiras gerações a ingressar em um curso de Arquitetura institucionalizado de forma independente, a formação que Paulo Mendes da Rocha seguiu no Mackenzie entre 1950 e 1954 esteve diretamente vinculada à concepção pedagógica e artística que o arquiteto Christiano Stockler das Neves imprimiu ao curso ${ }^{174}$ (diretor cuja força institucional garantiu o recrutamento de um quadro de docentes que deu condições à perpetuação de sua concepção de ensino e ocupou o cargo de diretor por quase 40 anos, entre 1917 e 1956).

173 Em depoimento ao jornalista: CAVERSAN, Luiz. "Uma relação espacial". Folha de S. Paulo, São Paulo, 4, dez de 2003. Caderno Cotidiano, p.14.

174 Tanto no momento de criação da formação de engenheiro-arquiteto, quanto na autonomização da formação do arquiteto, em São Paulo, a participação do arquiteto Christiano Stockler das Neves (1889-1982) foi central. PEREIRA, Gustavo. Christiano Stockler das Neves e a formação do curso de arquitetura no Mackenzie College. Um estudo sobre a disseminação dos métodos da "École des Beaux-Arts de Paris" e das "Fine-Arts Schools" Norte-americanas. Universidade Presbiteriana Mackenzie, São Paulo. 2005. (Dissertação de Mestrado); BREIA, Maria Teresa de Stockler. A transição do ensino da Arquitetura Beaux-Arts para o ensino da Arquitetura Moderna na Faculdade de Arquitetura do Mackenzie, 1947-1965. São Paulo: FAUUSP, 2005 (tese de doutorado). 
Mesmo após o desmembramento institucional das duas carreiras concorrentes - engenheiro-civil e arquiteto, em 1947 - quando da separação da Faculdade de Arquitetura das engenharias, a permanência efetiva de Stockler das Neves na instituição significou a continuidade do modelo de ensino acadêmico, com seus ateliês de desenho e composição, nos quais eram banidas as referências ao modernismo das formas. Diferente da USP, que teve a atuação de arquitetos engajados na estética moderna na criação da FAU, a reforma no ensino de arquitetura no Mackenzie não estava ancorada em uma postura que se considerava progressista em matéria de escolha estética.

O curso de Arquitetura do Mackenzie, desde sua criação em 1917, pelo próprio Stocker das Neves, adotava em seu programa curricular o paradigma beaux-arts, modelo de ensino cujos ateliês constituíam o eixo prático de repetição e inculcação, a partir da emulação da tradição clássica. A aprendizagem dos temas ligados ao projeto de arquitetura concentravamse em duas disciplinas anuais, "Pequenas Composições" e "Grandes Composições, para as quais as atividades propostas exigiam a reprodução de modelos, com formulação de fachadas, pórticos, pátios de palácios nos cânones clássicos, em que se indicava a utilização das proporções e ordens coríntias, jônicas e dóricas.

Stockler sempre se posicionou de forma ferrenhamente crítica aos ideais modernos, rejeitando as formas sem ornamentos, os caixotes de concreto e as paredes de vidro, formalismo arquitetônico que era julgado como ideologia comunista ou bolchevique ${ }^{175}$. Assumindo-se como bastião do "bom gosto", e com apreço apenas pela cultura clássica, reagia veementemente contra o que considerava o "surto modernista". Brise-soleil e fachada envidraçada eram vistos como formas inestéticas de apelo futurista. O funcionalismo e o utilitarismo dessa arquitetura, embora considerados como surto passageiro, eram criticados como uma ameaça à

175 A crítica à arquitetura moderna aparece em diversos textos, cujos títulos polêmicos são indicativos do fervor de suas convicções e da rejeição categórica à nova arquitetura: "A pretensa architetura moderna", 1929; "A machina de habitar do Pacaembu”; 1930 ;“O Comunismo Architetônico" (1930); "O Bluff architetônico" (1930), "Decadência artística" (1931), "Brazil Builds... Chaotic Buildings". FICHER, Sylvia. Os arquitetos da Poli: ensino e profissão em São Paulo. São Paulo, Fapesp: Edusp, 2005. p.392. 
profissão. Em diversos textos, jornais de grande circulação, revistas do Mackenzie e congressos, atacou de forma incisiva essas formas que considerava moda passageira, extravagante, sem valor estético. Preso a uma concepção de projeto devota aos cânones clássicos, às regras e às ordens ditadas pelo academicismo, aquilo que se produzia fora desse ideal de beleza era considerado índice do mau gosto e da falta de sintonia com as grandes civilizações europeias ${ }^{176}$. O novo estilo, em sua visão, não apresentava as qualidades indispensáveis do belo, e os arquitetos modernistas, ao simplificar as formas, eram considerados inimigos da beleza e da profissão.

Quando o estudante Mendes da Rocha entrou na instituição, em 1950, fazia apenas quatro anos que o curso havia se desmembrado. O ensino era amplamente questionado pelos alunos, que organizavam protestos para reivindicar a modernização do curso (BREIA, 2005). Para os estudantes, estava em jogo a redefinição da atividade profissional e do estatuto da profissão: libertos dos valores acadêmicos de cópia e repetição de modelos preestabelecidos, batalhavam para que os valores de originalidade, inventividade e criação emergissem como lastro grandioso da tarefa.

Os conflitos entre duas gerações acadêmicas, a velha guarda de docentes, que monopolizava as definições da "boa arquitetura" baseados no modelo neoclássico, e os estudantes, que se consideravam portadores da ruptura moderna, ilustram, no campo do ensino, a luta que os recémchegados tiveram que travar para impor nova sensibilidade, ou, de modo mais radical, consolidar nova crença no universo arquitetônico. Em um plano mais amplo, também estava em jogo o questionamento de uma "verdade ideal", baseada nas composições historicistas impostas pelo programa acadêmico - até então o definidor dos padrões arquitetônicos,

176 A convicção de Stockler das Neves sobre a primazia da arquitetura produzida na França se expressava frequentemente em seus textos: "No entanto, os célebres concursos franceses (Grand Prix de Rome, Beaux-Arts, Rougevin, Godeboeuf, etc) mostram, a` evidência, a superioridade do gênio artístico da França. Ninguém superou ainda as lindas construções que enchem as avenidas e ruas de Paris e Buenos Aires. $\mathrm{O}$ aspecto arquitetônico dessas comparado com o das nossas cidades mostram a nossa inferioridade na matéria, devida à errônea orientação da arquitetura no país, porque não está nas mãos dos arquitetos". 
contra a liberdade individual de criar a sua obra, encorajando o arquiteto a defender suas formas como expressões singulares. Não é sem razão que no embate entre as duas posturas, a reprodução dos cânones e a invenção do novo, uma das máximas repetidas em sala de aula por Christiano Stockler das Neves era "originalidade consiste em fazer bem-feito o que os outros fazem mais ou menos" (BREIA, 2005, 182). O que se vê é que nesse momento de questionamento do modelo estabelecido na instituição, o florescimento da convicção de que o arquiteto pode criar seus projetos sem repetir a tradição vem mobilizado com a noção da autonomia do arquiteto, que é a base para a ideia de subjetividade, criação e originalidade artística.

Em reação às investidas dos estudantes, que se manifestavam por meio de abaixo-assinados, pequenas greves, provocações aos professores, troças com os trabalhos das disciplinas e cartas com pedido de mudança, a escola foi obrigada diversas vezes a responder explicando sua posição pedagógica, como em 1952, quando Stockler das Neves, na Revista de Engenharia do Mackenzie, rechaça as tentativas de rebelião e ratifica suas concepções didáticas e estéticas. Como dominante no campo, o diretor arrogou para si a posição de definidor dos cânones, insistiu que a estética deveria ajustar-se ao "bom gosto" e acusou ingressantes de "afrontadores" do belo:

"A despeito do surto modernista destes últimos tempos, em que a técnica construtiva e o espírito utilitário pretendem fazer desaparecer a maior das artes do desenho, fruto do materialismo da presente época, talvez produto da moda, que é efêmera, a Faculdade de Arquitetura tem procurado conciliar aspecto acessório da Arquitetura, com princípios que vêm regendo a grande arte durante milênios. [...] Nossos alunos são, pois, aconselhados a não se excederem nessas tendências, aliás, passageiras, em todo os movimentos dessa natureza, "máxime", quando se afastam da tradição e dos princípios instáveis do belo, que é eterno. O ensino da arquitetura não pode estar à mercê da moda do momento, isto é, da preferência por esta ou aquela corrente artística, principalmente nos dias presentes, em que a técnica construtiva pessoal, que é um meio, pretenda suplantar a Arquitetura, que é um fim. A principal função da Arquitetura, a sua razão de ser é a beleza na edificação. Já estiveram em moda o Art Nouveau, o Bungalow, o 
'Colonial Brasileiro', 'Missões' e outros. Não nos consta que as escolas de arquitetura tenham modificado a sua orientação de ensino para atender a esses tipos pitorescos de edificação. A missão das escolas de arquitetura é aprimorar o gosto dos alunos, prepará-los, a fim de apresentarem bons trabalhos à sociedade em que vivem, que deve ser respeitada e livre das afrontas do mau gosto"177.

Ao relembrar sua passagem pela escola nesse momento de embate de posições e julgamentos de gosto, Paulo Mendes da Rocha salientou a irreverência com que colocava em questão o estrangeirismo da tradição clássica, propondo colunas em uma nova estética compositiva inspirada em elementos brasileiros clichês, um modo de confrontar o modelo estabelecido. Sem bater de frente com o diretor, o aluno respondia com ironia e humor às constrições de um ensino considerado conservador e passadista pelos estudantes, granjeando a malícia dos colegas:

"Entre as ordens gregas, eu inventei uma ordem brasileira onde havia macacos, bananas, tudo assim e passou. Os colegas gostavam muito e eu acredito que o Christiano sorriu muitas vezes para mim por causa disso. Aí eu fiz perfeitamente, de longe você não percebia o que era, porque estava bem acabado, como era de se esperar, um templo qualquer onde havia um frontão, mas se aproximando você via que a alegoria toda era feita na base do macaco, carro de boi, Monteiro Lobato." ${ }^{178}$

A rememoração que Paulo Mendes da Rocha tem de sua formação se apresenta de modo bem distinto de outros arquitetos que cursaram o Mackenzie sob as imposições de autoridade de Stockler das Neves ${ }^{179}$.

177 NEVES, Christiano Stockler das. Apud BREIA, 2005. p.182-183. (grifos meus)

178 Depoimento a Sergio Matera. MATERA, Sergio. Carlos Millan: um estudo sobre produção em arquitetura. São Paulo, FAU USP, 2005. (dissertação de mestrado) p.27.

179 Cito dois depoimentos de alunos do Mackenzie que cursaram a faculdade em diferentes períodos, Miguel Forte (1934-1939) e Jorge Wilheim (1947-1952), e que reiteram o ambiente de repressão em relação à arquitetura moderna. Miguel Forte recorda que a entrada de temas modernos se fazia às escondidas, distante dos olhos do professor, visto que a possibilidade de projetar fora do esquema beaux-arts era peremptoriamente menosprezada: "O Christiano era 
Tomada pela distância temporal, a soberba pedagógica de um diretor que encarnava as tomadas de posições estéticas dominantes até os anos 1950, pronto para rasgar os desenhos daqueles que desrespeitavam o paradigma estabelecido, foi decantada com o tempo, revelando a confiança de um produtor que conseguiu se impor ao modelo e escapar daquelas constrições. A elegância do depoimento no final dos anos 1990 é significativa da conduta de um dominante no campo, para quem o passado se apresenta revisto pela consagração que logrou conquistar. Paulo Mendes da Rocha, ao rememorar sua formação no paradigma beaux-arts, reconhece naquele treinamento os fundamentos que justificam a sua posterior utilização de estruturas construtivas de concreto:

"A minha escola, o Mackenzie, tinha um traço acadêmico, mas havia professores que liberavam essa visão. O Christiano Stockler das Neves, que foi para mim um grande mestre pela postura como arquiteto, era, entretanto, o que se chama um acadêmico. Nós fazíamos exercícios que hoje parecem não fazer sentido, mas eu seria capaz de fazê-los de

intransigente, ele não permitia que você pudesse ter ideias contemporâneas, que você pudesse gostar de arquitetura contemporânea [...] toda a estrutura de ensino dele estava ligada com a arquitetura no máximo neoclássica, com especial predileção pela francesa. Todos os temas que ele passava para os alunos deveriam ser desenvolvidos segundos suas ideias [...] Quase que escondidos dos nossos professores e projeto, ficávamos manuseando revistas e livros com a publicação desses arquitetos. E contávamos um para o outro: 'Você viu? Olha, eu comprei um novo livro, você viu a residência do Frank Lloyd Wright publicada?' 'Você viu aquela obra do Mies van der Rohe? [...] Quando estava no 5a ano, o Christiano passou um tema de um centro cultural e tinha que ser feito nos moldes de uma arquitetura neoclássica. Mas eu estava quase para me formar e queria fazer aquilo que eu achava que era certo [...] Então ele, passando pela minha mesa, olhou o projeto e disse: 'Olha Miguel, vou te contar uma coisa: se o teu projeto não estivesse colado na mesa, eu o rasgaria'. Ele ficou indignado. E não podíamos fazer nada, ficávamos quietos, porque também nós não tínhamos a liberdade com o professores como se tem agora". Depoimento de Miguel Forte a Renata Celano, in. FORTE, Miguel. Diário de um jovem arquiteto: minha viagem aos Estados Unidos em 1947. São Paulo: Editora Mackenzie, 2001, p.15. Jorge Wilheim, contemporâneo de Paulo Mendes da Rocha relembra que "o Christiano tinha uma personalidade muito forte [...] ele era cheio de preconceitos [...] Nós não tínhamos revistas de arquitetura moderna na biblioteca. Não tinha L'Architecture Aujourd'hui, não tinha Arts\&Architecture, não tinha Casabella, não tinha Domus. Para ele, a última palavra em arquitetura moderna era a simplificação do neoclássico [...] Os temas que ele dava, temas de projeto, eram temas típicos dos antigos, Belas Artes francesa: pavilhão no parque, ala direita de um palácio, entrada de um banco, então, era desenho formal que ele procurava e ele não ditava estilos, mas é claro que se você aparecia com uma coisa muito moderna, a nota não era boa. Todos os assistentes e professores de projeto eram convidados diretamente por ele, as notas eram dadas pelo professor da cadeira e convidados de outros anos, às vezes, até fora da faculdade, e esses professores não podiam dar nota mais alta do que a dele, Christiano dava a primeira nota e depois vinham os outros professores. Então, era um ditador, tinha uma personalidade muito forte". Depoimento a Sergio Matera, MATERA, Sergio. Carlos Millan: um estudo sobre a produção em arquitetura. FAU-USP, 2005. Dissertação de mestrado. 
novo: um templo circular à deusa Diana em estilo jônico, copiando ou reproduzindo literalmente a modulação grega. Aquilo tudo era tirado dos livros de Vignola. Bom, eu acho um exercício fantástico, uma codificação de caráter estético sobre a forma. Mas isso nos obrigava também a ver, pela história, como aquilo engendrou: qual o tamanho das pedras, como uma geometria pode fazer o corte de uma pedra de tal sorte que se supere a adversidade, qual seja, a força da gravidade que derruba os sólidos [...] Tudo isso foram lições extraordinárias, exercícios que eu nunca achei tolos. Compreendi que não era uma questão de academicismo ou não academicismo, que valia a pena fazer esses exercícios. Teve muita importância na minha formação compreender os espaçamentos das colunas por causa da verga que está lá em cima $[\ldots]^{\prime 180}$

A rememoração que faz da experiência da escola do implacável Stockler das Neves não é negativa. Como está exposto no depoimento, o jovem estudante Paulo Mendes da Rocha equacionou aquela formação considerada retrógrada revertendo-a em aprendizado de técnicas e na condensação de um raciocínio construtivo. Enquanto o padrão de ensino estava enquadrado no gosto pelas formas clássicas e na repetição dos cânones, o estudante sorvia as competências técnicas, atentando-se para a plasticidade dos materiais e para a ordenação da forma. Soma-se a isso a experiência familiar, que foi capaz de lhe oferecer um olhar técnico-científico e focar na engenhosidade dos objetos.

Uma vez que a relação específica com a técnica e a engenharia é reportada à assimilação lenta no ambiente doméstico, que aparece como raiz de sua vocação para o racionalismo moderno, a passagem pela universidade é apresentada como sistematização de um conhecimento com o qual já apresentava familiaridade. Para o filho de uma família ilustrada, a formação universitária sistemática representou a repetição de um conteúdo já inculcado na transmissão familiar:

"E assim, quando entrei numa faculdade de arquitetura - que decidi lá

180 ROCHA, Paulo Mendes da. América, natureza e cidade. São Paulo: op. cit. 2012.p.43. 
pelas tantas - o que eu vi foram confirmações, de uma forma erudita e organizada, do que eu já sabia, em vez de estar diante de uma total novidade. Eu tenho a impressão que minha formação é basicamente esta." ${ }^{181}$

Se as circunstâncias de decisão do ofício de arquiteto vêm acompanhadas da reconstituição em memórias das aventuras de criança, é porque a explicação também se presta a justificar suas próprias escolhas estéticas em seu campo profissional, distanciando-se de outros discursos em confronto, seja o apreço pelo jogo formal irrestrito, seja o compromisso político radicalizado.

Ao restituir suas escolhas a partir do filtro da longa tradição familiar nas grandes construções, o arquiteto avaliza uma definição de arquitetura explicitamente ligada à engenharia, à técnica, ao cálculo, à especificidade dos materiais, que se opõe a uma arquitetura beaux-arts, de repetição de temas clássicos, ou formalista, enunciada como arte pura, ou militante, baseada em palavras de ordens e discurso edificante. Dito de outra maneira, o enunciado cravado na justificativa técnica e nas soluções estruturais procura não ceder espaço nem ao pelo apelo estético nem à ação política. Se Vilanova Artigas falava em transformação da sociedade, em Paulo Mendes da Rocha o que ganha acento é a transformação da natureza. Como notou uma comentadora de sua obra, é "mais frequente ouvi-lo falar de ciência do que de ideologia militante"182, postura que o afasta do discurso partidarizado de Artigas, que, face à avaliação de inadequação da arquitetura tradicional à vida moderna, atou seu programa de renovação estética nas possibilidades de transformação social vislumbrada pela militância comunista ${ }^{183}$.

Diferente de Vilanova Artigas, que se formou no curso de engenheiro-

181 ROCHA, Paulo Mendes da. América, natureza e cidade. op. cit. p.29

182 TELLES, Sophia. “Documento: Paulo Mendes da Rocha. A casa no Atlântico". AU - Arquitetura \& Urbanismo, São Paulo, no60, jun/jul.1995, p.69-81.

183 CHAMPY, Florent, "L'engagement des professionnels comme conséquence de tensions consubstantielles à leur pratique : l'architecture moderne entre les deux guerres.", Sociétés contemporaines 1/2009 (n 73), p. 97-119. 
arquiteto na Escola Politécnica vinte anos antes, em momento que as propostas modernas ainda não eram frequentes na cidade, no período de formação da geração de Paulo Mendes da Rocha, o ambiente profissional, estava menos refratário à nova linguagem. Enquanto o Mackenzie permanecia como bastião em defesa da arquitetura neoclássica, outros espaços permitiam, para essa geração, o acesso às diretrizes e aos programas diferentes do modelo veiculados na faculdade. Sem conceder ao moderno, Stockler das Neves esteve na direção da escola até 1956, quando se aposentou, muito por conta dos conflitos que sua postura passadista representava, acusado de bloquear a modernização do curso.

Em meio a uma formação julgada reacionária e hierárquica, e a despeito da recusa do corpo administrativo e docente em fazer renovações, as ideias modernas entravam por outras vias, alimentando no alunato o sentimento de que poderiam ser portadores de uma renovação estética. Os estudantes buscaram complementar a formação engajando-se em diversas atividades, por exemplo, as de cunho técnico-construtivos. Seria preciso acompanhar o canteiro de obras para fixar um conhecimento prático não fornecido no espaço escolar. Se a arquitetura eclética vai utilizar estuques, madeiras, pedras, tijolo e cimento, a arquitetura moderna lançará mão mais amplamente da tecnologia do concreto armado, modelado em grandes formas de madeira. E os alunos propunham iniciativas para se atualizar na nova linguagem:

"Nós procurávamos o IAB, como sócio aspirante, e arranjávamos cursos tanto na área cultural quanto técnica. Nós tínhamos alguns professores - eram exceções - que nos levavam à obra. E, na visita à obra, se você não tivesse critérios, não enxerga o que interessa. Então, nós providenciamos nossas próprias visitas [...] A parte construtiva sempre foi muito falha na escola"184

Além das investidas coletivas para o efetivo contato com a

184 Alfredo Paesani, colega de turma e parceiro de concursos de Paulo Mendes da Rocha. PAESANI, Alfredo. Entrevista. O Arquiteto. Boletim do Sindicato dos Arquitetos do Estado de São Paulo, s/d. 1988. 
construção, o aprendizado do repertório moderno se fazia por outras instâncias. A circulação de revistas especializadas nacionais e estrangeiras, o estágio em escritórios de arquitetura, a frequentação das atividades mundanas do grupo, o contato com arquitetos estrangeiros com passagem pelas vanguardas europeias, o reconhecimento internacional da arquitetura moderna que se fazia no Rio de Janeiro desde meados dos anos 1930 e o contato com profissionais do Instituto dos Arquitetos do Brasil (IAB) modularam um conjunto de experiências propícias para a consolidação de novas matrizes do projeto arquitetônico e assimilação de concepções distantes da tradição acadêmica. A combinação de um repertório variado, que exigiria conhecimentos práticos e domínio técnico da construção, inserção nas redes sociabilidade e disposições cultas para apreensão dos modelos estrangeiros, é o que vai nobilitar o moderno arquiteto de prancheta.

Nesse sentido, vale destacar que em São Paulo, além de ter se firmado como um espaço em defesa dos interesses da categoria e de regulamentação das atribuições dos arquitetos, o IAB representou, desde a criação de sua seção regional em 1943, um impulso ao desenvolvimento da arquitetura moderna, uma vez que os diretores e organizadores que assumiram a entidade se colocaram como vocalizadores de um discurso de revolução simbólica. Tal hegemonia não viria sem disputas, pois outras associações profissionais que tentaram no âmbito nacional organizar a profissão e regulamentar os diplomas também concorriam com concepções distintas em relação ao ofício, ora se embatendo com os engenheirosarquitetos, que davam primazia à técnica, ora em contenda com os defensores do sistema beaux-arts, que explicitavam suas pretensões de exclusividade em relação à orientação estética, grupo formado em sua maioria por mackenzistas ${ }^{185}$.

Consciente do duplo arranjo entre ensino e profissão, o próprio Christiano Stocker das Neves participou da criação do Instituto Brasileiro

185 Entre elas, Sylvia Ficher relata a formação da Divisão de Arquitetura do Instituto de Engenharia, o Instituto Brasileiro de Arquitetos (fundado em 1921), Sociedade Central dos Arquitetos (1922), ambas reagrupadas no Instituto Central dos Arquitetos (1924), que passou a ser a ser chamado Instituto dos Arquitetos do Brasil, IAB, em 1935. FICHER, Sylvia. Os arquitetos da Poli: ensino e profissão em São Paulo. São Paulo, Fapesp: Edusp, 2005. p.180-184. 
dos Arquitetos, em 1921, e, no âmbito regional, foi o fundador do Instituto Paulista de Arquitetos, em 1930, com o qual tentou intervir contra as reformulações estéticas vanguardistas levadas a cabo por Lúcio Costa, então diretor da Escola Nacional de Belas Artes do Rio de Janeiro. Após contendas e reconfigurações, a centralização dos arquitetos em torno de uma entidade única viria em 1935, com Instituto de Arquitetos do Brasil, e em São Paulo, em 1943, com a criação do departamento regional. Localizado em região central da cidade, inicialmente no subsolo do edifício Esther, em frente à Praça da República e a partir de 1948, na sede definitiva, na rua General Jardim, também no centro, tornou-se um polo de reunião de profissionais ${ }^{186}$.

O concurso para o edifício-sede da instituição, realizado em 1946, três anos após a fundação do departamento do IAB paulista, é ilustrativo do trabalho coletivo em torno da fixação dos ideais modernos ${ }^{187}$, quando a partilha do primeiro prêmio se deu com um acordo entre três equipes vencedoras, todas convocadas a construir democraticamente um projeto coletivo em nome da arquitetura moderna paulista. Acrescenta-se que o florescimento de uma identidade profissional foi também viabilizado pelo programa desse edifício, cujo projeto reservou sete andares para venda e aluguel de salas para escritórios de arquitetos, contribuindo para a confluência e a fixação de práticas e ideias em comum ${ }^{188}$. Vilanova Artigas,

186 A primeira gestão do IAB, em 1943, teve a diretoria composta por Eduardo Kneese de Mello (presidente), Aldo Ferreira (vice), Vilanova Artigas (secretário), Hélio Duarte (segundo secretário) e Oswaldo Corrêa Gonçalves (tesoureiro). Kneese de Mello, Corrêa Gonçalves e Artigas se formaram como engenheiro-arquiteto, o primeiro no Mackenzie em 1931 e os dois últimos na Politécnica em 1939 e 1941, respectivamente. Hélio Duarte era carioca e havia feito o curso de Arquitetura na Escola Nacional de Belas Artes. Todos estavam diretamente implicados em atividades de difusão da arquitetura moderna. As gestões seguintes do IAB, pelo menos até meados da década de 1960, repete o mesmo padrão de recrutamento de engenheiro-arquitetos e arquitetos tanto da Poli-USP quanto do Mackenzie engajados nos princípios modernos, tornando a instituição o estandarte dessa estética.

187 O concurso teve como júri nomes estabelecidos uma geração desbravadora do cenário moderno brasileiro, entre eles, Oscar Niemeyer (1907-2012), Hélio Uchôa (1913-1971), Firmino Saldanha (1905-1985), e Fernando Saturnino de Brito, ambos formados na Escola Nacional de Belas Artes do Rio de Janeiro e amigos de curso e Gregori Warchavchik (18961972), representante pioneiro do modernismo em São Paulo. Como várias equipes foram classificadas em primeiro lugar, Niemeyer julgou interessante que todos os arquitetos participassem em solidariedade: Miguel Forte, Jacob Ruchti, Galiano Ciampaglia, Rino Levi e Roberto Cerqueira César, Hélio Duarte, Abelardo de Souza e Zenon Lotufo, compondo uma equipe única em defesa da arquitetura moderna paulista.

188 É assim divulgado o "sonho" dos arquitetos paulistas em terem sua sede: "Os arquitetos de São 
Ícaro de Castro Mello, Ariosto Mila, Rino Levi, Oswaldo Corrêa Gonçalves, Miguel Forte, Arnaldo Mindlin, Fábio Penteado e Paulo Mendes da Rocha tiveram por anos seus escritórios situados no edifício sede do $\operatorname{IAB}^{189}$, compondo um espaço que agrupava uma safra de arquitetos vindos das duas instituições - engenheiro-arquiteto da Politécnica e do Mackenzie e a nova geração de arquitetos formados nas mesmas instituições após a autonomização dos cursos. Em comum, esses arquitetos atuavam no ensino e também encampavam o debate sobre o métier e a militância na defesa da profissão.

Com efeito, a esquina da rua General Jardim com a rua Bento Freitas, onde está localizada a entidade, também se transformou em um espaço de sociabilidade entre arquitetos, artistas, intelectuais e interessados nas vanguardas culturais da cidade desde sua construção. No subsolo do IAB encontrava-se o Clube dos Artistas e Amigos da Arte, apelidado de Clubinho pelos frequentadores, espaço que reunia artistas como Francisco Rebolo, Aldemir Martins, Mário Gruber, com os quais Paulo Mendes da Rocha estabeleceu relações de amizade ${ }^{190}$. A partilha da sede do IAB $^{191}$ entre arquitetos e artistas do Clubinho até o final dos anos 1960 rendeu uma relação de proximidade e parceria, o que responde, no plano estético, a uma concepção vanguardista de união entre arte e arquitetura ${ }^{192}$.

Para os arquitetos, assumindo como legado as diretrizes da tradição

Paulo conhecem a força da cooperação. Assim, tornou-se possível iniciar-se a construção do edifício sede do IAB [...] dentro em breve, o departamento de São Paulo do IAB terá sua nova sede e a Capital Bandeirante um novo centro de arte, ponto de reunião de todos os artistas e amigos da boa arte". Acrópole, mai, no 121, 1948, p.2.

189 PENTEADO, Fábio. Fábio Penteado: ensaios de arquitetura. São Paulo: Empresa das Artes, 1998.

190 Depoimento de Paulo Mendes da Rocha sobre o IAB, disponível em: http://iabsp.org.br/? noticias=arquiteto-paulo-mendes-da-rocha-fala-sobre-o-predio-do-iab-sp. Acesso em: $15 / 12 / 2014$

191 A formação de um ambiente de parceria entre arquitetos e artistas esteve presente desde a abertura do Clubinho no IAB, no final dos anos 1940, quando o projeto foi desenhado pelo então estudante do Mackenzie, Jorge Wilheim, colega de turma de Paulo Mendes da Rocha, que participou de equipe com os arquitetos poloneses Victor Rief e Jorge Zalspzupin, ambos chegados no Brasil em 1950.

192 Cf. ARGAN, Giulio Carlo. Arte Moderna. São Paulo: Companhia das Letras, 1992. BENÉvOLO, Leonardo. História da Arquitetura Moderna. São Paulo: Perspectiva, 1998. PEDROSA, Mario. Dos murais de Portinari aos espaços de Brasília. São Paulo, Perspectiva, 198. 
alemã da Bauhaus e do racionalismo do francês Le Corbusier, a arte moderna deveria fazer parte da concepção do edifício, compondo uma totalidade formal. Se no plano das ideias, a síntese das artes acalentava uma noção de integração entre artistas e arquitetos interessados na fruição estética, na aplicação prática, a colaboração pode ser vista, como salienta José Carlos Durand, como uma "tática sem dúvida importante de arregimentação de forças para enfrentar a resistência do gosto estabelecido"193. A parceria entre arquitetos e artistas também representou o arranque na carreira dos postulantes ao métier artístico, muitas vezes artesãos de baixa extração social, cuja iniciação profissional se deu marcada pelo autodidatismo, os quais ofertaram seus trabalhos aos próprios arquitetos ou a partir da mediação deles, tiveram suas pinturas acessíveis à clientela de residências, cujas paredes foram decoradas com telas e afrescos modernos.

Nos anos 1950 em São Paulo floresceria um ambiente de transformações não apenas arquitetônicas, mas também urbanas, artísticas, intelectuais, literárias, dando ensejo à consolidação de novas linguagens, com novos públicos em cena. A geração de arquitetos que se formava, empenhada na modernização do país, tinha como estímulo o sucesso da arquitetura brasileira, que conquistava a crítica internacional e afirmava uma nova ortodoxia com a construção grandiosa de uma nova capital para o país.

\section{Requisitos de ingresso na profissão}

No ano de 1954, quando Paulo Mendes da Rocha se formou, foram diplomados 57 arquitetos no Mackenzie, um número elevado se considerado os três anos anteriores de início do curso de arquitetura, cuja média foi de

193 DURAND, José Carlos. Arte, privilégio e distinção: artes plásticas, arquitetura e classe dirigente no Brasil, 1855/1985. São Paulo: Perspectiva, 1989. p.151. 
27 novos arquitetos no mercado de trabalho ${ }^{194}$. O aumento do número de formados nessa instituição refletiu as mudanças feitas na faculdade, após a separação da engenharia, quando o curso triplicou o número de vagas à disposição. Ainda que tivessem reduzido o curso para uma formação de cinco anos, sob justificativa que a anterior, de seis anos, afugentava grande parte de interessados, o perfil do ingressante respondia às características sociais de quem pudesse cursar uma faculdade tempo integral e com acesso controlado por provas de desenho de aptidão artística. Tais condições de caráter fortemente seletivo contribuíram para o recrutamento de alunos provenientes de grupos sociais mais favorecidos, sobretudo filhos de proprietários de terra no interior do estado e classes médias urbanas com profissões liberais, alguns com enraizamento em grupos de classes dirigentes e proprietários de terras. Os novos ingressantes compunham um grupo razoavelmente heterogêneo, mas sobretudo de homens - até os anos 1960, o curso é praticamente masculino - provenientes de frações sociais que dispunham de um certo acúmulo de capitais econômicos e culturais, muitos deles herdeiros de famílias tradicionais, que validaram sua formação em escolas de elite como o Colégio São Luís e o Dante Alighieri.

No panorama nacional, como informa José Carlos Durand, a ampliação da matrícula de alunos durante os anos 1950, década que se situa entre a autonomização institucional dos cursos e a construção de Brasília, foi bastante elevada, passando de 64 alunos inscritos em 1945 a 1.600 alunos no final dos anos 1950, período do aumento do interesse pela profissão com a glorificação da arquitetura nacional encampada pelos preparativos da nova capital. Em São Paulo, a se levar em conta os registros de sócios do departamento regional do $I A B$, o número de aderidos saltou de 38 para 453 entre os anos e 1943 e $1955^{195}$. A expansão de vagas no Mackenzie respondia, assim, às dinâmicas mais amplas de institucionalização da profissão, acrescida de um interesse de novas gerações, filhos de grupos mais abastados que poderiam converter seus

194 Dados contabilizados a partir das listas de alunos formados por ano do Mackenzie. (BREIA, 2005).

195 DURAND, José Carlos. Arte, privilégio e distinção: artes plásticas, arquitetura e classe dirigente no Brasil, 1855/1985. São Paulo: Perspectiva, 1989. p.154 
capitais culturais para acesso ao um ensino superior de formação de elites.

Uma vez terminada a graduação, as opções de início profissional para o arquiteto recém-formado era, sobretudo, dar continuidade às atividades nos escritórios que estagiaram, principalmente se eram escritórios reputados na cidade, como Rino Levi e Oswaldo Bratke, passando para a posição de arquitetos efetivos. Todavia, ainda que houvesse a possibilidade de exercício de cargo em algum departamento público ou setor de obras municipais, escapar de um posto de caráter eminentemente técnico e assumir uma atuação em escritório próprio e autoral era a posição mais prestigiosa da área.

Uma das soluções encontradas para efetivar o ingresso no mercado de trabalho de forma autônoma era se estabelecer em sociedade a partir das amizades desenvolvidas durante o período de formação. A longa e contínua frequentação de um curso integral partilhado em ateliês propiciaria convívio intenso, deflagrador de proximidades intelectuais, artísticas e profissionais, operando de forma decisiva nos ajustes de práticas, afinando maneiras de pensar, vinculando expectativas profissionais, ou, em outros termos, estabelecendo um processo de reconhecimento e sintonização do habitus. Mesmo que o curso impusesse os padrões de exercício profissional ligados a uma estética neoclássica, os estudantes recorreriam a outros métodos.

O quadro abaixo procura agrupar alguns dos arquitetos que cursaram as primeiras turmas do Mackenzie, no final dos anos 1940 e início dos anos 1950 , e que se orientaram para a prática do projeto de arquitetura em São Paulo em escritório e atuando na produção de edifícios de linguagem moderna ${ }^{196}$. A partir da coleta de dados gerais sobre cada arquiteto, nem sempre disponíveis, procurou-se apontar algumas das propriedades sociais dessa geração, período de formação, início de carreira, projetos de estreia e

196 Alguns depoimentos posteriores de arquitetos citam um grupo de alunos que se assumiram um papel de disseminadores das ideias modernas em meio a alunato. Fábio Penteado assim registra o grupo: "quando eu estava no terceiro ano, um grupo de colegas que, como eu, entendia que eram notáveis aqueles homens do IAB se reunia na sala de desenho artístico, para desenhar, conversar, discutir e ler revistas. Faziam parte dele Jorge Wilheim, Telésforo Cristofani, Roberto Aflalo, Alfredo Paesani, Pedro Paulo de Melo Saraiva, Paulo Mendes da Rocha e, principalmente, Carlos Millan". PENTEADO, Fábio. Entrevista. Projeto Design, abril, no , 190, 2004. 
principais atividades em que atuaram.

Observa-se que esses arquitetos, provenientes, sobretudo, de famílias bem estabelecidas de classe média e classe alta, tiveram seu ingresso na profissão, de início com o desenvolvimento de pequenos projetos residenciais, feitos principalmente para familiares e pessoas dos círculos mais próximos de conhecidos. A expansão da clientela do escritório dependerá de uma maior divulgação dos trabalhos nas revistas especializadas e da participação em concursos, requisito de entrada para se conseguir projetos mais complexos e de grande porte. Os projetos sob encomenda do Estado possibilitariam maiores ousadias estruturais e formais e, assim, teriam maior visibilidade e uso coletivo, distintos, portanto, da limitação dos projetos privados, como as residências unifamiliares, cujo programa básico resume-se na alocação de sala, quartos, cozinhas, banheiros.

As competições de projeto, o engajamento com atividades da profissão, a presença em debates e eventos de sociabilidade mundana, a articulação nas entidades representativas, a atuação na divulgação sobre a arquitetura em revistas especializadas e revistas de ampla circulação concorriam como atividades para criar vínculos e fortalecer o ingresso na profissão. É relevante que uns dos principais requisitos de entrada e efetivação na carreira foram a passagem por concursos de Arquitetura e a atuação em instâncias de defesa corporativa. A passagem por esses espaços formativos é recorrente nas trajetórias dos arquitetos analisados, o que demonstra que tais instâncias funcionaram como inculcadoras de modos de pensar e condutas, atuando na modelação da expertise do ofício. É notável também a rotatividade nas parcerias em concursos, duplas e trios formados em frequente permuta entre os diversos colegas de faculdade, 0 que expõe um dinâmico e restrito círculo de sociabilidade.

\begin{tabular}{|l|l|l|l|l|l|}
\hline \multicolumn{2}{|l|}{ Quadro: Arquitetos expoentes formados nas primeiras turmas do Mackenzie } \\
\hline $\begin{array}{l}\text { Arquiteto } \\
\text { (ano } \\
\text { nascimento- } \\
\text { falecimento) }\end{array}$ & $\begin{array}{l}\text { Local } \\
\text { de } \\
\text { nascim. }\end{array}$ & Origem social & Período & $\begin{array}{l}\text { Início de carreira: } \\
\text { premiações/ } \\
\text { concursos }\end{array}$ & $\begin{array}{l}\text { Principais } \\
\text { obras/principal área } \\
\text { de atuação }\end{array}$ \\
\hline
\end{tabular}




\begin{tabular}{|c|c|c|c|c|c|}
\hline $\begin{array}{l}\text { Luiz roberto } \\
\text { Carvalho Franco } \\
(1926-2001)\end{array}$ & Araras, SP & 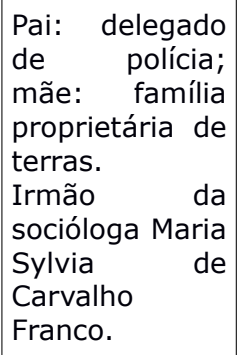 & $\begin{array}{l}1947- \\
1951\end{array}$ & $\begin{array}{lr}\text { 1951-2001: Início } \\
\text { como estagiário e } \\
\text { depois sócio diretor do } \\
\text { escritório de } & \text { Rino Levi. } \\
\text { 1951: rêmio } & \text { prtudantil com Carlos } \\
\text { estulan na I } & \text { Bienal de } \\
\text { Millan no } & \\
\text { Arte de SP. }\end{array}$ & $\begin{array}{l}\text { Revista Pilotis, } \\
\text { fundação. } \\
\text { 1956: terceiro lugar } \\
\text { Plano de Brasília. } \\
\text { Professor FAU-USP: } \\
\text { 1958-1962, disciplina } \\
\text { de Composições, e até } \\
\text { 1965 Desenho } \\
\text { Industrial. } \\
\text { Atuação no IAB. }\end{array}$ \\
\hline $\begin{array}{l}\text { Roberto Aflalo } \\
\text { (1926-1992) }\end{array}$ & $\begin{array}{l}\text { São Paulo, } \\
\text { SP }\end{array}$ & $S / d$ & 1950 & $\begin{array}{l}\text { 1952: Branco \& Preto, } \\
\text { móveis, com Carlos } \\
\text { Millan, Miguel Forte, } \\
\text { Jacob Ruchti. } \\
\text { 1962: vencedor do } \\
\text { concurso Peugeot, com } \\
\text { Croce e Gasperini. }\end{array}$ & $\begin{array}{l}\text { Sócio no Aflalo e } \\
\text { Gasperini, grande } \\
\text { escritório de arquitetua } \\
\text { comercial. } \\
\text { Edifício na rua Barão } \\
\text { Itapetininga. } \\
\text { Arquitetura } \\
\text { corporativa. }\end{array}$ \\
\hline $\begin{array}{l}\text { Carlos Millan } \\
(1927-1964)\end{array}$ & $\begin{array}{l}\text { São Paulo, } \\
\text { SP }\end{array}$ & $\begin{array}{l}\text { Família católica } \\
\text { de imigração } \\
\text { espanhola. }\end{array}$ & $\begin{array}{l}1947- \\
1951\end{array}$ & $\begin{array}{l}\text { 1952: Produção de } \\
\text { mobiliário na Branco \& } \\
\text { Preto com amigos da } \\
\text { faculdade. } \\
\text { 1951: prêmio } \\
\text { estudantil com Roberto } \\
\text { Carvalho Franco na I } \\
\text { Bienal de Arte de SP. }\end{array}$ & $\begin{array}{l}\text { Revista } \\
\text { fundação. } \\
\\
\text { Residências } \\
\text { Araraquara, reforma } \\
\text { irmão. } \\
\text { Edifício na rua Barão } \\
\text { Itapetininga. } \\
\text { 1955-1959: escritório } \\
\text { com Joaquim Guedes. } \\
\text { 1957: } \\
\text { Mackenzie. docente } \\
\text { 1958: docente FAU. }\end{array}$ \\
\hline $\begin{array}{l}\text { João Eduardo } \\
\text { Genaro } \\
(\mathbf{1 9 2 8 - 2 0 1 3 )}\end{array}$ & $\begin{array}{ll}\text { São } & \text { Paulo, } \\
\text { SP } & \end{array}$ & $S / d$ & $\begin{array}{l}1949 \\
-1954\end{array}$ & $\begin{array}{l}\text { 1957: concurso no } \\
\text { Ginásio do Clube } \\
\text { Atlético Paulistano. } \\
\text { 1964: } \quad \text { Prêmio no } \\
\text { Jockey } \\
\text { lub de Goiás. }\end{array}$ & $\begin{array}{l}\text { 1955-1967: Parceria } \\
\text { longa com Paulo } \\
\text { Mendes da Rocha. } \\
\text { 1967: Itauplan, } \\
\text { arquitetura comercial, } \\
\text { administrativa. }\end{array}$ \\
\hline $\begin{array}{l}\text { Paulo Mendes } \\
\text { da Rocha } \\
\text { (1928) }\end{array}$ & Vitória, ES & \begin{tabular}{|l|} 
Pai: \\
engenheiro, \\
professor na \\
Politécnica; \\
avô: \\
engenheiro.
\end{tabular} & $\begin{array}{l}1949 \\
-1954\end{array}$ & $\begin{array}{l}\text { 1957-58: concurso na } \\
\text { Assembleia. } \\
\text { 1957: Concurso no } \\
\text { Ginásio do Clube } \\
\text { Atlético Paulistano. } \\
\text { 1964: Prêmio no } \\
\text { Jockey Club de Goiás. }\end{array}$ & $\begin{array}{ll}\text { 1955: Residências } \\
\text { unifamiliares. } & \\
\text { 1958: } & \text { Clube } \\
\text { Paulistano. } & \\
\text { 1975: proposta } & \text { MAC- } \\
\text { USP com } & \text { Jorge } \\
\text { Wilheim. } & \\
\end{array}$ \\
\hline $\begin{array}{l}\text { Jorge Willhein } \\
\text { (1928-2014) }\end{array}$ & $\begin{array}{l}\text { Trieste, } \\
\text { Itália }\end{array}$ & $\begin{array}{l}\text { Família judia, } \\
\text { imigrantes } \\
\text { italianos, em } \\
\text { chega fugidos } \\
1940, \text { fascismo. } \\
\text { do } \\
\text { Pai: } \\
\text { comerciante, } \\
\text { vendedor. }\end{array}$ & $\begin{array}{l}1947 \\
-1952\end{array}$ & $\begin{array}{l}\text { 1952: Hospital da } \\
\text { Santa Casa de Jaú. }\end{array}$ & $\begin{array}{l}\text { Urbanista, } \\
\text { Fundação Fapesp (). } \\
\text { Parque do Anhembi } \\
\text { (1969). } \\
\text { 1975: proposta MAC- } \\
\text { USP com Paulo Mendes } \\
\text { da Rocha. } \\
\text { Ligado ao PCB. }\end{array}$ \\
\hline $\begin{array}{l}\text { Fábio Moura } \\
\text { Penteado } \\
(1929-2011)\end{array}$ & $\begin{array}{l}\text { Campinas, } \\
\text { SP }\end{array}$ & \begin{tabular}{|lr} 
Avôs: & \\
engenheiro & e \\
médico; & pai: \\
industrial & e \\
aviador. &
\end{tabular} & $\begin{array}{l}1948- \\
1953\end{array}$ & $\begin{array}{l}\text { 1954: Concurso no } \\
\text { Clube de Campinas. } \\
\text { 1964: Clube Harmonia } \\
\text { com Paesani. }\end{array}$ & $\begin{array}{l}\text { Parceria } \\
\text { Paesani.1958: } \\
\text { do IA. } \\
\text { Escritório no } \\
\text { andar). } \\
\text { 1956-62: } \\
\text { revista Visão. Editor } \\
\text { Revista Projeto. } \\
\text { 66-68: } \\
\text { nacional IAB. } \\
\text { 1975: editor retoria } \\
\text { Projeto. }\end{array}$ \\
\hline
\end{tabular}




\begin{tabular}{|c|c|c|c|c|c|}
\hline $\begin{array}{l}\text { Pedro Paulo de } \\
\text { Mello Saraiva } \\
\text { (1933) }\end{array}$ & $\begin{array}{l}\text { Florianópoli } \\
\text { S } \\
\text { SC }\end{array}$ & $\begin{array}{l}\text { Pai } \\
\text { amazonense. }\end{array}$ & $\begin{array}{l}1951- \\
1955\end{array}$ & $\begin{array}{l}\text { 1957: Concurso na } \\
\text { Assembleia Legislativa } \\
\text { de Santa Catarina, com } \\
\text { Paulo Mendes da } \\
\text { Rocha. }\end{array}$ & $\begin{array}{l}\text { 1962-1975: assistente } \\
\text { FAU-USP. } \\
\text { 1968-69: UnB. } \\
\text { Atuação em escritório, } \\
\text { edifícios comerciais, } \\
\text { administrativos, } \\
\text { escolares. } \\
\text { Concurso Centre } \\
\text { George Pompidou (12 } \\
\text { brasileiros). }\end{array}$ \\
\hline $\begin{array}{l}\text { Alberto Rubens } \\
\text { Botti } \\
(1931)\end{array}$ & $\begin{array}{l}\text { Santos, } \\
\text { SP }\end{array}$ & $S / d$ & $\begin{array}{l}1950- \\
1954\end{array}$ & $\begin{array}{l}\text { Estagiário de Oswaldo } \\
\text { Bratke. }\end{array}$ & $\begin{array}{l}\text { 1955: Escritório Botti } \\
\text { Rubin, de projeto e } \\
\text { construção, canteiro } \\
\text { de obras de casas, no } \\
\text { início. } \\
\text { 1957: diretor IAB. } \\
\text { 1963-65: presidência } \\
\text { IAB. } \\
\text { 1973: Secretário de } \\
\text { Obras na Emurb. } \\
\text { Atuação AsBEA. } \\
\text { Parceria com colega de } \\
\text { faculdade, Marc Rubin, } \\
\text { em mais de mil } \\
\text { edifícios. }\end{array}$ \\
\hline $\begin{array}{l}\text { Telésforo } \\
\text { Cristófani } \\
(1929-2002)\end{array}$ & Itália & $\begin{array}{l}\text { Pai: italiano; } \\
\text { mãe: } \\
\text { brasileira. Veio } \\
\text { com dois anos } \\
\text { aor Brasil, } \\
\text { depois ro do } \\
\text { falecimento do } \\
\text { pai. }\end{array}$ & ?-1952 & $\begin{array}{l}\text { Início de carreira na } \\
\text { construtora dos tios, } \\
\text { Salfacci\&Buchignani. } \\
\text { Projeto para edifício } \\
\text { Restaurante Vertical } \\
\text { Fasano e residência de } \\
\text { Fabrizio Fasano, devido } \\
\text { àq proximidade das } \\
\text { famílias italianas. }\end{array}$ & 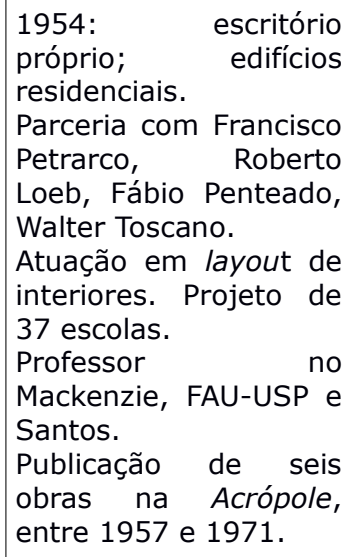 \\
\hline $\begin{array}{l}\text { Alfredo } \\
\text { Serafino } \\
\text { Paesani } \\
(\mathbf{1 9 3 0 - 2 0 0 2 )}\end{array}$ & São Paulo & $S / d$ & $\begin{array}{ll}1949 \\
1954\end{array}$ & $\begin{array}{l}\text { 1957: Concurso na } \\
\text { Assembleia Legislativa } \\
\text { de Santa Catarina } \\
\text { (com Paulo Mendes da } \\
\text { Rocha e Pedro Paulo } \\
\text { Saraiva). } \\
\text { 1964: Clube Harmonia } \\
\text { com Fabio Penteado. }\end{array}$ & $\begin{array}{l}\text { Estagiário de Oswaldo } \\
\text { Bratke. Parceria com } \\
\text { vários arquitetos, } \\
\text { Pedro Paulo Saraiva, } \\
\text { Paulo Mendes, Ícaro de } \\
\text { Castro. Sempre ficou } \\
\text { na parte técnica, } \\
\text { detalhamento, } \\
\text { especificação. } \\
\text { 1954: IAB. } \\
\text { 1971-1974: Presidente } \\
\text { Sindicato } \\
\text { arquitetos. } \\
\text { 1972- : fundador da } \\
\text { Revista Projeto. } \\
\text { Professor } \\
\text { Mackenzie. no }\end{array}$ \\
\hline \multicolumn{6}{|c|}{ 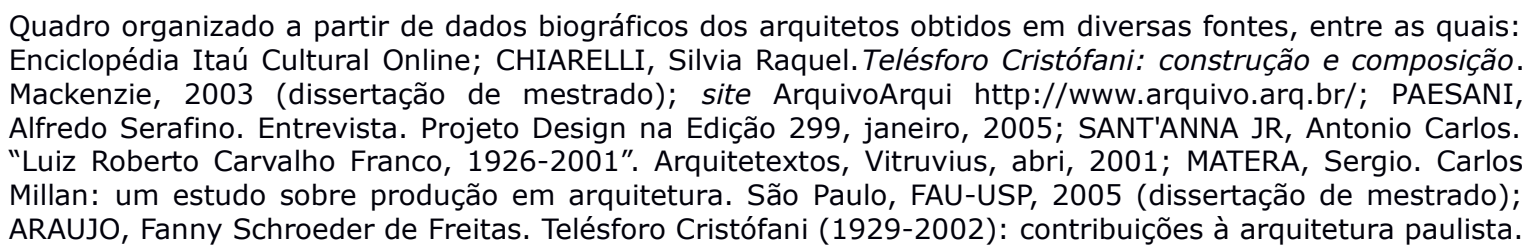 } \\
\hline
\end{tabular}


Faculdade de Arquitetura do Mackenzie, 2009 (dissertação de mestrado); PISANI, Daniele. Paulo Mendes da Rocha: obra completa. São Paulo, Gustavo Gilli, 2013; PENTEADO, Fábio. Fábio Penteado: ensaios de arquitetura. São Paulo: Empresa das Artes, 1998; DE GENNARO, João. Entrevista. Projeto Design, ago, 2005.

De posse do seu diploma de arquiteto em 1954, aos 26 anos, Paulo Mendes da Rocha vai iniciar sua carreira nas modalidades correntes para um recém-formado. Primeiro, fará o investimento inicial em alguns projetos residenciais entre os anos 1955 e 1956, no Guarujá e em locais que aludem a seus vínculos familiares, como Paquetá, no Rio de Janeiro, e no Espírito Santo. Esses projetos não foram executados, o que atesta a dificuldade de início em uma profissão liberal, cuja exigência necessária para rentabilidade de escritório próprio é uma carta diversificada de clientes em afinidade com as concepções estéticas do arquiteto e com recursos financeiros para materializar os desenhos em edifícios.

Nesse início de experimentações e tentativa de fixação do escritório, a dedicação intensiva a concursos de projetos permite franquear as condições de acesso à profissão. Essa modalidade de investimento possibilitaria ao arquiteto expor uma concepção autoral de sua arquitetura diante de um júri, com a esperança de ter construído um edifício de grande porte financiado pelo poder público ou um mecenas. Em sua maioria, os concursos eram organizados e difundidos pelo IAB, tendo suas chamadas e resultados publicados nos boletins da entidade, bem como nas revistas especializadas com diretrizes modernas, como a Acrópole e a Habitat, cujos integrantes estavam associados ao instituto.

Junto ao poder público e à sociedade, o empenho do IAB em disseminar, formular e exercer domínio sobre os concursos tinha como alvo a ampliação de debate em torno do ofício, a valorização do projeto de arquitetura como atividade exclusiva do arquiteto e a regulamentação da prática profissional, o que serviria também como intimidação contra o exercício ilegal da profissão. Aos arquitetos, a entidade contribuiria para dar unidade ao mister, fomentando a criação de um grupo com coesão de posicionamentos, práticas estéticas e tomadas de posição política, o que favoreceu o espraiamento e a consolidação das inovações arquitetônicas 
que despontavam desde os anos $1940^{197}$.

Os concursos são expressivos das estratégias de imposição de novos padrões de julgamento na profissão. Sob o ponto de vista da entidade, a abertura desses processos de concorrência seria a maneira mais eficaz de controlar, a partir da nomeação dos jurados e da definição dos programas, os critérios de seleção e julgamentos arquitetônicos, posto que seriam eles os responsáveis por monopolizar as novas codificações projetuais e estéticas. Em relação ao exercício, os concursos funcionaram como um espaço de trocas de ideias, afinamento de técnicas de representação, indicação de materiais e revestimentos, enunciação e resolução de problemas projetuais, técnicos, construtivos e de implantação urbana.

Sob o ponto de vista dos arquitetos, a convivência repetida nesses espaços transformaria as aquisições em aprendizagem implícita e explícita, capaz de produzir reconhecimento das regras do jogo. Os concursos funcionaram como espaço espiritual de coesão do grupo, de reforço de predileções e recusas, no qual compartilham gestos, traços, formas de pensar, falar, discursar, agir, vestir, ou seja, conformam estilos de vida reconhecíveis e próprio aos grupos. Aos recém-formados, essas experiências se apresentariam como instrumento de apropriação do conjunto de disposições válidas no campo, ajustando-os às expectativas em relação à apresentação de si, à realidade da prática construtiva, à escolha dos materiais e a um mercado de novas referências formais. A passagem por essas competições apresentou-se como um acesso privilegiado à entrada na carreira.

A competência certificada pelos ganhadores é, portanto, inseparável do cultivo dessas disposições que foram adquiridas de forma lenta e implícita, como um aprendizado tácito, nos diversos locais físicos e simbólicos que compõem a sociabilidade dos arquitetos modernos. A frequentação desses espaços favoreceu a familiaridade dos recém-chegados

197 Os boletins mensais do IAB passam a utilizar a Acrópole como meio de divulgação a partir de agosto de 1953, ocupando as primeiras páginas de cada edição. Os responsáveis são os arquitetos Jorge Wilheim e Luiz Roberto Carvalho Franco. 0 espaço funciona como vocalização da profissão e expressão das atividades, tanto administrativas quanto festivas. Além dos concursos, divulgavam-se viagens, congressos, exposições, cursos e reuniões, comemorações e festas. 
às exigências do grupo, permitindo que os participantes entrassem em contato com novas diretrizes tanto do gosto arquitetônico quanto do ethos da profissão, e assim propusessem respostas pertinentes a esses parâmetros. Como mecanismos de concorrência e validação de eleitos, o sucesso nos concursos contribuiu para creditar a presença de novos agentes no campo, investidos de saberes e disposições, e os disponibilizarem para assumir novos postos, formando uma geração com a autoridade reconhecida pelo grupo, apta a reafirmar os pressupostos da arquitetura moderna e dar prosseguimento à nova ortodoxia, seja radicalizando o modelo ou rotinizando-o.

Em 1957, três anos depois de formado, Paulo Mendes da Rocha esteve implicado no concurso da Assembleia Legislativa do estado de Santa Catarina, (junto com os colegas de faculdade de turmas de anos diferentes, Pedro Paulo de Melo Saraiva e Alfredo Paesani), com projeto que chegou a vencer em primeiro lugar. A proposta era um extenso edifício vertical em lâmina, com as estruturas marcando a fachada envidraçada. Os pontos de apoio marcantes em concreto aparente. No mesmo ano, participou do concurso de anteprojeto para instalações do Clube Atlético Paulistano, no Jardim América, na cidade de São Paulo, que previa a criação de anexo esportivo para conjunto de edifícios executados no final dos anos 1940 por Gregori Warchavichik e equipe de colaboradores que incluía outros nomes importantes do modernismo paulista, como o engenheiro-arquiteto uspiano Zenon Lotufo, e os arquitetos cariocas formados pela Escola Nacional de Belas Artes, Hélio Duarte e Abelardo Souza ${ }^{198}$. Intervir na remodelação do projeto do arquiteto considerado o pioneiro do modernismo paulista, além de ser um espaço de lazer restrito às elites paulistanas, exigiria compromisso e responsabilidade com a linhagem da vanguarda em São Paulo, esforço que seria recompensado com gratificações simbólicas de se

198 O projeto de Gregori, Warchavichik foi feito a convite do corpo diretivo do clube, no final dos anos 1940, representado por seu diretor-fundador Antonio Prado da Silva Junior, personalidade da elite política, econômica e cultural paulistana, também amigo do arquiteto. Vale destacar que diversos membros da família Prado foram incentivadores das artes modernas no começo do século $\mathrm{XX}$, e vários deles foram encomendantes de residências a Warchavchik, como a casa do próprio Antonio da Silva Prado, de Luiz da Silva Prado e o edifício Cícero Prado. Sobre o projeto inicial do Clube Paulistano, cf: LIRA, José. Warchavchik: fraturas da modernidade. São Paulo: CosacNaif, 2001. 
notabilizar em uma rede de arquitetos consagrados e fazer-se visível em meio às famílias endinheiradas frequentadoras do clube.

Nesse concurso, Mendes da Rocha mudou sua parceria e atuou junto com outro colega de faculdade, o arquiteto João Eduardo Gennaro. Entre os 24 concorrentes, a dupla foi a vencedora, deixando em segundo lugar a equipe de Pedro Paulo Saraiva e Júlio Neves, e em terceiro lugar, Jorge Wilheim, perfilando uma disputa entre colegas mackenzistas ${ }^{199}$. [fig. 41] Foram três arquitetos que compuseram o júri, todos nomes importantes da cena moderna paulista, representantes de escritório, da universidade e do IAB: Rino Levi (1901-1965), brasileiro formado na Escola Superior de Arquitetura de Roma em 1926 e que nessa época também era professor na FAU-USP; Plínio Croce (1921-1984), formado engenheiro-arquiteto no Mackenzie em 1946, exerceu um período como professor na FAU-USP e também era ativo integrante do corpo diretivo do IAB; e Rubens Carneiro Vianna (1914-1987), engenheiro-arquiteto formado pela Escola Politécnica em 1933, vencedor de inúmeros concursos nesse período 200.

A composição do júri de diferentes idades e instituições abarcava gerações distintas, mas todos arquitetos convertidos ao moderno, profissionais que tinham consolidado em São Paulo escritórios com vasta produção. Assim, a comissão julgadora era validada por arquitetos consagrados no espaço paulista, seja pela autoridade cultural, como Rino Levi, que pertencia a uma geração mais velha e com escritório amplamente reconhecido; seja pelos vínculos estabelecidos no IAB e na USP, como Croce; seja pela atuação e experiência em outros concursos e realização de inúmeras obras arquitetônicas na cidade, como Vianna. A seleção de um júri diversificado e afinado garantiria a legitimidade do julgamento.

Em 1961, quando as novas instalações esportivas do Clube Paulistano terminaram de ser construídas, o novo edifício foi condecorado com mais uma honraria, o "Grande Prêmio Presidente da República", na VI Bienal

199 FERRAZ, Geraldo. "Concurso de anteprojeto para as instalações do Clube Atlético Paulistano". Habitat nํㅜㄱ, mar, abr, 1958.

200 Sobre a biografia de Rubens Gouvêa Carneiro Vianna, cf. FICHER, Sylvia. Os arquitetos da Poli. p.306. 
Internacional de Arte de São Paulo, que tinha como júri cinco arquitetos bem cotados, sobretudo representantes de São Paulo e do Rio de Janeiro, e entre eles também um estrangeiro. Foram eles: o venezuelano Julien Ferris (?-2009), o carioca Affonso Reidy (1909-1964), o paulista Zenon Lotufo, que havia participado do primeiro projeto do Clube Paulistano e o carioca Eduardo Corona (1921-2001), formado pela Escola Nacional de Belas Artes e estabelecido em São Paulo, onde foi atuante no IAB e docente na FAU desde 1949; e o carioca Maurício Roberto (1921-1996), do escritório MMM Roberto. Tal comissão de julgamento formava novamente um conjunto de juízes altamente prestigiados, com trabalhos divulgados em revistas nacionais e internacionais e com atuação no sistema de ensino. Seria mais um espaço de visibilidade aos arquitetos ingressantes desejosos de granjear certa notoriedade e aceitação entre os pares.

A vitória de Paulo Mendes da Rocha e João Eduardo Gennaro no concurso de remodelação do Clube Atlético Paulistano e a sequente premiação na Bienal são frequentemente invocadas pelos comentadores e historiadores como marco significativo de início da carreira, a qual é imputada um percurso prestigioso. Esquecendo-se da repetida experiência de aquisição e apropriação de certos códigos e práticas, tanto nos espaços familiares quanto nos espaços educacionais e profissionais, as versões encantadas produzidas na narrativa historiográfica levam a definir alguns projetos como sendo "os projetos de estreia", demarcando-os como início da trajetória de sucesso. Esse início suposto é visto como o nascimento de um "projeto original", teologicamente tomado como uma "semente", origem de soluções que seriam retrabalhadas ao longo de uma trajetória artisticamente coerente ${ }^{201}$.

Essas leituras, que constituem tradicionalmente 0 modelo das biografias oficiais, operam com a produção de discurso que estabelece um corte de referência para designar e nomear, a posteriori, a identidade da linguagem do arquiteto. Ao ser instituído como momento inaugural, determinado projeto, muitas vezes aquele consagrado em concurso ou

201 Cf. Sobre a crítica de Pierre Bourdieu à noção de "projeto original" de J.P. Sartre, cf. BOURDIEU, Pierre. L'illusion biographique. Actes de la recherche en Sciences Sociales, no62-63. p.69-72, jun, 1986. 
premiação, é visto como um ponto estanque de florescimento de uma proposta autoral, pela qual emergiriam de forma inovadora escolhas estéticas "genuínas", "ousadas", "inaugurais". Nas posteriores análises da premiação de Paulo Mendes da Rocha, o nexo lógico dessas narrativas foi enfatizar que as qualidades de robustez, simplicidade, engenhosidade, nitidez da solução estrutural combinada à beleza plástica ${ }^{202}$ seriam a expressão de princípios que os jovens arquitetos dominariam desde seus projetos de estreia, sendo celebrada como invenções extraordinárias.

Sobre a importância dos concursos nos quais participou em início de carreira, Paulo Mendes da Rocha também deixa indicado o quanto a conformação da comissão julgadora poderia contribuir para a eleição de projetos em familiaridade com as propostas estéticas do corpo de jurados:

"Imediatamente depois, abriram-se as inscrições para o concurso de remodelação do Clube Atlético Paulistano. Com Plínio Croce e também Rino Levi no júri. O que eu quero dizer ao citar esses arquitetos: que era uma coisa bem-feita. Bem, eu ganhei esse concurso. E construí aquele ginásio que, três anos depois, já pronto, ganhou o Grande Prêmio Internacional na IV Bienal de São Paulo, com Afonso Eduardo Reidy no júri. Eu menciono o júri porque essas coisas dependem disso, não é?"203.

Como visto, a passagem pelos rituais de competição dos concursos se apresentou como uma prática corrente, em que os ingressantes na profissão testavam diversas combinações de equipes entre amigos, sobretudo mantendo os vínculos estabelecidos durante a faculdade. Nutridos pelo entusiasmo dos recém-chegados, o empenho com que se dedicavam a essas rituais de concorrência poderiam parecer, à primeira vista, fruto de trabalho com pouco esforço ou de atitude descompromissada

202 Reproduzindo algumas expressões proferidas pelo júri, Pisani expõe as razões da escolha. Segundo o historiador, "a justificativa do júri, do qual fizeram parte arquitetos do porte de Affonso Eduardo Reidy, explica claramente a decisão de premiar o projeto: 'pela simplicidade da solução, engenhosidade da estrutura e beleza plástica', isto é, pela capacidade de conjugar em termos arquitetônicos uma corajosa solução estrutural, ainda que 'tudo seja exposto com uma crua verdade, que deriva de razões concretas e precisas, logicamente concatenadas [...] a obra não se reduz à uma estrutura, é uma obra de arquitetura". PISANI, Daniele. Paulo Mendes da Rocha: obra completa. São Paulo, Gustavo Gilli, 2013. p.22.

203 ROCHA, Paulo Mendes da. América, natureza e cidade. São Paulo: Estação Liberdade, 2012. p.30. 
e irresponsável, segundo o relato de um dos participantes, testemunho que amaina as pretensões dos que entram no jogo dispostos a fazer parte. A construção narrativa dos depoimentos o conduz a concluir, sob a dúvida da "coincidência", que a participação no concurso teria ajudado, no sentido mais amplo, a travar relações de amizade e parceria com arquitetos já estabelecidos e, de modo mais específico, garantir convites para postos na universidade. É assim que o arquiteto Pedro Paulo de Melo Saraiva, colega de Paulo Mendes da Rocha, ora parceiro, ora adversário em concursos, relembra suas relações com seus colegas de turma no Mackenzie, as participações nas competições e os embaraços que elas traziam à eleição do grupo de discípulos:

"Nós, eu e Paulo [Mendes da Rocha], com Alfredo Paesani havíamos vencido o Concurso da Assembleia Legislativa de Santa Catarina. Em seguida, separamo-nos para participar do Concurso do Paulistano. Na época, éramos um pouco irresponsáveis, não no sentido pejorativo, mas no fazer arquitetura. Explico-me - não teorizamos demais, partimos para fazer arquitetura com muito entusiasmo [...] Não sei se foi coincidência ou não, mas o fato é que alguns anos mais tarde, Artigas nos convidou para sermos seus assistentes na FAU-USP, para grande espanto da comunidade acadêmica. Dois arquitetos do Mackenzie para lecionar na FAU não era uma coisa aceitável de pronto. [...] Nesse caleidoscópio de circunstâncias tenho a lembrança e o pesar que nós provocávamos muitas 'saias justas' para o Artigas. Ele era quase sempre membro de júri em concursos que Paulo Mendes e eu participávamos. Foi assim no 5a Avenida, no Clube da Orla, Escola Aeronáutica de Pirassununga e Petrobrás Rio"204.

Como informa o relato, a proximidade estabelecida com o arquiteto Vilanova Artigas foi um impulsionador da escolha de seus novos assistentes, Paulo Mendes da Rocha, em 1961, e Pedro Paulo de Melo Saraiva, em 1962, para assumir um posto no ensino de projeto de edificações na Faculdade de Arquitetura e Urbanismo da Universidade de São Paulo. Ao reconstituir a

204 SARAIVA, Pedro Paulo de Melo. Depoimento sobre Vilanova Artigas. PÓS - Revista do Programa de Pós-Graduação em Arquitetura e Urbanismo. , no 18, dez, 2005. p.25. 
carreira profissional de Paulo Mendes da Rocha, o reconhecimento do arquiteto como continuador de Artigas não pode ser desvinculado do cargo que exerceu, entre 1961 e 1998, como professor nas disciplinas de projeto da FAU-USP, posição ocupada sob intercessão de Artigas. Ambos também foram aposentados compulsoriamente pelo regime militar em 1969, intervenção institucional que os afastou da universidade por cerca de 16 anos. Ser convidado por Artigas e ser afastado no mesmo momento favoreceu a constituição de uma relação que chegou a ser nomeada pelo historiador Yves Bruand como uma convivência de mestre e discípulo.

Escrito no final dos anos 1960, o trabalho de Yves Bruand, Arquitetura Contemporânea no Brasil, consolidou uma vertente analítica que definiu e difundiu os nomes dos arquitetos que seriam os legítimos seguidores da "Escola Paulista", concedendo à figura de Vilanova Artigas a posição de protagonista. A lógica de seleção da nova geração de arquitetos "pertencentes à Escola" regeu-se pela qualificação estética do edifício e pela valorização da consciência social dos arquitetos. Nessa chave, a arquitetura foi valorizada como um manifesto estético e ideológico. Uso do concreto aparente, ausência de acabamentos, geometrias pesadas, bloco único elevado, fechamento para o interior do edifício, fluidez entre espaços internos e externos e iluminação zenital seriam apontadas como formalizações de um posicionamento radical perante a sociedade. Esses foram alguns dos elementos plásticos com os quais se procurou conferir a unidade estilística e doutrinária ao grupo.

Tendo em vista que Artigas abriu escritório em 1938 e a geração de Paulo Mendes da Rocha, em média, estabeleceu escritórios na passagem da década de 1950 para a seguinte, esses arquitetos foram classificados em dois grupos geracionais. A diferença de quase 20 anos entre a formação e o ingresso profissional de Vilanova Artigas e as do grupo de Paulo Mendes da Rocha levou Bruand a demarcar o primeiro como "chef de file" de uma nova geração, e o grupo seguinte como sucessores. Joaquim Guedes e Sérgio Ferro, formados na USP, e Paulo Mendes da Rocha e Carlos Millan, formados no Mackenzie, foram instituídos como discípulos, que ora radicalizaram, ora reproduziram as linhas e formas do Artigas. Entre eles, foi Paulo Mendes da 
Rocha que mais esteve próximo ao mestre, atuando no Departamento de Projeto, e construiu uma carreira de prestígio. A consagração do arquiteto esteve associada a essa "passagem de bastão", produto do efeito de deslizamento de carisma de um mestre que dispunha da autoridade para validar a existência de epígono legítimo. As palavras de Yves Bruand flagram o encantamento construído em torno da figura de Artigas:

"[...] raros os estudantes que passaram por essa escola sem terem ficados seduzidos pelo espírito brilhante, pela solidez de pensamento, pelo rigor doutrinário acompanhado de grande compreensão humana nas relações pessoais daquele que muitos dentre eles começaram a considerar como seu verdadeiro mestre. [...] Artigas se tornou, no plano local, uma espécie de profeta ouvido atentamente pela geração que surgia"205.

Passaporte de ingresso na comunidade de pares, os concursos de arquitetura e as redes de relações estabelecidas na universidade se ofereceram como espaço legítimo de percepção, troca, disseminação e fixação de acordos em relação às soluções estéticas consideradas válidas e eficazes no campo. Vencer um concurso, ser chamado para assumir a posição de assistente, vincular-se formalmente a essa tradição e enquadrarse no modelo estético foram etapas do ritual de aceitação no grupo, permitindo a ocupação de posições-chave nas instituições e se consolidando em um percurso de acúmulo de prestígio.

\section{Encomenda pública e privada, arquitetura erudita e de mercado}

Após a vitória no concurso do edifício esportivo no Clube Paulistano, Paulo Mendes da Rocha e João Eduardo de Gennaro firmaram uma parceria profissional que durou entre 1958 e 1967, tempo em que puderam se 
dedicar a encomendas para o setor público e para clientes privados. Nesses quase dez anos de trabalho conjunto em escritório, os dois arquitetos projetaram cerca de 50 edifícios, dos quais 30 saíram do papel, isto é, foram efetivamente construídos. Além do ginásio de esporte, a dupla também ganhou o primeiro lugar no concurso para o projeto da sede social do Jockey Club de Goiás [Fig. 47 e 48], em Goiânia, 1962, somando ao portfólio mais um edifício no qual ratificaram uma linguagem moderna marcada pelo uso das grandes estruturas em concreto aparente.

O escritório também esteve encarregado de projetar alguns edifícios públicos sob patrocínio estatal, referentes às obras vinculadas ao plano de desenvolvimento implementado pelo governo do estado de São Paulo entre 1959 e 1962, na gestão de Carlos Alberto Carvalho Pinto. A dupla foi chamada para projetar três edifícios de uso escolar e um fórum de justiça [fig. 42 a 46], somando-se ao amplo conjunto de edifícios que o governo estadual encomendou a diversos arquitetos, vários deles organizados no IAB-SP.

O Plano de Ação de Carvalho Pinto, conhecido como Page, previa o planejamento e racionalidade das ações administrativas ${ }^{206}$, indicando como meta a organização dos serviços públicos por meio de equipamentos urbanos e da implantação de ampla infraestrutura de água e esgoto, rede de transporte rodoviário, ferroviário e aeroportuário e de abastecimento no interior do estado de São Paulo e na capital. O choque de modernização se daria com a dotação de infraestrutura e a construção de edifícios que seriam responsáveis pelo desenvolvimento do estado em áreas de segurança pública, transporte, saúde e educação. Vale destacar que o modelo de aliar planejamento e desenvolvimento urbano estava em pauta, na esfera federal, com a construção de Brasília, concentrando os esforços de modernização do país. Na seara dos arquitetos, o plano em São Paulo previa a construção de inúmeros edifícios tais como fóruns de justiça, escolas, faculdades, delegacias, centrais de abastecimento, cadeias, hospitais e postos de assistência médica ${ }^{207}$, grande filão de projetos que

206 ROMÃo, Wagner de Melo. Sociologia e política nos anos 1960: a experiência do Cesit. São Paulo: Associação Editorial Humanitas, 2006.

207 Sobre as ações estatais do início da década de 1960 em São Paulo e os arquitetos: ALVES, André 
despertaria interesse dos profissionais reunidos no departamento paulista do IAB.

Na área de educação, cultura e pesquisa, o Page promoveu a construção de escolas de ensino primário, secundário, técnico e superior. Em relação ao ensino universitário, a principal meta era a instalação definitiva da Universidade de São Paulo no campus do Butantã, bem como a criação de uma fundação para gerenciar os recursos financeiros à investigação científica, que se materializou na Fapesp (Fundação de Amparo à Pesquisa do Estado de São Paulo), projeto desenvolvido por arquiteto dessa geração, Jorge Wilheim, que imprimiu no edifício a marca do concreto aparente e da grande estrutura exposta. Como adverte Wagner Romão, o apoio de docentes pesquisadores da USP na definição das ações de planejamento desempenharia o caráter de legitimação técnico-científica do plano, garantindo a efetivação de uma imagem de competência administrativa e modernização da gestão pública, e também "cumpriria um papel importante no pacto político que estava sendo firmado entre Carvalho Pinto e setores da Universidade ${ }^{\prime 208}$. No entanto, acrescenta o autor, ainda que diversos uspianos tivessem sido chamados a elaborar o plano e seus nomes estivessem creditados na elaboração das diretrizes, essas participações tiveram um caráter pontual, pois o quadro de técnicos foi aproveitado da própria máquina administrativa estadual.

Três nomes de docentes uspianos das áreas de economia e engenharia são lembrados por Plínio de Arruda Sampaio, o coordenador do Page, como participantes das ações de planejamento: Ruy Leme, formado na Politécnica e diretor à época da Faculdade de Ciências Econômicas e Administrativas; Delfim Neto, também da Economia; e Paulo Menezes Mendes da Rocha, professor da Escola Politécnica, pai de Paulo Mendes da

Augusto de Almeida. Arquitetura escolar 1959-1962: o Page, o Ipesp e os arquitetos modernos paulistas. São Paulo, FAU-USP, 2008. (tese de doutorado). CORDIDO, Maria Tereza Regina Leme; BUZZAR, Miguel Antonio e SIMONI, Lúcia. "O plano de ação governo Carvalho Pinto (1959/1963) em São Paulo: moderação política e modernização. XIII Encontro da Associação Nacional de Pós-graduação em Planejamento Urbano e Regional. Florianópolis, 2009. CAMARGO, Mônica Junqueira. Conexões Brutalistas Paulistas. Anais de Congresso. X Seminário Docomomo, Curitiba, outubro, 2013.

208 ROMÃO, Wagner de Melo. Op. Cit. p.105. 
Rocha ${ }^{209}$. Via Universidade de São Paulo, os arquitetos da FAU não foram diretamente chamados a participar da concepção do planejamento do Plano de Ação, o que mostra a dificuldade da categoria para impor seus serviços profissionais na esfera pública e atuar como aliada ao estado.

Todavia, prevendo um aumento da demanda por novos edifícios, a entidade representativa dos arquitetos tentou se organizar para ampliar sua participação nos futuros projetos do plano. O empenho do IAB-SP em buscar articulação com a gestão estadual é revelador do papel que os arquitetos vislumbravam no final dos anos 1950 junto à esfera pública. O modelo, para os arquitetos paulistas, era a construção de Brasília. A legitimidade que os arquitetos Lúcio Costa e Oscar Niemeyer tiveram na concepção e no desenvolvimento da nova capital serviu como referência aos arquitetos paulistas, desejosos de ocupar centralidade no processo de construção das insígnias da modernidade. Representados por sua instituição corporativa, plano desenvolvimentista proposto pelo governador Carvalho Pinto poderia se abrir como uma oportunidade de valorização da profissão, efetivação de contratos e disseminação da linguagem moderna por todo o estado com edifícios públicos infraestruturais.

Os arquitetos paulistas, entre os quais, alguns deles ligados à Universidade de São Paulo, como Vilanova Artigas, estavam interessados em abarcar essas novas encomendas e vislumbravam maior participação da categoria nas esferas decisivas de poder. $O$ debate se dividia entre incentivar a contratação do arquiteto como funcionário público, para que ele atuasse dentro da máquina administrativa, ou valorizar os escritórios de arquitetura, para que fornecessem serviços personalizados ao governo estadual.

Como mostra André Augusto de Almeida Alves, que analisou as atas

209 Em entrevista de Plínio de Arruda Sampaio a Amélia Império Hamburguer, ele cita a estratégia para divulgação do Plano de Ação no interior do estado: "Fizemos, para vender a ideia do plano, centenas de reuniões, em cidades e em bairros. Levávamos o Paulo Mendes da Rocha, o pai do arquiteto, que era muito mais idoso do que nós, um politécnico uspiano daqueles peso-pesado. Ele adorava ir conosco e, muito mais velho do que nós, dava um prestígio danado, sabia mais que todo mundo ali. Ele nos ajudou muito. Esse nosso time era muito bom. 0 Delfim Neto era muito mocinho, o Rui Aidar da Silva Leme". HAMBURGUER, Amélia Império (org.). FAPESP 40 anos: abrindo fronteiras. São Paulo: Edusp, 2004. p.514. 
das reuniões da entidade do final dos anos 1950, os arquitetos debatiam a necessidade de se posicionar quanto a essa oportunidade de trabalho. Aprovaram com unanimidade em assembleia que o papel do IAB-SP seria de promover, junto ao governo estadual, a importância da contratação dos arquitetos nas obras de desenvolvimento do estado de São Paulo (ALVES, 2008). Os acordos que conseguiram negociar definiu que os arquitetos trabalhariam como contratados do governo estadual, ou seja, externos ao funcionalismo público, reforçando a prática profissional autonomizada em escritórios. Sem condições políticas para impor a centralidade no processo, o modelo proposto pelos arquitetos foi a partilha dos projetos entre escritórios privados, resolvendo a enorme demanda a partir da pulverização de inúmeros contratos entre diversos profissionais, que barganhariam seus trabalhos de forma individualizada.

Diferentemente do plano de Brasília, os arquitetos paulistas, no plano desenvolvimentista do estado de São Paulo, não tiveram condições de ocupar uma posição de protagonistas, tal como aconteceu com Lúcio Costa, a quem coube o papel de projetar o desenho urbano de Brasília, e a Oscar Niemeyer, que projetou todos os novos edifícios. A despeito do que aconteceu no planejamento da nova capital, os arquitetos reunidos em torno do IAB-SP não conseguiram se impor, ao mesmo tempo, como autoridade técnica e cultural, validando o saber prático como portadores da modernização. Para serem incluídos nesse projeto de larga escala, tiveram que negociar taticamente seus honorários e forma de trabalho, sendo obrigados a se sujeitar à diminuição da remuneração para efetivar a contratação. Tal postura refletia também uma concepção sobre a profissão: a atuação em escritórios individualizados seria um modo de garantir que os projetos fossem feitos respeitando as propostas autorais dos arquitetos, postura que se distanciava da proposição de uma arquitetura padronizada e serializada.

Desse modo, o início da década de 1960 representou para diversos escritórios paulistas e também para o escritório de Paulo Mendes da Rocha e João de Gennaro a possibilidade de realização de projetos públicos, vinculados ao plano de desenvolvimento do estado de São Paulo. Seus 
projetos distribuíam-se por diversas cidades, tanto na região metropolitana, como São Bernardo do Campo, quanto no interior do estado, como Campinas, São José dos Campos e Avaré.

Se, na escala estadual, a negociação entre os arquitetos e o poder público visava garantir a inclusão da categoria na massa de novos projetos, no plano de implementação do novo campus da Universidade de São de Paulo, os arquitetos e docentes da Faculdade de Arquitetura e Urbanismo também articulariam apoio para construir os futuros edifícios que abrigariam as faculdades na cidade universitária instalada no bairro do Butantã. Uma dessas propostas foi o "corredor das Ciências Humanas", projeto que previa a implantação de um eixo interligando os edifícios das Faculdades de História, Geografia, Filosofia, Ciências Sociais, Letras, Geologia, Arquitetura e Urbanismo e Matemática. A tarefa de projetar cada um desses edifícios foi distribuída entre vários professores da FAU que ocupavam as cadeiras de projeto: o Departamento de História e Geografia ficou nas mãos de Eduardo Corona; o prédio da Letras ficou com Carlos Millan; Geologia com Pedro Paulo de Mello Saraiva; Arquitetura e Urbanismo com Vilanova Artigas; e Matemática com Joaquim Guedes. Mendes da Rocha e De Gennaro ficaram encarregados de projetar o edifício dos cursos de Filosofia e Ciências Sociais [fig. 49]. Desse conjunto, apenas dois foram realizados conforme autoria dos arquitetos indicados, o edifício dos departamentos de História e Geografia e o edifício da Faculdade de Arquitetura e Urbanismo, obras da estética brutalista que exibem os fragmentos de um programa não realizado, plano que poderia representar a afirmação da arquitetura do concreto bruto na cidade universitária.

O processo de afastamento dos arquitetos das decisões do poder público e a marginalização em relação às instâncias de poder foram apontados por trabalhos que se dedicaram à restruturação da profissão do arquiteto nos anos 1960, tanto no Brasil como na França (MOULIN, 1972; DURAND, 1972). No final da década de 1950 e durante a década de 1960, a tentativa dos arquitetos de fazer valer a posse de um saber especializado e legitimá-lo como autoridade artística e cultural frente ao poder público pode ser vista em meio às lutas de institucionalização da profissão e defesa 
contra o rebaixamento que enfrentava.

José Carlos Durand (1972), em seu trabalho sobre a profissão, localiza na década de 1960 o processo de diversificação das perspectivas de atuação do arquiteto, no qual se alteraram as condições sociais das práticas. De um lado, houve a valorização do perfil dos arquitetos artistas, baseado nos pioneiros da arquitetura moderna, atuação que se associa ao carisma da criação. Esse profissional é o responsável por inventar formas e oferecer uma solução artística ao edifício, que se materializa no modelo do profissional liberal. De outro, grande parte dos arquitetos foi ocupar cargos em serviços técnicos, cuja exigência de aplicação de um saber especializado detém primazia sobre a sensibilidade estética, o que indicaria em plano mais amplo, um movimento de assalariamento. O modelo de êxito na carreira, no entanto, ficou associado à profissão liberal, de um arquiteto que trabalha em escritório próprio e defende sua autoria. Enquanto o polo mais heterônomo pode ser apontado pela atuação do arquiteto assalariado, que responde a uma aplicação técnica de seus conhecimentos, o polo mais autônomo e mais valorizado foi ocupado pela atuação em escritório, nos quais os valores de criação, inventividade e talento se constituíram como as referências principais à afirmação do métier.

Diante da instabilidade das demandas de grande porte e dos projetos a serviço das iniciativas governamentais, é possível verificar que o escritório de Mendes da Rocha e De Gennaro mesclou ao longo dos anos 1960 suas atividades com projetos menores, de organização interna de edifícios, como alguns layouts de escritório e residências unifamiliares, programa de maior demanda da equipe. No período em que os dois trabalharam juntos, entre 1958 e 1967, tiveram construídos 13 projetos residenciais. Depois de terminada a parceria, Paulo Mendes da Rocha também se dedicou à realização de projetos de moradias, o que mostra que esse programa privado respondia às demandas de certos grupos interessados em construir sua casa dentro dos parâmetros da arquitetura moderna.

Em 1967, uma bifurcação na carreira dos dois arquitetos é expressiva do horizonte de atuação no campo. De Gennaro recebeu convite para assumir a coordenação de projetos para o Banco Itaú e para a Duratex, 
empresas de propriedade de Olavo Setúbal. Com a grande quantidade de projetos, foi criada a Itauplan, transformando o setor de arquitetura e obras em empresa independente, onde se realizavam todas as etapas do projeto do edifício, incluindo estrutura, hidráulica, elétrica. A dinâmica de trabalho para o setor privado exigia projeto e construção dos edifícios, que incluiu implantação de indústrias e mais de 300 agências bancárias, com a coordenação de centenas de funcionários ${ }^{210}$.

O fim da parceria entre os dois arquitetos expõe modelos antagônicos de atuação profissional. Eles devem ser pensados tendo em vista a reconfiguração que enfrentava o ofício ao longo da década de 1960, quando o profissional da arquitetura passa a ampliar suas formas de atuação tanto no setor público quanto em empresas privadas. Essa restruturação pode ser vista, na análise de Durand, como responsável pelo drama do ofício, que se defronta com o imperativo de uma ocupação técnica, responsável por um saber especializado, colocando em xeque a identidade antes firmada, de um profissional criador, cujo prestígio estaria ligado à sensibilidade artística.

Como mostra o sociólogo, a restruturação do sistema produtivo desse período impacta a identidade da profissão, que se organizará, em diversos gradientes, a partir de dois polos opostos: de um lado, o arquiteto com escritório autoral, que produz trabalho intelectual, em escala artesanal, carregado de significado artístico e, de outro, o profissional adaptado à burocratização do mundo corporativo, cuja habilidade requirida se concentra no domínio técnico. As duas carreiras configuram modelos assentados em valores opostos: no primeiro, o que conta é prestígio e a notoriedade com sentido artístico; no segundo, a valorização é quantificada pelo retorno monetário e não simbólico.

A polarização entre arte e dinheiro, que como mostra Bourdieu é estrutural ao mercado de produção de bens simbólicos, expressa-se de modo específico no campo da produção arquitetônica. As classificações e o sistema de crenças que organizam a profissão do arquiteto mantêm uma distinção entre arquitetura de autor e arquitetura de mercado, uma produção classificada como erudita, sob a qual se reconhece um valor

210 SERAPIÃO, Fernando. Entrevista com João De Gennaro. Projeto Design, no 306, ago, 2005. 
cultural, e outra vista como desclassificada, ou seja, desconsiderada como objeto de admiração da cultura dominante. Estabelece-se um corte em arquitetura extraordinária, que é validada por um artífice que conquistou nome próprio, e a arquitetura ordinária, sem assinatura, sem certificação, sem valor de patrimônio cultural.

Ao longo de sua trajetória, Paulo Mendes da Rocha vai ocupar a posição que defende a arquitetura autêntica, aquela que se supõe liberada das constrições materiais e cuja definição está assentada em intenção estética e valor artístico. A afirmação dessa posição foi sustentada por uma prática estética pura e desinteressada associada a um discurso de politização da arquitetura. O arquiteto construiu uma oratória intelectualizada, por vezes cambiante, carregada de metáforas, até mesmo obscuro, que reivindica o papel político dos arquitetos. Esse discurso absorvente exerceu e ainda exerce fascínio sobre os colegas arquitetos e diversas gerações de estudantes.

A carreira na Universidade de São Paulo como docente, a partir do convite de Artigas, contribuiu para fixar seu lugar como legítimo sucessor do "profeta", que transferiu os capitais simbólicos e o carisma acumulado. Ainda na universidade, a aposentadoria compulsória de ambos favoreceu a disseminação da condição de perseguidos pelo poder ditatorial, posição institucional que alimentou o heroísmo de um contestador do sistema autoritário. A dupla atuação em uma instituição de ensino e em escritório particular contribuiu para a legitimidade de suas posições. O docente se alimentou da experiência prática do exercício profissional, reiterando a atenção aos detalhes construtivos, o apelo à técnica, a expressão do concreto aparente, o que concorreu para fixar a estética de uma arquitetura despojada e depurada como padrão formal dominante no sistema de ensino.

As pesadas formas estéticas do concreto, a rigidez do material e a austeridade do edifício passam a ser lidas como expressão plástica de uma condição de enfrentamento político, como materialização estética de um projeto interrompido, uma arquitetura que passa a ser apresentada "como forma de resistência" (PISANI, 2013 p.171). A manutenção de escritório de 
pequeno porte, restrito a encomendas exclusivas, possibilitou que ostentasse a realização de projetos residenciais sem concessão ao gosto dos comanditários. A relação com uma clientela cultivada, que dá vazão às suas proposições autorais, bem como o investimento em projetos para espaços culturais, por excelência um espaço de valorização da liberdade estética no qual se pode exercer uma suposta razão de ser da arquitetura, concorrerão para reafirmar a aura de um arquiteto-artista. Consagra-se, assim, como aquele que não se submete aos imperativos do mercado, o que lhe dá condições de se firmar como legítimo criador.

\section{Concreto bruto para o gosto refinado}

Os projetos residenciais de Paulo Mendes da Rocha se valeram da linguagem estética do concreto em sua forma bruta, material que serviu tanto à função estrutural quanto à de revestimento. Esse uso vigoroso do cimento aparente com as marcas das ripas de madeira foi tratado pelos historiadores nos termos de "poética do concreto"211. O emprego do concreto sem argamassa para nivelar a superfície confere à moradia um ar cinzento, áspero e rústico, resultando em aparência livre de acabamento, o que remete ao enxuto, despojado, sóbrio, despretensioso. É com esse apelo formal, combinação de singeleza e austeridade, que o arquiteto procurou encarnar seu partido criativo. No entanto, a finalidade estética desse efeito de aparente simplicidade exigia a aplicação de técnica apurada. As formas utilizadas para a moldagem in loco do concreto deixam impresso nas fachadas e paredes internas a textura do molde. Tal procedimento é feito com placas justapostas a fim de se obter um resultado artístico por meio do decalque das nervuras da madeira.

Além do aspecto bruto e bem-acabado, misto de sofisticação estética e imperfeição, essas moradias exibem no seu contraponto arquitetônico a

2110 arquiteto Guilherme Wisnik, um dos historiadores do grupo, fala em "poética do menos". 0 filósofo Eduardo Subirats encontra na obra de Paulo Mendes da Rocha uma "poética formal". 
ousadia estrutural: grandes blocos geométricos apoiados em delgados pontos de apoio, que faz com que a casa "pareça magicamente suspensa" (PISANI, 2013, p.91). Como se fossem residências térreas erguidas, essas propostas arrojadas procuraram dar leveza à robustez do concreto bruto. A elevação da casa sob pilotis exige uma solução estrutural com detalhados cálculos de engenharia e mão de obra especializada no processo construtivo. A ênfase na estrutura se evidencia pelo uso de pórticos, pilares e grandes vigas que permite liberar longos vãos e garantir o arrojo da composição. A circulação do edifício é feita por elementos destacados da estrutura, geralmente grandes rampas ou escadas escultóricas, com as quais procura-se demarcar uma plasticidade expressiva. [fig. 52]

Quanto ao espaço interno, o projeto da casa se propõe a oferecer um ambiente doméstico aberto, desobstruído, a partir da criação de salões amplos com pé-direito alto ou duplo, espaços que também incorporam áreas ajardinadas e iluminados por aberturas zenitais. Segundo comentários correntes de historiadores, essa proposta de fluidez espacial se apresentaria como uma crítica à compartimentação da moradia tradicional, programa residencial que subdivide a casa em inúmeros cômodos (BASTOS e ZEIN, 2010; ACAYABA, 2011; PISANI, 2013). O programa da casa está organizado em um volume único, fechado em si mesmo. Esse agenciamento do espaço que foi interpretado como negação do ambiente da cidade, contra a hostilidade da sociedade. A fachada voltada para a rua muitas vezes foi fechada por empenas cegas, ou seja, grandes paredes de concreto sem janelas. Para dentro do lote, os espaços foram faceados por contínuas janelas de vidro, desenhadas especialmente para adequar-se ao projeto. Para Yves Bruand, seguindo o modelo louvado por Artigas, a proposta de Mendes da Rocha foi carregada de intenções políticas que previa a imposição de "um ideal de vida comunitária impedindo qualquer morador dessa casa escapar dele" definido por "preocupações ambiciosas que visavam propor soluções revolucionárias que influíssem no modo de vida dos moradores" (BRUAND, 1999, p.315).

Essas ideias que combinam fechamento em relação ao ambiente externo, isolamento no lote e fluidez espacial no da residência foram 
propaladas como uma proposta política materializadora de uma utopia social. Segundo essa versão, a postura de contestação dos modelos tradicionais burgueses também se expressaria na proposta de projetar quartos em dimensões reduzidas e, em contraste, salões amplos, forçando a família a frequentar um espaço de convivência coletiva. Alegava-se que os espaços fragmentados das casas tradicionais seriam os promotores de isolamento e "alienação" dos membros da família. Para "estimular" o uso dos espaços coletivos, os quartos são desenhados como pequenas alcovas, células de tamanhos reduzidos que "compele (os moradores) a executar grande parte de suas atividades não entre quatro paredes de um cômodo, mas sob signo do compartilhamento do espaço e da colaboração" (PISANI, 2013, p. 91). Em alguns de seus projetos, Paulo Mendes da Rocha sugere a interligação dos espaços privados (quartos) às áreas de uso coletivo com a adoção de paredes que não chegam a encontrar no teto, formando um pequeno vão de cerca de três centímetros entre a vedação e a cobertura (PISANI, 2013). [fig. 53]

Em 1967, um dos primeiros ensaios a propor uma interpretação alargada sobre a obra de Paulo Mendes da Rocha procurou explicitar a preocupação do seu trabalho com a integridade da arquitetura. Escrito por Flávio Motta, docente de "História da arte e Estética" da FAU-USP e grande amigo, o artigo publicado na revista Acrópole destacou que "a ideia de espaço arejado, iluminado, leve, de fácil acesso, de eficiente circulação, impregnado de boa biologia, pode até representar um anteparo premonitório àqueles que deverão defrontar 0 'subdesenvolvimento machucado'". A consciência da condição periférica e o período de tensões sociais da década de 1960 implicaram no acento às questões políticas e ao potencial revolucionário dessas residências. Para Motta, Mendes da Rocha produz uma arquitetura que se vale da "simplicidade de meios" e que:

"chega até ser precária, não por avareza, nem por problemas pecaminosos, mas por um otimismo que confia na solidariedade humana e nos processos de transformação. Não pensa, um minuto sequer, em reter o avanço social em suas formas várias e também novas [...]. 0 espaço como projeto social, este sim, já ali vai se precisando melhor por um relacionamento do viver em 'meio a favela racionalizada', onde cada 
um aceita o convívio com os demais, sem muradas sólidas, mas dentro de novas e procuradas condições de respeito humano. É a proposta que pede resposta, porque é trabalho criador com sua implícita responsabilidade social" 212

O artigo se vale de uma linguagem lírica e engajada que impactou as posteriores interpretações e, conforme detectam alguns de seus comentadores $^{213}$, chegou a penetrar no vocabulário de Paulo Mendes da Rocha e balizar as autointerpretações que o arquiteto propõe de seu próprio trabalho. Nesse mesmo texto, explicita-se rapidamente a relação arquitetocliente, indicando que o ato de habitar essas moradias exige renúncia da parte do morador e ímpeto transformador da parte do arquiteto:

"Alguns conseguem apenas transferir um espaço pessoal para outro, como se mudassem de uma estrutura para outra, em termos arquitetocliente. Por vezes penosa, essa transferência, não raro, é pura identificação de 'status'. Propor novos critérios de relacionamento entre os homens é uma das relações cruciais do artista [...] Paulo Mendes da Rocha se atira contra esse imobilismo com ganas de artista, brasileiro, arquiteto que é. Ele ainda nos permite estas investidas na medida em que interessam à arquitetura, porque interessam à arte e ainda porque interessam ao homem." 214

Ao se referir às casas projetadas por Paulo Mendes da Rocha, os discursos oficiais procuraram minimizar a destinação individual das residências, abonando-as com interpretações que expurgassem a condição de uso restrito que a dimensão privada impunha ao edifício. Tais

212 MOTTA, F.lávio L. Paulo Mendes da Rocha. Acrópole, São Paulo, n. 343, p. 17-18, set 1967. p.17.

213 Segundo Catherine Otondo: "É reconhecida a proximidade intelectual e afetiva que existe entre Flavio Motta e Paulo Mendes da Rocha, iniciada nos tempos em que ambos eram professores da FAU/USP. Trata-se de uma relação de troca de ideias tão intensa que por vezes ao ler frases escritas pelo professor Flavio Motta, podemos achar que já ouvimos Paulo Mendes da Rocha dizer a mesma coisa. Ao longo do tempo, conceitos levantados por Motta foram incorporados ao modo de pensar de Paulo Mendes da Rocha, como forma de explicitar seu próprio trabalho". OTONDO, Catherine. Desenho e espaço: relações entre pensar e fazer na obra de Paulo Mendes da Rocha. São Paulo, FAU USP (tese de doutorado), 2013. p.26.

214 MOTTA, F. L. Paulo Mendes da Rocha. Acrópole, São Paulo, n. 343, p. 17-18, set 1967. p.18. 
proposições ressaltaram a dimensão formal do edifício, abordagem que leva os críticos a destacar e valorizar essas casas por seu caráter radical, polêmico, crítico ao status quo, sugerindo que elas se apresentam como um "manifesto" estético e político. Como se observa pela narrativa que se aplicou a essas residências, os recursos estéticos formais e de agenciamento dos espaços foram pensados como formas de imposição da postura autoral do arquiteto a ponto de interferir nas formas de morar de seus proprietários. Vilanova Artigas, tal como confiou a Bruand, considerava que a austeridade da obra de Mendes da Rocha exigiria um "ato de heroísmo" por parte de seus moradores.

Ao apontar a radicalidade sem concessões de Paulo Mendes da Rocha, Yves Bruand definiu o projeto residencial do arquiteto como expressão de "brutalidade virulenta" a provocar mal-estar tal como um presídio. Mas a despeito da severidade e da sensação de clausura dos espaços externos e internos, reiterou a grandiloquência produzida pelos jogos de iluminação zenital e pela movimentação dos volumes. Se, por um lado, essas moradias são acusadas de impingir desconforto, por outro, a disciplina do espaço rigoroso é valorizada como expressão de uma elevação moral:

"[...] tudo é maciço, duro, sem a menor concessão à atmosfera de repouso e encanto que em geral se procura num programa desse gênero: a casa está orientada de modo a apresentar na fachada uma enorme parede digna de uma prisão; até mesmo os elementos que poderiam aliviar o aspecto externo por um contraste qualquer, como a marquise brise-soleil da frente ocidental e a escada de serviço que forma um só corpo com ela, servem para reforçar a impressão dominante e é difícil não experimentar uma sensação de mal-estar perante uma solução dessas. O interior inspira-se nos mesmos princípios mas a brutalidade do cimento nu desta vez é atenuada por vigorosos jogos de espaço e de luz que conferem uma inegável monumentalidade ${ }^{\prime 215}$

As moradias projetadas para uma específica fração de classe, grupos 
com condições materiais e pretensões socais de investir em um habitat com valor artístico, foram dotadas de uma sobrecarga universalizante. Ora escusando o caráter limitado desses projetos isolados, ora valorizando-os como anúncio da totalidade da obra do arquiteto, essa dupla justificativa, inseparavelmente estética e ética, foi articulada a fim de garantir um lugar sagrado a essas residências, dotando-as do status de experimento artístico e objeto legítimo da cultura. Se conseguiram serem identificadas como casas sublimes, no sentido de elevação moral e estética, isso se deu justamente por sublimarem o requinte, o luxo e a ostentação.

O que se observa é que essas moradias responderam às solicitações e ambições de um conjunto de poucos encomendantes dispostos a sustentar tão radicalmente essas escolhas estéticas e estilos de vida nos modos de morar. Entre os anos 1955 e 2011, o escritório de Paulo Mendes da Rocha registrou a elaboração de 88 projetos de residências unifamiliares, sendo que 33 foram efetivamente construídos ${ }^{216}$. A reduzida efetivação é índice da dificuldade de espraiamento de um modelo inusual de moradia, tanto pelo custo que impõe, a se considerar a compra do terreno e a manutenção do edifício, quanto pela abnegação que exige, selecionando aqueles que têm disposições para se dedicar a um modelo de vida estetizada.

Um exame circunstanciado dos encomendantes que acessaram o escritório de Paulo Mendes da Rocha nesse período nos possibilita apontar o grupo reduzido para quem a estética do concreto bruto pode contribuir como representação simbólica e marca de distinção. Esse arco temporal de mais de cinco décadas permite apontar transformações em relação ao recrutamento da clientela. Cumpre informar que essas residências estão localizadas em terrenos espaçosos dos bairros de classe alta de São Paulo, muitos em loteamentos planejados pela Cia City, tais como Pacaembu, Morumbi, Butantã, Jardim Guedala ou em locais de vilegiatura de famílias de alta renda, como Ilhabela, Guarujá e Campos de Jordão. São casas unifamiliares que têm entre 300 a $800 \mathrm{~m}^{2}$ e apresentam como diferencial a estética do cimento bruto.

216 Esses números foram sistematizados a partir da publicação "Obra Completa: Paulo Mendes da Rocha" que organizou todos os projetos desenvolvidos pelo escritório de Paulo Mendes da Rocha entre 1954 e 2011. cf. PISANI, 2013. 
Com vistas a compor um panorama amplo da clientela do escritório ao longo de 50 anos, procurou-se selecionar alguns clientes representativos para análise do perfil social do grupo e detalhar informações sobre profissão, formação escolar, origem social, gostos estéticos e práticas culturais, propriedades individuais que permitem localizar as aquisições culturais e as posições ocupadas no espaço social. Entre esses destinatários, incluem-se o advogado José Brasiliense (1960) $)^{217}$, a descendente de uma família da oligarquia paulista Heloísa Alves de Lima e Motta (1961), o engenheiro civil e proprietário de construtora Mário Masetti (1967), o galerista e marchand de arte Fernando Millan (1970), o artista plástico Marcello Nitsche (1973), a galerista Eliana Finkelstein (1999), o galerista Eduardo Leme (2000) e o empreendedor cultural e proprietário de lojas de design assinado Hussein Jarouche (2011). Para localizar socialmente essa clientela e apontar as propriedades que os caracterizam foram utilizados materiais de diversos registros: autobiografia, biografia, entrevista semidiretiva e fontes em jornais e revistas de decoração e estilos de vida. A fim de compreender o gosto e as escolhas estéticas, procurou-se analisar os projetos residenciais, a decoração interna dos espaços e as obras de artes adquiridas, informações coletadas a partir das plantas arquitetônicas, das fotografias divulgadas nos livros de história da arquitetura, da visita às residências e dos relatos nas entrevistas.

Tomando por referência a atuação profissional desses destinatários, é possível afirmar que o universo de recrutamento é amplo: advogados, juiz, médico, economista, engenheiro civil, artistas plásticos, marchand, proprietários de galeria de arte e rede de lojas de design, publicitário, professores universitários (Direito, Medicina, Geologia), psicanalista, proprietários de empresa dos setores de tecelagem, produção agrícola e construção civil. De modo geral, trata-se de profissões liberais e artísticas, mas também há presença de grupos provenientes dos setores produtivos que movimentam alto capital econômico, como indústria de tecido e produtores de açúcar. Os dados de origem social possibilitam entrever algumas famílias de descendentes de primeira ou segunda geração

217 A data que está entre parênteses refere-se ao ano da encomenda da residência. 
(alemães, libaneses, italianos e alguns judeus) fixados em São Paulo e de descendentes de famílias das aristocracias tradicionais, apoiados por rendas e heranças provenientes de capital imobiliário. Para cada um, a aquisição da casa reveste-se de uma justificativa que incarna a tradição, as memórias de um passado honrado de descendentes da elite cafeeira ou o apelo ao novo, que se impõe como reinvenção de uma nova posição na hierarquia social.

Entre os anos 1960 e 1980, a contratação do arquiteto se ajustou às representações simbólicas de alguns descendentes de aristocracias em declínio, sendo que um declara que sua casa foi inspirada na arquitetura bandeirante paulista. Também serviu de emblema progressista a novos grupos ingressantes na hierarquia social (encomendantes não oriundos das frações sociais tradicionais, aqueles cuja ascensão social se deu sobretudo pela profissionalização adquirida no sistema universitário). Uma parcela desses destinatários são egressos dos cursos tradicionais de elite de artistas plásticos que constituíram trajetória de reconhecimento no mundo das artes.

Em relação ao perfil cultural desses encomendantes, as práticas de decoração permitem inferir os capitais via transmissão familiar e sistema escolar. Observando um conjunto mais amplo das moradias projetadas por Paulo Mendes da Rocha, as fotografias ${ }^{218}$ dos espaços internos deixam à mostra um conjunto de artefatos que nos ajudam a localizar as escolhas estéticas de seus moradores: tapeçarias rústicas, lembranças de viagens para o exterior, principalmente países exóticos, quadros abstratos, entre eles, pintores consagrados na arte moderna e contemporânea brasileira, esculturas em bronze e mármore, mistura de móveis antigos e modernos com assinatura, rede de descanso, colecionismo de peças de arte sacra, potes de cerâmicas e tachos de ferro, presença de livros de arte, artefatos com caráter etnográfico (plumas, cocares, instrumentos musicais) e vasos e jardins exuberantes com plantas tropicais. Tal como prevê as prescrições de gosto que insistiram sobre a transparência das relações sociais, pode-se notar que as amplas janelas envidraçadas não possuem cortinas.

218 As monografias sobre Paulo Mendes da Rocha incluem descrição técnica dos projetos residenciais e também apresentam fotografias do interior das moradias. Cf. ACAYABA, 2011 e PISANI, 2013. Algumas dessas fotografias foram aqui reproduzidas no caderno de imagens. 
Os signos da cultura legítima estão condensados em objetos como um piano de cauda que ocupa o átrio central, grandes telas da vanguarda moderna e do concretismo brasileiro e amplas salas com estante de livros. Como um espaço expositivo de museu, o pé-direito duplo exibe obras de arte que se misturam aos elementos funcionais e estilísticos da residência, como escada de concreto em forma curvilínea, passagens suspensas e fendas geométricas para a entrada de iluminação natural, formando um conjunto que se oferece à fruição estética.

Esse amplo repertório de móveis, enfeites, obras de arte e instrumentos musicais pode ser visto como capitais culturais objetificados. A presença conjunta desses elementos variados explicita a capacidade em reconhecer um valor cultural e de se apropriar esteticamente de diversos registros da cultura material, tais como o vernacular, pop, kitsch, moderno, antigo, clássico e vanguarda. Trata-se de um reportório alargado de referências culturais, antropológicas, paisagísticas, históricas e artísticas mobilizadas para compor uma concepção do mundo e expressar um estilo de viver.

As preferências em matéria de moradia e decoração que direcionaram um conjunto de clientes a habitar essas casas arrojadas podem ser atribuídas à emergência de frações de classe que se estabeleceram economicamente, próximas aos arquitetos e dotadas de elevados capitais que orientam diversas práticas de consumo cultural, visivelmente objetivados nos espaços de moradia. A partir da eleição de uma estética que renuncia ao excesso e que se define pela ausência de ornamentos e revestimentos, a aquisição de uma casa de vanguarda é significativa dos investimentos intelectuais e artísticos de frações de classe que desejam assegurar sua distinção em matéria de habitação, decoração e estilo de vida. Em termos de preferências estéticas, a rudeza do concreto em estado bruto é uma afirmação nítida da pretensão ao despojamento e à austeridade, que poderiam passar como signos de modéstia e discrição, em contraste com uma arquitetura de materiais nobres, vistosos, carregada de brilho e luxo. O rendimento simbólico dessa forma denegada de exibição, em que se recusa a ostentação e o supérfluo, é exposição de outra forma de 
refinamento, a inclinação estética dos proprietários, cujo acúmulo cultural e econômico permite materializar na habitação o gosto por uma arquitetura concisa e depurada.

Se à primeira vista a ausência de ornamentos, o ar despojado e a rudeza do concreto aparente apresentam-se como falta de polimento e privação material, o sentido social dessa preferência é exatamente o contrário. A opção por uma arquitetura austera e circunspecta se exprime como um expediente de requinte cultural, matriz de gosto cuja condição de produção é tributária de um olhar puro, desinteressado e estetizante. Os princípios de primazia dos jogos formais ficam explícitos nessa afirmação:

"O concreto tanto triunfa dentro como fora: paredes, vigas e laje da cobertura são deixados como saem da forma, de acordo com um uso, agora bem implantado que conjuga finalidades práticas, doutrina intelectual e expressão plástica. Essa linguagem rude que se destaca pela frieza calculada, não deixa nada ao acaso; ela não exclui nem os jogos delicados, como o reflexo da luz no anteparo vertical instalado na extremidade da pérgola que prolonga o telhado a sudeste, nem a elaboração de dispositivos engenhosos, como caixilhos dos peitorais; aquilo que pode parecer primitivo ou grosseiro na realidade é fruto de um raciocínio apurado, intencional, jamais fruto de uma pura intuição ou de uma atitude de indiferença qualquer." (BRUAND, 2009, p.315.)

A constituição desse olhar sensível faculta a transformação daquilo que é apresentado como "grosseiro" e "malfeito" em valor artístico. Trata-se de uma forma de distinção social que confere sentido estético àquilo que poderia ser visto, por um olhar desinformado e não cultivado, ou seja, sem as codificações do mundo da arte, como arquitetura pobre, desprovida de luxo, inacabada, desleixada, destituída de valor.

\section{Uma casa bandeirista para cliente "quatrocentona"}


Ainda que tenha servido a restritas frações ilustradas das elites dominantes, diferentes narrativas dos moradores dão sentido a essa escolha estética. Quando a casa é encomendada por família que se apresenta como "quatrocentona", o relato da encomenda vem como insígnia da condição dominante, distendida pela ideologia que sustenta a posição social do grupo. Esse é o caso da residência projetada no início dos anos 1960 para Heloísa Alves de Lima e Motta (1904-?), ilustre descendente da aristocracia paulista, sobrinha do presidente Washington Luís. Ela narrou suas memórias em Uma menina paulista.

Nesse livro autobiográfico, Heloísa Motta, aos 87 anos, localiza as nobres origens sociais, revê sua trajetória, conta os feitos da família, valoriza as façanhas de sua vida, os enlaces e investimentos pessoais e as estratégias para evitar a desclassificação social, quando ficou viúva muito jovem. A nova residência em estilo bandeirista, construída quando ela tinha cerca de 55 anos, aparece como investimento que marca a chegada das novas gerações, o convívio com os netos e a continuidade da família.

No desfecho, nas últimas páginas do livro, é intrigante e reveladora a menção que faz à encomenda ao arquiteto e amigo Paulo Mendes da Rocha, uma combinação inusitada de casa de praia moderna referenciada na tradição bandeirante. É assim que a demanda e a execução foram relatadas:

"Após algum tempo aluguei minha chácara em Santo Amaro e construí uma casa em Ilhabela, à beira-mar, uma cópia da Casa do Bandeirante, projeto do grande arquiteto Paulo Mendes da Rocha. É uma casa muito repousante. Durante a construção fui quase todos os fins de semana, eu mesma dirigindo, para fiscalizar a obra. Isto era necessário pois os caiçaras são muito tranquilos e precisava estar em cima, caso contrário jamais ficaria pronta; assim mesmo levou quase um ano para terminar"219

Ainda que assinada por um arquiteto declaradamente moderno, a

219 MOTTA, Heloísa Alves de Lima. Uma menina paulista. São Paulo, Totalidade Editora, 1992. p.98. 
nova residência é apresentada como "cópia da Casa Bandeirante", decisão estética que cede a uma representação do emblema mítico dos cafeicultores de São Paulo. A casa, produto da negociação entre o arquiteto e a cliente, vem como um acerto e um comprometimento entre as necessidades simbólicas do destinatário e as tentativas de autonomia do produtor. Ao declarar que pretendia uma "cópia", ou seja, uma reprodução de um modelo estabelecido, a cliente faz questão de advertir que é ela quem define o estilo da encomenda. Ela se coloca na condição de impor seu gosto ao arquiteto, desobedecendo ao estatuto de originalidade do criador. Emprestando o repertório de estilo colonial rústico dos "desbravadores paulistas", com a adoção de planta retangular e compacta e o telhado de águas, a representação estética escolhida para a nova moradia pretende se ajustar à glória de seus antepassados, exaltação que está presente ao longo de sua narrativa biográfica como um atributo de honra de classe.

Ao descrever seu empenho no acompanhamento da obra da residência, a autora encarna os ideais de bravura reverenciados por uma família de origem oligárquica. $O$ investimento em uma residência inspirada nos pioneiros de São Paulo vem como um apelo à renovação, como símbolo de "energia e coragem" de quem enfrenta, tal como se diz na apresentação da biografia, as "vicissitudes da vida de forma admirável" e "encarna as virtudes da mulher paulista". Ao reforçar a obstinada dedicação pessoal na construção e fiscalização da obra, o discurso de enaltecimento expõe a identidade com a figura do bandeirante, a ideologia do trabalho e o apelo ao desbravamento. Em acordo com as representações do grandiosismo do colonizador, o relato reitera a ideia de que é preciso controlar e disciplinar o trabalhador local para garantir a ocupação do novo território. Tal como nos faz ver Maria Helena Bueno Trigo, ali estão presentes os símbolos da construção mítica de uma representação dominante, tão frequentes nas formas de "apresentação de si" de famílias que reivindicam linearidade entre a história de São Paulo e a condição elevada de suas posições de classe $^{220}$.

220 Para a autora, "Foi , possivelmente, a cultura do café que, acentuando uma tendência já esboçada no ciclo do açúcar - de que certas culturas são privilégios de uma classe contribuiu para reforçar a identidade entre a figura do bandeirante e a do cafeicultor [...] Apesar dos dados de realidade, durante meio século as glórias do bandeirante foram repetidamente 
Na narrativa, a presença da nova edificação vem se somar ao relato de outras formas de moradia que perpassaram a árvore genealógica da família, como a fazenda de café no interior do estado de São Paulo, "com suas casas todas mobiliadas com peças, objetos, tapetes e cortinas vindos da Europa; roupas e enxovais [que] vinham de Paris" ou o palacete em que nasceu na capital paulista, no início do século $X X$, em que "todo material para a construção da casa de meu avô veio da França, inclusive as telhas chamadas de Marselha" (MOTTA, 1992, p.23). Em deferência aos bandeirantes, a casa de temporada completa uma narrativa virtuosa e heroica.

Com a passagem da casa-grande isolada em propriedade rural para 0 solar urbano em São Paulo e, em seguida, para a casa de veraneio bandeirante em Ilhabela, a autora alinhava um balanço celebrativo das diversas casas que habitou, desde o nascimento, cada qual o modelo legítimo de seu tempo. A casa funciona como uma espécie de aprendizado cultural autêntico, o qual permite que toda uma linhagem celebre conquistas, reconte tradições, fixe um estilo de vida e depure uma narrativa de prestígio e privilégio. As descrições encarnam todas as espécies de capitais herdados, os bens culturais e materiais de "fino gosto" que atravessam gerações e sentenciam a antiguidade na classe:

"Conservo até hoje os originais dessas encomendas extraordinárias. Os pedidos vinham em detalhe e de acordo com a planta da casa. Para cada sala, saleta, salão, quarto de dormir, sala de jogos, tudo era bem detalhado. Os respectivos móveis, cortinas, objetos de adorno de cada cômodo vinham especificados. As roupas de cama e de mesa, tudo em damasco de linho com as iniciais 'B.P.' bordadas. Louças de 'Limoges', cristais 'Baccarat', enfim todo o necessário para montar uma mansão nos mínimos detalhes de requinte" (MOTTA, 1992, p.25)

contadas e construiu-se uma epopeia do bandeirantismo. Essa versão transformou-se em mito vivo e perpetuou-se como imagem real do bandeirante [...] Portanto, até algum tempo atrás, a versão oficial era de que o paulista teria herdado traços de caráter como grandeza, coragem e independência desse glorioso bandeirante." Cf. TRIGO, Maria Helena Bueno. Os paulistas de quatrocentos anos: ser e parecer. São Paulo. Annablume, 2001. p.30-31. 
Nas descrições mobilizadas ao longo da biografia de Heloísa Motta, o espaço da casa incorpora as representações das frações dominantes: locais que cristalizam as ações notáveis de seus antepassados e do tempo vivido nos objetos, artefatos e estilo de decoração, na escolha do arquiteto e na sobreposição de sua preferência. O relato glorioso sobre a frequentação da casa de praia inclui a presença de personalidades do ambiente político, como o governador do estado e sua família, reuniões para organização de ações de caridade com apoio de outras famílias ilustres, encontros do clã onde se fixa a genealogia aristocrática, enfim, um conjunto de práticas sociais que reafirmam o envolvimento com as classes dirigentes, 0 comprometimento com causas sociais e a certificação dos títulos de nobreza:

"Certa vez, em um dos almoços em casa, ocorreu um fato que vale a pena relatar pela sua coincidência. Entre os convidados, sentaram-se à mesa nada menos que cinco tataranetos do Visconde de Rio Claro, meu bisavô. Pareciam as raízes de um tronco que inesperadamente se aglutinavam [...] todos oriundos do grande bandeirante paulista José Estanislau de Mello Oliveira, Visconde de Rio Claro"221.

A sequência temporal que orienta as mudanças espaciais da família também organiza uma narrativa sobre as estratégias de manutenção da dominação dos grupos abastados em se apropriando dos modelos legítimos de arquitetura. Nesse sentido, a apresentação de uma trajetória social sob forma literária permite sinalizar com precisão o pertencimento social da encomendante e as disposições sedimentadas nos modos de morar. Como as descrições em torno da casa ocupam um lugar essencial na narrativa de Heloísa Motta, o relato biográfico evidencia que os espaços de moradia são materializadores do acúmulo de capitais e das redes de sociabilidade, tornando-se símbolo declarado de riqueza cultural, material, social e de controle sobre a história 222 .

221 MOTTA, Heloísa Alves de Lima. op. cit. p.98.

222 A referência às casas da família perpassa toda a narrativa e está presente nas fotografias, nome dos capítulos e no relato detalhado dos cômodos, móveis, decoração etc. A casa serve como referência para a apresentação da origem familiar nobre e para as mudanças sociais da família. 


\section{Casa, fazenda e apartamento}

Se a contratação do arquiteto se ajustou às representações simbólicas de alguns pertencentes às aristocracias em declínio, também serviu de emblema a novos grupos ingressantes na hierarquia social, encomendantes não oriundos das frações sociais tradicionais, cuja ascensão social se deu sobretudo pela profissionalização adquirida no sistema universitário. Uma parcela desses destinatários são egressos das carreiras de elite, como Direito, Engenharia e Medicina, sobretudo da Universidade de São Paulo.

Há também artistas plásticos que constituíram uma trajetória notória no mundo das artes, como o italiano Gaetano Miani (1920-2009), muralista, escultor e professor de desenho nos cursos do Masp, que residiu em São Paulo até final dos anos 1960. [fig. 58] Foi em 1947, aos 27 anos, que Miani se mudou para o Brasil, mesma época em que chegaram outros italianos em busca de inserção nas esferas artísticas, como Pietro Bardi, que lhe ajudaria com a escrita de textos de apresentação da obra ${ }^{223}$. No Brasil, o vínculo aos círculos de sociabilidade de um grupo de conterrâneos the representou possibilidades de aceso aos espaços artísticos, sobretudo ligados ao Masp, onde exerceu atividades de ensino e conseguiu se fixar como artista e galerista de arte. No entanto, diferentemente deles, Miani

Por exemplo, para falar de sua origem, a narradora retorna ao "Império" para trazer o casamento do avô com filha dos ramos nobiliárquicos, enlace que aproximava famílias de barões de Piracicaba com proprietários do interior paulista. Ao localizar seus antepassados, é interessante notar que a casa ocupa uma imagem representativa dos novos arranjos sociais. $\mathrm{Na}$ narrativa, casar é retratado junto com a ideia de ocupar a casa vazia, dar continuidade à família e reiterar os laços de nobreza: "A Fazenda possuía uma belíssima casa com um terreiro de pedra na frente e uma grande senzala ao lado. Era rodeada por um jardim muito bem cuidado e um pomar abundante em frutas como laranja, limão, goiaba, manga, pitanga etc. Este pomar era banhado por um açude onde se pescavam lambaris. A casa era extremamente bem cuidada por uma velha escrava, Zafira; o jardim e o pomar ficavam a cargo do escravo Tião. Mas meu avô, muito sozinho e desolado com a perda da esposa, resolveu viajar e foi à Europa. Visitou muitos países e muito aprendeu com seu espírito aberto e inteligente. Ao regressar de viagem, chegando à fazenda, sentiu-se muito só e resolveu casar de novo, pois achava a casa sozinha e abandonada. Começou a indagar um pouco sobre moças casadoiras e soube que um parente seu, Visconde de Rio Claro, tinha duas filhas solteiras". Cf. MOTTA, Heloísa Alves de Lima. Op. Cit.. p. 18.

223 FAGIOLO DELL'ARCO, Maurizio. Gaetano Miani in search of the lost paradise. Museu de Arte de São Paulo, 1988. 
era proveniente de uma família de camponeses sicilianos pobres. A vinda para o Brasil se colocou como uma oportunidade para deixar o trabalho na agricultura e "exercer seu talento"224 de pintor. Logo em 1948, recebeu encomendas para afrescos na nave da Igreja Santa Cruz, em Campinas, e em seguida, em 1954, para a Bolsa do Café, no centro de São Paulo. Atuante no mercado de arte, além de pinturas sobre a flora brasileira, afrescos em igrejas e prédios institucionais, foi proprietário de duas casas de venda de obras de arte em São Paulo e Nova Iorque ${ }^{225}$.

Em 1962, momento de consolidação do sucesso artístico e financeiro, quando já lograva certo prestígio no meio artístico, encomendou a Paulo Mendes da Rocha a moradia para abrigar a família. Localizada no bairro de Santo Amaro, na época uma região bem pouco ocupada, a residência foi inscrita na história da arquitetura como um dos exemplares mais radicais do brutalismo paulista, devendo a Vilanova Artigas as principais referências estéticas:

"a espessa estrutura mural externa, aliada aos vastos vãos permitidos pelo sistema, deu aos arquitetos uma grande liberdade de arranjo, deu a possibilidade de jogar com o desencontro dos níveis, de unir num todo contínuo o conjunto dos cômodos e os meios de circulação de uso comum: salão, sala de jantar, escadas, corredor-balcão dos quartos. Aí pode ser novamente encontrada a ideia de Artigas, sua maneira de acentuar os elementos destinados à simples passagem tanto quanto nas salas de estar propriamente ditas, enfim, o vocabulário que ele preferia" (BRUAND, 1999, p.314.)

Gaetano Miani residiu nessa casa com a mulher e três filhos por apenas sete anos. O motivo da curta permanência decorreu da situação de instabilidade pós-golpe militar e o recrudescimento das perseguições políticas, situação de temor que os levou a tomar a decisão de mudança de país, em 1969, logo depois que Paulo Mendes da Rocha foi aposentado compulsoriamente na universidade.

224 "O italiano que gostava de pintar a natureza brasileira", Folha de S. Paulo, 17/09/2009.

225 AYALA, Walmir (org.). Dicionário brasileiro de artistas plásticos. Brasília: MEC, 1980. 
De outro modo, o contexto de atribulações políticas do período também vincou a relação do arquiteto com outros artistas, mas, nesse caso, a encomenda da residência registra a emergência de um grupo que transfigurou a realidade social em material estético. No começo dos anos 1970, em pleno momento de acirramento dos conflitos políticos, Paulo Mendes da Rocha desenhou a moradia para Marcello Nitsche (1942) e Carmela Gross (1946), dois artistas plásticos ingressantes na carreira profissional e docente. Ambos descendentes de famílias de imigrantes alemães estabelecidas em São Paulo no começo do século $X X$, o casal se conheceu no curso de Artes Plásticas da FAAP, instituição onde estudaram na segunda metade dos anos 1960. [fig. 54] Nesse momento de graduação e promissor início profissional, Nitsche e Gross estavam vinculados à geração de artistas que a partir de uma práxis estética questionava a ditadura militar e expressava em suas obras as lutas contra a repressão, postura que os aproximou dos círculos artísticos de esquerda ${ }^{226}$. A explicitação da violência do regime se fazia a partir da absorção da cultura de massa e da linguagem do pop art, programa estético que trazia de modo inventivo o questionamento de suportes e técnicas tradicionais, como pincel e tela. Experimentando novos materiais, linguagem e técnicas, propuseram a reinvenção das formas de expressão com a utilização de novas mídias, como história em quadrinhos, carimbo, xerocópia, vídeo e áudio. O estreitamento da amizade entre arquiteto e os dois artistas veio com a participação conjunta no projeto do pavilhão que Paulo Mendes da Rocha desenhou para representar o Brasil na Feira de Osaka, em 1970. Na equipe, além do arquiteto e o casal, estavam outros arquitetos do grupo paulista, entre eles, Ruy Ohtake, Julio Katinsky, Jorge Karon e o amigo Flávio Motta, que se ocupou da idealização da museografia do espaço e havia sido o professor de artes de Nitsche e Gross na faculdade.

É de 1972 a encomenda da casa localizada no Butantã, ano em que Carmela Gross inicia carreira docente na Escola de Comunicação e Artes da Universidade de São Paulo. Por ser uma casa projetada para artistas, a proposta do arquiteto procurou contemplar a integração do ateliê de

226 AMARAL, Aracy. Arte para que?: a preocupação social na arte brasileira (1930-1970). São Paulo, Nobel, 1987. 
trabalho à área social, solução espacial que foi interpretada como uma tentativa de tirar o artista do isolamento sagrado e integrá-lo à vida cotidiana (PISANI, 2013, p.145). Para além da questão formal do espaço ao qual foi atribuída a exigência de plena vivência artística, o que chama a atenção é o depoimento da filha mais velha do casal, Lua Nitsche, que nasceu no ano anterior ao término da construção. A narrativa sobre a casa reverbera o discurso propalado pelo grupo paulista, para os quais os modos de habitar incidem sobre o morador, transformando as relações sociais e induzindo novas formas de viver:

"Eu acho que começou quando começou a minha história também, porque eu nasci em 1972 e essa casa ficou pronta em 1973. E a maior parte do tempo a gente passou brincando e correndo na sala, no jardim, para fora. O contato entre o jardim e a casa é muito fácil, é muito generoso, não tem degrau, as portas ficam abertas, mesmo se estiver frio, se vocês estiver dentro, você fica olhando para fora. Você vive melhor, você vive de uma maneira que talvez você nem realize. Eu acho que eu realizei depois que eu virei arquiteta e consegui voltar na história e falar: eu vivi assim porque a casa também era assim. Mas mesmo que não seja arquiteto e que não realize, você tem uma vida que é espacialmente bem resolvida. Como se isso condicionasse seu jeito de se movimentar, o seu jeito de se organizar, o jeito de você descansar. Já levei várias ideias daqui, acabei de voltar de uma reunião de clientes que eu fiz uma casa e tem muita influência dessa casa: é uma salona também, com cozinha aberta, com uma estante do lado. Eu tenho outras casas que a gente fez na praia que são sempre muito abertas, os quartos são sempre ligados com a sala, geralmente uma boa integração com o lado de fora, vidros. Eu acho que a gente foi com certeza influenciado pela vivência na casa, eu, o Pedro e o João."227

Lua junto com os dois irmãos Pedro e João comandam um escritório de arquitetura, Nitsche Associados, aberto em 2001. Os dois mais velhos, formados na FAU, ocupam-se dos projetos de edifícios, principalmente

227 NITSCHE, Lua. "Moby Visita | Casas Paulistas | Casa Marcello Nitsche". Depoimento em vídeo. Moby, Revista Amarello, 2013. Disponível em: https://www.youtube.com/watch? v=EeaameuUiUg_Acesso: 26/08/2015. 
residenciais, e o irmão caçula, formado, tal como os pais, em Artes Plásticas na FAAP, voltou-se para as atividades de programação visual e design. Como explicita no depoimento, que serve de peça publicitária ao escritório, o ambiente que habitou the rendeu a incorporação de gestos, linguagem, noção de tempo e espaço, e percepção do mundo, em outros termos, é o abrigo modelador da existência artística da família. O esforço em acentuar a experiência vivida organiza a própria trajetória do clã artístico e dá sentido às escolhas profissionais que fizeram. Tudo se passa como se a casa, em termos físicos e arquitetônicos, fosse a responsável pelo destino social dos moradores. E, de fato, a se levar em conta as apostas no mercado de futuros, que os apresenta "como se transparências nas quais cresceram tivessem impregnado seus pensamentos arquitetônicos"228, a residência de Paulo Mendes da Rocha funciona como carimbo de legitimidade aos herdeiros da casa paulista.

Extravagante enquanto espaço de moradia, a adesão a essa forma de habitar exigiria inclinações apuradas em matéria de gosto no agenciamento dos espaços, expediente formal que se expressa também nas escolhas dos detalhes da decoração. Essas disposições seriam adquiridas nos sistemas formais de ensino, em viagens ao exterior, no contato repetitivo e duradouro com outras formas de arte, entre elas, música, teatro e cinema, na prática do colecionismo de arte moderna e contemporânea (de artistas consagrados, como Tarsila do Amaral, Anita Malfatti, Alfredo Volpi, Francisco Rebolo, Mário Gruber, Clóvis Graciano, Fúlvio Penacchi, Dario Mecatti, Geraldo Telles de Oliveira - GTO, Cláudio Tozzi etc) e peças de arte sacra

228 A reportagem em uma revista de arquitetura mostra os estágios que os arquitetos fizeram junto a reconhecidos arquitetos e os prêmios recebidos, o que mostra o início de uma trajetória de consagração. "Filhos de artistas plásticos e crescidos em uma casa projetada por Paulo Mendes da Rocha, os irmãos Lua Nitsche, 37, e Pedro Nitsche, 35, começaram a fazer seus projetos no ateliê de sua mãe, Carmela Gross, depois de formados na FAUUSP - em 1996 e em 2000, respectivamente. Ao mesmo tempo, Lua estagiou com Felipe Crescenti, Andre' Vainer e Guilherme Paoliello e Isay Weinfeld, e Pedro com Ruy Othake e no escritório Piratininga. Em 2001, formalizam a parceria no Nitsche Arquitetos Associados. Como se as transparências nas quais cresceram tivessem impregnado seus pensamentos arquitetônicos, os dois irmãos projetaram uma série de casas em que a compartimentação de espaços e a divisão interiorexterior é transgredida pelo vidro - como nas residências Barra do Sahy (2002) e a Iporanga, SP (2o prêmio no Jovens Arquitetos 2007) - as duas no litoral paulistano, além da casa em Atibaia, SP, vencedora na categoria projeto do Jovens Arquitetos em 2009. Também no Jovens Arquitetos de 2009, o escritório recebeu menção honrosa por seu edifício comercial João Moura, na rua paulistana de mesmo nome, cujas fundações começam agora a ser construídas. ". JUAÇABA, Carla. “Diretório 25 jovens arquitetos”. Revista AU, Edição 197, Agosto, 2010. 
barroca, e nos círculos de sociabilidade de elites culturais. De posse desses atributos, esses agentes ousaram definir seus gostos elegendo uma estética de vanguarda para a construção de suas casas, por excelência, locus da reprodução familiar e da formação do gosto e, com isso, expressão duradoura de um habitus cultivado, que atuará como elemento de coesão dos novos membros do grupo.

Um outro encomendante que bem explicita a rara conjunção de trunfos sociais, culturais e econômicos necessários para formar disposições cultas e aquisições distantes da necessidade é o engenheiro civil paulistano Mário Masetti (1922-2015). Filho dos italianos Aquiles Masetti e Adalgisa Médici Masetti, seus pais, que vieram para o Brasil no início do século $X X$, tornaram-se comerciantes e proprietários de várias joalherias, a Casa Masetti $^{229}$. A família de imigrantes prosperou rapidamente em país estrangeiro e foi morar em um palacete eclético na Alameda Campinas. Mário, o filho mais velho do casal, estudou quando adolescente no Colégio Dante Alighieri e em seguida cursou Engenharia Civil na Escola Politécnica na Universidade de São Paulo, onde se formou no final dos anos 1940. Logo em seguida, abriu com seu amigo de faculdade, João Marino, uma construtora de edifícios. Especializada no cálculo e na execução de concreto protendido, tecnologia nova no período, a empresa conseguiu se estabelecer tornando-se uma empreiteira de grande porte com a prestação de serviço em obras públicas nos anos 1960 e 1970, entre as quais, por exemplo, os edifícios escolares do governo do estado e as centrais telefônicas da companhia Telesp.

A formação escolar, o interesse por obras de arrojado cálculo estrutural, o sucesso financeiro da empresa e os vínculos de amizade com arquitetos da vanguarda paulista decantaram o gosto e orientaram os investimentos de Masetti na arquitetura do concreto aparente, dos grandes vãos e balanços. Não por acaso, esse cliente possuiu três residências desenhadas por Paulo Mendes da Rocha: uma casa em São Paulo, no bairro do Pacaembu, construída em 1968; a cobertura do edifício Jaraguá,

229 Dados coletados com Mário Masetti, filho do encomendante, nascido em 1958, sociólogo formado na Université de Nanterre e diretor de teatro. Morou cerca de dez anos na residência de Perdizes, projetada por Paulo Mendes da Rocha. Entrevista realizada 07/12/2015. 
empreendimento coletivo construído em 1984; e uma casa de campo na fazenda da família, em Cabreúva, construída em 1994. [fig. 62 a 70] O contato com Paulo Mendes da Rocha se deu por meio do arquiteto Carlos Millan, primo de segundo grau e grande amigo de Masetti. O grau de parentesco entre as mães, Adalgisa Masetti e Amadora Millan, levou à convivência. Mário Masetti estabeleceu amizade de infância com os três jovens Millan, que também cresciam em ambiente de incentivo e estímulo às disposições cultas: o mais velho, Roberto, tornou-se médico cirurgião plástico, Fernando, advogado, atuou como galerista e colecionador de obras de arte, proprietário da loja de antiquários Ouro-Preto e da Galeria Millan, e Carlos, o caçula, arquiteto.

A amizade de infância floresceu em parceria profissional. Carlos Millan projetou um edifício residencial para a construtora de Masetti, em 1959, na rua Arthur de Azevedo, prédio de quatro andares com oito apartamentos de cerca de $80 \mathrm{~m}^{2}$, construído pelo proprietário para investimento imobiliário. Millan também foi responsável por projetar a casa de veraneio da família Masetti, na praia da Lagoinha, em Ubatuba, em 1964, mesmo ano em que o arquiteto faleceu de forma trágica, em acidente de automóvel. A contratação de Paulo Mendes da Rocha veio por indicação do irmão de Millan, o galerista Fernando Millan, que também encomendou a Mendes da Rocha, em 1970, o projeto de sua residência no bairro do Morumbi. [fig. 56]

Como é recorrente em família que acumula diversos capitais, sobretudo culturais, a relação com a arquitetura moderna e o domínio das artes em geral perpassam várias escolhas em matéria de gosto, práticas de consumo cultural e aquisições. Logo após o casamento com Maju Masetti, no final dos anos 1940, Mário comprou um apartamento no Louveira, no terceiro andar, edifício projetado por Vilanova Artigas, e, novamente, nos anos 1970 adquiriu um segundo apartamento, no sexto andar, para abrigar o filho que voltava da graduação em Paris. Na residência do casal, a mobília que compôs a decoração do apartamento foi comprada na Branco \& Preto, da qual Carlos Millan era um dos proprietários e designer dos móveis. Masetti também teve contato pessoal com o pintor Alfredo Volpi, com quem fez aulas de pinturae adquiriu vários de seus quadros. Viagens pela Europa 
eram recorrentes, assim como pelo interior do país, com o sócio João Marino, que ocupou o cargo de diretor do Museu de Arte Sacra de São Paulo. Essas expedições contribuíram para arrematar uma coleção pessoal de peças religiosas do barroco brasileiro, como esculturas, santos, altares, móveis e pia batismal ${ }^{230}$.

Após a mudança do edifício Louveira, a primeira encomenda de Mário Masetti foi, em 1968, uma casa de cerca de $650 \mathrm{~m}^{2}$ construída por sua empresa em terreno de grande declive no bairro do Pacaembu, na rua Manoel Maria Tourinho [fig. 65]. A residência, feita para o casal e seus três filhos, na época ainda crianças, foi organizada com quatro suítes, sala de estar, sala de jantar, escritório com biblioteca, cozinha - todos esses espaços concentrados no mesmo andar, um piso elevado sob quatro pilotis exibindo grande arrojo estrutural. No térreo, encontra-se a área de lazer, com piscina, um grande pátio, jardins e garagem para automóveis. No subsolo, aproveitando o declive do terreno e separada do corpo principal, foi localizada a área de serviço, com dois dormitórios de empregada com banheiro. Essa residência foi amplamente publicada nos livros de história de arquitetura, que a notabilizaram como sendo um dos projetos residenciais mais representativos da trajetória de Paulo Mendes da Rocha (BASTOS e ZEIN, 2010; ACAYABA, 2011; PISANI, 2013).

Quando os filhos cresceram e se casaram, o casal mudou para a cobertura localizada no edifício Jaraguá, projetado por Paulo Mendes da Rocha, em 1984 [fig. 62 a 64]. Esse empreendimento fez parte de um projeto orquestrado por amigos que escolheram o terreno, contrataram o arquiteto, incorporaram e construíram um edifício com oito apartamentos, um por andar, reunindo pessoas de um mesmo círculo de sociabilidade, entre eles um renomado médico psicanalista, um arquiteto e outro construtor, interessados em investir no mercado imobiliário e ao mesmo tempo garantir a execução de um espaço de moradia que os agrupasse.

230 "Com seu acervo ampliado ao longo de oito anos pelo engenheiro e colecionador de arte João Marino, morte em janeiro último, o museu passou em fevereiro à batuta de sua filha. Ela é Mariangela Marino, nome indicado pela Secretaria de Estado da Cultura e referendada pela Cúria Metropolitana, proprietária de parte do acervo e do prédio". Folha de S. Paulo, Ilustrada, 09 de junho de 1997. 
A concentração de diversas formas de capitais acumulados em sequentes gerações e transmitidas sobretudo no espaço doméstico ratifica a constituição de uma nobreza cultural. Para os membros da família, esses diversos investimentos na aquisição dos trunfos culturais foram assimilados em todos os estados: incorporados nos modos de ser, maneiras de falar e na própria relação com a arte; materializados em objetos, obras de arte e propriedades imobiliárias; certificados por diplomas e títulos ${ }^{231}$. A entrevista com o filho de engenheiro, Mário Masetti Filho, escritor, diretor de teatro, dramaturgo e produtor de cinema, mostra a persistência dos valores e das aquisições herdados em família, tanto em patrimônio material, ou seja, os bens físicos transmitidos, quanto em patrimônio cultural, o que definiu uma relação específica com a arte, um usufruto espiritual. A precocidade na aquisição da cultura legítima é capital de origem que incide de forma inconsciente e perene na formação dos membros da família e orienta tacitamente as maneiras, aprendizagens, condutas, conformando uma relação de excelência com a cultura e a arte ${ }^{232}$. Vale destacar que as outras duas irmãs formaram-se em Artes Plásticas, nos anos 1970, sendo que a mais velha não atuou na profissão pois desde cedo se ocupou da administração dos imóveis da família e a mais nova conduziu sua formação para a área de marketing cultural.

Estimulado pelos pais a adentrar no universo da cultura e a se interessar pelo teatro, Mário Filho foi estudar Sociologia com ênfase em Cinema em Paris, na Université de Nanterre, nos anos 1970, momento de acirramento da censura militar, depois de ter entrado ainda com 16 anos em contato com o grupo do diretor Augusto Boal, no qual participou da montagem de peças, entre elas, Arena conta Zumbi. De volta ao Brasil, continuou a carreira no meio artístico e cultural paulistano, onde atua na

231 Cf. BOURDIEU, Pierre. Escritos de Educação / Maria Alice e Afrânio Catani (org.). Petrópolis, RJ: Vozes, 1999, pp. 71-79. Publicado originalmente em: Bourdieu, Pierre, "Les trois états du capital culturel", in Actes de la recherche en sciences sociales, Paris, n. 30, novembro de 1979, p. 3-6.

232 Nas palavras de Bourdieu: “[...] o capital cultural incorporado das gerações anteriores funciona como uma espécie de avanço (no duplo sentido de vantagem inicial e de crédito ou usufruto antecipado) que, garantindo-lhe de imediato o exemplo da cultura realizada em modelos familiares, permite que o recém-chegado comece, desde a origem, ou seja, da maneira mais inconsciente e insensível, a aquisição dos elementos fundamentais da cultura legitima". Cf. BOURDIEU, Pierre. A distinção: crítica social do julgamento. São Paulo, Edusp, Porto Alegre, Zouk, 2007. p.70. 
área do teatro e cinema. Além do extenso espólio herdado, o patrimônio adquirido se manifesta na ampla biblioteca que percorre toda a sua residência, na prática do colecionismo de obras de arte de vários artistas brasileiros, na aquisição de poltronas e estantes de designers reconhecidos no panorama nacional, em suma, no conjunto de práticas em afinidade com seus investimentos culturais incorporados desde infância. A imersão precoce no universo de práticas e objetos cultos se traduziu, com maior força, na dedicação à cultura e, em termos simbólicos, no "amor pela arte", essa forma específica de herança, síntese profunda da conversão de todos os investimentos familiares, que o impulsionou a se doar à criação artística e à plena participação no mercado cultural do país, atuando como legítimo filho da cultura.

\section{Recentes reconfigurações no recrutamento da clientela}

Em busca de caracterizar o perfil atual da clientela de Paulo Mendes da Rocha, procurou-se analisar os encomendantes de projetos recentes. 0 arco temporal de mais de 50 anos de atuação do arquiteto permite sugerir que as novas encomendas passam a servir a grupos cuja exibição da marca distintiva dessa arquitetura de valor artístico atuaria como índice efetivo de reconhecimento simbólico para os proprietários, sobretudo jovens endinheirados que se valem da notoriedade construída em torno do arquiteto.

Nesse período, vale sinalizar que arquiteto pavimentou uma trajetória de renome nacional e internacional, mesmo momento em que se observa a multiplicação de projetos para espaços ligados à arte, tais como museus e centros culturais. Entre eles, cita-se a reforma da Pinacoteca do Estado de São Paulo (1993), o Museu Brasileiro de Escultura (1995), o Centro Cultural Fiesp (1996), museu e teatro Cais das Artes, em Vitória (2007), a Praça de Museus da USP (2000 e 2011), o Museu dos Coches (2015), em Lisboa, projetos no Brasil e no exterior que contribuem para fixar presença na 
esfera artística. A consagração amealhada pelo arquiteto culminou no Pritzker, prêmio de grande peso mundial. Essa certificação tem servido de chamariz a interessados em rentabilizar com o prestígio do arquiteto em investimentos pessoais e profissionais.

Se as encomendas antes estavam destinadas a grupos próximos do espaço social do arquiteto, sobretudo profissionais formados em cursos de elite, acessíveis pelas relações familiares e círculos de amizade politizados, as novas encomendas são destinadas a frações sociais mais amplas, sobretudo jovens empreendedores em áreas culturais, como arte, moda, design e publicidade. Para esses novos proprietários engajados nas áreas de gestão da cultura, a marca distintiva de uma arquitetura com valor artístico e classificada como patrimônio cultural parece oferecer vantagem simbólica. Com isso, é possível lançar a hipótese que, nos últimos anos, a notoriedade amealhada pelo arquiteto tem servido de chamariz para sua nova clientela.

Para dois jovens galeristas que começaram a atuar no mercado de arte contemporânea nos anos 2000, o arquiteto forneceu tanto a assinatura do projeto de moradia quanto dos edifícios que abrigam os espaços expositivos, uma espécie de "cubo-branco" transgredido, que permite tanto o espaço hermético do interior quanto a abertura, no exterior, para intervenções que dialogam com a cidade. Eles são Eduardo Leme, da Galeria Leme, e Eliana Finkelstein, da Galeria Vermelho, que ingressaram no mercado da arte com a proposição de uma agenda de internacionalização para arte contemporânea brasileira. [fig. 73 a 75]

Formada em Relações Públicas na FIAM-FAAM, uma instituição pouco prestigiada, Eliana Finkelstein (1966-) trabalhou nos anos 1990, na área de marketing em grandes agências de publicidade e, em 2000, colaborou com a organização da Bienal de São Paulo, experiência que gabaritou para abrir, em 2002, com Eduardo Brandão, uma promissora galeria, que passou a representar renomados artistas como Dora Longo Bahia, Lia Chaia, Chelpa Ferro, Iván Argote, Carmela Gross, Detanico Lain e Rosângela Rennó. Integrante de uma equipe de empreendedores culturais que promovem a ideia de "economia criativa", as atividades que Finkelstein desenvolve procuram alargar os negócios no mundo da arte, promovendo investimentos 
"híbridos" como eventos na área de edição de livros e produção de vídeos, tal como o Projeto Tijuana e a abertura de uma sala de cinema ${ }^{233}$. Já assumiu o cargo de presidente da Associação Brasileira de Arte Contemporânea (Abat), tendo como principal bandeira a internacionalização dos artistas brasileiros, e também apoia diversos projetos culturais, como 0 do centro cultural Casa do Povo, instituto da comunidade israelita paulistana que promove atividades na área de edição de livros, de arte e também do teatro. O sócio, Eduardo Brandão, é fotógrafo, professor da FAAP, e também trabalhou como editor de fotografia da Revista da Folha. A posição de docente na instituição facilita a eleição de alunos que serão incorporados ao portfólio da galeria e apresentados como "novos talentos".

A matéria do caderno "Ilustrada", da Folha de S.Paulo, ao divulgar a abertura da Vermelho em 2002, assim anunciou o novo empreendimento:

"Tinta fresca no circuito das artes plásticas brasileiras. São Paulo ganha a partir de hoje, um novo e ambicioso espaço dedicado à produção artística contemporânea. Galeria Vermelho é seu nome. Um vermelho que não se vê nas paredes brancas projetadas pelo arquiteto maiúsculo Paulo Mendes da Rocha. Vermelho é a cor das bandeiras soviética ou nazista, de grandes e radicais transformações. É a mudança que propõe o espaço de Eduardo Brandão e Eliana Finkelstein [...] Vermelho será pensada como uma galeria dupla-face, como um casaco que se pode vestir do avesso. Espécie de cubo branco, a galeria permite que se exponha nos dois andares do seu interior, ou na sua generosa superfície externa"234.

A contratação dos serviços de Paulo Mendes da Rocha, no final dos anos 1990, foi concomitante ao momento em que Eliana Finkelstein converteu a experiência no mercado de arte para atuar como galerista. Casada com o administrador de empresas Candido Vinícius Boicaiúva Barnsley Pessoa, Eliana havia encomendado ao arquiteto a reforma da casa

233 RAHE, Nina. "Galeria Vermelho inaugura sala de cinema focando videoarte". Folha de S.Paulo, $14 / 02 / 2016$.

234 MACHADO, Cassiano Elek. "Nova galeria vira casa da fotografia-arte". Folha de S.Paulo, $17 / 05 / 2002$. 
em 1999, prevendo grande intervenção no edifício já existente, propriedade da família. Tanto no espaço da galeria quanto no espaço da residência, o arquiteto seria chamado para transformar um edifício antigo, tradicional, ordinário, em uma nova obra arquitetônica, chancelada por uma arquitetura depurada e icônica.

Ao comentar as intervenções que Mendes da Rocha fez na residência do casal, Daniele Pisani procurou situá-las no percurso inventivo do arquiteto. Em um primeiro momento insistiu nas continuidades em relação à concepção do espaço, ressaltando a marca do arquiteto de transformar a natureza, em que se destaca principalmente a reconstrução da topografia, com a proposição de um novo arranjo que aplainou o terreno íngreme. Em relação ao edifício, deixou indicado que o tom "virulento" das casas dos anos 1960 e 1970 perdeu o ímpeto violento. Restou apenas um tom "sóbrio e discreto", mas não mais radical. Na interpretação da historiadora, os "contrastes dramáticos de outrora" amainaram-se em resposta ao gosto dos novos moradores, possivelmente clientes que, adeptos "às novas formas de vida", seriam menos propensos a ratificar a arquitetura pesada e radical do concreto bruto.

Em relação à trajetória de Paulo Mendes da Rocha, diante desse abrandamento estético que a historiografia identificou, é interessante notar que as análises passam a construir interpretações que focam na qualidade técnico-construtiva do profissional, que se volta para a resolução de problemas de iluminação, estrutura, aberturas e agenciamento dos cômodos. A análise dá destaque ao apuro técnico, e o toque transcendente é dado pela insistência na transformação da natureza, que passa a ser registrada pela ideia de "engenhosidade do homem":

"Em 1999, é contratado por Cândido Pessoa e Eliana Finkelstein para transformar em residência do casal uma moradia medíocre e sem graça, de estilo vagamente neocolonial, localizada em Perdizes. Da construção preexistente, o arquiteto mantém a volumetria e o sistema estrutural, alterando completamente a distribuição dos cômodos e a aparência. A principal decisão do projeto é construir, ao longo do perímetro do lote, um percurso em nível [...] é a comprovação do sucesso da construção de um terreno que antes não existia, ou seja, o produto da 'engenhosidade' 
do homem na reconfiguração da natureza [...] A casa se permite falar em um tom sóbrio e discreto. Já não há espaço para os contrastes dramáticos de outrora; destacam-se o perfeito controle da luz natural, a distribuição inteligente da abertura, o equivalente bem equilibrado entre as 'sugestões de novas formas de vida' e o respeito às exigências dos moradores" (PISANI, 2013, p.315, grifos meus).

Já o galerista Eduardo Leme optou por adquirir uma residência já existente de Paulo Mendes da Rocha, que havia sido construída, no Morumbi, em 1970 para o conhecido galerista e marchand de arte Fernando Millan. Contemporânea ao projeto do Pavilhão de Osaka, a "Casa Millan", tal como nomeada pela historiografia da arquitetura, foi anunciada como o modelo exemplar da linguagem estética do arquiteto. "Introspectiva", "arredia", "complexa", "introvertida" foram os adjetivos que a crítica utilizou para caracterizar a casa, relacionando-a com o recrudescimento da repressão militar. Em 2000, a casa foi comprada por Eduardo Leme, que contratou os serviços de Paulo Mendes da Rocha para restaurá-la. A grande residência permitiria abrigar a

"[...] a vasta coleção de arte, o mobiliário rico em design, os gostos e as pequenas manias de Eduardo. São lembranças de viagens, obras de arte e instalações de nomes como Dora Bahia, Aurélio Flores, Arthur Casas, entre outros. 'Para quem gosta de arquitetura como eu, a casa já é, por si, uma obra de arte', acrescenta"235.

O principal índice de que se trata de uma moradia para colecionadores de arte é o pátio central da moradia, núcleo da residência, que exibe um amplo salão com pé-direito duplo atravessado por uma passarela. Com todas as paredes em concreto, o ambiente hermético funciona como um museu, a expor parte do acervo do novo proprietário. A mesma casa antes propriedade de um notório galerista brasileiro, 30 anos

235 "Conheça a casa do galerista Eduardo Leme". Disponível em: http://bamboonet.com.br/posts/conheca-a-casa-do-galerista-eduardo-leme Consulta em: 08/01/2016. 
depois, passa a ser habitada por um novo empreendedor do mundo das artes. Tal transferência de propriedade material e simbólica parece evidenciar uma operação de deslizamento de credenciais estéticas.

Economista de formação e então investidor do mercado financeiro, Eduardo Leme (1964-) iniciou sua coleção de obras de arte quando tinha 20 anos, por conta da influência de amigos e parentes atuantes na cena de arte contemporânea de São Paulo, com os quais adquiriu um "conhecimento empírico e informal"236. A frequentação rotineira de galerias e a participação de atividades no Museu de Arte Moderna ampliaram o interesse no mercado, e o que antes era um hobby, transformou-se em atividade profissional. Em 2004, aos 40 anos, abriu a Galeria Leme, "uma necessidade de tornar física toda essa experiência de vida e de convívio que me é muito rica". Ao explicar a encomenda do projeto, Eduardo Leme deixa explícitas as razões que o levou a chamar o arquiteto de sua predileção, autor de verdadeiras "obras de arte", em que acentua a experiência na concepção de espaços museográficos. O depoimento também explicita os investimentos que vêm sendo feitos para a internacionalização da galeria, com a ampliação do portfólio com artistas estrangeiros e a participação em feiras internacionais:

"Optei por fazer uma edificação do zero e construir um espaço físico planejado. Diferentemente de várias galerias, que se adaptaram às circunstâncias de um imóvel já existente, a Leme foi planejada pelo Paulo Mendes da Rocha. Além de admirá-lo muito, o Paulo é um arquiteto que já havia feito projetos e reformas em museus; me identifico muito com seu conceito de espaço e sabia que ele teria plenas condições de montar uma estrutura adequada. Abri a galeria no final de 2004 e iniciei com apenas seis artistas representados, sendo dois ingleses e quatro brasileiros. Hoje, contamos com um time de quase 30. Pela própria vivência no exterior, acabei trazendo muitos estrangeiros para cá. Parei de focar tão somente a arte brasileira, para enxergar uma arte global. Obviamente, cada país tem algumas nuances e características, mas, hoje em dia, isso está cada vez mais diluído e

236 Depoimento de Eduardo Leme. Disponível em: http://brasileiros.com.br/2011/03/eduardoleme/ Consulta em: 08/01/2016. 
globalizado." 237

A Galeria Leme, localizada no bairro do Butantã, assim como a reforma da Galeria Vermelho, no bairro de Higienópolis, exibem nos seus amplos espaços a marca registrada do arquiteto. [fig. 73] Abrigadas por uma arquitetura reconhecidamente de vanguarda, esses espaços são celebrados como obras de arte. Essa arquitetura não é apenas invólucro para os trabalhos dos artistas. Ela se torna suporte para a intervenção de artistas nacionais e estrangeiros, que, a convite de seus curadores, elaboram instalações específicas para o local, respondendo aquilo que é chamado na classificação do mundo da arte de "site specific". A galeria Leme, por exemplo, tem abrigado uma série de exposições em seus espaços externos, no vão entre os dois blocos de concreto dos salões de exposição, originalmente pensado como garagem de automóveis. O arquiteto português e jovem curador da Leme, Bruno de Almeida ${ }^{238}$, organizador da mostra "Situ" reconhece que a arquitetura de Mendes da Rocha possibilita ser explorada como elemento da paisagem artística ${ }^{239}$. Nessas obras, o espaço é convocado a interagir com a própria obra de arte exposta e o artista "dialoga com a arquitetura". Para a galeria, o espaço físico foi concebido como aposta estética que possibilita dinamizar os artistas e obras representadas pela galeria.

O investimento na aquisição de um espaço físico de apelo artístico se soma a outras estratégias de visibilidade efetivadas por galerias emergentes. Criadas na década de 2000, essa geração de jovens galeristas

237 Depoimento de Eduardo Leme. Disponível em: http://brasileiros.com.br/2011/03/eduardoleme/ Consulta em: 08/01/2016.

238 Visita à Galeria Leme e conversa com organizador da exposição realizada no dia 08/12/2015.

239 Interessante notar que outras galerias têm ocupado edifícios de arquitetos consagrados e têm se valido desses espaços diferenciados para convidar artistas. Uma delas é a Galeria Luciana Brito. A proprietária recentemente adquiriu e restaurou uma casa classificada como patrimônio cultural pelo departamento municipal de São Paulo com vistas a transformá-la na sede da galeria. Originalmente projetada pelo arquiteto Rino Levi para uso residencial, a casa no bairro dos Jardins foi restaurada seguindo padrões rigorosos, inclusive com a manutenção do jardim original, projetado por Burle Marx. Para a abertura da casa, uma exposição intitulada "Residência Moderna" convidou artistas consagrados para "criarem obras e intervenções que dialoguem com ela". MARINHO, Mariana. "Galeria Luciana Brito muda para casa nos Jardins projetada por Rino Levi". Folha de S. Paulo, 27/03/2016. 
precisou ampliar o leque de ações para serem portadoras de crédito no mercado de arte nacional e internacional. Como mostra Ana Letícia Fialho, tanto a Galeria Vermelho quanto a Leme têm conduzido suas ações visando à fixação no mercado nacional e à inserção internacional, seja selecionando artistas estrangeiros para entrar no portfólio, seja representando artistas nacionais por meio da participação em diversas feiras estrangeiras, seja investindo em viagens para contatar colecionadores na Europa e na América do Norte ${ }^{240}$. A arquitetura é mais um requisito dentro de um circuito que mira a notoriedade dos espaços culturais. E nesse sentido, Paulo Mendes da Rocha, entre os arquitetos brasileiros contemporâneos, é um dos que mais se presta a oferecer uma certificação legítima no mundo da arte. O reconhecimento obtido com o projeto de espaços museográficos de grande peso institucional e a consagração internacional do arquiteto oferecem às galerias um distintivo cartão de visitas.

Além desses dois jovens galeristas, o empresário Hussein Jarouche, dono de uma loja de design de luxo e móveis de autor no bairro dos Jardins, a Micasa, também investiu, aos 36 anos, em uma residência de Paulo Mendes da Rocha. [fig. 71] Primeira geração de filhos de libaneses que imigraram para o Brasil nos anos 1950, Jarouche foi educado em uma família muçulmana tradicional, o que não impediu que estivesse conectado a um circuito de "jovens moderninhos", um meio cultural ampliado que inclui festas badaladas, organizações de desfile de moda, lançamentos, exposições de arte e do mercado editorial e toda sorte de eventos e "experimentos artísticos", nos quais, por vezes, atua como DJ. O interesse pelo mercado de moda, cinema, arte e design se manifesta no colecionismo de objetos não clássicos, como carros antigos de luxo e brinquedos de infância, práticas que podem ser associadas ao gosto por objetos da indústria cultural, flertando com o pop art. O empreendedor cultural, que é considerado em seu meio um bon vivant "meio descolado, meio jovem, meio empreendedor e meio várias outras coisas"241 atrai para sua loja de

240 Cf. FIALHO, Ana Letícia do Nascimento. L'insertion internationale de l'art brésilien. Une analyse de la présence et de la visibilité de l'art brésilien dans les institutions et dans le marché. (Thèse de doctorat), Paris, EHESS, 2006. FIALHO, Ana Letícia do Nascimento (coord.) Pesquisa Setorial: $o$ mercado de arte contemporânea no Brasil. Projeto Latitute, 2014.

241 FIORATII, Gustavo. “Su casa”. Caderno Serafina, Folha de S.Paulo, 03/08/2008. 
design, aberta quando tinha 25 anos, uma "clientela jovem, sintonizada com a moda", público estiloso e abastado, tal como o proprietário. Esse grupo forma uma geração de jovens interessados tanto em objetos culturais legítimos, de artistas reconhecidos na história da arte e da arquitetura, quanto estão abertos para a aquisição de novas peças de design coloridas, arrojadas, debochadas ou pouco convencionais produzidas por jovens designers nacionais e estrangeiros, que, na descrição da empresa, são expressivas da "criatividade contemporânea"242.

Jarouche comprou a casa originalmente projetada em 1967 para o engenheiro Mário Masetti. Com a aquisição, o novo proprietário recontratou Mendes da Rocha para restaurar a moradia, uma forma de garantir que se respeitasse o "desenho original" e a assinatura do arquiteto. A readequação dos espaços foi divulgada por uma revista de colunismo social com uma acolhida festiva e laudatória. A seguir, a longa citação da reportagem permite tanto explicitar a publicidade em torno do novo proprietário quanto evidenciar o discurso celebrativo em torno da residência icônica, apresentada como uma grande "obra-prima", cujo investimento evidencia a pretensão de entrar para a história oficial da arquitetura com "um dos mais importantes exemplares da arquitetura brasileira":

"Dono da Micasa, simplesmente uma das lojas mais incríveis do país e representante das maiores marcas de mobiliário do mundo, Jarouche sabe distinguir um bom desenho de longe. Não é à toa que ele agora passa seus dias de descanso em um imóvel concebido por ninguém menos que o ganhador do Prêmio Pritzker, Paulo Mendes da Rocha. O arquiteto, hoje já com seus 80 e tantos anos, foi convidado pelo atual proprietário a comandar uma reforma mais de 4 décadas depois de ter concluído o projeto original. É por isso que essa é uma casa tão especial. Afinal, não é sempre que se pode 'reescrever' a própria história [...] Como em toda obra-prima, o empresário sabia que seria um pecado interferir em qualquer detalhe que fosse dessa criação. Assim a tal

242 O site da empresa exibe as referências culturais e artísticas que envolvem as orientações de decoração. Conforme a descrição, Micasa é definida como loja que prioriza "um atendimento personalizado, os consultores de venda apresentam o case Modos de Vida para seus clientes, com referências da arquitetura, do design, das artes plásticas, do cinema, da música, e da moda, auxiliando-os a entender as peças que melhor se adequam aos seus lifestyles. Uma seleção de obras de arte são introduzidas como complemento". www.micasa.com.br 
reforma foi, na realidade, uma restauração, onde cada porta, revestimento ou cor que tinha sido alterado ao longo dos anos, voltou ao seu estado inicial. Com vidros trocados e alguns acabamentos refeitos, a única mudança aconteceu de acordo com um desejo do próprio arquiteto, um desejo de 45 anos atrás: a piscina foi finalmente pintada de preto. [...] Durante toda essa operação de restauro, Paulo Mendes da Rocha contou com a ajuda do estúdio de um ex-aluno seu, Eduardo Colonelli. Ao lado do mestre, Eduardo ajudou a dar vida nova à casa que resume o estado da arte da arquitetura brasileira" ${ }^{\prime 243}$.

A casa, no entanto, não é utilizada como moradia principal de seu atual proprietário, que se divide entre apartamento no centro de São Paulo, moradia em Nova Iorque e outras viagens internacionais para captação de relíquias de decoração. A residência esteticamente fotogênica se tornou um espaço de acolhimento de eventos comerciais e mundanos organizados por Jarouche, tais como lançamento de coleções de decoração, festas para os clientes e hospedagem de artistas e designers convidados pela empresa. 0 espaço funciona como cenário publicitário dos produtos comercializados em sua loja, conversão de função que evidencia as estratégias para fixação da marca com o empréstimo da notoriedade do arquiteto.

No cruzamento entre arte e negócio, a afirmação de um estilo de vida por meio dos modos de morar e dos espaços de trabalho oferece uma caução de inserção profissional, que transmite aos empreendedores atributos de engajamento pleno às esferas artísticas. Tendo em vista esses enlaces, pode-se afirmar que há uma relação de afinidade entre arquitetura consagrada, arte contemporânea, mundo dos negócios e uma geração de jovens empreendedores culturais. O recrutamento de jovens galeristas com passagem pelo mercado financeiro e pela publicidade aponta que o elevado investimento na aquisição de edifícios de grife opera em um jogo de rentabilidade simbólica. No espaço concorrencial das novas galerias brasileiras, a insígnia "Paulo Mendes da Rocha" parece ser um investimento

243 LOURENÇO, Bruna. "Casa de 1969 por Paulo Mendes da Rocha". Revista Glamour, 27 abril, 2012. Disponível em: http://colunas.revistaglamour.globo.com/referans/2012/01/27/casa-de1969-por-paulo-mendes-da-rocha/ Acesso: 25/08/2015 
que comunica ao campo competência e credibilidade estética. A adesão a uma arquitetura de autor, erudita e refinada, apresenta-se como uma forma concreta de declarar comprometimento com o universo da arte.

A aquisição de uma casa consagrada na história da arquitetura, tanto como espaço de moradia ou como espaço profissional, exprime as disposições e as ambições artísticas dos novos pretendentes a ingressar no campo da cultura. Como se trata de um negócio personalizado e personificado na figura do proprietário, o trabalho de galerista e de empreendedor cultural exige a exibição de credenciais na área. Uma arquitetura tão reputada quanto a de Paulo Mendes da Rocha contribui para compor o cenário prestigioso de quem quer construir um nome nas artes. Morar em uma "obra arte" é uma forma de se apresentar esteticamente engajado e vanguardista, sinalizando que a arte está internalizada em todos os diversos domínios da existência. Em outros termos, a moradia, que é espaço íntimo e definitivo de exibição dos gostos, funciona como confirmação integral de talentos estéticos e tino comercial.

Para esses jovens que atuam profissionalmente no mercado artístico, gestores de diversos domínios da cultura, a casa de vanguarda encarna um símbolo de excelência estética, emblema que assegura uma postura arrojada, estilosa e culta. Nesse sentido, ao mobilizarem para si o prestígio de um habitat moderno, essas frações de empreendedores culturais em ascensão no mercado de artes se apresentam como vocacionados à estética. Mais do que a exibição material, as mostras de pertencimento total à arte figuram como um capital simbólico de grande valor para o mercado cultural. A casa que exibe assinatura representa uma grife que exerce domínio sobre aqueles que podem decodificar seu valor social, o que contribui para pleitear uma distinção entre os produtores concorrentes e também uma autoridade específica entre os clientes de seus produtos.

As operações em jogo parecem modelar uma nova concepção de investimento na cultura e na arte contemporânea. "Economia criativa", "ação de marketing", "gestão de criatividade", "projetos customizados": são alguns dos termos que rondam as explicações dessa geração de empresários que tem a cultura como área de ação. Em relação ao mercado 
arquitetônico, o empreendedorismo com selo estético está presente na criação de imobiliárias-boutique, agências que se voltaram para a comercialização de imóveis de arquitetos renomados.

Essas empresas mantêm em seu portfólio os chamados "imóveis especiais", notadamente casas e apartamentos projetados pelos principais arquitetos da chamada "Escola Paulista". O tipo de serviço oferecido é definido como "curadoria", termo claramente emprestado do circuito artístico. São serviços que se orientam, conforme anunciam, para um público de apaixonados pela arquitetura, aqueles que declaram "amor pelo design, devoção à estética". [fig. 76 a 78]. Uma dessas empresas é a Axpe, criada no início dos anos 2000 por publicitários e "amantes da arquitetura moderna brasileira", que anuncia seus produtos sob o slogan: "imóveis com arte, estilo e história"244. Conforme informa o site "Portal do Luxo":

"A Axpe lança conceitos novos no mercado imobiliário, valorizando a arquitetura e o design, com atendimento sob medida [...] Amante da arquitetura e do design, a imobiliária-boutique Axpe seleciona individual e criteriosamente os imóveis que entram em sua carteira: unidades que tenham aspectos como estilo, caráter, charme e qualidade de vida, associada à proximidade de jardins, parques, escolas e comércios [...] Muitos dos apreciadores da arte e conhecedores de grandes nomes da arquitetura brasileira não abrem mão de viver ou trabalhar em uma construção singular, cujo projeto representa extremo bom gosto arquitetônico, mesmo que antigo. Focado neste perfil, a Axpe criou classificações para as unidades que negocia: Vintage, Vistas Especiais, Descolados, Arquitetura de Autor, Jardins Especiais, ou Imóveis Especiais, onde todas elas têm um toque de tradição, exclusividade excentricidade e muito charme [...] Contentando todos os perfis de compradores, a inovadora imobiliária Axpe oferece verdadeiros ícones da arquitetura e do design, que, contemporâneos ou históricos, têm a identidade conceitual da empresa-boutique inserida nos detalhes, como charme, originalidade e conforto sob medida para o exigente e apurado senso dos que querem viver com arte ${ }^{245 "}$.

244 Site Portal do Luxo. www.webluxo.com.br Consultado em 14/11/2013.

245 Outras reportagens anunciam a emergência de empresas especializadas em imóveis com assinatura: Cf: “Corretoras se destacam com oferta de imóveis descolados”. Revista Veja São 
A constituição recente de empresas especializadas no comércio de "obras de arte" de uso residencial expõe novas formas de aquisição da arquitetura de autor. Moradias originalmente encomendadas por frações da elite cultural paulistana são disponibilizadas a novos interessados, notadamente ingressantes nos circuitos artísticos, clientes devotados à estilização da vida. A emergência dessas empresas evidencia a dinâmica de transmissão desses imóveis entre grupos com exigências estéticas. São negócios que respondem ao aparecimento de uma nova geração interessada na aquisição de obras modernas que acumularam valor de arte na história da arte e da arquitetura. Procurando uma clientela que não herdou esses imóveis por via familiar, colocam em circulação casas cuja passagem do tempo garantiu o estatuto de excepcionalidade. O lucro comercial é extraído das operações de valorização simbólica. São empresas que operam na circulação da grife de um arquiteto, oferecendo um ganho de distinção que antes estava concentrado nas heranças materiais de um grupo que se lançou como pioneiro do estilo. Abrem, assim, uma porta de acesso àqueles que a cultura e o dinheiro permitem adquirir um emblema de excelência, garantido a afirmação de um modo de morar que se impõe como "arte de viver".

Paulo, 06/12/2012 e "Moradores se dividem sobre reforma de apartamento em prédio antigo". Caderno Classificados. Folha de S. Paulo, 28/04/2013 e "Imobiliária butique". Revista Casa e Jardim, 02/07/2013. 


\section{CAPÍTULO 04}

\section{A consagração de uma estética: o Pritzker de Paulo Mendes da Rocha}

"Em 2006, quando o Prêmio Pritzker foi concedido ao arquiteto Paulo Mendes da Rocha, nós, arquitetos paulistas, nos consideramos igualmente premiados. Porque as palavras do júri falam, por extensão, da nossa arquitetura: 'seus materiais de concreto, que são sua assinatura, e seus métodos de construção inteligentes e notavelmente diretos, criam prédios poderosos e expressivos reconhecidos internacionalmente'. Também a carreira foi guiada por um senso de responsabilidade pelos habitantes de seus projetos assim como pela sociedade como um todo. É inegável o mérito de Paulo Mendes da Rocha, mas a formação de muitos de nós se deu a partir deste exemplo."

Marlene Milan Acayaba, arquiteta egressa da FAU-USP e historiadora da arquitetura brasileira ${ }^{246}$.

\section{Apogeu de uma trajetória, triunfo de uma escola}

Em 2006, aos 77 anos de idade, o arquiteto brasileiro Paulo Mendes da Rocha foi condecorado com o Prêmio Pritzker, honraria que goza de máxima legitimidade dentro e fora do universo da arquitetura. A premiação pode ser considerada a mais importante da área, reconhecida entre pares arquitetos, críticos e historiadores. Ela também apresenta maior visibilidade nos espaços comerciais e midiáticos, sendo frequentemente replicada na 
grande imprensa. Para além da autoridade de instituir nomes e outorgar aos arquitetos o selo mais prestigioso do ofício, a premiação encarna a visão assentada no campo da arquitetura de que a profissão não se restringe à tarefa de fazer uma simples construção; mais do que isso, a arquitetura é reivindicada como produto de intenção plástica.

Criado em 1979, em um momento de crise dos referenciais modernos na história da arquitetura, desde então, o Prêmio Pritzker eleva à máxima consequência essa crença instituída no campo. A produção arquitetônica é apresentada como expressão artística, merecedora de análises que focam os elementos formais. Torna-se, então, digna de receber um olhar prioritariamente estético e, assim, ser julgada por parâmetros de sensibilidade. Desde a instituição do prêmio, ocorreram 37 edições do Pritzker, laureando 40 nomes da arquitetura mundial, entre eles, dois brasileiros, que até 2015 haviam sido os únicos latino-americanos chamados a fazer parte desse seleto grupo de arquitetos, celebrados por instâncias internacionais.

O Pritzker de Paulo Mendes da Rocha não apenas relançou a arquitetura brasileira no cenário mundial, mas o fez com a eleição de um arquiteto classificado como representante da chamada "Escola Paulista", envaidecendo historiadores, críticos, postulantes a herdeiros e demais partidários dessa tradição ${ }^{247}$. Ao falar em tradição, pretende-se mostrar que

247 Após a premiação, no mesmo ano de 2006, o Centro Universitário Maria Antônia da USP sediou uma mostra de projetos intitulada "Coletivo: arquitetura paulista contemporânea", reunindo seis atuantes escritórios de arquitetura de São Paulo, todos constituídos por arquitetos formados na FAU-USP. Os eleitos foram: Andrade Morettin, MMBB, Núcleo de Arquitetura, Puntoni/SPBR Arquitetos, Projeto Paulista e Una Arquitetos. Alguns pleiteiam no nome, de forma explícita, uma referência a São Paulo, possível chave de acesso à linhagem. Outros têm na sua trajetória o contato com Paulo Mendes da Rocha, seja como orientador na FAU-USP, seja como parceiro ou sócio em diversos projetos. A exposição foi logo transformada em livro, publicado pela CosacNaif, editora que se mostra interessada na divulgação da arquitetura paulista e possui em catálogo monografias sobre Vilanova Artigas e Paulo Mendes da Rocha. Um comentário à exposição, feito por um arquiteto, crítico e editor, repete a combinação discursiva que se imprimiu sobre a "Escola Paulista" tal como leitmotiv do grupo - a desqualificação da moradia individual e a valorização dos projetos de conteúdo social: "Reside aqui a maior restrição à exposição, que se ressente de uma curadoria mais autônoma, que poderia ter ampliado um pouco mais o número de arquitetos, optado por um arranjo temático menos confuso e evitado a presença de projetos de interesse mais restrito, como é o caso de residências unifamiliares. Mas isso é de somenos se considerarmos que o visitante da exposição se depara com uma impressionante coleção de excelentes projetos de escolas e centros de pesquisa; conjuntos habitacionais de interesse social e reurbanização de favelas; praças e parques públicos; terminais do sistema de transporte coletivo; centros culturais e bibliotecas; 
houve um esforço em se formar uma linhagem, com entusiastas, filiados e sucessores, que garantem o pertencimento e a força do grupo. Cumpre lembrar que o arquiteto havia sido apontado pela historiografia, desde o final dos anos 1960, como discípulo que adotou as formas de Vilanova $\operatorname{Artigas}^{248}$, e as radicalizou com uma "brutalidade [que] surge ainda mais virulenta", transformando-as em "meio de expressão artística associado a um programa revolucionário"249. Para Yves Bruand, visão sedimentada nas sequentes interpretações, Paulo Mendes da Rocha incorporou a linguagem do mestre e foi mais "longe no sentido de rudeza e frieza", chegando a uma "concepção de choque e excessos, expressão de um estilo cem por centro brutalista"250. Ao endossar o vocabulário de Artigas e levá-lo às ultimas consequências formais, conquistou nome próprio e foi dignificado a ocupar uma posição de destaque dentro de uma tradição que passava a ser reconhecida como "Brutalismo Paulista", disseminando algo que figuraria como reminiscência de um ideal de esquerda. De início, um sucesso regional e em seguida expandido para outros estados, esse grupo passa a adquirir expressão nacional. O Pritzker é um selo que nobilita o movimento estético, orgulha seus filiados e dá coesão.

O timbre da premiação encontrou na escrita do crítico italiano Francesco Dal Co todos os elementos de uma postura encomiástica. Convocado a escrever o ensaio de homenagem ao arquiteto na cerimônia de premiação, Dal Co assumiu posição de porta-voz autorizado do grupo. Na renomada revista italiana Casabella, deixou registrado seu contentamento com a decisão do júri, em uma sequência de exaltação que contém todos os elementos de construção de uma trajetória heroica, tanto do arquiteto como da escola que ele personifica. Nessa versão, os passos da biografia de

equipamentos esportivos e de saúde. São obras que, mesmo considerando visíveis diferenças nas opções formais, se filiam à tradição moderna paulista". GUERRA, Abílio. "Arquitetura para Todos". Revista Bravo!, no 110, out. 2006

248 É notável que nas recentes comemorações do centenário de Vilanova Artigas, amplamente festejadas ao longo de 2015, Paulo Mendes da Rocha tenha sido chamado para proferir seu testemunho em homenagem ao mestre em palestras, conferências, depoimento em filme, seminários, e assim retribuir, para ficar com um termo da antropologia do dom de Marcel Mauss, a "mana" que lhe foi ofertada.

249 BRUAND, Yves. Op.Cit. p.312.

250 BRUAND, Op. Cit. p.314. 
Mendes da Rocha ordenam o fio histórico que atravessa o grupo paulista. 0 arquiteto é canonizado como o "herdeiro confiável [...] digno da melhor tradição e dos mais sólidos valores". O nexo estabelecido se move pela combinação de princípios sociais e expressividade plástica. A longa citação tem o intuito de tornar patente os episódios da construção dessa narrativa, pontos que serão melhor analisados ao longo deste capítulo:

"Desde 1979, o Júri que confere anualmente o Prêmio Pritzker nos tem habituado a surpresas agradáveis e desilusões desanimadoras. Em 2006, decidindo conferir o Prêmio a Paulo Mendes da Rocha (1928), o Júri nos presenteou com a mais agradável das surpresas. Era impossível encontrar uma escolha melhor e mais inteligente. Mendes da Rocha, de fato, entre aqueles ativos na segunda metade do século 20 , é um dos arquitetos mais originais, coerentes e corajosos. Autor de poucas obras, Mendes da Rocha é estranho à cena atualmente ocupada pelos mais histriônicos entre os protagonistas da arquitetura internacional. Desde 1958, quando a inusitada síntese de vitalidade formal e de concretude estrutural representada pelo Clube Atlético Paulistano em São Paulo Ihe fez merecer a atenção dos mais atentos críticos internacionais, até 1988, ano no qual completou uma outra das suas obras-primas, o Museu Brasileiro de Escultura, sempre em São Paulo, a carreira de Mendes da Rocha conheceu momentos de sucesso e de dificuldade, estes últimos devido às perseguições políticas que os governos ditatoriais que se sucederam no Brasil submeteram os melhores arquitetos do País. A coerência que Mendes da Rocha soube dar prova no curso da sua vida, e da vida transferir às suas construções, merece respeito e admiração. A clareza das concepções estruturais, a exemplaridade das escolhas formais, a límpida tectônica, o rigor e a essencialidade de cada solução construtiva, a intransigência no emprego dos materiais, o desprezo pelo supérfluo e a indiferença pela aparência de atualidade, a segura racionalidade, fundem-se na marca das obras de Mendes da Rocha. Entre os fundadores de uma magnífica Escola, como aquela formada no Brasil na segunda metade do século 20, Mendes da Rocha é herdeiro confiável e continuador consequente, genial e digno da melhor tradição e dos mais sólidos valores que deveriam nutrir a cultura arquitetônica"251.

251 DAL CO, Francesco. Paulo Mendes da Rocha - Pritzker Prize 2006. Arquitextos, São Paulo, ano 
Até então, o único brasileiro a ganhar essa medalha havia sido, em 1988, Oscar Niemeyer (1907-2012), arquiteto cuja inserção internacional teve início precoce, quando participou em 1936 de uma equipe que projetou - Ministério da Educação e Saúde, no Rio de Janeiro, apadrinhada pelo grande nome da arquitetura moderna europeia, Le Corbusier ${ }^{252}$. Ainda que em escala global a conquista de Niemeyer tenha propiciado a disseminação da excelência de uma produção rotulada como "arquitetura brasileira", dentro das disputas nacionais a medalha de Niemeyer foi contabilizada como trunfo específico da "Escola Carioca". Dezoito anos depois, ao emplacar mais um brasileiro no grupo de elite da arquitetura mundial, a premiação de Paulo Mendes da Rocha foi saboreada por uma parte dos agentes como o merecido reconhecimento da vertente paulista, passo decisivo para firmar uma estirpe.

Os materiais oficiais de anúncio do vencedor replicaram as interpretações correntes entre historiadores e críticos brasileiros, que assentaram no campo nacional a importância da figura de Mendes da Rocha na consolidação de uma tradição paulista de concepção arquitetônica. Nas disputas para caracterizar o que seria a "Escola Paulista", aparecem os desacordos sobre definições, demarcações e pertencimentos, embates que só asseguram o empenho dos agentes em incluir, excluir e instituir. No discurso de anúncio do prêmio, sem deixar de fazer referência à instabilidade dos contornos classificatórios, Mendes da Rocha foi citado como arquiteto que faz "parte do que era então considerada a vanguarda em São Paulo, espontaneamente conhecidos como criadores da arquitetura brutalista paulista"253. Fazendo eco a essas representações, na grande

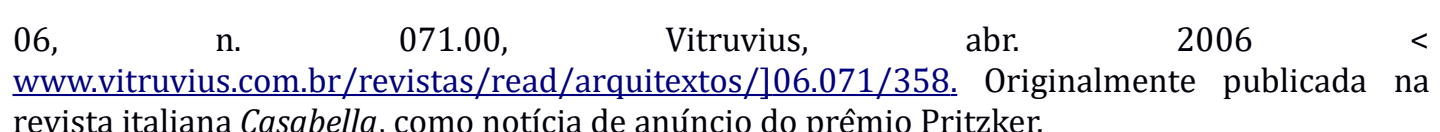
revista italiana Casabella, como notícia de anúncio do prêmio Pritzker.

252 DURAND, José Carlos e SALVATORI, Elena. "A gestão da carreira dominante de Oscar Niemeyer". Tempo Social, Revista de Sociologia da USP, v.25, n2. Novembro, 2013. pp. pp.157-180.

253 Tradução da autora. No discurso de anúncio do prêmio, a referência à "Escola Paulista Brutalista" aparece como: "The new laureate began his career in the 1950s and was part of what was then considered the avant-garde in São Paulo, known loosely as creators of the Paulist brutalist architecture [...]". Disponível em: www.pritzkerprize.com/2006/announcement Acesso em: 09/09/2014 
imprensa, em artigo de anúncio do prêmio no jornal New York Times, o arquiteto é referido como um "decano não oficial do movimento brutalista da cidade de São Paulo"254. Já no discurso cerimonial do júri, presidido por lorde Peter Palumbo, um promotor imobiliário milionário, Mendes da Rocha é entronado como importante nome da arquitetura brasileira, em continuidade e rupturas com a tradição local.

Vale acrescentar aqui informações sobre o lorde inglês, que dão o tom da grandeza da premiação, instada a solicitar a presença de personalidades fora do espaço dos especialistas, como caução midiática da premiação. Amante de arquitetura, Peter Palumbo é colecionador de obras de arte e ícones da arquitetura, tem em seu portfólio residências emblemáticas dos arquitetos amplamente consagrados, como Mies Van der Rohe, Le Corbusier e Frank Lloyd Wright ${ }^{255}$. Na visão do lorde Peter Palumbo, Mendes da Rocha é o expoente de uma nova geração oriunda na sequência gloriosa de arquitetos modernos brasileiros, entre os quais são citados os arquitetos Lúcio Costa, Oscar Niemeyer, Lina Bo Bardi e o paisagista Roberto Burle Marx. No entanto, Palumbo procura marcar diferenças em relação ao primeiro brasileiro vencedor do Pritzker:

"Se as obras de Oscar Niemeyer são notáveis por suas exuberantes e expressivas qualidades e também suas formas marcantes na paisagem, as obras de Paulo Mendes da Rocha são notáveis pela busca de uma maior racionalidade e o diálogo com a paisagem"256.

254 POGREBIN, Robin. "Paulo Mendes da Rocha of Brazil Wins the Pritzker Architecture Prize". NYTimes, 10, abr, 2006. "Paulo Mendes da Rocha of Brazil, known for his provocative ways with concrete and steel, has won the 2006 Pritzker Architecture Prize, considered the profession's highest honor. Mr. Mendes da Rocha, 77, is best known for his Brazilian Sculpture Museum in São Paulo, where he is considered the unofficial dean of the city's Brutalist movement."

255 O lorde inglês Peter Palumbo é responsável por diversos investimentos em obras de arte e arquitetura, comprando casas e objetos de design de arquitetos emblemáticos do movimento moderno. Em 1972, ele comprou uma das mais famosas residências de Mies Van der Rohe nos Estados Unidos, a Casa Farnsworth, projetada em 1951 para Edith Farnsworth, médicaurologista. De Le Corbusier, é proprietário da Maison Jaoul, também construída nos meados dos anos 1950, para um industrial do setor siderúrgico, em bairro nobre de Paris. De Frank Lloyd Wright, adquiriu a Casa Kentuck Knob, do mesmo período, projetada para proprietários de uma empresa de laticínios em uma região montanhosa da Pensilvânia, nas vizinhanças da Casa Kaufmann, a famosa Casa da Cascata do mesmo arquiteto. Disponível em: http://lordpeterpalumbo.com/biography.html Acesso em: 16/10/2015.

256 Tradução da autora, no original: "If the works of Oscar Niemeyer are remarkable for their exuberant and expressive qualities, and as striking forms in the landscape, those of Paulo Mendes 
Tal visão sobre as diferenças entre as duas tradições arquitetônicas brasileiras retoma o recorrente modelo de caracterização das linhas curvas, leves, expressivas e plásticas dos cariocas em contraponto às linhas retas, pesadas, concisas e politizadas dos paulistas, em oposição entre formalismo e racionalidade, arte e técnica, formalismo e engajamento, termos que também remete a uma narrativa de contraste e disputa entre dois polos de produção cultural.

A cerimônia de outorga do prêmio a Paulo Mendes da Rocha foi realizada em Istambul, às margens do rio Bósforo, no Palácio Dolmabahçe, edifício sede do Império Otomano, local cuja escolha feita por parte da comissão organizadora também busca se afirmar como mais uma insígnia ritual do prêmio. Diante de autoridades políticas (o primeiro-ministro da Turquia e o prefeito de Istambul), dos patronos da premiação (Cindy Pritzker e seu filho, Thomas Pritzker, então presidente da Fundação Hyatt) e de outros arquitetos já laureados ${ }^{257}$, o arquiteto apresentou uma fala munida de intenções elevadas, garantindo o tom solene do discurso de aceitação do prêmio. [fig. 79 a 81] Paulo Mendes da Rocha reafirmou a história do lugar, a ligação entre Ocidente e Oriente e o compromisso dos arquitetos em construir uma civilização, um país, a América. A arquitetura, alargada em ideais, foi evocada como uma "pedra angular" para a construção da paz e, ao ofício do arquiteto, Mendes da Rocha reservou o altivo papel de interferir na natureza e transformar o espaço.

O discurso proferido pelo arquiteto ganha em sentido se toda a dinâmica da premiação for entendida na moldura de uma manifestação ritual instituidora da distinção. A fala se apresenta como uma saudação ao próprio caráter do prêmio e tem o efeito de redobrar a crença nele. Ao demarcar o compromisso social do arquiteto, acena à toda a linhagem da "Escola Paulista". Quando recebe a condecoração e aceita pertencer a essa série de premiados, o arquiteto é instituído como porta-voz autorizado da

da Rocha are remarkable for the pursuit of greater rationality, and their striking dialogue with the landscape“. Discurso da cerimônia de Lord Palumbo, presidente do júri. Disponível em: http://www.pritzkerprize.com/2006/ceremony speech2b Acesso em: 09/09/2014.

257 Estavam presentes o austríaco Hans Hollein, o alemão Gottfried Böhm e o norte-americano Thom Mayne, arquitetos premiados, respectivamente, nas edições do Pritzker de 1985, 1986 e 2005. 
profissão, defendendo seu caráter nobre, sua função transcendente e seu compromisso com a humanidade. Tudo se passa como se o portador da láurea fosse investido de uma procuração para falar em nome do ofício, do próprio valor do prêmio, de seus semelhantes e, como tal, deve propagar essa missão universal e justificar sua presença nessa lista de eleitos.

Práticas constantes do meio cultural e artístico, as condecorações, medalhas, troféus, entre outras recompensas, podem ser vistos como formas simbólicas de reconhecimento que operam instituindo distinções entre os agentes de um universo cultural específico ${ }^{258}$. Tais prêmios se apresentam como marcas de diferenciação que selecionam indivíduos e conferem a eles um caráter de excepcionalidade, em nome de valores que estão sedimentados em cada campo. Esses valores são compartilhados pelo conjunto de agentes e instituições, eles mesmos participantes e principais interessados na produção da crença no valor distintivo da distinção (BOURDIEU, 1996, 2015; ENGLISH, 2005). A força da consagração está em mobilizar os agentes com diferentes capitais para instituir uma sanção simbólica de distinção. Nesse sentido, o ato de consagração é um rito social estabelecido coletivamente que sacraliza um objeto. Ele tem um caráter ritual, pois se apresenta como momento de mudança de estatuto. Ele tem um caráter coletivo, pois na presença do grupo, ou seja, com a confirmação dos pares e validação dos participantes, torna-se uma sanção certificada publicamente.

Essas questões trazem ao centro da investigação as lógicas de acumulação de capital simbólico e as vias que levam à consagração artística e, ainda, à notoriedade midiática. A validação de um produtor como artista,

258 Faço uso aqui do trabalho recentemente publicado pela Editora Seuil, que organizou os seminários de Pierre Bourdieu no Collège de France entre os anos 1981 e 1983. Embora esses cursos tenham sido realizados antes da escrita do livro As regras da Arte, nota-se que em suas aulas Bourdieu preocupou-se em destrinchar de forma mais profunda sobre o ato de consagração. BOURDIEU, Pierre. Sociologie Générale. Volume I. Cours ai Collège de France (1981-1983). Paris, Raison d'agir, Seuil, 2015, especialmente o seminário do dia 02 de junho de 1982. Também sobre o tema da consagração, três outros trabalhos aqui me servem de referência teórica. Cf: HEINICH, Nathalie. De la visibilité : excellence et singularité en régime médiatique. Paris : Éditions Gallimard, 2012. QUEMIN, Alain. Les stars de l'art contemporaine. Notoriété et consécration artistiques dans les arts visuels. Paris : CNRS Éditions, 2013. ENGLISH, James. The Economy of Prestige. Prizes, Awards and the Circulation of Cultural Value. Cambridge/London, Harvard University Press, 2005. 
a hierarquização dos artistas e das obras, a construção de um panteão de notáveis, a rotulação de uma escola ou estilo estético são elementos intrínsecos aos mundos da arte. São nesses espaços relativamente autônomos que se constroem os valores artísticos que definem quem terá estatuto de criador e quais artefatos poderão ser considerados como objeto de arte enquanto tal. Gratificações nomeadamente de caráter simbólico, as premiações e honrarias participam desse jogo de produção e circulação dos valores.

É sob o olhar de uma sociologia da produção e da circulação de valores que se pretende dar entrada à análise da consagração do arquiteto Paulo Mendes da Rocha e da estética que representa. A presença do Brasil em uma premiação de grande impacto internacional lança algumas questões sobre o funcionamento do campo da arquitetura brasileira, as formas de construção de visibilidade e as disputas internas por reconhecimento. Essa entrada possibilita levantar indagações sobre a formação de uma elite arquitetônica com capacidade de ultrapassar as fronteiras de seu país e circular internacionalmente, seja por meio de exposições em grandes museus, publicações em revistas estrangeiras, homenagens em grandes livros, ou, de maneira definitiva, com a construção das obras, a partir de convites para projetar edifícios por meio dos quais o arquiteto fixa sua marca e ratifica sua assinatura.

Nesse sentido, o Pritzker pode ser tomado como modelo sintético das definições legítimas no campo da arquitetura, pelo qual se assentam os valores sobre o papel do arquiteto e se acordam os instrumentos de intelecção desse espaço simbólico. Com isso, a própria construção do respeito e do prestígio do prêmio, para que seja um validador eficiente da carreira de sucesso dos arquitetos, precisa ser considerada. Torna-se necessário expor os trânsitos entre os polos da cultura, do poder e da economia que perpassam toda a dinâmica da premiação e borram suas fronteiras, em arranjos que garantem visibilidade e status a esse processo de eleição.

A reconstituição da trajetória de Paulo Mendes da Rocha a partir dessas várias escalas de lutas e espaços de construção de legitimidade 
permite escrutinar os mecanismos de produção de valor nesse mundo social, visto tanto na escala nacional, onde ocorrem as disputas em torno da definição do movimento "Escola Paulista", quanto na dinâmica da circulação internacional das reputações, que seleciona indivíduos para compor um seleto grupo de prestígio cosmopolita. A partir dessa perspectiva analítica, é possível compreender a trajetória de Paulo Mendes da Rocha como o encontro de um habitus em um campo, destacando de que forma investimentos individuais foram operacionalizados e reativados nos jogos da consagração artística. Ou seja, o cruzamento entre a história individual e as exigências do campo artístico, este também com sua historicidade, é uma abordagem que permite entender os mecanismos de produção de notoriedade, reconhecimento artístico e representações que os grupos constroem para si.

Como se vê, o prêmio atravessa toda a estrutura do campo da arquitetura. E isso tem consequência para a abordagem que aqui se propõe fazer. Se o Pritzker pode ser assumido como um modelo decantado dos valores que norteiam a prática autoral da arquitetura, expressando de modo sintético o resultado da acumulação de consagrações recebidas ao longo de uma trajetória profissional, a vitória do discípulo dileto de Vilanova Artigas é reveladora da linha ideológica que foi triunfante na arquitetura paulista. Ao ser premiado, Paulo Mendes da Rocha imanta toda a linhagem, tanto aqueles que se almejam continuadores quanto os antecessores.

Com isso, pretende-se afirmar que o evento de consagração não é uma curiosa crônica da vida mundana do meio arquitetônico. Mais do que um acontecimento, é um episódio conclusivo e eloquente da legitimação da ideologia oficial do grupo paulista, versão posta em circulação por seus próprios integrantes e confirmada por um ativo sacerdócio. Em suas autoconstruções, o grupo se pretende distinguível por um ethos em que suas realizações estéticas estariam assentadas em posturas socialmente $\operatorname{avançadas}^{259}$. Uma análise pormenorizada dos rituais que envolvem a

259 Faço uma aproximação à análise que Raymond Williams fez à fração Bloomsbury, identificados como anunciadores de valores estéticos e sociais, conjunto de produtores culturais cujas raízes estavam na Universidade de Cambrigde. cf. WILLIAMS, Raymond. "A fração Bloomsbury". In: Plural; Sociologia, USP, São Paulo, 6: 139-168, 1999. 
consagração no Pritzker aparece como via de entrada para reconstituir o mito sacralizante que circunda o arquiteto, responsável por produzir um criador purificado pelo desinteresse e engajado na transformação do mundo, preceito que funciona como leitmotiv da "Escola Paulista".

\section{Instituição de uma raridade no campo da arquitetura}

A concessão da máxima medalha da arquitetura mundial pode ser vista como o acúmulo de um lento processo de construção de si, reconhecimento entre pares arquiteto que culminou em notoriedade internacional, quando passou a ser citado em monografias e coletâneas de referência sobre a história da arquitetura. As etapas da conquista de reconhecimento passam pela legitimação em diversas escalas e instituições.

As homenagens e os rituais institucionais são momentos em que agentes declaram em alta voltagem suas intenções e autoconstrem uma interpretação da trajetória. Paulo Mendes da Rocha, no Memorial do Concurso para professor titular, em 1998, deixou registrado que sua formação foi "marcada pela Universidade de Paulo [...] e na lição de João Batista Vilanova Artigas, por cujas mãos entrei nesta Escola"260. Em 2000, em mais um momento de reiteração institucional da força da "Escola Paulista", respondeu à obtenção do título de professor emérito da USP, convocando a memória do mestre e a excepcionalidade de uma tradição que propala a aliança entre crítica e técnica:

"Agora, vejam os senhores, como fui sempre afortunado, como dizem os italianos, em minha vida! Assim, já talvez, digamos de modo inaugural, bem formado, fui convidado por Vilanova Artigas para vir lecionar nesta Escola e reinaugurar, na minha vida, um novo aprendizado extraordinário [...] Foi um momento extraordinário porque vi, com clareza, aquilo que é o privilégio particular desta Escola, a associação inexorável, mas nem sempre cultivada como e com a força com a qual

260 Memorial do Concurso de para Professor Titular, 1998. 
se deve cultivar, a visão crítica e a visão técnica. Uma engenharia que reflete sobre si mesma quanto à questão de sua importância na construção da habitabilidade do planeta, qual seja a posição da arquitetura. Uma escola que sempre formulou, cultivou, de maneira concisa, a técnica e a crítica. Essa é a chave desta Escola que vi inaugurar naqueles momentos difíceis"261.

Essas declarações podem ser vistas como momentos de controle da exposição de si, a produzir uma versão coerente de sua própria trajetória. Em seu conteúdo, evidenciam os vínculos que quer reiterar e o lugar que pretende ocupar. Essas autodefinições foram replicadas pelos historiadores filiados à Escola, até ser repercutida em escala internacional na premiação do Priztker.

Entrar para o grupo dos arquitetos laureados e ter seu nome fixado na elite global expressam o reconhecimento crescente devotado a Paulo Mendes da Rocha e a arquitetura paulista no mercado internacional. Cada vez mais frequente, a circulação de sua obra internacionalmente pode ser contabilizada por exposições e aquisição de desenhos, convites para o acervo de consagrados museus. O Centre Georges Pompidou, sediado em Paris, organizou duas mostras sobre o arquiteto, em 2011 e 2014, nas quais foram exibidos desenhos e maquetes adquiridos para a coleção da instituição, um empenho de apresentar a produção brasileira para além de Oscar Niemeyer 262 . Vale destacar que a ligação do arquiteto com o Centro se deu quando Mendes da Rocha participou do concurso de anteprojetos para as novas instalações do museu, em 1971, competição em que ficou classificado entre os 30 finalistas.

261 ROCHA, Paulo Mendes da. "Paulo Mendes da Rocha recebe título de professor emérito da Fauusp". In. Revista Pós, V.17, no 28, São Paulo, dez, 2010. p.220-227. p.227.

262 O Centre Georges Pompidou abriga em sua coleção mais de 30 documentos do arquiteto, entre eles, croquis, fachadas, cortes, maquetes, material doado pelo próprio arquiteto. Valentina Moimas, responsável pela coleção, assim expressou o interesse pela arquitetura brasileira contemporânea: "Je ne doute pas que toute cette architecture gagnera bientôt la scène internationale. Il y a aujourd'hui un vrai mouvement d'historiens qui est en train de montrer l'identité brésilienne, dont le génie ne se limite pas à Niemeyer. Pour 2015, le MoMA prépare également une grande exposition sur l'architecture en Amérique latine." Disponível em: http://mediation.centrepompidou.fr/education/ressources/ENSArchitecture/\#achitecture am erique latine Consulta em: 18/11/2015 
Em 1996, dez anos antes da premiação do Pritzker, Paulo Mendes da Rocha havia sido objeto de uma primeira monografia estrangeira sobre sua obra, editada pela reconhecida editora de Barcelona Gustavo Gilli. O material foi escrito pelo arquiteto catalão, crítico, organizador de exposições e professor da Escola Técnica de Arquitetura de Barcelona Josep Maria Montaner, que despontava no cenário espanhol com ensaios de crítica de arquitetura. Nesse catálogo dedicado exclusivamente ao arquiteto, Mendes da Rocha foi apresentado como um dos maiores expoentes da arquitetura brasileira, continuador do projeto moderno, aparecendo, em meio às descrenças pós-vanguardas, como impassível convicto na "capacidade de articulação e regeneração" da arquitetura moderna ${ }^{263}$. O arquiteto brasileiro se encaixava no projeto mais amplo de análise arquitetônica empreendida pelo crítico nos anos 1990, para o qual se buscava constituir um balanço de fechamento do século $X X$, ordenando e nomeando a produção contemporânea mundial frente às rupturas e continuidades em relação ao movimento moderno ${ }^{264}$. Tal tarefa de recomposição dos rumos da história da arquitetura de um século se coaduna com o empenho do crítico em produzir uma interpretação em escala global, investimento decisivo para se lançar como crítico de circulação internacional.

O esforço de contestação herética fica evidente pelo partido analítico que Montaner assume - emblematizado pelos títulos taxativos de seus livros Depois do Movimento Moderno e Modernidade Superada, perfil incisivo de quem pretende inaugurar uma nova tradição interpretativa e de se colocar como anunciador de outra ortodoxia. Para o crítico, Paulo Mendes da Rocha sustentaria sua confiança no "domínio tecnológico", "na criação de uma nova monumentalidade mediante o uso cuidadoso da técnica do concreto armado e do aço". Montaner caracteriza a produção do arquiteto

263 MONTANER, Josep Maria e VILLAC, Maria Isabel. Mendes da Rocha. Barcelona, Gustavo Gilli, 1996.

264 Os diversos livros publicados na década de 1990 sinalizam o empenho do crítico em engendrar uma nova interpretação para a arquitetura, estabelecendo um balanço sobre as mudanças no século XX: MONTANER, Josep Maria. Después del Movimiento Moderno. Barcelona, Gustavo Gilli, 1993. MONTANER, Josep Maria. Museos para el nuevo siglo/Museums for the new century. Barcelona. Gustavo Gili, 1995. MONTANER, Josep Maria. Less is more: minimalismo en arquitectura y otras artes. Barcelona, Actar, 1996. MONTANER, Josep Maria. La modernidad superada: ensayos sobre arquitectura contemporánea, Barcelona, Gustavo Gilli, 1997. 
como uma mistura de diversos ingredientes: "monumentalidade", "vocação social" e "amor pela materialidade", resultando em um conjunto que ele nomeou de "arquitetura minimalista", termo cujo conteúdo faz alusão ao uso reduzido de materiais, isto é, a uma arquitetura que se vale de elementos essenciais e que, segundo o autor, buscaria a atemporalidade das formas.

Chama atenção que a aplicação da noção classificatória vem emprestada das classificações do mundo artístico, o minimal art, termo até então utilizado nas artes plásticas para agrupar um conjunto de obras e uma geração de artistas da década de 1960, somando-se à sequência de denominações e distinções práticas que tentavam compreender e instituir os ingressantes no universo artístico pós-vanguarda. Todavia, não é de se estranhar que, ao lançar Paulo Mendes da Rocha nas redes de consagração internacional, o crítico se vale de instrumentos de classificação e formas de nomeação que são expressivos das lutas por reconhecimento, operando uma estratégia de legitimação do arquiteto e, ao mesmo tempo, validando a pretensão de estrear como introdutor e crítico oficial de sua obra. Com efeito, o crítico aparece como aquele que "descobre" um criador e mobiliza seus capitais simbólicos para ativar o jogo do duplo reconhecimento.

Em relação às classificações disponíveis no campo da arquitetura brasileiro, Montaner retomou as interpretações de Yves Bruand sobre a oposição entre a "Escola Paulista" e a "Escola Carioca", e fez circular com maior força a ideia, assentada no panorama nacional, de que o arquiteto paulista representaria um novo protagonista da arquitetura brasileira, dando continuidade ao prestígio antes conquistado por Oscar Niemeyer e Lúcio Costa. Porém, questionando os pressupostos formais dos dois pioneiros, localiza a nova geração a partir de variações principalmente estilísticas em torno de um eixo comum, comparando-os ao arquiteto de maior renome internacional, Le Corbusier. A baliza externa de referência garante o posicionamento da produção brasileira no cenário internacional, ativando uma narrativa chancelada pelos empréstimos entre o local e o universal. A produção brasileira é situada como um episódio da arquitetura mundial e não apenas uma manifestação de caráter local. 
Em suas análises, Montaner conferiu primazia aos aspectos formais e à linguagem espacial dos edifícios, caracterizando-os pelo emprego de jogos de oposição que se expressam em um conjunto de proposições abstratas, como irracionalidade-racionalidade, exuberância-essencialidade, transparência-massa, fluidez-peso. Nas palavras do crítico:

"Se a obra de Oscar Niemeyer significou a introdução de elementos irracionais, poéticos, expressivos, exuberantes e formalistas, dentro da linguagem formalista do mestre Le Corbusier, a obra de Paulo Mendes da Rocha, em contrapartida, segue um caminho inverso rumo a uma maior racionalidade, sistematicidade, essencialidade e redução. Se Costa e Niemeyer se afastaram da solidez e frontalidade da arquitetura de Le Corbusier, perseguindo formas tangenciais, transparentes, fluidas e expressivas, João Vilanova Artigas, Paulo Mendes da Rocha e a escola paulista seguiram o itinerário inverso, em direção a massa e ao peso, ainda que essa mantenha uma posição de difícil equilíbrio"265.

Amplamente ilustrado com fotografias, desenhos a mão livre, croquis, imagens de maquete e plantas dos edifícios, o catálogo foi editado em duas versões, uma bilíngue inglês e espanhol, pela editora de Barcelona, e outra em português, pela editora Blau, de Lisboa. Isso demonstra a amplitude de circulação da obra do arquiteto, ressoando inclusive em outros comentadores, como o crítico espanhol, teórico da arquitetura e também editor Hélio Piñón ${ }^{266}$, que publicou em 2003 um livro em que Paulo Mendes da Rocha figura como elo de uma "geração perdida" a recuperar as premissas heroicas e engajadas do movimento moderno.

Depois da publicação de Montaner, um segundo patamar de consagração da obra do Paulo Mendes da Rocha foi conquistado com duas premiações estrangeiras, que mais uma vez contribuíram para a circulação internacional de sua obra. O arquiteto foi indicado ao Mies van der Rohe

265 MONTANER, Josep Maria e VILLAC, Maria Isabel. Mendes da Rocha. Barcelona, GG, 1996. p.9-10. (tradução minha)

266 PINON, Hélio. Paulo Mendes da Rocha, Escuela Técnica Superior de Arquitectura de Barcelona (ETSAB), Barcelona, 2003. Cf. PASSARO, Andrés Martín. A descoberta de uma geração perdida. Resenhas Online, São Paulo, ano 02, n. 016.02, Vitruvius, abr. 2003 <www.vitruvius.com.br/revistas/read/resenhasonline/02.016/3217> 
Prize for Latin American Architecture ${ }^{267}$, em duas edições do evento, em 1998 e 2000. Na primeira, uma de suas obras havia ficado entre as finalistas, e na segunda edição, o arquiteto recebeu a honraria máxima.

De modo distinto ao Pritzker, essa premiação volta-se para a eleição de edifícios construídos nos países latino-americanos, e não para carreiras de arquitetos. Na primeira edição, junto com Paulo Mendes da Rocha, figuraram edifícios de outros 24 indicados ${ }^{268}$ de diversos países, entre eles, Argentina, Venezuela, Uruguai, Chile, Colômbia, México, Cuba, o que mostrou um esforço de dar visibilidade global a experiências "autóctones", guiadas pela máxima miesiana "menos é mais", vistas como variações regionais dos modelos modernos dos países centrais, ou como ajustes e aplicações locais de linguagens europeias.

Nessa honraria latino-americana, Mendes da Rocha foi premiado pelo projeto de reforma e adaptação do Edifício da Pinacoteca do Estado de São Paulo, na região da Luz. Na mesma edição de 2000, o arquiteto brasileiro concorreu com outro projeto, a reforma do Centro Cultural Fiesp, localizado na avenida Paulista. [fig. 82 a 85] Na premiação anterior, em 1998, também havia ficado entre os finalistas, com mais um projeto de uso expositivo e artístico: o Museu Brasileiro de Esculturas (MuBe), edifício que ocupa ampla quadra no bairro dos Jardins. Em três locais distintos da cidade de São Paulo, no final dos anos 1990, Paulo Mendes da Rocha deixaria sua marca no espaço urbano com projetos para museus e espaços de exposição. Vale destacar o caráter cultural dos edifícios projetados. As instituições artísticas, interessadas em afirmar a singularidade de seus edifícios e associá-los a uma concepção autoral, demandam maior arrojo nas soluções estéticas. Em homologia com a vocação criativa tão cara à figura do

267 Com apoio da Comissão Europeia, o prêmio foi oferecido pela Fundação Mies van der Rohe de Barcelona. A instituição se dedica principalmente, desde 1987, a premiar a produção de arquitetos europeus. A incorporação de uma premiação exclusiva aos latino-americanos restringiu-se a somente duas edições. As bases para a escolha dos edifícios, segundo as regras da premiação, é a escolha de projetos que apresentem uma "combinação de virtudes tais como excelência e autenticidade do projeto, seu genuíno e inovador caráter e a alta e boa qualidade de sua construção". Ver catálogo do prêmio: Fundação Mies Van der Rohe. 1st Mies van der Rohe Award for Latin American Architecture. Barcelona: Fundação Mies Van der Rohe, 1998.p.8.

268 Na premiação Mies Van der Rohe de 1998, entre os 24 finalistas, 14 edifícios estavam destinados aos espaços sagrados da cultura, em projetos de museus, centros culturais, memoriais, biblioteca nacional e conservatório de música. 
arquiteto, museus e salas de exposição dão validade ao valor artístico da arquitetura e se valem do efeito simbólico da assinatura do arquiteto. $O$ prêmio do edifício também replica a aura artística da instituição.

Diferente dessa premiação que certifica um edifício construído, o Pritzker se propõe a ser uma homenagem a um indivíduo. Sua lógica de nomeação não é a indicação de diversas obras edificadas, mas a eleição de um arquiteto vivo por ano, independente do país, premiando o que poderia ser definido como "conjunto da obra" ou "contribuições de uma vida toda". Segundo os critérios do prêmio, trata-se da seleção de um indivíduo de trajetória excepcional na totalidade do universo arquitetônico. Tal configuração personalista, que privilegia o produtor e não a obra, contribui para a formação de um grupo de eleitos com ampla visibilidade internacional. Por ser uma premiação transnacional em termos de abrangência geográfica, o prêmio de um caráter universalizante. O arquiteto escolhido é incluído em uma elite mundial.

O Pritzker busca instituir uma autoridade global que é restrita a poucos arquitetos. Pela sua seletividade, o prêmio se apresenta como uma raridade e se impõe como a premiação no campo da arquitetura que tem maior eficácia simbólica. Tal como vencer um Oscar no cinema, ou um Nobel na literatura, ser laureado com o Pritzker passa a adquirir um valor absoluto, uma qualidade em si, o que faz validar a atribuição de excepcionalidade dos prêmios congêneres. Os arquitetos ganhadores passam frequentemente a ser citados na imprensa, tanto na ampliada quanto na especializada, pelo epíteto "ganhador do Prêmio Pritzker", sendo que raramente se oferecem informações sobre a lógica premiação da honraria, a fundação que a subsidia e o processo de nomeação.

O critério de premiação do "conjunto da obra" favorece a escolha de um arquiteto que amealhou diversas formas de reconhecimento ao longo de sua carreira. Com isso, é possível dizer que a medalha premia a culminação de um longo trabalho de acúmulo de reputações em diversas instâncias de consagração. Isso pode ser confirmado quando se verifica que a maioria dos laureados, no âmbito internacional, também já havia conquistado previamente outros prêmios, como o reconhecido Mies Van der Rohe e a 
medalha da União Internacional dos Arquitetos (UIA). O prêmio funciona, assim, como o saldo de investimentos e rendimentos validados no campo, em espaços específicos, ligados aos circuitos hegemônicos, principalmente norte-americanos. Essa especificidade tem um caráter emblemático: a enunciação do vencedor atua como caixa de ressonância dos valores que são considerados legítimos como definição do padrão de desempenho do ofício de arquiteto e do modelo vocacional da profissão. O caráter inventivo dos edifícios e a valorização formal da arquitetura ratificam um tipo específico de êxito profissional que privilegia o ofício enquanto domínio artístico.

O caráter seleto e global do Pritzker, a configuração cerimonial do evento, o amplo envolvimento de experts da área, a lógica do patrocínio privado e a divulgação midiática são aspectos que contribuem para compor, em diversos níveis, a garantia de raridade da distinção e o reforço de sua legitimidade. Esses ingredientes agem como uma alquimia simbólica da premiação. Nessa perspectiva, o Pritzker pode ser visto como uma instância de consagração que produz valor distintivo e desempenha um caráter hierarquizador no campo. Ser reconhecido como vencedor do prêmio assegura uma assinatura e a constituição de uma grife no universo arquitetônico, mecanismo de sanção da figura do arquiteto-artista.

\section{Sociologia de uma premiação: quais critérios, quem premia, quem é premiado}

Mesmo não sendo uma condecoração concedida pela Fundação Nobel $^{269}$, o Pritzker é sempre designado com o epíteto "Nobel da

269 O Prêmio Nobel foi criado em 1901, por Alfred Nobel, para prestigiar pessoas das áreas de física, química, fisiologia, medicina, literatura e paz, independentemente da nacionalidade. Sobre análises sociológicas do prêmio Nobel, cf. LAROCHE, Josepha. Le Nobel comme enjeu symbolique dans les relations internationales. In: Revue française de science politique, $44^{\mathrm{e}}$ année, $\mathrm{n}^{\circ} 4$, 1994. pp. 599-628. Para uma análise de prêmios homólogos ao Nobel,cf. LEBARON, Frédéric. Le "Nobel" d'économie. In: Actes de la recherche en sciences sociales. Vol. 141-142, mars 2002. Science. pp. 62-65. 
Arquitetura", alusão que faz ressoar o caráter de autoridade universal que o prêmio pleiteia. De fato, ao se considerarem alguns de seus critérios, formas de premiação, recompensa e rituais de celebração, pode-se dizer que o Pritzker tomou, em seus princípios de organização, o Prêmio Nobel como modelo. O propósito de consagrar um "talento que significativamente contribuiu para a humanidade"270 é expressão do projeto grandioso do prêmio. Tal como o Nobel, não se trata de consagrar um indivíduo e uma carreira associando à distinção a glorificação de uma nação específica. Ao contrário, a abrangência internacional da condecoração é uma forma de instituir uma classificação global e, assim, reivindicar um representante universal em determinada área do saber e das artes. Ambas as honrarias homenageiam a obra completa de um produtor ainda vivo, condição que dá o tom particular de excelência. O indivíduo laureado passa a pertencer a uma minoria que detém prestígio e, sendo assim, é incorporado a uma elite transnacional (LAROCHE, 2012). O processo de formação dessa elite de arquitetos tem efeitos sobre a circulação internacional dos laureados.

Para melhor compreender o Pritzker, convém expor o propósito de sua criação bem como os interesses enredados nesse patrocínio. Mais uma vez seguindo a inspiração de Alfred Nobel, a premiação surge a partir de uma iniciativa individual, com o patrocínio ancorado em uma instituição privada. Não por acaso o prêmio leva o nome de seus protetores, o casal Jay e Cindy Pritzker. Cabe explicitar que família é essa e de onde vem tal afluência financeira.

Jay Pritzker (1922-1999) é descendente de segunda geração de uma família pobre de imigrantes judeus que se fixou em Chicago no final do século XIX. Inicialmente formado em Direito, orientou sua carreira como empreendedor, prosperando nos negócios e acumulando grande riqueza. Com investimentos principalmente no setor hoteleiro, os Pritzker concentram uma das maiores fortunas dos Estados Unidos ${ }^{271}$. Além de cassinos, empresas de seguro e navios de cruzeiro, são proprietários da

270 A história e o objetivo do Prêmio Pritzker, as informações sobre os laureados e a dinâmica das cerimônias estão disponíveis em seu site oficial: $\underline{w w w . p r i t z k e r p r i z e . c o m . ~}$

271 Segundo a coleta da revista econômica Forbes, a família Pritzker está entre os clãs mais ricos dos Estados Unidos. 
cadeia internacional de hotéis Hyatt ${ }^{272}$, fundada em 1954, rede de luxo que atualmente conta com mais de 535 empreendimentos nos Estados Unidos e no exterior. Para um empresário, colecionador de artes, filantropo e homem de espírito cosmopolita, conceder uma honraria de grande visibilidade internacional coaduna com a imagem de si que pretende construir. $O$ teor artístico do prêmio contribui para ratificar a identidade da família no mundo das artes, associando-se ao prestígio da sofisticada arquitetura de autor. Dentro de uma lógica corporativa e das estratégias de grupos de elite, o dispêndio de energia e dinheiro para instituir uma premiação não é um investimento a fundo perdido: patrocinar um evento desse porte na área da cultura representa uma vitrine que confere renome e status à família e aos negócios.

A decisão de instituir um prêmio especificamente em arquitetura é justificada pelo ambiente efervescente que floresceu em Chicago na passagem do século XIX para o século XX, com a construção dos arranhacéus comerciais. Pela cidade, passaram os principais nomes da produção arquitetônica norte-americana, Louis Sullivan, Frank Lloyd Wright, Mies van der Rohe, entre outros, que marcaram o movimento modernista na região ${ }^{273}$. Valendo-se da reputação de uma Chicago que legou modernistas arquitetos de destaque internacional, a honraria surgiu, então, com o objetivo de homenagear a cada ano um arquiteto vivo cuja carreira combinaria, na definição dos proponentes, "talento, visão e compromisso", a ponto de inspirar maior criatividade na profissão.

Mais uma vez como o Nobel, o prêmio oferece a cada premiado uma medalha de bronze comemorativa, um certificado oficial e a quantia financeira de 100 mil dólares. A medalha, desenhada pelo arquiteto Louis

272 "Jay Pritzker: Jay Pritzker, pioneer of the modern hotel chain, died on January 23rd, aged 76". The Economist, 28 de janeiro 1999.

273 O filho mais velho de Jay Pritzker, atual presidente da Fundação Hyatt, assim explica: "Como um nativo de Chicago, não é surpreendente que nossa família estivesse bem ciente da arquitetura, vivendo no berço dos arranha-céus, uma cidade repleta de prédios projetados pelas lendas da arquitetura, como Louis Sullivan, Frank Llyod Wright, Mies van der Rohe, e muitos outros". A citação em inglês: "'As native Chicagoans, it's not surprising that our family was keenly aware of architecture, living in the birthplace of the skyscraper, a city filled with buildings designed by architectural legends such as Louis Sullivan, Frank Lloyd Wright, Mies van der Rohe, and many others."'. Fonte: site oficial do Priztker. 
Sullivan, traz escrita em inglês a tríade vitruviana firmness, commodity, delight (no original em latim, firmitas, utilitas e venustas), repondo a ideia clássica de arquitetura como construção técnica, somada à beleza e à utilidade. [fig. 80] A caução financeira é dada pela empresa da família, a Fundação Hyatt, responsável por organizar todas as etapas do prêmio, indicar os jurados, definir os locais de premiação e garantir o pagamento ao vencedor. As cerimônias de consagração seguem protocolos solenes, com anúncio oficial do premiado, defesa do júri e discurso de aceitação do homenageado.

O exame dos procedimentos de designação dos premiados ajuda a compreender a lógica de seleção dos arquitetos. Ele será aqui tomado como recurso investigativo que permite destrinchar o envolvimento dos agentes nessa instância de consagração bem como a crença que é produzida e compartilhada no meio. De modo específico, cabe entender as particularidades do Pritzker, os critérios pelos quais se operam a seleção do homenageado e a reprodução dos valores próprios ao campo. De forma mais ampla, o prêmio procura distinguir arquitetos comprometidos com "a arte de fazer arquitetura", concepção que situa a produção arquitetônica sobretudo na esfera da criação artística pura, da qual se assimilam valores como talento, individualidade, vocação, domínio técnico, expressão estética e originalidade.

O processo de nomeação de candidatos é um elemento central para o entendimento da seleção que se opera nessa premiação. Os nomes de possíveis concorrentes ao Pritzker são indicados a cada ano pelos anteriormente laureados, e também por arquitetos, acadêmicos, políticos e profissionais da área. A fundação também autoriza que um postulante se autoindique, submetendo sua candidatura ao júri. Essa configuração pretende assegurar um julgamento entre os pares e intelectuais engajados na disciplina, garantindo legitimidade no interior do campo profissional e, ao mesmo tempo, prestando-se à validação das crenças já assentadas.

A crença no valor do prêmio é caucionada por uma diversidade de atores que possuem distintas formas de capitais e legitimidades, tanto culturais quanto econômicas. A correlação entre o econômico e o cultural 
fica evidente quando se levantam as posições sociais dos indivíduos que compõem o júri, nomes provenientes de diversas áreas com autoridade acadêmica, institucional e artística, que formam uma expertise nesse domínio. Historiador de arquitetura, crítico de cultura, diretor de museu de arte, jornalista de revista de ampla circulação, editor de livros e colecionador de objetos arquitetônicos são os agentes com autoridade no campo cultural selecionados para dar o veredicto ${ }^{274}$.

Uma análise sistemática das propriedades sociais dos participantes do júri de 2006, quando Paulo Mendes da Rocha foi eleito, é reveladora dos arranjos estabelecidos entre os setores mais legítimos, representados pelos pares arquitetos, críticos e especialistas; e os setores menos legítimos, em termos simbólicos, mais ligados às estruturas de poder e prestígio econômico. Entre os oito jurados empossados, três são arquitetos que trabalham com projeto, dois são representantes de editoras e publicações, um é representante de negócios na área de design, um é representante da universidade, e o presidente, Lord Palumbo, como já apresentado, uma figura extravagante, que reúne tanto capitais culturais quanto econômicos, concentrados na figura de um magnata inglês investidor no mercado imobiliário, colecionador de arte, amante da cultura e presidente de honra de diversas instituições culturais inglesas. Notável destacar que a menção de participação no júri do Pritzker aparece informada nos currículos e sites biográficos de todos os integrantes, o que mostra o status que tal posição rende.

Tendo em vista a localização geográfica dos arquitetos que compuseram o júri de 2006, nota-se a abrangência dos países representados (Índia, Canadá, Costa Rica), diversidade que visa garantir ao prêmio a universalidade pretendida quando afirmam laurear arquitetos sem distinção de nacionalidade. Entre esses arquitetos, é patente que a presença no júri se deve ao reconhecimento internacional que lograram conquistar, seja pela legitimidade angariada em sua trajetória, por meio de

274 Seguindo a hipótese de Bourdieu (1984), desenvolvida no trabalho sobre o julgamento e a legitimidade dos intelectuais franceses, é possível verificar que há uma homologia entre as características dos julgadores e as características dos premiados. Uma análise mais aprofundada das homologias entre eleitos e julgadores depende de uma ampla coleta de dados de morfologia social. 
parcerias com nomes históricos do movimento moderno, seja por conversão de sua carreira no mercado norte-americano. O indiano Balkrishna Vithaldas Doshi, por exemplo, construiu o reconhecimento de sua carreira em grande medida por estar em contato, nos anos 1950, com a equipe de Le Corbusier para a construção de Chandigarh, na qual ele foi supervisor do projeto do escritório francês na nova capital indiana; e como docente, teve o cargo de professor visitante em diversas universidades norte-americanas. A presença de Frank Gehry, um dos maiores stars da arquitetura contemporânea, concentra todo o efeito simbólico do prêmio, uma vez que ele mesmo já havia sido premiado em 1989. Sua legitimidade na instituição reverberou no contrato para construção de um pavilhão cultural em área nobre de Chicago, cujo edifício tem o nome "Jay Pritzker", em homenagem ao patrono do prêmio. O costa-riquenho Carlos Jimenez, representante da nova geração de arquitetos, é responsável por um escritório nos Estados Unidos, pequeno mas de grande visibilidade, que desfruta de publicações monográficas em importantes editoras. Além da atividade de projetos, atua como docente na Rice University e professor visitante em outras universidades em seu país. Embora seja latino-americano, o arquiteto fez sua trajetória escolar (colégio e graduação) em Houston, onde permanece com seu escritório desde 1983. Desse modo, é possível considerar que sua participação na comissão de julgamento se deve à sua fixação institucional e profissional, e não à sua nacionalidade.

É possível afirmar que os arquitetos que compuseram o corpo de jurados específico de Paulo Mendes da Rocha, ainda que sejam oriundos de diferentes nacionalidades, construíram sua trajetória em contato com o campo norte-americano, o que mostra que dispunham anteriormente de reconhecimento validado no país.

Quanto aos demais integrantes da comissão julgadora, as intersecções entre os polos da economia e da cultura são uma evidência na composição do júri. Tal verificação se expressa pela presença de críticos, escritores e diretor de museu que combinam em sua carreira trunfos conquistados no mundo dos negócios e no mundo da arte. Como se pode ver no quadro sintético apresentado a seguir, trata-se de agentes híbridos, 
que ocupam ao mesmo tempo posições tanto nos meios empresariais quanto nos meios artísticos, construindo sua legitimidade nessa dupla acumulação de capitais. Dois dos jurados que poderiam inicialmente ser identificados no polo da legitimidade acadêmica, como crítico, escritor e historiador de arquitetura, construíram suas trajetórias ligados às instâncias de circulação, participando de cargos centrais em grandes editoras da área ou como proprietária de conglomerado nos meios de comunicação impresso. É o caso da crítica de arquitetura Karen Stein, cuja carreira está ligada ao alto cargo que ocupou como editora da área de arte na Phaidon, empresa de grande prestígio no mercado de livros de arquitetura, e da estudiosa de arquitetura Victoria Newhouse, casada com o bilionário proprietário da Advance Publications, grande companhia responsável pela publicação de dezenas de revistas em diversas áreas, entre elas moda, beleza, lifestyle, e também arte, arquitetura, literatura, tais como Vogue, Allure, Vanity Fair, Architectural Digest, The New Yorker, entre outras.

Se os setores responsáveis pelas dinâmicas da circulação estão representados por agentes dos meios de comunicação e do mercado editorial, o domínio empresarial produtivo está representado pela presença de industriais do setor moveleiro. É o caso do terceiro integrante do júri, o alemão Rolf Fehlbaum, proprietário da Vitra, empresa de fabricação de móveis de alto padrão, com filiais em mais de 17 países (Estados Unidos, Suíça, Japão, China, França, Espanha, Bélgica, México, entre outros), especializada na fabricação dos clássicos mobiliários assinados por grandes designers. O empresário também foi responsável no final dos anos 1990 por construir um "parque arquitetônico" com edifícios de grandes celebridades da arquitetura contemporânea. Ali se encontra o Vitra Museum Design, projetado por Frank Gehry, espaço de exposição da coleção particular de Fehlbaum sobre história do design de móveis. Além de Gehry, outros stars projetaram os principais edifícios: o pavilhão de conferências foi desenhado pelo arquiteto japonês Tadao Ando, o ateliê de fabricação pelo português Alvaro Siza, o posto de bombeiros é da iraquiana Zaha Hadid e o showroom da loja foi assinado pela dupla suíça Herzog \& de Meuron. O fato de todos os arquitetos contratados para os projetos terem sido premiados pelo Pritzker é expressivo do encorajamento material e artístico que o 
empresário-encomendante cumpre no meio, tanto aplicando investimentos econômicos para patrocinar grandes arquitetos, quanto resgatando esses investimentos no plano simbólico, ao valorizar as mercadorias que movimentam seu negócio.

Mesmo se tratando de um evento de consagração simbólica, os deslocamentos por vezes ambíguos entre arte e dinheiro, valorização estética e empreendimento comercial estruturam as dinâmicas da premiação. É importante advertir, no entanto, que não se trata de jogo cínico ou de cálculo consciente travestido de declaração de amor pela arquitetura, mas um envolvimento com o prêmio cujo investimento faz parte de uma transação simbólica, em que noções de prestígio, status e renome estão atravessadas de significados econômicos. Quando ampliados para os espaços de produção simbólica, os termos por vezes associados a recompensas financeiras, tais como empréstimo, retorno e lucro, contribuem para clarificar a circularidade das transações entre economia e cultura, principalmente em sistemas de trocas não exclusivamente monetários.

A eficácia cultural do prêmio está justamente na união entre estética e economia, entre desinteresse e autopromoção, o que reafirma o axioma principal dos administradores das premiações, para os quais o prestígio dos prêmios tem relação direta com o dos juízes, um garantindo ao outro status e honra275. No caso do Pritzker, é a dupla concentração de capitais simbólicos e econômicos que constitui a força da honraria, o que a faz emergir como uma autoridade global de credenciamentos dos arquitetos de elite, sustentada em regime de visibilidade midiática.

\begin{tabular}{|l|l|l|l|l|l|}
\hline \multicolumn{2}{|l|}{ Quadro: Propriedades Sociais dos membros participantes do Júri Pritzker 2006} \\
\hline Membros & $\begin{array}{l}\text { Presença } \\
\text { no júri do } \\
\text { Pritzker }\end{array}$ & país & $\begin{array}{l}\text { Trunfos } \\
\text { específicos }\end{array}$ & $\begin{array}{l}\text { Área de atuação } \\
\text { profissional }\end{array}$ & $\begin{array}{l}\text { Circulação } \\
\text { internacional }\end{array}$ \\
\hline $\begin{array}{l}\text { Lord Palumbo } \\
\text { presidente } \\
(1935)\end{array}$ & $\begin{array}{l}2005 \text { até o } \\
\text { momento }\end{array}$ & $\begin{array}{l}\text { Reino } \\
\text { Unido }\end{array}$ & $\begin{array}{l}\text { Magnata } \\
\text { colecionador de } \\
\text { arte, relações com }\end{array}$ & $\begin{array}{l}\text { Promotor } \\
\text { imobiliário, } \\
\text { colecionador de de }\end{array}$ & Elite internacional \\
\hline
\end{tabular}

275 ENGLISH, James. The Economy of Prestige. Prizes, Awards and the Circulation of Cultural Value. Cambridge/London, Havard University Press, 2005. p.122-123 


\begin{tabular}{|c|c|c|c|c|c|}
\hline & & & a nobreza inglesa & arte & \\
\hline $\begin{array}{l}\text { Balkrishna } \\
\text { Vithaldas } \\
\text { Doshi } \\
(1927)\end{array}$ & $2005-2007$ & Índia & $\begin{array}{l}\text { Trabalhou com Le } \\
\text { Corbusier entre } \\
\text { 1951-1954, } \\
\text { Discípulo de Louis } \\
\text { Kahn }\end{array}$ & $\begin{array}{l}\text { Arquiteto, autor } \\
\text { de projetos, } \\
\text { professor } \\
\text { diplomado na } \\
\text { School J. } \\
\text { Architecture } \\
\text { Mumbai }\end{array}$ & $\begin{array}{l}\text { Doutor honorário da } \\
\text { Universidade da } \\
\text { Pennsylvania; } \\
\text { professor visitante em } \\
\text { diversas universidade } \\
\text { norte-americanas }\end{array}$ \\
\hline \begin{tabular}{|l|} 
Rolf Fehlbaum \\
$(1941)$
\end{tabular} & $2004-2010$ & $\begin{array}{l}\text { Alema- } \\
\text { nha }\end{array}$ & $\begin{array}{lr}\text { Contato } & \text { com } \\
\text { grandes arquitetos } \\
\text { para produção de } \\
\text { móveis } & \\
\text { certificados, } & \\
\text { empresário } & \text { e } \\
\text { cliente } & \text { de } \\
\text { arquitetura } & \text { de } \\
\text { autor } & \end{array}$ & 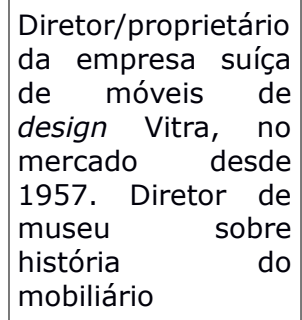 & $\begin{array}{l}\text { Empresário } \\
\text { internacional, } \\
\text { empresa em mais de } \\
17 \text { países, entre eles, } \\
\text { Suíça, China } \\
\text { Alemanha, EUA, } \\
\text { Áustria, Suécia, } \\
\text { Bélgica, França, Japão, } \\
\text { México etc. }\end{array}$ \\
\hline $\begin{array}{l}\text { Frank Gehry } \\
(1929)\end{array}$ & $\begin{array}{l}1993-1995 \text { 2003- } \\
2006\end{array}$ & $\begin{array}{l}\text { Canadá } \\
\text { e } \\
\text { Estados } \\
\text { Unidos }\end{array}$ & $\begin{array}{lr}\text { Vencedor } & \text { do } \\
\text { prêmio em 1989, } \\
\text { considerado } \\
\text { grande star da } \\
\text { arquitetura } & \\
\text { contemporânea; } \\
\text { autor do projeto do } \\
\text { pavilhão r Jay } \\
\text { Pritzker, r em } \\
\text { Chicago } & \end{array}$ & 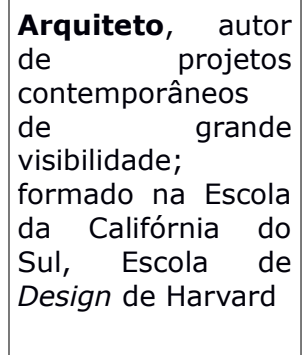 & $\begin{array}{l}\text { Museu de Bilbao, obras } \\
\text { na Austrália, França, } \\
\text { República } \quad \text { Tcheca, } \\
\text { exposição de sua obra } \\
\text { no Centre Georges } \\
\text { Pompidou }\end{array}$ \\
\hline $\begin{array}{l}\text { Carlos } \\
\text { Jimenez } \\
(1959)\end{array}$ & 2001-2011 & $\begin{array}{l}\text { Costa } \\
\text { Rica }\end{array}$ & $\begin{array}{l}\text { Reconhecido nos } \\
\text { EUA; } \\
\text { escritório } \\
\text { Houston; } \\
\text { docente visitante } \\
\text { em diversos países }\end{array}$ & $\begin{array}{l}\text { Arquiteto, Studio } \\
\text { Carlos Jimenez }\end{array}$ & $\begin{array}{lr}\text { Várias } & \text { publicações } \\
\text { sobre sua obra, nas } \\
\text { editoras } & \text { Princeton } \\
\text { (1996), } & \text { Dap } \\
\text { Distributed Art (2009), } & \text { revista monográfica 2G }\end{array}$ \\
\hline $\begin{array}{l}\text { Victoria } \\
\text { Newhouse }\end{array}$ & $2005-2008$ & $\begin{array}{l}\text { Estados } \\
\text { Unidos }\end{array}$ & $\begin{array}{l}\text { Esposa de } \\
\text { empresário } \\
\text { bilionário do setor } \\
\text { de publicações na } \\
\text { área de cultura, } \\
\text { estilo, moda, como } \\
\text { Vogue, Vanity Fair, } \\
\text { The New Yorker }\end{array}$ & $\begin{array}{l}\text { Escritora, crítica, } \\
\text { editora de livros, } \\
\text { diretora da } \\
\text { Architectural } \\
\text { History Foundation }\end{array}$ & Elite internacional \\
\hline Karen Stein & 2004-2012 & $\begin{array}{l}\text { Estados } \\
\text { Unidos }\end{array}$ & $\begin{array}{l}\text { Editora da Phaidon, } \\
\text { líder mundial na } \\
\text { publicação de } \\
\text { livros de arte e } \\
\text { arquitetura }\end{array}$ & $\begin{array}{l}\text { Escritora, crítica } \\
\text { editora }\end{array}$ & $\begin{array}{l}\text { Editora em uma } \\
\text { companhia } \\
\text { circulação internacional }\end{array}$ \\
\hline $\begin{array}{l}\text { Martha Thorne } \\
\text { (diretora } \\
\text { executiva) }\end{array}$ & $\begin{array}{l}2005 \text { até o } \\
\text { momento } \\
\text { (não tem direito a } \\
\text { voto) }\end{array}$ & $\begin{array}{l}\text { Estados } \\
\text { Unidos }\end{array}$ & $\begin{array}{l}\text { Curadora na área } \\
\text { de arquitetura do } \\
\text { Instituto de Arte } \\
\text { ed Chicago }\end{array}$ & $\begin{array}{lr}\text { Professora } & \text { na } \\
\text { Escola } & \text { de } \\
\text { Arquitetura } & \text { e } \\
\text { Design de Madri } & \end{array}$ & $\begin{array}{l}\text { Docente na escola de } \\
\text { Madri; bacharelado em } \\
\text { Artes na University of } \\
\text { New York }\end{array}$ \\
\hline
\end{tabular}

Se por um lado a composição da comissão de julgamento contou com agentes que capitalizam trunfos nos polos econômicos e culturais, a carga de maior legitimidade ao prêmio de Paulo Mendes da Rocha veio com o ensaio incluso no material da condecoração, encomendado ao renomado historiador italiano Francesco Dal Co (1945). Eminente crítico de arquitetura 
e professor da Escola de Veneza, Dal Co acumulou sua autoridade especificamente entre os pares desde o início da carreira, em meados dos anos 1970, quando produziu análises sobre história da arquitetura moderna com Manfredo Tafuri (1935-1994). Esses trabalhos tinham como alvo as ideologias da arquitetura moderna, assumindo a partir de uma abordagem marxista uma crítica radical às utopias das vanguardas e às relações entre arquitetura e produção capitalista ${ }^{276}$. Desde 1996, Dal Co assumiu a diretoria da revista Casabella, uma das principais publicações mundiais da área, e também dirige o departamento de arquitetura da editora Mondadori, maior editora italiana, que possui um ramo especializado em publicações de arte, para a qual foi também de autor monografias sobre os arquitetos Frank Gehry e Tadao Ando, ambos arquitetos pertencentes à elite do Pritzker. O relacionamento com o mercado editorial global e com agentes da premiação impulsionou em 2009, três anos após ser premiado, uma pesquisa sobre Paulo Mendes da Rocha, encomenda que saiu em livro monográfico: Paulo Mendes da Rocha Obra Completa, a publicação mais extensa sobre o arquiteto. Foi Dal Co que indicou seu antigo aluno Daniele Pisani, arquiteto e historiador da Escola de Veneza, para fazer o trabalho de catalogação e análise da obra de Mendes da Rocha. O livro foi lançado em italiano em 2013 pela Electa; em 2014, em português pela espanhola Gustavo Gilli, e em 2015 em inglês pela editora Rizzoli - uma variedade de edições e traduções que evidenciam o empenho e a aposta na difusão internacional da obra do arquiteto brasileiro.

Além da presença de agentes com circulação internacional, a articulação com primeiros-ministros ou funcionários do alto escalão do governo dos países-sede, é reveladora dos jogos econômicos, culturais e políticos que se enredam na premiação. O deslocamento geográfico, a cada edição, da cerimônia de premiação, pode ser entendido como uma

276 Os principais trabalhos do crítico e do grupo reunido em torno de Tafuri, no final dos anos 1960 e início dos anos 1970, são: DAL CO, Francesco. Note per la critica dell'ideologia dell'architettura moderna: da Weimar a Dessau. Contropiano, Materiali Marxisti, no. 1, 1968, 153-171. TAFURI, Manfredo; CACCIARI, Massimo e DAL CO, Francesco. De la vanguardia a la metropoli: critica radical a la arquitetura. Barcelona, Gili, 1972. Dal Co, F., ed., Architettura o rivoluzione: Hannes Meyer, Scritti 1921-1942, Padova, 1969. Sobre a base filosófica da crítica da Escola de Veneza: Cf. FRAJNDLICH, Rafael Urano. Tafuri: tempo da cidade longínquia. São Paulo, FAU USP, 2014. tese de doutorado. 
estratégia de ampliação da repercussão da premiação, ação que se soma aos imperativos de difusão e construção de uma autoridade global para o Pritzker. A itinerância se apresenta como um investimento que garante o aumento da reputação da premiação e dos arquitetos condecorados. Uma vez que são chamados a participar do cerimonial convidados de honra e a elite política do país ou da região, os vínculos estabelecidos podem representar o acesso a um patronato estatal com poder decisório sobre novas encomendas.

Conforme explicitação no material de divulgação do Pritzker, a cada edição, o evento é realizado em um local diferente, dentro ou fora dos Estados Unidos, tendo como critério a escolha de um edifício de "significativa arquitetura". A eleição dessa obra arquitetônica também participa do sistema de reputações, o que fica evidente pelo material apresentado junto a cada laureado, onde se justifica a escolha da cidade e do edifício, valorizando o caráter histórico do projeto. São escolhidos, na maioria das vezes, museus, galerias de arte, palácios, ou seja, espaços de referência na área das artes e da cultura ${ }^{277}$. Os edifícios selecionados buscam representar estilos arquitetônicos de diferentes escolas e períodos. Embora os promotores da premiação prezem pela distribuição geográfica, uma análise dos 37 locais em que foram realizadas as cerimônias revelam grande concentração em países do hemisfério norte, principalmente Estados Unidos e Europa. Mais da metade das edições ocorreram nos Estados Unidos, com preferência para as cidades de Chicago e Washington. Inglaterra, Itália e Espanha sediaram duas edições do prêmio. Na América do Sul, a única cidade já escolhida foi Buenos Aires, em 2009, dois anos depois da inauguração do primeiro hotel Hyatt na Argentina.

Quanto aos premiados, análise feita com todos os laureados ${ }^{278}$

277 São exemplos de espaços: Metropolitan Museum of Art, em Nova Iorque; Palácio de Versalhes, em Paris; um castelo em Praga; Museu Guggenheim Bilbao, de Frank Gehry, na Espanha; Campidólio de Michelangelo (Roma) e Palazzo Grassi (Veneza), na Itália; um templo budista no Japão; e até mesmo o Parque Arqueológico de Jerusalém, em Israel.

2780 site do Pritzker possui galeria com apresentação de todos arquitetos premiados. Embora a análise detida desse material pudesse revelar de forma mais ampla os padrões de premiação do Pritzker, uma vez que o interesse é especificamente a presença de Paulo Mendes da Rocha no prêmio, optou-se aqui por apenas apresentar algumas linhas gerais, mais do que a dinâmica da premiação em um corte diacrônico. 
permite expor algumas características de idade, gênero, nacionalidade e formação escolar. A idade dos condecorados - maioria com mais de 55 anos à época da premiação - sugere que a consagração na carreira de arquiteto se completa na maturidade. Há ganhadores que receberam o prêmio aos 90, 85 e 80 anos. Os mais novos ganharam aos 44 e 49 anos, e a média de idade fica em torno de 63 anos. A irrelevante presença de mulheres entre os premiados chama a atenção e foi motivo de grande polêmica em 2013, quando uma estudante de Harvard mobilizou assinaturas reivindicando a inclusão entre os laureados do nome de Denise Scott Brown, parceira profissional e esposa de Robert Venturi. Venturi havia ganhado o prêmio em 1991, mas a seleção do Pritzker apenas concedeu a láurea ao arquiteto, desconsiderando que ela havia sido parceira em projetos arquitetônicos e também em importantes referências teóricas da arquitetura, como Aprendendo com Las Vegas (1977). Dentre os 40 eleitos da lista, apenas duas foram mulheres, a iraquinana naturalizada inglesa Zaha Hadid, em 2004, e a japonesa Kazuyo Sejima, em 2010, baixíssimo índice quando se tem em conta que o métier de arquiteto é predominantemente feminino ${ }^{279}$.

Ainda que o imperativo da premiação seja garantir ampla distribuição geográfica e condecorar arquitetos independentemente de "nacionalidade, raça, credo ou ideologia", observa-se que os premiados são em sua maioria arquitetos norte-americanos e europeus. No entanto, para além da nacionalidade, é passagem por instituições de ensino norte-americanas,

279 Estatísticas recentes sobre a presença feminina na arquitetura mostram que o exercício profissional de mulheres concentra-se no trabalho assalariado e no funcionalismo público, polo de menor prestígio e sem chance de notoriedade quando comparado ao polo legitimado e artístico, ou seja, a atuação autônoma em escritórios e firmas associadas - que dá o tom da profissão liberal tal como ela é reconhecida na chave do talento. Na falta de estatísticas globais, usou-se como referência uma recente pesquisa francesa, encomendada pelo Ministère de la Culture et de la Communication, intitulada "Statistiques de la profession d'architecte 19982007 Socio-démographie et activités économiques", coordenada por Olivier Chadoin e Thérèse Evette. No Brasil, os egressos dos cursos de Arquitetura passam a ser em sua maioria mulheres a partir dos anos 1980, tendência que permanece na primeira década do século XXI. Como mostra o trabalho de Flávia Carvalho de Sá, o aumento da presença feminina na profissão concentrou-se na área de decoração de interiores, espaço doméstico associado ao universo feminino. Em relação ao contrato de trabalho, as mulheres são também maioria a assumir a condição de freelancers, forma de atuação sem vínculo empregatício e sujeita à instabilidade de rendimento mensal. Cf. SÁ, Flávia Carvalho de. Profissão: Arquiteta. Formação Profissional, mercado de trabalho e projeto arquitetônico na perspectiva das relações de gênero. São Paulo, FAU USP, 2010. (dissertação de mestrado). 
como Harvard, Princeton, Instituto Tecnológico de Chicago e MIT (Instituto Tecnológico de Massachusetts), seja na graduação em Arquitetura ou na docência, que contribuiu para colocá-los em contato com uma rede de consagração hegemônica. Em sua maioria, são arquitetos que desfrutavam de grande reputação, com obras construídas em diversos países e reconhecidos por serem "stars" da arquitetura mundial. Fazem parte dos circuitos de celebração, com obras consideradas emblemáticas da arquitetura moderna ou pós-moderna.

A se levar em conta os capitais internacionais acumulados pelos arquitetos que conquistaram a honraria, pode-se verificar que Paulo Mendes da Rocha é um daqueles que menos dispunha desses trunfos. A consagração do arquiteto foi constituída, sobretudo, em território nacional, reforçada pelos críticos, historiadores e divulgadores da arquitetura brasileira que assumiram o trabalho simbólico de valorização da arquitetura produzida em São Paulo enfatizando o virtuosismo estético e engajamento político. Cumpre ressaltar que a inclusão do brasileiro no panteão universal dos arquitetos causa estranheza pela pouca reverberação internacional de que ele dispunha naquele momento, principalmente quando se tem em conta que, até então, não havia construído nenhum edifício fora do território brasileiro.

Ainda que Mendes da Rocha possa ser visto como o menos festejado dos arquitetos condecorados, sua presença entre os eleitos se explica por um valor distintivo radical. Ele encarna com eloquência a figura exemplar do arquiteto criador, aquele que, "fiel a si mesmo", a tudo renuncia para incorporar uma profissão de fé em nome de uma arquitetura austera e rigorosa, versão formal de uma conduta pura e desinteressada, com a qual se coloca distante de qualquer espetacularidade, recusando qualquer emblema de ostentação. Para o Pritzker, o caráter ascético e modesto da trajetória de Mendes da Rocha contribui para imprimir ao prêmio o valor sublime da arquitetura que não se conforma às exigências do mercado. 


\section{Celebração de um arquiteto-autor}

Como apontado, no Prêmio Pritzker, os diversos materiais que oficialmente compõem o ritual de consagração - a organização e a escolha do local da cerimônia, a seleção dos integrantes do júri, o texto de anúncio do ganhador, a avaliação dos julgadores, o ensaio assinado por um crítico e historiador de arquitetura, o discurso de aceite por parte do ganhador, a produção de um resumo biográfico e a seleção dos principais trabalhos do premiado - são expressivos da economia simbólica do prêmio ${ }^{280}$. Todas essas práticas e discursos não são anódinas, são elementos constitutivos da produção de sentidos sobre a crença estabelecida no campo da arquitetura, para o qual a posição mais legítima do arquiteto é a condição de indivíduo criador.

O prêmio ratifica, em termos simbólicos, operações de acumulação de prestígio e reputação que são produzidas no campo da arquitetura e validadas pelos pares. Por seu efeito de consagração, essa premiação eleva à máxima visibilidade a maior propriedade de um arquiteto, que é aquisição de um nome, ser conhecido por sua assinatura, ter uma concepção arquitetônica avaliada como coerente, uma produção que possa ser identificada pelo "traço do arquiteto" ou, em termos mais amplos, ser distinguido por uma expressão original. Como instância de consagração, o Pritzker confere validade e faz circular a ideia de um arquiteto que desfruta da posição de autor, reconhecido, sobretudo, por sua imaginação, extravagância e inovação estética, qualidades inventivas plasmadas por uma expressão individual. Trata-se de uma premiação que implica o reconhecimento da figura de um arquiteto criador, ou seja, um praticante da profissão a quem se credita uma personalidade artística singular.

Originalidade e gratuidade são elementos centrais que sustentam o culto à capacidade criadora do arquiteto. O estatuto de criador do qual os

280 O site do prêmio disponibiliza, de todos os condecorados, diversas peças que compõem o ritual da premiação: pronunciamento do vencedor, breve biografia, citação do júri, ensaio assinado por um especialista amplamente reconhecido na área, seleção das principais obras do arquiteto, detalhes sobre o local da cerimônia, com imagens e vídeos. É sobre esse material denso em informações que se baseia as análises que se seguem. 
arquitetos se beneficiam oferece à profissão uma imagem demiúrgica, ou seja, a convicção profunda no poder de um ente divino que, seguindo suas inspirações mais autênticas, organiza e projeta o universo. Esse sistema de valor é assegurado pela responsabilidade moral que sustenta uma motivação desinteressada em produzir o belo, isto é, de organizar a vida por padrões de sensibilidade.

Essas representações correntes nas leituras ${ }^{281}$ sobre o arquiteto têm como fundamento a noção de talento, para a qual se prevê capacidades artísticas inatas provenientes de uma benção divina. Essa visão, que nos termos de Pierre Bourdieu pode ser nomeada de "ideologia carismática", fica explicitada nas citações da comissão de julgamento e nos textos de anúncio de Paulo Mendes da Rocha. O arquiteto é visto como um artista em potencial. Ele é exaltado como personagem heroico, valente e ousado, que, crente de seus ideais, segue seus instintos em nome da proposta autoral. Audácia, sensibilidade, atemporalidade são as qualidades que compõem o retrato de um profissional digno de triunfar na premiação. O léxico hagiográfico empregado é expressivo da reiteração da imagem do arquitetoautor, responsável por projetos criativos, que exprime sua originalidade como vocação, e que, como se estivesse respondendo a esse chamado mágico, devota seu amor à arte de fazer arquitetura.

Os documentos textuais, que são parte integrante do ritual, deixam indicados os padrões de excelência adotados pelas instituições de consagração. Uma mostra dos termos empregados no Pritzker oferece indícios significativos da invocação autoral que se propõe a legitimar: "criatividade", "coragem", "lições universais", "arrojo", "luta heroica", "irrequieto", "inventivo", "destemor," "sem medo de correr riscos", "poética do espaço", "exuberância formal", "formas visionárias", "projeto audacioso", "lírica dos materiais", "sensibilidade poética", entre outros que se apoiam na crença do valor inefável da arquitetura. Quando referidas ao edifício, tais

281 Cito apenas um entre os vários exemplos para demonstrar o tom apologético que essas representações disseminam na imprensa ampliada: "Paulo Mendes da Rocha é o retrato do arquiteto, o artista, aquele que une à técnica uma visão cósmica, espiritual, política do homem. E ele consegue expor esse pensamento com outra virtude humana indispensável: o humor, e colocações desconcertantes [...]" Entrevista com Arquiteto, "A natureza é um Trambolho", In Revista Caros Amigos, abril, 2002. 
expressões presumem uma noção de arquitetura estreitamente ligada à ideia de arte pura, em que o apelo ao formal se impõe como instrumento da sublimação do universal. Quando referidos ao arquiteto, esses termos pressupõem uma carreira coerente de arquiteto artista, cuja excelência é avaliada pela expressão e pela personalidade criativa. Indivíduo e obra são apresentados como entidades descontextualizadas. A contemplação estética figura como matriz de análise dos edifícios e o enaltecimento da trajetória singular reproduz essa visão demiúrgica do papel do arquiteto, aquele que com seus poderes divinos inventa formas a partir do nada.

O discurso que o Pritzker dissemina é de celebração da figura do arquiteto que legou para humanidade uma contribuição capaz de fazê-lo entrar para história da arquitetura e para o panteão dos notáveis. Tal visão está assentada na ideia de uma valorização da concepção autoral da arquitetura, dando primazia à inovação estética e à habilidade artística individual. Essa posição encontra um paralelo evidente no mundo da arte e na dinâmica dos artistas, para os quais o poder expressivo individual e plasticidade das formas, no discurso e na prática artística, detêm a primazia. Não é à toa que os ganhadores estão associados a movimentos de vanguarda na história da arquitetura, fazem parte de movimentos artísticos e tem suas obras avaliadas dentro dos parâmetros da crítica estética, cujas formas de apreciação e julgamento recaem sobre a avaliação de aspectos formais e da fruição artística. Do mesmo modo que no mundo da arte, a profissão do arquiteto tensiona a oposição que separa em dois polos antagônicos: o sucesso comercial, produto de uma atividade associada aos negócios, e o reconhecimento simbólico, acúmulo de reputações e consagrações legitimadas no campo.

Como é próprio da lógica da produção de bens simbólicos ${ }^{282}$, a sacralização da figura do criador vem acompanhada de uma postura de afastamento do mundo econômico. A recusa do comercial encontra na

282 A denegação do econômico, o interesse pelo desinteresse e o recalque dos lucros comerciais são questões centrais na teoria de Pierre Bourdieu sobre a lógica de funcionamento do mercado de bens simbólicos. 0 aporte teórico aqui utilizado são, especialmente, os artigos compilados, no Brasil, em dois livros: BOURDIEU, Pierre. Economia das Trocas Simbólicas. São Paulo, Perspectiva. BOURDIEU, Pierre. A produção da crença: contribuição para uma economia dos bens simbólicos. Porto Alegre: Zouk, 2008. 
arquitetura seu correspondente na depreciação da produção arquitetônica identificada com a submissão aos desejos do encomendante ou presa a soluções utilitárias, produção que é tachada de "arquitetura de negócios" ou "arquitetura burguesa". A figura do arquiteto criador se opõe à figura do arquiteto empresário: enquanto o primeiro está associado ao mundo da arte e dos valores estéticos, centrado na figura de um produtor, o segundo está associado a uma postura pragmática, ligada à atuação em um escritório que responde aos imperativos de rentabilidade mercantil e da mera visibilidade midiática. O arquiteto criador é aquele que, liberto de preocupações materiais, declara seu amor a uma arquitetura enquanto jogo de volumes no espaço, condensando um olhar puro sobre o objeto arquitetônico. Os arquitetos que triunfam nas instâncias de consagração, cujo caráter é eminentemente simbólico, são aqueles que conseguiram controlar sua trajetória em direção a uma concepção de arquitetura enquanto forma, comprometendo-se a ressoar os valores historicamente assentados no campo.

Na arquitetura de Paulo Mendes da Rocha, a denegação do econômico e a recusa pelos efeitos mais emblemáticos da estética burguesa tomam forma no uso dos materiais, na concepção estética dos edifícios e nos programas dos espaços. A constituição do artista puro, alheio às imposições mundanas, é entoada pelos comentadores da obra do arquiteto, que reiteram valores de desprendimento e pureza, reificando a atuação de um artista isolado, em contato único com seu fazer. Obra depurada e vida purificada convergem na recusa de requinte e na negação do luxo. Rejeitando os acabamentos e os revestimentos polidos, a austeridade do concreto aparente emerge como um esforço de controlar esteticamente um material ordinário. A resolução do programa em um edifício compacto, com elementos simples e facilmente identificáveis, muitas vezes um cubo suspendido ou uma forma fechada em si mesma, é apresentada como índice de coerência estilística, precisão técnica e rigor formal. Os críticos e historiadores esforçam-se para definir a singularidade dessa produção, ressaltando os poucos elementos construtivos utilizados - concreto e aço como característica de um essencialismo poético ou um recolhimento introspectivo do arquiteto. 
Por seu caráter exemplar, cito um trecho da homenagem que Hugo Segawa, historiador e professor da FAU-USP, faz ao arquiteto, quando ele recebeu o título de professor emérito da mesma instituição. O registro, que pretende inserir Paulo Mendes da Rocha como expressão do universal, acaba por desencarná-lo da tradição paulista, absolutizando-o em nome da figura heroica de um criador que expressa uma subjetividade única:

"Esse essencialismo é uma das chaves para o entendimento da obra de Paulo Mendes da Rocha: uma intuição que busca apreender não só as características estruturais comuns das coisas, mas a unidade superior que relaciona a arquitetura, a arte, a política, a vida [...]. Ao buscar o essencial, o arquiteto permanentemente refaz uma mesma trajetória atrás dessa essência. Ele nunca estabelece um caminho de volta, um retorno, um recomeço para cada obra. Há sempre um fio condutor, aproveitando um caudal de ideias ricas ou estimulantes que, agregadas à capacidade de criar, conduzem a soluções originais e inesperadas. Valores universais cuja depuração sintetiza o mínimo, transformando a concisão no cerne da espirituosidade. Ao depurar o essencial dos valores, cria uma visão própria de mundo, rejeitando um vasto e supostamente inarticulado universo externo, excluindo outras medidas de referência que, certamente, tornam mais difíceis a comunhão dessas essências e a fruição dessa arquitetura. Caminha-se para a introspecção. Dois extremos da experiência poética e humana: a comunhão e a solidão. A essência como uma dimensão poética do recolhimento introspectivo." ${ }^{283}$

Essas tomadas de posição estéticas são frequentemente associadas pelos críticos a uma postura de singeleza, desprendimento e abnegação. $\mathrm{Na}$ história da arquitetura, a limitação de componentes e a ausência de revestimentos foi difundida com a denominação de "verdade dos materiais", princípio estético cujo discurso pretendeu ressaltar a pureza de uma arquitetura sem truques e simulações, tão cara às concepções de Vilanova Artigas. São leituras que associam a produção do arquiteto a uma

283 SEGAWA, Hugo. "Paulo Mendes da Rocha recebe título de professor emérito da Fauusp". In. Revista Pós, V.17, no 28, São Paulo, dez, 2010. p.220-227. p.227. 
postura ética de desapego, simplicidade, radicalidade, pureza de intenções e compromisso social. Na visão dos porta-vozes do brutalismo paulista, o amor pelo concreto bruto é uma forma de amor ao absoluto. $O$ arquiteto é valorizado como uma profissional que produz pouco pois não cede à especulação imobiliária nem ao gosto dos clientes nem aos valores individualistas, que na visão dos comentadores, seria produzir para condomínios fechados. Como estamos no terreno do simbólico, o artista é consagrado distante do mundo econômico, o que permite que o arquiteto possa se ausentar do mundo do mercado e atuar no ponto mais legítimo do valor estético e ético.

O estiramento da oposição entre recusa econômica e ganho simbólico é patente nas análises da obra do arquiteto. No ensaio do Pritzker, Francesco Dal Co define a produção de Mendes da Rocha como uma poética regida pela "elegância da pobreza", característica formal considerada como sua contribuição única e original. A justaposição de termos que frequentemente se apresentam como pares de opostos chama a atenção. Tudo se passa como se o arquiteto tivesse a capacidade mágica de extrair beleza dos elementos brutos, sem valor, transformando desalinho em requinte, rudeza em refinamento. O crítico replica uma visão assentada sobre a obra do arquiteto, em que as escolhas estéticas são analisadas como emanações poéticas e vistas como decantação de uma pureza formal alheia às vicissitudes comerciais. A recusa ao excesso se apresenta como defesa da arquitetura simples e rigorosa, árdua e áspera, materialização de uma postura de quem não se submete ao luxo e alarde, termos que passam a ser associados ao repertório burguês e a estilos de estilos de vida dispendiosos. Por fim, tal exigência crítica é creditada à força formativa de Vilanova Artigas:

"Artigas reforçou a conviç̧ão de Mendes da Rocha que arquitetura deve ser praticada em 'sua dimensão humana' guiada pelo compromisso com a sociedade, com a vida, utilizando as ferramentas em mãos e com a consciência de que 'nunca se pode construir um edifício acabado'"'284

284 DAL CO, Francesco. "Paulo Mendes da Rocha: Listen to and observe a master". Ensaio de premiação. Site Pritzker. No original: “Artigas reinforced Mendes da Rocha's conviction that 
Ao iniciar o ensaio em homenagem ao premiado, a epígrafe que o crítico coloca em destaque é justamente uma citação feita pelo próprio arquiteto, também repetida em outra de suas monografias ${ }^{285}$, na qual Mendes da Rocha enuncia suas categorias de apreciação:

"Ao contrário de muitas pessoas que têm medo da pobreza, sempre fui atraído por ela, para coisas simples, sem saber por quê. Não dificuldades, mas a humildade de coisas essenciais. Eu acho que tudo supérfluo é irritante. Tudo o que não é necessário se torna grotesco, especialmente em nosso tempo"286.

O realce dado ao testemunho do arquiteto coloca em evidência a lógica em jogo, para a qual a grandiosidade da arquitetura reside na despretensão e na sobriedade. Os pares de oposição empregados explicitam o confronto entre uma arquitetura pura, essencial, baseada em elementos fundamentais, contra uma arquitetura conspícua que se afirma pelo excesso e pela ostentação, que se vale de artifícios e que descambaria em futilidade. Opõe-se o necessário contra o supérfluo. Exasperar-se com a profusão de ornamentos, com a arquitetura extravagante, ou na palavra do arquiteto, com o "grotesco", se apresenta tanto como tomada de posição estética quanto de posição ética. A escolha estética pelo necessário não se trata, obviamente, de uma imposição pela privação, como o destino das classes populares, cuja aceitação do necessário se impõe sem escolha. A escolha do necessário, do oportuno, do austero e do sóbrio se apresenta como elemento de distinção que se realiza pela modéstia - a negação da vaidade e a afirmação de uma

architecture must be practiced in "sua dimensão humana" guided by a commitment to society, the times, life, using the tools at hand, and in awareness of the fact that "you can never build anything finished"

285 PINON, Hélio. Paulo Mendes da Rocha, Escuela Técnica Superior de Arquitectura de Barcelona (ETSAB), Barcelona, 2003.

286 Citação de Paulo Mendes da Rocha usada como epígrafe no ensaio crítico ao arquiteto: DAL CO, Francesco. "Paulo Mendes da Rocha: Listen to and observe a master". Disponível em: www.pritzkerprize.com/sites/default/files/file fields/field files inline/2006 essay 0.pdf Acesso em 22/01/2015. 
arquitetura que se basta com o minimamente necessário projetam sentimentos de nobreza e virtuosismo moral.

Tal conduta também se expressa quanto à aparente virtude dos programas de edifícios, para os quais haveria uma divisão ética entre aqueles que, de um lado, são nobres e valorizados por seu uso coletivo, utilidade urbana, por fim, sua missão social, e aqueles que são desqualificados por responderem às necessidades únicas de uma encomenda familiar. Assim, de um lado, encontram-se projetos urbanos e conjuntos habitacionais, dependentes do patronato estatal, e, de outro, as residências unifamiliares, patrocinadas pelo interesse individual. Essa oposição pulsa na relação burguesa com a propriedade privada e com uma suposta negação de submissão dos arquitetos a esses comanditários, vinculação e compromissos que procuraram escamotear ao enquadrar a questão social, a resolução dos grandes problemas da cidade moderna dentro de um discurso de engajamento da profissão.

O sociólogo das profissões Florent Champy procurou extrair as razões e as implicações que o engajamento nas questões sociais adquiriu entre os arquitetos modernos no período entreguerras, para mostrar que tal postura responderia às necessidades de legitimação social da profissão e às tentativas de contestar e se desvincilhar do passado tido como elitista da arquitetura anteriormente produzida pelo sistema beaux-arts ${ }^{287}$. Ao assumir uma pauta elevada para a profissão, os arquitetos procuraram ratificar a validade social de suas novas práticas, transformando-as em agenda virtuosa para a resolução de problemas sociais da cidade moderna. Por meio das formas racionalizadas, os grandes pavilhões para moradia popular, as novas cidades planejadas e toda uma sorte de intervenções urbanas em larga escala seriam mobilizados, reforçando a identidade dos novos arquitetos que então entravam em cena. Segundo Champy, a adoção dessa pauta social, fomentada nos Congressos Internacionais de Arquitetura Moderna (Ciam), contribuiria para dotar os arquitetos de autoridade propositiva em relação aos programas políticos encabeçados

287 CHAMPY, Florent, "L'engagement des professionnels comme conséquence de tensions consubstantielles à leur pratique : l'architecture moderne entre les deux guerres », Sociétés contemporaines, 2009/1 n 73, p. 97-119. 
pelo Estado, cavando novas demandas de trabalho. Diante da superioridade dos grandes temas, o restrito programa da moradia unifamiliar adquiriu um lugar menos honrado, alvo muitas vezes de apagamento ou desvalorização. Também inspirados pelas proposições dos congressos internacionais, tais representações atravessaram as condutas e os discursos dos arquitetos modernos brasileiros, principalmente se considerado o momento político em que tais ideias chegaram no país, período de afirmação do progresso e de nacional-desenvolvimentismo, seja no Estado Novo, seja no programa JK ${ }^{288}$.

$\mathrm{Na}$ arquitetura paulista, Vilanova Artigas encampou de modo grandiloquente a utopia de mudança social pela arquitetura, transformando-a em agenda política e manifesto estético. No entanto, para justificar o programa menos honrado da moradia individual, o arquiteto diretamente vinculado às concepções etapistas do Partido Comunista, propõe tratá-la como educação moral da burguesia. No discurso de Paulo Mendes da Rocha, uma vez que a militância comunista não fornece lastro a uma justificativa pedagógica de formação das classes dominantes, o relato sobre o lugar das moradias em sua produção vem na forma de autocensura, em expressão que confronta a impossibilidade de recusa a um sentimento de mea culpa:

"Eu fiz casas, fiz escolas, não fiz tantas casas assim. De qualquer modo, eu posso dizer, que eu por mim, eu não faria casa nunca, pois já nessa época nós tínhamos consciência absoluta que a única casa possível da cidade contemporânea é feita num edifício vertical, para você poder estar junto a metrô, transporte público, escolas, enfim. Por mim, não teria feito nunca uma casa isolada, num lote tipo de terrenos da Companhia City"289.

288 Os diversos materiais de intervenção política e defesa da profissão escritos pelos arquitetos brasileiros desde os anos 1920 explicitam com veemência o conteúdo de engajamento que a arquitetura moderna deveria assumir quando implantada no Brasil. A crítica ao formalismo, a importância social da arquitetura para uma sociedade que se modernizava, a missão social, a tarefa nacionalista, a vinculação com o progresso, o desejo de enfrentar o problema da habitação aparecem, de diferentes matizes, como compromisso ético no discurso dos arquitetos de toda uma geração. XAVIER, Alberto (org.) Depoimento de uma geração: arquitetura moderna brasileira. São Paulo, CosacNaif, 2003.

289 Entrevista do arquiteto a`Folha de São Paulo, material em vídeo disponível em 
Mas seguindo o tom imprimido a Vilanova Artigas, a união entre ética e estética é uma leitura recorrente entre os analistas da obra de Paulo Mendes da Rocha, interpretação que se apresenta em diversas versões.

Em um dos trabalhos dos comentaristas, a comparação com outros arquitetos ganhadores do Pritzker serve para caracterizar e distinguir a peculiaridade de uma personalidade reconhecida por suas virtudes de rigor e austeridade, em oposição a arquitetos cuja notoriedade seria mais estridente ou espetacular. O cotejo com os arquitetos que atingiram a condição de celebridade mundial - nomeados de "star-system"290 - visa diferenciar Paulo Mendes da Rocha de um grupo de profissionais cuja produção estética está associada a uma arquitetura caracterizada como "high tech", termo utilizado para classificar aqueles que se apoiam no recurso tecnológico como elemento de afirmação estética. Ao contrário deles, o que é valorizado em Mendes da Rocha é a produção de uma arquitetura mínima, essencial, discreta, simples, isto é, sem recursos mirabolantes - definições que pretendem recusar um efeito de alarde e exibicionismo. Ao contrário das formas retorcidas, dos vidros espelhados e das placas de titânio, a dureza do material ríspido do concreto é transmutada em desapego à comodidade, ao conforto e à ostentação, valores vêm associados ao bem-estar burguês. A crítica aos valores burgueses é apresentada como postura de engajamento e de resistência politica, bate-estaca que controla a interpretação reverenciadora dos arquitetos paulistas.

As leituras sobre a obra de Mendes da Rocha forçam uma coerência virtuosa entre prática profissional, manifestação estética e estilo de vida. A capitalização da glória do arquiteto distancia-se de outros ganhadores do

http://videos.bol.uol.com.br/video/tv-folha-83--bloco-3-paulo-mendes-da-rocha 04024C9A3264C0B94326 Acesso em: 07/11/2015

290 Vale acrescentar que o sistema do "star-system" se apresenta como mecanismo de afirmação de celebridades em vários universos culturais, como no cinema, artes plásticas, mercado editorial, pop music etc. Sobre a dinâmica simbólica e o valor econômico que a lógica do "star-system" ocupa no mercado de bens culturais, cf: BENHAMOU, Françoise. L'économie du star-system. Paris: Odile Jacob, 2002. 
Pritzker, arquitetos que ocupam a condição de vedetes internacionais, como o inglês Norman Foster, o italiano Renzo Piano, a iraquiana Zaha Hadid, o polonês naturalizado norte-americano Daniel Libeskind, o holandês Rem Koolhaas, o canadense Frank O. Ghery, o chinês Ieoh Ming Pei e os franceses Jean Nouvel e Christian de Portzamparc, que se estabeleceram em escritórios importantes e frequentemente são requisitados pelo caráter icônico dos edifícios para grandes projetos, formando um conjunto de notáveis já amplamente confirmados na dinâmica de celebração mundial. Enquanto esses vencedores do Pritzker atuam em empresas maiores e consolidaram seus nomes em marcas famosas de uma arquitetura considerada grandiosa, Paulo Mendes da Rocha, que também desfruta de um lugar entre esses eleitos, é reverenciado por uma conduta modesta e recolhida, de alguém que:

"trabalha em escritório 'enxuto', sem equipe de projetistas e sem computadores. Realiza poucos projetos ao mesmo tempo, o que lhe permite estabelecer uma relação próxima com cada um deles. Tem uma rotina de vida que nada se assemelha à de seus pares contemporâneos, dos ditos arquitetos do star system [...] Ao contrário destes, o arquiteto Paulo Mendes da Rocha mantém uma vida bem 'espartana': não possui celular, site, carro $[\ldots]^{\prime 291}$.

Como se pode ver pelo relato, o contraste estabelecido com outros arquitetos contemporâneos ranqueados pelo Pritzker pressupõe uma censura àqueles que exploram economicamente a notoriedade, que se explicita na condenação do sucesso associado ao ganho financeiro em contraposição à excelência moral daqueles cujo êxito estaria associado a qualidades estritamente artísticas. Nesse discurso, enquanto os arquitetos do "star-system" são reprovados pelo uso comercial de suas imagens, Paulo Mendes da Rocha é reverenciado por se colocar supostamente distante dessa lógica. A oposição entre arquitetos no interior de um sistema de notoriedade ganha em sentido quando se tem em conta que a formação dos profissionais do "star-system" pressupõe a diferenciação de

291 OTONDO, Catherine. Desenho e espaço: relações entre pensar e fazer na obra de Paulo Mendes da Rocha. São Paulo, FAU USP (tese de doutorado), 2013. p.15. 
carreiras como atributos especiais, atuando como estratégia de distinção de uma elite de arquitetos com circulação internacional.

É o que mostra Géraldine Molina ${ }^{292}$ quando investiga os recursos utilizados pelas celebridades no universo da arquitetura. A pesquisa evidencia que os profissionais que alcançaram um lugar nesse grupo de prestígio e visibilidade midiática respondem a um trabalho permanente de construção de si e de diferenciação entre os concorrentes, que se explicita em diferentes modos de exposição pública de suas imagens. Essas representações constroem personalidades bem demarcadas que são expressas por diversos materiais tais como discursos em conferências, autobiografias, vídeos que circulam na televisão ou filmes sobre a trajetória e o modo de concepção artística do arquiteto. Esse recurso de apresentação de si em identidades reconhecíveis é mais um traço das estratégias de diferenciação entre indivíduos que pretendem ocupar o estatuto de criador e firmar uma posição singular em um grupo de elite.

Nessa dinâmica de afirmação de uma personalidade criadora, Paulo Mendes da Rocha ocupa, entre os ganhadores do Pritzker, o espaço do arquiteto depurado, que mobiliza um discurso comedido no qual a técnica ganha conteúdo poético, produzindo uma arquitetura despojada dos emblemas de luxo, pompa e excesso. A imagem que é utilizada como representação do arquiteto é de um artista desprendido dos valores comerciais e de bens materiais, que renuncia à fama imediata e se coloca como não participante do sistema de celebridades. Em outros termos, a conquista do prestígio de Mendes da Rocha passa pela recusa do sistema de celebração e das insígnias de ostentação.

O próprio espaço físico do escritório é tomado como símbolo dessa recusa, como se pode ver pelas fotografias veiculadas em livros em sua homenagem e matérias da imprensa especializada. O local de trabalho do arquiteto reafirma uma imagem de desprendimento e desinteresse material, com a exibição de um cenário de simplicidade e retidão,

292 MOLINA, Géraldine. "Mise en scène et coulisses du "star-system" architectural: la théâtralisation des vedettes et ses paradoxes". Espaces et Sociétés, no,156-157, pp.197-212, 2014. 
composto por móveis antigos, com ar obsoleto, paredes com a pintura descascando, piso de taco desgastado, mesa de trabalho onde se acumulam papéis e artefatos improvisados, maquetes e ensaios de volumetria de edifícios já construídos ou de projetos que não saíram do papel, e grande lousa verde preenchida com croquis de projetos desenhados com giz, pronta para improvisar espontâneos raciocínios construtivos e soluções formais. Essas representações se oferecem como antítese tanto dos escritórios de arquitetos contemporâneos veiculados nas revistas especializadas e mundanas (que mostram ambientes meticulosamente desenhados, estilizados e tecnológicos), ou dos tradicionais escritórios do ecletismo paulistano do início do século XX, cuja composição dos elementos se coloca como emblema representativo dos códigos e valores clássicos de autoridade cultural e sucesso profissional requisitados na época ${ }^{293}$.

A exaltação como o "arquiteto da recusa" veio à tona com toda intensidade em mais uma premiação que o arquiteto recebeu em 2016, quando foi homenageado com o Leão do Ouro da Bienal de Arquitetura de Veneza. Para o historiador Guilherme Wisnik, arquiteto formado na FAUUSP, professor da mesma instituição, também responsável pela curadoria de exposições e ensaios sobre o arquiteto, Paulo Mendes da Rocha, ao não ceder ao mercado, resguarda sua condição de intelectual. O arquiteto valorizado por não fazer qualquer concessão a clientes, ao mercado ou à própria lógica de consagração:

"Era divertido saber da perplexidade de jornalistas e possíveis clientes estrangeiros dez anos atrás, quando, a anúncio do Prêmio Pritzker, ligavam para o escritório do arquiteto e eram atendidos por uma

293 Cabe lembrar aqui a análise que Sergio Miceli faz da fotografia do escritório de Ramos de Azevedo e sua posterior execução em forma de pintura, feita no final dos anos 1920 por Oscar Pereira da Silva, retrato que, na análise do sociólogo "busca dar conta da inserção de um profissional bem-sucedido e unanimemente reconhecido e laureado em seu ambiente profissional de trabalho; ao mesmo tempo faz dos diversos elementos e objetos incluídos na composição emblemas alusivos das inúmeras esferas em que se desdobravam suas aptidões e interesses: o empreiteiro e homem de negócios representado pelo cofre-forte e pelo tinteiro de prata; o arquiteto e desenhista insinuados pela régua, compassos e plantas baixas enroladas; o colecionador e incentivador das artes espelhados nas esculturas e telas". MICELI, Sergio. Nacional e estrangeiro: história social do modernismo artístico em São Paulo. São Paulo, Companhia das Letras, 2003. p.37. 
secretária que não falava inglês. De um ponto de vista pragmático, é evidente que teria sido fácil resolver esse 'problema'. Mas há, certamente, uma afirmação nessa recusa. Paulo nunca aceitou virar vítima de prêmios. E sabe que a atitude de dobrar-se ao ponto de vista do outro, em tempos de grossa globalização, representaria sua morte. Assim, mantendo-se fiel a si mesmo, discursa sobre o lugar do arquiteto e do intelectual no mundo de hoje. E é exatamente isso que tem sido reconhecido pela crítica mundial. Sua intransigência é um ethos precioso, cada vez mais raro"294.

A contraposição entre o sucesso deslumbrado daqueles que fazem uma arquitetura ruidosa pronta para ser reconhecida imediatamente pelas prestigiosas instâncias de consagração e os reveses daquele que faz uma arquitetura recolhida, fora dos holofotes, é mais um par de antagonismos usado para justificar a dedicação do arquiteto às mais altas virtudes. Assim, entre os eleitos no Pritzker, a Mendes da Rocha é dada a posição mais legítima e preciosa: daqueles que apenas se valem de uma consagração pura, desprovida de ganhos materiais, imagem que é constantemente reiterada por seus comentadores. E é justamente aí que reside a eficácia: a valorização do não-sucesso contribui para canonizar o arquiteto. Ele se coloca distante dos valores dominantes do campo, e sem se rebaixar à celebração pragmática, Paula Mendes da Rocha é considerado o arquiteto sacrificado que acima de tudo honra sua arquitetura.

O crítico de arquitetura Francesco Dal Co chama atenção para a postura coesa e coerente do arquiteto, identificando como um profissional que "é estranho à cena atualmente ocupada pelos mais histriônicos entre

294 WISNIK, Guilherme. Aprendendo com Paulo Mendes da Rocha. Folha de S. Paulo, 16/05/2016. Os próprios organizadores do prêmio da Bienal de Veneza reiteram a coerência ideológica como o traço característico da postura estética do arquiteto: "Muitas décadas após serem construídos, cada um de seus projetos resiste ao avanço do tempo, tanto estilisticamente e fisicamente. Essa consciência estarrecedora deve ser a consequência de sua integridade ideológica e sua genialidade estrutural. Ele é um desafiador inconformado e, ao mesmo tempo, um realista apaixonado" in Paulo Mendes da Rocha receberá o Leão de Ouro da Bienal de Veneza. Portal G1. Disponível em: http://g1.globo.com/pop-arte/noticia/2016/05/paulomendes-da-rocha-recebera-o-leao-de-ouro-da-bienal-de-veneza.html Consulta em: 06/05/2016. 
os protagonistas da arquitetura internacional"295. Enquanto muitos laureados são indigitados pelo manejo dos louros da premiação na busca de uma vistosa fama publicitária, Mendes da Rocha é sempre situado em posição de comedimento, refratário às vantagens pessoais e ao exagero midiático. Tais contrastes evocam um dos princípios centrais do campo artístico, para o qual o lucro do mercado simbólico, quando intocado pelo dinheiro, torna-se imaculado, e se apresenta como mais valioso e autêntico que os lucros do mercado material. No Brasil, o historiador Hugo Segawa faz eco a essa representação:

"A formação do jet set da arquitetura passa pela filtragem dessas premiações: para alguns arquitetos, significará uma carteira mais recheada de projetos; para outros, um reconhecimento simbólico por seus pares e apreciadores do refinamento cultural e estético que envolve a arquitetura. Nem sempre essas duas condições se sobrepõem ou dialogam. A outorga do Prêmio Pritzker em 2006 para Paulo Mendes da Rocha o introduziu no universo daqueles com reconhecimento simbólico." 296

Com essas recorrentes representações, a construção discursiva em torno do arquiteto consegue infundir a imagem do artífice exemplar, a figura irretorquível do artista em seu sentido mais puro, sem se abster do "senso de responsabilidade" pela sociedade. As aparições públicas também dão reforço a esse sentido de alto calibre espiritual. Em conferências, entrevistas e debates, a fala de Paulo Mendes da Rocha, frequentemente expressando seu espanto com a técnica e a capacidade do homem de dominar a natureza, assume um tom encantatório, de teor quase sobrenatural, cheia de inversões e reversões, que produz um efeito hipnótico na plateia, ou, para os menos convencidos, pode desaguar em

295 DAL CO, Francesco. Paulo Mendes da Rocha - Pritzker Prize 2006. Arquitextos, São Paulo, ano 06, n. 071.00, Vitruvius, abr. 2006. <www.vitruvius.com.br/revistas/read/ arquitextos/06.071/358> Originalmente publicada na revista italiana Casabella, como notícia de anúncio do prêmio Pritzker.

296 SEGAWA, Hugo. "Paulo Mendes da Rocha recebe título de professor emérito da Fauusp". In.Revista Pós, V.17, no 28, São Paulo, dez, 2010. p.220-227. p.222. 
acusação de divagação ${ }^{297}$. O discurso sedutor atua entre o apelo profético e o elogio ao rigor da técnica, conciliando a posição de um arquiteto que exibe seu savoir-faire construtivo, seu compromisso com a dimensão social e seu virtuosismo formal, tudo em nome da retidão de espírito abnegado.

Ao atingir o mais alto grau jamais cogitado pelos plebeus da comunidade de arquitetos, Mendes da Rocha encarna, por excelência, o mito do arquiteto moderno, o mandarim da profissão, ou o "detentor comprovado de qualidades mágicas" ${ }^{298}$, que responde a um sistema de consagração cuja incumbência é diferenciar os produtores ordinários e os extraordinários, a arquitetura rotineira e a arquitetura digna de significado cultural. Em torno dele, e garantindo o prolongamento desse poder, um conjunto de agentes se empenha no trabalho religioso de disseminar os mandamentos sagrados de uma Escola que se construiu como portadora de uma estética edificante ou uma ética estilizada.

Se tomada pelo ponto de vista mais abrangente da produção simbólica, a sociologia da religião de Max Weber pode nos fornecer uma chave de compreensão das transações entre o arquiteto, os porta-vozes do grupo e os destinatários dessa arquitetura. Fundamental para a legitimação da crença de que os arquitetos da "Escola Paulista" são portadores de uma transformação ético-revolucionária, os discípulos estendem de modo duradouro a ideologia que o grupo aplicou sobre si mesmo. Persuadidos pela dignidade da mensagem, convictos de sua própria excelência e "da perfeição de sua conduta de vida"299, os que participam do culto e do trabalho de canonização se sentem, como bem disse um agente paulista, "igualmente premiados", e sobretudo satisfeitos

297 Essa é percepção compartilhada por diversos estudantes de arquitetura e arquitetos e assim aparece, por exemplo, em um de seus comentadores: "Quem já ouviu Paulo Mendes falar ou leu suas entrevistas transcritas literalmente, sem edição (como a publicada recentemente pela revista Caros Amigos em abril de 2002) sabe que seu discurso é rico de imagens e beira o limite da divagação." ANELLI, Renato. Um olhar intensivo. Resenhas Online, São Paulo, ano 01, n. 012.01, Vitruvius, dez. 2002. Disponível em: www.vitruvius.com.br/revistas/read/resenhasonline/01.012/3227> Acesso em 18/12/2015.

298 WEBER, Max. "Os letrados chineses". In: Ensaios de Sociologia. 2 ed. Rio de Janeiro: Zahar, 1971. p.490.

299 BOURDIEU, Pierre. "Apêndice I: uma interpretação da teoria da religião de Max Weber. In. Economia das Trocas Simbólicas". São Paulo: Perspectiva, 2007. p.87. 
de participar de um sistema de justificativas que Ihes assegura uma posição social e uma razão reconfortante.

De modo mais amplo, a importância prática da premiação é contribuir para alargar a missão da profissão e encantar o métier, dignificando os arquitetos em relação a outras profissões da construção que não desfrutam da vantagem e do privilégio de serem consideradas como produtoras de bens simbólicos. Ao entrar para o conjunto dos premiados pelo Pritzker, Mendes da Rocha tem sua presença justificada pela retidão que representa e faz estender a honra da profissão em direção à pureza e à modéstia. Nas disputas locais, a presença do arquiteto no conjunto dos notáveis faz triunfar uma linha de força da arquitetura paulista que tem a pretensão de ungir continuadores e modelar uma "nova geração". Serve, assim, de garantia ideológica ao valor artístico do prêmio, aos encomendantes e também àqueles que se enfileiram na linhagem proclamando-se um coletivo de legítimos "arquitetos paulistas". 


\section{CONSIDERAÇÕES FINAIS}

Distante das abordagens estéticas (que deram centralidade aos artefatos arquitetônicos, assumindo-os como obra artística), ou da historiografia da arquitetura (que se empenhou em render homenagem e legitimar os arquitetos a partir da primazia do discurso formal), a pesquisa se propôs a analisar conjuntamente produtores, propagadores e público a quem se destinou essa mercadoria de alto valor simbólico. A opção por unir as duas pontas - oferta e demanda - se deveu ao interesse em compreender as afinidades e cumplicidades sociais que uniram arquitetos e clientes em torno de um projeto estético e ético em comum, atentando-se àquilo que pode ser pensado como condições sociais de produção dos produtores e consumidores de bens simbólicos.

A articulação procurou por expor determinada experiência social que deu fundamento à renovação estética da arquitetura moderna em São Paulo. A afirmação dessas mudanças se deu em um contexto de complexificação do tecido social da cidade, que ganhou força em meados do século $X X$, e que esteve marcado pelo trinômio imigraçãourbanização-industrialização. Nesse processo de modernização e metropolização, a cidade de São Paulo passa a construir posição hegemônica no cenário nacional. Essa dinâmica de profundas mudanças sociais e políticas possibilitou a proliferação de instituições culturais e educacionais, sobretudo universitárias. A fundação de duas faculdades de arquitetura em São Paulo é resultado dessa construção social. O empenho em formar profissionais dedicados a pensar o espaço urbano e o espaço arquitetônico ajustava-se ao impulso modernizador que convulsionava a metrópole. A institucionalização da arquitetura no sistema de ensino permitiu a constituição de um mercado de diplomados provenientes das primeiras turmas dos cursos criados no final dos anos 1940. Nos primeiros anos de 1950, a USP e o Mackenzie disponibilizaram 
um contingente expressivo de egressos dos cursos de Arquitetura, profissionais com competências específicas que se diferenciavam dos engenheiros civis e dos arquitetos formados na escola de belas-artes. Nesse momento de estruturação do campo e constituição da legitimidade da profissão, a politização tornou-se importante recurso para diferenciarse das profissões concorrentes e dos arquitetos estabelecidos. Possuidores de um saber especializado exclusivo, técnico e estético, esses profissionais colocaram-se como responsáveis pelo fornecimento de novas representações simbólicas e novos regimes discursivos, definindose como portadores da modernização. A ideia de modernização surge atrelada a um compromisso de transformação do país, no qual os arquitetos desempenhariam um papel central de fornecedores de soluções para o espaço construído, na escala da cidade, da casa e do mobiliário.

O processo mais amplo de transformação social viabilizou a formação de um mercado de consumo privado de residências de autor, estruturado pela emergência de clientes de extrações diversas, em sua maioria descendentes de imigrantes ou frações sociais locais que aproveitavam as novas oportunidades oferecidas. Esses consumidores, egressos das universidades e ligados às instituições culturais, asseguraram a produção de arquitetura assinada. Essas frações emergentes do processo de reconfiguração social acompanharam os novos andamentos da cultura e, assim, vislumbraram exprimir seus gostos artísticos e posicionamentos políticos nas formas de morar.

Uma das tarefas da pesquisa foi o levantamento das definições e classificações infundidas pelos integrantes, críticos e historiadores, sujeitos munidos de propriedades sociais e interesses. Enquanto participantes da criação e do juízo de valores artísticos, conceberam visões, inclusões e exclusões, e assentaram uma linha dominante de consagração dos arquitetos dessa geração. Em um momento de constituição do campo, o espaço de lutas tensionou uma divisão discursiva entre "arquitetura burguesa" e "arquitetura social", conflito enfrentado por aqueles que pretendiam atuar no espaço arquitetônico e 
do design em formação. Moderno versus tradicional, novo versus antigo, artesanal versus industrial, arquitetura de interiores versus decoração, móveis sob encomenda versus produção serializada, mobiliário popular versus móveis de elite, "causa" versus "estilo", conjunto habitacional versus residência unifamiliar, intenção plástica versus construção técnica são alguns dos jogos de oposição que se expressavam nos posicionamentos dos profissionais e nas acusações recíprocas.

Esse conjunto de tomadas de posição foi localizado em um espaço de disputa concorrencial por visibilidade e reconhecimento. Nesse espaço estão em negociação modalidades de ganhos materiais (tas como patrocínio estatal, encomendas privadas, cargos públicos, postos acadêmicos, assessorias em projetos urbanos), e simbólicos (tais como entrada em circuitos de prestígio, premiações internacionais, difusão em mídias ampliadas, publicações de obra completa nas editorias especializadas, exposições nacionais e internacionais, curadoria, venda de desenhos para acervos e coleções de museus). Essas modalidades de gratificação estiveram disponíveis a alguns agentes inseridos no universo da arquitetura. Para compreender as posições alcançadas, cada uma das trajetórias foi localizada no conjunto das possibilidades em jogo, a partir das quais os indivíduos conseguiram manejar suas disposições, seus trunfos pessoais e sua rede de relações, de forma a assumir postos, angariar clientes, granjear projeção e inscrever seus nomes como representantes legítimos da arquitetura brasileira.

A nomeação "Escola Paulista" exerceu a função de aproximá-los em torno de um programa estético em comum, reconhecido pelo uso dos materiais, formas e modos de projetar. No entanto, os arquitetos reunidos no movimento não se identificaram e nem defenderam o termo dentro de um enquadramento regionalista da arquitetura brasileira, ou seja, como movimento de cores locais em confronto com "Escola Carioca". Procuraram ser englobados como produtores da "arquitetura brasileira" tout court, preocupados com um projeto de país. A missão nacional contribuiu para que afastassem a possibilidade de rotulação regionalista. Desse modo, conseguiram construir e controlar a hegemonia 
do grupo sem serem considerados "provincianos" ou "pitorescos". Foram reconhecidos como produtores de uma arquitetura legitimamente nacional, o que confirma a capacidade de se impor para além das nomeações que se reduzem a um caráter localista.

Pregadores de um discurso de mudança social, um dos pontos que chama atenção no posicionamento dos arquitetos estudados é a recusa de identificação como formuladores de um estilo, termo visto como depreciativo, pois indicaria a rotinização de uma estética que se quer de alto calibre. Tal desqualificação de amaneiramento dissolveria o intuito dos arquitetos de articular forma estética e conteúdo social. Interessados na construção de habitação popular e imbuídos de uma missão nacional, previam que a industrialização da construção civil pudesse contribuir como recurso tecnológico para resolver o problema habitacional. A despeito do discurso engajado, prevaleceu uma prática ambígua em relação ao programa da moradia, que esteve majoritariamente voltada a projetos unifamiliares.

A casa foi inflada e reabilitada como intervenção que pretenderia responder à escala da cidade. Aparece, então, como manifestação urbana, e não como objeto isolado que responde aos imperativos da família encomendante. Em que pese sua reduzida circunscrição ao lote, o que a torna um espaço delimitado pela propriedade privada, a residência foi supervalorizada sob a égide de reinvenção de uma nova urbanidade e novas relações sociais. Tais definições, longe de se apresentar como simples formulações, pretendiam ampliar os horizontes de expectativas da casa moderna e sentenciar valor nobre e legítimo aos espaços domésticos, sobrecarregando-os de sentido profundo e intenções louváveis. O projeto da casa individual teve que ser reconhecido em sua limitada perspectiva de transformação social. Foi, por isso, defendido como manifesto sintético da utopia moderna, e as residências foram acionadas como portfólio estético e político de validação das práticas do grupo. Essas dimensões discursivas, que se expressam em rejeições e assentimentos, expõem fraturas entre as intenções e as realizações dessa geração. 
No entrelaçamento entre as enunciações dos arquitetos e dos críticos, as versões reverberadas enraizaram uma linha interpretativa que procurou enfatizar a invenção de uma estética racionalizada, de apelo progressista. Reivindicada por lideranças e porta-vozes, a versão vitoriosa disseminou que os arquitetos seriam responsáveis por criar uma poética ideologicamente engajada e artisticamente inovadora. A articulação entre os princípios estéticos e políticos garantiu força à interpretação. Diversas expressões utilizadas por historiadores e críticos de arquitetura contribuíram para fixar um significado elevado a essas moradias, valendo-se de termos que combinam um caráter moral a um prazer estético. As casas foram apresentadas por expressões dignificadoras: "campo de prova", "laboratório formal", "obras-primas", "espaço de experimentação", "narrativa sintética", "profissão de fé", "documento extraordinário de suas aspirações". Essas interpretações tomam a residência, ao mesmo tempo, como objeto formal, preso à análise da linguagem e objeto político, denso de injunções sociais. Tais discursos, longe de se apresentar como simples formulações inócuas, empenham-se em ampliar os horizontes de expectativas da casa moderna e sentenciar um valor nobre e prestigiado aos espaços domésticos, sobrecarregando-os de sentido profundo e intenções louváveis. Esse empenho expressou-se, sobretudo, na defesa de uma coerência estética e de uma dimensão ética do projeto residencial.

A estratégia ideológica dos arquitetos (e reverberada na narrativa redentora da historiografia) foi creditar virtudes urbanas, políticas e revolucionárias a essas habitações particulares, no momento mesmo em que ascendem a objetos de deleite estético. Incorporando o trabalho simbólico produzido no campo, a casa foi autonomizada de suas condições de possibilidade e ganhou estatuto de contemplação artística. Com isso, reforçou-se o modelo de excelência que se impôs ao campo: o trabalho do arquiteto-artista em sua aura de criador; um produtor carismático que, não submisso a seus comanditários, está livre para exprimir sua arte.

O enaltecimento em relação à arquitetura doméstica expõe um 
esforço de assegurar dignidade a um programa considerado de menor prestígio. O fato de frequentemente ser embutida uma justificativa que confere razão superior e postura grandiosa a essas moradias dá mostras do valor rebaixado e aviltado que o projeto residencial contraiu na profissão, cujo grande mérito seria equacionar o problema de habitação popular. Pode-se, assim, compreender a preocupação dos arquitetos e agentes responsáveis pelos discursos oficiais de suas obras em superestimar o projeto de espaços de uso doméstico como tentativa de justificar um tipo de serviço considerado, no interior da profissão, de menor importância, uma vez que estaria se prestando a servir as representações de uma clientela abastada. Com efeito, o arquiteto afirma sua posição de autor, desembaraçando-se das exigências dos encomendantes e aderindo a uma posição resignada e desconfortável de sua fração de classe. No entanto, heroicamente, ao impor soluções "radicais", "severas", "incômodas", que rejeitam o supérfluo e a ostentação, os arquitetos aparecem como prestadores de serviços rebeldes, provocativos e insubmissos. São apresentados como arquitetos inconformados. O discurso politizado é tomado como integridade ideológica que garantira o engajamento a uma arquitetura consciente de sua missão social ao mesmo tempo que se defende a autonomia formal e o desinteresse.

Não é a toa que as narrativas historiográficas, muitas vezes se valendo de formulações dos próprios interessados, tenderam a produzir um texto em apologia ao arquiteto, que passa a ser reverenciado por sua "singularidade" e canonizado em nome de "originalidade" e "genialidade", termos que conferem protagonismo a um produtor isolado do espaço social. O caráter individualista das monografias, centradas na excepcionalidade da figura do criador, ratificou o poder mágico de nomes, artistas e obras, lançados como objetos de culto. Como se procurou mostrar, a sacralização ocorreu em relação às casas e aos móveis produções que foram tomados como formas desprovidas de agência, isto é, desenraizadas da experiência social. Esses objetos logo foram consagrados e passaram a figurar na história da arquitetura como artefatos singulares, padrão de "bom gosto" e dignos de valor artístico. 
Quando enredados nas trajetórias dos encomendantes, esses produtos se revelam materializadores de ambições estéticas, cumplicidades sociais, utopias políticas, redes de cooperação, apostas intelectuais e arranjos familiares de seus proprietários.

$\mathrm{Na}$ contramão das intenções, o projeto residencial unifamiliar se abriria como espaço possível de atuação, ainda que não prioritariamente desejável, mas aquele em que conseguiriam apoio do mecenato burguês. Esse conflito contribuiu para reforçar um discurso estético em nome da radicalidade formal e da ousadia criativa, justificativa que os eximia de se submeter a uma arquitetura padronizada. A emergência de grupos sociais inclinados a manifestar seu gosto erudito por meio da moradia é o que deu vazão a essa arquitetura como objeto de arte, que se pretende politicamente virtuosa mesmo consciente da limitação do alcance social. 


\section{REFERÊNCIAS}

ABOULKER, Delphine. "Les chefs d'œuvre de l'architecture domestique du mouvement moderne américain vus par la sociologie et I'histoire de I'architecture". In. GIREL, Sylvia. Sociologie des Arts. Un état de la reherche. Paris: L'Harmattan, 2006.

ACAYABA, Marlene Milan. Brutalismo Caboclo e as residências paulistas. Projeto, São Paulo, n73, mar, 1985, p.46-48.

. Vilanova Artigas: amado mestre. Projeto, n76, jun, 1985, p.50-54.

- Residências em São Paulo. São Paulo: Romano Guerra Editora, 2011.

Branco \& Preto: uma história de design brasileiro nos anos 1950. São Paulo: Instituto Lina Bo e P.M. Bardi, 1994.

ALBUQUERQUE, Roberto Portugal. Uma escola de arquitetura FAUUSP: edifícios e ensino. São Paulo: FAUUSP, 2004. (dissertação de mestrado)

ALMEIDA, Paulo Mendes de. De Anita ao Museu. São Paulo: Perspectiva, 1976.

ALVES, André Augusto de Almeida. Arquitetura escolar 1959-1962: o Page, o Ipesp e os arquitetos modernos paulistas. São Paulo: FAUUSP, 2008. (tese de doutorado).

AMARAL, Aracy. Arte para que?: a preocupação social na arte brasileira (1930-1970). São Paulo: Nobel, 1987.

ANDRADE, Mario de. "Brazil Builds". In: Folha da Manhã, São Paulo, 23 de março de 1944.

ANDRIEUX, Jean-Yves et CHEVALIER, Fabienne. La reception de I 'architecture du Mouvement moderne: image, usage, heritage. Saint-Étienne, Publications de I'Université de Saint Etienne, 2005.

ANELLI, Renato. "Um olhar intensivo". Resenhas Online, São Paulo, ano 01, n. 012.01, Vitruvius, dez. 2002.

ARANTES, Otília Beatriz Fiori. Lúcio Costa e a 'boa causa' da arquitetura moderna. In. O sentido da formação: três estudos sobre Antonio Cândido, Gilda de Mello e Souza e Lucio Costa. São Paulo: Paz e Terra, 1997.

ARANTES, Pedro Fiori. Arquitetura Nova. Sérgio Ferro, Flávio Império e Rodrigo Lefèvre, de Artigas aos mutirões. São Paulo: Ed. 34, 2002.

ARAUJO, Fanny Schroeder de Freitas. Telésforo Cristófani (1929-2002): contribuições à arquitetura paulista. Faculdade de Arquitetura do Mackenzie. 2009 (dissertação de mestrado) 
ARGAN, Giulio Carlo. Arte Moderna. São Paulo: Companhia das Letras, 1992.

Paul ARON, Frédérique MATONTI, Gisèle SAPIRO, eds., «Le réalisme socialiste en France».Sociétés \& Représentations, 15, 2002.

ARRUDA, Maria Arminda do Nascimento. Metrópole e Cultura: São Paulo no meio do século. Bauru, SP: EDUSC, 2001.

. "A sociologia no Brasil: Florestan Fernandes e a "escola paulista". In. MICELI, Sergio (org.) História das ciências sociais no Brasil, v.02, São Paulo: Sumaré, 1995.

ARTIGAS, Rosa (org). Paulo Mendes da Rocha. São Paulo: Cosac\&Naify, 2000.

. Por enquanto, João Batista. In. Vilanova Artigas. São Paulo: Instituto Tomie Ohtake, 2003.

ARTIGAS, Vilanova. Uma falsa crise. In. XAVIER, Alberto (org). Depoimento de uma geração: arquitetura moderna brasileira. São Paulo: Cosac \& Naif, 2003.

- Depoimento. In XAVIER, Alberto. Depoimento de uma geração: arquitetura moderna brasileira. São Paulo: Cosac \& Naif, 2003.

AYALA, Walmir (org.). Dicionário brasileiro de artistas plásticos. Brasília: MEC, 1980.

BACELLI, Ronei. A presença da Cia. City em São Paulo e a implantação do $1^{\circ}$ bairro-jardim 1915-1940. São Paulo: FFLCH/USP, 1982. (dissertação de mestrado)

BANHAM, Reyner. The new brutalism: ethic or aesthetic?. Londres: Architectural Press, 1966.

BARDI, Lina Bo. Tempos de Grossura: o design no impasse. São Paulo: Instituto Lina Bo e P. M. Bardi, 1994.

. Contribuição propedêutica ao ensino da teoria da arquitetura. São Paulo: Editora Marprint / Instituto Lina Bo e P.M. Bardi, 2002.

BASTOS, Maria Alice Junqueira; ZEIN, Ruth Verde. Brasil: arquiteturas após 1950. São Paulo: Perspectiva, 2010.

BAXANDALL, Michel. Olhar renascente: pintura e experiência social na Itália da Renascença. Rio de Janeiro: Paz e Terra, 1991.

BENEVOLO, Leonardo. História da Arquitetura Moderna. São Paulo: Perspectiva, 1998.

BENHAMOU, Françoise. L'économie de la culture. Paris: La Découverte, 2011.

BENTON, Tim. Les villas parisiennes de Le Corbusier 1920-1930, I 'invention de la Maison moderne. Paris: Edition de la Villette, 2007. 
BÉRA, Mathieu; LAMY, Mattieu. Sociologie de la culture. Paris: Armand Colin, 2008.

BIAU, Véronique. "Sociologie des architectes". Urbanisme n²93, 1997, pp. 61-63.

. "Stratégies de positionnement et trajectoires d'architectes", Sociétés Contemporaines n² 29, 1998. pp. 7-25.

. "Marques et instances de la consécration en architecture". Cahiers de la Recherche Architecturale et Urbaine n²-3, 1999.

- La consécration en architecture: l'émergence de nouvelles élites architecturales en France. Thèse pour le doctorat de sociologie, École des Hautes Études en Sciences Sociales, 2000.

. "La consécration des 'grands architectes'". Regards Sociologiques, $n^{\circ} 25 / 26,2003$.

BIGAZZI, Anna Rosa Campagno. "In defesa della razza" Os judeus italianos refugiados do fascismo e o anti-semitismo do governo Vargas 1938-1954. São Paulo, FFLCH-USP, 2007. Tese de doutorado.

BRAGA, Juliana. Ver não é só ver: dois estudos a partir de Flávio Motta. FAU/USP. Dissertação de mestrado, 2010.

BOLAFFI, Gabriel e CHERKEZIAN. Henry. BNH, bode expiatório. Novos Estudos, n013, outubro, 1985.

BORIS, Fausto. Negócios e Ócios: história da imigração. São Paulo: Companhia das Letras, 1997.

. Memórias de um Historiador de Domingo. São Paulo: Companhia das Letras, 2010.

BOURDIEU, Pierre. "Le coutorier et sa griffe: contribuition à une théorie de la magie". Actes de la Recherche en Sciences Sociales, $n^{\circ} 1$, p.736, janeiro, 1975.

. La Distinction: critique sociale du judement. Paris: Minuit, 1979.

. "Les trois états du capital culturel", in Actes de la recherche en sciences sociales, Paris, n. 30, novembro de 1979

. Gostos de classe e estilos de vida. In: Ortiz, Renato (org.). Pierre Bourdieu: sociologia. (Grandes Cientistas Sociais). Atica: São Paulo, 1983.

. "Mais qui a crée les créateurs?" In. Questions de Sociologie. Paris, Les Éditions de Minuit, 1984.

. "L'illusion biographique". Actes de la recherche en Sciences Sociales, n062-63. p.69-72, jun, 1986.

. "Gostos de classe e estilos de vida". In Pierre Bourdieu. ORTIZ, Renato (org). 2a. ed.,São Paulo: Ática, 1994 [1976] 
. "Un placement de père de famille. La maison individuelle, spécificité du produit et logique du champ de production". Actes de la Recherche em Sciences Sociales, n. 81/82, 1990.

- As regras da arte: gênese e estrutura do campo literário. São Paulo: Cia. das Letras, 1996.

. "A casa kabyle ou o mundo às avessas". Cadernos de Campo, São Paulo, n08, 1999.

- Escritos de Educação / Maria Alice e Afrânio Catani (org.). Petrópolis, RJ: Vozes, 1999

. Questions de sociologie. Paris: Les Éditions de Minuit, 2002.

As estruturas sociais da economia. Porto: Campo das Letras, 2006.

A dominação masculina. Rio de Janeiro: Bertrand Brasil, 2007.

. A Distinção. Crítica social do julgamento. São Paulo: EDUSP: ZOUK, 2007.

- A produção da crença. Contribuição para uma economia dos bens simbólicos. Porto Alegre, Zouk, 2008.

. O poder simbólico. Rio de Janeiro: Bertrand Brasil, 2011.

. Homo academicus. Florianópolis: Editora da UFSC, 2011.

. "Espaço físico, espaço social e espaço físico apropriado", Estudos Avançados, n27, (79), 2013. pp.133-144.

- Manet: une révolution symbolique. Cours au Collège de France (1981-1983). Paris, Raison d'agir, Seuil, 2015.

. Sociologie Générale. Volume I. Cours au Collège de France (19982000). Paris, Raison d'agir, Seuil, 2015.

BOURDIEU, Pierre \& SAINT MARTIN, Monique de "Anatomie du gôut". Actes de la Recherche en Science Sociales, vol.2, número 5, 1976.

BOURDIEU, Pierre \& DARBEL, Alain. Amor pela Arte. Os museus de arte na Europa e seu público. São Paulo: Edusp, 2003.

BRAGA, Milton. O concurso de Brasília: sete projetos para uma capital. São Paulo, CosacNaify, Imprensa Oficial, 2010.

BREIA, Maria Teresa de Stockler. A transição do ensino da Arquitetura Beaux-Arts para o ensino da Arquitetura Moderna na Faculdade de Arquitetura do Mackenzie, 1947-1965. São Paulo: FAUUSP, 2005 Tese de doutorado.

BRUAND, Yves, « L'expérience de Brasília : essai de synthèse des principales critiques concernant la nouvelle capitale du Brésil », in : L'information de I'histoire de l'art, sept.-oct. 1961, pp. 111120, nov.-déc. 1961 , pp. 142-152.

Questões pedagógicas. Metologia da História, Teoria da História e 
História da Historiografia. Revista de História. n054, 20 trimestre, 1963. p.516.

. "Baroque et rococo dans l'architecture de Minas Gerais". Extrait de la Gazette des Beaux-Arts, mai 1966, pp. 321-338.

- L'architecture contemporaine au Brésil. sous la direction d'André Chastel] / Lille: Service de reproduction des thèses de l'université de Lille III, 1973.

- Arquitetura Contemporânea no Brasil. São Paulo: Perspectiva, 1999.

BRUN, Eric. Les situationnistes: une avant-garde totale. Paris: CNRS Editions, 2014.

BUZZAR, Miguel Antonio. João Batista Vilanova Artigas: elementos para a compreensão de um caminho da arquitetura brasileira, 19381967. São Paulo: Unesp: Senac São Paulo, 2014.

CAMARGO, Mônica Junqueira. Joaquim Guedes. São Paulo: Cosac\&Naify, 2000.

. "Conexões Brutalistas Paulistas". Anais de Congresso. X Seminário Docomomo, Curitiba, outubro, 2013.

CANDIDO, Antonio. Formação da Literatura Brasileira: momentos decisivos, 1750-1880. Rio de Janeiro: Outro sobre Azul, 2007. [1957]

CARDOSO, Irene. A universidade da comunhão paulista. São Paulo: Cortez, 1982.

CARVALHO, Maria Cristina Wolff de. Ramos de Azevedo. São Paulo: Editora da Universidade de São Paulo, 2000.

CARVALHO, Vânia Carneiro de. Gênero e Artefato: o sistema doméstico da perspectiva da cultura material - São Paulo, 1870-1920. São Paulo: EDUSP/FAPESP, 2008.

CASTELNUOVO, Enrico. Retrato e Sociedade na Arte Italiana: ensaios de História Social da Arte. São Paulo: Companhia das Letras, 2006.

CAVALCANTI, Lauro (org). Modernistas na repartição. Rio de Janeiro, UFRJ/Paço Imperial, 1993 e Moderno e brasileiro: a história de uma linguagem na arquitetura (1930-1960). Rio de Janeiro: Jorge Zahar Ed., 2006.

CAVALCANTI, Lauro Pereira. Moderno e Brasileiro. A história de uma nova linguagem (1930-1960). Rio de Janeiro: Jorge Zahar Ed., 2006.

CAVERSAN, Luiz. "Uma relação espacial". Caderno Cotidiano. Folha de São Paulo, São Paulo, 4, dez de 2003.

CHADOIN, Olivier; EVETTE, Thérèse (coord). "Statistiques de la profession d'architecte 1998-2007 Socio-démographie et activités économiques", Ministère de la Culture et de la Communication, 2010. 
CHARLE, Christophe. Histoire sociale de la France au XIXe siècle. Paris: Éditions du Seuil, 1991.

- Les intellectuels em Europe au XIXe siècle: essai d'histoire comparée. Paris: Éditions du Seuil, 2001.

CHARLE, Christophe; VERGER, Jacques. Histoire des universités: XIIe-XXI siècle. Paris: PUF, 2012.

CHAMPY, Florent. Sociologie de l'architecture. Paris: La Découverte, 2001.

. «L'engagement des professionnels comme conséquence de tensions consubstantielles à leur pratique: I'architecture moderne entre les deux guerres», Sociétés contemporaines, n73, P; 97-119, 2009.

CHASIN, François. Un Corbusier. Paris : Seuil, 2015.

CHIARELLI, Silvia Raquel. Telésforo Cristófani: construção e composição. Mackenzie, 2003 (dissertação de mestrado).

CHOAY, Françoise. L'urbanisme, utopies et réalités: une anthologie. Paris: Seuil, 1965.

CODATO, Adriano e BONAMIN, Giovana. "Patrimônio Histórico e dominação simbólica". Caxambu, Minhas Gerais, $34^{\circ}$ Encontro Anual da Anpocs, 2010.

COELHO, Julio; CAMPOS, Antonio Carlos (org.) Giocondo Vilanova Artigas: o formador de cirurgiões. Curitiba: Relisul: 1991.

CONAN, Michel. Frank Lloyd Wright et ses clients: essai sur la demande adressée par des familles aux architectes. CTSB, Paris: Plan Construction e Architecture, 1988.

CONTIER, Felipe de Araújo. O edifício da Faculdade de Arquitetura e Urbanismo na Cidade Universitária: projeto e construção de uma escola. Tese (doutorado). Instituto de Arquitetura e Urbanismo de São Paulo, 2015.

CORONA, Eduardo. Oscar Niemeyer: uma lição de arquitetura. São Paulo: FUPAM, 2001

CORDIDO, Maria Tereza Regina Leme; BUZZAR, Miguel Antonio e SIMONI, Lúcia. "O plano de ação governo Carvalho Pinto (1959/1963) em São Paulo: moderação política e modernização". XIII Encontro da Associação Nacional de Pós-graduação em Planejamento Urbano e Regional. Florianópolis, 2009.

CORRÊA, Larissa. Rocha. "Trabalhadores e os doutores da lei: direitos e Justiça do Trabalho na cidade de São Paulo 1953 a 1964". Histórica (São Paulo. Online), v. 26, p. 1-12, 2007.

COSTA, Lúcio. Registro de uma vivência. Brasília: Empresa das Artes, UNB, 1995.

COULANGEON, Philippe. Sociologie des pratiques culturelles. Paris: La Découverte, 2005. 
Les métamorphoses de la distinction: inégalités culturelles dans la France d'aujourd'hui. Paris : Éditions Grasset \& Fasquelle, 2011.

CUCHE, Denys. La notion de culture dans les sciences sociales. Paris: La Découverte, 2004.

CUNHA, Gabriel Rodrigues. Uma análise da produção de Vilanova Artigas entre 1967 a 1976. Dissertação (mestrado). Escola de Engenharia de São Carlos da Universidade de São Paulo, 2009.

CZAPSKI, Silvia. O cavaleiro da saúde: a saga de Juljan Czapski, criador dos planos de saúde no Brasil. Osasco: Novo Século, 2011.

DAL CO, Francesco. Note per la critica dell'ideologia dell'architettura moderna: da Weimar a Dessau. Contropiano, Materiali Marxisti, no. $1,1968,153-171$.

DAL CO, Francesco. Architettura o rivoluzione: Hannes Meyer, Scritti 19211942, Padova, 1969.

. "Paulo Mendes da Rocha: Pritzker Prize 2006". Arquitextos, São Paulo, ano 06, n. 071.00, Vitruvius, abr. 2006.

. "Paulo Mendes da Rocha: Listen to and observe a master", Prêmio Pritzker, Fundação Pritzker, 2006.

DEMETERCO, Solange Menezes da Silva. Sabor e saber: livros de cozinha, arte culinária e hábitos alimentares, 1902-1950. Dissertação de Mestrado. Curitiba: UFPR, 2003.

DURAND, José Carlos. A profissão de arquiteto: estudo sociológico. Rio de Janeiro: CREA, 1972.

Arte, privilégio e distinção. Artes Plásticas, Arquitetura e Classe Dirigente no Brasil, 1855/1985. São Paulo: Perspectiva/EDUSP, 1989.

. "Négociation politique et rénovation de l'architecture". In: Actes de la recherche em sciences sociales. Vol.88, juin. pp.61-77, 1991.

DURAND, José Carlos e SALVATORI, Elena. "A gestão da carreira dominante de Oscar Niemeyer". Tempo Social, Revista de Sociologia da USP, v.25, n2. Novembro, 2013. pp. pp.157-180.

EATON, Leonard K. Two Chicago Architects and their clients. Frank Lloyd Wright and Howard Van Doren Shaw. MIT Press Cambrigde, 1969.

ELIAS, Norbert. Mozart: Sociologia de um gênio. Rio de Janeiro: Jorge Zahar, 1995.

- Estabelecidos e Outsiders. Sociologia das relações de poder a partir de uma pequena comunidade. Rio de Janeiro: Zahar, 2000.

. Sociedade de Corte. Rio de Janeiro: Zahar, 2001

ENGLISH, James. The Economy of Prestige. Prizes, Awards and the Circulation of Cultural Value. Cambridge/London, Havard 
University Press, 2005.

ESQUINAZZI, Jean-Pierre. Sociologie des œuvres. Paris: Armand Coli, 2007.

. Sociologie des publics. Paris: La Découverte, 2009.

FABIANI, Jean-Louis. La sociologie comme elle s'écrit: de Bourdieu à Latour. Paris: Éditions de I'EHESS, 2015.

FAGIOLO DELL'ARCO, Maurizio. Gaetano Miani in search of the lost paradise. São Paulo: Museu de Arte de São Paulo, 1988.

FERRAZ, Geraldo. "Concurso de anteprojeto para as instalações do Clube Atlético Paulistano". Habitat n047, mar, abr, 1958.

FERRAZ, Marcelo Carvalho. Lina Bo Bardi. São Paulo: Empresa das Artes, 1993.

- Vilanova Artigas. São Paulo: Inst. Lina Bo \& Fundação Vilanova Artigas, 1997.

FERRO, Sérgio. Arquitetura e Trabalho Livre. São Paulo: Cosac\&Naif, 2006.

Artes Plásticas e trabalho livre: de Dürer a Velázquez. São Paulo: Editora 34, 2015.

FERRO, Sérgio \& LEFEVRE, Rodrigo. "Proposta inicial para um debate: possibilidades de atuação". São Paulo: GFAU, 1963.

FIALHO, Ana Letícia do Nascimento. L'insertion internationale de l'art brésilien. Une analyse de la présence et de la visibilité de l'art brésilien dans les institutions et dans le marché. (Thèse de doctorat), Paris, EHESS, 2006.

FIALHO, Ana Letícia do Nascimento (coord.) Pesquisa Setorial: o mercado de arte contemporânea no Brasil. Projeto Latitute, 2014.

FICHER, Sylvia. Ensino e profissão: o curso de engenheiro-arquiteto da Politécnica de São Paulo. São Paulo: EDUSP, 2005.

FICHER, Sylvia e ACAYABA, Marlene Milan. Arquitetura Moderna Brasileira. São Paulo: Projeto Editores, 1982.

FIORATII, Gustavo. "Su casa". Caderno Serafina, Folha de S.Paulo, 03/08/2008.

FLADRIN, Jean-Louis. A distinção pelo gosto. CHARTIER, Roger. História da Vida Privada 3: da Renascença ao século das Luzes. São Paulo: Companhia das Letras, 2009.

FRAJNDLICH, Rafael Urano. Tafuri: tempo da cidade longínquia. São Paulo, FAU USP, 2014. tese de doutorado.

FRIEDMAN, Alice T. Women and the making of the Modern House: a social and a architectural history. Yale Press, 2007. 
FORTE, Miguel. Diário de um jovem arquiteto: minha viagem aos Estados Unidos em 1947. São Paulo: Editora Mackenzie, 2001.

FORTY, Adrian. Objeto de desejo - design e sociedade desde 1750. São Paulo: Cosac Naify, 2007.

Fundação Mies Van der Rohe. 1st Mies van der Rohe Award for latin american architecture. Barcelona: Fundação Mies Van der Rohe, 1998.

GAMA, Lúcia Helena. Nos bares da vida: produção cultural e sociabilidade em São Paulo,1940-1950. São Paulo: Editora Senac, 1998.

GFAU (vários autores), Corredor das Humanas. São Paulo: GFAU, outubro, 2009.

GARCIA, Sylvia. Destino Ímpar: Sobre a Formação de Florestan Fernandes. São Paulo: Ed. 34, 2002.

GÓES, Marta. Alfredo Mesquita: um grã-fino na contramão. São Paulo: Editora Terceiro Nome, 2007.

GRIGNON, Claude; PASSERON, Jean-Claude. Le savant et le populaire: misérabilisme et populisme en sociologie et en littérature. Paris: Éditions du Seuil/Gallimard, 1989.

GROSSMAN, Vanessa. Le PCF a changé! Niemeyer et la siège du parti communiste (1966-1981). Paris: Édition B2, 2013.

GUIOLDI, Rodolfo. "A estética à luz do marxismo". Fundamentos, janeiro, 1951.

HALL, Peter. Cidades do amanhã: uma história intelectual do planejamento e do projeto urbano no século XX. São Paulo: Perspectiva, 2002.

HASKELL, Francis. Mecenas e Pintores: arte e sociedade na Itália Barroca. São Paulo: Edusp, 2007.

HAMBURGUER, Amélia Império (org.). FAPESP 40 anos: abrindo fronteiras. São Paulo: Edusp, 2004. p.514.

HEINICH, Nathalie. La sociologie de Norbert Elias. Paris: La Découverte, 2002.

. La sociologie de l'art. Paris: La Découverte, 2004.

. De la visibilité : excellence et singularité en régime médiatique. Paris: Éditions Gallimard, 2012.

HEINICH, Nathalie et SAPIRO, Roberta. De l'artification. Enquêtes sur le passage à l'art. Paris: Édition de l'EHESS, 2012.

HEINICH, Nathalie; SCHAEFFER, Jean-Marie, TALON-HUGON, Carole. Pardelà de beau et le laid: enquêtes sur les valeurs de l'art. Rennes: Presses Universitaires de Rennes, 2014. 
HOMEM, Maria Cecília Naclério. O palacete paulistano e outras formas urbanas de morar da elite cafeeira: 1967-1918. São Paulo: Editora Martins Fontes, 2010.

IRIGOYEN, Adriana. Wright e Artigas: duas viagens. São Paulo: Ateliê Editorial/FAPESP, 2002.

JARCY, Xavier de. Le Corbusier: un fascisme français. Paris: Albin Michel, 2015.

JUCÁ, Christina Bezerra de Mello. João Batista Vilanova Artigas, arquiteto: a gênese de uma obra (1934-1941). Brasília: UnB, 2006. (dissertação de mestrado).

JUAÇABA, Carla. "Diretório 25 jovens arquitetos". Revista AU, Edição 197, Agosto, 2010.

KAMITA, João Masao. Vilanova Artigas. São Paulo: Cosac\&Naif, 2000.

KEINERT, Fábio Cardoso. Cientistas sociais entre a ciência e política (Brasil, 1968-1985). Tese (Doutorado em Sociologia). Faculdade de Filosofia, Letras e Ciências Humanas, Universidade de São Paulo, São Paulo, 2011.

KOURY, Ana Paula. Grupo Arquitetura Nova. Flávio Império, Rodrigo Lefèvre e Sérgio Ferro. São Paulo: EDUSP, 2003.

LAHIRE, Bernard. À quoi sert la sociologie? Paris: La Découverte /Poche, 2004.

LAROCHE, Josepha. "Le Nobel comme enjeu symbolique dans les relations internationales". In: Revue française de science politique, 44eannée, n4, 1994. pp. 599-628.

LAUDANNA, Mayra. Maria Bonomi da gravura à arte pública. São Paulo: Editora da Universidade de São Paulo, Imprensa Oficial, 2007.

LEMOS, Carlos Alberto Cerqueira. Arquitetura Brasileira. São Paulo: Melhoramentos, Edusp, 1979.

- Viagem pela carne. São Paulo: Editora da Universidade de São Paulo, 2005.

LEON, Ethel. IAC. Instituto de Arte Contemporânea: Escola de Desenho Industrial do MASP (1951-1953): Primeiros estudos. Dissertação de Mestrado. São Paulo: FAU USP, 2006.

LEON, Ethel. "Zanine, o mago da madeira". In. Memórias do Design Brasileiro. São Paulo: Editora Senac, 2009.

LIRA, José Tavares Correira de. Warchavchik: fraturas da vanguarda. São Paulo: Cosac Naify, 2011.

LOPES, Juarez Rubens Brandão. "As ciências sociais, a cidade e o arquiteto". Revista Pós, FAUUSP, agosto, 1995. 
LOPES, Juarez Brandão. "O consumo da arquitetura nova" Revista Ou... n4, junho, 1971.

LOURENÇO, Maria Cecília França. Museus acolhem o Moderno. São Paulo: Edusp, 1999.

LOURENÇO, Bruna. "Casa de 1969 por Paulo Mendes da Rocha". Revista Glamour, 27 abril, 2012.

LEBARON, Frédéric. Le "Nobel" d'économie. In: Actes de la recherche en sciences sociales. Vol. 141-142, mars 2002. Science. pp. 62-65.

LEBARON, Frédéric ; LE ROUX, Brigitte. La méthodologie de Pierre Bourdieu em action : espace culturel, espace social et analyse des données. Paris, Dunod, 2015.

MACHADO, Cassiano Elek. "Nova galeria vira casa da fotografia-arte". Folha de S.Paulo, 17/05/2002.

MADEIRA, Wagner Martins. Formas do Teatro de comédia: a obra de Oduvaldo Vianna. FFLCH/Letras, 2003 (tese de doutorado).

MATONTI, Frédérique. Intellectuels Comunistes. Essai sur l'obéissance politique. La Nouvelle Critique (1967-1980). Paris: La Découverte, 2005.

MATOS, Olgária. In Memorian, Pós, v.15, n²4, São Paulo, dezembro, 2008. p.232-248.

MATERA, Sergio. Carlos Millan: um estudo sobre produção em arquitetura. São Paulo, FAU USP, 2005. (dissertação de mestrado).

MARINHO, Mariana. "Galeria Luciana Brito muda para casa nos Jardins projetada por Rino Levi". Folha de S. Paulo, 27/03/2016.

MAUSS, Marcel. Sociologia e antropologia. São Paulo: Cosac \& Naify, 2003.

MEDRANO, Leandro Silva; RECAMÁN, Luiz. Vilanova Artigas: habitação e cidade na modernização brasileira. Campinas, SP: Editora da Unicamp, 2013.

MELO, Alexandre Penedo Barbosa de. Móveis Artísticos Z: 1948-1961. Dissertação de Mestrado, São Paulo: EESC-USP, 2001.

MEMORIAL Vilanova Artigas, FAUUSP, 1981.

MENGER, Pierre-Michel. La différence, la concurrence et la disproportion: sociologie du travail créateur. Paris: Collège de France/Fayard, 2014.

MENDONÇA, Rivadávia. "Pelegos a serviço da reação". Fundamentos, abril, 1950.

MICELI, Sergio. "Condicionantes do desenvolvimento das Ciências Sociais no Brasil 1930-1960". Revista Brasileira de Ciências Sociais, São Paulo, v. 2, n. 5, p. 5-26, 1987. 
Imagens negociadas: retratos da elite brasileira. São Paulo: Companhia das Letras, 1996.

. Intelectuais à brasileira. São Paulo: Companhia das Letras, 2001.

- Nacional Estrangeiro: história social e cultural do modernismo artístico em São Paulo. São Paulo: Companhia das Letras, 2003.

MICELI, Sergio (org). História das ciências Sociais no Brasil. São Paulo: Vértice/Idesp/FINEP, 1989. vol 1.

MIGUEL, Jorge Marão Carnielo. A Casa. São Paulo: Imprensa Oficial do Estado de São Paulo, 2003.

MOLINA, Géraldine. "Mise en scène et coulisses du "star-system" architectural: la théâtralisation des vedettes et ses paradoxes". Espaces et Sociétés, no,156-157, pp.197-212, 2014.

MONNIER, Gérard. Histoire Critique de I'Architeture em France: 19181950. Paris: Philippe Sers Editeur, 1990.

- L'architecture: la réception immédiate et la réception diferée. $L$ 'oeuvre jugé, l'édifice habité, le monument célébre. Paris: Publications de La Sorbonne, 2006.

MONTANER, Josep Maria. Después del Movimiento Moderno. Barcelona: Gustavo Gilli, 1993.

- Museos para el nuevo siglo/Museums for the new century. Barcelona: Gustavo Gili, 1995.

. Less is more: minimalismo en arquitectura y otras artes. Barcelona: Actar, 1996.

- La modernidad superada: ensayos sobre arquitectura contemporánea, Barcelona: Gustavo Gilli, 1997.

MONTANER, Josep Maria e VILLAC, Maria Isabel. Mendes da Rocha. Barcelona: GG, 1996.

MONTLIBERT, Christian. L'impossible autonomie de l'Architecte. Sociologie de la production architecturale. Strasbourg: Presses Universitaires de Strasbourg et Maison des Sciences de l'Homme,, 1995.

. «Permanences et changements dans la profession d'Architecte», Strasbourg, 1987

MONTAIGNE, Marion, PINÇON, Michel et PINÇON-CHARLOT, Monique. Riche: pourquoi pas toi? Bruxelles: Éditions Dargaud, 2013.

MONTELLO, Jessé (org). Giorgio Mortara: publicação comemorativa do centenário de seu nascimento. Rio de Janeiro: IBGE, 1985.

MONTEIRO, Ana Carla de Castro Alves. Os hotéis da metrópole. O contexto histórico e urbano da cidade de São Paulo através da produção arquitetônica hoteleira (1940-1960). São Paulo: FAUUSP, 2006. Dissertação de Mestrado. 
MONTLIBERT, Christian et MARQUART, F. «Division du travail et concurrence en architecture». Revue Française de Sociologie, XI (1970), p. 363-389.

MORAES, Vinicius. Para viver um grande amor. São Paulo: Companhia das Letras, 2010.

MORSE, Richard M. De comunidade à metrópole. Biografia de São Paulo. Comissão do IV Centenário da Cidade de São Paulo. 1954.

MOTA, Valdemar. Visconde de Porto Martim: Um benemérito açoriano no Brasil, Instituto Açoriano de Cultura, Angra do Heroísmo, 1978.

MOTTA, F.lávio L. Paulo Mendes da Rocha. Acrópole, São Paulo, n. 343, p. 17-18, set 1967. p.17.

MOTTA, Heloísa Alves de Lima. Uma menina paulista. São Paulo, Totalidade Editora, 1992. p.98.

MOULIN, Raymonde. Les architectes. Métamorphose d'une profession libérale. Paris, Calmann-Lévy, 1973.

. Le marché de l'art: mondialisation et nouvelles tecnologies. Paris: Éditions Flamarion, 2009.

MOURA, Flavio Rosa de. Obra em construção: a recepção do neocentrismo e a invenção da arte contemporânea no Brasil. 2011. Tese (Doutorado em Sociologia) - Faculdade de Filosofia, Letras e Ciências Humanas, Universidade de São Paulo, São Paulo, 2011.

NIEMEYER, Oscar. "Contradição na Arquitetura" In.XAVIER, Alberto (org). Depoimento de uma geração. São Paulo: Cosac \& Naif, 2003.

NITSCHE, Lua. "Moby Visita, Casas Paulistas: Casa Marcello Nitsche". Depoimento em vídeo. Moby, Revista Amarello, 2013.

NOBRE, Ana Luíza; WISNIK, Guilherme; MILHEIRO, Ana Vaz. Coletivo: 36 projetos da arquitetura paulista contemporânea. São Paulo, Cosac Naify, 2006.

OTONDO, Catherine. Desenho e espaço: relações entre pensar e fazer na obra de Paulo Mendes da Rocha. São Paulo, FAU USP (tese de doutorado), 2013.

PAESANI, Alfredo. Entrevista. O Arquiteto. Boletim do Sindicato dos Arquitetos do Estado de São Paulo, s/d. 1988.

PANOFSKY, Erwin. Arquitetura Gótica e escolástica. Sobre a analogia entre arte, filosofia e teologia na Idade Média. São Paulo, Martins Fontes, 1991.

"A história da arte como uma disciplina humanística". In 0 significado nas artes visuais. São Paulo: Perspectiva, 2012.

O significado nas artes visuais. São Paulo: Perspectiva, 2012. 
PEDROSA, Mário. "Da Missão Francesa - seus obstáculos políticos". In: ARANTES, Otília Beatriz Fiori. Acadêmicos e modernos: textos escolhidos III. São Paulo: Edusp, 1998.

PENTEADO, Fábio. Fábio Penteado: ensaios de arquitetura. São Paulo: Empresa das Artes, 1998.

. "Entrevista". Projeto Design, abril, no, 190, 2004.

PENTEADO, Yolanda. Tudo em cor de rosa. São Paulo: Edição da Autora, 1977.

PEQUIGNOT, Bruno. Sociologie des Arts. Paris: Armand Colin, 2009.

"A sociologia das artes e da cultura na França. Gênese, desenvolvimentos e atualidade de uma área de pesquisa. In: QUEMIN, Alain e VILLAS-BOAS, Glaucia (dir). Arte e Vida Social. Marseille, OpenEdition Press, 2016.

PEREIRA, Gustavo. Christiano Stockler das Neves e a formação do curso de arquitetura no Mackenzie College. Um estudo sobre a disseminação dos métodos da "École des Beaux-Arts de Paris" e das "Fine-Arts Schools" Norte-americanas. Universidade Presbiteriana Mackenzie, São Paulo. 2005.

PETROSINO, Maurício Miguel. João Batista Vilanova Artigas - residências unifamiliares: a produção arquitetônica de 1937 a 1981. Dissertação de Mestrado, FAUUSP, 2009.

PEVSNER, Nicolau. Génie de l'architecture européenne. Paris: Le livre de Poche, 1970.

PINÇON, Michel et PINÇON-CHARLOT, Monique. Châteaux et Châtelains. Les siècles passent, les symbole demeure. Paris: Éditions Anne Carrière, 2005.

. Grandes Fortunes: dynasties familiales et formes de richesse em France. Paris : Petite Bibliothèque Payot, 2006.

. Paris: quinze promenades sociologiques. Paris Èdition Payot: Paris, 2009.

PINON, Hélio. Paulo Mendes da Rocha, Barcelona: Escuela Técnica Superior de Arquitectura de Barcelona (ETSAB), Barcelona, 2003.

PISANI, Daniele. Paulo Mendes da Rocha: obra completa. São Paulo: Gustavo Gilli, 2013.

POGREBIN, Robin. "Paulo Mendes da Rocha of Brazil Wins the Pritzker Architecture Prize". NYTimes, 10, abr, 2006.

PONTES, Heloísa. Destinos Mistos: os críticos do Grupo Clima em São Paulo. São Paulo: Companhia das Letras, 1998.

PRADO, Maria Lígia Coelho. Cidades universitárias: patrimônio urbanístico e arquitetônico da USP. São Paulo, EDUSP, 2004. 
PULICI, Carolina. Entre Sociólogos: versões conflitantes da "condição de sociólogo" na USP dos anos 1950-1960. São Paulo: EDUSP, 2008.

. O charme (in)discreto do gosto burguês paulista: estudo sociológico da distinção social. Tese de Doutorado, São Paulo: FFLCH, 2010.

QUEMIN, Alain. Les stars de l'art contemporaine. Notoriété et consécration artistiques dans les arts visuels. Paris: CNRS Éditions, 2013.

RAHE, Nina. "Galeria Vermelho inaugura sala de cinema focando videoarte". Folha de S.Paulo, 14/02/2016.

RIDENTI, Marcelo. Em busca do povo brasileiro. Rio de Janeiro: Record, 2000.

O fantasma da revolução brasileira. São Paulo: Ed. UNESP, 2010.

ROCHA, Paulo Mendes. Entrevista com Arquiteto, "A natureza é um Trambolho", In Revista Caros Amigos, abril, 2002.

. América, natureza e cidade. São Paulo: Estação Liberdade, 2012.

RODRIGUES, Lidiane Soares. A produção social do marxismo universitário em São Paulo: mestres, discípulos e "Um Seminário". São Paulo, FFLCH USP, 2011. tese de doutorado.

ROMÃO, Wagner de Melo. Sociologia e política nos anos 1960: a experiência do Cesit. São Paulo: Associação Editorial Humanitas, 2006.

ROSATTI, Camila Gui. Roberto Schwarz: Arquitetura e Crítica. Dissertação de Mestrado, São Paulo: FAU-USP, 2010.

. "Lina, Ruchti e Zanine: três modernos na encruzilhada dos anos 1950". In: CALHEIROS, Alex. MARI, Marcelo, RUFINONI, Priscila R. Mobiliário Moderno: das pequenas fábricas ao projeto da UnB. Brasília, Editora Universidade de Brasília, 2014.

RUBINO, Silvana. "O mapa do Brasil passado". In. Revista do IPHAN, n. 24. 1996.

- Rotas da modernidade: trajetória, campo e história na atuação de Lina Bo Bardi. Tese de Doutorado, Campinhas, IFCH UNICAMP, 2002.

. "A escrita de uma arquiteta". RUBINO, S. e GRINOVER, M. (org) Lina por escrito. Textos escolhidos de Lina Bo Bardi. São Paulo: Cosac \& Naify, 2009.

. "Corpos, cadeira e colares: Charolette Perriand e Lina Bo Bardi". Cadernos Pagu, 34, janeiro-junho, 2010, pp.331-362.

RUCHTI, Valéria. Jacob Ruchti e a modernidade paulista (1940-1970). São Paulo: Dissertação de Mestrado, FAU-USP, 2011.

SÁ, Flávia Carvalho de. Profissão: Arquiteta. Formação Profissional, mercado de trabalho e projeto arquitetônico na perspectiva das 
relações de gênero. São Paulo, FAU USP, 2010. (dissertação de mestrado).

SAMARA, Eni de Mesquita. Diretores da Escola Politécnica da Universidade de São Paulo: vidas dedicadas a uma instituição. São Paulo: Edusp, 2003.

SANT'ANNA JR, Antonio Carlos. "Luiz Roberto Carvalho Franco, 1926-2001". Arquitetextos, Vitruvius, abr, 2001.

SANTOS, Cecília Rodrigues dos (org.). Le Corbusier e o Brasil. São Paulo: Tessela: Projeto Editora, 1987.

SANTOS, Cecília Rodrigues dos. "Paulo Mendes da Rocha: os lugares como páginas da dissertação de uma existência". Arquitextos, julho, 2003.

SANTOS, Maria Cecília Loschiavo. Tradição e Modernidade no Móvel Brasileiro: visões de utopia na obra de Carrera, Tenreiro, Zanine e Sérgio Rodrigues. Tese de Doutorado, São Paulo, FFLCH USP, 1993.

Móvel Moderno no Brasil. São Paulo: Studio Nobel/FAPESP/EDUSP, 1995.

. O móvel moderno no Brasil/Modern furniture in Brazil. São Paulo: Editora Olhares, 2015 (edição revisada e bilingue).

SANVITTO, Maria Muiza. Brutalismo paulista, uma análise compositiva das residencias paulistanas entre 1957 e 1972. Dissertação de mestrado apresentada à Faculdade de Arquitetura da Universidade Federal do Rio Grande do Sul. Porto Alegre, 1994.

SAPIRO, Gisele. La guerre des écrivains 1940-1953, Paris, Fayard, 1999.

- La sociologie de la littérature. Paris : La Découverte, 2014.

SARAIVA, Pedro Paulo de Melo. "Depoimento sobre Vilanova Artigas". PÓs Revista do Programa de Pós-Graduação em Arquitetura e Urbanismo. no 18, dez, 2005.

SARLO, Beatriz. Modernidade Periférica. Buenos Aires 1920 e 1930. São Paulo: Cosac Naify, 2010.

SCHWARZ, Roberto. Um mestre na periferia do capitalismo: Machado de Assis. São Paulo: Duas Cidades; Ed.34, 2000.

. "Cultura e política, 1964-1969". In: O pai de família e outros estudos. Rio de Janeiro: Paz e Terra, 1978.

. "Um seminário Marx". Novos Estudos, n050, março, 1998.

SEGAWA, Hugo. Arquiteturas no Brasil: 1900-1990. São Paulo: EDUSP, 2002.

. "Ensaio". In: Zer Zanine. Rio de Janeiro: Centro Cultural Banco do Brasil, 2003. (catálogo de exposição) 
"Paulo Mendes da Rocha recebe título de professor emérito da Fauusp". In.Revista Pós, V.17, no 28, São Paulo, dez, 2010. p.220227.

SERAPIÃO, Fernando. Entrevista com João De Gennaro. Projeto Design, no 306, ago, 2005.

Arquitetura revista: a Acrópole e os edifícios de apartamento em São Paulo (1938-1971). Universidade Presbiteriana Mackenzie, 2006 (dissertação de mestrado).

SILVA, Suely Ferreira da Silva (org). Zanine: Sentir e Fazer. Rio de Janeiro: Agir, 1995.

SILVA, Joana Mello de Carvalho e. O arquiteto e a produção da cidade: a experiência de Jacques Pilon em perspectiva (1930-1960). São Paulo. Faculdade de Arquitetura e Urbanismo, Universidade de São Paulo, 2010. Tese de Doutorado.

SOUZA, Francisco Cornejo. As formas da forma: o design brasileiro entre o modernismo e a modernização. Tese de Doutorado, São Paulo, FFLCH USP, 2011.

SIMIONI, Ana Paula. "Anatomia de um móvel moderno: algumas questões em torno do mobiliário da Casa Modernista, de Gregori Warchavichik". ARS (São Paulo), v. 20, p. 42-55-55, 2012.

SILVA, Suely Ferreira da Silva (org). Zanine: Sentir e Fazer. Rio de Janeiro: Agir, 1995.

STUCHI, Fabiana Terenzi. Revista Habitat: um olhar moderno sobre os anos 50 em São Paulo. FAUUSP, 2007 (dissertação de mestrado)

TAFURI, Manfredo; CACCIARI, Massimo e DAL CO, Francesco. De la vanguardia a la metropoli: critica radical a la arquitetura. Barcelona, Gili, 1972.

TAPIE, Guy. Sociologie de l'habitat contemporain: vivre l'architecture. Marseille : Éditions Parenthèses, 2014.

TELLES, Sophia. "Documento: Paulo Mendes da Rocha. A casa no Atlântico". AU - Arquitetura \& Urbanismo, São Paulo, n60, jun/jul.1995, p.69-81.

THOMAZ, Dalva. Um olhar sobre Vilanova Artigas e sua contribuição à arquitetura brasileira. Dissertação de Mestrado, FAUUSP, 1997.

TRIGO, M. H. Bueno. Os paulistas de quatrocentos anos: Ser e Parecer. São Paulo: Annablume, 2001.

VIANNA, Deocélia. Companheiros de Viagem. São Paulo: Brasiliense, 1984.

VILLAÇA, Flávio. Espaço intra-urbano no Brasil. São Paulo: Studio Nobel, FAPESP, 2001.

VIOLEAU, Jean-Louis. Rem Koolhas : le bom, la brute. Paris : Éditions B2, 2014. 
WEBER, Max. Ensaios de Sociologia. 2 ed. Rio de Janeiro: Zahar, 1971.

. Economia e Sociedade: fundamentos da sociologia compreensiva. Brasília, Editora da Universidade de Brasília: São Paulo, Imprensa Oficial, 1999.

. Hindouisme et bouddhisme. Paris, Champs Flammarion, 2003.

WHITE, Harrison et WHITE, Cyntia. La carrière des peintres au XIXe siècle. Paris : Champs Arts, 2009.

WILLIAMS, Raymond. "A fração Bloomsbury". In: Plural; Sociologia, USP, São Paulo, 6: 139-168, 1999.

. O campo e a cidade. São Paulo: Cia das Letras, 2011.

WOLF, Silvia Ferreira Santos. Jardim América: o primeiro bairro-jardim de São Paulo e sua arquitetura. São Paulo: EDUSP, FAPESP, Imprensa Oficial, 2001.

XAVIER, Alberto (org). Depoimento de uma geração. São Paulo: Cosac \& Naif, 2003.

ZANINI, Walter. Arte e História da arte. Estud. av., São Paulo, v. 8, n. 22, Dec. 1994.

ZAPPA, Regina e SOTO, Ernesto. 1968: eles só queriam mudar o mundo. Rio de Janeiro, Zahar, 2008.

ZEIN, Ruth V. Arquitetura Brasileira, Escola Paulista e as casas de Paulo Mendes da Rocha. Dissertação de mestrado. Porto Alegre, PROPAR/UFRGS, 2000.

. Brutalismo, Escola Paulista: entre o ser e o não ser. Arqtexto 2, 2002.

ZEIN, Ruth V. A Arquitetura da Escola Paulista Brutalista: 1953-1973. Porto Alegre, UFRGS, 2005. Tese de Doutorado.

\section{Jornais, Revistas e Sites}

"Consultora Sentimental e culinária". Diário de Notícias, 27 de dezembro de 1951.

Revista O movimento Feminino, dezembro de 1951.

Jornal de Notícias, 02 de fevereiro de 1950.

Jornal Diário da Noite, 13 de fevereiro de 1950.

"Quem construiu o Brasil Moderno". Jornal O empreiteiro, 31/05/2012.

Habitat, números 1 a 10, 1950 a 1953.

Diário de São Paulo, 22 de agosto de 1948 
Acervo Estado de São Paulo

Hemeroteca Biblioteca Nacional

Revista O Cruzeiro.

Revista Readers Digest.

"Corretoras se destacam com oferta de imóveis descolados". Revista Veja São Paulo, 06/12/2012

"Moradores se dividem sobre reforma de apartamento em prédio antigo". Caderno Classificados. Folha de S. Paulo, 28/04/2013

"Imobiliária butique". Revista Casa e Jardim, 02/07/2013.

http://www.pritzkerprize.com

"Jay Pritzker: Jay Pritzker, pioneer of the modern hotel chain, died on January 23rd, aged 76". The Economist, 28 de janeiro 1999. 


\section{APÊNDICE A \\ Roteiro de coleta de informações sobre encomendante}

Roteiro de Questões para pesquisa sobre Arquitetura Moderna Paulista e seus clientes

Pesquisa de Doutorado I Camila Gui Rosatti processo FAPESP 2012/14020-0 
Data/ Hora: Terça feira, 13/05/2014, às $15 \mathrm{~h}$

prejEntrevista com:

Grau de parentesco:

contato:

Local:

Arquivo Gravação:

Arquivo transcrição

Duração:

Observação:

\begin{tabular}{|l|l|l|}
\hline \multicolumn{2}{|l|}{ DADOS GERAIS } & \multicolumn{2}{l|}{} \\
\hline encomendante & \\
\hline arquiteto & \\
\hline ano da casa & projeto & \\
\hline & construção & \\
\hline localização & Rua \\
\hline bairro & Butantã \\
\hline Quem é o arquiteto? & \\
\hline
\end{tabular}

DADOS PESSOAIS do ENCOMENDANTE -

data de nascimento

local

\begin{tabular}{|c|c|c|c|c|c|}
\hline \multicolumn{6}{|l|}{ Nome do pai } \\
\hline & \multicolumn{2}{|r|}{ nascimento } & \multirow[t]{3}{*}{ Formação escolar } & \multirow[t]{3}{*}{ profissão } & \multirow[t]{3}{*}{ religião } \\
\hline & local & & & & \\
\hline & ano & & & & \\
\hline \multicolumn{6}{|c|}{ Migração - motivo? } \\
\hline \multicolumn{6}{|l|}{ Nome da mãe } \\
\hline & \multicolumn{2}{|r|}{ nascimento } & Formação escolar & profissão & religião \\
\hline & local & & & & \\
\hline & ano & & & & \\
\hline
\end{tabular}

Migração - motivo?

* Há alguma biografia/pesquisa sobre encomendante? 
DADOS dos IRMAOS -

nome

\begin{tabular}{|l|l|l|l|l|}
\hline \multicolumn{1}{|c|}{ nascimento } & & Formação escolar & profissão & religião \\
\hline local & & $\begin{array}{l}\text { 1o e 2o grau } \\
\text { púb. ou priv. }\end{array}$ & \\
\hline ano & & $\begin{array}{l}\text { Superior } \\
\text { púb. ou priv. }\end{array}$ & \\
\hline
\end{tabular}

DADOS FORMAÇAO ESCOLAR dO ENCOMENDANTE

Ensino básico

Ensino superior

Pública / particular

Pública / particular

\section{PROFISSAO dO ENCOMENDANTE -}

Há um currículo completa da trajetória profissional?

Início Profissional

Profissão no momento

da encomenda

\section{DADOS PESSOAIS dO CONJUGE}

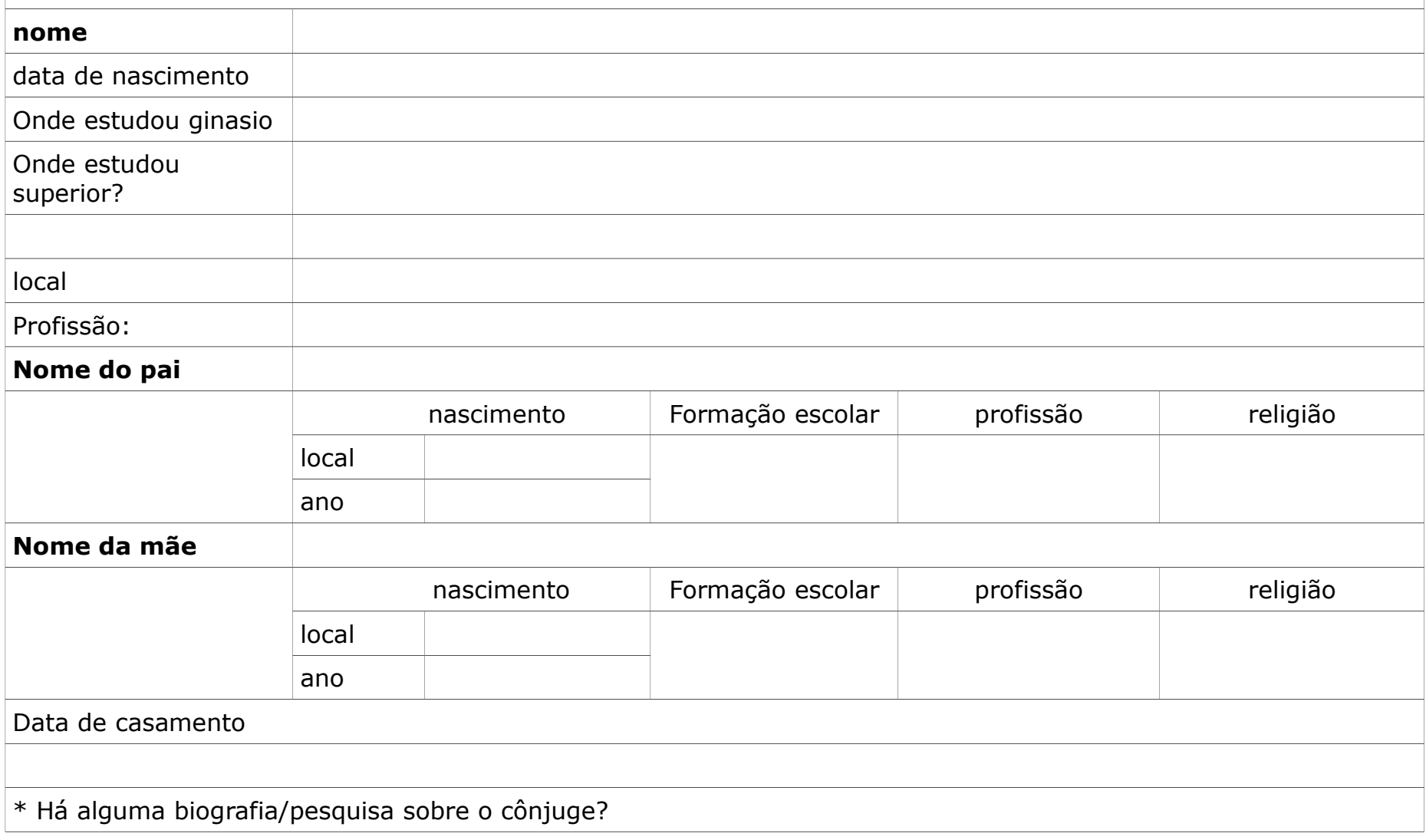




\section{DADOS da FAMILA}

no.de filhos

Onde se

conheceram?

Observação casamento

\section{nome}

\section{CONDICOES de ENCOMENDA da CASA}

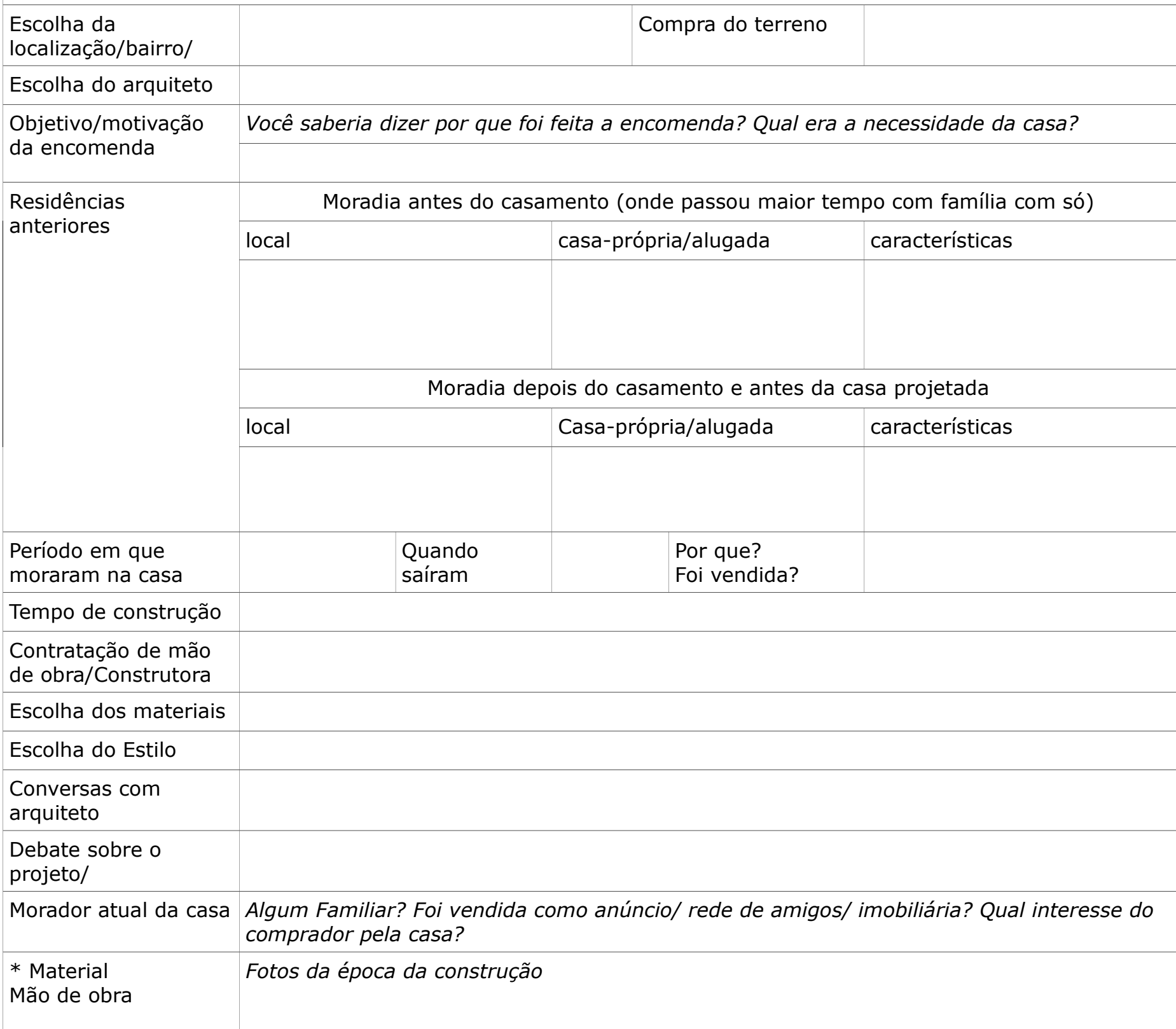

\section{CARACTERISTICAS da CASA}

\begin{tabular}{|c|c|c|c|c|c|}
\hline $\begin{array}{l}\text { Número de } \\
\text { moradores da } \\
\text { Casa }\end{array}$ & Pai/ Mãe & Filhos & Parentes/ Agregados & \multicolumn{2}{|c|}{$\begin{array}{l}\text { Empregados Domésticos } \\
\text { babá, cozinheira, jardineiro, } \\
\text { mordomo, motorista }\end{array}$} \\
\hline \multicolumn{6}{|l|}{$\begin{array}{l}\text { Como você } \\
\text { descreveria a casa }\end{array}$} \\
\hline $\begin{array}{l}\text { Quem frequentava a } \\
\text { casa? }\end{array}$ & parentes & $\begin{array}{l}\text { Amigos da } \\
\text { família }\end{array}$ & Amigos dos filhos & $\begin{array}{l}\text { Festa/Reuniões/ } \\
\text { Eventos }\end{array}$ & $\begin{array}{l}\text { Animais de } \\
\text { estimação }\end{array}$ \\
\hline
\end{tabular}




\begin{tabular}{|c|c|c|c|c|c|}
\hline Objetos da Casa & Mobiliário & Quadros & Instrumentos musicais & Obj. de Design & Eletrodoméstico \\
\hline Percepção da Casa & $\begin{array}{l}\text { Iluminação } \\
\text { Casa era } \\
\text { escura? }\end{array}$ & $\begin{array}{l}\text { Térmica } \\
\text { Casa era } \\
\text { fria? }\end{array}$ & $\begin{array}{l}\text { Acústica } \\
\text { Casa era barulhenta? }\end{array}$ & $\begin{array}{l}\text { Espaço } \\
\text { Casa ampla? }\end{array}$ & \\
\hline \multirow[t]{9}{*}{ Detalhes } & pisos & & & & \\
\hline & azulejos & & & & \\
\hline & janelas & & & & \\
\hline & cores & & & & \\
\hline & $\begin{array}{l}\text { Jardim/ } \\
\text { área externa/ } \\
\text { piscina }\end{array}$ & & & & \\
\hline & quartos & & & & \\
\hline & banheiros & & & & \\
\hline & cozinha & & & & \\
\hline & $\begin{array}{l}\text { Quarto de } \\
\text { empregada }\end{array}$ & & & & \\
\hline \multicolumn{6}{|l|}{$\begin{array}{l}\text { Quais as } \\
\text { características mais } \\
\text { marcante da casa? }\end{array}$} \\
\hline \multicolumn{6}{|l|}{$\begin{array}{l}\text { Qual opinião dos } \\
\text { amigos que } \\
\text { frequentavam a casa? }\end{array}$} \\
\hline \multicolumn{6}{|l|}{$\begin{array}{l}\text { Qual a opinião da } \\
\text { vizinhança? as } \\
\text { críticos? }\end{array}$} \\
\hline $\begin{array}{l}\text { Que adjetivos você } \\
\text { associaria à casa? }\end{array}$ & \multicolumn{5}{|c|}{3 ou 4 palavras sínteses } \\
\hline \multicolumn{6}{|l|}{$\begin{array}{l}\text { Algum problema da } \\
\text { casa? }\end{array}$} \\
\hline * Material & $\begin{array}{l}\text { Fotos antigas } \\
\text { Cartas Trocada }\end{array}$ & a família na & & & \\
\hline
\end{tabular}

GOSTOS CULTURAIS / PRATICAS CULTURAIS tendo como referência o ambiente familiar

\begin{tabular}{|l|l|l|l|}
\hline \multirow{2}{*}{ Literatura/Livros } & Aquisição familiar & Frequentação Externa & Estudo/Curso/Formação \\
\cline { 2 - 4 } & Búsicateca & & \\
\hline Artes Plásticas & Instrumentos Musicais & Concerto/Show/ & Música \\
\cline { 2 - 4 } & & & \\
\hline Quadro/Escultura/Painel & Exposição/Museu/Galeria & Desenho/Pintura/Hist.Arte \\
\hline
\end{tabular}




\begin{tabular}{|l|l|l|l|}
\hline \multirow{2}{*}{ Filmes } & & \\
\cline { 2 - 4 } & Preferência gênero/origem & Cineclubes/Cinemas & \\
\hline Curso de Línguas & & & \\
\cline { 2 - 3 } & & Em que época da vida? & Viagens ao exterior? \\
\hline
\end{tabular}

\section{PARTICIPACAO POLITICA/ ASSOCIAÇOES / MILITANCIA}

\begin{tabular}{|l|l|l|}
\hline $\begin{array}{l}\text { Como se interessou } \\
\text { pela política?? }\end{array}$ & $\begin{array}{l}\text { A família era } \\
\text { politizada? }\end{array}$ & Ano de filiação \\
\hline Filiação a Partido & $\begin{array}{l}\text { Foi perseguido, preso? } \\
\text { Como conseguiu } \\
\text { escapar da } \\
\text { "contingência } \\
\text { política?" }\end{array}$ & \\
\hline $\begin{array}{l}\text { Qual grupo político a } \\
\text { época do golpe } \\
\text { militar? }\end{array}$ & corrente/segmento & \\
\hline Cargo Ocupado & & \\
\hline Amigos de Militância & & \\
\hline Publicações & & \\
\hline $\begin{array}{l}\text { Participação de } \\
\text { Alguma Associação } \\
\text { Profissional/ Social }\end{array}$ & & \\
\hline
\end{tabular}

\section{LOCAIS DE LAZER do ENCOMENDANTE / FAMILA}

Casa na praia

Casa de campo

Associações/Clubes

Comunidade Religiosa Importância da religião para a família asquenazitas ou sefarade?

Bares/Restaurantes

Grupos de amigos

Vocês frequentavam outras casas projetadas por Artigas?

E de outros arquitetos modernos?

Novos Contatos /Nome/Telefone: 


\section{APÊNDICE B}

\section{Quadro: Clientela do Studio Palma - dados de encomenda de mobiliários e localização social dos clientes}

Os dados de encomenda foram levantados a partir do acervo do Instituto Lina Bo Bardi, onde constam as fichas de orçamento feitas pela arquiteta entre os anos 1949 e 1950. Os dados sociais do encomendantes foram coletados a partir de consulta à hemeroteca da Biblioteca Nacional, com busca da aparição dos nomes desses clientes em jornais dos anos 1940 a 1980 . São 26 encomendas de mobiliário para clientes privados decorarem suas residências particulares e 05 encomendas de móveis para espaços comerciais/culturais (Cine Art Palácio, Teatro Cultura Artística, MASP, Hotel Comodoro, Diários Associados,).

\begin{tabular}{|c|c|c|c|c|c|}
\hline cliente & $\begin{array}{l}\text { Ano do } \\
\text { pedido }\end{array}$ & Móveis orçados & $\begin{array}{l}\text { Valor do } \\
\text { orçamento } \\
\text { (aprox.) }\end{array}$ & $\begin{array}{l}\text { Endereço } \\
\text { registrado no } \\
\text { orçamento }\end{array}$ & Dados sociais do encomendante \\
\hline $\begin{array}{l}\text { Cinema Art } \\
\text { Palácio }\end{array}$ & 09/05/1949 & $\begin{array}{l}\text { "Orçamento para poltronas e divãs para a sala de espera" } \\
\text { poltronas em guaiçara com pés cobertos de latão e assento em } \\
\text { couro, divãs, poltrona com braços estofados, }\end{array}$ & $\mathrm{S} / \mathrm{d}$ & $\mathrm{S} / \mathrm{d}$ & $\begin{array}{l}\text { Avenida São João, } 419 \\
3119 \text { poltronas } \\
\text { Projeto de Rino Levi, inaugurado em 1936. Uma das primeiras } \\
\text { salas de cinema na região que ficou conhecida como Cinelândia } \\
\text { Paulistana. }\end{array}$ \\
\hline $\begin{array}{l}\text { Paulo } \\
\text { Matarazzo } \\
\text { (A/C Danielle } \\
\text { Calabi) }\end{array}$ & $12 / 05 / 1949$ & $\begin{array}{l}\text { "Orçamento para substituição de esquadrias das janelas da } \\
\text { casa no Guarujá" } \\
8 \text { janelas em madeira de cedro com batente especial em proba, } \\
\text { caixilho do tipo guilhotina com veneziana }\end{array}$ & S/d & $\mathrm{S} / \mathrm{d}$ & $\begin{array}{l}\text { Indicação de Danielle Calabi, arquiteto italiano, que assim como } \\
\text { Lina Bo Bardi, emigra para o Brasil em razão da II Guerra } \\
\text { Mundial. Calabi ficou no Brasil entre } 1939 \text { e } 1949 . \text { " Em 1949, } \\
\text { saudoso da terra natal e insatisfeito com a prática profissional } \\
\text { no Brasil, restrita à colônia e dependente da obra, retorna à } \\
\text { Itália, onde retoma com sucesso sua atividade de arquiteto." } \\
\text { site itaucultural. No período que esteve no Brasil, atuou junto } \\
\text { com Rino Levi. }\end{array}$ \\
\hline Sr. Falsoni & 20/05/1949 & $\begin{array}{l}\text { Estante com armário e bar medindo } 4,5 \times 2,9 \text { em madeira } \\
\text { compensada de cedro. Desenhos apresentados por Sr. Calabi }\end{array}$ & $\mathrm{S} / \mathrm{d}$ & $\mathrm{S} / \mathrm{d}$ & $\begin{array}{l}\text { Luciano Falzoni, italiano, residente a rua Bento de Andrade, } 351 \\
1959 \\
\text { Aparece no jornal como "industrial milionário" }\end{array}$ \\
\hline $\begin{array}{l}\text { Ambrógio } \\
\text { Bonomi }\end{array}$ & $12 / 07 / 1949$ & $\begin{array}{l}\text { "Conforme pedido de Sr. Calabi " } \\
\text { Portas a serem colocadas na reforma da moradia em pau } \\
\text { marfim, jacarandá, ferragem em latão }\end{array}$ & S/d & $\begin{array}{l}\text { Avenida Paulista, } \\
824\end{array}$ & $\begin{array}{l}\text { Casado com Georgina Martinelli Bonomi, filhos Angelo e Maria } \\
\text { Bonomi. Georgina é filha de José Martinelli, industrial. } \\
\text { Presidente da Sociedade Anônima Martinelli. Engenheiro. }\end{array}$ \\
\hline $\begin{array}{l}\text { Natália } \\
\text { Falsoni }\end{array}$ & 27/07/1949 & $\begin{array}{l}\text { Instalação em diversos aposentos: sala de jantar, dormitório, } \\
\text { escritório, living: mesa redonda, } 8 \text { cadeiras, console, duas }\end{array}$ & $\mathrm{S} / \mathrm{d}$ & $\mathrm{S} / \mathrm{d}$ & Casada com engenheiro Luciano Falzoni. \\
\hline
\end{tabular}




\begin{tabular}{|c|c|c|c|c|c|}
\hline & & $\begin{array}{l}\text { camas, mesinhas, divã, banquetas estofadas, estante para } \\
\text { biblioteca, escrivaninha, poltrona, sofá 5lugares, bergères, } \\
\text { sofá } 4 \text { lugares, poltronas, baquinho, bar com duas cadeiras, } \\
\text { mesinhas retangulares, mesinhas redondas }\end{array}$ & & & $\begin{array}{l}\text { Nome de nascimento: Natália Douglas, pai inglês e mãe russa. } \\
\text { Tinha romance com Geraldo Junqueira, cineastra que foi } \\
\text { assassinado em } 1960 \text {. }\end{array}$ \\
\hline $\begin{array}{l}\text { Elphy } \\
\text { Rosenthal }\end{array}$ & $15 / 08 / 1949$ & $\begin{array}{l}6 \text { cadeiras de pau-marfim, mesa, escrivaninha em guaiçara, } \\
\text { estante em guaiçara, poltrona de balanço com tecido feito a } \\
\text { mão, mesinha de pau marfim, poltrona em tecido ferrugem, } \\
\text { poltrona de madeirit, porta-revista }\end{array}$ & $\begin{array}{l}\text { Total: } \\
15.149,00 \\
\text { com } \\
\text { desconto: } \\
\text { CR } \$ 13.631 \\
00\end{array}$ & $\begin{array}{l}\text { Avenida } 9 \text { de } \\
\text { Junho, } 584 \\
11^{\circ} \text { andar, apto } \\
1101\end{array}$ & $\begin{array}{l}1950 \text { - projeto da casa de Elphy Rosenthal feito por Vilanova } \\
\text { Artigas. Endereço: Rua Heitor de Moraes, 507, Pacaembu. } \\
\text { Entrevista feita em } 2013 \text { com filha do casal. }\end{array}$ \\
\hline $\begin{array}{l}\text { Rino Levi } \\
\text { (Cultura } \\
\text { Artística) }\end{array}$ & $19 / 08 / 1949$ & $\begin{array}{l}\text { "móveis a serem instalados na nova sede da Sociedade Cultura } \\
\text { Artística) } \\
\text { Toillete das senhoras: sofá para } 4 \text { pessoas, } 3 \text { poltronas, } 1 \\
\text { mesinha, } 3 \text { cadeiras em cetim-seda. } \\
\text { Foyer: } 4 \text { conjuntos com sofá, } 2 \text { poltronas cobertas em cetim- } \\
\text { seda, } 1 \text { mesa baixa. }\end{array}$ & CR\$ $9.880,00$ & Avenida Ipiranga & 1942: edifício projeto de Rino Levi. \\
\hline $\begin{array}{l}\text { Jacques } \\
\text { Pilon } \\
\text { (Diários } \\
\text { Associados) }\end{array}$ & $01 / 09 / 1949$ & $\begin{array}{l}\text { "Orçamento para os lambris do hall de entrada do prédio } \\
\text { Guilherme Guinle" }\end{array}$ & $\mathrm{S} / \mathrm{d}$ & Rua 7 de abril & $\begin{array}{l}\text { Sede do jornal Diários Associados, construída entre } 1943 \text { e } \\
\text { 1947, cujo proprietário foi Assis Chateubriand. }\end{array}$ \\
\hline $\begin{array}{l}\text { Alfredo } \\
\text { Mesquita }\end{array}$ & 19/09/1949 & $\begin{array}{l}\text { "Móveís para serem colocados no terraço de sua residência" } \\
\text { sofá } 4 \text { lugares com almofasas soltas, mesa de jogo com tampo } \\
\text { de camurça verde. }\end{array}$ & $\mathrm{S} / \mathrm{d}$ & $\begin{array}{l}\text { Livraria Jaraguá, } \\
\text { rua Marconi. }\end{array}$ & $\begin{array}{l}\text { 1907-1986. Faculdade e Direito São Francisco (1932). Filho } \\
\text { caçula de Julio Mesquita, proprietário do jornal Estado de São } \\
\text { Paulo, ao invés de assumir os negócios familiares, enveredou-se } \\
\text { pelo patrocínio de experiências culturais na cidade de São Paulo. } \\
\text { Fundador do EAD (1948) eTBC (1949). } \\
\text { Autor e diretor de peças de teatro. } \\
\text { 1942: Livraria Jaraguá, Revista Clima. }\end{array}$ \\
\hline $\begin{array}{l}\text { Thomas } \\
\text { Farkas }\end{array}$ & $05 / 10 / 1949$ & $\begin{array}{l}\text { Mesa de abrir, } 1 \text { console com } 4 \text { gavetas, } 2 \text { consoles pequenos, } \\
\text { moldura de espelho, porta-revista }\end{array}$ & CR $\$ 7.200,00$ & & Fotógrafo. \\
\hline $\begin{array}{l}\text { Adriano } \\
\text { Grego }\end{array}$ & $11 / 11 / 1949$ & $\begin{array}{l}\text { Mesa de abrir, } 4 \text { cadeiras cobertas em cetim, poltrona e pau- } \\
\text { marfim, móvel embutido para bar em fórmica, } 2 \text { poltronas } \\
\text { estofadas, } 1 \text { mesinha bandeja }\end{array}$ & $\begin{array}{l}\text { CR } \$ \\
15.090,00\end{array}$ & $\begin{array}{l}\text { Rua Dom José } \\
\text { de Barros, } 186 \\
50 \text { andar, apto } \\
55\end{array}$ & $\begin{array}{l}\text { Italiano, escritor, exilado no Brasil expulso pelo fascismo, } \\
\text { chegou ao Brasil em 1941, luta contra Mussolini. } \\
\text { Autor de "Quando os marechais se rendem" livro de ficção sobre } \\
\text { a guerra. (Atena Editora, 1942) } \\
\text { Jornalista colaborador em reportagens especiais para a revista } \\
\text { "Diretrizes", fundado em } 1938 \text { e que ficou em circulação até } \\
\text { 1944, publicação com tendência de esquerda no Estado Novo. } \\
\text { Assinou reportagens sobre judeus, guerra, espionagem, guetos }\end{array}$ \\
\hline
\end{tabular}




\begin{tabular}{|c|c|c|c|c|c|}
\hline $\begin{array}{l}\text { Nina de Paula } \\
\text { Eduardo } \\
\text { (Hotel } \\
\text { Esplanada) }\end{array}$ & $30 / 11 / 1949$ & $\begin{array}{l}\text { "Orçamento dos móveis a serem colocados em sua residência" } \\
\text { Living, dormitório, quarto de vestir, outro quarto: } \\
\text { sofás de ângulo, mesa baixa em pau-marfim, móvel comprido, } \\
\text { mesa retangular em pau-marfim, } 2 \text { poltronas em fazenda } \\
\text { amarela, } 6 \text { cadeiras em pau-marfim estofado violeta, móvel } \\
\text { com pratileiras e bar até o forro, cama estofada, colchão, } \\
\text { criado-mudo, poltrona em forma de concha, camiseira, toilette, } \\
\text { poltronazinha, sofá-cama em pau-marfim, escrivaninha, } \\
\text { cadeira estofada. }\end{array}$ & $\begin{array}{l}\text { CR } \$ \\
51.920,00\end{array}$ & Avenida Angélica & Não foram encontradas informações sobre a cliente. \\
\hline Dr. Vergilis & $30 / 11 / 1949$ & $\begin{array}{l}\text { "mobiliário de sua residência" } \\
\text { Sala de estar, terraço, escritório, cozinha, hall, dormitório } \\
\text { grande, dormitório pequeno, }\end{array}$ & $\mathrm{S} / \mathrm{d}$ & $\mathrm{S} / \mathrm{d}$ & $\mathrm{S} / \mathrm{d}$ \\
\hline $\begin{array}{l}\text { Paulo Alves } \\
\text { Pinto }\end{array}$ & $06 / 12 / 1949$ & $\begin{array}{l}\text { "orçamento de móveis conforme desenho escolhido por v.s." } \\
1 \text { penteadeira em pau-marfim com parte da tampa com } \\
\text { espelho, } 1 \text { cadeirinha em pau-marfim com molas, } 1 \text { poltrona } \\
\text { tipo P4 cetim azul amrinho e bordeaux }\end{array}$ & CR $\$ 4.500,00$ & $\begin{array}{l}\text { Rua Marconi, } \\
\text { no } 138,11^{\circ} \\
\text { andar }\end{array}$ & $\mathrm{S} / \mathrm{d}$ \\
\hline \multirow{2}{*}{$\begin{array}{l}\text { Francisco } \\
\text { Matarazzo } \\
\text { Sobrinho }\end{array}$} & $02 / 01 / 1950$ & \multirow{2}{*}{$\begin{array}{l}\text { Móveis para apartamento } \\
\text { Dormitório: revestimento da parede em listras de pau-marfim } \\
\text { listras, } 5 \text { prateleiras para livro, mesa curva com gaveta, } \\
\text { montante par quadros, camiseira, sofá-cama, colchão com } \\
\text { molas, } 4 \text { almofadas em couro, poltronazinha em compensado, } \\
2 \text { poltronas laqueadas }\end{array}$} & & $\begin{array}{l}\text { Rua Estados } \\
\text { Unidos, } 1093\end{array}$ & \\
\hline & & & CR\$ 18.950 & & \\
\hline $\begin{array}{l}\text { Guita Vareta } \\
\text { (A/C Saul } \\
\text { Vareta) }\end{array}$ & $06 / 02 / 1950$ & $\begin{array}{l}1 \text { biblioteca componível em Guaiçara, } 1 \text { mesa de abrir em pau- } \\
\text { marfim, } 1 \text { escrivaninha em guaiçara, } 6 \text { cadeiras em pau-marfim } \\
\text { C12, } 2 \text { móveis em pau-marfim com prateleira, } 2 \text { poltronas } \mathrm{P} 4\end{array}$ & CR $\$ 8945,00$ & $\begin{array}{l}\text { Rua Melo Alves, } \\
285 \text { e } 294\end{array}$ & Não foram encontradas informações sobre a cliente. \\
\hline $\begin{array}{l}\text { Helena } \\
\text { Sangirardi }\end{array}$ & 09/02/1950 & $\begin{array}{l}\text { Cadeira de balanço amarela, sofá com poltronas soltas, bergère } \\
\text { com cetim bleu, poltrona madeirit, poltrona embuia, poltrona } \\
\text { com fazenda mexicana, bergère verde, espreguiçadeira } \\
\text { amarela em pau-marfim, } 7 \text { mesinhas em madeirit, } 6 \text { cadeiras } \\
\text { em madeirit e lona, cadeira de dobrar em couro amarelo, } \\
\text { poltrona de cetim e embuia, mesinha redonda em embuia }\end{array}$ & $\begin{array}{l}\text { CR } \$ \\
21.320,00\end{array}$ & $\begin{array}{l}\text { Rua Lia (Sá?) } \\
\text { Ferreira. } 188 \\
\text { Copacabana, Rio } \\
\text { de Janeiro }\end{array}$ & $\begin{array}{l}\text { Nasceu em Ribeirão Preto, casada com Sangirardi Jr, tem duas } \\
\text { filhas, Maria Lúcia e Silvia Helena. } \\
\\
\text { "Radialista que se dedica aos assuntos femininos" (Revista do } \\
\text { Rádio, } 6 \text { de janeiro de } 1953 \text { ) muito conhecida nos anos } 1950 . \\
\text { Trabalha na revista O Cruzeiro (Diários Associados), responsável } \\
\text { por seção sobre culinária. Apresenta "Doce Lar" na TV Tupi, } \\
\text { "Bazar feminino", "Cartazes Luminosos". Programa na Radio } \\
\text { Nacional desde } 1944 \text {. Programa sobre boas maneiras, conselhos } \\
\text { sentimentais, receitas, dicas de economia doméstica. Livro de } \\
\text { receita "A alegria de cozinhar", livro best-seller na época. } \\
\text { Nos anos } 1950 \text {, figura em diversas propagandas de produtos } \\
\text { para consumo da casa: panela de pressão, latas de sardinha, } \\
\text { achocolatado em pó, liquidificador, dedetizador de baratas, } \\
\text { margarina vegetal. } \\
\text { "Se não houver censura, talvez "O Cruzeiro" publique umas } \\
\text { linhazinhas a seu respeito no dia 22/04/1950, nas minhas }\end{array}$ \\
\hline
\end{tabular}




\begin{tabular}{|c|c|c|c|c|c|}
\hline & & & & & páginas" Um abraço da Helena Sangirardi. \\
\hline \multirow[t]{5}{*}{$\begin{array}{l}\text { Zilda } \\
\text { Hamburguer }\end{array}$} & $23 / 02 / 1950$ & $\begin{array}{l}6 \text { cadeiras em pau-marfim cobertas com tecido verde-garrafa, } \\
\text { mesa em pau-marfim de abrir, móvel para livros, móvel-bar, } \\
\text { móvel para discos, sofá } 5 \text { lugares, poltrona em madeira com } \\
\text { tiras de lona, mesa bandeja }\end{array}$ & $\begin{array}{l}\text { CR } \$ \\
22.268,00\end{array}$ & $\begin{array}{l}\text { Rua Martins } \\
\text { Fontes, } \mathrm{n}^{\circ} 403, \\
\text { apto } 42\end{array}$ & \multirow{5}{*}{$\begin{array}{l}\text { Casada com Josep Hamburger. } \\
\text { Zilda Medice Hamburguer: irmã de Marina Medice Misasi } \\
\text { Cantora lírica e atriz, naquele momento atuava em papéis } \\
\text { secundários em peças no TBC. Aparece foto de rosto na Revista } \\
\text { Habitat, tirada por Thomas Farkas. } \\
\text { Revista Habitat, no9, assim aparece: } \\
\text { "Zilda Medice Hambuerguer, a nossa melhor cantora de música } \\
\text { de câmara, obteve grande sucesso na B.B.C. de Londres. Canta } \\
\text { agora com mesmo sucesso na Itália" p.96 }\end{array}$} \\
\hline & \multirow[t]{2}{*}{ 05/06/1950 } & $\begin{array}{l}\text { Móveis entregues } \\
6 \text { cadeiras estofadas com fazenda a mão, } 1 \text { mesa de abrir em } \\
\text { pau-marfim, móvel em pau-marfim com } 10 \text { prateleiras, móvel } \\
\text { bar e discos, sofá de } 5 \text { lugares, poltronas em madeirit com } \\
\text { almofadas soltas, } 2 \text { mesinhas bandeja, } 1 \text { prateleira grande em } \\
\text { pau-marfim e madeirit }\end{array}$ & $\begin{array}{l}\text { CR\$ } \\
24.688,00\end{array}$ & & \\
\hline & & $\begin{array}{l}\text { Carrinho para chá embuia e madeirit, poltrona modelo P4 com } \\
\text { fazenda feita a mão, escrivaninha secretaire, cadeira verde, } \\
\text { mosaico com pedras e vidros }\end{array}$ & $\begin{array}{l}\text { CR } \$ \\
11.515,00\end{array}$ & & \\
\hline & $15 / 06 / 1950$ & $\begin{array}{l}\text { Mesa em pau-marfim, prateleiras, discoteca, } 3 \text { vidros bisotê, } \\
\text { lustração de cadeiras, reforma de uma cadeira, reforma de um } \\
\text { sofá e lustração, pintura fundo bar e discoteca, transporte }\end{array}$ & CR\$ $5.470,00$ & & \\
\hline & $22 / 06 / 1950$ & $\begin{array}{l}\text { Criados-mudos azul claro, penteadeira com gavetas e tampo de } \\
\text { cristal, móvel armário, porta-livro, espelho e secretaire }\end{array}$ & $\begin{array}{l}\text { CR } \$ \\
14.100,00\end{array}$ & & \\
\hline $\begin{array}{l}\text { Alberto } \\
\text { Mortara } \\
(1920-?)\end{array}$ & $27 / 02 / 1950$ & $\begin{array}{l}8 \text { cadeiras em pau-marfim, mesa de abrir, móvel estante para } \\
\text { livro, mesa em pau-marfim, sofá com tiras de lona e almofadas } \\
\text { soltas, bergère grande, } 2 \text { poltronas, floreira, móvel com } 4 \\
\text { gavetas e duas prateleiras }\end{array}$ & $\begin{array}{l}\text { CR } \$ \\
23.440,00\end{array}$ & $\begin{array}{l}\text { Prédio } \\
\text { Matarazzo, } 60 \\
\text { andar }\end{array}$ & $\begin{array}{l}\text { Filho de Giorgio Mortara, advogado italiano, estatístico do IBGE } \\
\text { (1885-1967). Giorgio casou com Laura Ottolenghi, doutor em } \\
\text { ciências econômicas e seu colega de trabalho do Jornal, nasceu } \\
\text { Marcella, Alberto, e Guido Valerio. } \\
\text { Alberto nasceu na Italia em XXXX, naturalizado brasileiro em } \\
\text { 1947. Industrial - industria Matarazzo, técnico da Ford Motor, } \\
\text { diretor anos } 60 \text { : agente financeiro. } \\
\text { 1949: L'organizzazione bancaria brasiliana trabalho feito para } \\
\text { Cepal. } \\
\text { Casamento: Alberto Mortara e Carmem Araújo Arruda de } \\
\text { Albuquerque: } 22 \text { janeiro } 1953 \text {. }\end{array}$ \\
\hline \multirow[t]{4}{*}{$\begin{array}{l}\text { Yolanda } \\
\text { Penteado } \\
\text { Matarazzo }\end{array}$} & $04 / 04 / 1950$ & $\begin{array}{l}\text { "Custos de cortina executados num quarto da residência de } \\
\text { vossa senhoria" } \\
\text { mão de obra, suportes, rodízios, costuras, trilhos, serviço de } \\
\text { pedreiro, madeira }\end{array}$ & CR $\$ 4.580,00$ & & \multirow[t]{4}{*}{ Minha Vida Cor de Rosa: biografia } \\
\hline & 03/05/1950 & Carrinho em pau-marfim & CR\$ 990,00 & & \\
\hline & $03 / 05 / 1950$ & $\begin{array}{l}\text { "Nota de serviço executado" } \\
\text { móveis de ferro para terraço, } 4 \text { cristais lapidados para móveis, } \\
2 \text { cristais para fotografia, reajustamento da armação das } \\
\text { cortinas }\end{array}$ & CR\$ $4.700,00$ & & \\
\hline & $08 / 05 / 1950$ & "Serviço de tapeçaria executado no quarto da residência" & CR $\$ 3.420,00$ & & \\
\hline
\end{tabular}


mão de obra, suportes, rodízios, trilhos

\begin{tabular}{|c|c|c|c|c|c|}
\hline & & mão de obra, suportes, rodízios, trilhos & & & \\
\hline \multirow[t]{2}{*}{$\begin{array}{l}\text { José Mário } \\
\text { Taques } \\
\text { Bitencourt }\end{array}$} & $06 / 05 / 1950$ & $\begin{array}{l}\text { Sofá cama em pau-marfim, colchão em molas, } 2 \text { poltronas } \\
\text { estofadas, mesa de abrir, espreguiçadeira estofada com } \\
\text { fazenda feita a mão, } 8 \text { cadeiras em madeirit, } 1 \text { carrinho de chá } \\
\text { em pau-marfim, } 1 \text { móvel biblioteca com } 10 \text { prateleiras, móvel } \\
\text { bar }\end{array}$ & $\begin{array}{l}\text { CR } \$ \\
25.715,00\end{array}$ & $\begin{array}{l}\text { Rua Victorino } \\
\text { Carmello, } 453 \\
\text { São Paulo }\end{array}$ & \multirow[t]{2}{*}{$\begin{array}{l}\text { 1949: Projeto de Vilanova Artigas para casa na rua Taboão, } \\
\text { 32, esquina com rua Votuporanga, Sumaré. Área construída: } \\
\text { 169m² }\end{array}$} \\
\hline & $18 / 07 / 1950$ & $\begin{array}{l}\text { Duas poltronas de madeirit modelo p4 estofadas com molas } \\
\text { fazenda feita a mão, } 1 \text { mesa de pau-marfim de abrir } 1,80 \\
\text { tampa com plástico preto, } 1 \text { espreguiçadeira estofada com } \\
\text { molas coberta em plástico preto e branco, } 8 \text { cadeiras em pau- } \\
\text { marfim modelo c12, com plástico amarelo-limão, carrinho de } \\
\text { chá, móvel biblioteca, armário com cabides, móvel para rádio e } \\
\text { discos, } 2 \text { mesinhas bandeja, } 3 \text { poltronas para varanda, } 1 \text { mesa } \\
\text { penteadeira com espelho de cristal, } 1 \text { revestimento de madeira } \\
\text { de lei atrás da cama de casal, } 2 \text { criados mudos suspensos e } 2 \\
\text { gavetas, } 1 \text { biblioteca com } 3 \text { elementos até o forro com } 15 \\
\text { prateleiras }\end{array}$ & $\begin{array}{l}\text { CR } \$ \\
36.990,00\end{array}$ & & \\
\hline \multirow[t]{2}{*}{$\begin{array}{l}\text { Adolpho } \\
\text { Goldestein }\end{array}$} & $06 / 05 / 1950$ & $\begin{array}{l}\text { Floreira, paredinha para plantas, sofá } 2 \text { lugares almofadas } \\
\text { tecido feito a mão, mesinha de pau-marfim, } 2 \text { poltronas em } \\
\text { madeirit, mesinha bandeja, cadeira estofada, biblioteca de um } \\
\text { elemento e } 5 \text { prateleiras, }\end{array}$ & $\begin{array}{l}\text { CR } \$ \\
20.720,00\end{array}$ & $\begin{array}{l}\text { Alameda Santos, } \\
835\end{array}$ & \\
\hline & $12 / 06 / 1950$ & $\begin{array}{l}\text { Floreira com revestimento em chapa metálica, paredinha em } \\
\text { listras, sofá } 2 \text { lugares, mesinha em pau-marfim, } 2 \text { poltronas } \\
\text { em madeirit, poltrona bergère em pau-marfim e estofada com } \\
\text { tecido feito a mão }\end{array}$ & $\mathrm{CR} \$ 8970,00$ & & \\
\hline Marina Misasi & $11 / 05 / 1950$ & $\begin{array}{l}\text { Living, sala de jantar, jardim de inverno: } \\
\text { sofá } 5 \text { lugares com desenho exclusivo, } 1 \text { bergère, sofá } 4 \\
\text { lugares, poltronas madeira de lei, mesinha baixa tampas e } \\
\text { pernas em madeira de lei, armação para mesinha tampo a } \\
\text { escolher marmore, cristal mosaico, mesa grande com tampa } \\
\text { com pé trabalhado em osso, } 2 \text { bancos estofados com mola } \\
\text { grande móvel de } 5,8 m \text {, composto de } 5 \text { peças, } 12 \text { cadeiras } \\
\text { estofadas, armação para mesa madeira de lei, mesa de abrir } \\
\text { tampo plavinil, } 6 \text { cadeiras de dobrar assento em lona, sofá } 3 \\
\text { lugares, mesinha baixa, } 3 \text { poltronas em tubo e lona, móvel-bar } \\
\text { curvo, } 3 \text { baquinhos para bar estofamento plavinil }\end{array}$ & $\begin{array}{l}\text { CR\$ } \\
77.480,00 \\
53120\end{array}$ & $\begin{array}{l}\text { Rua Holanda, } \\
214\end{array}$ & $\begin{array}{l}\text { Presença entre colunáveis da vida social. } \\
\text { Casada com Tulio Misasi, advogado formado na São Francisco, } \\
\text { colação de grau 07/09/1931 } \\
\text { Marina Medice Misasi: irmã de Zilda Medice Hamburguer: }\end{array}$ \\
\hline Oleg Kaduno & $19 / 05 / 1950$ & $\begin{array}{l}\text { Sofá } 3 \text { lugares, almofadas com molas estofada em cetim com } \\
\text { vivos, } 2 \text { poltromnas modelo P12, } 1 \text { mesinha modelo M4 }\end{array}$ & $\begin{array}{l}\text { CR } \$ 9.000 \\
00\end{array}$ & $\begin{array}{l}\text { Rua Monte } \\
\text { Alegre, } 1120,1^{0} \\
\text { andar, apto } 8\end{array}$ & Não foram encontradas informações sobre a cliente. \\
\hline $\begin{array}{l}\text { Fúlvio } \\
\text { Penacchi }\end{array}$ & $30 / 05 / 1950$ & $\begin{array}{l}\text { Sofá em madeirit } 2 \text { lugares em lona amarela, } 2 \text { poltrona em } \\
\text { madeirit forrado com lona dupla }\end{array}$ & CR $\$ 5.880,00$ & & $\begin{array}{l}\text { 1905-1992. Italiano, nasceu na Toscana, estudou Pintura em } \\
\text { Lucca, Desenho em Florença, vem para o Brasil em 1929, }\end{array}$ \\
\hline
\end{tabular}




\begin{tabular}{|c|c|c|c|c|c|}
\hline & & & & & $\begin{array}{l}\text { escapando do fascismo. No Brasil, trabalhou em colaboração } \\
\text { com Galileo Emendabili. Divide com Rebolo Santa Helena, } \\
\text { inciando o grupo que mais tarde seria reconhecido. Faz painéis e } \\
\text { afrescos para projetos residenciais de muitas famílias paulistas. } \\
\text { Muralista, na época da encomenda tinha } 44 \text { anos, } 4 \text { anos depois } \\
\text { de ter se casado com Filomena Maria dall'Aste Brandoline } \\
\text { Matarazzo, sobrinha do conde Andrea Matarazzo. } \\
1948 \text { - inauguração da casa da Rua Espanha. } 312\end{array}$ \\
\hline Julio Llorenti & $07 / 06 / 1950$ & $\begin{array}{l}6 \text { poltronas modelo P9 estofadas com molas em madeirit e } \\
\text { fazenda feita a mão }\end{array}$ & $\mathrm{CR} \$ 8.100,00$ & & \\
\hline \multirow[t]{3}{*}{$\begin{array}{l}\text { Museu de } \\
\text { Arte de São } \\
\text { Paulo }\end{array}$} & $07 / 06 / 1950$ & $\begin{array}{l}1 \text { escrivaninha em madeirit, } 1 \text { mesinha para telefone em } \\
\text { jacarandá, } 1 \text { mesinha para telefone em guaiçara, } 6 \text { poltronas } \\
\text { em ferro esmaltado, } 1 \text { poltrona em ferro esmaltado em lona e } \\
\text { couro }\end{array}$ & $\begin{array}{l}\text { CR } \$ \\
10.630 .00\end{array}$ & & \multirow{3}{*}{$\begin{array}{l}\text { Museu inaugurado em } 02 \text { de abril em } 1947 \text { por Assis } \\
\text { Chateubriand, tendo escolhido como curador o marchand } \\
\text { italiano Pietro Bardi, que ficaria responsável por montar a } \\
\text { coleção de obras de arte. É por esse convite que o casal muda } \\
\text { para o Brasil e se instala em São Paulo. } \\
\text { Antes da sede definitiva, na avenida Paulista, o museu } \\
\text { funcionou até } 1968 \text { na rua } 7 \text { de Abril, no Edifício Guilherme } \\
\text { Guinle, onde também localizava-se o Diários Associados. A } \\
\text { reordernação do } 1^{\circ} \text { e } 2^{\circ} \text { para abrigar o Museu foi feita por Lina } \\
\text { Bo Bardi, assim como o projeto do edifício-sede também seria } \\
\text { dado à arquiteta. }\end{array}$} \\
\hline & 07/06/1950 & $\begin{array}{l}1 \text { escrivaninha em Guaiçara, } 2 \text { mesas para máquina de } \\
\text { escrever em perobinha e guaiçara, } 1 \text { cadeira em compensado } \\
\text { aviação folheada em jacarandá bahia, } 1 \text { cadeira em madeirit } \\
\text { com assento estofado, } 1 \text { cadeira em guaiçara com assento em } \\
\text { couro esticado }\end{array}$ & $\mathrm{CR} \$ 6.380,00$ & & \\
\hline & $08 / 05 / 1950$ & $\begin{array}{l}\text { "móveis entregues ao Museu de Arte" } \\
1 \text { escrivaninha em guaiçara, } 2 \text { mesas para máquina de } \\
\text { escrever, } 1 \text { cadeira estofad em compensado aviação folheada, } 1 \\
\text { cadeira em madeirit, } 1 \text { cadeira em guaiçara assento em couro } \\
\text { estofado, } 1 \text { escrivaninha em madeirit, } 6 \text { poltronas em ferro } \\
\text { esmaltado com forro em lona, } 1 \text { poltrona em ferro esmaltado }\end{array}$ & $\begin{array}{l}\text { CR\$ } \\
19.760,00\end{array}$ & & \\
\hline $\begin{array}{l}\text { Companhia } \\
\text { Hotéis } \\
\text { Comodoro }\end{array}$ & $15 / 06 / 1950$ & $\begin{array}{l}\text { Quartos: armação de madeira, móvel para livros, camiseira, } \\
\text { penteadeira em pau-marfim, com espelho e luz interna, cadeira } \\
\text { madeirit estofada, poltrona em pau-marfim estofada, trabalho } \\
\text { de tapeçaria, fazenda para cortinas, cortina curta, fazenda para } \\
\text { colchão }\end{array}$ & $\begin{array}{l}\text { CR } \$ \\
11.030,00\end{array}$ & & $\begin{array}{l}\text { Avenida Duque de Caxias, esquina com Conselheiro Nebias. } \\
\text { Local era o terreno do palacete de Olívia Guedes Penteado } \\
\text { Inaugurado em } 25 \text { de janeiro de } 1952 . \\
19 \text { andares. } \\
\text { Painel de mosaico de Portinari, "Bandeirantes". }\end{array}$ \\
\hline Alfredo Costa & $30 / 06 / 1950$ & $\begin{array}{l}2 \text { poltronas em madeirit modelo P6 com lona, } 6 \text { cadeiras em } \\
\text { pau-marfim, } 1 \text { mesa baixa forma triangular, } 1 \text { sofá pau-marfim } \\
4 \text { lugares tiras de lona branca }\end{array}$ & CR\$ 8170,00 & $\begin{array}{l}\text { Rua Líbero } \\
\text { Badaró, } 127\end{array}$ & $\begin{array}{l}\text { O nome "Alfredo Costa", quando procurado na hemeroteca da } \\
\text { Biblioteca Nacional, apresenta inúmeras entradas, das quais } \\
\text { não é possível distinguir informações específicas do } \\
\text { encomendante. }\end{array}$ \\
\hline Carlos Castek & $25 / 07 / 1950$ & $\begin{array}{l}1 \text { mesa de pau-marfim, } 4 \text { cadeiras de madeirit assento e } \\
\text { encosto de plástico }\end{array}$ & $\mathrm{CR} \$ 3.310,00$ & $\begin{array}{l}\text { Rua Projetada, } \\
82\end{array}$ & Não foram encontradas informações sobre a cliente. \\
\hline $\begin{array}{l}\text { Reynaldo } \\
\text { Pastore }\end{array}$ & $18 / 08 / 1950$ & $\begin{array}{l}12 \text { cadeiras assento em mola, encosto em estofado, pés de } \\
\text { perobinha, } 3 \text { poltronas conforme desenho }\end{array}$ & & & Não foram encontradas informações sobre a cliente. \\
\hline
\end{tabular}




\section{APÊNDICE C}

Quadro Geral Sintético: clientela de arquiteto Vilanova Artigas e Paulo Mendes da Rocha (projetos residenciais)

\begin{tabular}{|c|c|c|c|c|c|c|}
\hline cliente & Arq. & encomenda & ano & $\begin{array}{l}\text { Profissão do } \\
\text { cliente }\end{array}$ & Origem & Vínculo amizade \\
\hline \begin{tabular}{|l} 
Vitor \\
Brecheret
\end{tabular} & $\begin{array}{l}\text { Vilanova } \\
\text { Artigas }\end{array}$ & Casa-ateliê & 1943 & Artista, escultor & $\begin{array}{l}\text { Imigrante } \\
\text { italiano, veio } \\
\text { para Brasil com } \\
10 \text { anos } \\
\end{array}$ & $\begin{array}{l}\text { Construção do } \\
\text { "Monumento às } \\
\text { Bandeiras" (Artigas } \\
\text { foi calculista) }\end{array}$ \\
\hline $\begin{array}{l}\text { Rio Branco } \\
\text { Paranhos }\end{array}$ & $\begin{array}{l}\text { Vilanova } \\
\text { Artigas }\end{array}$ & $\begin{array}{l}\text { Residência no } \\
\text { Pacaembu }\end{array}$ & 1943 & Advogado, jurista & $\begin{array}{l}\text { Família de } \\
\text { Goiânia }\end{array}$ & Militância PC \\
\hline $\begin{array}{l}\text { Rivadávia } \\
\text { Mendonça }\end{array}$ & $\begin{array}{l}\text { Vilanova } \\
\text { Artigas }\end{array}$ & $\begin{array}{l}\text { Residência no } \\
\text { Pacaembu }\end{array}$ & 1944 & Advogado, jornalista & $\begin{array}{l}\text { Família de } \\
\text { Goiânia }\end{array}$ & $\begin{array}{l}\text { Militância PC, irmão } \\
\text { de Paranhos }\end{array}$ \\
\hline $\begin{array}{l}\text { Alfredo } \\
\text { Mesquita } \\
\text { (Esther e } \\
\text { Lia) }\end{array}$ & $\begin{array}{l}\text { Vilanova } \\
\text { Artigas }\end{array}$ & $\begin{array}{l}\text { Ed. Louveira } \\
\text { (30 aptos.) }\end{array}$ & 1945 & $\begin{array}{l}\text { Autor de teatro, } \\
\text { EAD, TBC, herdeiro }\end{array}$ & $\begin{array}{l}\text { Família } \\
\text { tradicional de } \\
\text { São Paulo }\end{array}$ & $\begin{array}{l}\text { Círculos da Cultura, } \\
\text { fundção do MAM }\end{array}$ \\
\hline \begin{tabular}{|l} 
Febus \\
Gikowate
\end{tabular} & $\begin{array}{l}\text { Vilanova } \\
\text { Artigas }\end{array}$ & $\begin{array}{l}\text { Residência Jardim } \\
\text { Europa }\end{array}$ & 1948 & $\begin{array}{l}\text { Médico- } \\
\text { pneumonologista }\end{array}$ & $\begin{array}{l}\text { Imigrante } \\
\text { Polônia }\end{array}$ & Militância trotskista \\
\hline $\begin{array}{l}\text { José Mário } \\
\text { Tacques } \\
\text { Bitencourt }\end{array}$ & $\begin{array}{l}\text { Vilanova } \\
\text { Artigas }\end{array}$ & $\begin{array}{l}3 \text { residências no } \\
\text { Pacaembu }\end{array}$ & $\begin{array}{l}1949 \\
1959 \\
1981\end{array}$ & $\begin{array}{l}\text { Médico neurologista } \\
\text { HC USP }\end{array}$ & & $\begin{array}{l}\text { Círculos intelectuais } \\
\text { de SP. Publicou } \\
\text { textos na Revista } \\
\text { Clima. }\end{array}$ \\
\hline \begin{tabular}{|l|} 
Jlyan \\
Czapsky \\
Alice Brill
\end{tabular} & $\begin{array}{l}\text { Vilanova } \\
\text { Artigas }\end{array}$ & Residência no Sumaré & 1949 & Médico e fotógrafa & $\begin{array}{l}\text { Casal imigrante } \\
\text { ela alemã judia, } \\
\text { ele polonês }\end{array}$ & $\begin{array}{l}\text { Círculos da Cultura, } \\
\text { fundação do MAM }\end{array}$ \\
\hline $\begin{array}{l}\text { Elphy } \\
\text { Rosenthal } \\
\text { Emília } \\
\text { Goldentein } \\
\text { Rosenthal }\end{array}$ & $\begin{array}{l}\text { Vilanova } \\
\text { Artigas }\end{array}$ & $\begin{array}{l}\text { Residência no } \\
\text { Pacaembu }\end{array}$ & 1950 & $\begin{array}{l}\text { Exportação café, } \\
\text { comércio de pedras } \\
\text { e jóias, colecionador } \\
\text { de arte }\end{array}$ & $\begin{array}{l}\text { Imigrante de } \\
\text { origem russa } \\
\text { judia }\end{array}$ & $\begin{array}{l}\text { Círculos intelectuais } \\
\text { Simpatizante PC }\end{array}$ \\
\hline $\begin{array}{l}\text { Oduvaldo } \\
\text { Vianna } \\
\text { Deocélia } \\
\text { Vianna } \\
\end{array}$ & $\begin{array}{l}\text { Vilanova } \\
\text { Artigas }\end{array}$ & $\begin{array}{l}\text { Residência na rua Dr. } \\
\text { Arnaldo }\end{array}$ & 1950 & $\begin{array}{l}\text { Jornalista, radio- } \\
\text { teatro, dramaturgo }\end{array}$ & Paulistano. & $\begin{array}{l}\text { Militância PC, } \\
\text { suplente deputado } \\
\text { em } 1946 .\end{array}$ \\
\hline $\begin{array}{l}\text { David } \\
\text { Rosenberg } \\
\text { Concepción } \\
\text { Abovsky }\end{array}$ & $\begin{array}{l}\text { Vilanova } \\
\text { Artigas }\end{array}$ & $\begin{array}{l}\text { Residência em } \\
\text { Pinheiros }\end{array}$ & 1950 & $\begin{array}{l}\text { Médico-cirurgião } \\
\text { Escola Paulista de } \\
\text { Medicina }\end{array}$ & $\begin{array}{l}\text { Judeu nascido } \\
\text { na Bessarábia } \\
\text { (Romênia), } \\
\text { imigrou para o } \\
\text { Brasil com } 4,5 \\
\text { anos }\end{array}$ & $\begin{array}{l}\text { Militância PC } \\
\text { Fundação revista } \\
\text { Brasiliense (1955) }\end{array}$ \\
\hline $\begin{array}{l}\text { Olga } \\
\text { Bohomoletz } \\
\text { Sebastião } \\
\text { Henriques } \\
\text { Baeta }\end{array}$ & $\begin{array}{l}\text { Vilanova } \\
\text { Artigas }\end{array}$ & City Butantã & 1956 & $\begin{array}{l}\text { Pesquisadores } \\
\text { Instituto Butantã, } \\
\text { laboratório de } \\
\text { Bioquímica (1950- } \\
\text { 1964) }\end{array}$ & $\begin{array}{l}\text { Minas Gerais, } \\
\text { vieram para SP } \\
\text { depois de } \\
\text { formados em } \\
\text { medicina na } \\
\text { UFMG. Ela: filha } \\
\text { de médico russo }\end{array}$ & $\begin{array}{l}\text { Militância PC, } \\
\text { universidade }\end{array}$ \\
\hline $\begin{array}{l}\text { Rubens } \\
\text { Mendonça }\end{array}$ & $\begin{array}{l}\text { Vilanova } \\
\text { Artigas }\end{array}$ & Residência no Sumaré & 1958 & $\begin{array}{l}\text { Advogado } \\
\text { trabalhista }\end{array}$ & $\begin{array}{l}\text { Família de } \\
\text { Goiânia }\end{array}$ & $\begin{array}{l}\text { Militância PC, irmão } \\
\text { de Paranhos }\end{array}$ \\
\hline $\begin{array}{l}\text { Leo Pereira } \\
\text { Lemos } \\
\text { Nogueira } \\
(11 / 09 / 192 \\
9)\end{array}$ & $\begin{array}{l}\text { Vilanova } \\
\text { Artigas }\end{array}$ & $\begin{array}{l}\text { Residência no } \\
\text { Ibirapuera }\end{array}$ & 1959 & $\begin{array}{l}\text { Químico, trabalhou } \\
\text { na Klabin, agente } \\
\text { mercado financeiro, } \\
\text { Inicio anos } 1960, \\
\text { fazenda cultivo uva } \\
\text { em Jundiai }\end{array}$ & $?$ & $?$ \\
\hline Ivo Viterito & Vilanova & Residência no & 1962 & médico & & \\
\hline
\end{tabular}




\begin{tabular}{|c|c|c|c|c|c|c|}
\hline & Artigas & Ibirapuera & & & & \\
\hline $\begin{array}{l}\text { Manuel } \\
\text { Mendes } \\
\text { André }\end{array}$ & $\begin{array}{l}\text { Vilanova } \\
\text { Artigas }\end{array}$ & $\begin{array}{l}\text { Residência Vila } \\
\text { Mariana }\end{array}$ & 1966 & $\begin{array}{l}\text { Proprietário } \\
\text { companha de } \\
\text { seguros }\end{array}$ & $\begin{array}{l}\text { Família de } \\
\text { origem } \\
\text { portuguesa }\end{array}$ & Militância PC \\
\hline Elza Berquó & $\begin{array}{l}\text { Vilanova } \\
\text { Artigas }\end{array}$ & $\begin{array}{l}\text { Residência Chácara } \\
\text { Flora }\end{array}$ & 1967 & Demógrafa, & & \\
\hline $\begin{array}{l}\text { Paulo Seixas } \\
\text { Queiroz }\end{array}$ & $\begin{array}{l}\text { Vilanova } \\
\text { Artigas }\end{array}$ & Residência Itaim-Bibi & 1967 & & & \\
\hline $\begin{array}{l}\text { Gilberto } \\
\text { Krutman }\end{array}$ & & Residência Moema & 1968 & & & \\
\hline Telmo Porto & $\begin{array}{l}\text { Vilanova } \\
\text { Artigas }\end{array}$ & Residência Perdizes & 1968 & $\begin{array}{l}\text { Engenheiro civil } \\
\text { prof. Politécnica }\end{array}$ & & \\
\hline $\begin{array}{l}\text { Ariosto } \\
\text { Martirani }\end{array}$ & & $\begin{array}{l}\text { Residência Alto de } \\
\text { Pinheiros }\end{array}$ & 1969 & & & \\
\hline $\begin{array}{l}\text { Juvenal } \\
\text { Venâncio }\end{array}$ & $\begin{array}{l}\text { Vilanova } \\
\text { Artigas }\end{array}$ & $\begin{array}{l}\text { Residência Jardim } \\
\text { Guedala }\end{array}$ & 1972 & $\begin{array}{l}\text { Advogado, deputado } \\
\text { dirigente CECAP } \\
\text { 1971-75, presidente } \\
\text { do São Paulo } \\
\text { Futebol Club }\end{array}$ & $\begin{array}{l}\text { Santa-Rosa, } \\
\text { interior de SP }\end{array}$ & $\begin{array}{l}\text { Amizade Estádio do } \\
\text { Morumbi, } 1952 \\
\text { CECAP, } 1967\end{array}$ \\
\hline $\begin{array}{l}\text { Alfred } \\
\text { Günter } \\
\text { Domschke, } \\
\text { Lydia } \\
\text { Meneghini } \\
\text { Domschke } \\
\text { (20/11/192 } \\
9)\end{array}$ & $\begin{array}{l}\text { Vilanova } \\
\text { Artigas }\end{array}$ & $\begin{array}{l}\text { Residência Alto da } \\
\text { Boa Vista }\end{array}$ & 1974 & $\begin{array}{l}\text { Engenheiro } \\
\text { mecânico, professor } \\
\text { Escola Politécnica }\end{array}$ & $\begin{array}{l}\text { Ele: engenheiro } \\
\text { mecânico } \\
\text { Ela bióloga }\end{array}$ & \\
\hline $\begin{array}{l}\text { Geraldo } \\
\text { Camargo } \\
\text { Demétrio }\end{array}$ & $\begin{array}{l}\text { Vilanova } \\
\text { Artigas }\end{array}$ & Residência Sumaré & 1976 & & & \\
\hline $\begin{array}{l}\text { José Mário } \\
\text { Taques } \\
\text { Bitencourt }\end{array}$ & $\begin{array}{l}\text { Vilanova } \\
\text { Artigas }\end{array}$ & Residência Sumaré & 1981 & médico & & \\
\hline cliente & Arq. & encomenda & ano & $\begin{array}{l}\text { Profissão do } \\
\text { cliente }\end{array}$ & Origem & Vínculo amizade \\
\hline $\begin{array}{l}\text { Fábio } \\
\text { Monteiro de } \\
\text { Barros } \\
\text { Maria Célia } \\
\text { Monteiro de } \\
\text { Barros (?) }\end{array}$ & $\begin{array}{l}\text { P.M. } \\
\text { Rcoha }\end{array}$ & $\begin{array}{l}\text { Residência } \\
\text { Rua Antonio Gouveia, } \\
\text { Alto de Pinheiros }\end{array}$ & 1958 & $\begin{array}{l}\text { Ciências das } \\
\text { Finanças } \\
\text { Economista }\end{array}$ & & \\
\hline $\begin{array}{l}\text { Bolivar } \\
\text { Ferraz } \\
\text { Navarro* } \\
\text { Marília } \\
\text { Penteado } \\
\text { Navarro }\end{array}$ & $\begin{array}{l}\text { P.M. } \\
\text { Rocha }\end{array}$ & $\begin{array}{l}\text { Rua Prof. Vahia de } \\
\text { Abreu, Itaim Bibi }\end{array}$ & 1960 & Juiz & & $\begin{array}{l}\text { Irmão da primeira } \\
\text { esposa }\end{array}$ \\
\hline $\begin{array}{l}\text { José Raul } \\
\text { Brasiliense } \\
\text { Carneiro* } \\
\text { (07/07/193 } \\
\text { 1) }\end{array}$ & $\begin{array}{l}\text { P.M. } \\
\text { Rocha }\end{array}$ & $\begin{array}{l}\text { Rua D Henriques, } \\
\text { Moema }\end{array}$ & 1960 & advogado & $\begin{array}{l}\text { Família } \\
\text { descendente } \\
\text { aristocracia, } \\
\text { rentista imóvel } \\
\text { Pacamebu }\end{array}$ & $\begin{array}{l}\text { Indicação arq. Carlos } \\
\text { Millan }\end{array}$ \\
\hline $\begin{array}{l}\text { Gaetano } \\
\text { Miani* } \\
(1920-2009)\end{array}$ & $\begin{array}{l}\text { P.M. } \\
\text { Rocha }\end{array}$ & $\begin{array}{l}\text { Rua São Mateus, } \\
\text { Santo Amaro }\end{array}$ & 1961 & $\begin{array}{l}\text { Italiano. Veio para o } \\
\text { Brasil m } 1947\end{array}$ & $\begin{array}{l}\text { Família } \\
\text { camponesa, } \\
\text { trabalhou na } \\
\text { agricultura antes } \\
\text { de vir para o } \\
\text { Brasil }\end{array}$ & \\
\hline $\begin{array}{l}\text { Heloisa } \\
\text { Alves de } \\
\text { Lima Motta }\end{array}$ & $\begin{array}{l}\text { P.M. } \\
\text { Rocha }\end{array}$ & Residência Ilhabela & 1961 & $\begin{array}{l}\text { Voluntariado } \\
\text { rentista }\end{array}$ & $\begin{array}{l}\text { Família } \\
\text { aristocracia, } \\
\text { elite dirigente, }\end{array}$ & $\begin{array}{l}\text { Amigo, círculo social } \\
\text { Autobiogafia: } \\
\text { Uma menina paulista }\end{array}$ \\
\hline
\end{tabular}




\begin{tabular}{|c|c|c|c|c|c|c|}
\hline & & & & & $\begin{array}{l}\text { sobrinha de } \\
\text { Washington Luiz }\end{array}$ & \\
\hline $\begin{array}{l}\text { Celso } \\
\text { Silveira } \\
\text { Melo* }\end{array}$ & $\begin{array}{l}\text { P.M. } \\
\text { Rocha }\end{array}$ & Residência Piracicaba & 1962 & $\begin{array}{l}\text { Fazendas Ometto, } \\
\text { maiores produtores } \\
\text { de cana, grupo } \\
\text { Cosan }\end{array}$ & $\begin{array}{l}\text { Descendente de } \\
\text { proprietários de } \\
\text { terras }\end{array}$ & \\
\hline $\begin{array}{l}\text { Bento Odilon } \\
\text { Moreira }\end{array}$ & $\begin{array}{l}\text { P.M. } \\
\text { Rocha }\end{array}$ & Goiânia & 1933 & & & \\
\hline $\begin{array}{l}\text { Francisco } \\
\text { Malta } \\
\text { Cardoso }\end{array}$ & $\begin{array}{l}\text { P.M. } \\
\text { Rocha }\end{array}$ & $\begin{array}{l}\text { Rua Todos os Santos, } \\
\text { Morumbi }\end{array}$ & 1963 & & & \\
\hline $\begin{array}{l}\text { Silvio } \\
\text { Albanese }\end{array}$ & $\begin{array}{l}\text { P.M. } \\
\text { Rocha }\end{array}$ & $\begin{array}{l}\text { Rua Manoel Vieira de } \\
\text { Souza, Mooca }\end{array}$ & 1964 & & & \\
\hline $\begin{array}{l}\text { Luiz } \\
\text { Gonzaga e } \\
\text { Lina Cruz } \\
\text { Secco }\end{array}$ & $\begin{array}{l}\text { P.M. } \\
\text { Rocha }\end{array}$ & $\begin{array}{l}\text { Praça Monteiro } \\
\text { Lobato, Butantã }\end{array}$ & 1964 & Engenheiro civil & & $\begin{array}{l}\text { Esposa: irmã de } \\
\text { Paulo Mendes da } \\
\text { Rocha }\end{array}$ \\
\hline $\begin{array}{l}\text { Paulo } \\
\text { Mendes da } \\
\text { Rocha }\end{array}$ & $\begin{array}{l}\text { P.M. } \\
\text { Rocha }\end{array}$ & $\begin{array}{l}\text { Praça Monteiro } \\
\text { Lobato, Butantã }\end{array}$ & 1964 & Próprio arquiteto & $\begin{array}{l}\text { Pai engenheiro } \\
\text { avô engenheirp }\end{array}$ & \\
\hline $\begin{array}{l}\text { Mário } \\
\text { Masetti } \\
\text { Maria Judit } \\
\text { Dores } \\
\text { Masetti }\end{array}$ & $\begin{array}{l}\text { P.M. } \\
\text { Rocha }\end{array}$ & Residência Perdizes & 1967 & $\begin{array}{l}\text { Engenheiro-civil } \\
\text { Politécnica }\end{array}$ & Pai: comerciante & $\begin{array}{l}\text { Amigo Carlos Millan. } \\
\text { (hoje residência } \\
\text { Jarouche) }\end{array}$ \\
\hline $\begin{array}{l}\text { Fernando } \\
\text { Milan }\end{array}$ & $\begin{array}{l}\text { P.M. } \\
\text { Rocha }\end{array}$ & $\begin{array}{l}\text { Avenida Circular do } \\
\text { Bosque, Morumbi }\end{array}$ & 1970 & $\begin{array}{l}\text { Marchand de arte, } \\
\text { galerista. Irmão de } \\
\text { Carlos Milan (arq.) }\end{array}$ & $\begin{array}{l}\text { Pai espanhol } \\
\text { comerciante }\end{array}$ & $\begin{array}{l}\text { Irmão Carlos Millan, } \\
\text { indicação } \\
\text { * hoje: Eduardo leme } \\
\text { (Galeria Leme) }\end{array}$ \\
\hline $\begin{array}{l}\text { Nabor } \\
\text { Ricardo Rüeg } \\
(12 / 07 / 193 \\
1- \\
24 / 01 / 1982 \\
) \\
\text { Elza Flores } \\
\text { Rüegg } \\
(12 / 01 / 192 \\
9-?\end{array}$ & $\begin{array}{l}\text { P.M. } \\
\text { Rocha }\end{array}$ & Guarujá & 1970 & $\begin{array}{l}\text { Ele: Geólogo, } \\
\text { professor do } \\
\text { Departamento de } \\
\text { Mineralogia e } \\
\text { Petrologia da USP, e } \\
\text { UNESP (Rio Claro) } \\
\text { Ela: Licenciada pela } \\
\text { FFCL-USP, em 1959, } \\
\text { História Natural } \\
\text { Cargo de Biologista } \\
\text { IB }\end{array}$ & & \\
\hline $\begin{array}{l}\text { Marcello } \\
\text { Nitsche e } \\
\text { Carmella } \\
\text { Gross }\end{array}$ & $\begin{array}{l}\text { P.M. } \\
\text { Rocha }\end{array}$ & $\begin{array}{l}\text { Rua Álvares Florence, } \\
\text { Butantã. }\end{array}$ & 1970 & $\begin{array}{l}\text { Ambos artistas } \\
\text { plásticos, formados } \\
\text { FAAP, final anos } \\
1960 .\end{array}$ & $\begin{array}{l}\text { Família de } \\
\text { imigrantes } \\
\text { alemães }\end{array}$ & $\begin{array}{l}\text { Amigo, trabalho } \\
\text { conjunto Pavilhão de } \\
\text { Osaka }\end{array}$ \\
\hline $\begin{array}{l}\text { James } \\
\text { Francis King }\end{array}$ & $\begin{array}{l}\text { P.M. } \\
\text { Rocha }\end{array}$ & $\begin{array}{l}\text { Rua Angra dos reis, } \\
\text { Chácara Flora }\end{array}$ & 1972 & $\begin{array}{l}\text { Industrial inglês, } \\
\text { residente no Brasil }\end{array}$ & & \\
\hline $\begin{array}{l}\text { Artêmio } \\
\text { Furlan Filho }\end{array}$ & $\begin{array}{l}\text { P.M. } \\
\text { Rocha }\end{array}$ & $\begin{array}{l}\text { Casa de Praia } \\
\text { Ubatuba }\end{array}$ & 1973 & & & \\
\hline $\begin{array}{l}\text { Dalton } \\
\text { Macedo } \\
\text { Soares }\end{array}$ & $\begin{array}{l}\text { P.M. } \\
\text { Rocha }\end{array}$ & $\begin{array}{l}\text { Rua Olegário Mariano, } \\
\text { Morumbi }\end{array}$ & 1973 & engenheiro & & \\
\hline $\begin{array}{l}\text { Ignácio } \\
\text { Gerber } \\
\text { Raquel } \\
\text { Gerber }\end{array}$ & $\begin{array}{l}\text { P.M. } \\
\text { Rocha }\end{array}$ & $\begin{array}{l}\text { Residência Angra dos } \\
\text { Reis - RJ }\end{array}$ & & $\begin{array}{l}\text { Ignácio: engenheiro, } \\
\text { psicanalista } \\
\text { Raquel: Cineasta e } \\
\text { socióloga }\end{array}$ & Origem judaica & \\
\hline $\begin{array}{l}\text { Maria Alice } \\
\text { Abbondanza }\end{array}$ & $\begin{array}{l}\text { P.M. } \\
\text { Rocha }\end{array}$ & Reforma e ampliação & 1973 & & & \\
\hline $\begin{array}{l}\text { Antonio } \\
\text { Junqueira de } \\
\text { Azevedo } \\
(1939-2009)\end{array}$ & $\begin{array}{l}\text { P.M. } \\
\text { Rocha }\end{array}$ & $\begin{array}{l}\text { Rua Guaonés, } \\
\text { Morumbi }\end{array}$ & 1976 & $\begin{array}{l}\text { Advogado, Professor } \\
\text { Direito (USP), } \\
\text { diretor entre 1990- } \\
\text { 1994. Fundador } \\
\text { Faculdade Direito } \\
\text { USP Ribeirão Preto. }\end{array}$ & $\begin{array}{l}\text { Família } \\
\text { tradicional de } \\
\text { barões paulistas }\end{array}$ & \\
\hline
\end{tabular}




\begin{tabular}{|c|c|c|c|c|c|c|}
\hline $\begin{array}{l}\text { Carlos } \\
\text { Eduardo } \\
\text { Pereira } \\
\text { Corbertt }\end{array}$ & $\begin{array}{l}\text { P.M. } \\
\text { Rocha }\end{array}$ & $\begin{array}{l}\text { Rua Doutor Jesuíno de } \\
\text { Abreu, Morumbi }\end{array}$ & 1978 & $\begin{array}{l}\text { Médico (USP, 1962- } \\
\text { 1967), Docente USP } \\
\text { patologia endemias } \\
\text { tropicais }\end{array}$ & & \\
\hline $\begin{array}{l}\text { James } \\
\text { Francis King }\end{array}$ & $\begin{array}{l}\text { P.M. } \\
\text { Rocha }\end{array}$ & $\begin{array}{l}\text { Casa de praia } \\
\text { Guarujá }\end{array}$ & 1980 & & Família inglesa & \\
\hline $\begin{array}{l}\text { Maurício } \\
\text { Thomaz } \\
\text { Bastos }\end{array}$ & $\begin{array}{l}\text { P.M. } \\
\text { Rocha }\end{array}$ & Guarujá & 1982 & $\begin{array}{l}\text { Irmão Marcio } \\
\text { Thomaz Bastos }\end{array}$ & & \\
\hline $\begin{array}{l}\text { Antonio } \\
\text { Gerassi Neto }\end{array}$ & $\begin{array}{l}\text { P.M. } \\
\text { Rocha }\end{array}$ & $\begin{array}{l}\text { Rua Carlos Norberto } \\
\text { de Souza Aranha, } \\
\text { Pinheiros }\end{array}$ & & $\begin{array}{l}\text { engenheiro civil, é } \\
\text { membro do } \\
\text { Conselho de } \\
\text { Administração da } \\
\text { Cetesb-SP } \\
\text { (Companhia de } \\
\text { Tecnologia de } \\
\text { Saneamento } \\
\text { Ambiental). Foi } \\
\text { superintendente do } \\
\text { Incra-SP (governo } \\
\text { Sarney). }\end{array}$ & & \\
\hline $\begin{array}{l}\text { Mário } \\
\text { Massetti }\end{array}$ & $\begin{array}{l}\text { P.M. } \\
\text { Rocha }\end{array}$ & $\begin{array}{l}\text { Casa na Fazenda, } \\
\text { Cabreúva }\end{array}$ & 1994 & $\begin{array}{l}\text { Engenheiro, } \\
\text { proprietário de } \\
\text { construtora. }\end{array}$ & $\begin{array}{l}\text { Comerciante } \\
\text { imigrante } \\
\text { italiano }\end{array}$ & Contato Carlos Millan \\
\hline $\begin{array}{l}\text { Candido } \\
\text { Vinícius } \\
\text { Boicaúva } \\
\text { Brasley } \\
\text { Pessoa e } \\
\text { Eliana } \\
\text { Filkenstein }\end{array}$ & $\begin{array}{l}\text { P.M. } \\
\text { Rocha }\end{array}$ & $\begin{array}{l}\text { Rua Monte Alegre, } \\
\text { Perdizes, } \\
\text { (restauro da casa) }\end{array}$ & 1999 & $\begin{array}{l}\text { Colecionador de } \\
\text { arte, proprietários } \\
\text { da galeria Vermelho }\end{array}$ & Origem judaica & \\
\hline $\begin{array}{l}\text { Idel } \\
\text { Arcuschin e } \\
\text { Isabella } \\
\text { Prata }\end{array}$ & $\begin{array}{l}\text { P.M. } \\
\text { Rocha }\end{array}$ & $\begin{array}{l}\text { Rua Carlos Milan, } \\
\text { Pinheiros, }\end{array}$ & 2000 & $\begin{array}{l}\text { Economista (USP), } \\
\text { empresário } \\
\text { marketing cultural e } \\
\text { esportivo }\end{array}$ & & \\
\hline $\begin{array}{l}\text { Eduardo } \\
\text { Leme }\end{array}$ & $\begin{array}{l}\text { P.M. } \\
\text { Rocha }\end{array}$ & $\begin{array}{l}\text { Avenida Circular do } \\
\text { Bosque. Morumbi }\end{array}$ & 2000 & $\begin{array}{l}\text { Galerista, } \\
\text { proprietário da } \\
\text { galeria Leme, }\end{array}$ & & $\begin{array}{l}\text { Galeria Leme, } \\
\text { localizada no } \\
\text { Butantã, } \\
\text { projeto de P.M. Rocha } \\
\text { (antiga casa } \\
\text { Fernando Milan) }\end{array}$ \\
\hline $\begin{array}{l}\text { Teresa } \\
\text { Genesini }\end{array}$ & $\begin{array}{l}\text { P.M. } \\
\text { Rocha }\end{array}$ & $\begin{array}{l}\text { São Bento do Sapucaí, } \\
\text { Campos do Jordão }\end{array}$ & 2007 & $\begin{array}{l}\text { psicanalista } \\
\text { Instituto de } \\
\text { psicanálise lacaniana } \\
\text { (Jorge Forbes }\end{array}$ & $\begin{array}{l}\text { Família de } \\
\text { origem italiana }\end{array}$ & \\
\hline $\begin{array}{l}\text { Hussein } \\
\text { Jarouche }\end{array}$ & $\begin{array}{l}\text { P.M. } \\
\text { Rocha }\end{array}$ & $\begin{array}{l}\text { Rua Dr Manoel Maria } \\
\text { Tourino, Perd }\end{array}$ & 2011 & $\begin{array}{l}\text { Proprietário da } \\
\text { Micasa, loja de } \\
\text { móveis e design nos } \\
\text { Jardins }\end{array}$ & $\begin{array}{l}\text { Família } \\
\text { muçulmana, }\end{array}$ & $\begin{array}{l}\text { (antiga casa de } \\
\text { casa Mário Masetti) }\end{array}$ \\
\hline
\end{tabular}


Caderno de Imagens 


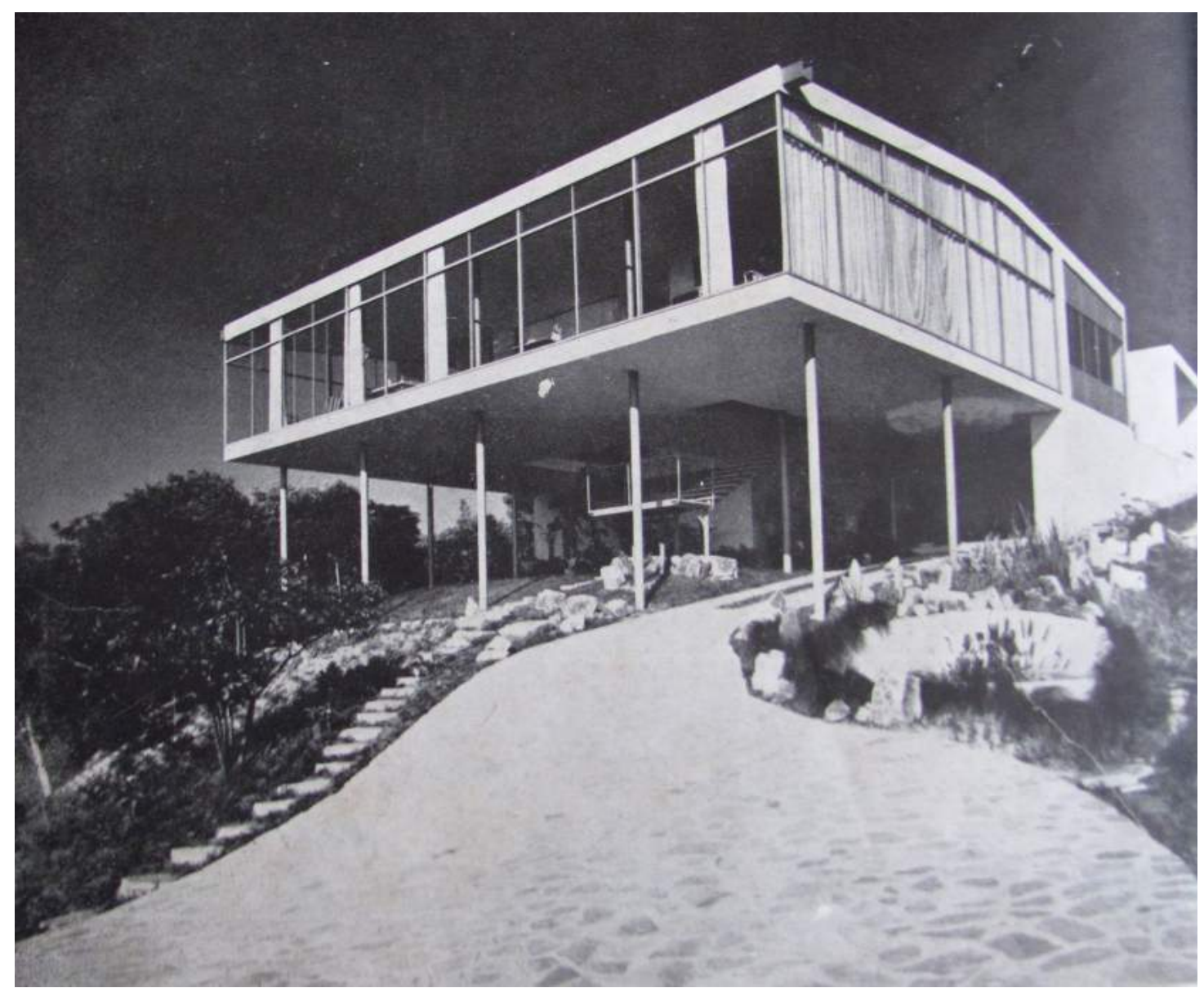

Figura 01: Casa de Vidro, residência do casal Pietro Bardi e Lina Bo Bardi localizada no Morumbi, projeto da arquiteta de 1950. Volume da sala de estar sob pilotis dá destaque ao acervo artístico dos proprietários.

Fonte: Revista Habitat, nº 10, p.32.

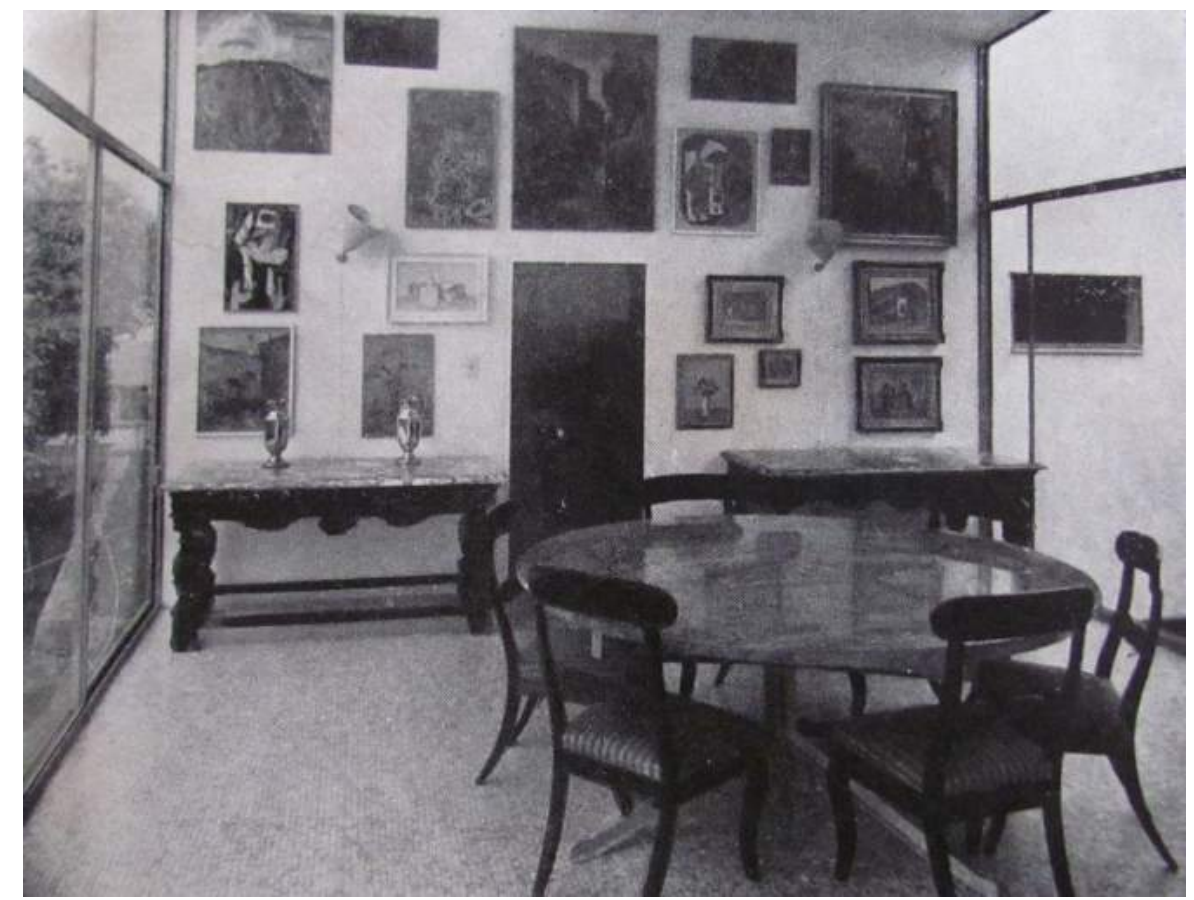

Figura 02: Interior da Casa de Vidro, Sala de Jantar da casa, em que a legenda original assim aparece: "Parede decorada com pinturas de Rouault, Morandi, Severini, Sironi, de Pisis, Papazoff, Stradone, Rosai". Fonte: Habitat, no 10, p.39. 
Figura 03:

Lina Bo Bardi e Gregori Warchavichik, no Baile do Mau Gosto em 1949.

Fonte: FERRAZ, Marcelo. Lina Bo Bardi. Instituto Lina Bo Bardi, 1993. p.75

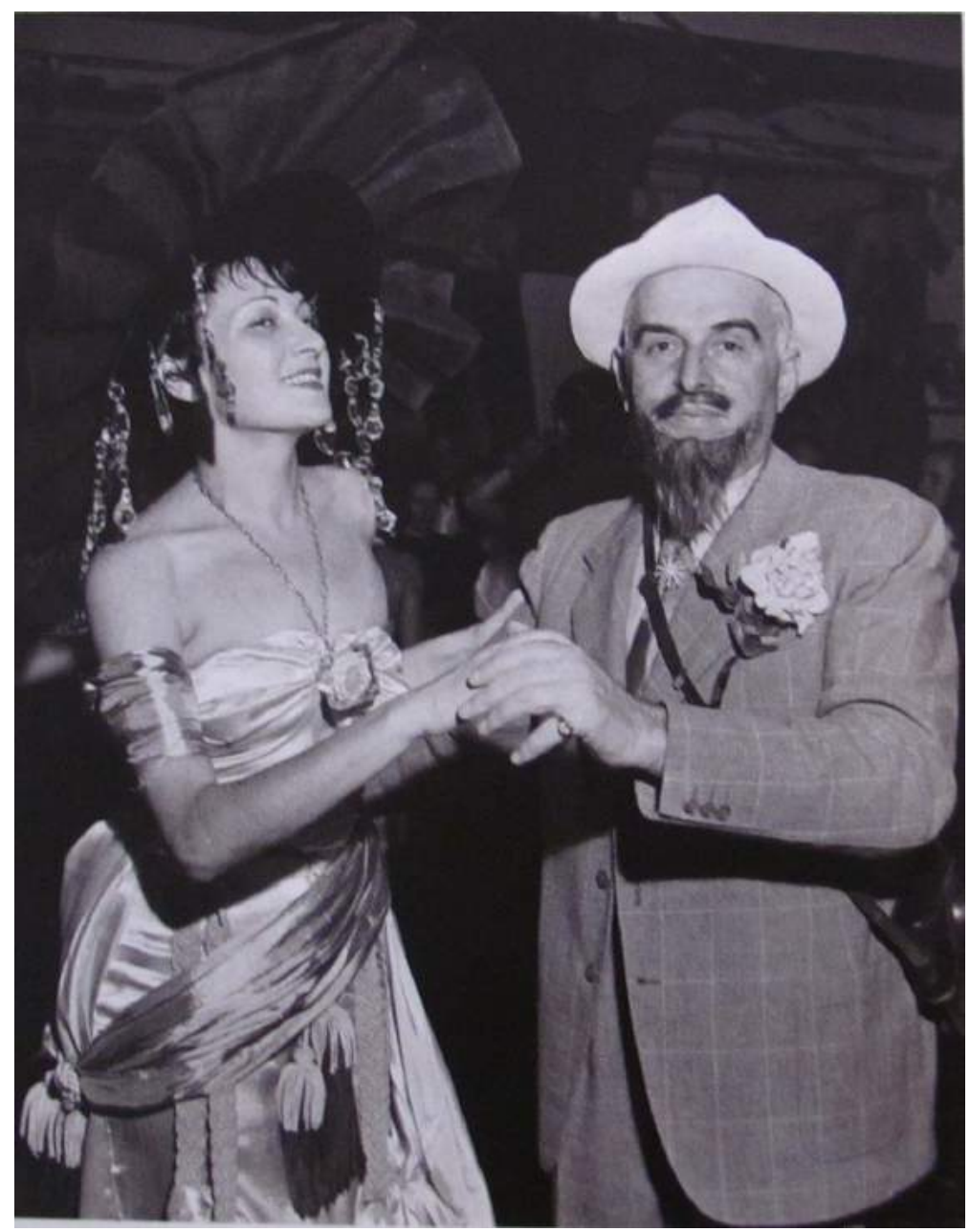

Figura 04:

Primeira cadeira projetada por Lina para pequeno auditório do MASP

da rua Sete de Abril, antes da criação do Studio Palma. Fonte: FERRAZ, Marcelo. Lina Bo Bardi.

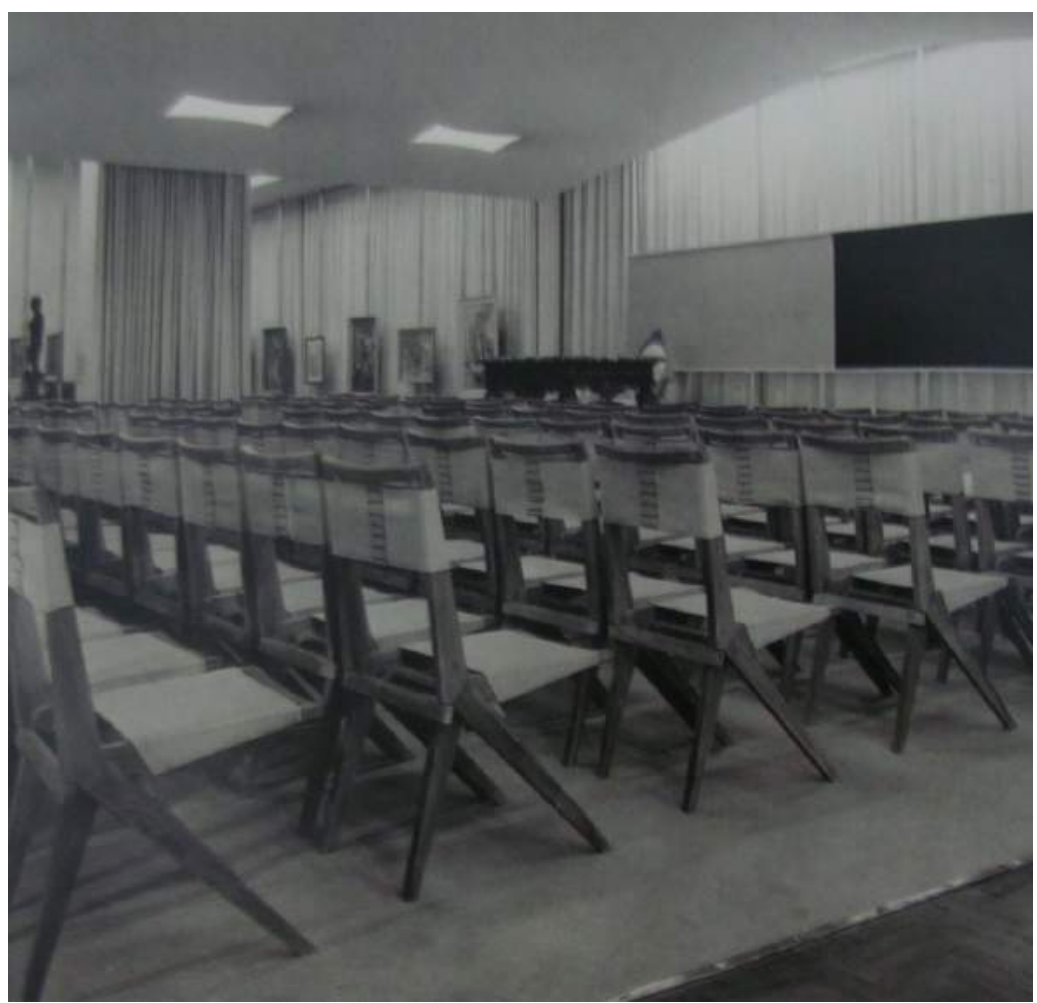



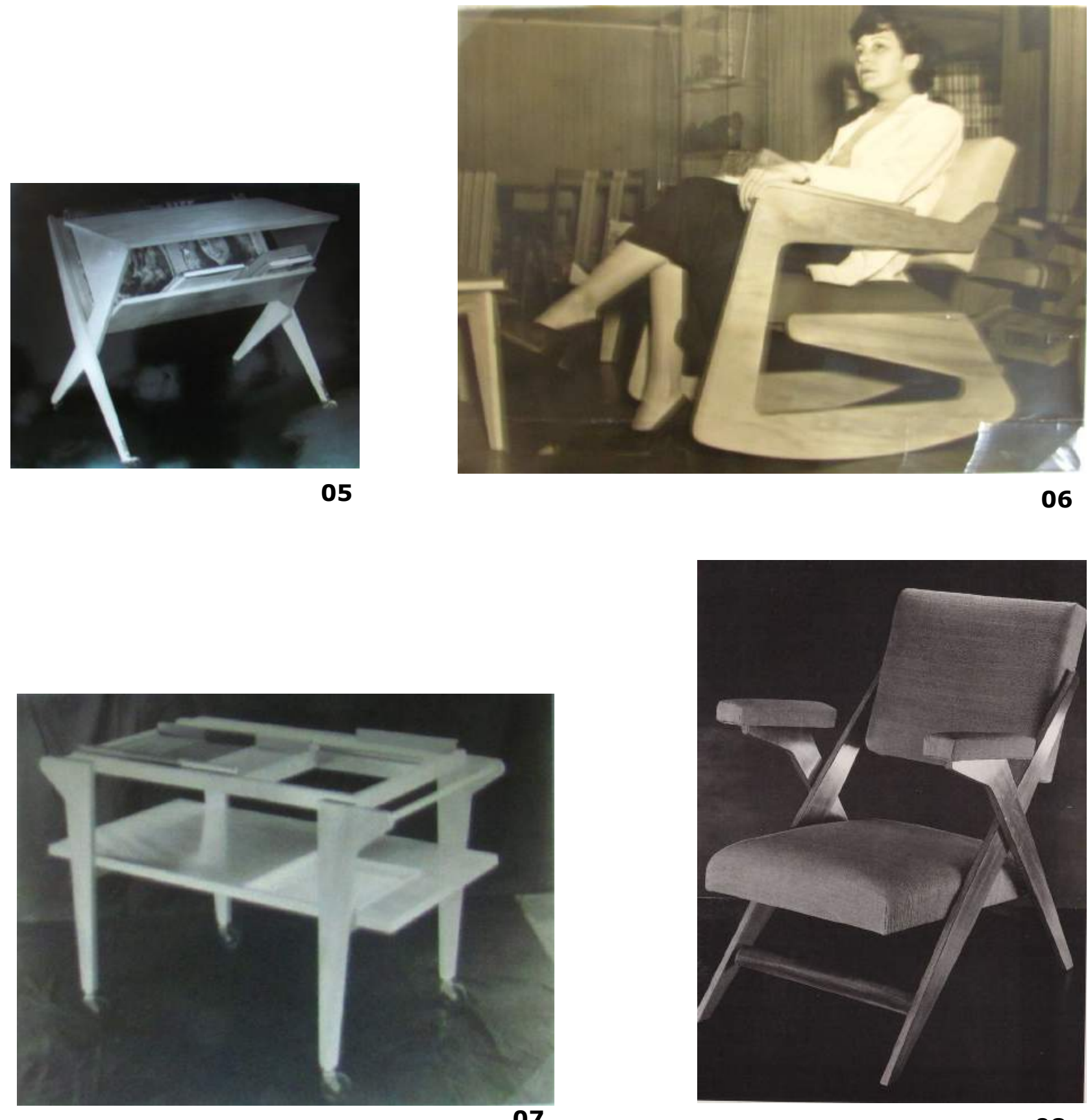

07

08

Figuras

05060708 09:

Portfólio de alguns móveis do Studio Palma: revisteiro, poltrona, carrinho de chá, cadeira e espreguiçadeira. Fonte: Acervo Instituto Lina Bo Bardi

09

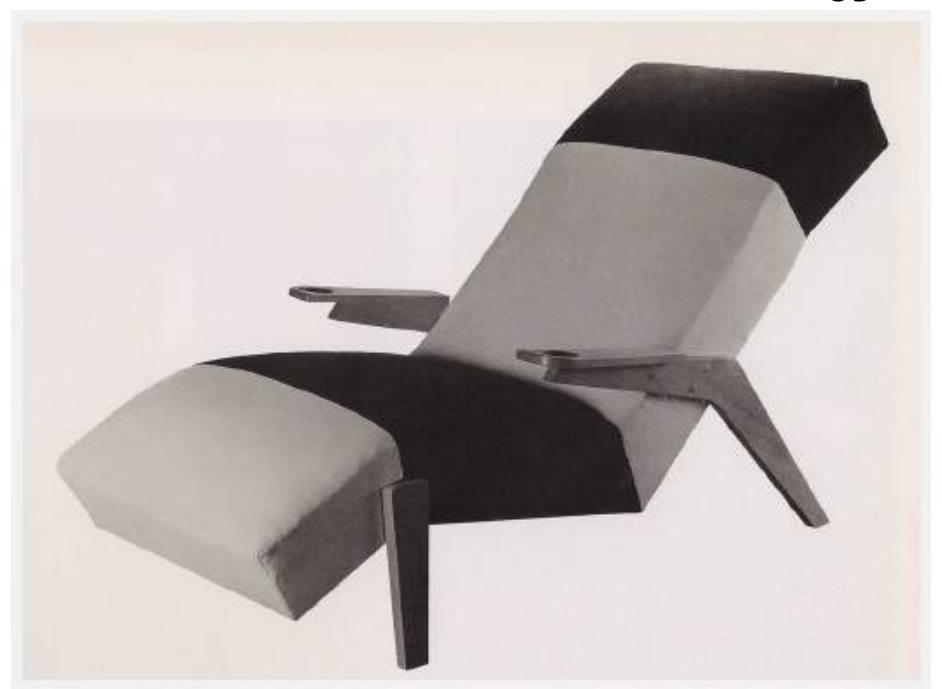




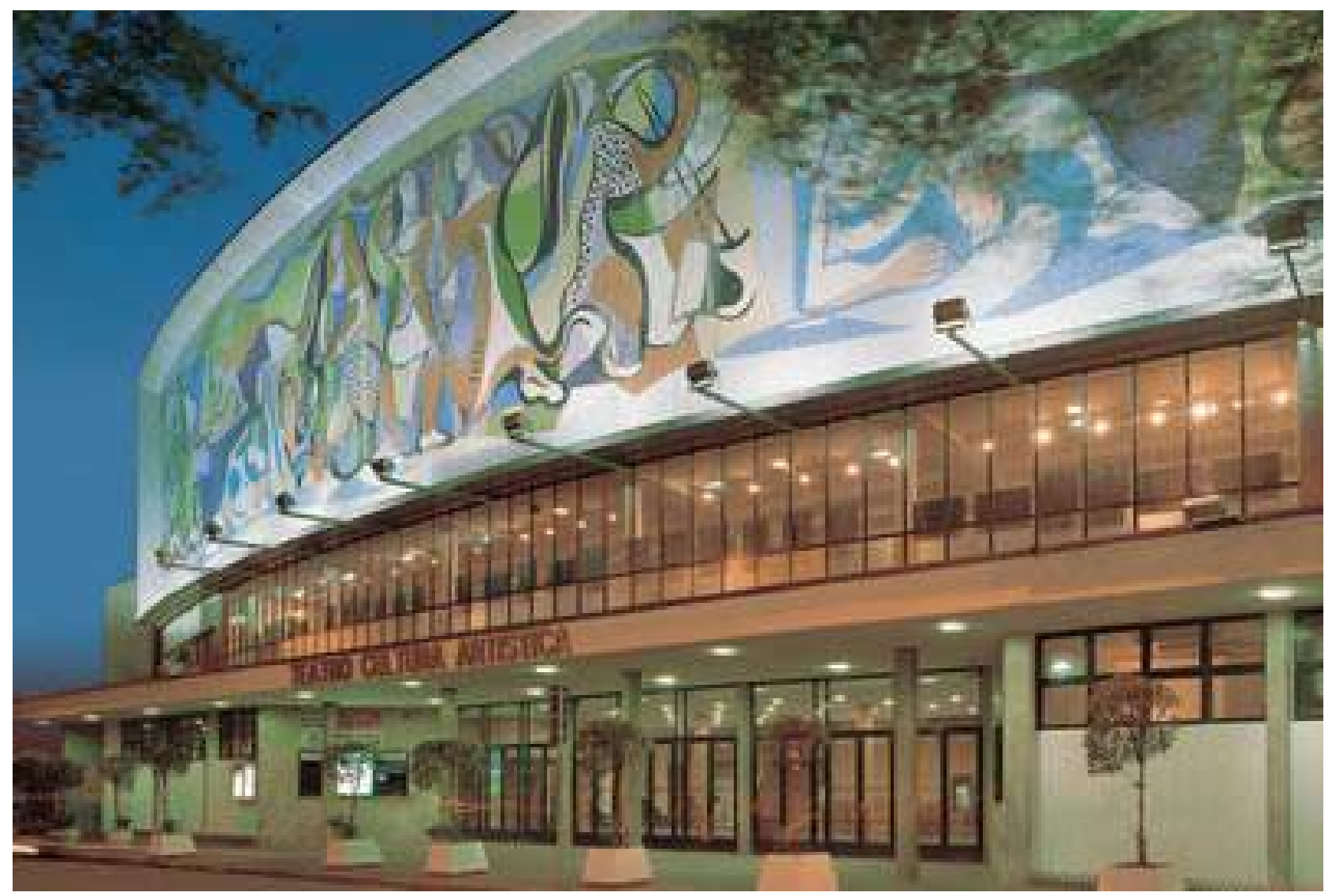

Figura 10: Prédio do Teatro Cultura Artística, projetado por Rino Levi em 1949, com painel em mosaico desenhado por Di Cavalcanti.

Fonte: Site Oficial Teatro Cultura Artística.

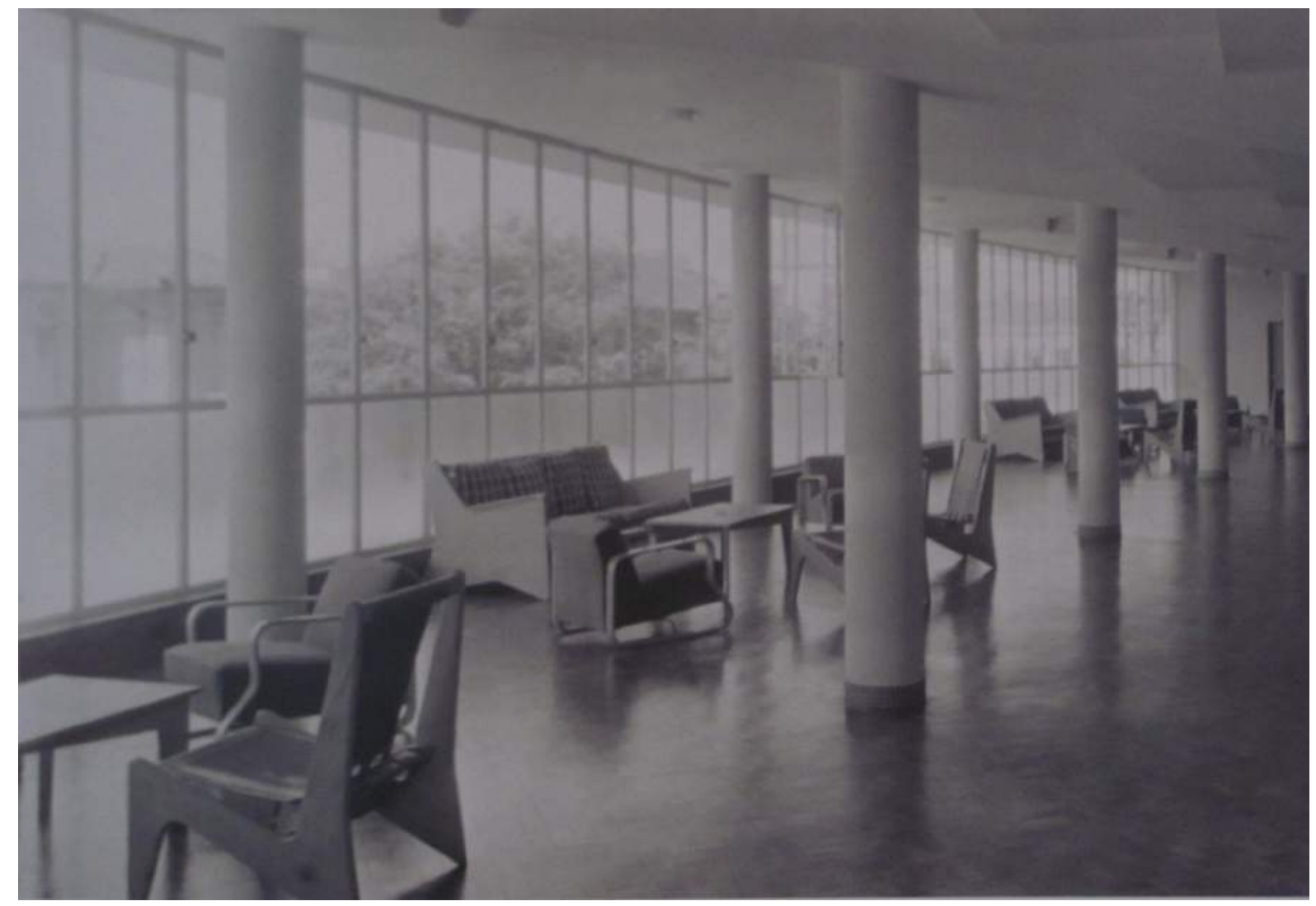

Figura 11: Foyer Principal do Teatro Cultura Artística, com mobiliário do Studio Palma. Fonte: ANELLI, Renato; GUERRA, Abilio; KON, Nelson. Rino Levi, arquitetura e cidade. São Paulo, Romano Guerra, 2001. p.151. 


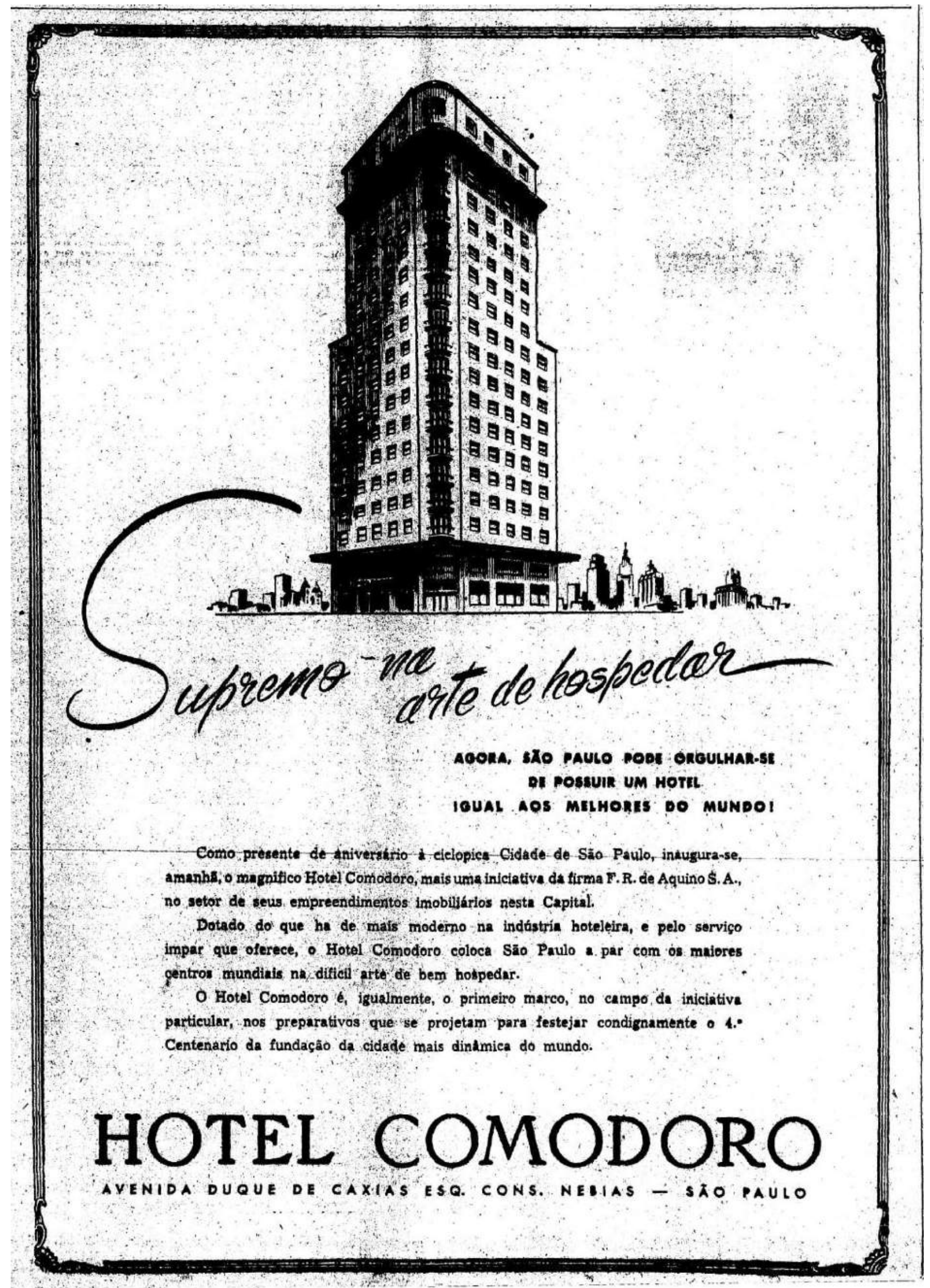

Figura 12: Anúncio publicitário do Hotel Comodoro, "como presente de aniversário à ciclópica cidade de São Paulo, inaugura-se amanha o magnífico Hotel Comodoro" (...) o primeiro marco, no campo da iniciativa particular, nos preparativos que se projetam para festejar condignamente o $4^{\circ}$ Centenário da fundação da cidade mais dinâmica do mundo". Fonte: Jornal Estado de São Paulo, 03 de fevereiro de 1952. 


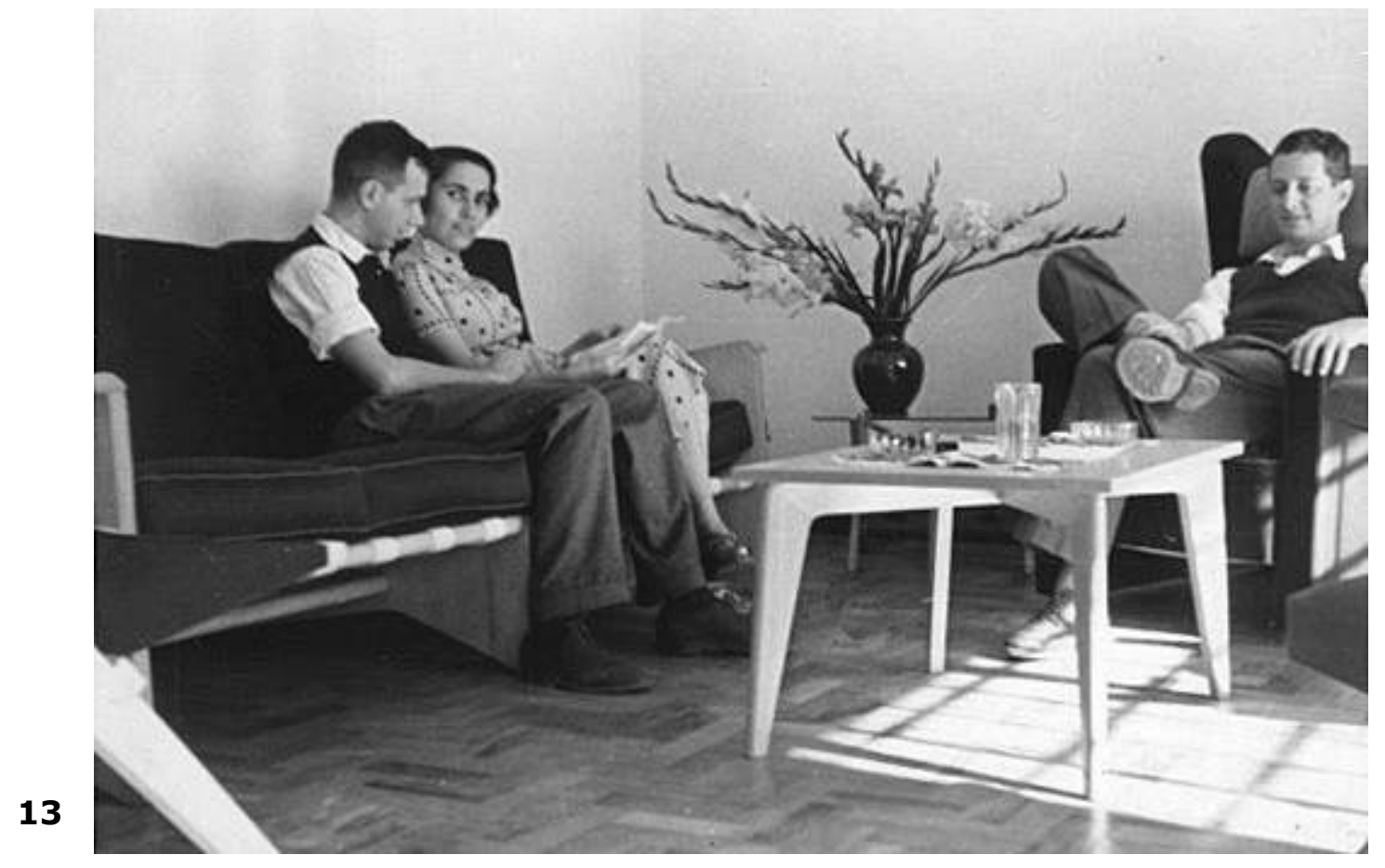

14

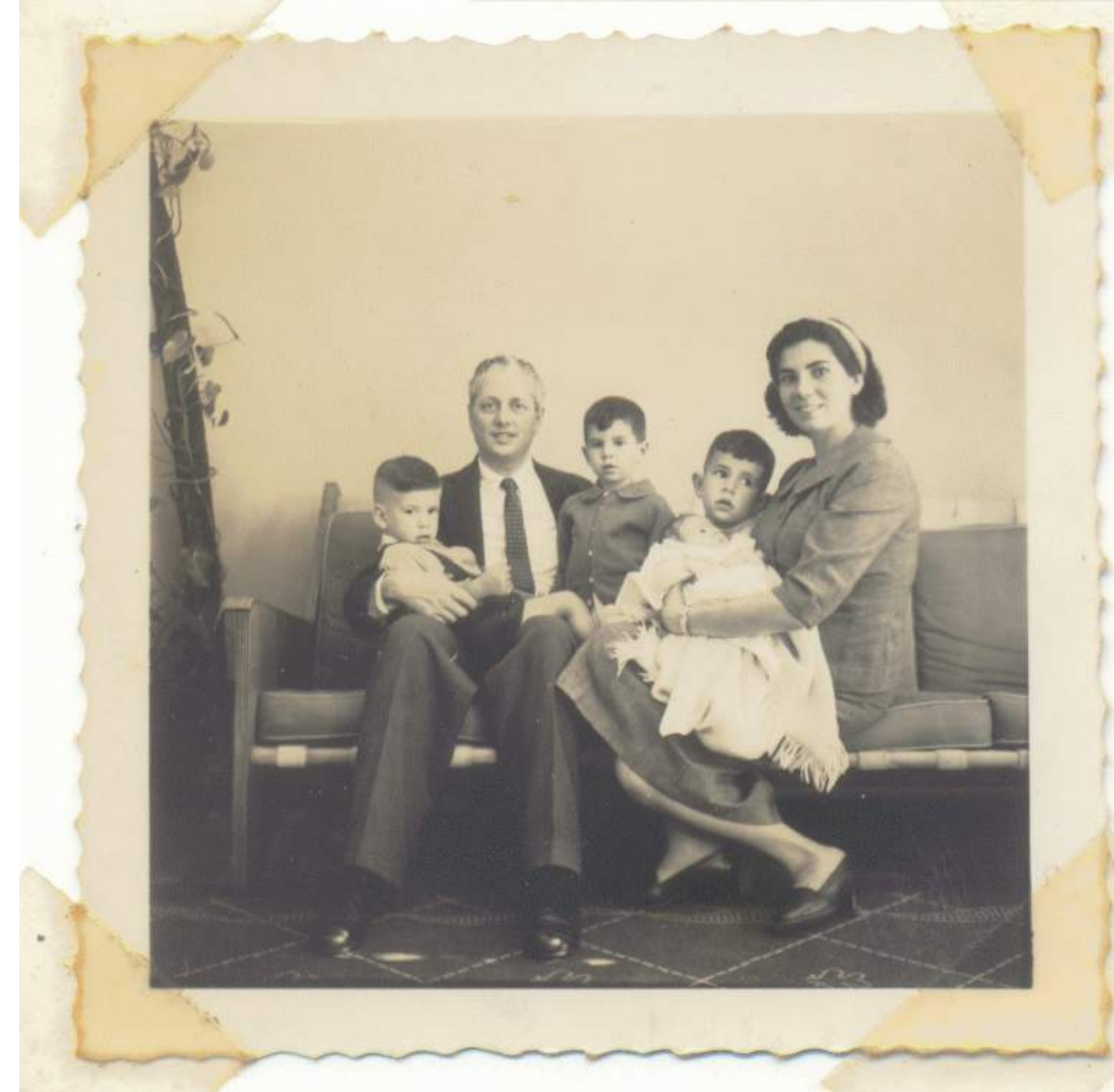

\section{Figuras 13 14:}

Álbum da Família Mortara, com fotos das reuniões na sala de estar na residência no Brooklin Novo (rua Indiana). Na primeira, Alberto Mortara recebe visitas, imagem em que aparece sofá de lona e almofadas soltas, bergère e mesa de centro em pau-marfim. $\mathrm{Na}$ segunda imagem de 1958, Alberto Mortara e Carmen Arruda de Albuquerque, com os filhos Bruno, Renato, Fábio e a bebê Maria Luísa.

Fonte: Álbum de Família. 


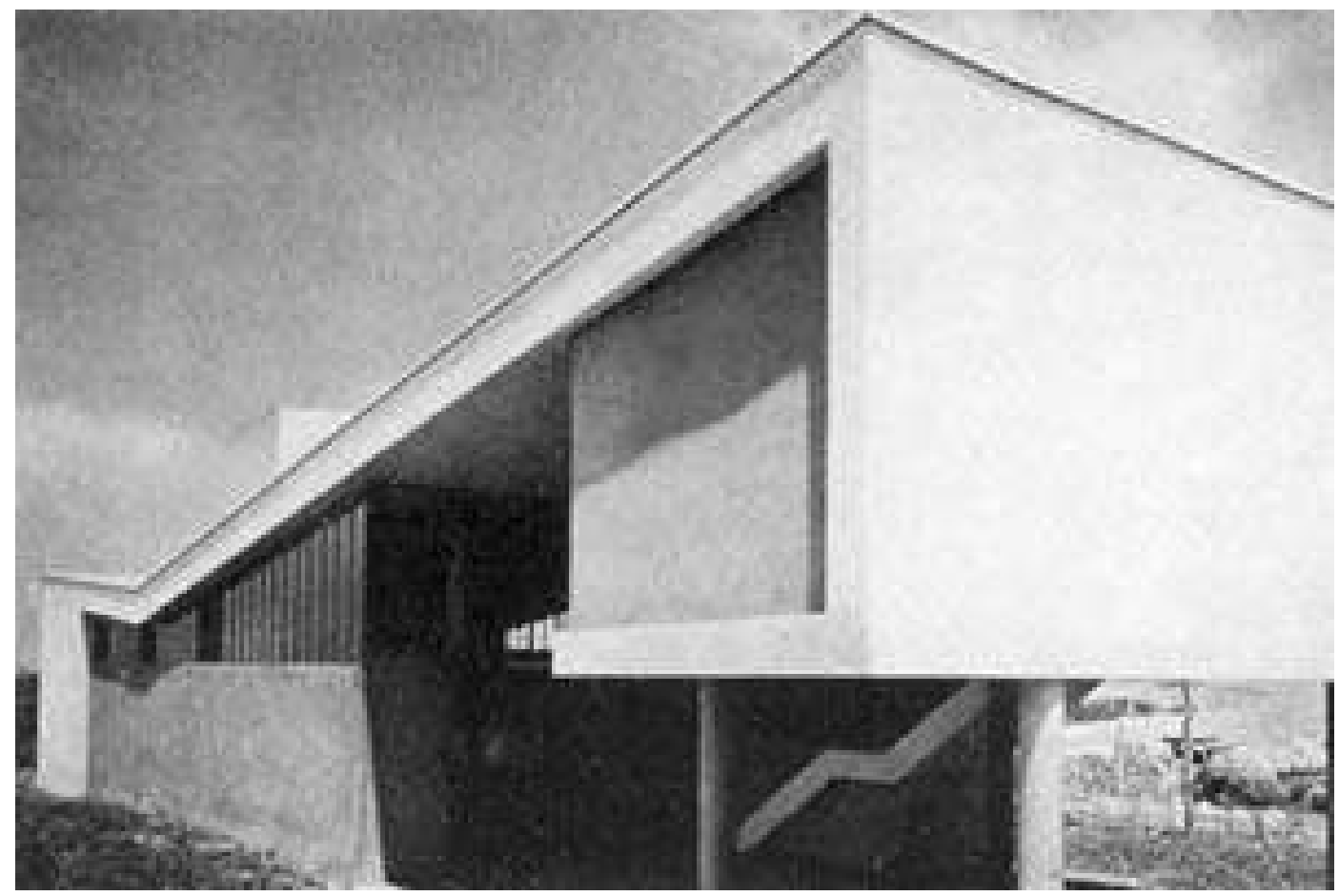

Figura 15: Casa de José Mário Taques Bitencourt. Projeto da casa de Vilanova Artigas, localizada no Sumaré, São Paulo, 1949.

Fonte: Habitat, n01. "Casas de Artigas".p.4

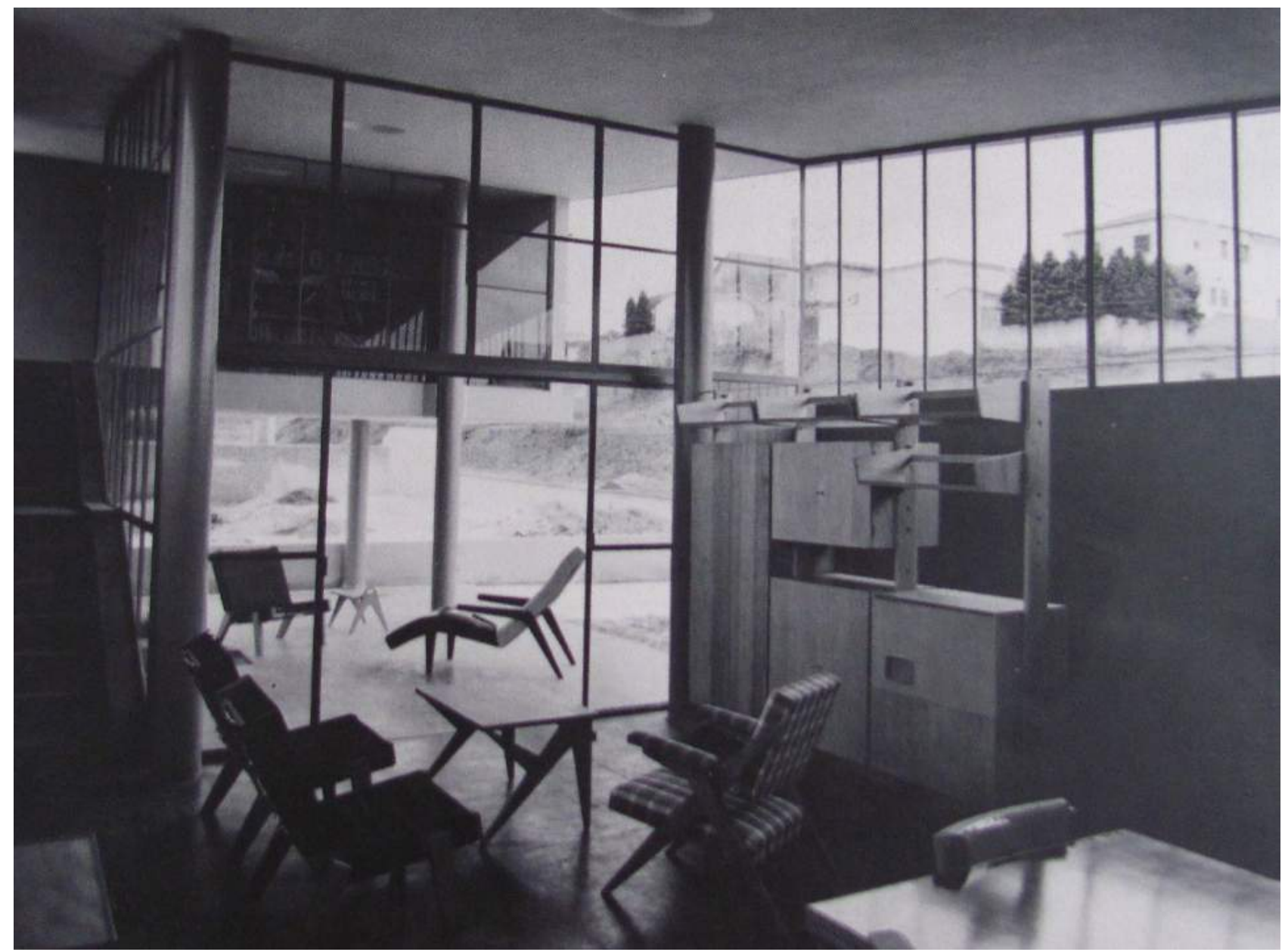

Figura 16: Casa de José Mário Taques Bitencourt. Móveis projetados pelo Studio Palma integrados ao espaço fluido da residência projetada com Vilanova Artigas.

Fonte: Habitat, n01. "Casas de Artigas".p.4 


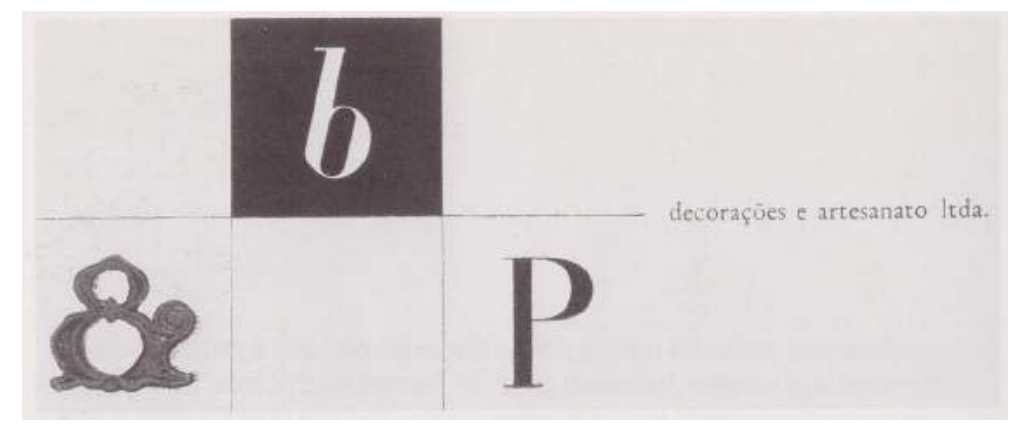

Figura 17: Logomarca Branco e Preto desenhada por Jacob Ruchti. Fonte: SANTOS, Maria Cecília Loschiavo. $O$ móvel moderno no Brasil. São Paulo: Studio Nobel: FAPESP: EDUSP, 1995.p.112

Figura 18: Branco e Preto. Poltrona listrada desenhada por Jacob Ruchti. Fonte: Acrópole nº177, Janeiro, 1953, p.331.
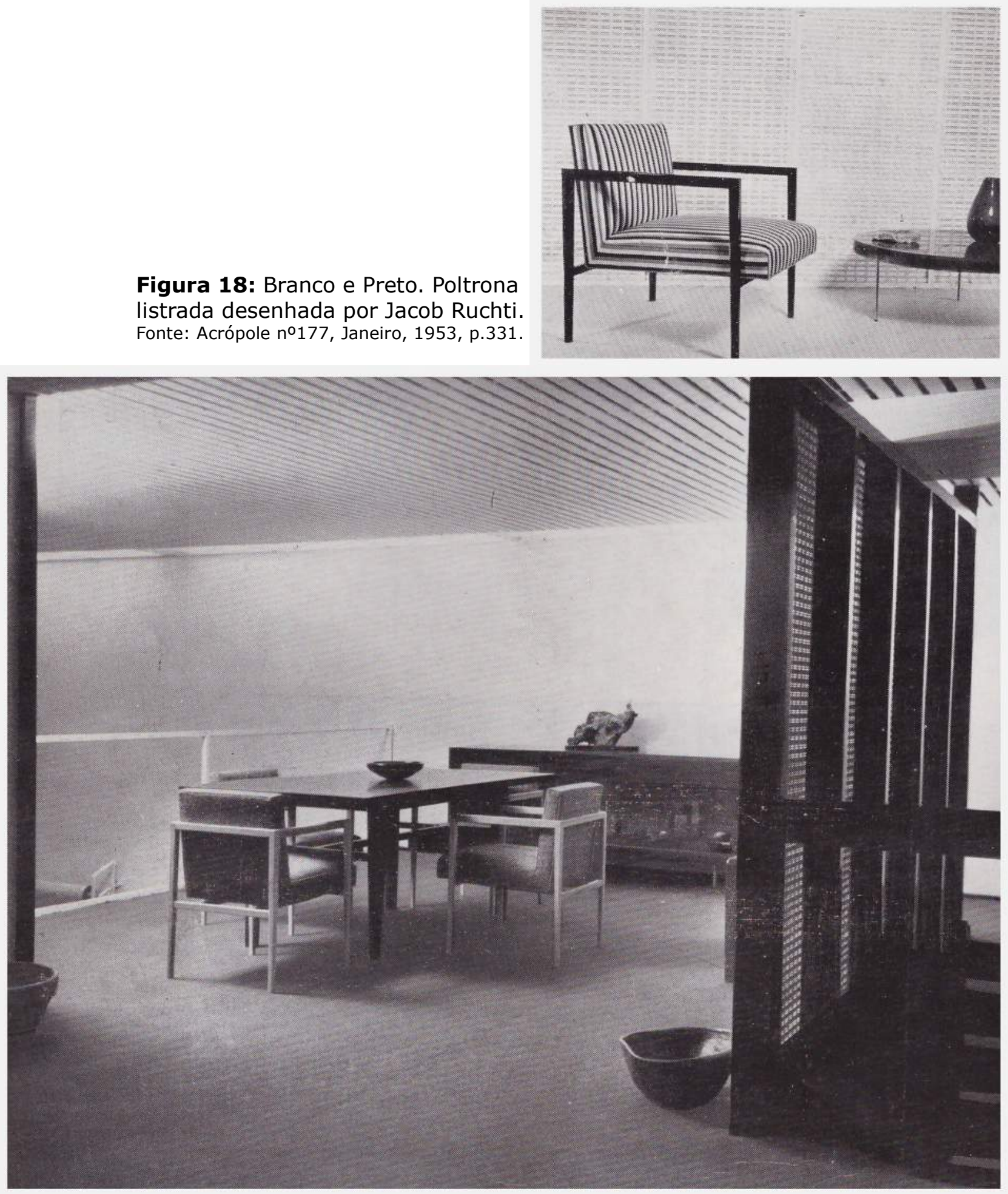

Figura 19: Branco e Preto. Conjunto para sala de jantar, disposto no mezanino da loja. Fonte: Revista Acrópole nº177, Janeiro, 1953, p.330. 


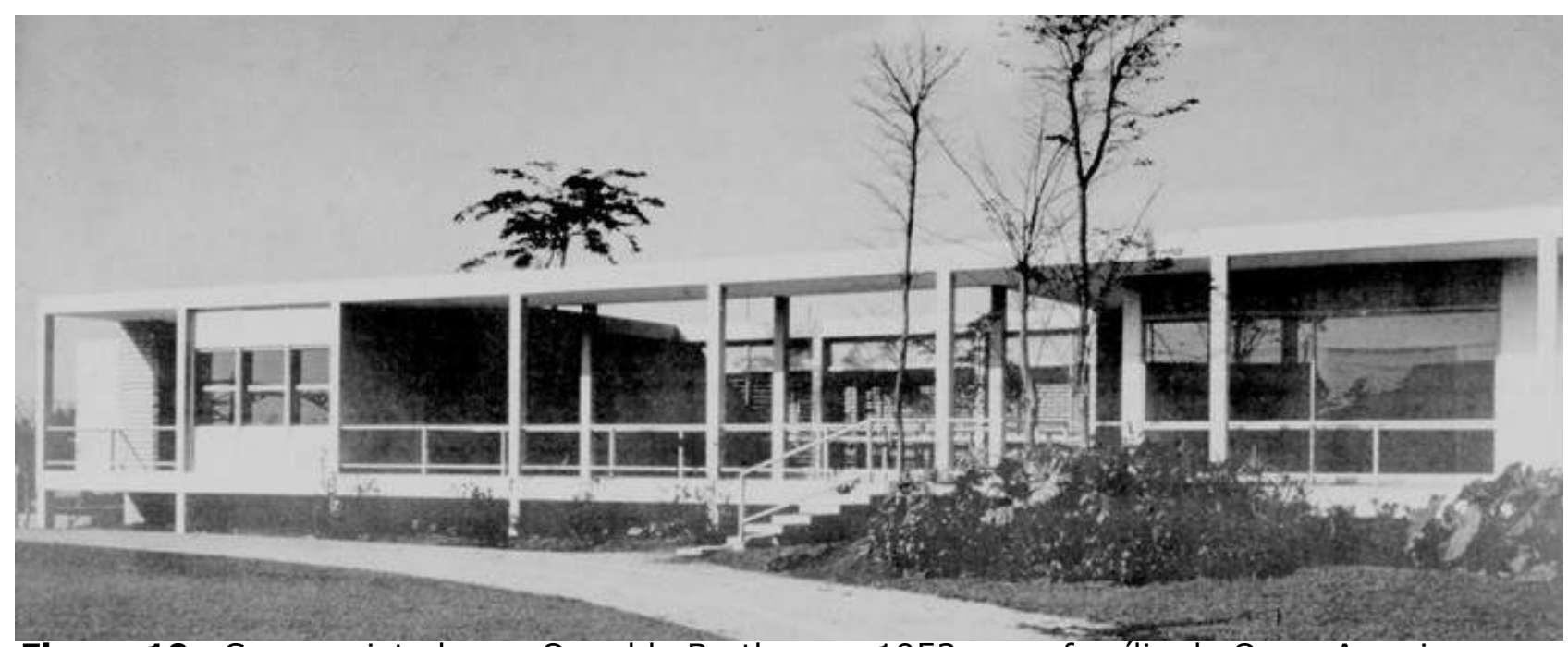

Figura 19: Casa projetada por Oswaldo Bratke, em 1953, para família de Oscar Americano. Fonte: http://www.archdaily.com.br/br/01-33190/classicos-da-arquitetura-residencia-oscar-americano-oswaldo-br

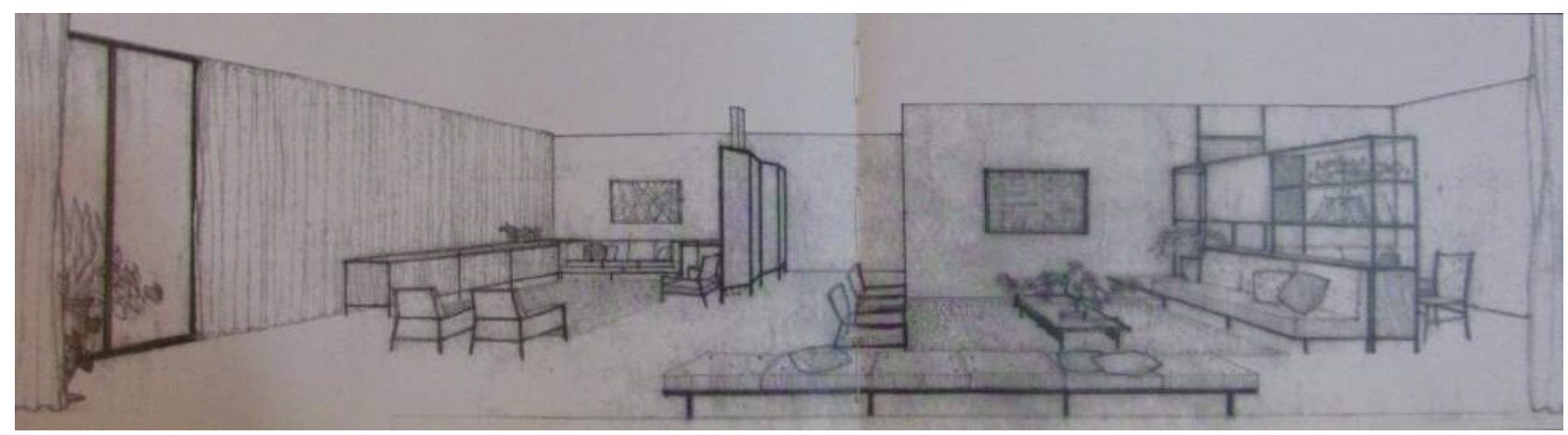

Figura 20: Perspectiva com projeto de design de interiores da Branco e Preto para residência de Oscar Americano, projeto arquitetônico elaborado por Oswaldo Bratke.

Fonte: ACAYABA, Marlene. Branco e Preto. p.96-97.

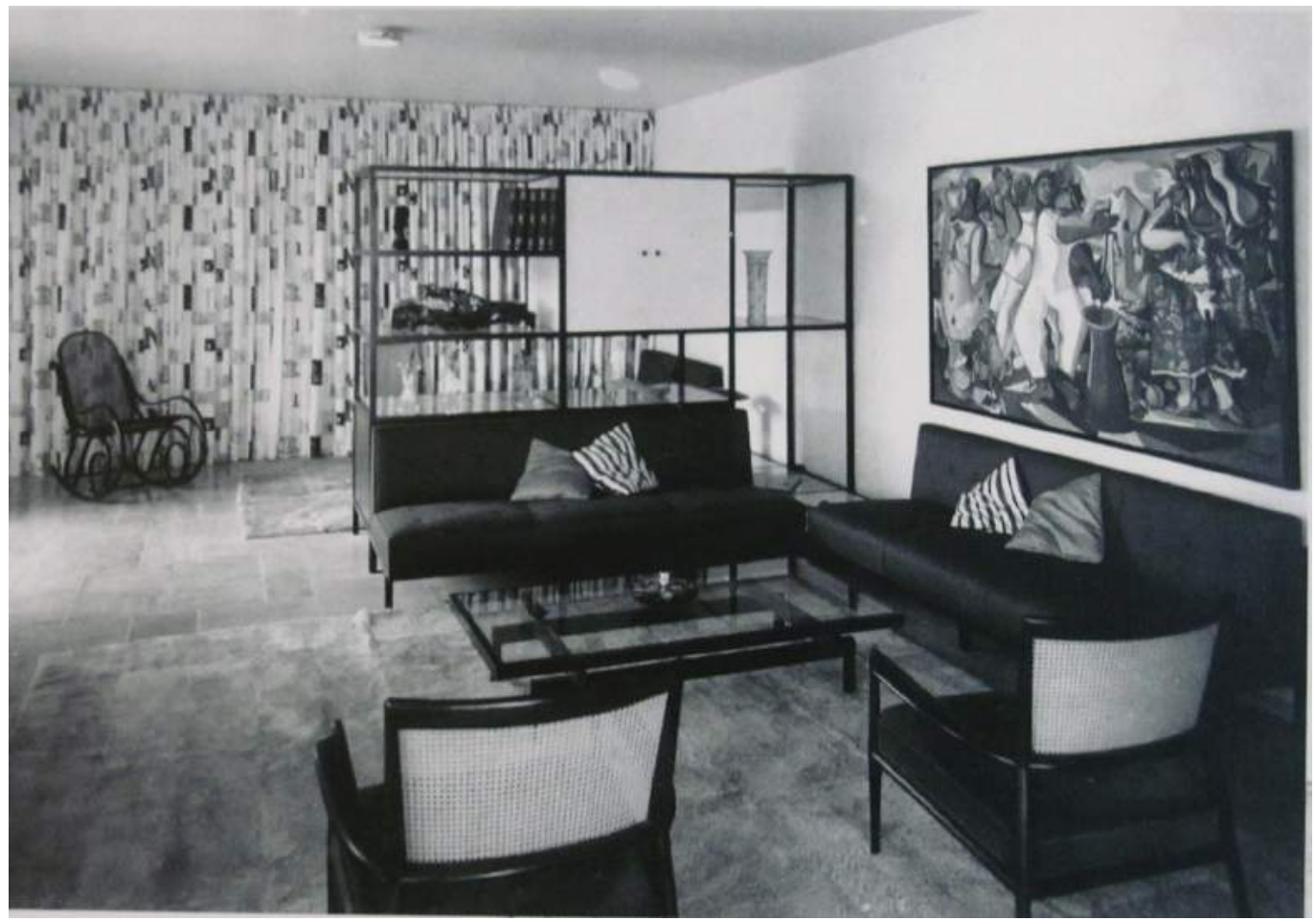

Figura 21: Uma das salas projetados pela Branco e Preto, para a residência de Oscar Americano, onde se vê as cadeiras de palhinha, os sofás em linhas retas e o móvel-estante, numa espaço decorado com obras de arte. Fonte: ACAYABA, Marlene. Branco e Preto. p.97. 


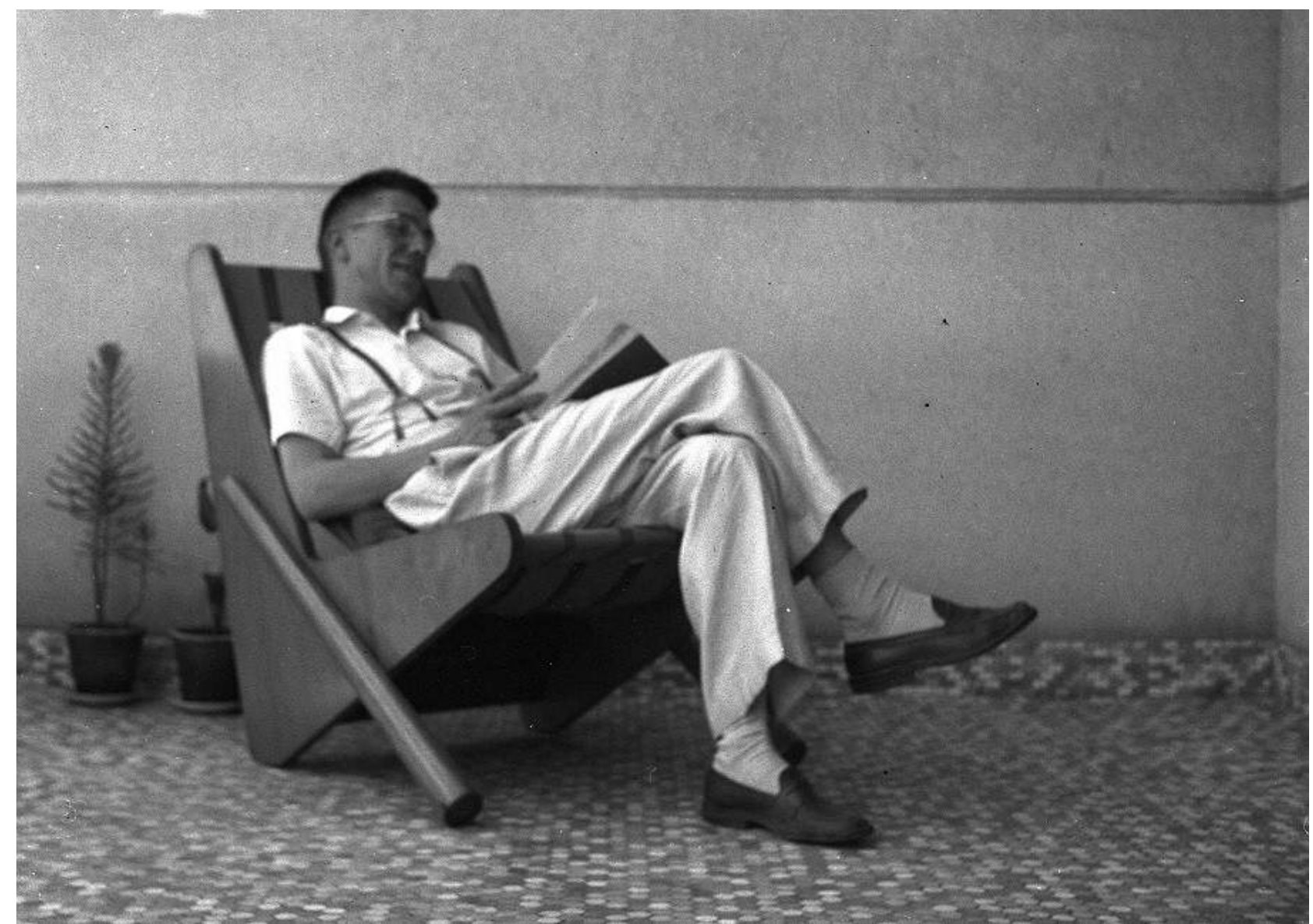

Figura 22: Vilanova Artigas sentado em poltrona que projetou, cuja execução foi feita por Zanine Caldas. Fonte: Acervo Pessoal Vilanova Artigas, doação de Rosa Artigas.

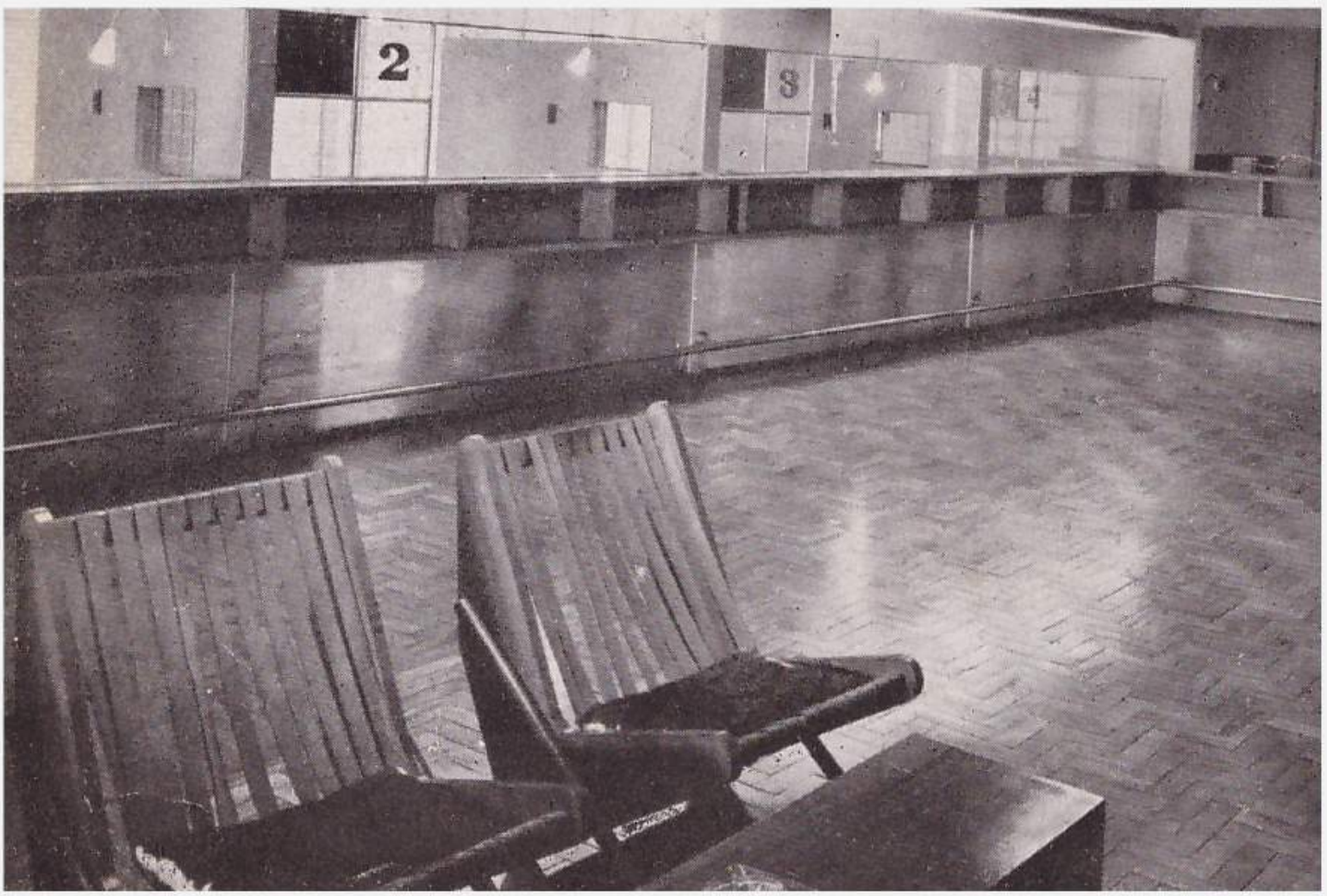

Figura 23: Empresa de Seguros A Equitativa, saguão central com móveis projetados por Artigas e marcenaria de Zanine Caldas.

Fonte: Revista AD Arquitetura e Decoração, N01, agosto/setembro, 1953 (sem paginação) 


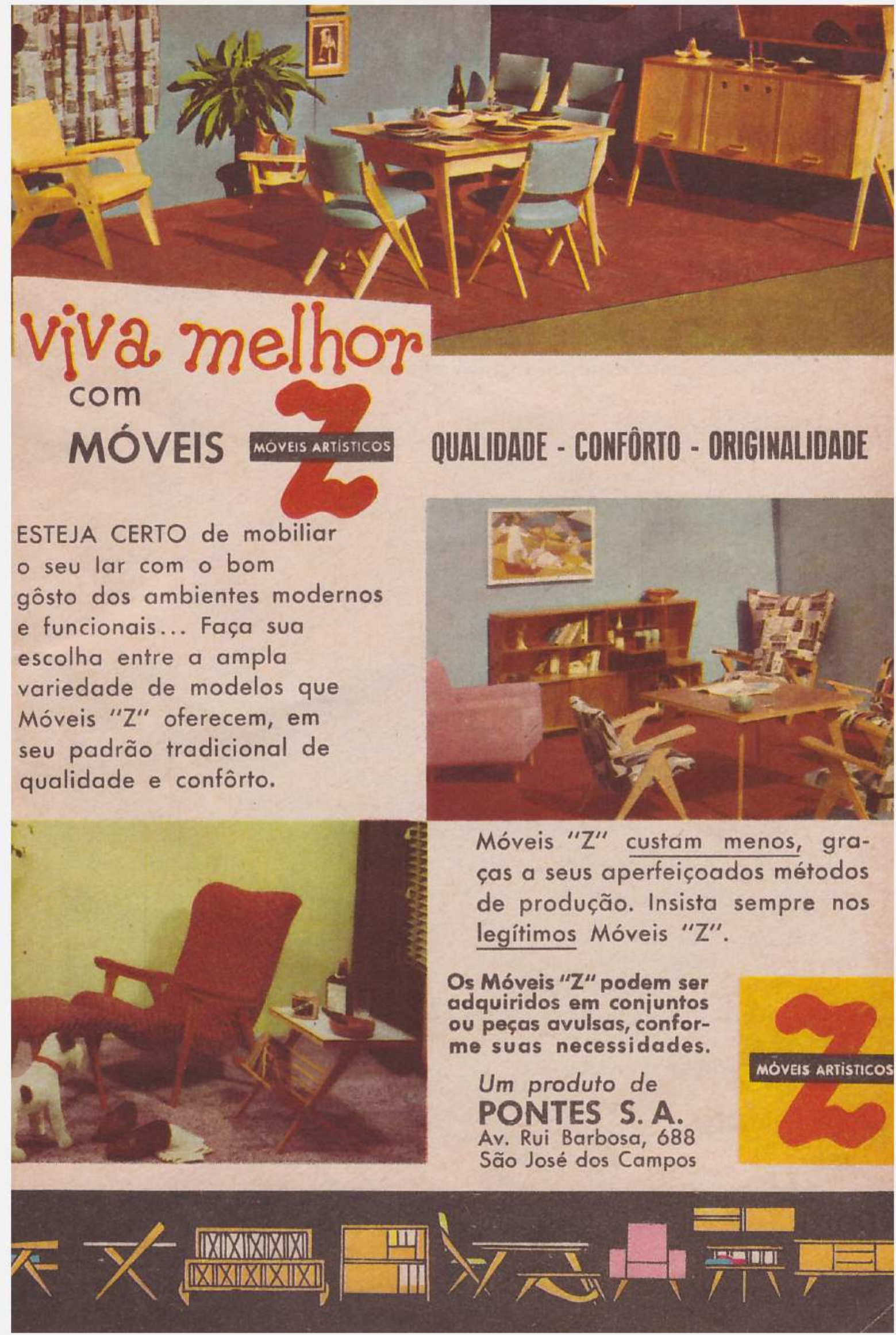

Figura 24: Móveis $Z$ na disseminação do gosto moderno: produção de móveis em série e veiculação de anúncios em revistas. Fonte: Revista Readers Digest, 1957. 


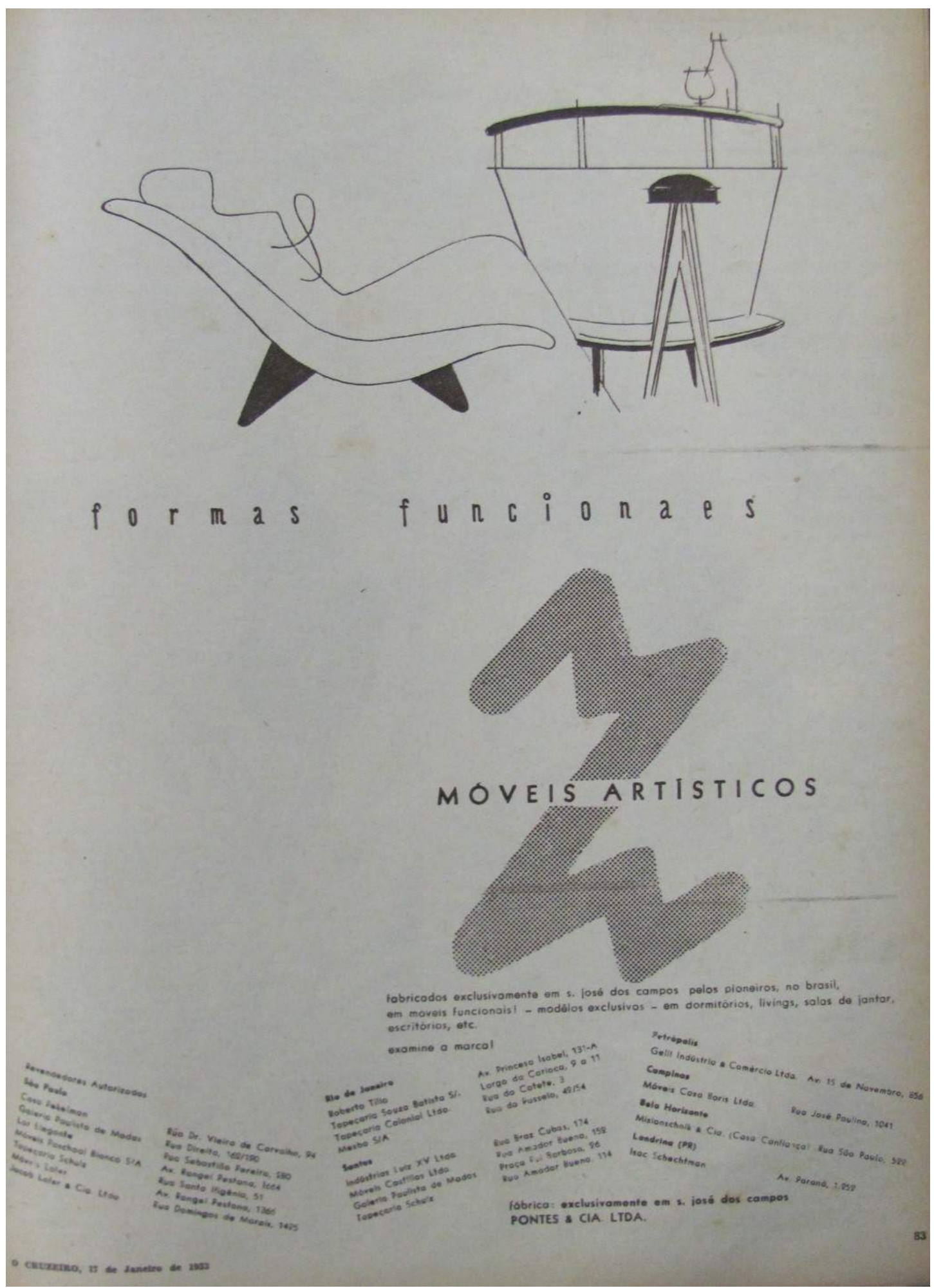

Figura 25: Anúncio da Móveis $Z$ veiculado na revista semanal O Cruzeiro, tiragem indicada na capa 550.000 exemplares.

Fonte: Revista O Cruzeiro, no 14, 17 de janeiro de 1953. p.83 


\section{Com o novo revolucionário encôsto $Z$, Mais u ma cientificamente aprovado, proporcionando a V.um Poltrona repouso completo devido ao relaxamento total dos músculos. Uma exclusividade dos Móveis $\mathbf{Z}$ - em madeira de lei.}

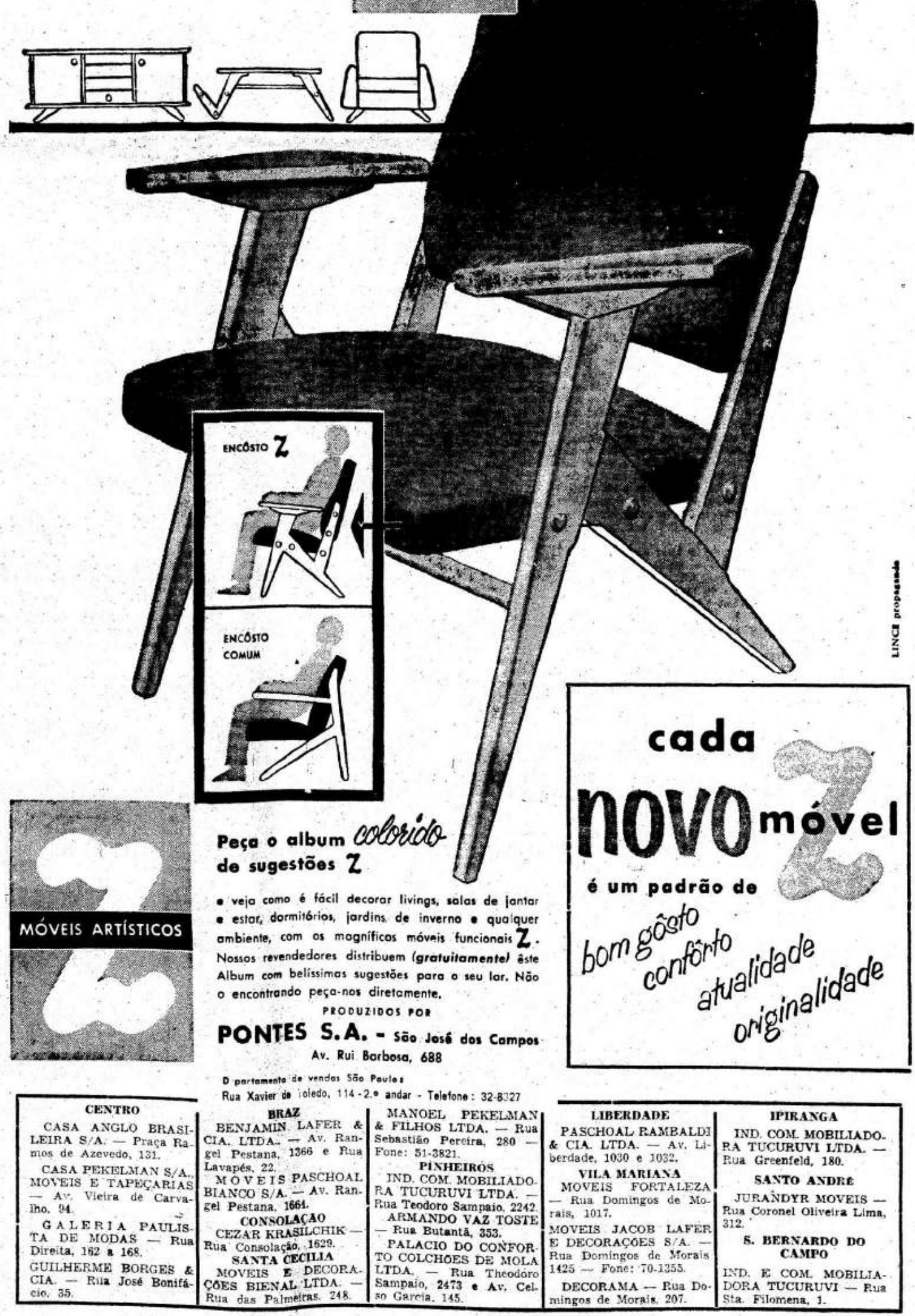

Figura 26: Anúncio da Móveis $Z$ veiculado em jornal, presença em várias lojas em São Paulo e cidades adjacentes. Fonte: Estado de São Paulo, 06 de agosto de 1957. p.15. 


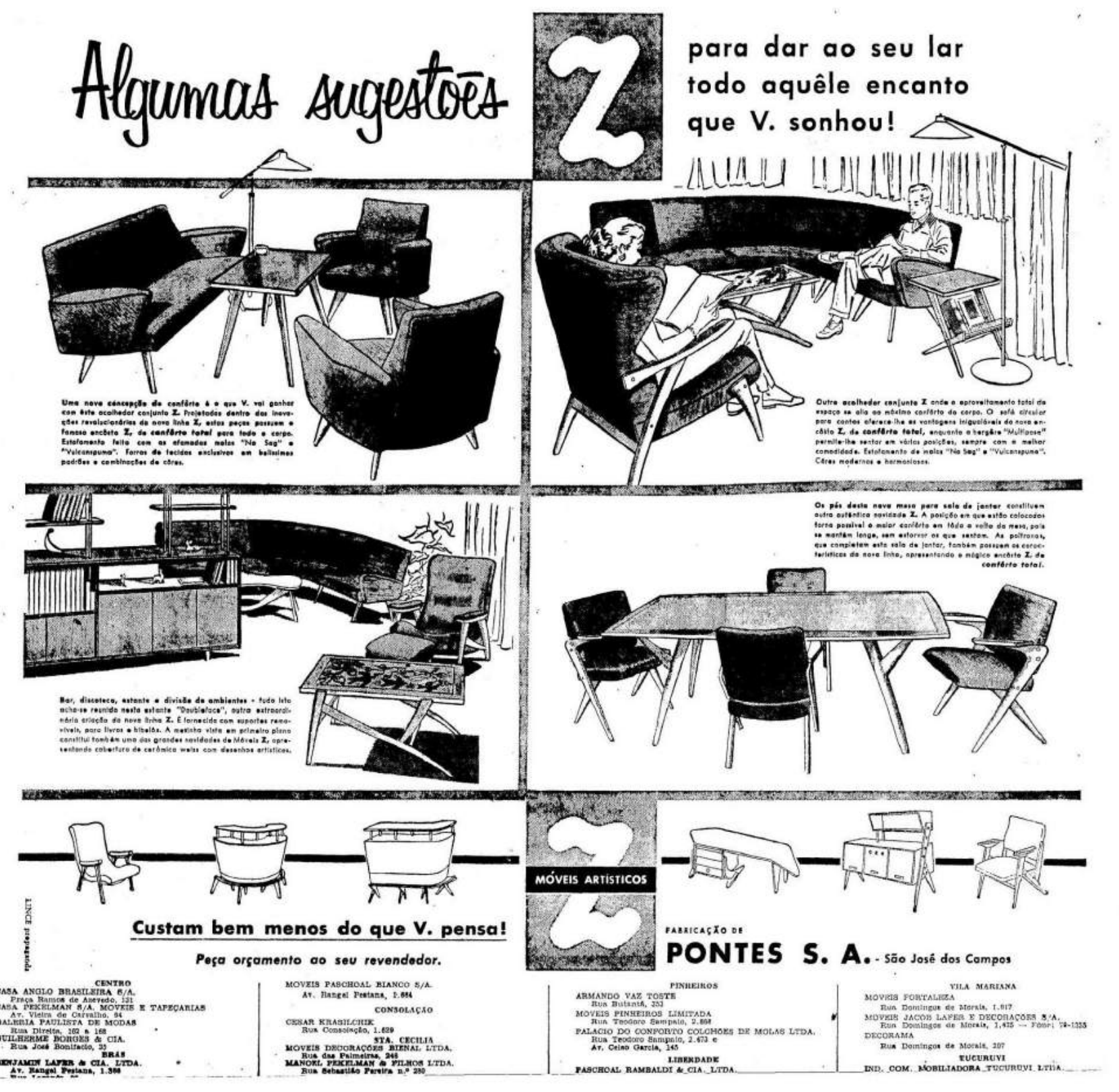

Figura 27: Anúncio da Móveis Z veiculado em jornal, mostrando o portfólio da firma. Fonte: Estado de São Paulo, 04 de julho de 1957. p.9. 


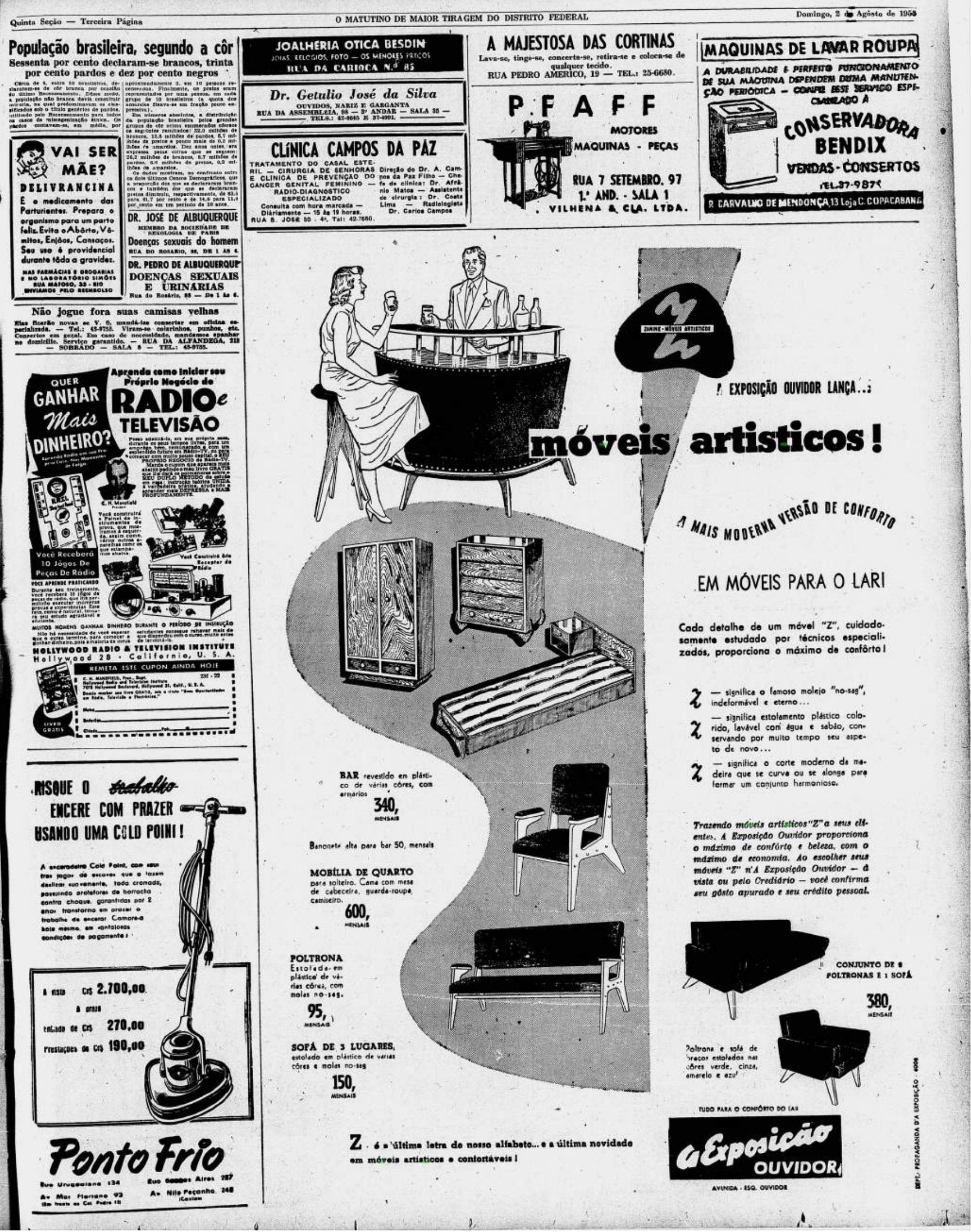

Figura 28: Anúncio da Móveis $Z$ ocupando grande página em jornal. "O máximo de conforto e beleza com máximo de economia (...) À vista ou pelo crediário, você confirma seu gosto e seu crédito pessoal". Fonte: Jornal Diário de Notícias, 02 de agosto de 1953. 


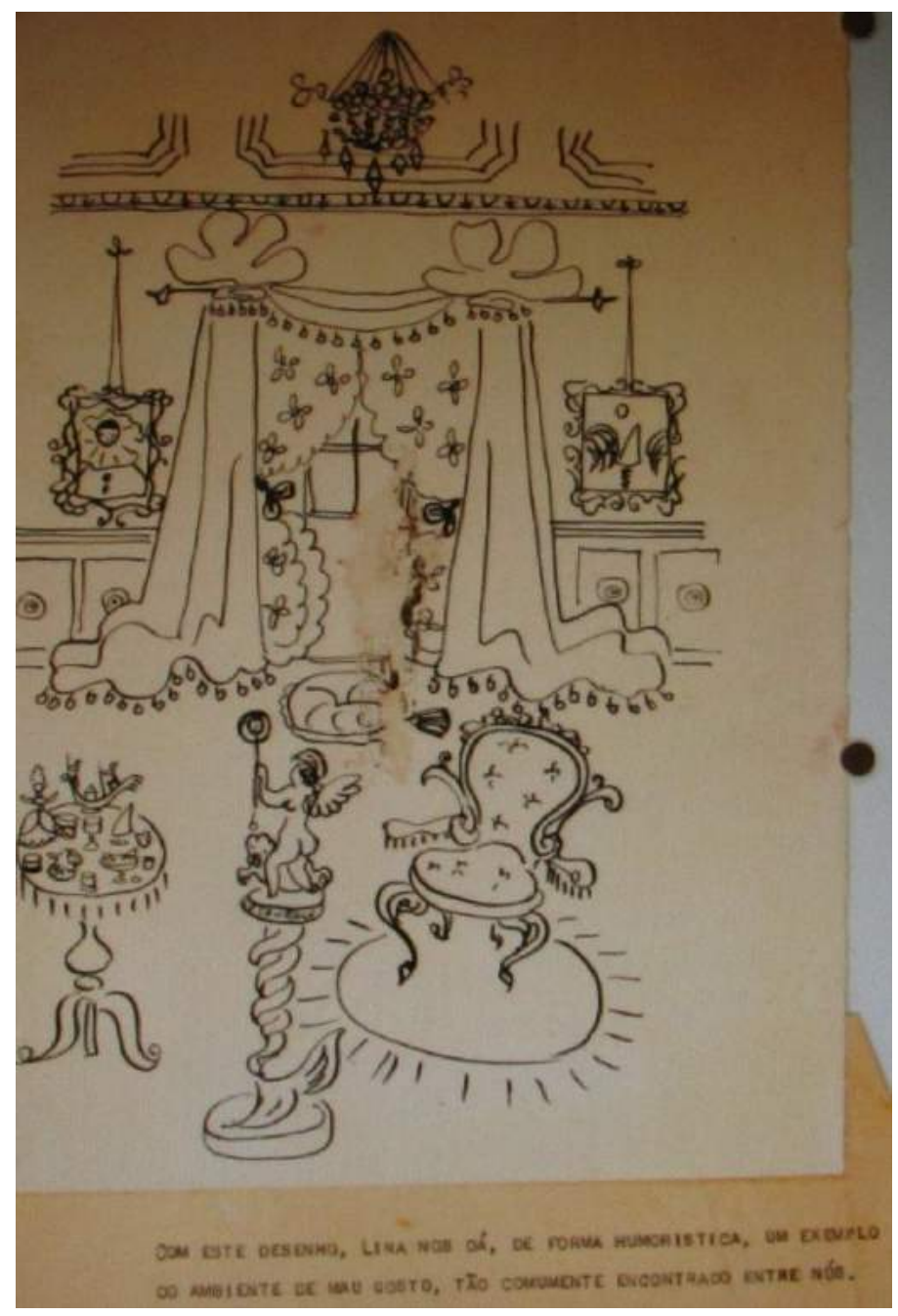

Figura 29: Desenho de Lina Bo Bardi, com a legenda, sem autoria "Com este desenho, Lina nos dá, de forma humorística, um exemplo do ambiente de mau gosto, tão comumente encontrado entre nós" pessoal". Fonte: Acervo Instituto Lina Bo Bardi.

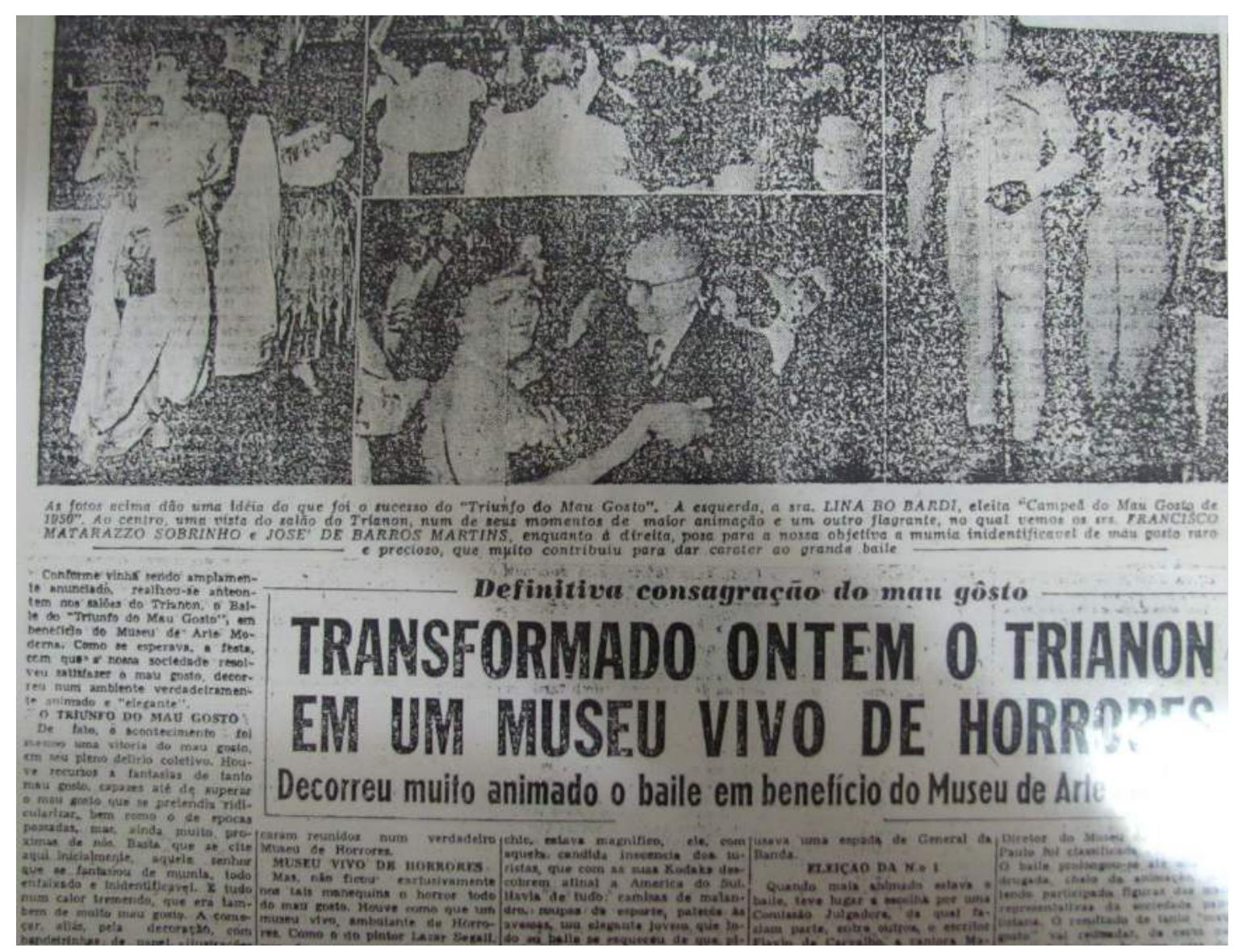

Figura 30: Matéria no jornal de época sobre o Baile "Triunfo da Mau-gosto". Fonte: Diário da Noite, 13 de fevereiro de 1950. 


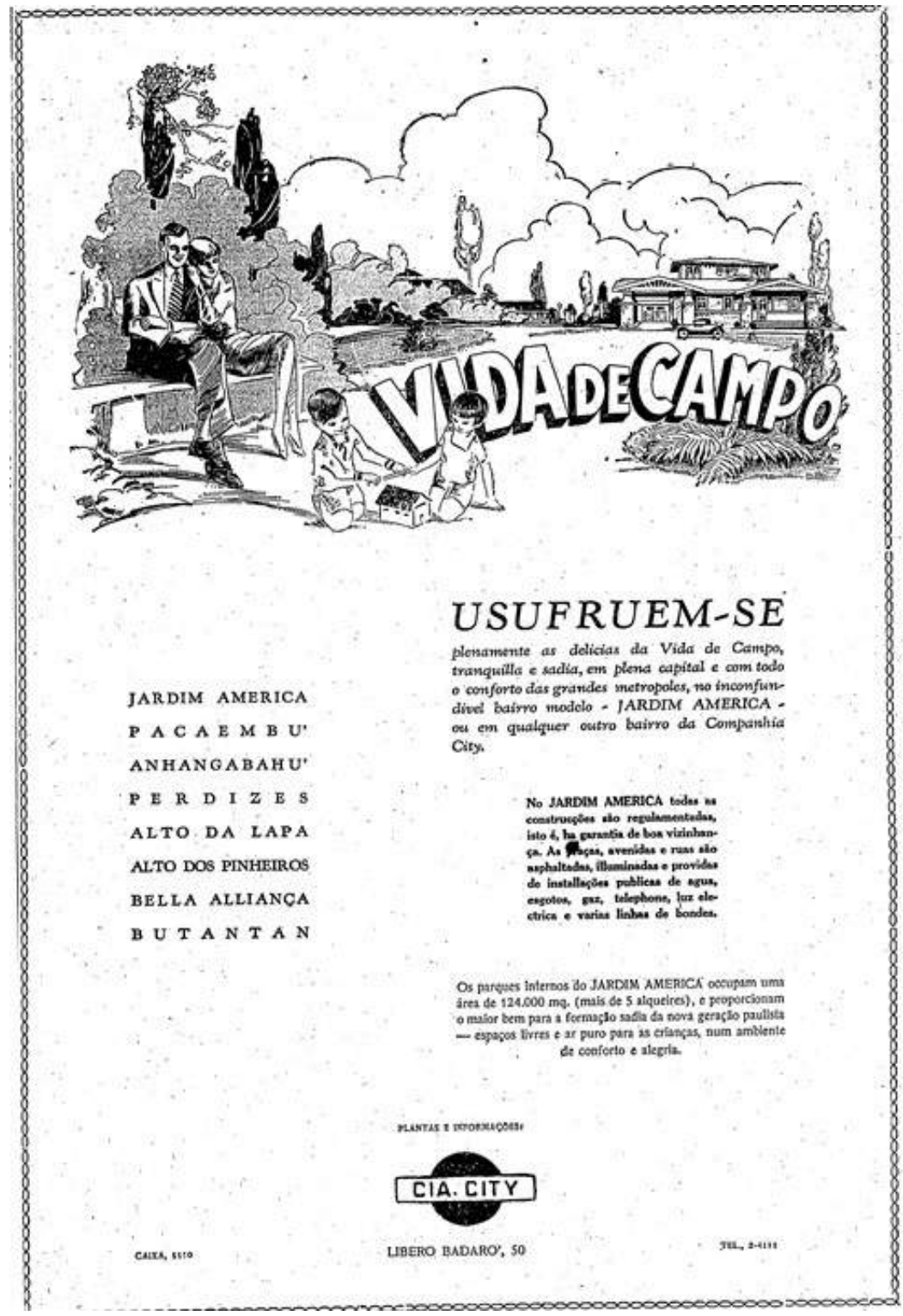

Figura 31:

Jornal Estado de São Paulo, 01 de setembro de 1929

\section{CONSTRUA - SEU LAR No PACAEMBU A NOVA MARAVILHA URBANA}

Figura 32:

Jornal Estado de São Paulo, 14 de novembro de 1937

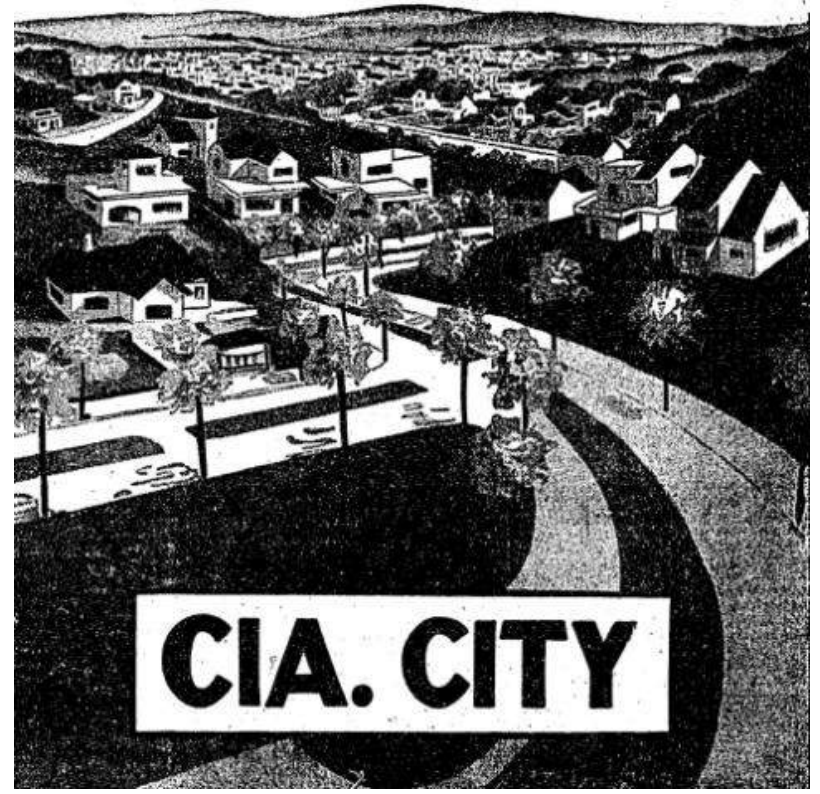




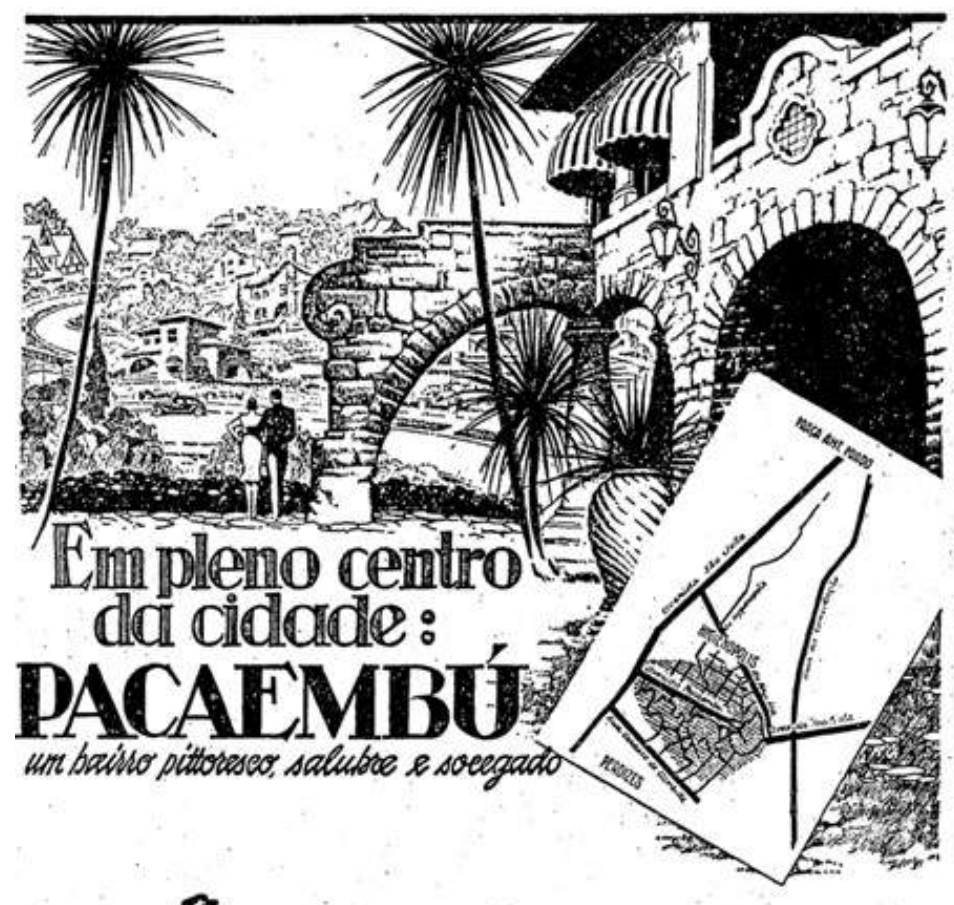

$\jmath_{n}$ (acaembú é o bairro Projectado e construido pela Companhia City, de accôrdo com as normas rigorosas do urbanismo, espraia-se maravilhosamente entre Hygienopolis Perdizes, attingindo os seus limites as Avenidas Angelica e Paulista, a Rua Cardoso de Almeida e a Avenida São João. Em pleno centro da cidade, portanto, o Pacaembú dispõe de todo o conforto moderno, constituindo - bairro residencial por excellencia da nossa metropole. - Constrúa, pois, o seu lar no Pacaembú - a nova maravilha urbanal

Mais do 5 kilometros de ruas asphaltadas - Lotes a partir de 1378000 por mez' - Financiamento IMMEDIATO para sonstrucçles, independento do pagamento integral do terreno.

\section{Figura 33:}

Jornal Estado de São Paulo, 21 de janeiro de 1930.

\section{COMPANHIA CITY}

COAn 89. RUA LIBERO BADARO
Figura 34:

Jornal Folha da Manhã, 01 de julho de 1930

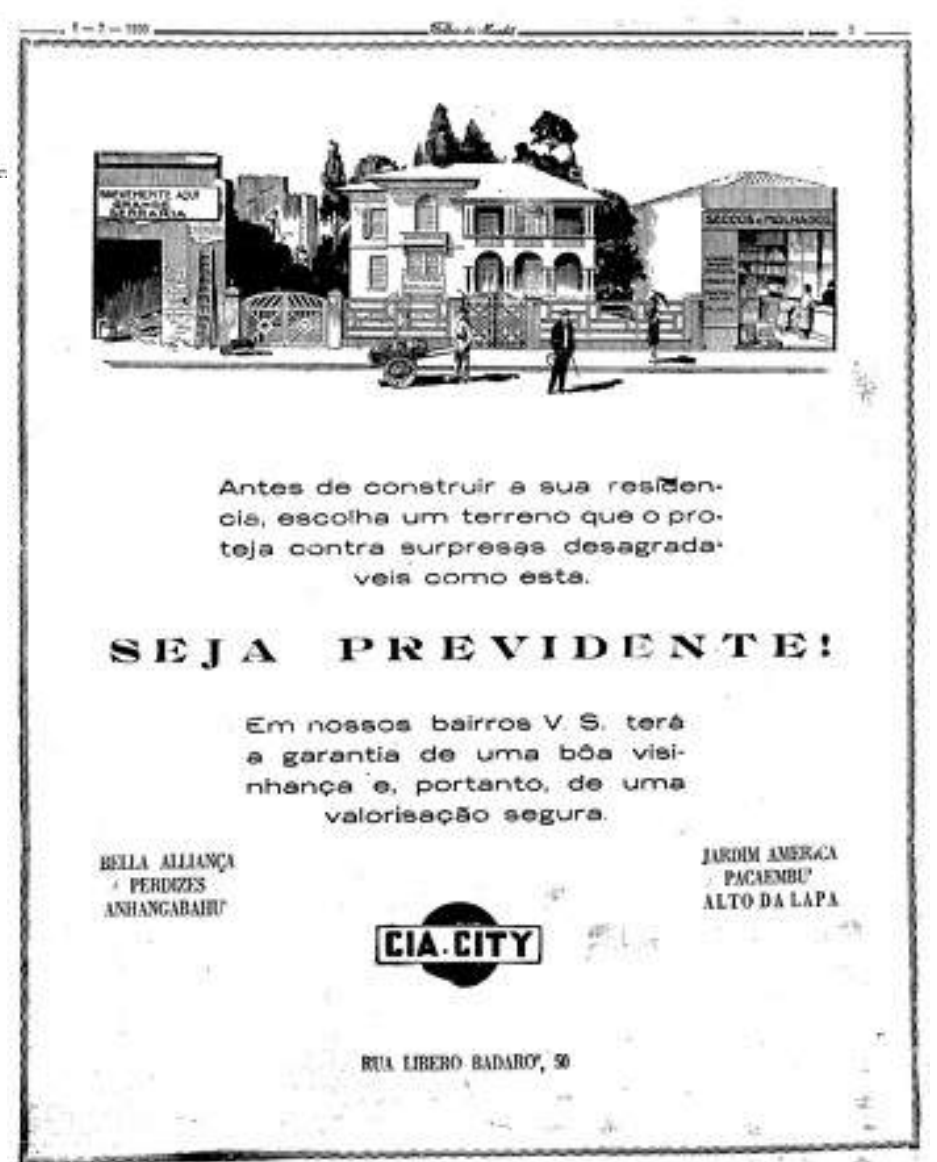


Figura 35: Conjunto de Residências para José Coelho Pamplona - 1942 r. Capitão Mor-Goncalo Monteiro, 23 a 55, Barra Funda

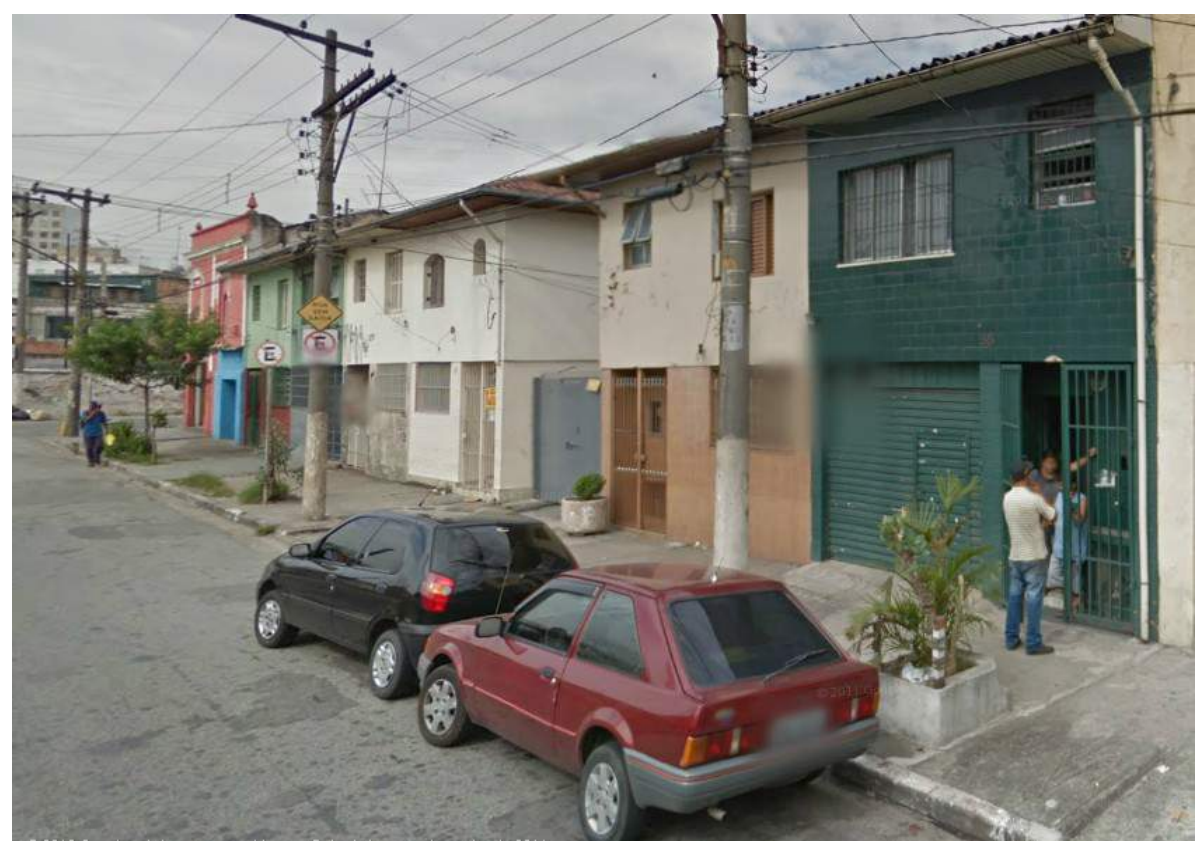

Conjunto de 12 casas projetadas e construídas por Marone \& Artigas para cliente José Coelho Pamplona. 1942, Bairro Barra Funda, São Paulo. Portão cinza para acesso às casas a partir de pátio interno. Ao fundo da rua sem saída, localiza-se linha férrea. (Fonte: Google Street View, 2011.) 


\section{Conjunto de Figuras 36:}

Casa de Rio Branco Paranhos - 1942

r. Heitor de Moraes, 120 Pacaembu
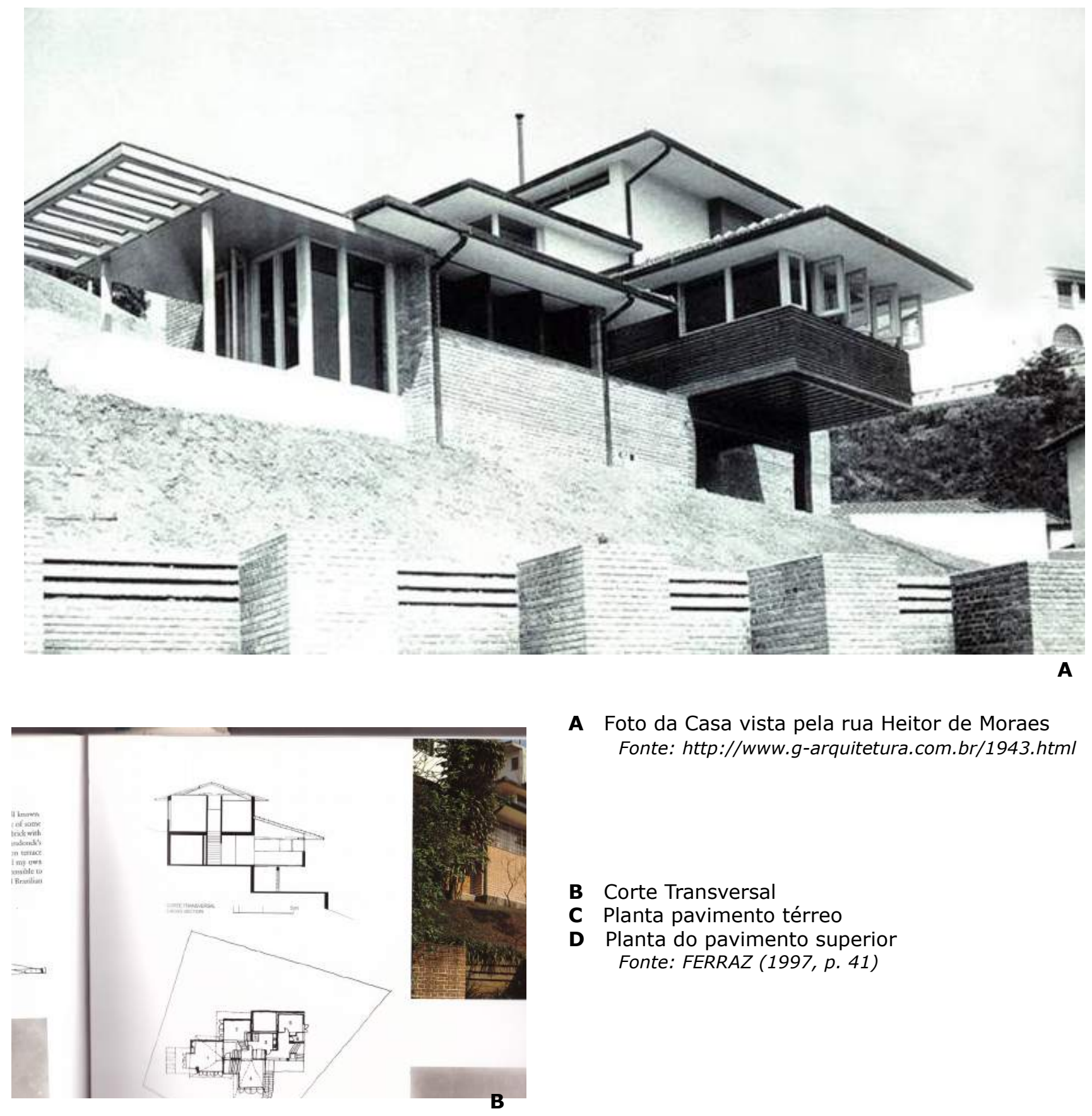

A Foto da Casa vista pela rua Heitor de Moraes Fonte: http://www.g-arquitetura.com.br/1943.htm/

B Corte Transversal

C Planta pavimento térreo

D Planta do pavimento superior Fonte: FERRAZ (1997, p. 41)
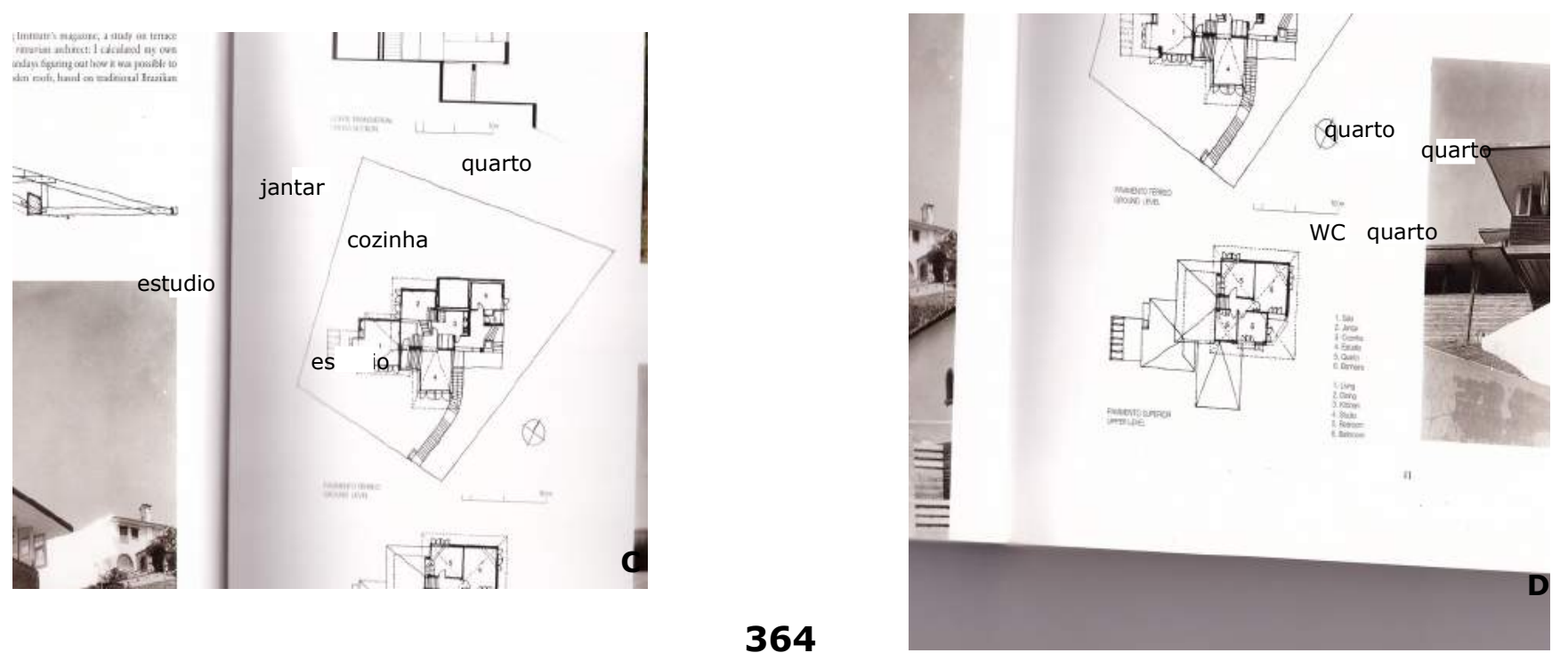


\section{Conjunto de Figuras 37:}

Casa de Rubens Mendonça, 1958

Rua Guaçu, 176 Sumaré
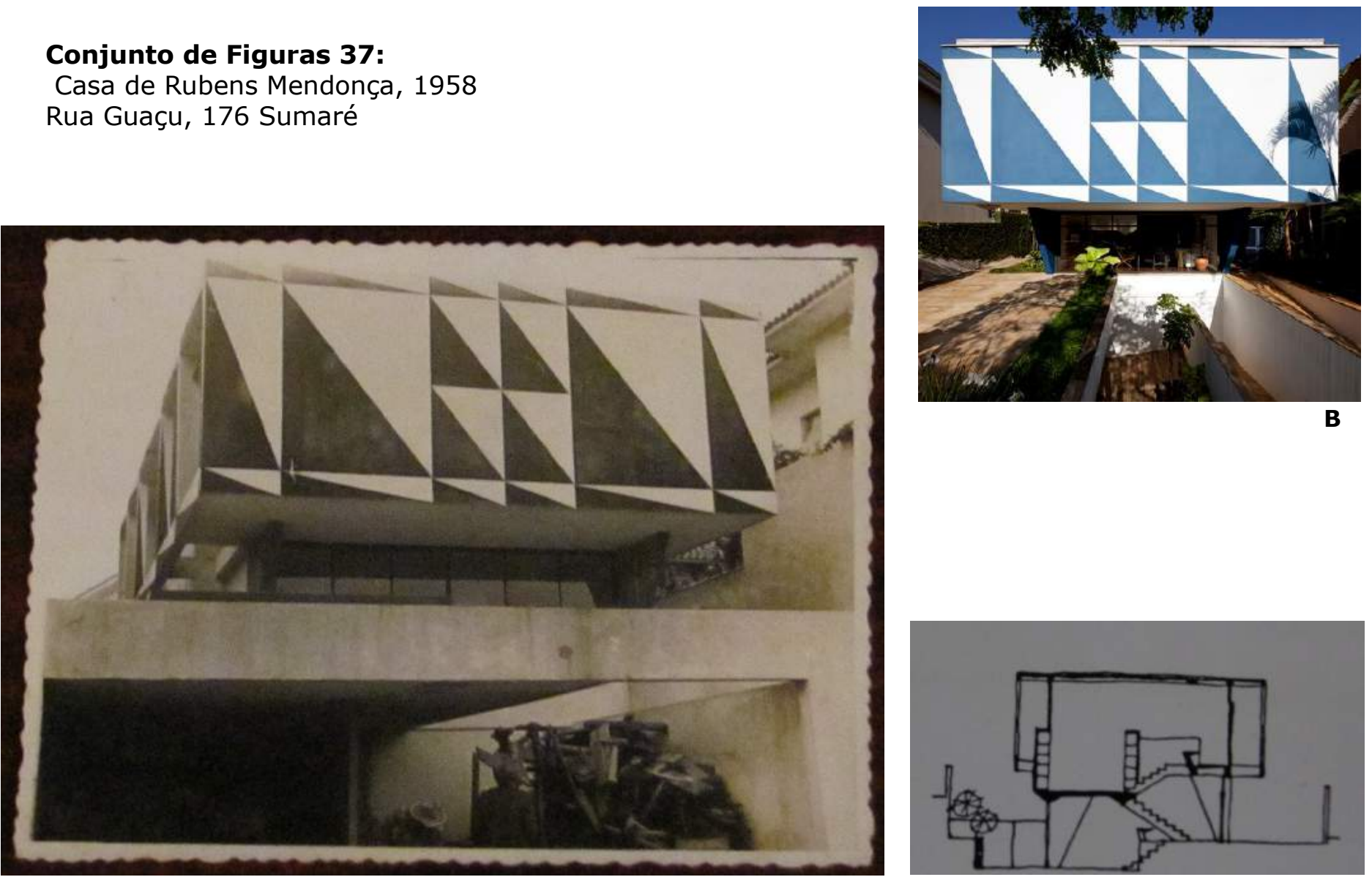

\section{A}

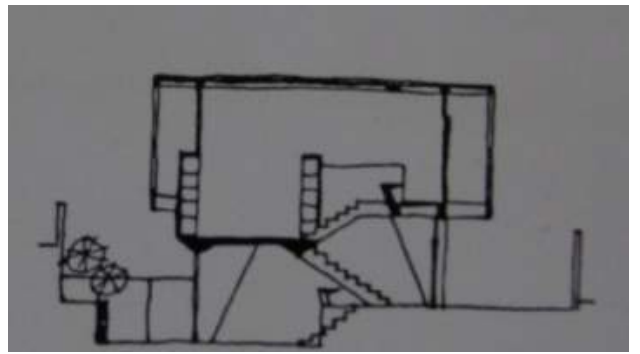

C

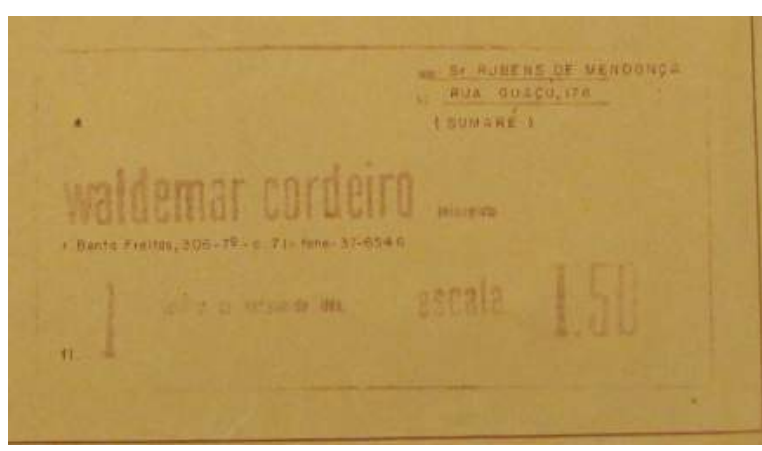

D

\section{Casa de Rubens Mendonça: ensaio concretista}

A Fachada da casa na época da construção. (Fonte: Álbum de Fotografia da Família Mendonça)

B Cores do Painel da fachada, estudo de Mário Gruber e pintura de Francisco Rebolo. (Fonte: leonardofinotti.blogspot.com)

C Corte transversal, volume suspendo em 6 pontos de apoio (Fonte: FERRAZ, 1997: 79)

D Carimbo de Assinatura do Projeto Paisagístico de Waldemar Cordeiro. (Fonte: Acervo de Projetos Família Mendonça)

E Foto da entrada onde se vê a integração entre os espaços Internos. (Fonte: leonardofinotti.blogspot.com)

F Foto da da sala de estar, ao fundo, na parede, tela de Rebolo. (Fonte: Foto de Acervo Pessoal, 2013)
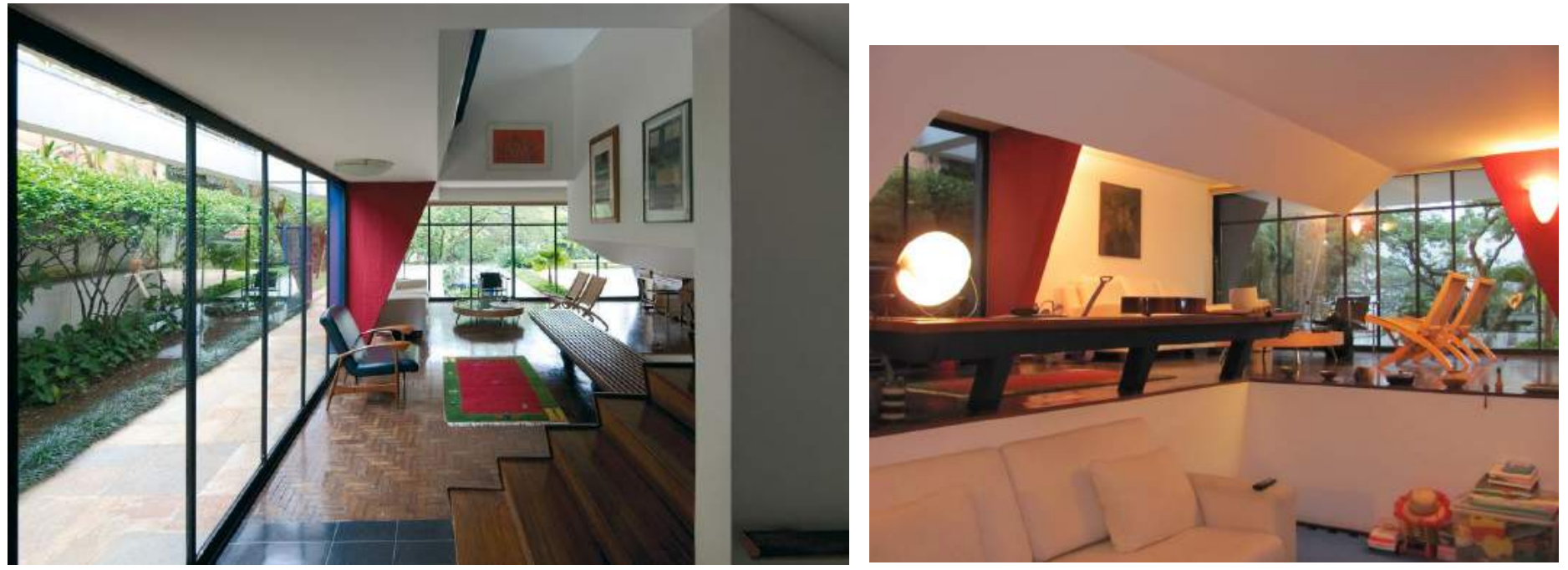


\section{Conjunto de Figuras 38:}

Edifício Louveira - 1946. Alfredo, Esther e Lia Mesquita

Praça Vilaboim, Higienópolis

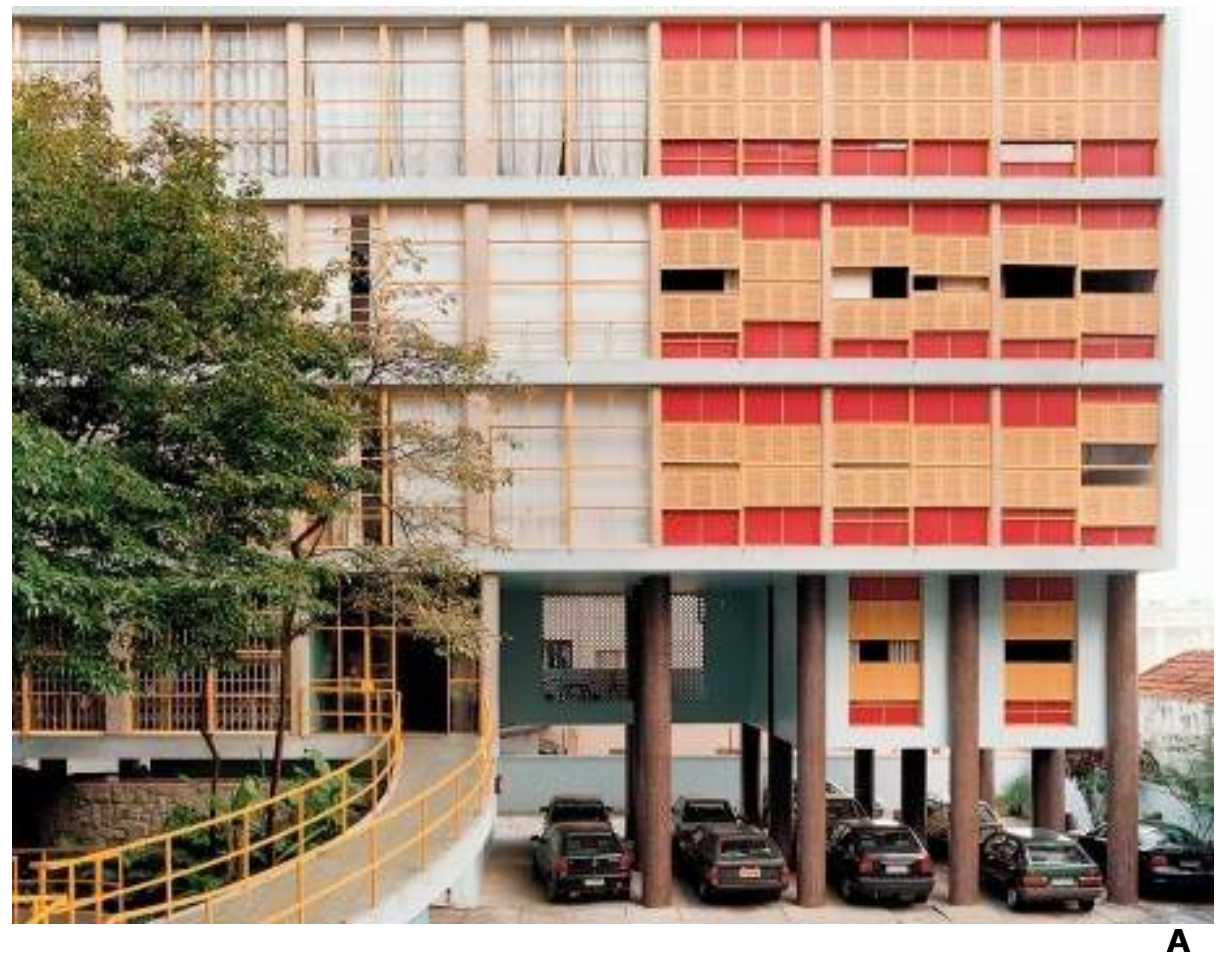

\section{Edifício Louveira}

A Pilotis e acesso ao bloco residencial

B Duas lâminas paralelas, interligadas por jardim

C Planta do andar-tipo, com dois apartamentos por andar. Os apartamentos possuem 3 quartos, 1 banheiro, sala, varanda, cozinha, lavanderia com acesso ao quarto de empregada.
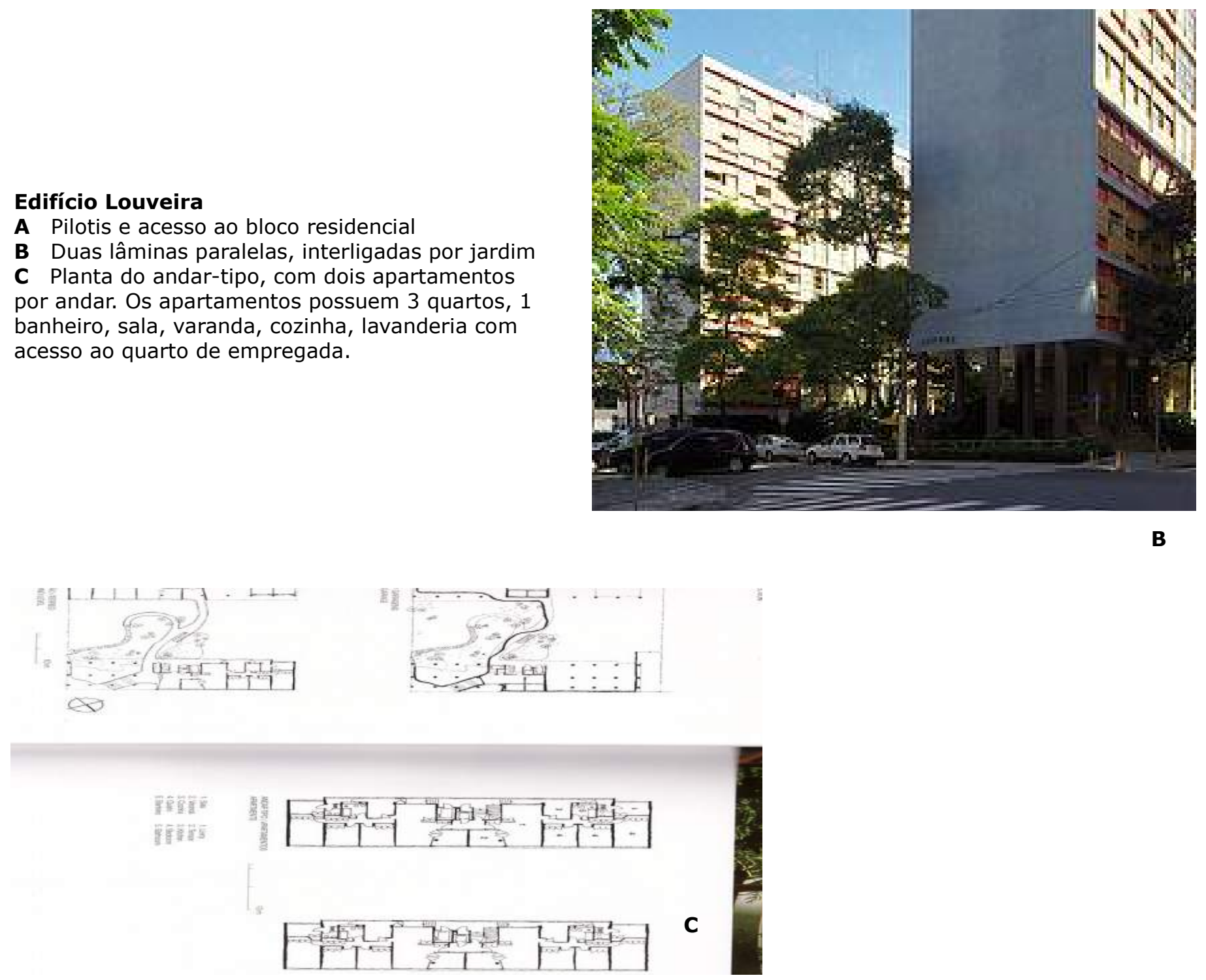


\section{Conjunto de Figuras 39:}

Alice Brill e Juljan Czapski, 1949

Rua André Dreifuss, 284, Sumaré

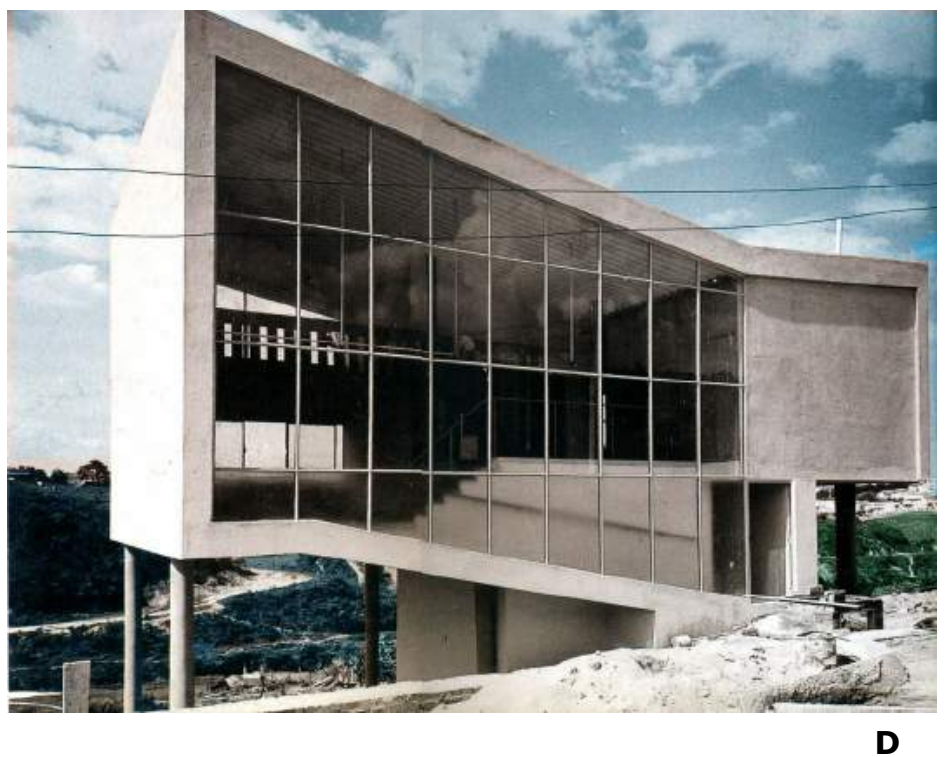

\section{Figura}

A Corte Longitudinal

B Implantação no terreno, piso térreo com acesso da rua, com estúdio fotográfico, quarto e banheiro.

C Pavimento Superior, com sala, dois quartos, cozinha e sala de jantar.

D Foto da Casa, com ampla janela da sala

E Foto da casa, ao fundo Sumaré, ainda sendo ocupado (Fonte: FERRAZ, 1997: 60)

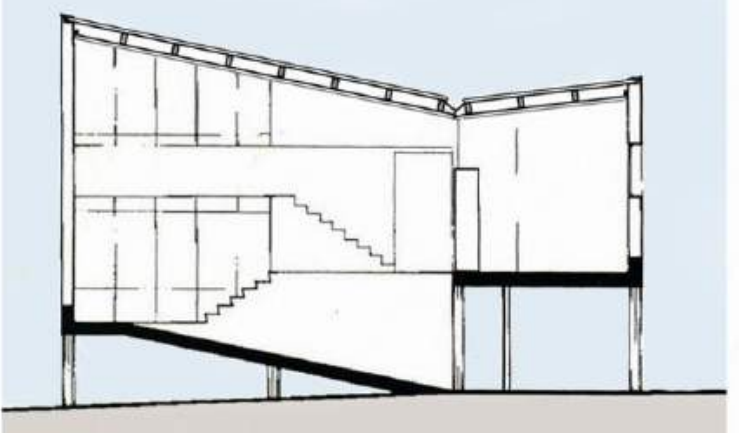

A
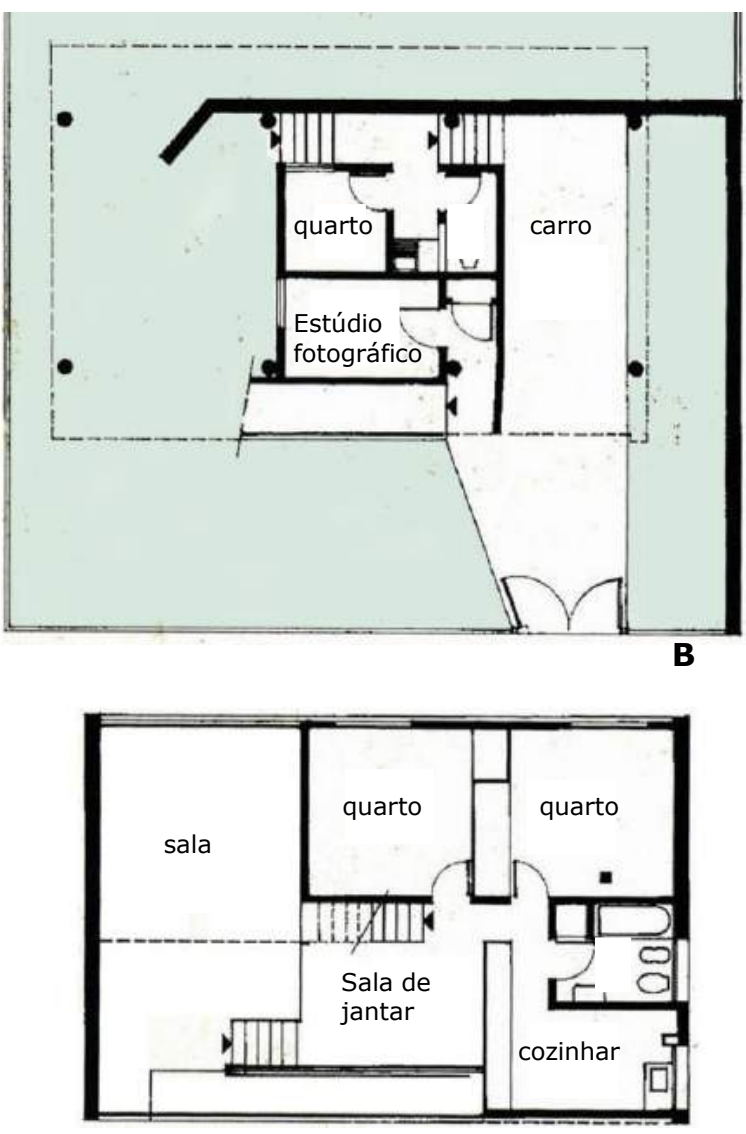

C

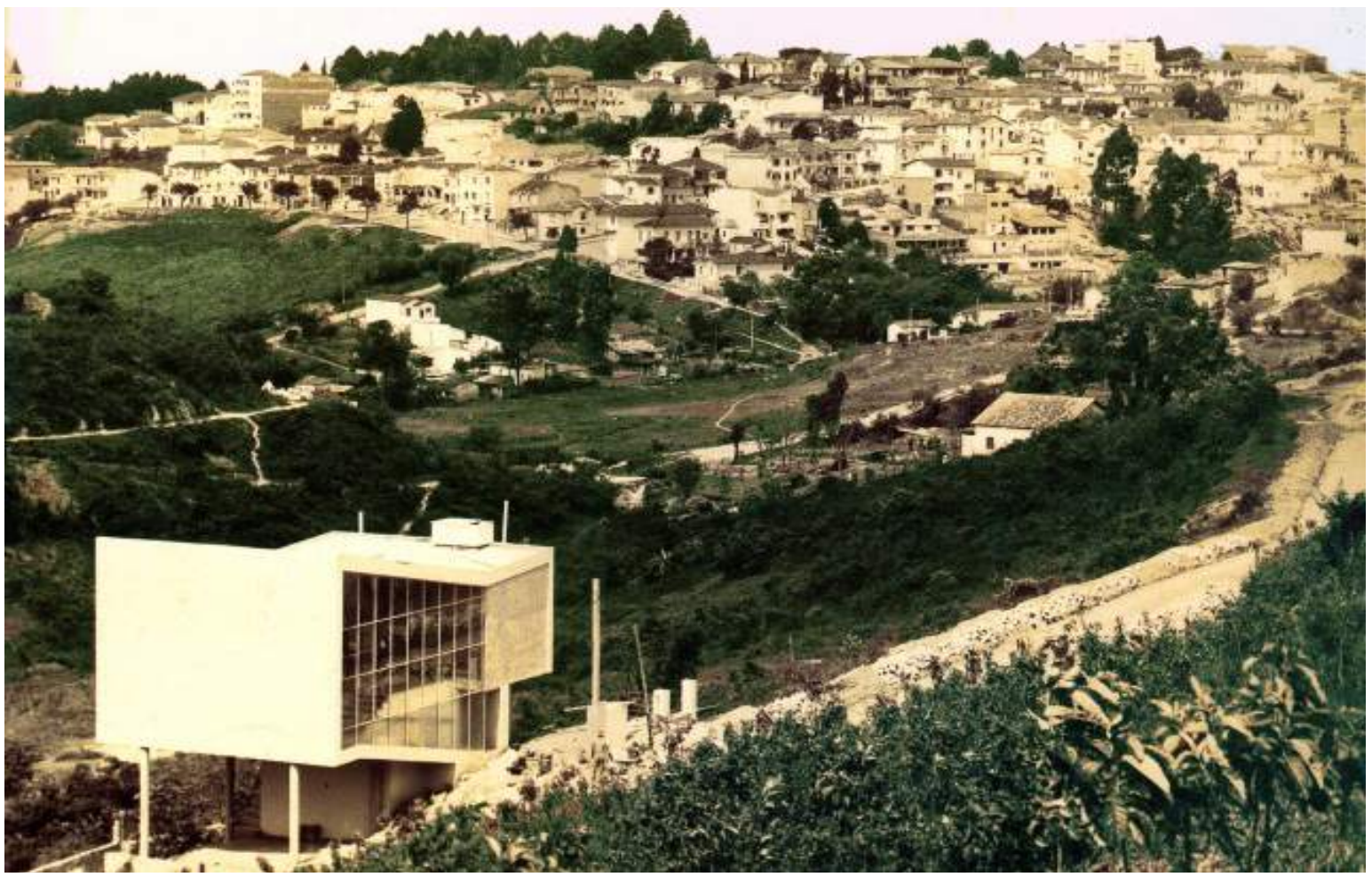


Conjunto de Figuras 40:

Casa de Oduvaldo Vianna

e Deocélia Vianna - 1951

av. Dr. Arnaldo, 1384, Sumaré
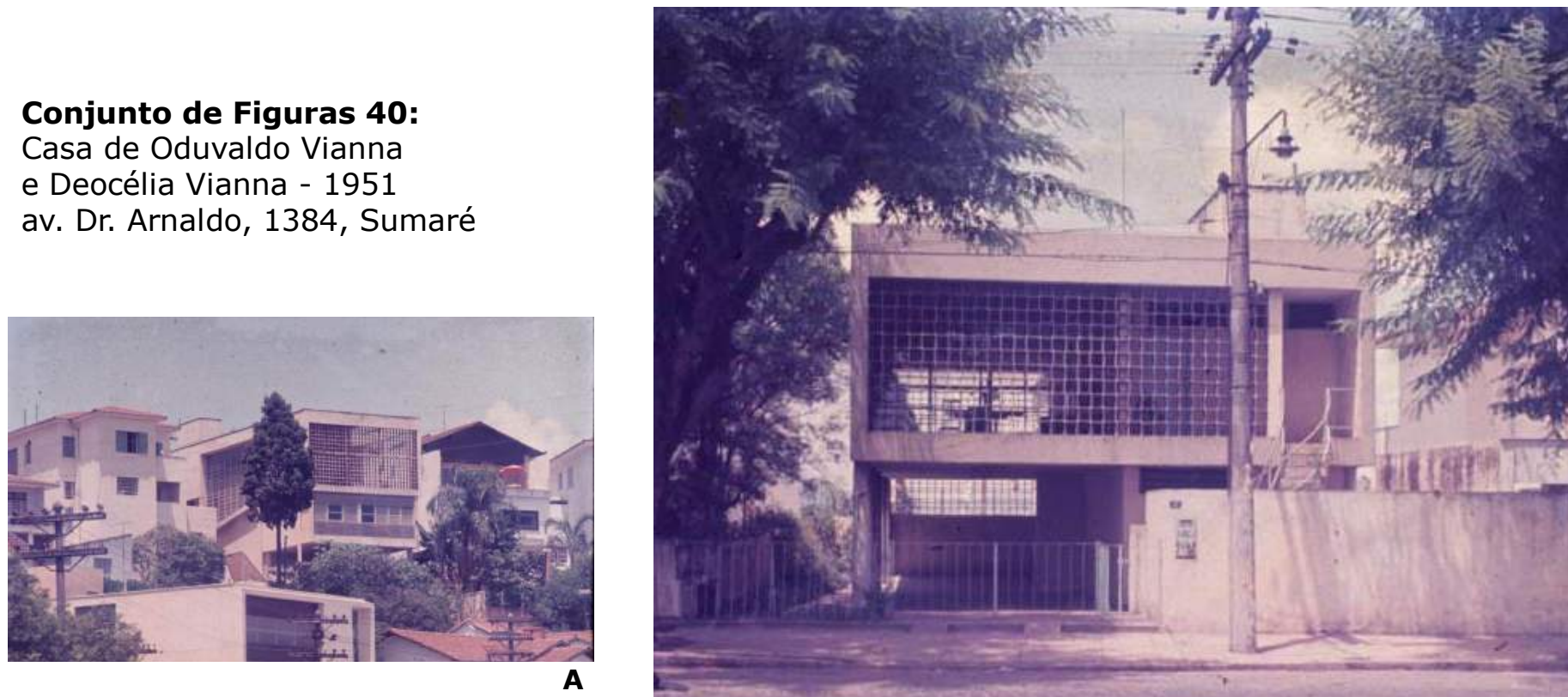

Acervo Vilanova Artigas - FAU USP

A Vista do bairro, fundos da casa

B Vista da fachada de frente

B

Revista Acrópole - Outubro, 1955

C Corte longitudinal

D Planta pavimento superior

E Planta pavimento inferior

F Vista da sala, com painel de Clóvis Graciano, "As Catadeiras de Café"

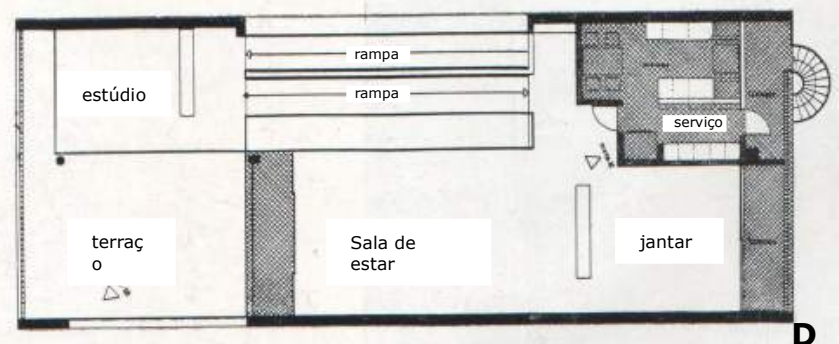

E
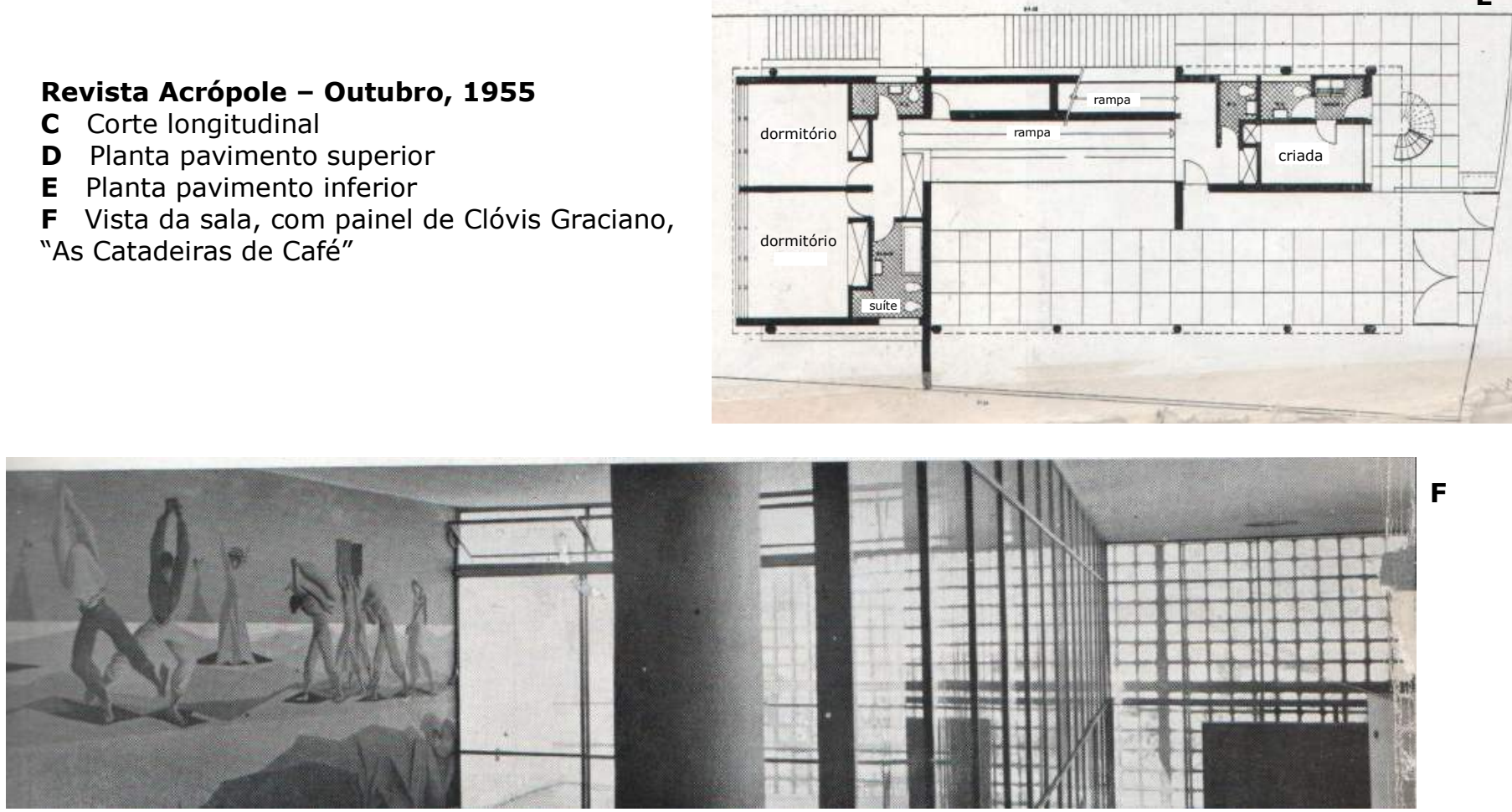


\section{Figura 41:}

Projeto construído do Ginásio do Clube Atlético Paulistano, Fonte: Revista Acrópole, novembro, 1961. p.410

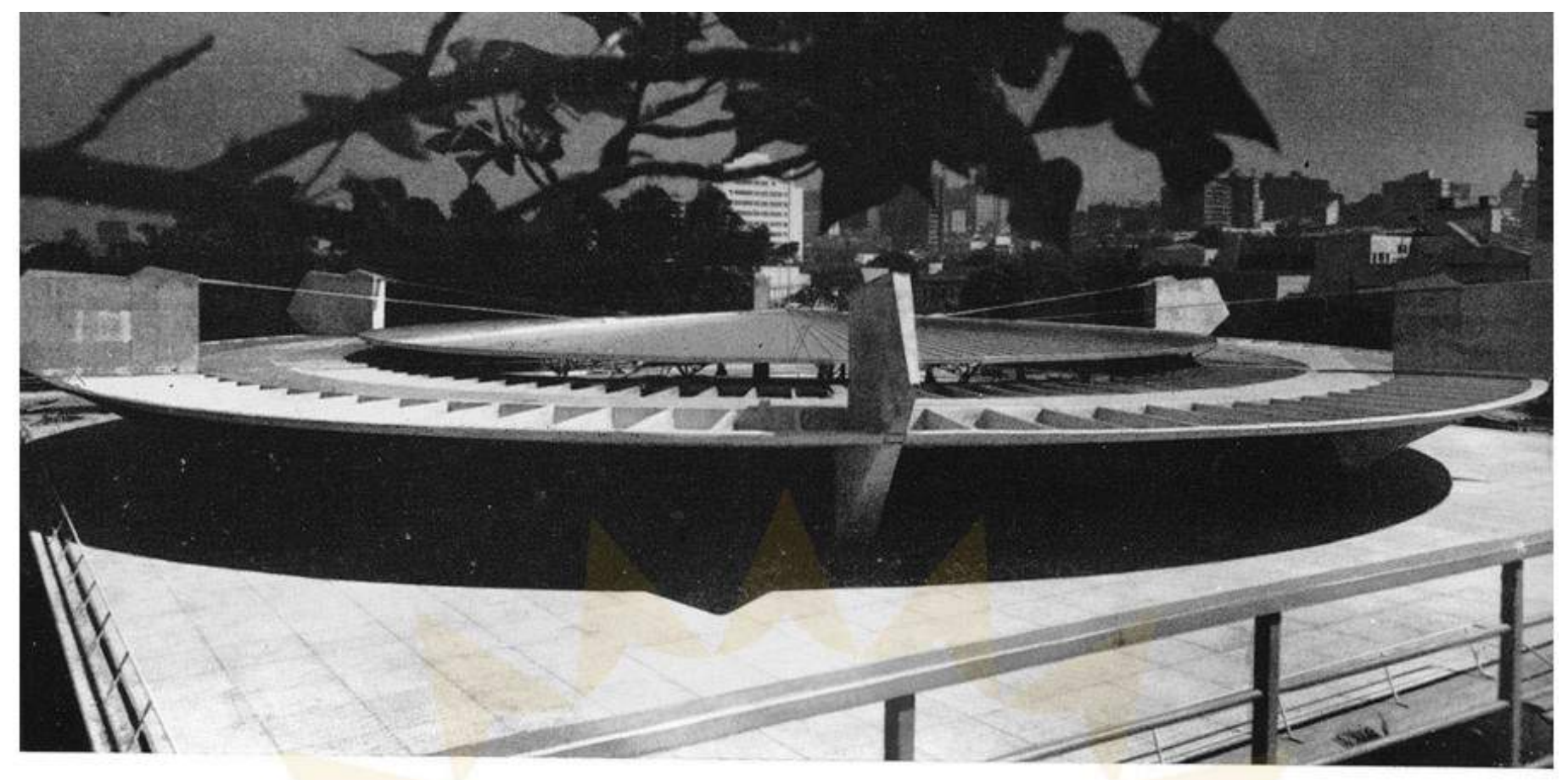

Fotos: Josè Moscardi

\section{GINÁSIO COBERTO}

GRANDE PREMIO PRESIDENTE DA REPOBLICA

1. Prêmio (Diploma e Medalha) - Edifício para fins de recreação 


\section{Projetos ligados ao Plano de Desenvolvimento do governo Carvalho Pinto (1959-1962)}

fonte: Revista Acrópole, Agosto, 1967, n 342 p.15-39.

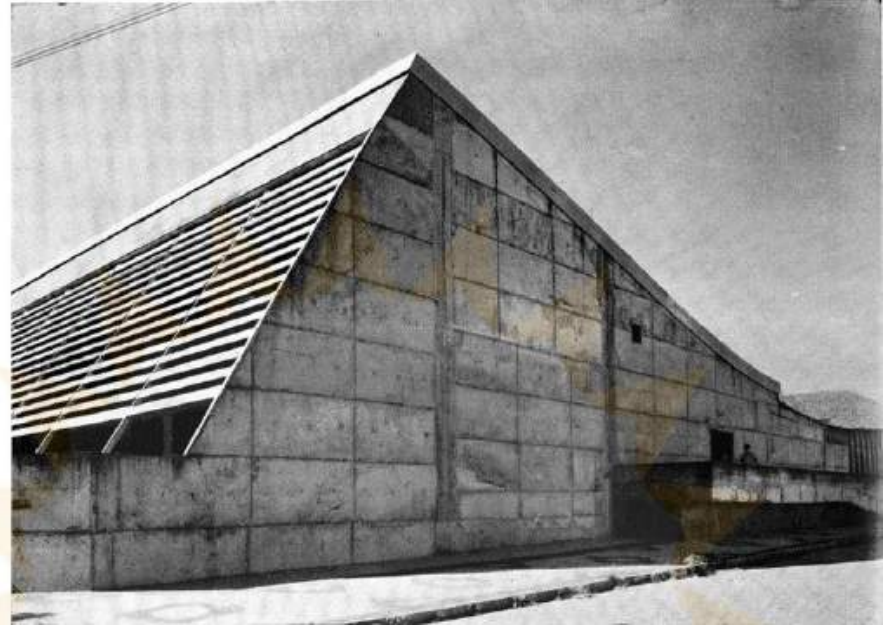

Figura 42: Grupo Escolar de Campinas (1960)

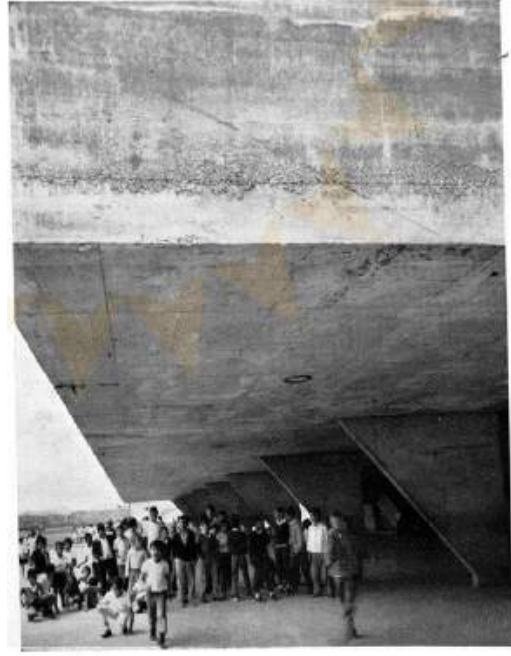

Figura 43: Grupo Escolar de São José dos Campos (1961)
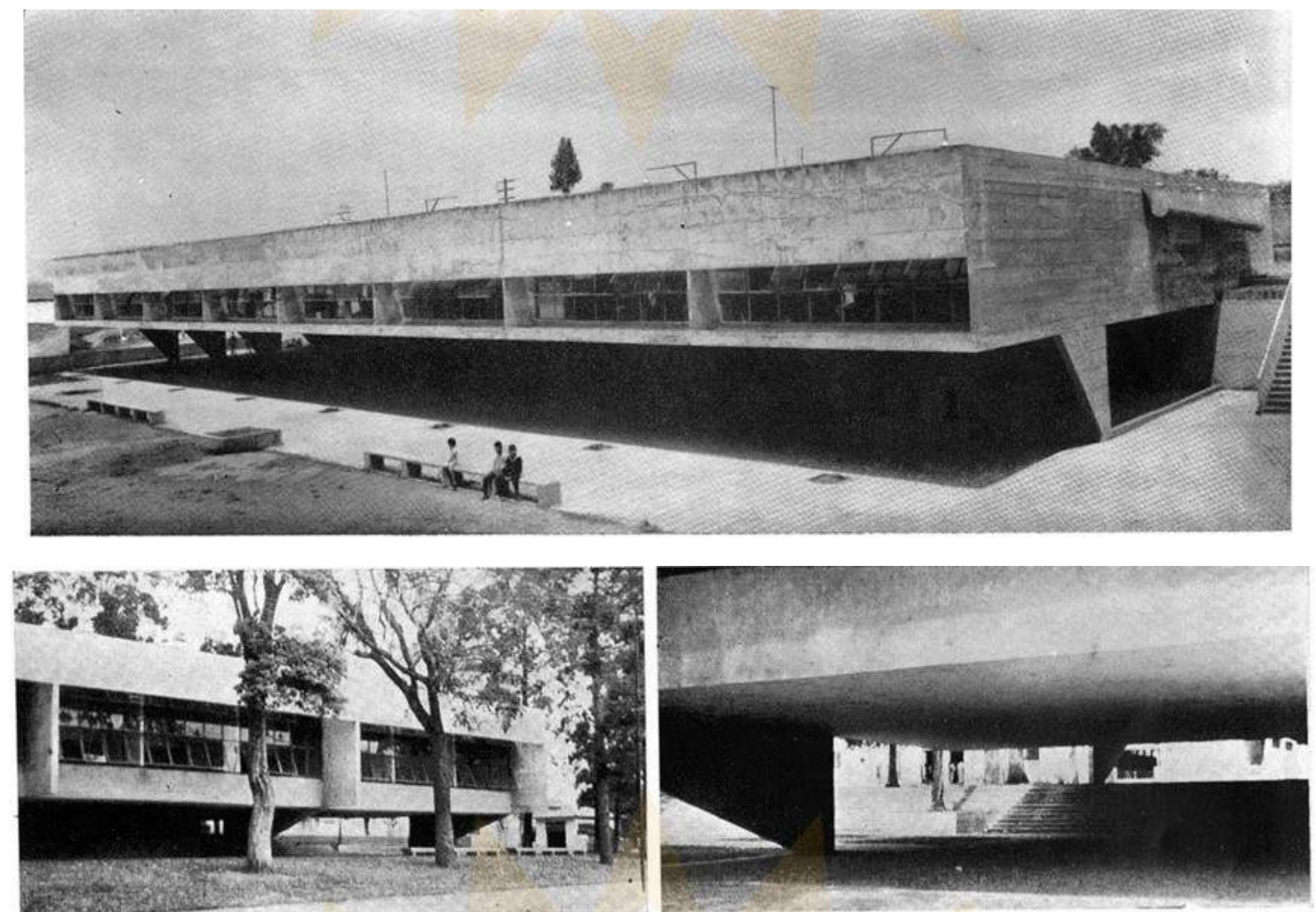

Figuras

4445 46: Fórum de Avaré (1961) 


\section{Jóquei Clube de Goiás}

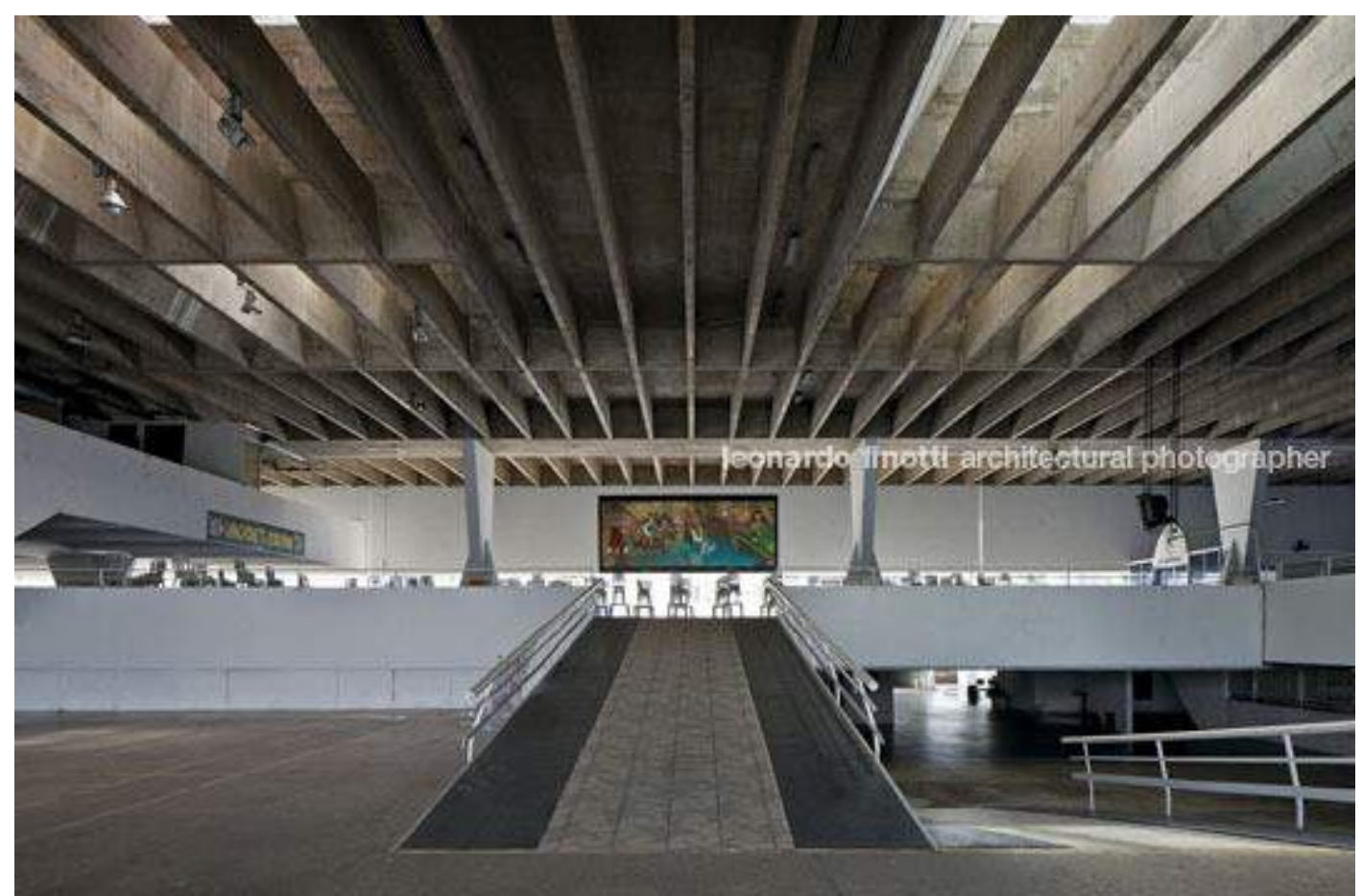

47

48

Figura 47 48:

Jóquei Clube de Goiás.

Fonte: Leonardo Finotti

http://www.leonardofinotti.com/projects/goia s-jockey-club/image/07855-120123-012d

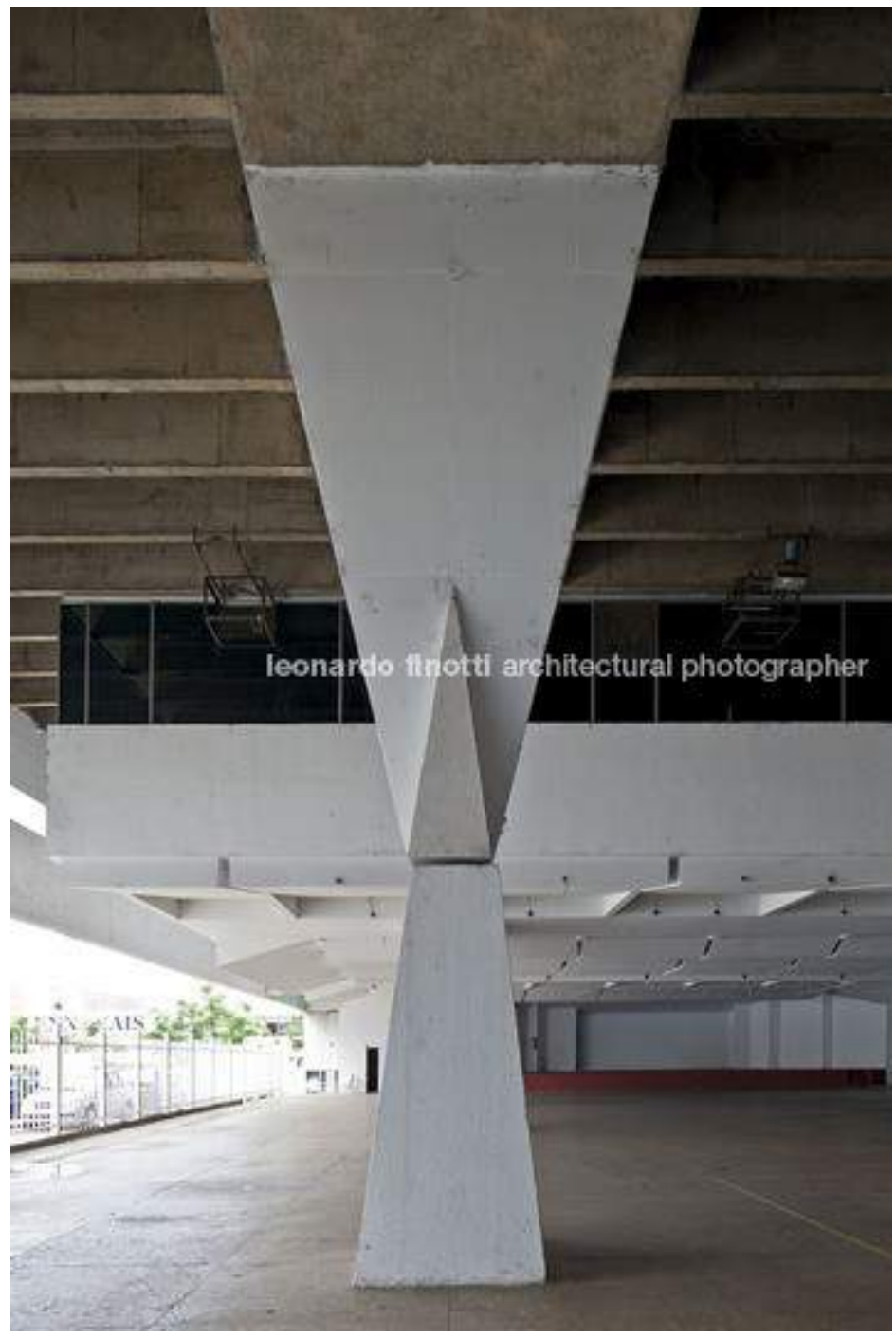

371 


\section{Projeto Edifício Faculdade de Filosofia - Cidade Universitária}

fonte: Revista Acrópole, Agosto, 1967, no 342 p.15-39.

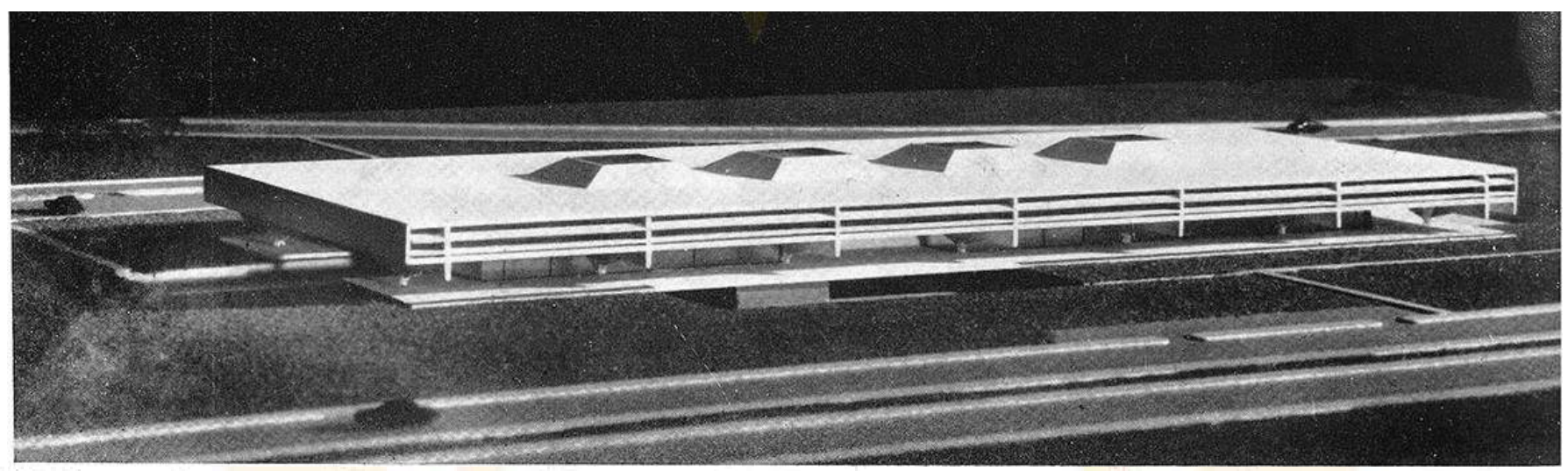

Básicamente o projeto se constitue na soluçâo de um espaço interno transparente à verdade das atividades exercidas e de um clima de luz e temperatura propicias ao trabalho.

São amplas as visuais para os recintos de museu, biblioteca, anfiteatro e galerias. Pátios privativos do museu e da biblioteca, rebaixados em relaçôo aos jardins, complementam as respectivas áreas internas: parte do museu e leitura ao or livre.

Figura 49: Maquete e programa do edifício Faculdade de Filosofia (1962)
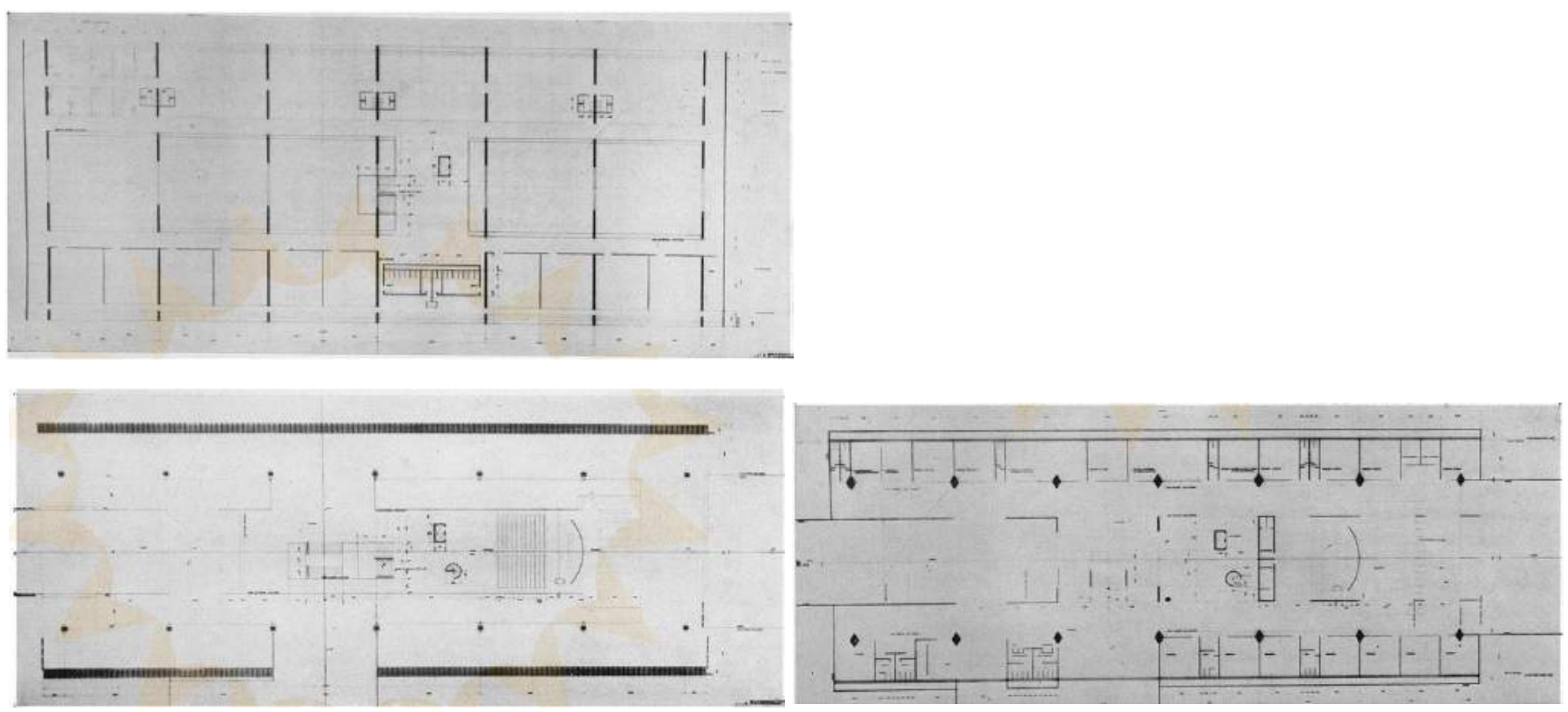

P

Planta superior: Vestibulo, escadas, elevadores, salāo de estar; ligaçăo entre as 2 galerios

Planta no nivel do estacionamento. Penetraçóo pelo rua secundária. Patamar sâbre o museu, escadas do vestibulo geral, nivel superior do auditório. Vazio do museu à esquerdo e da biblioteca à direita

Planta no nível da entrada de pedestres: Pátio, portaria, cantina, grêmio. Museu, salas de preparo do museu. Pátio-jardim do museu (à esquerda), secretaria. Palco do auditório, biblioteca, pátio, jardim da biblioteca (à direita), salas para seminários

Figura 50: Plantas e legenda do projeto Faculdade de Filosofia (1962) 


\section{Projetos residenciais: concreto aparente e arrojo formal}
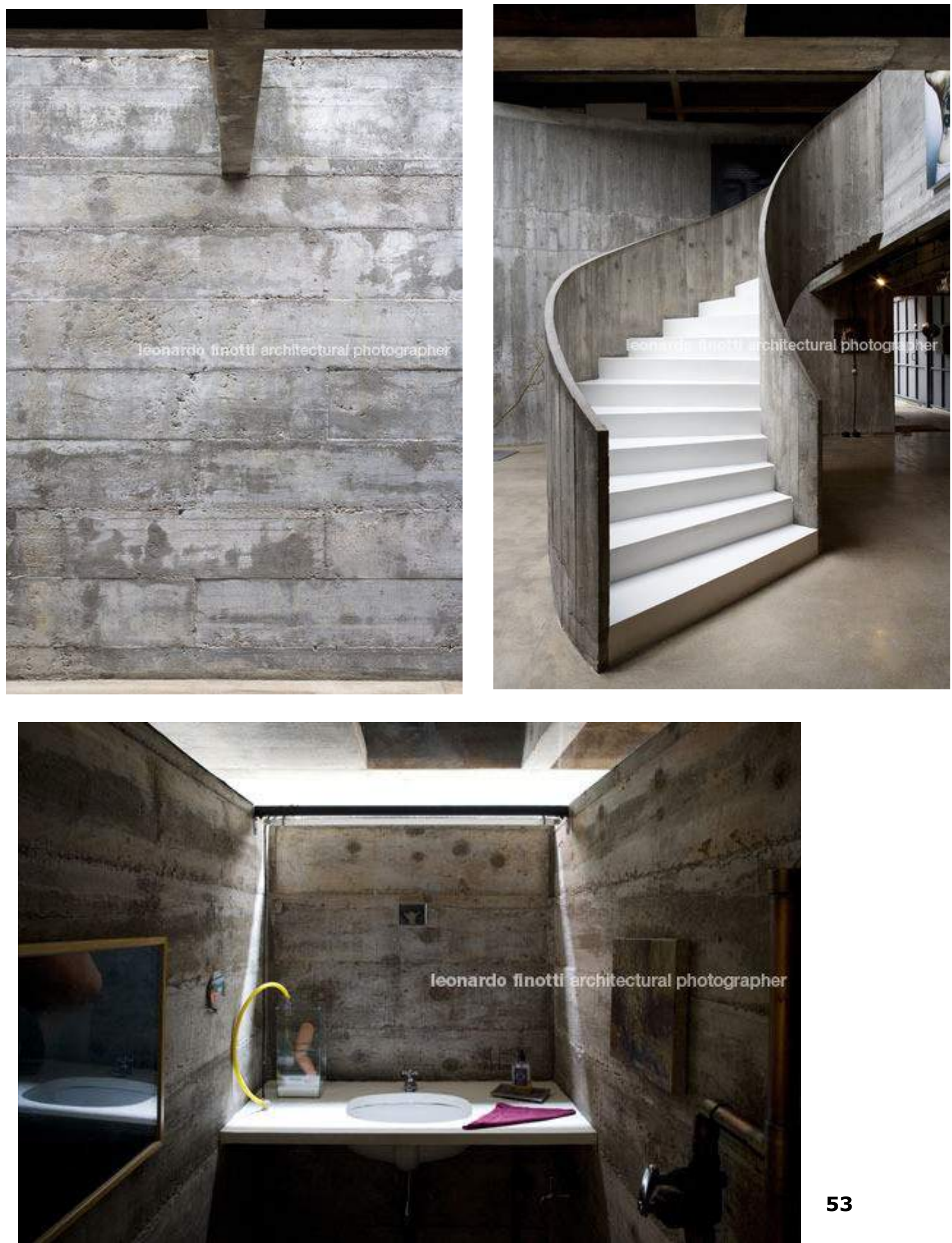

53

Figuras 51, 52, 53: Residência do galerista Eduardo Leme, projetada por Paulo Mendes da Rocha em 1966, para o galerista Fernando Milan. Decalque da madeira no concreto, escala em caracol e banheiros com paredes que não tocam o teto.

Fonte: Leonardo Finotti http://www.leonardofinotti.com/projects/leme-s-house-former-millanhouse/image/07817-071213-061d 


\section{Projetos residenciais}

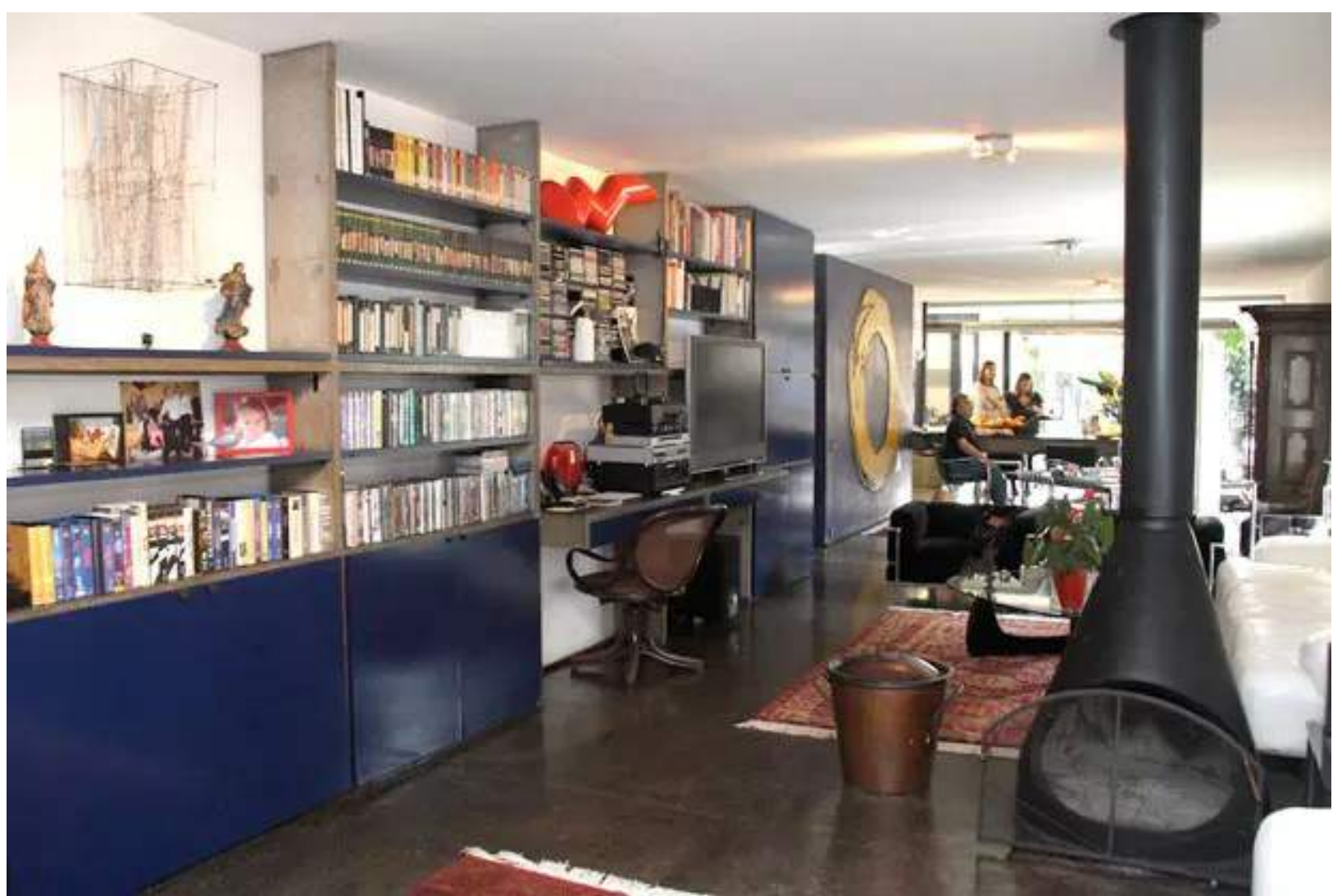

Figura 54: Residência do artista plástico Marcelo Nitsche, projetada por Paulo Mendes da Rocha em 1966, obras de arte contemporânea e arte sacra.

Fonte: http://casavogue.globo.com/Arquitetura/noticia/2013/06/o-resgate-da-boa-arquitetura-em-sp.html

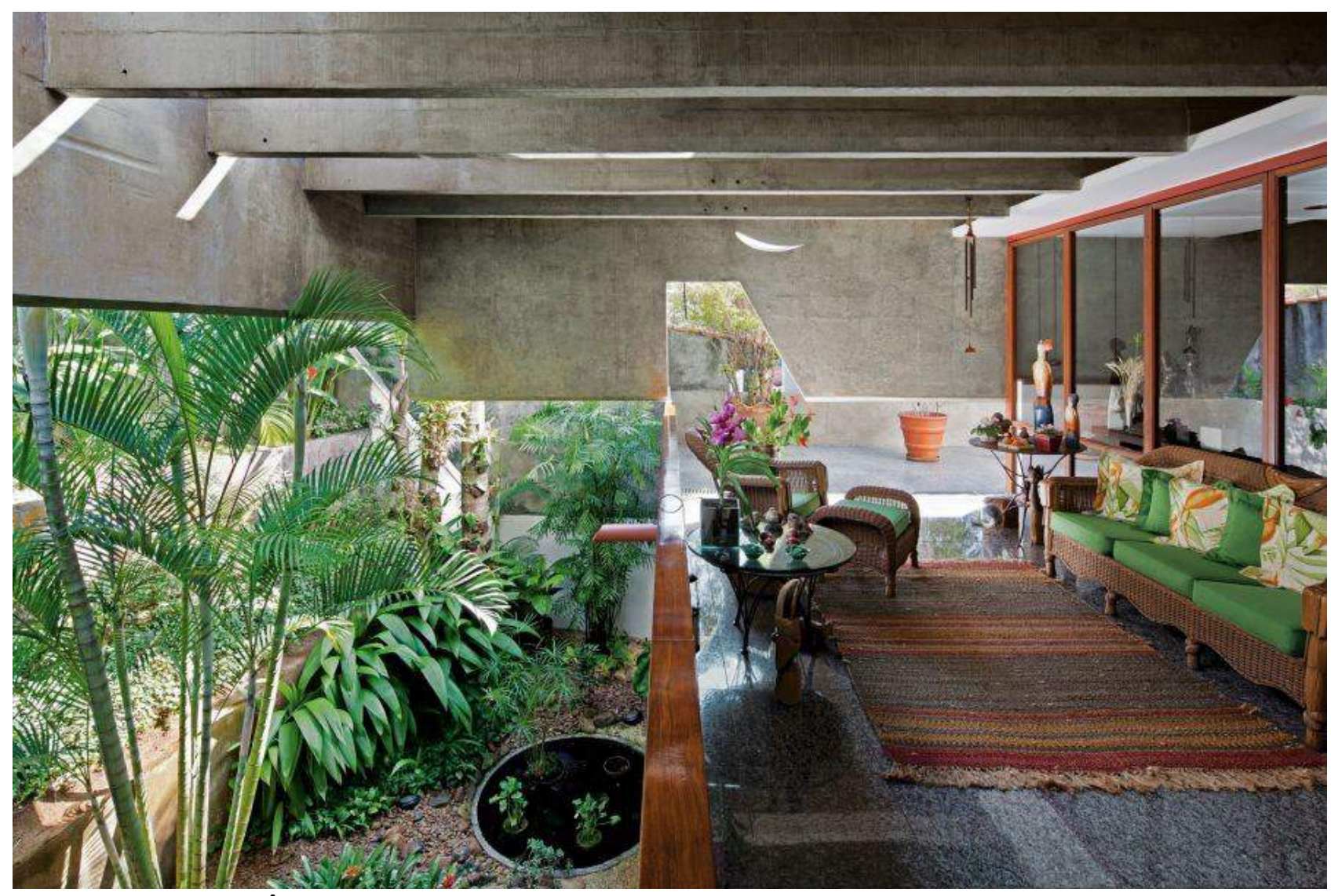

Figura 55: Residência de Francisco Matla Cardoso, projetada por Paulo Mendes da Rocha em 1963, área ajardinada e móveis de vime. Fonte: fotógrafo Leonardo Finotti (PISANI, 2013, p.108) 


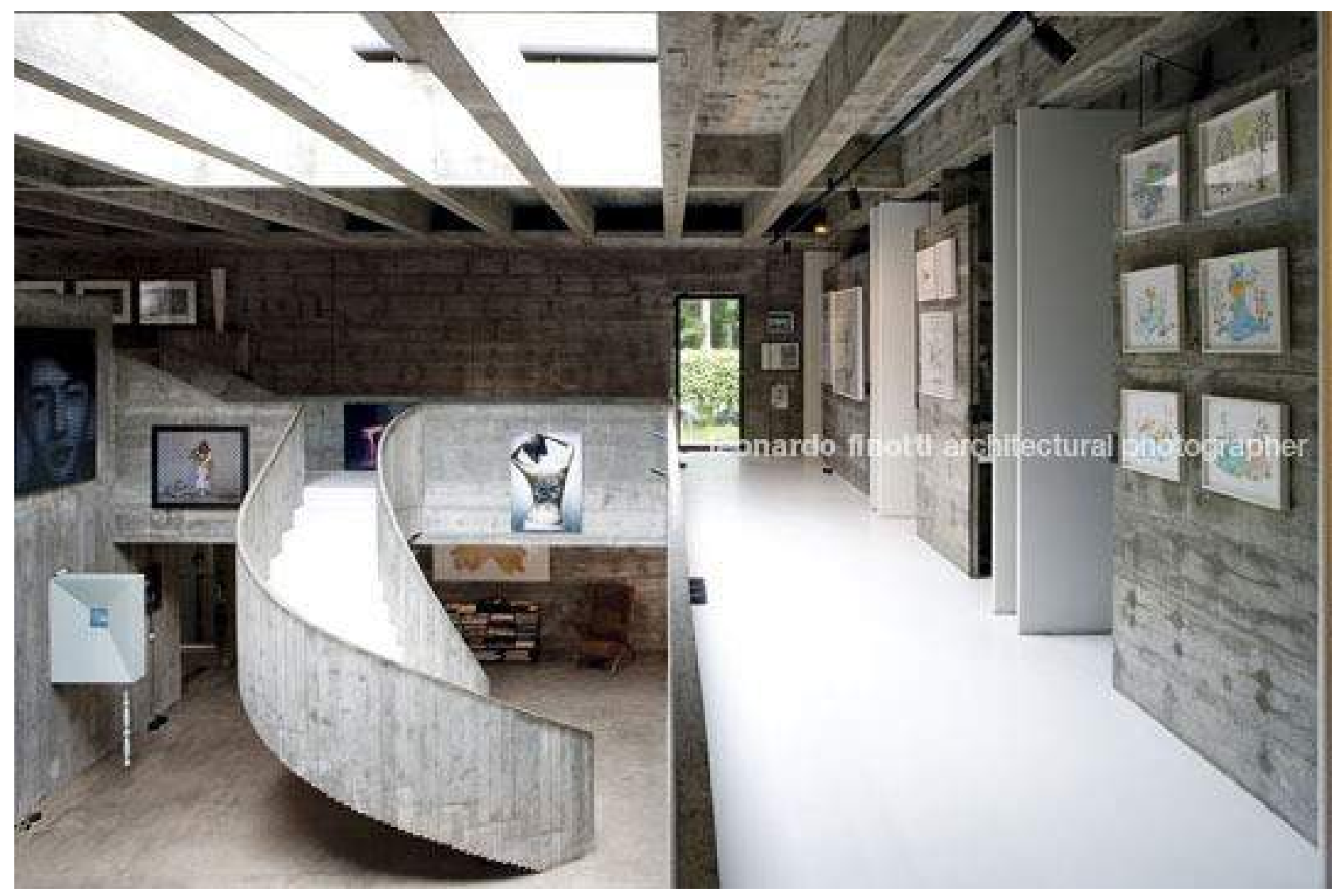

Figura 56: Residência do galerista Eduardo Leme, projetada por Paulo Mendes da Rocha em 1966, para o galerista Fernando Millan.

Fonte:

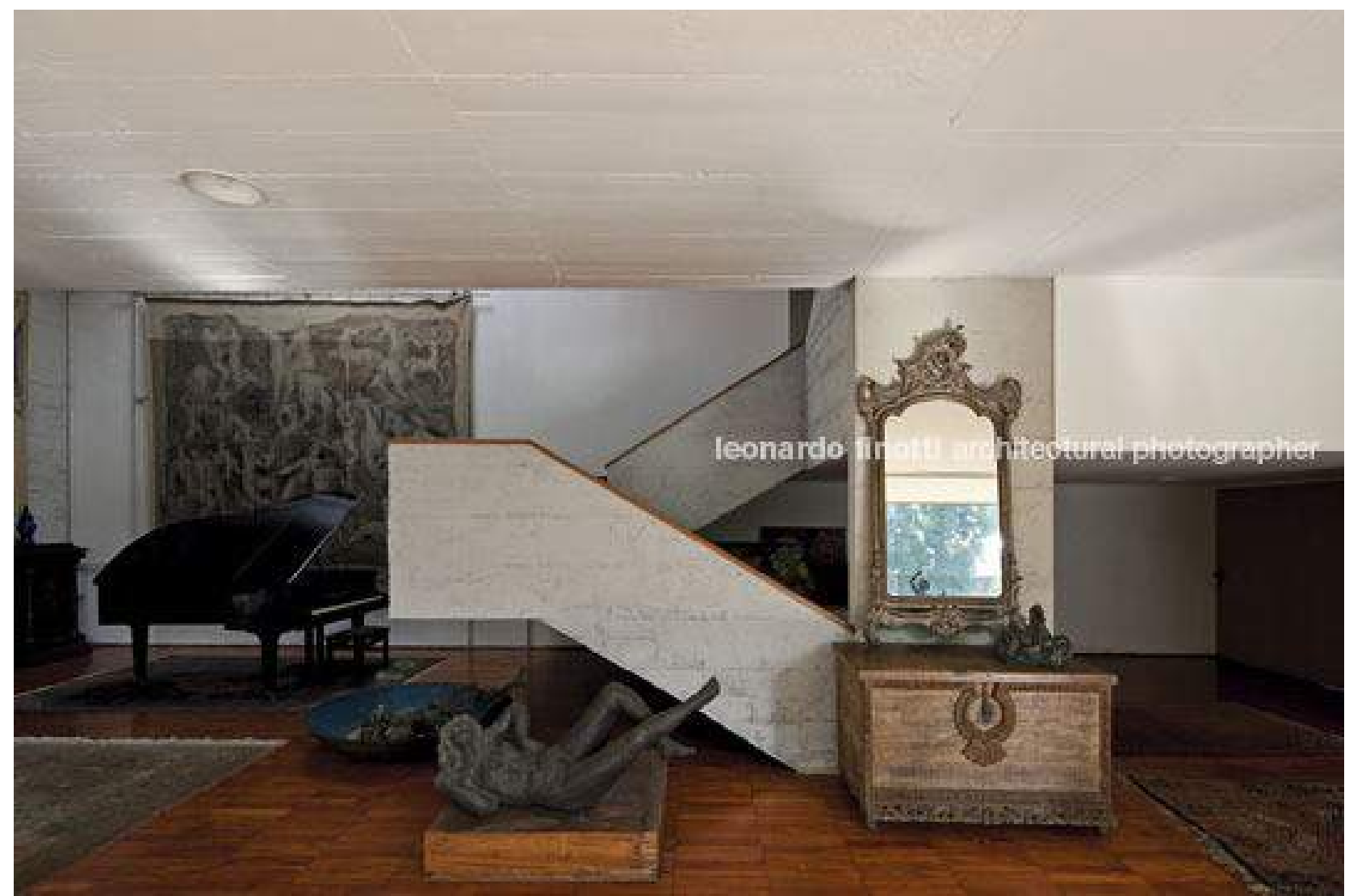

Figura 58: Residência do artista plástico italiano Gaetano Miani (1920-2009), que chegou ao Brasil em 1947. Projetada por Paulo Mendes da Rocha em 1961.

Fonte:Leonardo Finotti. http://www.leonardofinotti.com/projects/miani-house 


\section{Projetos residenciais}
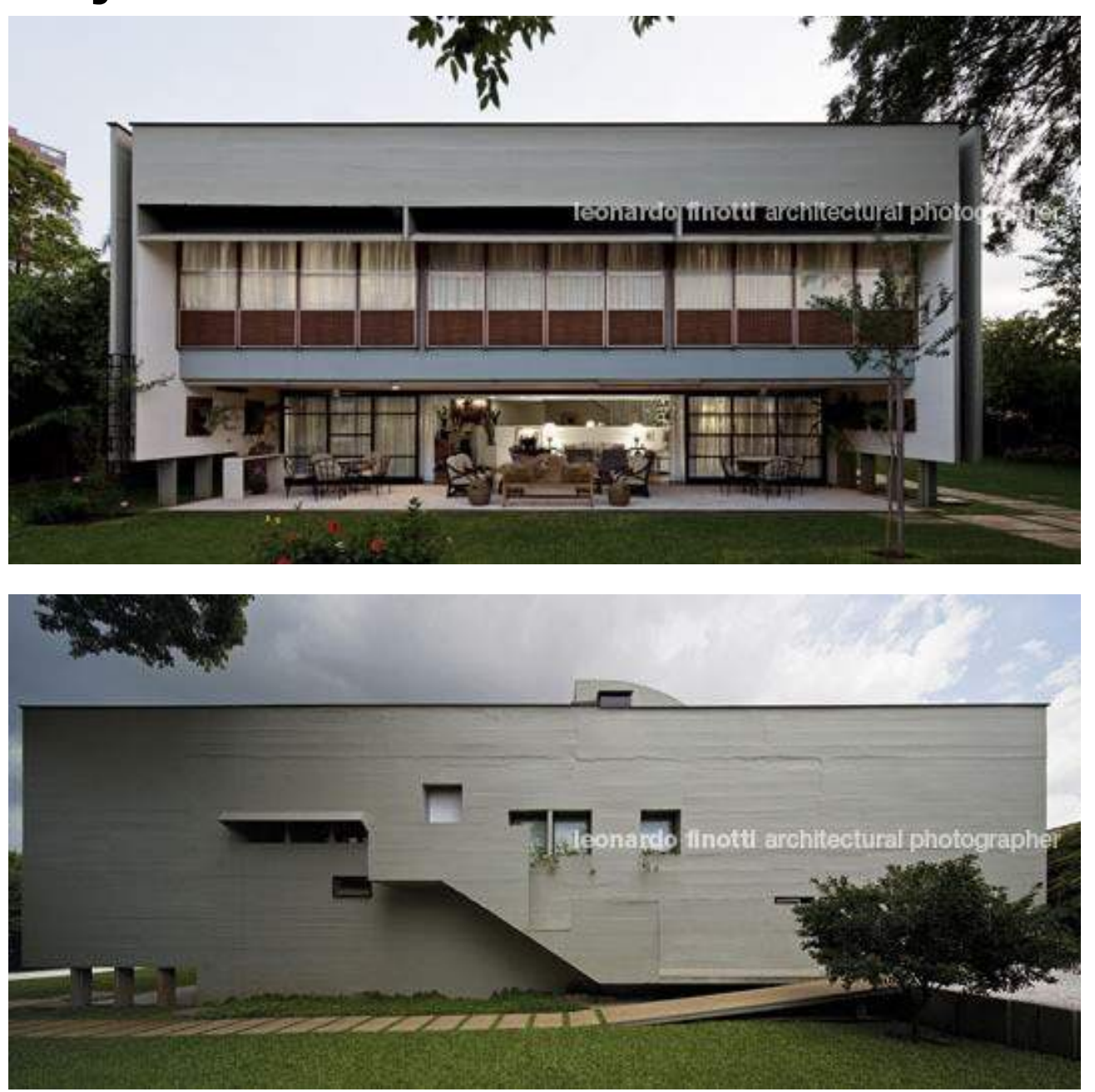

Figuras 59, 60, 61, 62: Residência em Piracicaba de Celso Silveira Melo, produtor de cana de acuçar do Grupo Consan. Projetada por Paulo Mendes da Rocha em 1962, obras de arte contemporânea e arte sacra. Fonte: Leonardo Finotti

http://www.leonardofinotti.com/projects/silveira-melohouse/image/07843-111206-007p

60
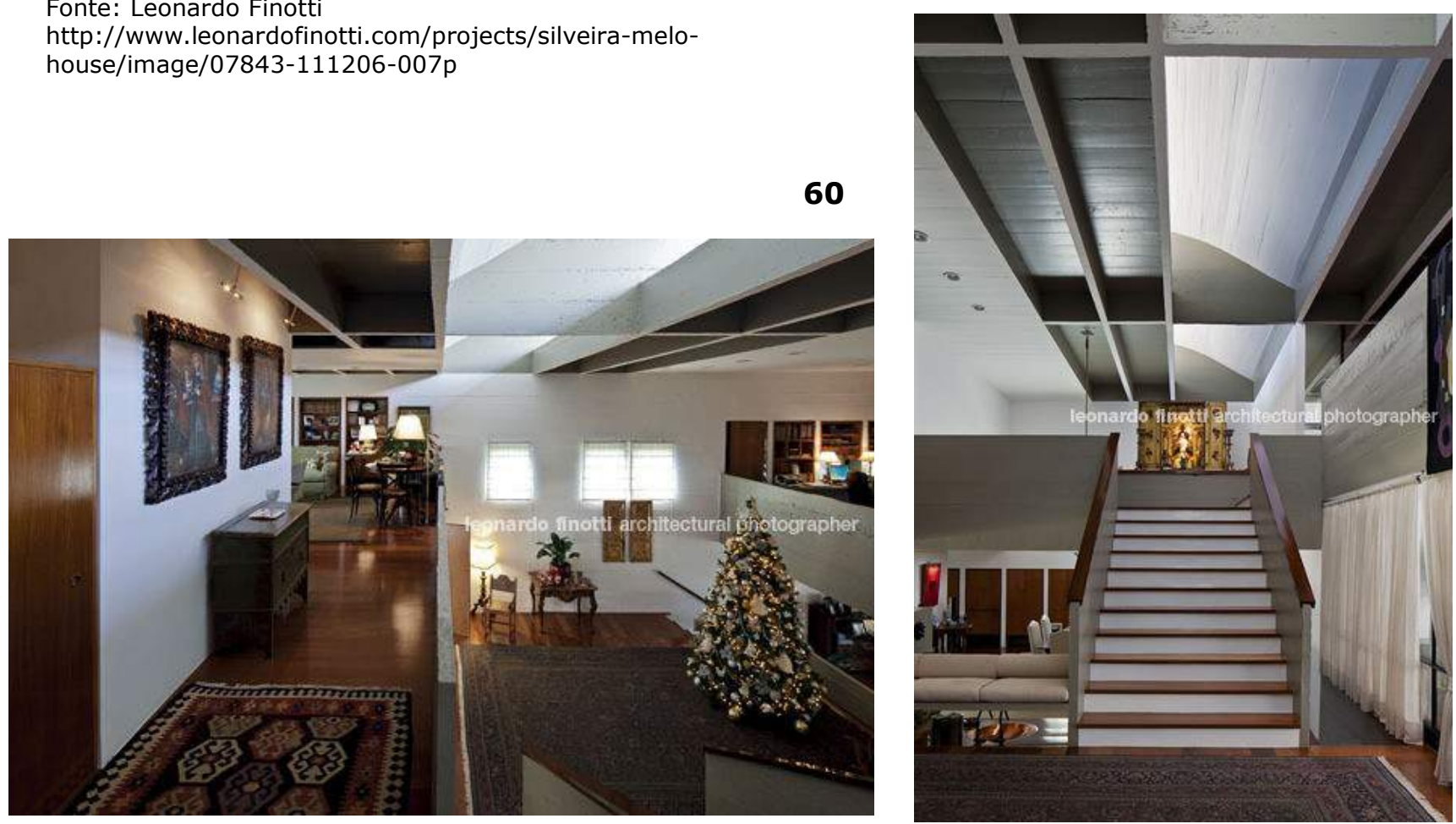


\section{Edifício Jaraguá, cobertura decorada}

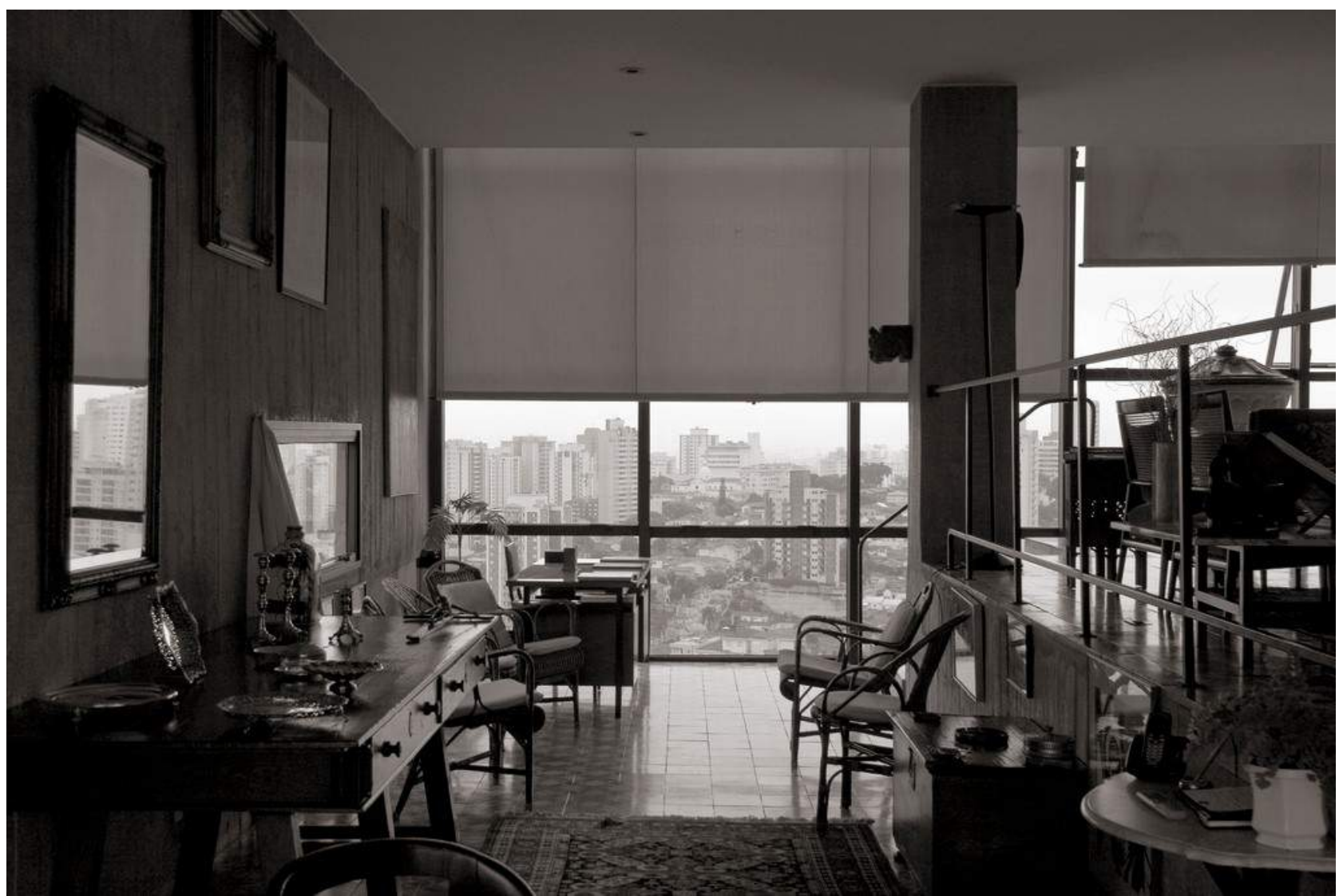

Figuras 62 63: Apartamento na cobertura de Mário e Maju Masetti, decoração com obras de arte do Barroco Brasileiro e móveis modernos. Fonte: fotógrafo Nelson Kon e Eduardo Pompeu

https://www.flickr.com/photos/eduardopompeo/2987198621/ in/album-72157607559017622/
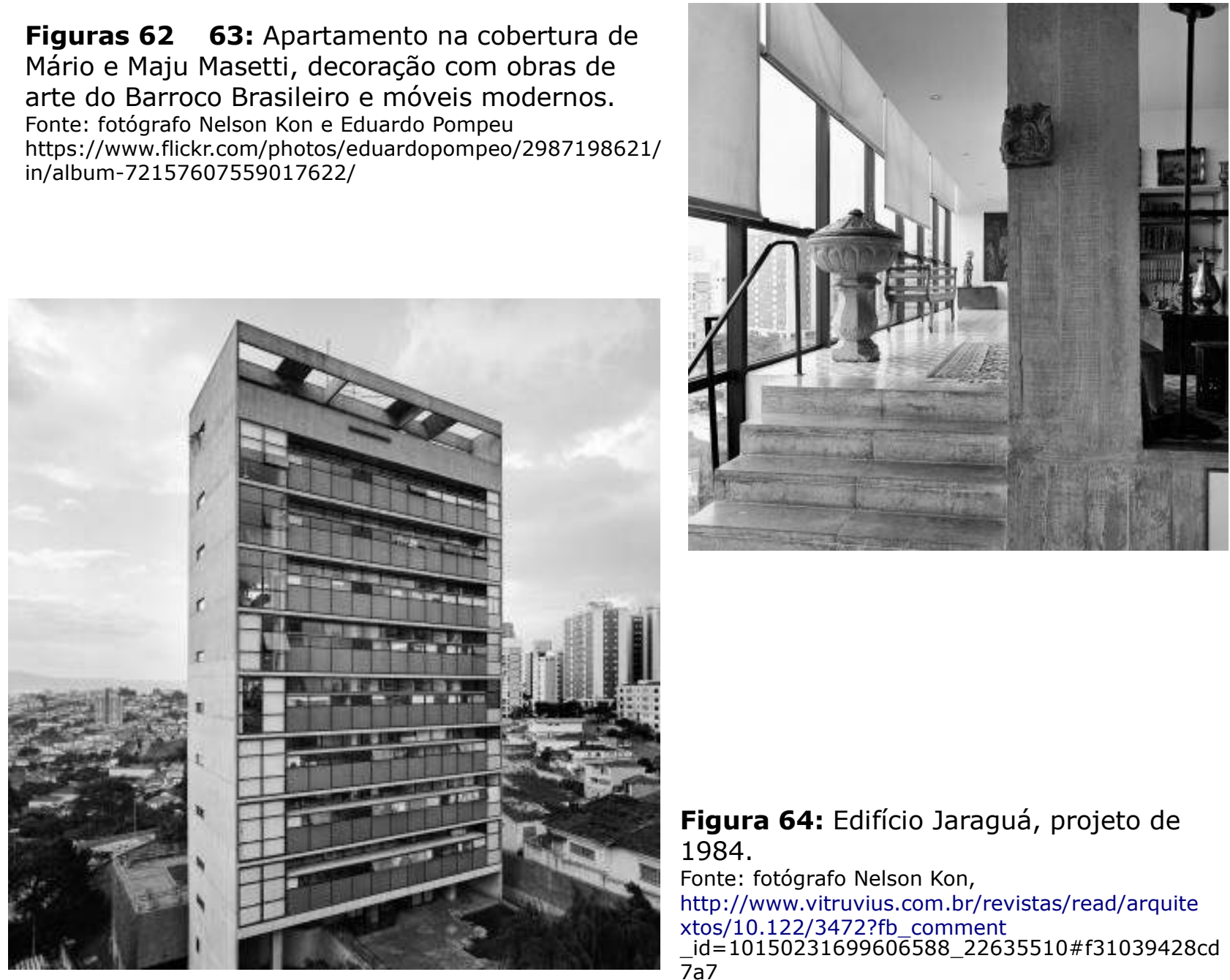

Figura 64: Edifício Jaraguá, projeto de 1984.

Fonte: fotógrafo Nelson Kon,

http://www.vitruvius.com.br/revistas/read/arquite xtos $/ 10.122 / 3472$ ?fb comment

_id=10150231699606588_22635510\#f31039428cd 


\section{Residência da rua Manuel Tourinho, Pacaembu}

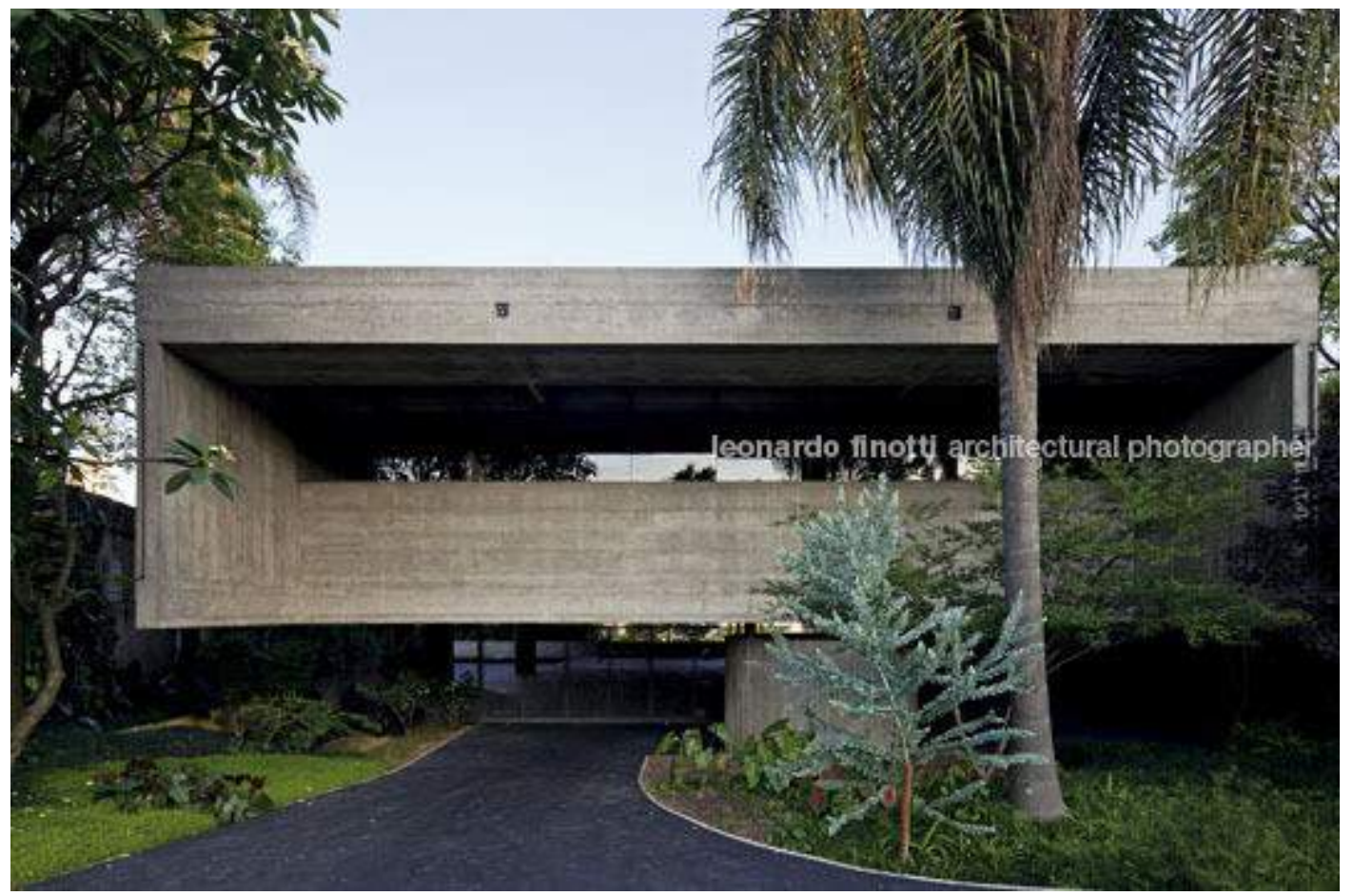

Figura 65: Residência de Mário Masetti, projeto de 1967. Bloco suspendido em quatro pontos de apoio. Revestimento e asfalto no nível térreo.

Fonte:Leonardo Finotti, http://www.leonardofinotti.com/projects/masetti-house/image/07841-111125-027p

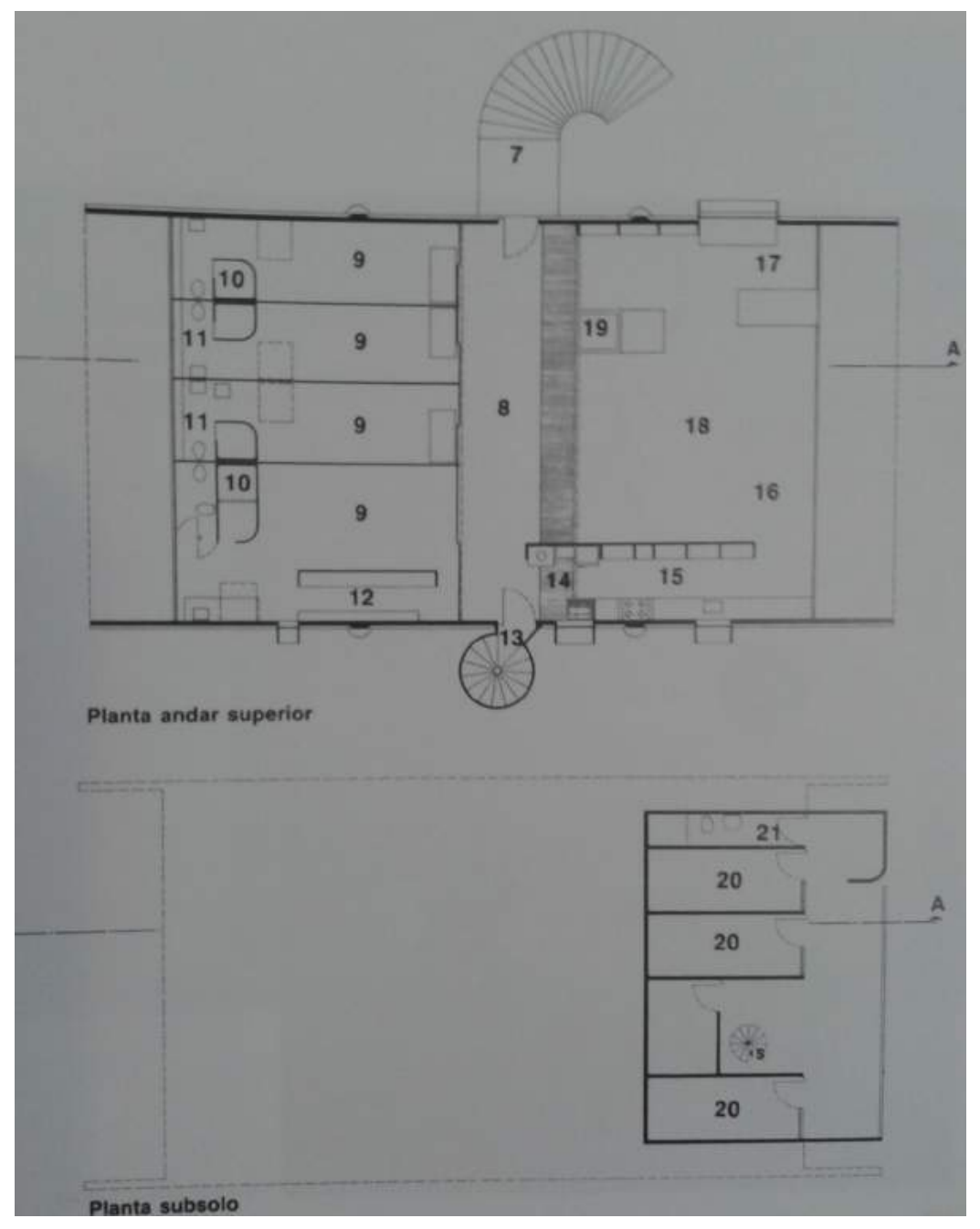

378
Figura 66: Planta da Residência de Mário Masetti, projeto de 1967. Nível superior, com áreas de uso da família e subsolo, dormitórios de empregados.

Fonte:ACAYABA, 2011, p. 289 


\section{Residência da rua Manuel Tourinho, Pacaembu}

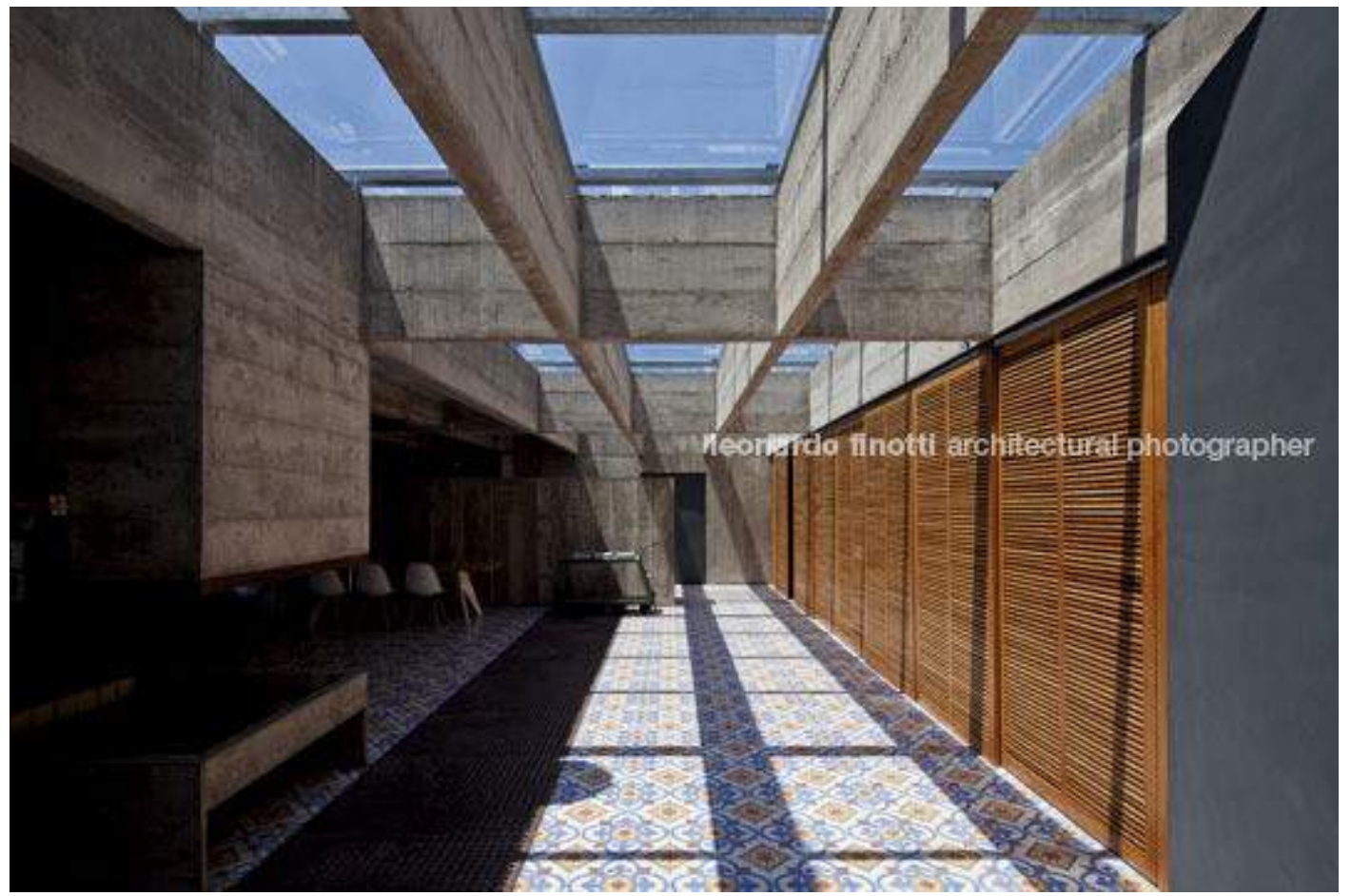

67

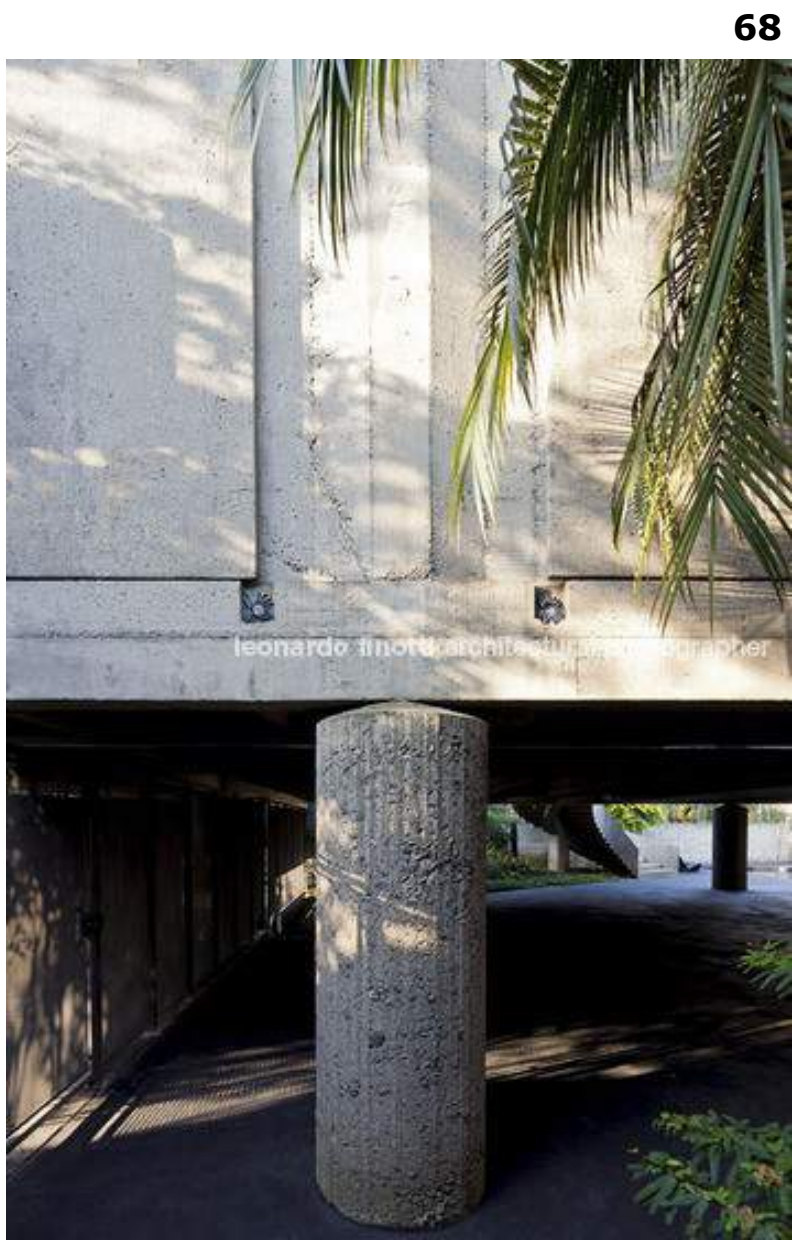

69

Figuras 676869 Residência encomendada por Mário Masetti, projeto de 1967. Ocupação atual de Jarouche Hussein. Área interna e área externa. Bloco suspendido em quatro pontos de apoio. Revestimento e asfalto no nível térreo, piscina revestida de marrom.

Fonte:Leonardo Finotti, http://www.leonardofinotti.com/projects/masetti-house/image/07841-111125-027p 


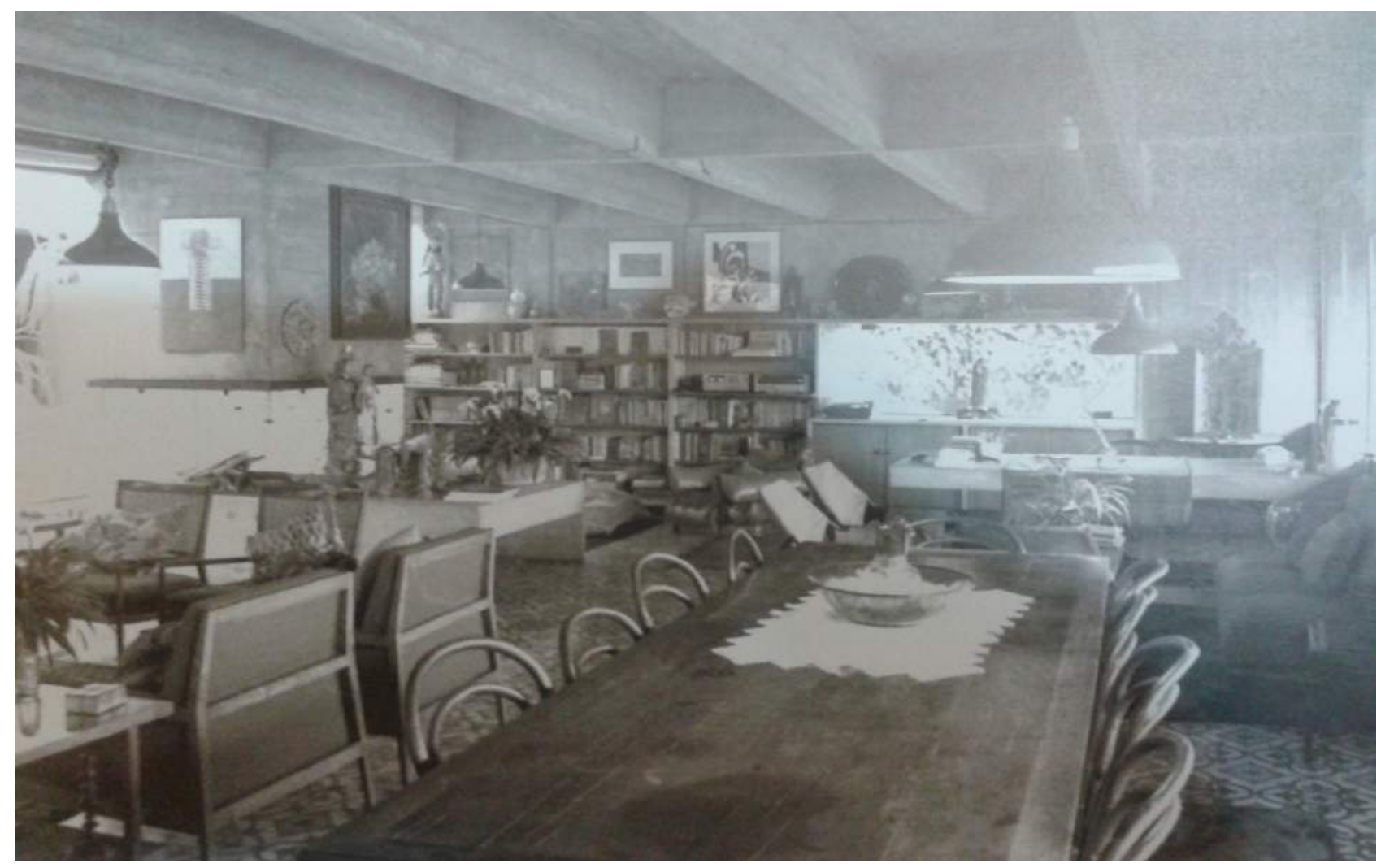

Figura 70: Interior da Residência de Mário Masetti, projeto de 1967. Mobiliário Branco \& Preto e cadeiras Thonet.

Fonte:ACAYABA, 2011, p. 293.

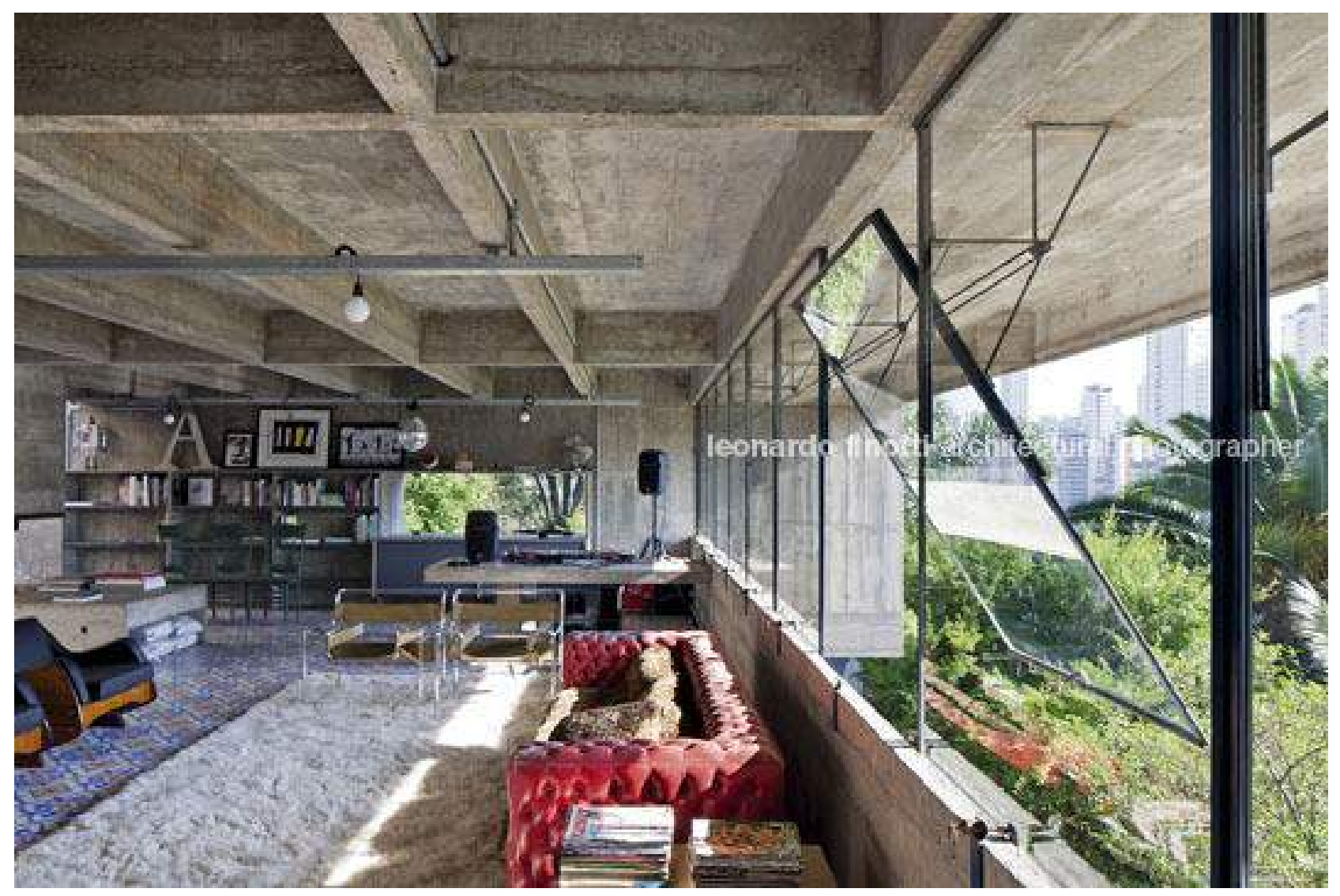

Figura 71: Interior da Residência do Hussein Jarouche, antiga residência de Mário Masetti, restaurada em 2011, mesmo ângulo da fotografia.

Fonte:Leonardo Finotti. http://www.leonardofinotti.com/projects/masetti-house/image/07841-111125-027p 


\section{Residência Eduardo Leme e Galeria Leme}
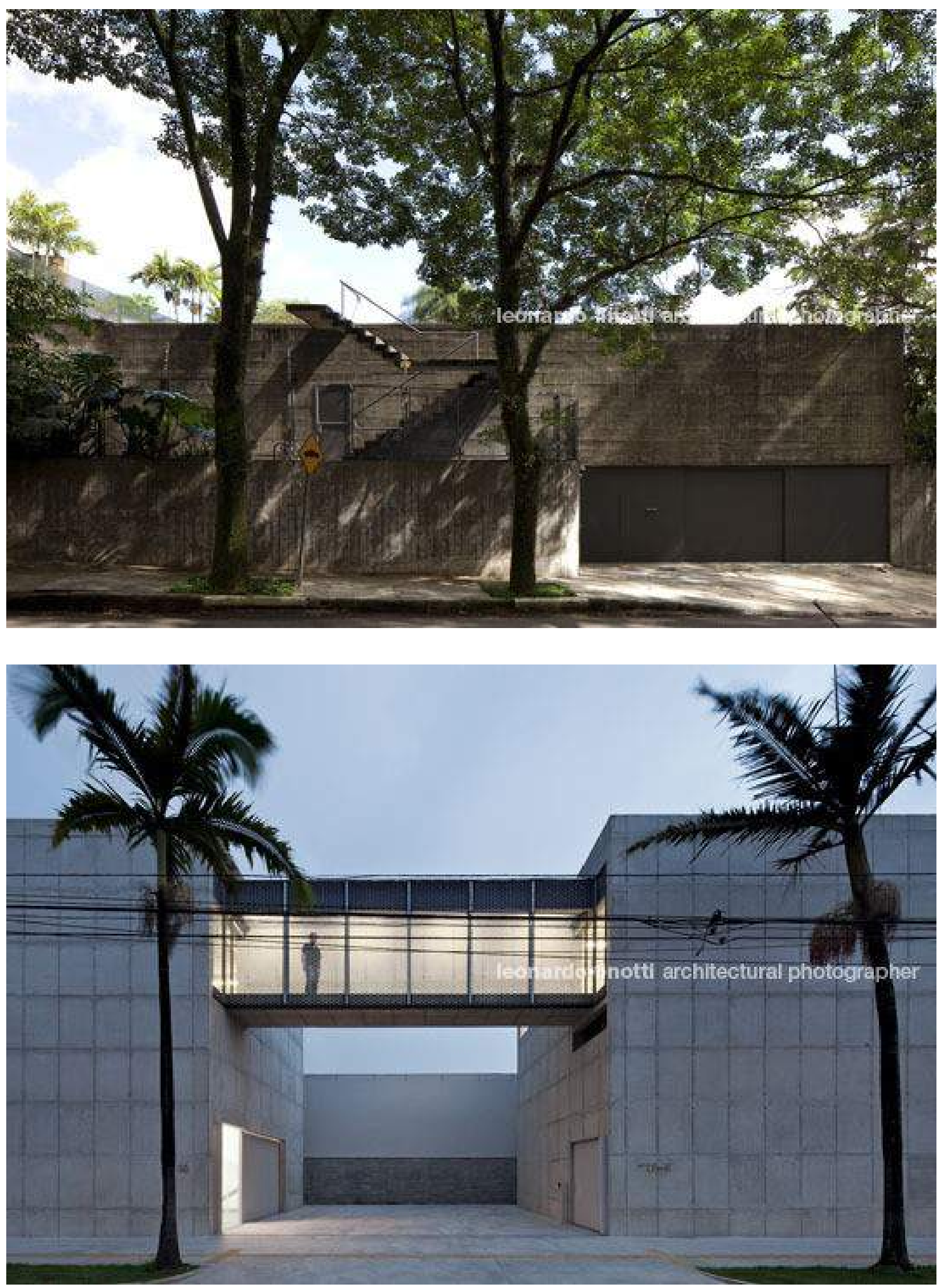

Figuras 72 73: Dois blocos dos espaços expositivos da Galeria Leme, Butantã, projeto original de 2004 e nova-sede de 2011.

Fonte: Leonardo Finotti http://www.leonardofinotti.com/projects/new-leme-s-gallery/image/07851-120119-040d 


\section{Galeria Vermelho}
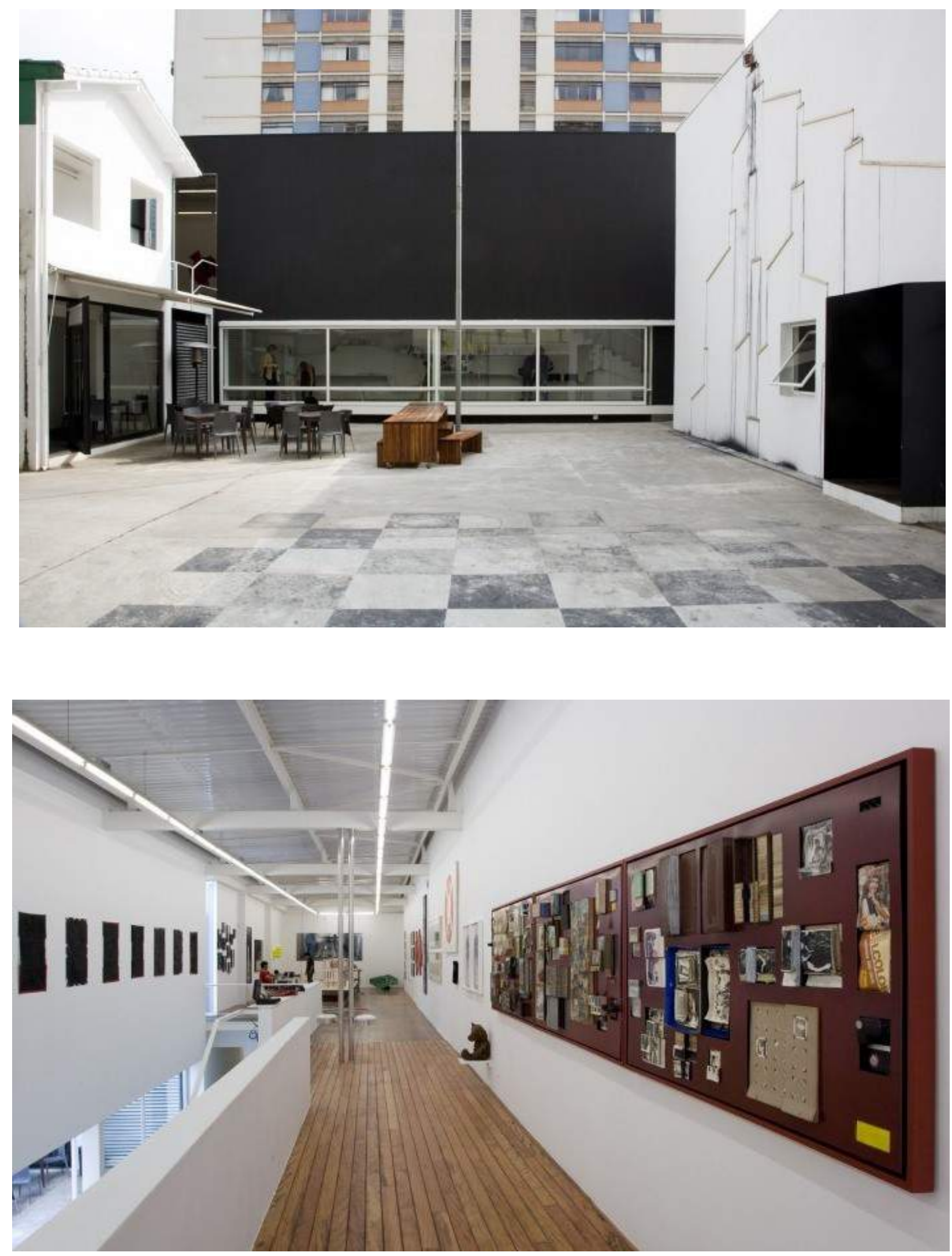

Figuras 74 75: Galeria Vermelho, bairro Higienópolis, projeto de adequação de antigo edifício realizado por Paulo Mendes da Rocha e José Armênio de Brito Cruz, entre 2003 e 2007. Fonte: Ding Musa, http://smtp.romanoguerra.com.br/revistas/read/projetos/12.138-139/4385/en 


\section{Imobiliária de casas e apartamentos de arquitetura de autor}

\section{Imóveis com a sua cara}

O que é um imóvel especial? Pode ser o que tem uma vista absurdamente linda. Ou talvez você valorize mais a arquitetura. Tem gente que gosta de luz, muita luz. Outros preferem o silêncio, com exceção aberta aos passarinhos. Há quem queira um imóvel espaçoso, com lugar para todos os seus sonhos. Um imóvel especial é aquele que tem um algo a mais, que não se encontra em toda a esquina.

\section{Corretores com o olhar treinado}

$\mathrm{Na}$ Axpe, nós perseguimos o belo em todos os cantos da cidade. A boa arquitetura e o bom design são antes de tudo, belos. Procuramos beleza na simetria de um projeto, na maneira como a luz entra por uma janela, no desenho de um móvel, na simplicidade de um pequeno jardim. É essa busca que guia nosso trabalho, todos os dias.

Paixão por arquitetura, amor pelo design, devoção à estética

Se é verdade que a beleza está nos olhos de quem vê, tudo o que você quer na hora de encontrar um imóvel é a ajuda de alguém que veja beleza no mesmo lugar que você. Alguém que entenda e compartilhe suas referências e preferências, para quem você não precise explicar, por exemplo, por que colunas gregas não têm nada a ver com a nossa cultura. Nossos corretores são assim. Você fala e eles entendem. Porque sabem exatamente do que você está falando.

\section{É uma imobiliária. Só que reinventada e dirigida por publicitários}

Os publicitários têm essa capacidade de fazer qualquer coisa se tornar atraente. É o trabalho deles. Um dia, um publicitário resolveu transformar uma imobiliária em uma coisa atraente. Chamou outros publicitários. Pensaram, repensaram, planejaram, tiveram ideias, tiveram mais ideias e idealizaram a Axpe, uma imobiliária com uma visão diferente do morar. Deu muito trabalho. Mas todos ficaram extremamente felizes com o resultado.

\section{Curadoria Axpe. Visitar imóveis comuns? Ninguém merece}

A devoção pela estética é o que define nosso trabalho. Ela apura o olhar do nosso nossos curadores e os torna mais exigentes. Mas essa é a grande diferença da Axpe. Aqui, ninguém vai levar você para ver um imóvel sem graça.

\section{Ouvir. Ouvir. Ouvir. Para você não perder seu tempo}

Você fala, fala, fala o que procura, do que precisa, o que quer. A gente ouve atentamente. Afinal, você está contando um sonho. Depois a gente trabalha, trabalha, trabalha e seleciona apenas o que tem a ver com o que você falou.

\section{Detalhe é tudo}

Um atendimento cuidadoso é aquele que não deixa nada passar despercebido. Por isso, nós somos da teoria que não existe detalhe pequeno demais para ser deixado de lado. Do primeiro contato até a assinatura do contrato, você vai sentir uma grande diferença na maneira como conduzimos as coisas. Tudo para você ter certeza que, aqui na Axpe, não são apenas os imóveis que são tão especiais. Nossos clientes também. Porque seu tempo é curto e precioso, e a gente sabe bem disso.

Nosso escritório é uma delícia. A vista é linda, com direito a por do sol todos os dias, e ainda está num prédio modernista projetado pelo arquiteto Rino Levi.

Axpe é uma pequena aldeia no País Basco, Espanha. É um local especial, onde a quietude é quebrada apenas pelo sininho das ovelhas no pasto. Em basco, Axpe (diz-se Aspe) significa "casa ao pé da pedra" em referência à montanha Anboto.

Figura 76: Anúncio para comercialização de imóveis assinados. Fonte: http://www.axpe.com.br/busca/estilo 


\section{Imobiliária de casas e apartamentos de arquitetura de autor}

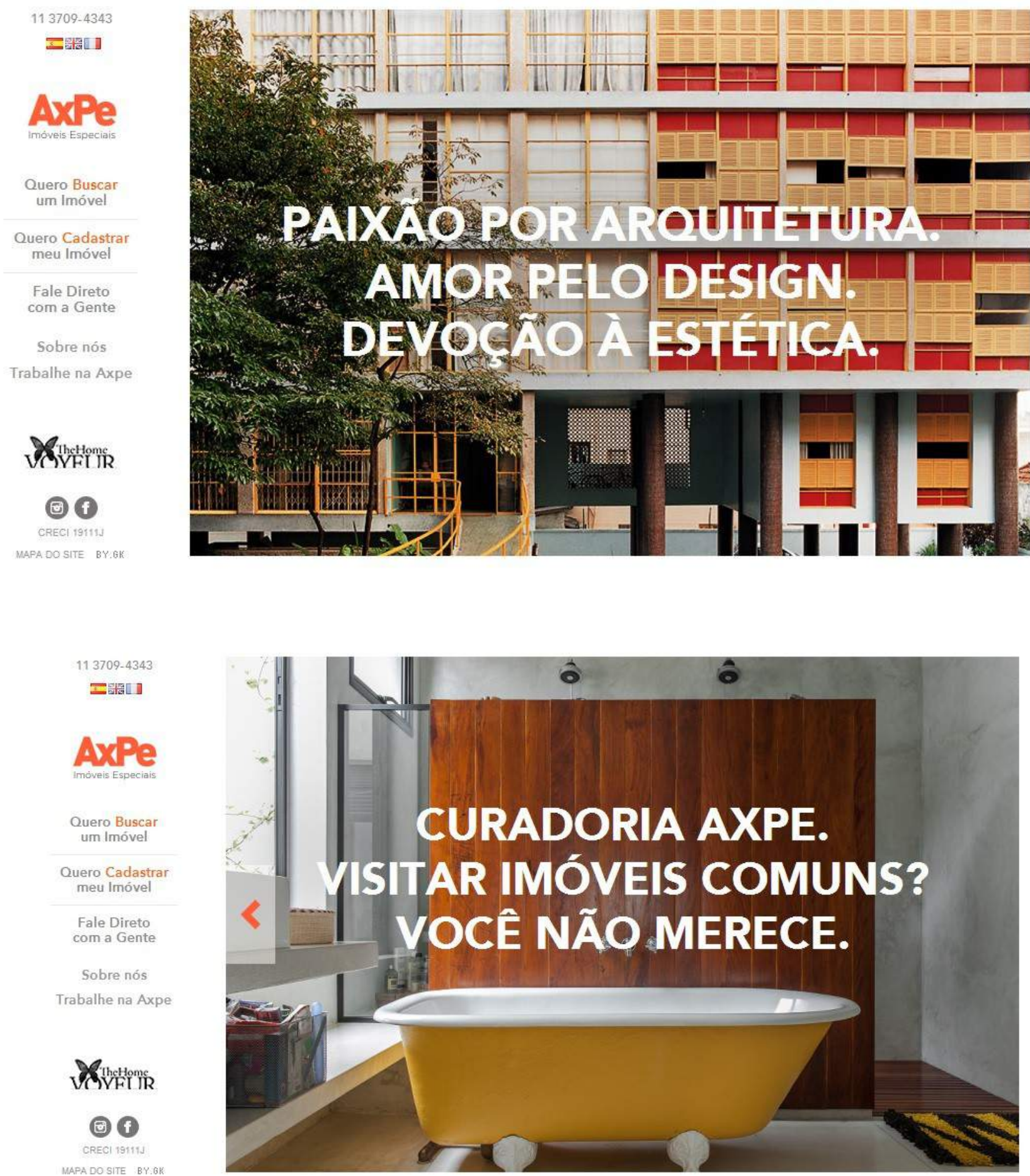

Figuras 77 78: Anúncios para divulgação de "imobiliária-boutique", serviços de curadoria pressupõe imóvel como obra de arte. Fonte: http://www.axpe.com.br/busca/estilo 


\section{Ritual do Prêmio Pritzker}

\section{The Pritzker Architecture Prize}

Sponsored by The Hyatt Foundation
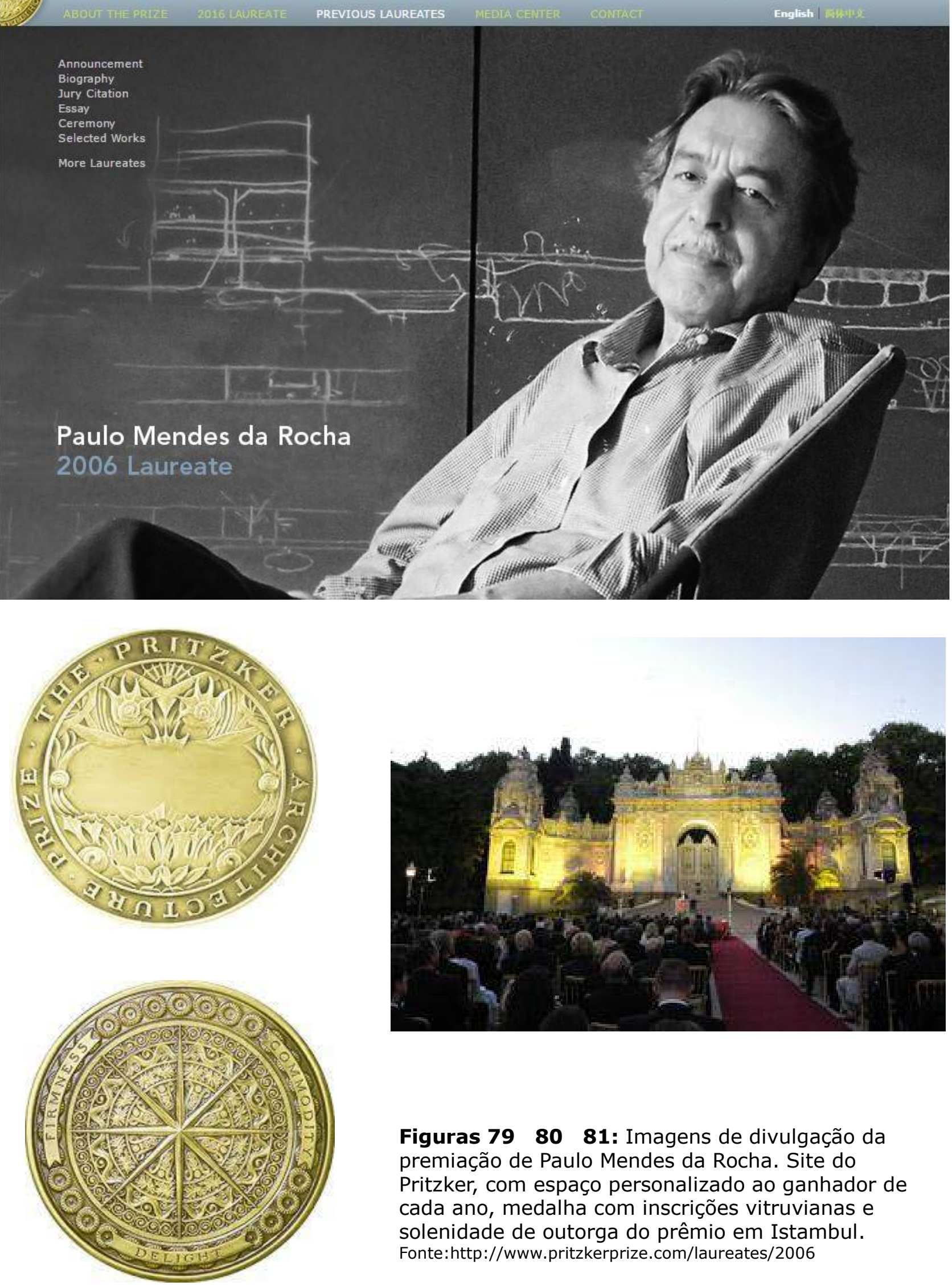

Figuras 7980 81: Imagens de divulgação da premiação de Paulo Mendes da Rocha. Site do Pritzker, com espaço personalizado ao ganhador de cada ano, medalha com inscrições vitruvianas e solenidade de outorga do prêmio em Istambul. Fonte:http://www.pritzkerprize.com/laureates/2006 


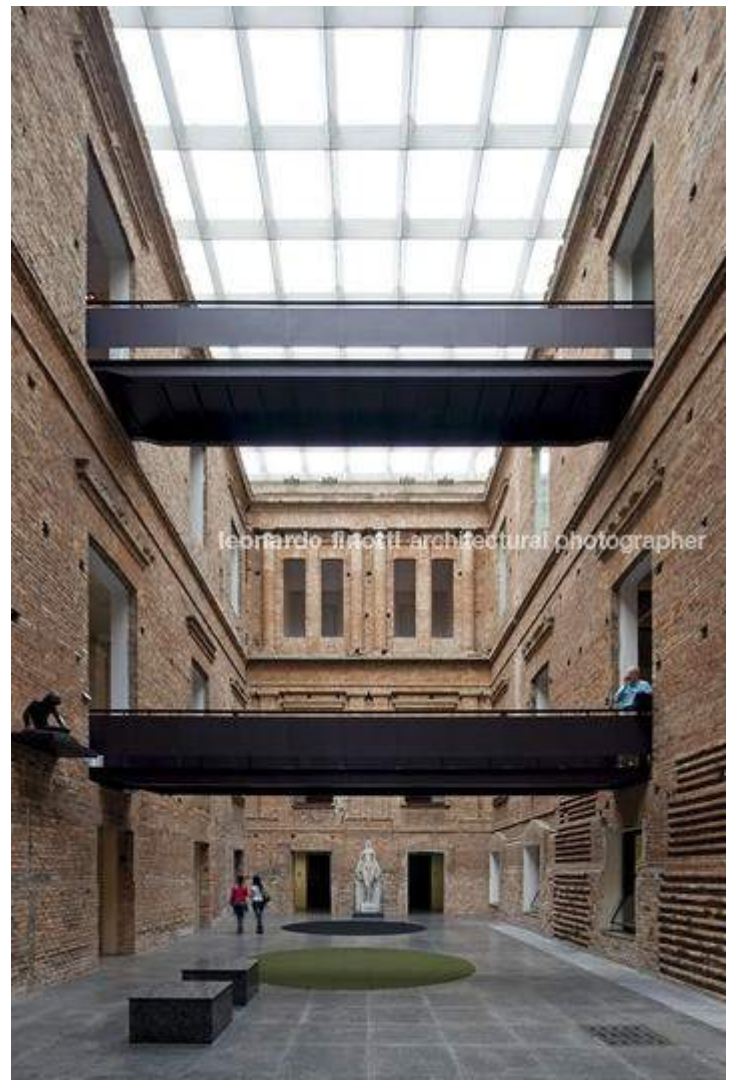

\section{Espaços museográficos}
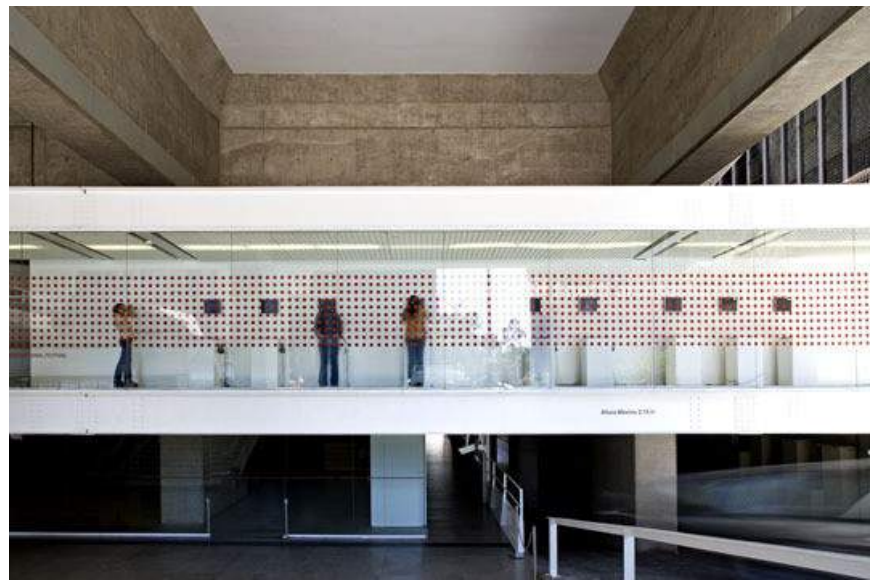

Figuras 828384 85:

Reforma do edifício da

Pinacoteca, Pórtico do

Patriarca, intervenções no

centro de São Paulo;

Reforma de readequação de

Centro Cultural no edifício

da FIESP, avenida Paulista e

Museu Brasileiro de

Escultura e Fonte, bairro

Jardins. Fonte:

http://www.leonardofinotti.co

$\mathrm{m} /$ projects/fiesp-cultural-

center/image/07809-060822-

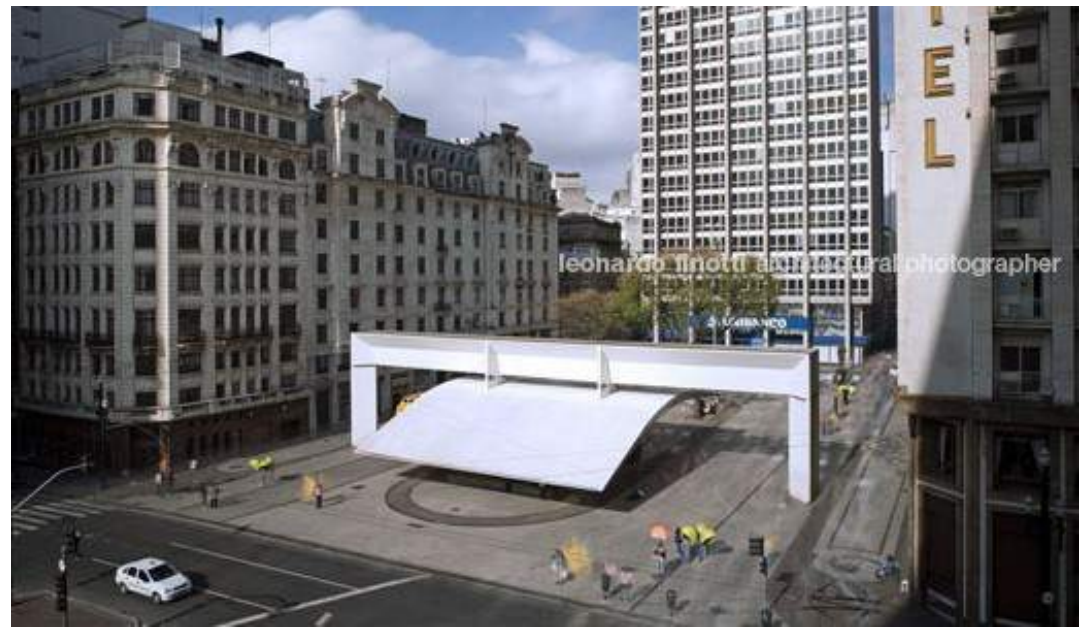

019d

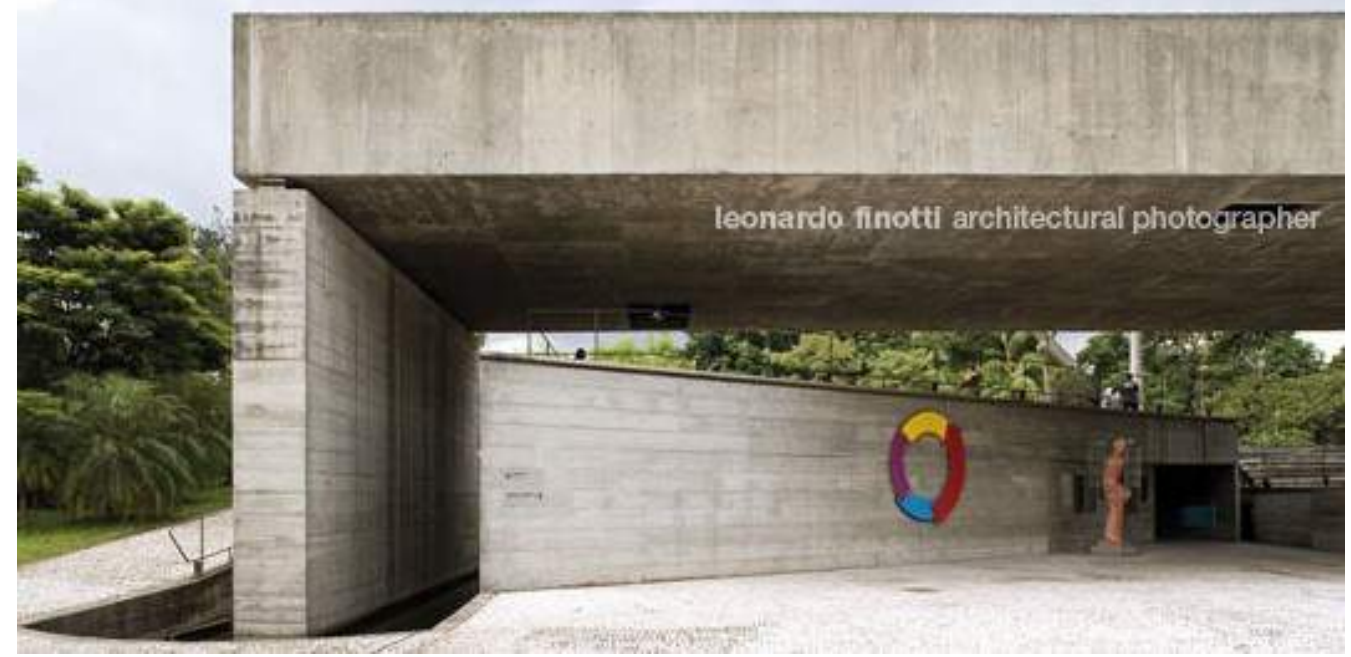

